EDSON BEAS RODRIGUES JUNIOR

\title{
A PROTEÇ̃̃O INTERNACIONAL DO PATRIMÔNIO BIOCULTURAL IMATERIAL A PARTIR DA CONCEPÇÃO DE DESENVOLVIMENTO SUSTENTÁVEL
}

Tese de Doutorado

Área de Concentração: Direito Internacional

Orientadora: Profa. Dra. Maristela Basso

Universidade de São Paulo

Faculdade de Direito

São Paulo - 2009 


\section{FOLHA DE APROVAÇÃ̃o}

Nome: Edson Beas Rodrigues Junior

Título da tese: A Proteção Internacional do Patrimônio Biocultural Imaterial a partir da Concepção de Desenvolvimento Sustentável

Tese apresentada à Faculdade de Direito da Universidade de São Paulo para a obtenção do título de Doutor em Direito

Área de concentração: Direito Internacional

Aprovado em:

\section{Banca Examinadora}

$\begin{array}{lr}\text { Prof(a). Dr(a). } & \text { Instituição: } \\ \text { Julgamento: } & \text { Assinatura: } \\ \text { Prof(a). Dr(a). } & \text { Instituição: } \\ \text { Julgamento: } & \text { Assinatura: } \\ \text { Prof(a). Dr(a). } & \text { Anstituição: } \\ \text { Julgamento: } & \text { Instituição: } \\ \text { Prof(a). Dr(a). } & \text { Assinatura: } \\ \text { Julgamento: } & \text { Instituição: } \\ \text { Prof(a). Dr(a). } & \text { Assinatura: }\end{array}$


Para minha mãe, irmã e avó Para o povo humilde e laborioso do Brasil 


\section{AGRADECIMENTOS}

Agradeço a Deus e a Jesus pela oportunidade de realizar o presente trabalho, bem como pelas muitas instituições e pessoas por Eles colocadas em meu caminho, a fim de viabilizar sua concretização. Dentre elas, primeiramente, agradeço à minha orientadora, professora Maristela Basso, pelo apoio irrestrito ao longo dos últimos anos, sobretudo nos momentos de grande dificuldade.

Agradeço ao Instituto de Direito do Comércio Internacional e Desenvolvimento (IDCID) pela oportunidade do trabalho material e por me oferecer as condições para o desenvolvimento de meu interesse pela pesquisa científica. Agradeço igualmente à Fundação Ford cujo apoio financeiro foi fundamental para as atividades científicas do Instituto.

Agradeço ao Instituto Espanhol, Português e Latino Americano e à Universidade de Utrecht pela concessão da bolsa Prins Bernhard, que me permitiu conduzir pesquisas na Holanda. Também gostaria de agradecer imensamente ao Centro de Política de Propriedade Intelectual da Universidade McGill pela oportunidade de lá pesquisar.

Por fim, agradeço aos seguintes colegas pelos ensinamentos e apoio intelectual, sem os quais o presente trabalho seria muito pobre: Abbe Brown, Bo Hallgren, Carl Gustav Thornström, David Lametti, Edward Richard Gold, Elaini Cristina Gonzaga da Silva, Eliana Rodrigues, Henry Olsson, Joseph Henry Vogel, Lucky Belder, Patricia Shields, Tania Bubela e Tarja Koskinen-Olsson. 
"Vós, porém, que ouvistes a história do Círculo de Giz, Segui o conselho dos velhos:

As coisas devem caber aos que as sabem fazer melhor.

As crianças, às mulheres de coração maternal, para que sejam bem criadas.

Os carros, aos bons condutores, para que a viagem seja boa, E o vale, aos que o abasteçam de água, para que as colheitas sejam abundantes."

\section{Bertolt Brecht ${ }^{1}$}

"Na verdade das coisas, o que somos é a nova Roma. Uma Roma tardia e tropical. O Brasil é já a maior das nações neolatinas, pela magnitude populacional, e começa a sê-lo também por sua criatividade artística e cultural. Precisa agora sê-lo no domínio da tecnologia da futura civilização, para se fazer uma potência econômica, de progresso auto-sustentado. Estamos nos construindo na luta para florescer amanhã como uma nova civilização, mestiça e tropical, orgulhosa de si mesma. Mais alegre, porque mais sofrida. Melhor, porque incorpora em si mais humanidades. Mais generosa, porque aberta à convivência com todas as raças e todas as culturas e porque assentada na mais bela e luminosa província da Terra."

\section{Darcy Ribeiro ${ }^{2}$}

\footnotetext{
${ }^{1}$ BRECHT, 2002, p. 190.

${ }^{2}$ RIBEIRO, 2006, p. 411.
} 


\section{RESUMO}

O patrimônio biocultural imaterial (PBI) é composto por três grandes grupos de recursos bioculturais imateriais (RBIs), a saber, recursos da diversidade biológica (biodiversidade), conhecimentos tradicionais (CTs) e expressões culturais tradicionais (ECTs). Há muito, o PBI dos países em desenvolvimento e de suas comunidades tradicionais vem sendo apropriado sistematicamente pelas instituições dos países industrializados, por meio da reivindicação de direitos de propriedade intelectual sobre produções intelectuais deles derivadas.

Desde a década de 60, sem sucesso, os países em desenvolvimento vêm se empenhando em alcançar a adoção de regimes internacionais, apropriados à proteção dos RBIs. Com a entrada em vigor do Acordo sobre Aspectos dos Direitos de Propriedade Intelectual relacionados ao Comércio da Organização Mundial do Comércio (Acordo TRIPS), em 1995, os países em desenvolvimento se viram na situação de terem de conceder proteção legal a produções intelectuais derivadas de RBIs, ainda que estes tenham sido obtidos ilicitamente. Em contra-resposta, tais países se articulam em negociar regimes internacionais de proteção das diversas categorias de RBIs, no âmbito da Conferência das Partes da Convenção sobre Diversidade Biológica (CCDB), da Organização Mundial do Comércio (OMC) e da Organização Mundial da Propriedade Intelectual (OMPI). As propostas negociadas nesses foros se assentam sobre o obsoleto regime de propriedade intelectual e são julgadas adequadas a proteger os RBIs, porquanto se mostram hábeis a reprimir sua apropriação indébita por terceiros não-autorizados.

Contudo, os negociadores dos países em desenvolvimento ainda não atentaram que os RBIs não se confundem com as produções intelectuais geradas no seio da sociedade ocidental, pois contam com três dimensões peculiares, a saber, as dimensões humana, ambiental e cultural, além da dimensão imaterial.

Partindo do imperativo de salvaguardar, simultaneamente, as múltiplas dimensões do PBI, o presente trabalho propõe um quadro conceitual de desenvolvimento sustentável, competente a desempenhar o papel de um tipo ideal, composto pelos elementos fundamentais que qualquer regime de proteção dos RBIs deve encerrar. A aplicação do quadro conceitual viabiliza a identificação das fraquezas e fortalezas das principais propostas de regimes internacionais em negociação/construção; permitiu ainda identificar as virtudes e fraquezas de mecanismos de proteção calcados em direitos de propriedade, direitos de quase-propriedade, regimes de responsabilidade e regras de pliability. Por fim, a aplicação do quadro conceitual de desenvolvimento sustentável ensejou a identificação de um arranjo legal e institucional apto a tutelar o PBI, de modo a promover, simultaneamente, a repressão de sua apropriação indébita (i), o uso amplo e facilitado de grande parte dos RBIs para fins produtivos (ii); a geração de recursos materiais em favor da conservação/restauração da biodiversidade e da melhoria da qualidade de vida das comunidades tradicionais (iii), e a proteção de alguns valores culturais centrais, conservados pelas comunidades tradicionais (iv).

Palavras-chave: biodiversidade, conhecimentos tradicionais, expressões culturais tradicionais, proteção internacional, desenvolvimento sustentável. 


\section{ABSTRACT}

Intangible biocultural heritage (IBH) is made up of three groups of intangible biocultural resources (IBRs), namely, biological resources (BR), traditional knowledge (TK) and traditional cultural expressions (TCEs). Historically, institutions based in industrialized countries have systematically misappropriated the IBH belonging to communities in developing countries by means of claiming Intellectual Property Rights over products derived.

Since the 1960s, developing countries have unsuccessfully endeavored to reach international agreements suitable for protecting IBRs. After the Agreement on TradeRelated Aspects of Intellectual Property Rights (TRIPS Agreement) came into effect in 1995 , those countries have been obliged to grant legal protection to intellectual products derived from IBRs, even if those products resulted from acts of misappropriation.

In response to this challenge, developing countries came together to negotiate international regimes to protect the different categories of IBRs at the Conference to the Parties to the Convention on Biological Diversity (COP-CBD), before the World Intellectual Property Organization (WIPO) as well as at the World Trade Organization (WTO). Their proposals, however, are rooted in the anachronistic intellectual property paradigm, ill-suited with respect to providing adequate tools to protect those resources. The negotiators representing the interests of developing countries have not realized yet that they should not treat IBRs in the same fashion as typical intellectual products originating from Western countries, provided IBRs are categorically distinct, featuring three particular dimensions-human, environmental and cultural - not present in intellectual property as traditionally understood, in addition to the traditional intangible intellectual element.

With the end of safeguarding the multiple dimension of IBH, the present work proposes an ideal sustainable development framework based upon the essential elements that any international regime devoted to protect IBH should embrace.

The application of the sustainable development framework reveals the strengths and weaknesses of the most relevant proposals of international regimes currently under construction on the international level. Furthermore, it identifies the advantages and disadvantages of legal mechanisms based on property rights, quasi property rights, liability rules, and pliability rules. Finally, the application of this sustainable development framework outlines a concrete legal and institutional arrangement, capable of simultaneously (i) protecting IBRs against acts of misappropriation, (ii) fostering the wider and facilitated use of IBRs for productive purposes, (iii) generating economic resources in favor of the conservation/restoration of natural ecosystems and the improvement of the quality of life of local communities, (iv) as well as safeguarding certain core cultural values of traditional communities.

Keywords: biodiversity, traditional knowledge, traditional cultural expressions, international protection, sustainable development. 


\section{LISTA DE ILUSTRAÇÕES}

Figura 1: Figura indicando a presença do material genético no interior das células dos seres vivos; a composição deste material pelos nucleotídeos A, C, G e T, e seu papel na produção de proteínas, que sustentam os organismos vivos.

Quadro 1: Associação entre a noção de desenvolvimento sustentável, as dimensões do PBI

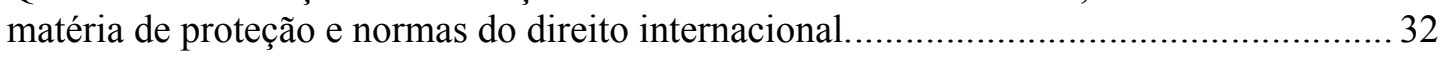

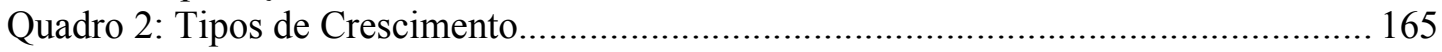

Quadro 3: Critérios de operacionalização que integram o quadro conceitual de

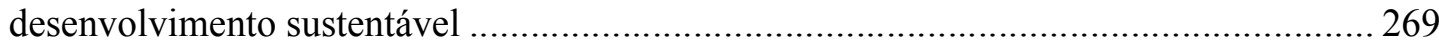

Quadro 4: Autorizações obtidas previamente e durante a consecução do projeto....

Quadro 5: Elementos alterados nas propostas de regime de propriedade para RBIs em relação aos regimes convencionais de proteção da PI.....

Quadro 6: Sumário dos elementos essenciais de um regime internacional apto a proteger as

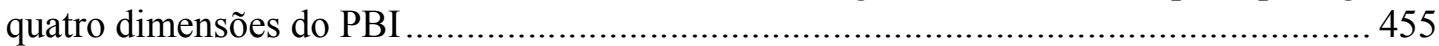

Quadro 7: Sumário dos elementos centrais das propostas de regimes legais em construção/discussão na arena internacional 


\section{LISTA DE SIGLAS E ABREVIAÇÕES}

\section{Sigla}

AEP

AGONU

AIFAO

AIPPI

CB

CCDB

CCI

CCMA

CCPR

CDB

CDESC

CDM

CERD

CESCR

CIG

\section{Descrição da Sigla}

Avaliação Estratégica Prévia

Assembléia Geral da Organização das Nações Unidas

Acordo Internacional da FAO sobre

Recursos Fitogenéticos

Associação Internacional para a Proteção da Propriedade Intelectual

Convenção de Berna para a proteção das obras literárias e artísticas

Conferência das Partes da Convenção sobre Diversidade Biológica

Câmara de Comércio Internacional

Comitê da Organização Mundial do

Comércio sobre Comércio e Meio

Ambiente

Committee on Civil and Political Rights

Convenção sobre Diversidade Biológica

Comitê sobre Direitos Econômicos, Sociais e Culturais

Convenção das Nações Unidas sobre Direito do Mar

Committee on the Elimination of Racial Discrimination

Committee on Economic, Social and Cultural Rights

Comitê Intergovernamental sobre Propriedade Intelectual, Recursos Genéticos, Conhecimentos Tradicionais e Folclore da Organização Mundial da Propriedade Intelectual 
CIIA

CNUCD

CONUMAD

COPCBD

CPLI

CPPDEC

CPRCG

CQMC

CSPCI

CT

CTA

$\mathrm{CP}$

DPI

DUDH

e.g.

ECOSOC

ECT

EEP
Centro Internacional de Investigação

Agronômica

Convenção das Nações Unidas de Combate à Desertificação

Conferência das Nações Unidas sobre Meio Ambiente e Desenvolvimento

CONFERENCE OF THE PARTIES TO THE CONVENTION ON BIOLOGICAL DIVERSITY

Consentimento prévio, livre e informado

Convenção sobre a Proteção e a Promoção da Diversidade das Expressões Culturais

Convenção para a Prevenção e a Repressão do Crime de Genocídio

Convenção Quadro das Nações Unidas sobre Mudanças do Clima

Convenção para a Salvaguarda do Patrimônio Cultural Imaterial

Conhecimento tradicional

Conhecimento tradicional associado à biodiversidade

Convenção de Paris para a proteção da propriedade industrial

Direito de Propriedade Intelectual

Declaração Universal dos Direitos do Homem

exempli gratia

United Nations Economic and Social Council

Expressão Cultural Tradicional ou Folclórica

Escritório Europeu de Patentes 
FAO

FUNAI

GCIAI

i.e.

ICC

ICSU

JPO

OEA

OGCD

OGCPBI

OGD

OIT

$\mathrm{OMC}$

OMPI

OMS

ONU

OSC

OTCA

P\&D

Para.

PBI

PCT
Food and Agriculture Organization of the United Nations

Fundação Nacional do Índio

Grupo Consultivo para a Investigação Agronômica Internacional

Id est

International Chamber of Commerce

International Council for Science

Escritório Japonês de Patentes

Organização dos Estados Americanos

Organização de gestão coletiva de direitos

Organização de Gestão Coletiva do

Patrimônio Biocultural Imaterial

Organização de gestão de direitos

Organização Internacional do Trabalho.

Organização Mundial do Comércio

Organização Mundial da Propriedade Intelectual

Organização Mundial da Saúde

Organização das Nações Unidas

Órgão de Solução de Controvérsias

Organización del Tratado de Cooperación Amazónica

Pesquisa e Desenvolvimento

Parágrafo

Patrimônio Biocultural Imaterial

Patent Cooperation Treaty 
PI

PIDCP

PIDESC

PNUMA

RBI

RI

RR

RRC

SCBD

SIE

TRIPS

TIRFAA

UE

UNCED

UNEP

UNESCO

UNGA

UNIFESP
Propriedade intelectual

Pacto Internacional sobre Direitos Civis e Políticos

Pacto Internacional sobre Direitos

Econômicos, Sociais e Culturais

Programa das Nações Unidas para o Meio Ambiente

Recurso Biocultural Imaterial

Regime internacional, a ser adotado no marco da $\mathrm{CDB}$, que disciplinará o acesso e o uso dos recursos da biodiversidade e dos CTAs

Regime de responsabilidade

Regime de responsabilidade compensatória

Secretariat of the Convention on Biological Diversity

Sociedade Internacional de Etnobiologia

Acordo sobre Aspectos dos Direitos de Propriedade Intelectual relacionados ao Comércio

Tratado Internacional sobre Recursos

Fitogenéticos para a Alimentação e Agricultura

\section{União Européia}

United Nations Conference on Environment and Development

United Nations Environment Programme

Organização das Nações Unidas para a Educação, a Ciência e a Cultura

United Nations General Assembly

Universidade Federal de São Paulo 
UPOV

USPTO

WPPT

WTO
International Union for the Protection of New Varieties of Plants

Escritório de Patentes e Marcas dos Estados Unidos da América

Tratado da OMPI sobre Interpretação ou Execução e Fonogramas

World Trade Organization 


\section{SUMÁRIO}

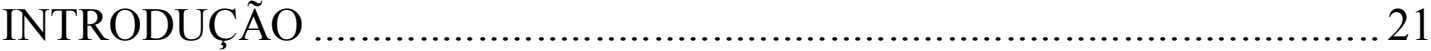

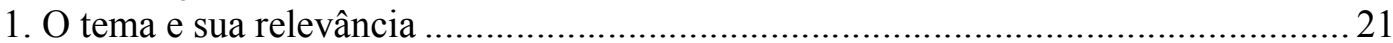

2. Esclarecimentos preliminares a respeito do quadro conceitual proposto ................... 30

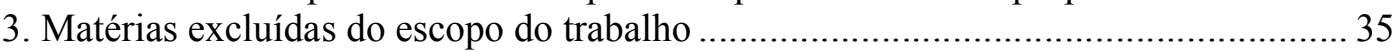

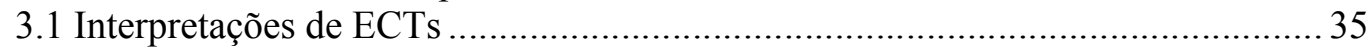

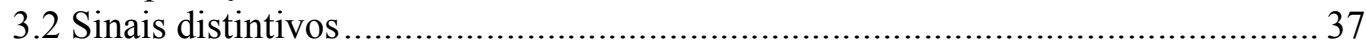

3.3 Recursos marinhos fora das jurisdições dos Estados contratantes da Convenção da

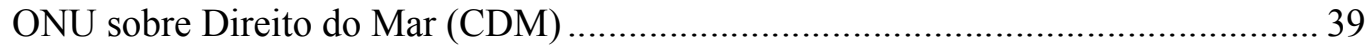

3.4 Recursos da agrobiodiversidade regidos pelo TIRFAA …............................. 40

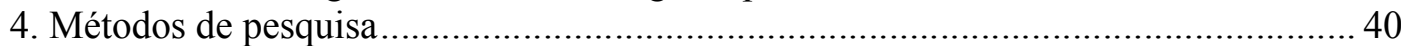

5. Plano do trabalho e as regras utilizadas para citação............................................... 41

\section{DEFINIÇÃO DE CONHECIMENTOS TRADICIONAIS, RECURSOS} DA BIODIVERSIDADE E EXPRESSÕES CULTURAIS TRADICIONAIS

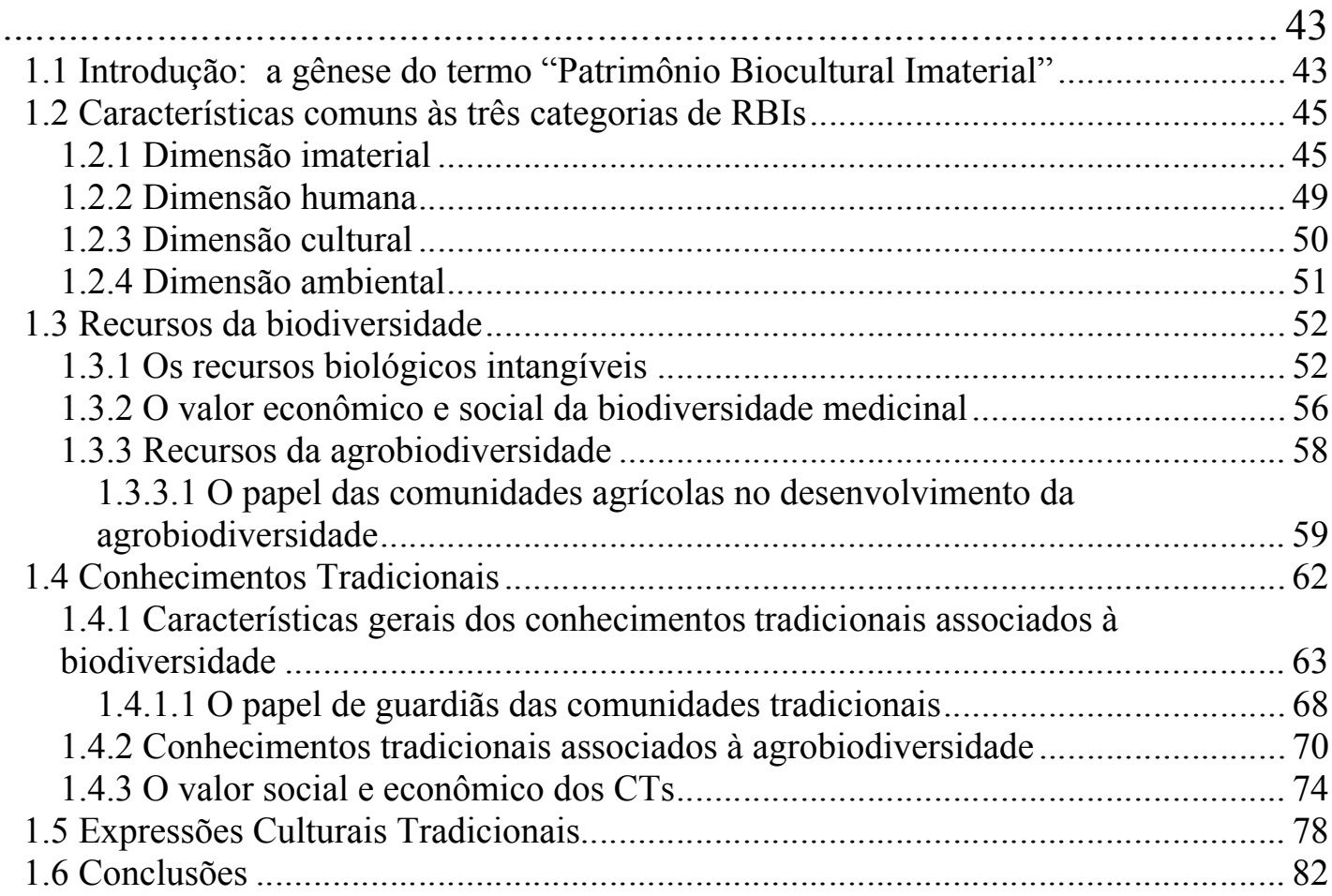

2. O PAPEL DOS DPIS NA APROPRIAÇÃO INDÉBITA DOS RBIs E A EMERGÊNCIA DO CONTRAMOVIMENTO DOS PAÍSES EM

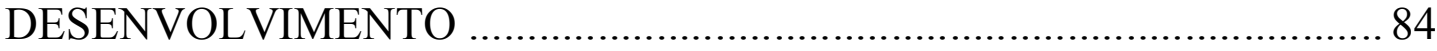

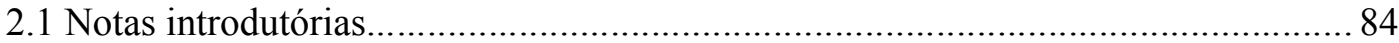

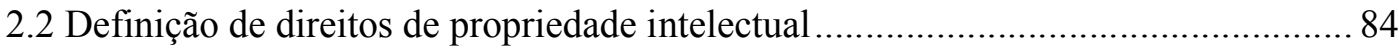

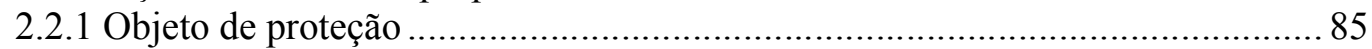

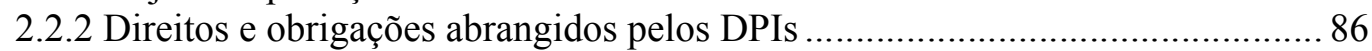

2.2.3 Estímulo à criatividade versus proteção do pré-existente ............................... 89 
2.2.4 Fundamento comum da obrigação de proteção das produções intelectuais geradas na sociedade ocidental e no âmbito de comunidades tradicionais................ 90

2.3 A inadequação dos direitos autorais para tutelar as ECTs .................................. 96

2.3.1 Inaplicabilidade dos regimes de direitos autorais às ECTs ........................... 99

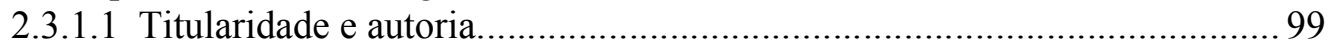

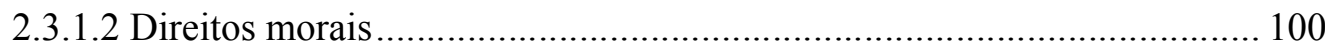

2.3.1.3 Proteção temporalmente limitada...................................................... 101

2.3.1.4 Requisito da fixação em um substrato permanente................................. 101

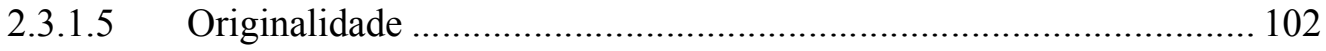

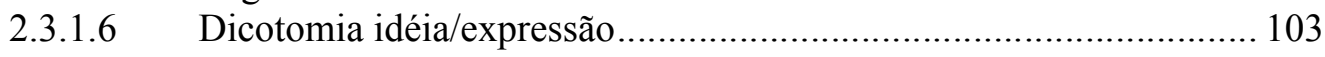

2.3.1.7 Limitações aos direitos autorais.................................................. 104

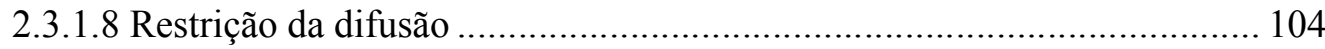

2.3.2 Iniciativas internacionais para a correção do caráter discriminatório dos direitos

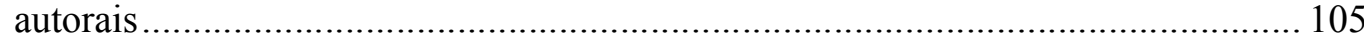

2.4 Expansão do direito das patentes sobre as invenções biotecnológicas e sua inaptidão para tutelar os CTs e os recursos da biodiversidade............................................ 108

2.4.1 O desenvolvimento da biotecnologia e as mudanças empreendidas nos regimes

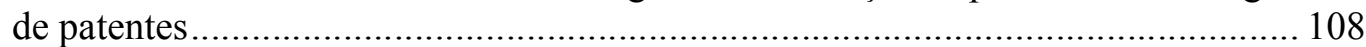

2.4.2 O problema da biopirataria ......................................................................... 110

2.4.3 Papel do direito das patentes na apropriação dos CTs e dos recursos da

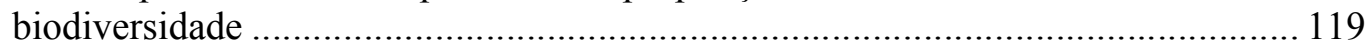

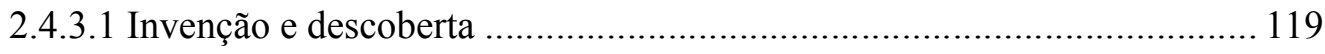

2.4.3.2 Autoria da invenção ................................................................ 121

2.4.3.3 As três condições substantivas de patenteabilidade e a apropriação dos CTs

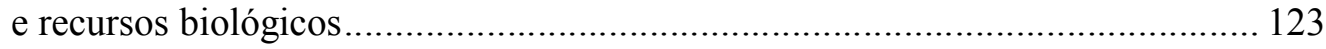

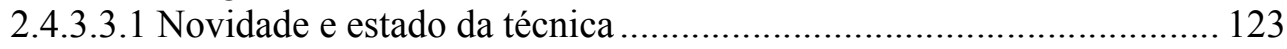

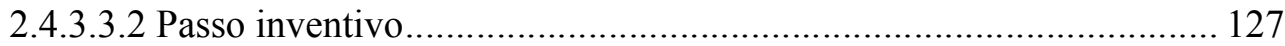

2.4.3.3.3 Aplicabilidade industrial .......................................................... 129

2.4.4 Segredos comerciais: um instrumento útil para tutelar os CTs? ................... 130

2.4.4.1 Fraquezas dos segredos comerciais.................................................... 133

2.5 A emergência da CDB e seu esvaziamento pela OMC e pelos acordos bilaterais de

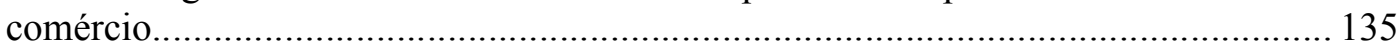

2.5.1 Acordo TRIPS e o esvaziamento da CDB ................................................... 142

2.5.1.1 Flexibilidades oferecidas pelo Acordo TRIPS para mitigar seu conflito com

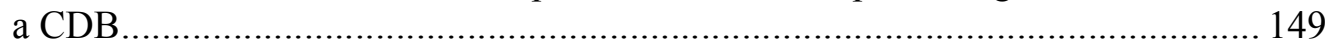

2.5.2 Os acordos de livre comércio e a supressão das flexibilidades do Acordo TRIPS

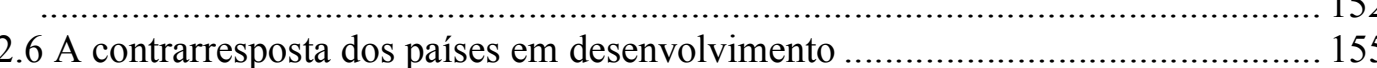

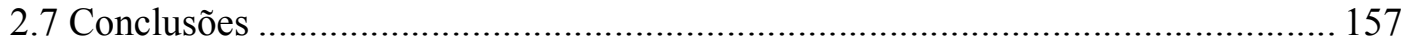

\section{CONSTRUÇÃO DO QUADRO CONCEITUAL DE} DESENVOLVIMENTO SUSTENTÁVEL ............................................. 160

3.1 A concepção de desenvolvimento sustentável e um breve histórico de seu desenvolvimento no direito internacional contemporâneo ......................................... 160

3.1.1 O pilar cultural da concepção de desenvolvimento sustentável ..................... 173

3.1.1.1 As relações construtivas entre as diversidades cultural e biológica.......... 179

3.1.2 O status legal da concepção de desenvolvimento sustentável........................ 183

3.2 A relação entre as dimensões do PBI e os pilares de sustentação da concepção de desenvolvimento sustentável........................................................................ 188 
3.2.1 Critérios de operacionalização do quadro conceitual de desenvolvimento sustentável....

3.2.1.1 Critério de operacionalização 1: Geração de benefícios econômicos derivados dos RBIs e sua reversão obrigatória em favor da conservação da biodiversidade e da melhoria da qualidade de vida das comunidades tradicionais 192 3.2.1.1.1 A relação entre o direito à terra e o direito à autodeterminação das comunidades tradicionais

$\S 1 \mathrm{~A}$ fragilidade do direito das comunidades tradicionais e o imperativo de se gerar renda em seu favor....

3.2.1.1.2 O papel das ECTs na geração de benefícios econômicos no curto prazo

3.2.1.2 Critério de operacionalização 2: Direito de acesso amplo e facilitado ao PBI

3.2.1.2.1 O domínio público, os DPIs e o direito de acesso ao conhecimento.. 213 $\S 1$ Os DPIs e a limitação global do direito de acesso ao domínio público informacional 217

§1.1 As patentes e o esvaziamento do domínio público......................... 219 3.2.1.2.2 A importância da liberdade de acesso ao PBI pelas comunidades tradicionais e pela sociedade dominante 222

$\S 1$ A relevância do acesso amplo e facilitado pelas comunidades tradicionais

ao PBI de outras comunidades.................................................................... 222

$\S 2$ A relevância do acesso amplo ao PBI pela sociedade dominante............. 224

3.2.1.3 Critério de operacionalização 3: Direitos Morais ................................ 235

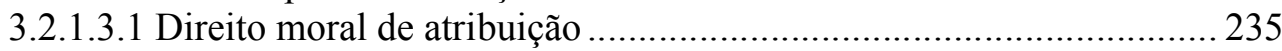

3.2.1.3.2 Direito moral de integridade .................................................... 237

3.2.1.4 Critério de operacionalização 4: Efetividade dos regimes de proteção em

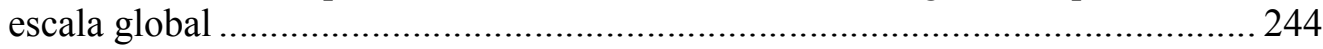

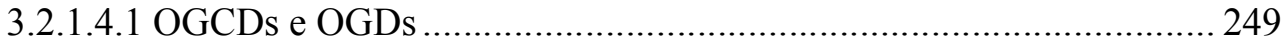

$\S 1$ Registro obrigatório dos RBIs protegidos e uma rede de instituições

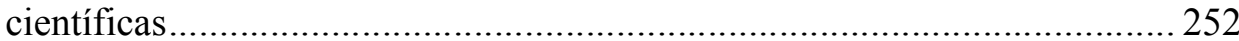

§ 1.1 Rede de instituições científicas .................................................. 254

$\S 1.2$ Outras razões para o condicionamento da proteção dos RBIs ao seu

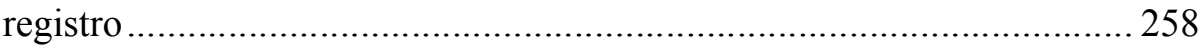

1.2.1 Identificação dos cotitulares de RBIs....................................... 258

\$1.2.2 Promoção do uso amplo e facilitado aos RBIs .......................... 258

§1.2.3 Conservação dos RBIs para as futuras gerações.......................... 259

§1.2.4 Proteção das ECTs sagradas contra usos culturalmente

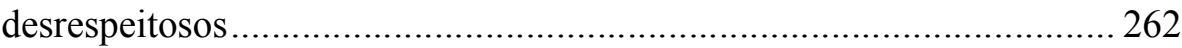

$\S 1.2 .5$ Compromissos internacionais ............................................ 262

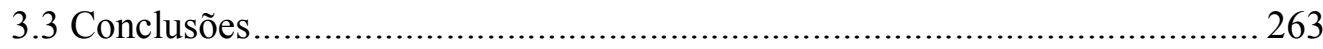

4. AVALIAÇÃO DAS PROPOSTAS DE MECANISMO DE PROTEÇÃO INTERNACIONAL DO PBI EM FACE DO QUADRO CONCEITUAL DE DESENVOLVIMENTO SUSTENTÁVEL ............................................. 271

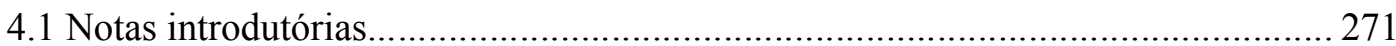

4.2 Propostas fundadas em direito de propriedade................................................ 272

4.2.1 Relação entre CPLI e direito de propriedade ............................................... 272 
4.2.2 Exame das propostas em negociação na CCDB, OMC e OMPI, sustentadas em

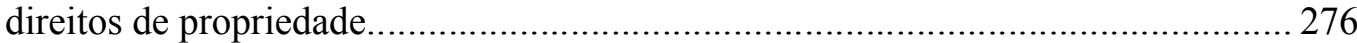

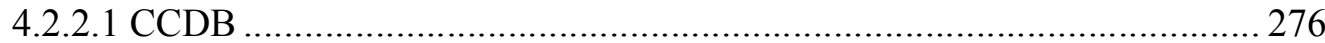

4.2.2.1.1 Elementos da proposta da CCDB para a proteção dos recursos da

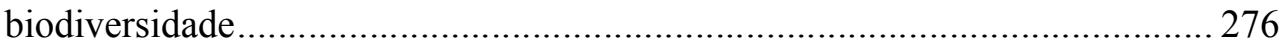

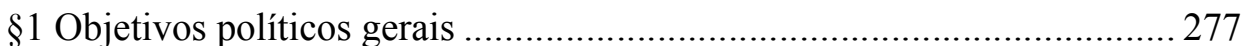

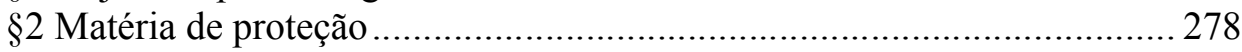

§3 Formalidades para obtenção da proteção............................................... 279

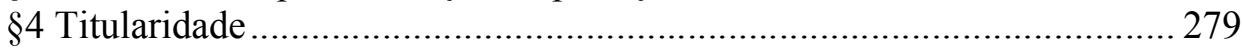

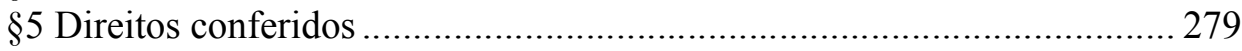

§6 Limitações aos direitos conferidos........................................................ 279

§7 Duração dos Direitos........................................................................ 280

§8 Organização de apoio aos Estados para assegurar a observância dos direitos

\$9 Vinculação dos benefícios recebidos ao seu investimento na melhoria da qualidade de vida das comunidades e na conservação da natureza .............. 282

4.2.2.1.2 Elementos da proposta da CCDB para a proteção de conhecimentos tradicionais associados à biodiversidade (CTAs) .......................................... 282

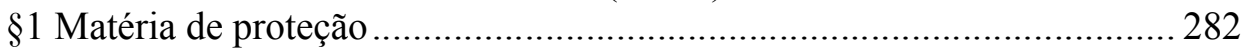

§2 Formalidades para a obtenção de proteção .......................................... 283

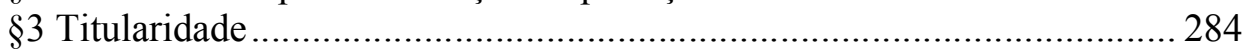

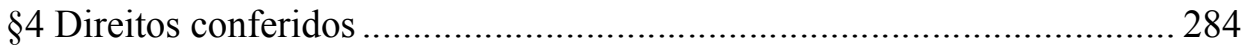

§5 Limitações aos direitos conferidos................................................... 284

§6 Duração dos Direitos ........................................................................... 285

§7 Organização de apoio às comunidades tradicionais para assegurar a

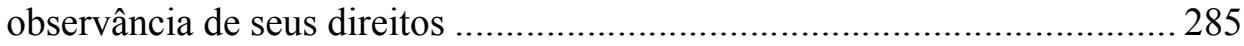

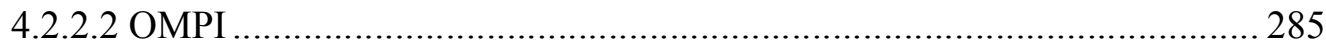

4.2.2.2.1 Projeto de disposições da OMPI para a proteção de CTs ................ 286

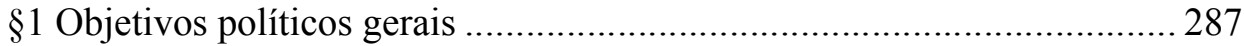

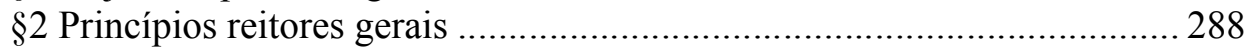

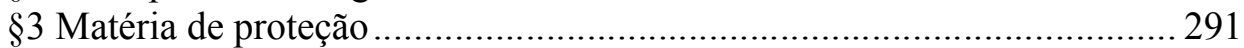

§4 Formalidades para obtenção da proteção.............................................. 292

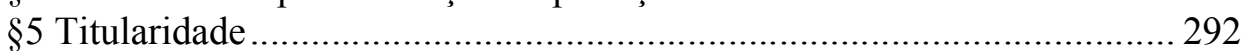

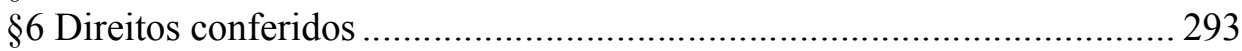

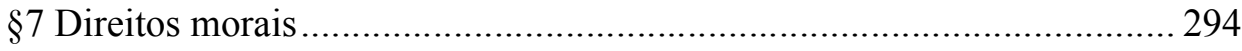

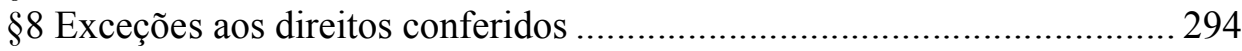

$\S 9$ Duração dos Direitos ........................................................................ 295

$\S 10$ Organização de apoio às comunidades tradicionais para assegurar a observância dos direitos ...................................................................... 295

§11 Vinculação dos benefícios recebidos à sua aplicação na melhoria da qualidade de vida das comunidades tradicionais e na conservação da natureza

4.2.2.2.2 Projeto de disposições da OMPI para a proteção das ECTs ................ 296

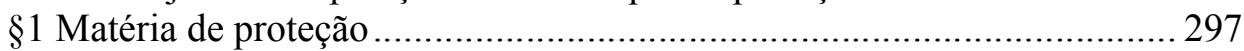

§2 Formalidades para obtenção da proteção.............................................. 297

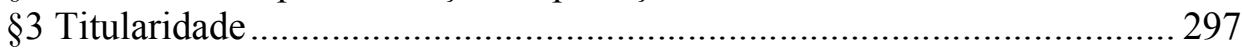

$\S 4$ Direitos conferidos (incluindo direitos morais) .................................... 298

§5 Limitações aos direitos conferidos....................................................... 300

§6 Duração dos Direitos ........................................................................ 301 
§7 Organização de apoio às comunidades tradicionais para assegurar a observância dos direitos 301

$\S 8$ Vinculação dos benefícios recebidos ao investimento na melhoria da qualidade de vida das comunidades e na conservação da natureza ............. 302

4.2.3 Elementos e problemas comuns das propostas............................................. 302

4.2.3.1 PROBLEMA I: A fragmentação da titularidade e a tragédia dos anticomuns

.

4.2.3.1.1 Titularidade compartilhada entre comunidades ou Estados.............. 303

4.2.3.1.2 RBIs compartilhados por grandes contingentes humanos ................. 308

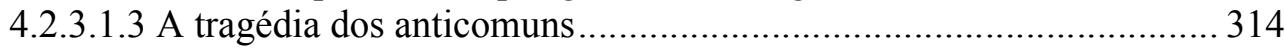

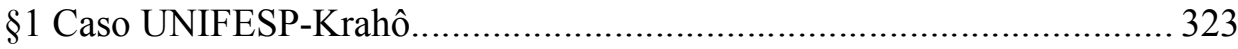

4.2.3.2 PROBLEMA II: Princípio da exaustão de direitos .................................. 329

4.2.3.3 PROBLEMA III: Ausência de um registro obrigatório para os RBIs protegidos 333

4.2.3.4 PROBLEMA IV: Reivindicações de direitos de longo alcance .............. 334

4.2.3.5 PROBLEMA V: Inadequação das limitações aos direitos de exclusivo... 337

4.2.3.6 PROBLEMA VI: Termo de proteção..................................................... 340

4.2.3.7 PROBLEMA VII: Liberdade contratual .............................................. 341

4.2.3.7.1 Alguns resultados alcançados pela implementação da CDB ............. 343

4.2.4 Avaliação da adequação das propostas em construção e debates na CDB e OMPI em face dos quatro critérios de operacionalização do quadro conceitual de

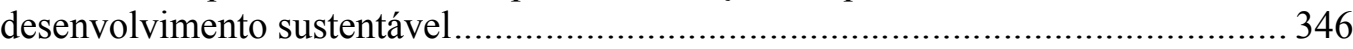

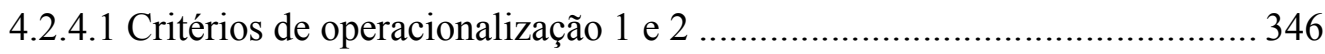

4.2.4.2 Critério de operacionalização 3 ........................................................ 351

4.2.4.3 Critério de operacionalização 4 ......................................................... 352

4.2.5 OMC: proposta dos países em desenvolvimento de emenda do Acordo TRIPS

4.2.5.1 Supostos benefícios e reais problemas do proposto art. 29bis................ 357

4.2.5.1.1 Fácil cumprimento das obrigações ............................................... 357

4.2.5.1.2 Economia dos recursos escassos dos países em desenvolvimento..... 359

4.2.5.1.3 Segurança jurídica e transparência ................................................... 359

4.2.5.1.4 Melhoria da qualidade das patentes concedidas............................. 361

§1 Inutilidade da divulgação de origem para a avaliação da novidade......... 362

§2 Inutilidade da divulgação de origem para a avaliação do passo inventivo

4 2.5.1.5 Ampliação da participação das comunidades tradicionais no processo

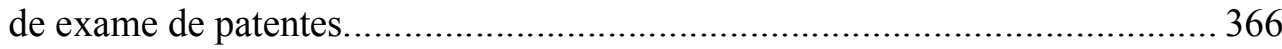

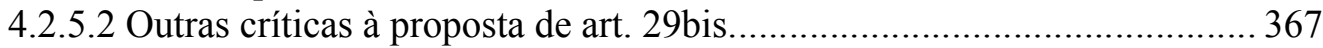

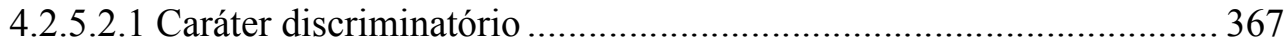

4.2.5.2.2 Exclusão dos CTAs populares .................................................... 368

4.2.5.2.3 Exclusão das ECTs do escopo da proposta de emenda do Acordo

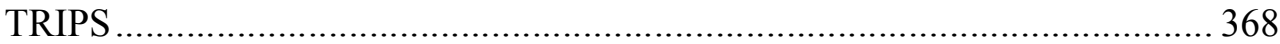

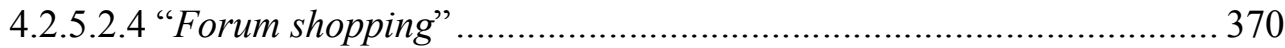

4.2.5.2.5 Restrição do uso do sistema de patentes......................................... 371

4.2.5.2.6 Manutenção em “domínio público” dos CTAs e recursos biológicos

publicamente acessíveis ............................................................................. 372

4 2.5.2.7 Desvinculação do recebimento dos benefícios econômicos de sua

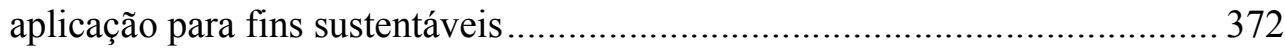

4.2.6 Contrapropostas de alguns países industrializados .................................. 373

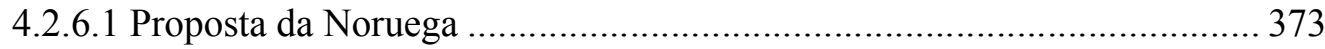




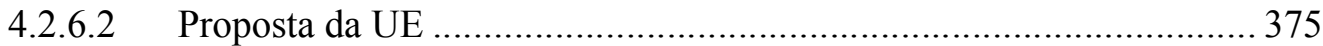

4.2.6.3 Proposta da Suíça ...................................................................... 376

4.2.7 Avaliação da proposta do art. 29bis em face do quadro conceitual de

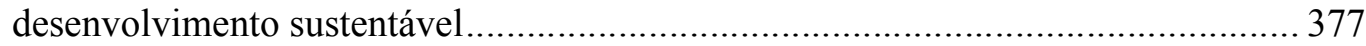

4.3 Regras de repressão da concorrência desleal ....................................................... 380

4.3.1 Uma breve introdução ao funcionamento do sistema de repressão da

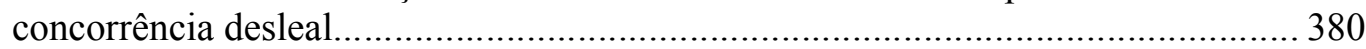

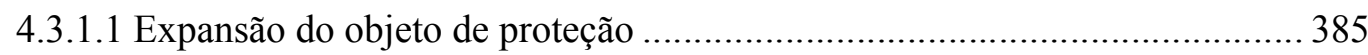

4.3.2 O projeto de disposições da OMPI para a proteção dos CTs ......................... 390

4.3.2.1 Cláusula geral de repressão aos atos de apropriação indébita do

projeto de disposições para CTs ................................................................... 390

4.3.2.2 Apropriação dos CTs por meios desleais ou desonestos .................... 391

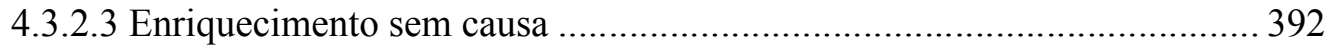

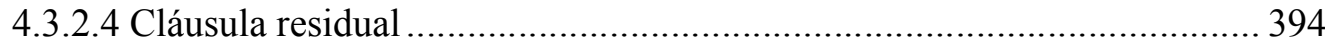

4.3.2.5 Aplicação do art. 10 bis da CP em favor das comunidades tradicionais... 394

4.3.2.5.1 Indicações ou alegações falsas sobre a relação entre os produtos ou serviços providos e comunidades tradicionais .............................................. 395

4.3.2.5.2 Atos suscetíveis de criar confusão a respeito da fonte dos produtos ou

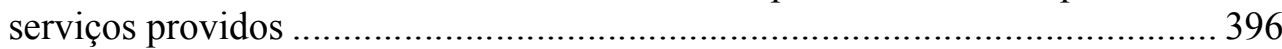
4.3.2.5.3 Atos voltados a gerar descrédito dos produtos e serviços prestados por

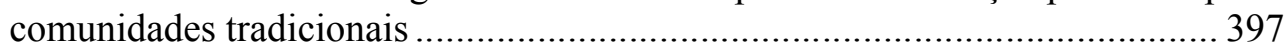

4.3.3 Avaliação dos dispositivos do projeto da OMPI de proteção dos CTs em face do

quadro conceitual de desenvolvimento sustentável.............................................. 397

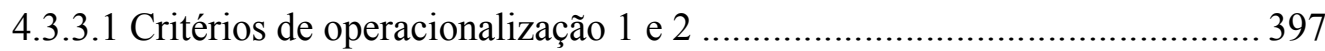

4.3.3.1.1 Dificuldades técnicas e econômicas para a defesa dos direitos das

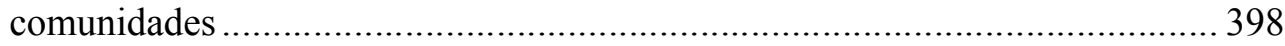

4.3.3.1.2 Ausência de proteção positiva aos CTs ........................................... 400

4.3.3.1.3 Problemas relacionados aos regimes baseados em direito de

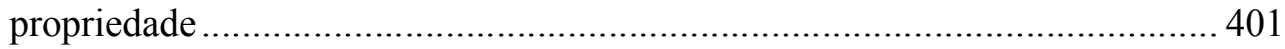

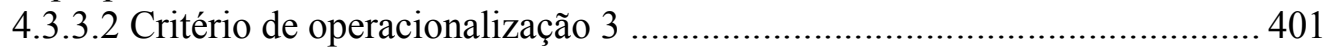

4.3.3.3 Critério de operacionalização 4 ..................................................... 402

4.4 Propostas assentadas sobre um regime de responsabilidade................................ 403

4.4.1 Os problemas do projeto da OMPI para ECTs ........................................ 405

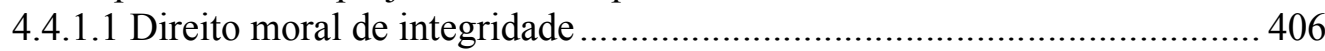

4.4.1.2 Pagamento de uma remuneração eqüitativa ............................................. 406

4.4.1.3 Abstenção do uso de alegações falsas ou enganosas ............................. 407

4.4.1.4 Um regime de propriedade disfarçado de RR ....................................... 408

4.4.2 Conhecimentos tradicionais e regime de responsabilidade............................. 409

4.4.2.1 Repetição do erro: direito de propriedade velado para CTs publicamente

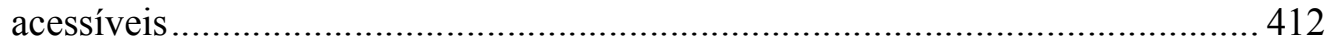

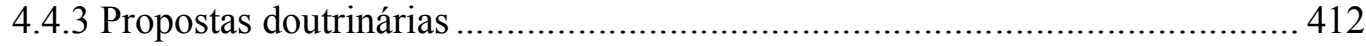

4.4.3.1 Proposta de Reichman \& Lewis ......................................................... 413

4.4.3.1.1 As fraquezas da proposta de Reichman \& Lewis........................... 415

$\S 1$ Direito de exclusivo conferido sobre os CTs tal qual registrados........... 415

\$2 Proteção temporalmente limitada...................................................... 415

§3 Proteção das inovações derivadas de CTs por meio de um RRC ............ 416

§4 Exclusão dos CTs populares do escopo de proteção............................... 417

$\S 5$ Desrespeito ao direito moral de atribuição das comunidades tradicionais417

§6 Incapacidade para a proteção das ECTs sagradas .................................. 418

§7 Não inclusão no RRC dos recursos da biodiversidade e ECTs ............... 418 
§ Caráter nacional da OGCD e o princípio da exaustão nacional de direitos

.

4.4.3.2 O Cartel da Biodiversidade de Joseph Vogel ....................................... 419

4.4.3.2.1 As fraquezas da proposta de Vogel .............................................. 422

$\S 1$ Falta de uma licença gratuita para fins não-comerciais ........................ 422

$\$ 2$ Taxa de remuneração única ............................................................ 422

$\S 3$ Exclusão dos CTAs publicamente acessíveis, inclusive dos CTAs populares

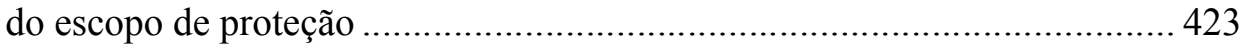

§4 Incapacidade para proteção de ECTs ................................................ 423

§5 Desincentivo ao intercâmbio de RBIs ................................................ 423

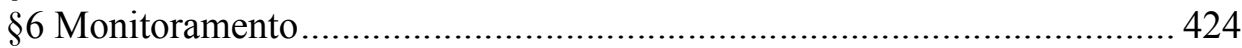

$\S 7$ Falta de um registro obrigatório ......................................................... 424

4.4.4 Avaliação da adequação das propostas examinadas em face do quadro conceitual de desenvolvimento sustentável ..................................................... 425

4.4.4.1 Critérios de operacionalização 1 e 2 ................................................ 425

4.4.4.2 Critério de operacionalização 3 ….................................................. 427

4.4.4.3 Critério de operacionalização 4 ........................................................ 427

4.4.5 Algumas experiências concretas de RRs................................................ 427

4.4.6 As fortalezas de um regime de responsabilidade para a proteção de RBIs...... 433

4.5 Proposta de mecanismo legal e institucional de proteção do PBI ......................... 436

4.5.1 Características da OGCPBI ................................................................... 440

4.5.1.1 Fusão funcional entre uma OGCD e uma OGD ................................. 440

4.5.1.2 Alcance global ......................................................................... 442

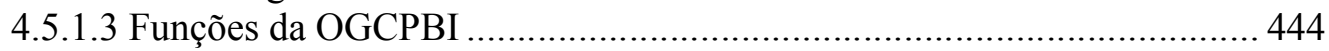

4.5.1.4 Alcance internacional da rede de organizações científicas ....................... 448

4.5.1.5 Fundo de gestão dos benefícios econômicos derivados da exploração do PBI

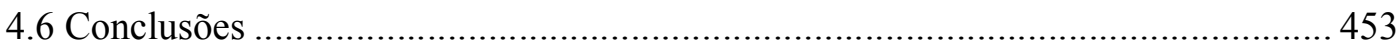

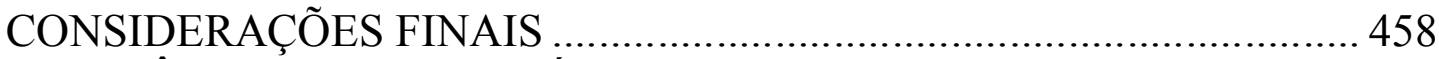

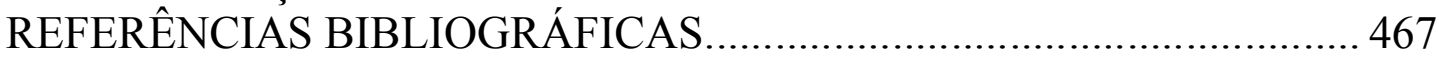

APÊNDICE I - Estados Contratantes dos principais instrumentos internacionais, que apóiam o quadro conceitual de desenvolvimento

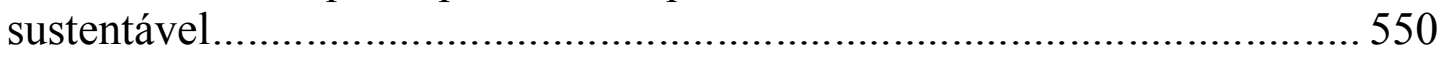




\section{INTRODUÇÃO}

\section{O TEMA E SUA RELEVÂNCIA}

A partir da segunda metade do século XX, a informação alcançou a posição de fator de produção mais importante da atualidade. Como conseqüência natural, os setores produtivos passaram a demandar um fluxo cada vez mais afluente de insumos informacionais para se manterem atualizados e competitivos, já que seus produtos estão sujeitos a um ciclo de vida produtiva cada vez menor. ${ }^{3}$

Dentre os insumos informacionais demandados e utilizados pelos setores produtivos temos os RBIs, isto é, os "conhecimentos, inovações e práticas" relevantes ou não "à conservação e à utilização sustentável da diversidade biológica" ${ }^{4}$ (conhecimentos tradicionais - CTs), as expressões artísticas tradicionais (as chamadas expressões culturais tradicionais ou folclóricas - ECTs) e os recursos da biodiversidade. Estas três categorias de RBIs compõem o $\mathrm{PBI}^{5}$, criado e conservado fundamentalmente por comunidades tradicionais, freqüentemente baseadas nos países em desenvolvimento. $\mathrm{O}$ termo comunidade tradicional ou comunidade local é entendido neste trabalho como um "grupo de pessoas que compartilha as referências constitutivas de uma identidade cultural em comum, desejando preservá-la e desenvolvê-la." ${ }^{6}$ Em termos mais simples, comunidades tradicionais são compostas por integrantes de povos indígenas, ${ }^{7}$ tribais $^{8}$, de minorias étnicas, lingüísticas ou religiosas e de outros grupos portadores de culturas, modos de viver diferenciados em relação àqueles vigentes na sociedade dominante, ainda que não estejam dela totalmente apartados. No Brasil, podemos mencionar os povos indígenas, os quilombolas, os ribeirinhos e os caiçaras como grupos representativos de comunidades tradicionais.

\footnotetext{
${ }^{3}$ Cf. KUNDNANI, 1998-1999, p. 49 et seq.

${ }^{4}$ Art. 8(j), CDB.

${ }^{5}$ Acerca do significado do termo ver item 1.1

${ }^{6}$ Artigo 2(c), GRUPO DE FRIBURGO, Declaração de Friburgo.

${ }^{7}$ A Convenção no. 169 da OIT define, em seu artigo $1^{\circ}$ alínea (b), povos indígenas como os descendentes "de populações que habitavam o país ou uma região geográfica pertencente ao país na época da conquista ou da colonização ou do estabelecimento das atuais fronteiras estatais e que, seja qual for sua situação jurídica, conservam todas as suas próprias instituições sociais, econômicas, culturais e políticas, ou parte delas".

${ }^{8}$ Em seu artigo $1^{\circ}$, alínea (a), a Convenção no. 169 da OIT define povos tribais como aqueles "cujas condições sociais, culturail e econômicas os" distinguem "de outros setores da coletividade nacional, e que" são "regidos, total ou parcialmente, por seus próprios costumes ou tradições ou por legislação especial”.
} 
Por conta da facilidade com que as informações e seus produtos podem ser apropriados globalmente, o direito da propriedade intelectual (DPI) ganhou posição de destaque na agenda internacional, impulsionada pelos países industrializados, por figurar como um instrumento hábil a controlar sua exploração, independentemente da distância física que separa seu titular dos usuários.

Desde a década de 80, uma plêiade de novos acordos bilaterais e multilaterais de proteção da propriedade intelectual (PI) foi adotada pela comunidade internacional. Tais acordos expandiram o escopo das matérias tuteladas pelos regimes de proteção da PI, bem como sua abrangência territorial. Assim sendo, os países em desenvolvimento passaram a estar legalmente obrigados a tutelar até mesmo inovações e criações desenvolvidas a partir de seus RBIs, ainda que apropriados indebitamente.

O processo de hipertrofia dos DPIs deu-se de maneira discriminatória. Os únicos grupos que tiveram seus interesses tutelados pelos novos tratados bilaterais e multilaterais compreendem os indivíduos e instituições que atuam no contexto do sistema de inovação ${ }^{9}$ e criatividade ocidental. ${ }^{10}$ Porquanto os regimes de DPI refletem as peculiaridades da sociedade ocidental, apenas excepcionalmente mostram-se úteis para tutelar os RBIs, ao mesmo tempo em que chancelam sua apropriação sistemática pelos criadores e inovadores do ocidente. ${ }^{11} \mathrm{Na}$ divisão internacional do trabalho, foi assegurado às comunidades locais e países em desenvolvimento o papel de simples provedores de insumos informacionais aos setores produtivos dos países industrializados, sem o correspondente direito de reivindicar quaisquer benefícios materiais e morais pelo uso de seus aportes informacionais.

Em paralelo ao intenso processo de expansão substantiva e territorial dos regimes de PI, os países em desenvolvimento perseguem, desde a década de 60 do último século, a proteção internacional de seus RBIs: nos anos 60, tentaram, sem êxito, emendar a Convenção de Berna para a proteção das obras literárias e artísticas (CB), com o objetivo

\footnotetext{
9 Os termos inovação e Pesquisa e Desenvolvimento (P\&D) serão utilizados neste trabalho como sinônimos. Inovação, conforme a definição de Feldman (2002, p. 49), consiste em um "specific type of economic activity that is concerned with the development of products, processes, or organizational methods that create novelty - the stroke of human genesis that produces originality and uniqueness. [...] Innovation is the ability to blend and weave different types of knowledge into something new, different, and unprecedented that has economic value."

${ }^{10}$ Cf. KUNDNANI, 1998-1999, p. 56.

${ }^{11}$ Cf. POSEY, 2004a, p. 173.
} 
de inserir em seu rol de matérias elegíveis para proteção as ECTs. Entre os anos 70 e 80, a OMPI e a Organização das Nações Unidas para a Educação, a Ciência e a Cultura (UNESCO) propugnaram conjuntamente uma minuta de acordo internacional para a proteção das ECTs, a qual não logrou receber apoio suficiente da comunidade internacional. Na segunda metade da década de 80 e início dos anos 90, os países em desenvolvimento se empenharam em alcançar um acordo internacional de proteção de seus recursos da biodiversidade e conhecimentos tradicionais a eles associados (CTAs), esforços estes que culminaram na adoção da Convenção sobre Diversidade Biológica (CDB), em 1992. A CDB condiciona o acesso aos recursos da biodiversidade e CTAs à obtenção de autorização, respectivamente, dos Estados e comunidades que os detêm. Os países industrializados, regiões onde se concentram os usuários destes RBIs, embora em sua maioria tenham ratificado a $\mathrm{CDB}$, acabaram por não adotar qualquer medida doméstica para dotá-la de aplicação em seus territórios.

No contexto presente, marcado pela inexistência de um regime internacional eficaz dedicado à proteção dos RBIs, o único meio que os países em desenvolvimento encontraram para protegê-los foi adotar marcos legais domésticos, que se mostraram ineficientes, porquanto:

i. O uso comercial dos RBIs ocorre centralmente nos países industrializados; ${ }^{12}$

ii. Em caso de infrações cometidas por nacionais de outros Estados, as partes prejudicadas enfrentarão dificuldades para demandar a proteção de seus direitos perante tribunais estrangeiros. Além de litígios judiciais serem tremendamente custosos, seus resultados são imprevisíveis. ${ }^{13} \mathrm{Na}$ ausência de um regime de proteção que vincule tanto países provedores como países usuários de RBIs, é improvável que seus detentores deles extraiam qualquer benefício de ordem material;

iii. A insegurança resultante da falta de um regime internacional que efetivamente proteja os RBIs contra atos de apropriação indébita estimula as comunidades

\footnotetext{
${ }^{12}$ Cf. BIBER-KLEMM, 2004, p. 101.

${ }^{13}$ Cf. HOWELL, [200-?], p. 17-18.
} 
locais e os países ricos em termos biológicos a se fecharem para intercâmbios com as comunidades científica e industrial;

iv. A proliferação de diversos regimes nacionais esfacela a previsibilidade e a segurança jurídica. E, por conseguinte, esfria o interesse dos potenciais usuários em se enveredar em processos burocráticos $;{ }^{14} \mathrm{e}$

v. Recursos biológicos, CTs e ECTs não respeitam fronteiras políticas, podendo ser compartilhados por dois ou mais Estados ou comunidades tradicionais, fixadas em Estados diferentes. A ausência de um regime internacional que estabeleça patamares mínimos de proteção favorece o acesso aos RBIs naqueles países onde inexistem normas disciplinando sua proteção. Conforme sublinhado por Vogel, a falta de alcance regime internacional estimula a instauração de uma concorrência destrutiva entre codetentores de um mesmo RBI, em prejuízo dos interesses materiais das comunidades tradicionais e dos países em desenvolvimento. ${ }^{15}$

Reconhecendo a ineficácia dos regimes nacionais de proteção de RBIs e estimulados pela expansão de regimes internacionais iníquos de DPIs, no presente, países em desenvolvimento se articulam em diversos foros, objetivando construir um marco legal internacional de proteção do $\mathrm{PBI}$, que vincule tanto países usuários quanto países provedores. Os principais foros em que atuam são a OMC, a OMPI e a CCDB. No passado recente, igualmente atuaram no âmbito da UNESCO, e aí alcançaram um acordo internacional, que confere proteção fraca e indireta aos RBIs não associados à biodiversidade. Nos demais foros, as propostas seguem em discussão.

Entre as décadas de 50 e 80 , as convenções e recomendações ${ }^{16}$ adotadas pela UNESCO dedicadas à proteção de bens culturais centraram-se na preservação de bens culturais tangíveis, e.g. monumentos arquitetônicos, obras de arte, manuscritos, ${ }^{17}$ exemplares raros de zoologia, botânica, paleontologia, arqueologia, ${ }^{18}$ sítios de interesse

\footnotetext{
${ }^{14}$ Cf. SAMPATH, 2005, p.144-145. No mesmo sentido, ver SCBD, UNEP/CBD/WG8J/2/7, p. 2.

${ }^{15} \mathrm{Cf}$. VOGEL, 1995; no mesmo sentido ver SCBD, UNEP/CBD/WG8J/5/INF/10, para. 41.

${ }^{16}$ Ver UNESCO, Recommendation concerning the International Exchange of Cultural Property.

${ }^{17}$ Cf. art. 1o, UNESCO, Convention for the Protection of Cultural Property in the Event of Armed Conflict with Regulations for the Execution of the Convention.

${ }^{18}$ Cf. art. $1^{\circ}$, UNESCO, Convención sobre las Medidas que Deben Adoptarse para Prohibir e Impedir la Importación, la Exportación y la Transferencia de Propiedad Ilícitas de Bienes Culturales.
} 
arqueológico. ${ }^{19}$ A Recomendação sobre Salvaguarda da Cultura Tradicional e Folclore de $1989^{20}$ prenuncia a mudança da UNESCO em direção à proteção dos bens culturais imateriais. $^{21}$ A mudança concreta se deu quatorze anos mais tarde, com a adoção da Convenção para a Salvaguarda do Patrimônio Cultural Imaterial (CSPCI), a qual se dedica a tutelar os aspectos imateriais do patrimônio cultural dos diversos povos e grupos, que compõem a humanidade. ${ }^{22}$

A expansão do rol de matérias com que se ocupa a UNESCO não veio acompanhada de mudança de abordagem. A UNESCO continua a centralizar sua preocupação na criação de inventários de artefatos, bens e paisagens culturais, isto é, em medidas de proteção que dissociam os bens culturais de suas fontes humanas ${ }^{23} \mathrm{e}$ biológicas. Essa abordagem conduz ao enriquecimento de bancos de dados, em paralelo ao extermínio paulatino das fontes que os geraram e alimentam. ${ }^{24}$

O próprio verbo latino que deu origem à palavra cultura - colere significa cultivar, cuidar, tomar conta - deixa transparecer que a proteção da cultura e de suas expressões intelectuais depende de seu cultivo permanente. Da mesma forma que as diversas culturas nascem da interação contínua do homem com a natureza e do cultivo diário de modos de

${ }^{19}$ Cf. art. 1o, UNESCO, Convention for the Protection of the World Cultural and Natural Heritage.

${ }^{20}$ Esta Recomendação trata sobre a proteção da cultura tradicional e popular, que compreende "el conjunto de creaciones que emanan de una comunidad cultural fundadas en la tradición, expresadas por un grupo o por individuos y que reconocidamente responden a las expectativas de la comunidad en cuanto expresión de su identidad cultural y social; las normas y los valores se transmiten oralmente, por imitación o de otras maneras. Sus formas comprenden, entre otras, la lengua, la literatura, la música, la danza, los juegos, la mitología, los ritos, las costumbres, la artesanía, la arquitectura y otras artes." Cf. UNESCO, Recomendación sobre la salvaguardia de la cultura tradicional y popular, item "A".

${ }^{21}$ Cf. BELDER, 2007.

22 A CSPCI propõe-se a proteger o patrimônio cultural imaterial das comunidades locais dos Estados Contratantes, notadamente, "a) tradiciones y expresiones orales, incluido el idioma como vehículo del patrimonio cultural inmaterial; b) artes del espectáculo; c) usos sociales, rituales y actos festivos; d) conocimientos y usos relacionados con la naturaleza y el universo; e) técnicas artesanales tradicionales" (art.2(1)).

${ }^{23}$ Cf. BARSH, 1999, p. 25.

${ }^{24}$ A abordagem adotada pela UNESCO para proteção do patrimônio cultural imaterial é a construção de inventários. Em novembro de 2008, foi publicada uma lista representativa de obras maestras da cultura universal. O Brasil, país de dimensões continentais e acervo cultural único, conta com tão-somente duas expressões intangíveis de seu patrimônio registradas no inventário do patrimônio cultural da humanidade, a saber, a arte gráfica dos índios Wajapi e a Roda de Samba do Recôncavo Baiano. O site da UNESCO esclarece que estas duas obras maestras sofrem o perigo de desaparecer, porquanto as gerações mais jovens não se interessam em conservar essas tradições. Esta simples afirmação já seria o suficiente para se questionar a efetividade de um simples inventário para manter vivas tradições culturais intelectuais em perigo de extinção (UNESCOPRESS, 2008). 
vida, valores, instituições sociais, econômicas e religiosas por grupos humanos distintos, a conservação dos RBIs não foge deste mesmo caminho. ${ }^{25}$

As comunidades locais não demandam a conservação dos RBIs cirurgicamente isolados de suas fontes humanas e culturais. Suas demandas ${ }^{26}$ são mais amplas e incluem o estabelecimento de um marco legal que permita, ${ }^{27}$ inter alia, obrigar terceiros a reconhecer a fonte dos RBIs utilizados em seu processo criativo (i) ${ }^{28}$ impedir a exploração nãoautorizada e usos culturalmente desrespeitosos de RBIs de natureza sagrada (ii); receber benefícios materiais pelo uso econômico de seus RBIs (iii); compartilhar amplamente seus RBIs a fim de estimular seu uso e aprimoramento contínuo em âmbito comunitário e extracomunitário (iv), e conservar os ecossistemas naturais em que vivem, que servem de base natural à sua vida física e cultural $(\mathrm{v}){ }^{29}$

Na CCDB, OMC e OMPI, apesar da oposição sistemática dos países industrializados, ${ }^{30}$ sob o impulso dos países em desenvolvimento, são formalizadas paulatinamente propostas de regimes internacionais de proteção dos RBIs, que associadas formam uma grande proposta de regime internacional de proteção do PBI. No âmbito da OMC e da $\mathrm{CCDB}$, o foco das propostas é a repressão de atos de apropriação indébita dos CTAs e dos recursos da biodiversidade. Já na esfera da OMPI, as propostas focam na proteção dos CTs em geral e das ECTs.

As referidas propostas associam basicamente três mecanismos legais para a proteção dos RBIs, ${ }^{31}$ aplicáveis segundo as características do objeto de proteção:

i. Direito de propriedade: o aspecto característico de qualquer regime calcado no direito de propriedade é a investidura, em seu titular, do direito a priori de excluir

${ }^{25}$ Cf. EAGLETON, 2000, p. 4.

${ }^{26}$ Há uma imensa diversidade de grupos agregados sob o manto do termo "comunidade local", que apresentam interesses diferentes. Não existe, pois, uma única posição coesa de todos os grupos detentores de PBI sobre quais interesses gostariam de ver tutelados por um regime internacional. Por esta razão, identificamos apenas os interesses mais comumente reivindicados por estes grupos e organizações que os representam. Cf. COOMBE, 2001-2002, p. 277.

${ }^{27}$ Cf. WIPO, 2001, p. 128, 134 et seq. No mesmo sentido, ver LI; LI, 2007, p. 143.

${ }^{28}$ Cf. MGBEOJI, 2001, p. 172.

${ }^{29}$ Cf. SCBD, UNEP/CBD/WG8J/4/INF/18, p. 3.

${ }^{30} \mathrm{Cf}$. WIPO, WIPO/GRTKF/IC/12/5(b)), p. 136 do anexo.

${ }^{31}$ Cf., e.g., Id., WIPO/GRTKF/IC/9/INF/4, paras. 4-10 do anexo I; Id., WIPO/GRTKF/IC/6/4, para. 37-46; WTO, IP/C/3/383, para. 62; COPCBD, DECISION IX/12; SCBD, UNEP/CBD/WG-ABS/5/2. 
terceiros que não observarem todas as condições por ele fixadas. Teoricamente, esta categoria de mecanismos de proteção ofereceria aos detentores de RBIs a oportunidade para deles extrair benefícios econômicos e fixar as condições de seu uso, por meio da celebração de contratos de licenciamento. ${ }^{32}$

ii. Sistema de repressão da concorrência desleal (ou direitos de quasepropriedade): regime marcado pela repressão de atos de apropriação indébita de bens intelectuais, infratores de determinados padrões de conduta julgados honestos. Assim, os bens tutelados por um regime de repressão da concorrência desleal são livremente acessíveis por todos, salvo quando infringidos determinados parâmetros, fixados em lei, em termos amplos e genéricos.

iii. Regime de responsabilidade (liability rules): em termos genéricos, sua característica fundamental é a investidura, nos titulares de direitos, de um direito de remuneração pelo uso comercial de seus bens; todos os interessados podem utilizá-los independentemente da vontade do titular de direitos, desde que paguem a remuneração devida.

Esses três regimes são julgados adequados por um número expressivo de países em desenvolvimento e comunidades tradicionais, por parecerem aptos a reprimir a apropriação indébita dos RBIs por terceiros não-autorizados. ${ }^{33}$ Aqueles que advogam em favor destas propostas partiram da premissa de que, se determinados instrumentos historicamente se mostraram aptos a tutelar as produções intelectuais da sociedade ocidental, também o seriam para tutelar os RBIs.

Contudo, defendemos no presente estudo a tese que um marco legal internacional verdadeiramente apto a proteger os RBIs não deve limitar-se a reprimir sua apropriação indébita. Embora os RBIs compartilhem a natureza informacional com os bens intelectuais tutelados pelos DPIs, portam outras dimensões específicas: ${ }^{34}$ os RBIs se assentam sobre uma trama cujos fios que a compõe são agrupamentos humanos, economicamente

${ }^{32} \mathrm{Cf}$. SCBD, UNEP/CBD/WG8J/2/7, para. 54.

${ }^{33}$ Cf., e.g., WIPO, WIPO/GRTKF/IC/9/INF/4; MEDAGLIA, 2009 (assevera que o projeto da OMPI de disposições legais para a proteção dos conhecimentos tradicionais estaria em "total harmonia" com a CDB, sem ao menos avaliar se a proposta seria capaz de promover ou limitar a realização dos objetivos da CDB).

${ }^{34}$ Cf. Item "F", alíneas (a) e (b)(i), UNESCO, Recomendación sobre la salvaguardia de la cultura tradicional y popular. 
marginalizados e culturalmente diferenciados; e uma intensa interação destes grupos com os ecossistemas naturais, em que vivem. ${ }^{35}$ Por conta dessas singularidades, defendemos que os regimes de proteção dos RBIs devem atentar à sua natureza informacional (dimensão imaterial) e aos imperativos de assegurar uma existência digna às gerações presentes e futuras das comunidades tradicionais que os conservam (dimensão humana), com o objetivo de lhes proporcionar as condições necessárias para conservar e desenvolver seu arcabouço cultural (dimensão cultural) e os ecossistemas, que dão substrato à sua vida física e cultural (dimensão ambiental). ${ }^{36}$

Ademais, em um cenário marcado pela negligência dos Estados para com as necessidades mais básicas de suas comunidades tradicionais e para com o imperativo de conservação da natureza, sustentamos também que a proteção multidimensional dos RBIs depende de recursos econômicos, que apenas poderão ser gerados, se houver uma cooperação entre os detentores de RBIs e os setores produtivos, com o objetivo de viabilizar sua aplicação comercial e industrial. Ora, sem recursos econômicos os Estados continuarão a não possuir recursos para investirem na conservação da biodiversidade; as comunidades tradicionais não terão os meios para viverem condignamente em harmonia com a natureza e, por fim, não será possível financiar ações legais voltadas à repressão de atos de apropriação indébita em escala global. Portanto, a proteção multidimensional do RBIs não pode ser dissociada do resguardo dos interesses de terceiros de acessá-los e utilizá-los produtivamente, para fins de desenvolvimento material da sociedade como um todo.

Assentado sobre as premissas de que os RBIs se compõem de quatro dimensões, cuja proteção depende da realização do direito de terceiros de aplicá-los produtivamente, propomos um quadro conceitual de desenvolvimento sustentável, que servirá como uma ferramenta analítica alternativa àquela freqüentemente aplicada pelas organizações da sociedade civil, políticos de países em desenvolvimento e a literatura em geral, que se limita a avaliar a capacidade das propostas de mecanismos de proteção dos RBIs para prevenir sua apropriação indébita por terceiros.

\footnotetext{
${ }^{35}$ Cf. POSEY, 1998, p. 53.

${ }^{36} \mathrm{Cf}$. art. 4o, UNGA, Declaration on the Rights of Persons Belonging to National or Ethnic, Religious and Linguistic Minorities. Ver também WIPO, WIPO/GRTKF/IC/9/INF/4, para. 18 do anexo I. As quatro dimensões do PBI serão melhor examinadas nos itens 1.2.1, 1.2.2, 1.2.3, 1.2.4.
} 
O quadro conceitual de desenvolvimento sustentável desempenha o papel de um "tipo ideal prático", ${ }^{37}$ formado pelo agregado de elementos fundamentais, que qualquer regime verdadeiramente comprometido em tutelar os RBIs em suas múltiplas dimensões deverá compreender. Em termos mais concretos, o quadro conceitual de desenvolvimento sustentável será aplicado como uma ferramenta de análise da capacidade dos regimes propostos, na esfera internacional, para: prevenir a apropriação indébita dos RBIs (i); promover a melhoria da qualidade de vida das comunidades tradicionais, no sentido de fomentar a realização do conjunto de direitos humanos conferidos aos componentes destes grupos (ii); assegurar o respeito a alguns valores culturais centrais, conservados pelas comunidades tradicionais (iii); conservar os ecossistemas naturais que sustentam as comunidades tradicionais e seu PBI (iv); e, finalmente, fomentar o desenvolvimento material da sociedade em geral, a partir do exercício de sua liberdade de utilizar intensiva e respeitosamente os RBIs (v).

Em um segundo momento, a contraposição das propostas em debate na esfera internacional ao quadro conceitual de desenvolvimento sustentável ensejará a identificação de um arranjo normativo e institucional, apto a proteger os RBIs em sua integralidade.

É importante ter presente que a substituição da lente de análise das propostas de proteção dos RBIs e do parâmetro reitor do delineamento dos regimes de proteção desta matéria é encorajada, ainda que tacitamente, pelo Comitê de Direitos Econômicos, Sociais e Culturais, ${ }^{38}$ pela OMPI ${ }^{39}$, pela Agenda $21^{40}$ e pela CDB. ${ }^{41}$ No marco da CDB, a mudança de abordagem configura condição para assegurar seu fiel cumprimento: nos termos de seu art. 14(1)(b), seus Estados contratantes estão obrigados a realizar avaliações estratégicas prévias (AEPs) ${ }^{42}$ dos potenciais impactos ambientais, sociais e culturais ${ }^{43}$ resultantes da

${ }^{37} \mathrm{O}$ presente estudo aplicou a metodologia desenvolvida por SHIELDS e TAJALLI (2006, p. 324 et seq).

38 O Comitê recomendou aos Estados Contratantes do Pacto Internacional sobre Direitos Econômicos, Sociais e Culturais a condução de estudos de impactos sobre a realização de direitos humanos, previamente à adoção de, inter alia, regimes dedicados à proteção de RBIs (CESCR, E/C.12/GC/17, para. 35; CESCR, E/C.12/2001/15, para. 18).

${ }^{39}$ Ver recomendações 15, 37 e 38, WIPO, 2007.

${ }^{40}$ Ver item 8(4), capítulo 8, UNCED, Agenda 21.

${ }^{41}$ Cf. COPCBD, Decision VI/10, item (F), para. 40; COPCBD, Decision VII/19; COPCBD, Decision IX/12, para. $13(\mathrm{e}))$

${ }^{42}$ AEP é um instrumento utilizado no nível macro-político, que se presta a reduzir a probabilidade de adoção de políticas, inclusive medidas legais, que direta ou indiretamente incentivem o uso insustentável da biodiversidade (Cf. art. 11, CDB; UNGA, Resolution A/42/427, cap. 6, para. 64; UNGA, Resolution 37/7, para. 16). Para isto, um processo de avaliação dos impactos ambientais de propostas políticas é realizado nas fases iniciais de sua redação e discussão, "a fim de assegurar que as questões ambientais se incorporem 
adoção de regimes legais de proteção dos conhecimentos tradicionais e recursos da biodiversidade.

\section{ESCLARECIMENTOS PRELIMINARES A RESPEITO DO QUADRO CONCEITUAL PROPOSTO}

A concepção de desenvolvimento sustentável ganhou força e relevância política a partir dos anos 70, época em que comunidade internacional tomou consciência de que o crescimento econômico massivo, ocorrido no pós $2^{\mathrm{a}}$ Guerra Mundial, promoveu a expansão localizada das riquezas materiais, em detrimento do respeito devido ao meio ambiente e à dignidade da pessoa humana em muitas regiões do globo. Desde então, ao menos teoricamente, a comunidade internacional passou a valorizar o conteúdo do desenvolvimento, ao invés de apoiar a mera multiplicação de recursos econômicos. ${ }^{44}$

A concepção de desenvolvimento sustentável é fundada no direcionamento das políticas de crescimento econômico para a viabilização da apropriação dos direitos fundamentais pelo ser humano, sobretudo das liberdades positivas, ${ }^{45}$ de modo a conferirlhe a autonomia necessária para perseguir a vida que considere satisfatória. ${ }^{46}$ Simultaneamente, considerando que o bem-estar humano depende da conservação da natureza, o desenvolvimento econômico deve respeitar os limites por ela impostos, com o objetivo de conservá-la em favor das presentes e futuras gerações, conservando, assim, suas opções de desenvolvimento em aberto. ${ }^{47}$

Originalmente, a concepção de desenvolvimento sustentável se assentava sobre três pilares interdependentes, a saber, a realização dos direitos humanos, o crescimento econômico e a conservação ambiental. Neste sentido, o princípio $1^{\circ}$ da Declaração do Rio sobre Meio Ambiente e Desenvolvimento costura esses três pilares ao colocar o "ser humano [...] [no] centro das preocupações relativas ao desenvolvimento sustentável",

plenamente e sejam abordadas adequadamente na fase mais cedo possível de adoção de decisões, conjuntamente com considerações econômicas e sociais" (COPCBD, Decision VI/7, anexo, item 1(b)).

43 Apesar do silêncio da $\mathrm{CDB}$, em virtude do reconhecimento da relação causal entre conservação da diversidade cultural e conservação da diversidade biológica (UNEP/CBD/WG8J/2/6/Add.1, para. 3), as partes contratantes da $\mathrm{CDB}$, quando da realização de um estudo de $\mathrm{AEP}$, devem avaliar, além dos impactos diretos da política proposta sobre a conservação da biodiversidade, também seus impactos culturais e sociais sobre as comunidades tradicionais. Nesse sentido ver COPCBD, Decision VI/10, anexo II, item (f).

${ }^{44}$ Cf. DAG HAMMARSKJÖLD FOUNDATION, 1975, p. 25.

${ }^{45}$ Cf. SACHS, 2007e, p. 352.

${ }^{46}$ Id., $2007 f$, p. 101.

${ }^{47}$ Ibid., p. 97-98. 
assim como ao lhe reconhecer "o direito à uma vida saudável e produtiva, [...] [desde que] em harmonia com a natureza." ${ }^{48}$ Em 2005, a Convenção da UNESCO sobre Proteção e Promoção da Diversidade das Expressões Culturais (CPPDEC) explicitou inequivocamente um pilar da concepção de desenvolvimento sustentável até então negligenciado: a diversidade cultural.

A diversidade cultural, nas palavras da Convenção, "é condição essencial para um desenvolvimento sustentável das gerações presentes e futuras.” (art. 2(6)) A partir da atualização conceitual realizada pela UNESCO, o desenvolvimento sustentável é aquele em que o crescimento econômico foca na realização dos direitos humanos, dentre eles o direito à proteção da diversidade cultural, e que observa os limites impostos pelo meio ambiente. Em síntese, a concepção de desenvolvimento sustentável é antropocêntrica, porquanto objetiva "o desenvolvimento integral de cada homem e de todos os homens", 49 dando preponderância às obrigações em matéria de direitos humanos sobre as políticas econômicas, ${ }^{50}$ mas envolve outras três dimensões interdependentes: a expansão econômica, a sustentabilidade ambiental ${ }^{51}$ e a promoção da diversidade cultural.

O quadro conceitual de desenvolvimento sustentável proposto se funda na associação das quatro dimensões do PBI aos quatro pilares de sustentação da concepção de desenvolvimento sustentável. Tais dimensões e pilares se estribam, por sua vez, em normas do direito internacional que vinculam uma parcela expressiva da comunidade internacional $^{52}$ (quadro 1); assim sendo, a concepção de desenvolvimento sustentável carrega consigo valor normativo vinculante. ${ }^{53}$ Avaliaremos cada uma das propostas em negociação/construção na CCDB, OMC e OMPI, assentadas sobre direitos de propriedade, quase-propriedade e regime de responsabilidade, contra o quadro conceitual de desenvolvimento sustentável. Isto permitirá identificar quais mecanismos legais poderiam

\footnotetext{
48 Adotada na Conferência das Nações Unidas sobre Meio Ambiente e Desenvolvimento, que tomou lugar entre 3 e 14 de junho de 1992, no Rio de Janeiro.

${ }^{49}$ Cf. SACHS, 2007d, p. 265.

${ }^{50} \mathrm{Cf}$. SCBD, UNEP/CBD/WG8J/2/6/Add.1, para. 25.

${ }^{51} \mathrm{Cf}$. WORLD SUMMIT ON SUSTAINABLE DEVELOPMENT, 2002, para. 2.

52 As normas de acordos internacionais, que compõem o quadro conceitual de desenvolvimento sustentável, são representativas dos valores perseguidos pela comunidade internacional, uma vez que suas partes contratantes abrangem países de todos os níveis de desenvolvimento econômico, de todas as regiões, portadores de culturas diferenciadas. Sem embargo, é importante termos claro que o quadro conceitual proposto seria útil, sobretudo, aos Estados parte dos acordos, cujos dispositivos integram-no. No apêndice 1 é possível visualizar os Estados contratantes dos instrumentos internacionais que integram o quadro conceitual de desenvolvimento sustentável.

${ }^{53}$ Cf. item 3.1.2.
} 
ser adotados, em face de sua aptidão para proteger integralmente cada categoria de RBI; o quadro permitirá também exercer, ao nível teórico, uma "ação corretiva" sobre os rumos das políticas internacionais de proteção dos RBIs, ${ }^{54}$ sempre que necessário.

Quadro 1: Associação entre a noção de desenvolvimento sustentável, as dimensões do PBI matéria de proteção e normas do direito internacional

\begin{tabular}{|c|c|c|}
\hline $\begin{array}{c}\text { Os pilares da concepção } \\
\text { de desenvolvimento } \\
\text { sustentável }\end{array}$ & As dimensões do PBI & $\begin{array}{c}\text { Principais normas } \\
\text { internacionais associadas } \\
\text { aos pilares da concepção } \\
\text { de desenvolvimento } \\
\text { sustentável e às } \\
\text { dimensões do PBI }\end{array}$ \\
\hline $\begin{array}{l}\text { Desenvolvimento humano: } \\
\text { Desenvolvimento social de } \\
\text { todos os grupos, que } \\
\text { integram a humanidade }\end{array}$ & $\begin{array}{c}\text { Dimensão Humana: } \\
\text { melhoria da qualidade de } \\
\text { vida das comunidades } \\
\text { tradicionais }\end{array}$ & $\begin{array}{c}\text { Pacto Internacional sobre } \\
\text { Direitos Econômicos, } \\
\text { Sociais e Culturais } \\
\text { (PIDESC) }\end{array}$ \\
\hline $\begin{array}{l}\text { Conservação ambiental: } \\
\text { Conservação } \\
\text { diversidade biológica }\end{array}$ & $\begin{array}{l}\text { Dimensão ambiental: } \\
\text { conservação e/ou } \\
\text { restauração dos } \\
\text { ecossistemas naturais, } \\
\text { especialmente daqueles de } \\
\text { que dependem as } \\
\text { comunidades tradicionais }\end{array}$ & $\mathrm{CDB}$ \\
\hline $\begin{array}{l}\text { Desenvolvimento } \\
\text { econômico: } \\
\text { desenvolvimento industrial } \\
\text { e científico da sociedade, a } \\
\text { partir do uso amplo, mas } \\
\text { lícito dos RBIs }\end{array}$ & $\begin{array}{l}\text { Dimensão imaterial: } \\
\text { proteção dos RBIs contra a } \\
\text { prática de atos de } \\
\text { apropriação indébita }\end{array}$ & PIDESC e CDB \\
\hline $\begin{array}{l}\text { Diversidade cultural: } \\
\text { Promoção da diversidade } \\
\text { cultural }\end{array}$ & $\begin{array}{l}\text { Dimensão cultural: } \\
\text { Respeito aos valores } \\
\text { culturais das comunidades } \\
\text { tradicionais e oferecimento } \\
\text { das condições essenciais } \\
\text { para que as comunidades } \\
\text { tradicionais conservem seu } \\
\text { PBI em desenvolvimento } \\
\text { contínuo. }\end{array}$ & $\begin{array}{l}\text { CDB, PIDESC, Pacto } \\
\text { Internacional sobre } \\
\text { Direitos Civis e Políticos } \\
\text { (PIDCP), CPPDEC; } \\
\text { CSPCI. }\end{array}$ \\
\hline
\end{tabular}

${ }^{54}$ Cf. PANEL OF EXPERTS CONVENED BY THE SECRETARY-GENERAL OF THE UNITED NATIONS CONFERENCE ON THE HUMAN ENVIRONMENT, 2002, p. 38. 
O quadro conceitual de desenvolvimento sustentável se afasta da trilha comumente palmilhada pela literatura especializada, centrada na realização dos interesses das comunidades locais e países ricos em recursos biológicos, ${ }^{55}$ ainda que em detrimento dos interesses de outros grupos que merecem igual respeito. É ilustrativo o quadro conceitual proposto por Posey e Dutfield - Traditional Resource Rights (TRR) ${ }^{56}$-, composto por um grupo de normas convencionais internacionais, que serviriam de guia para a construção de um regime de propriedade intelectual sui generis para a proteção das dimensões humana, ecológica e cultural do PBI. Fundamentalmente, o TRR apresenta duas fraquezas: a primeira está em tutelar tão-somente os interesses e direitos das comunidades locais. Somos testemunhas de que a superproteção dos direitos de um grupo, quando se negligencia os interesses dos demais, pode conduzir a abusos. Isto é o que observamos no cenário atual, em que apenas os interesses dos criadores e inventores ocidentais são tutelados pelo regime internacional de proteção da PI, em detrimento dos interesses das comunidades tradicionais, países em desenvolvimento e usuários em geral de produções intelectuais. O segundo aspecto está em eleger de antemão a instituição da propriedade como o mecanismo legal adequado para a proteção do PBI, sem examinar analiticamente, se este é efetivamente um instrumento adequado vis-à-vis as dimensões singulares da matéria de proteção. É um equívoco presumir que a adoção de um regime de proteção do PBI, fundado em direitos de propriedade, salvaguardará automaticamente suas múltiplas

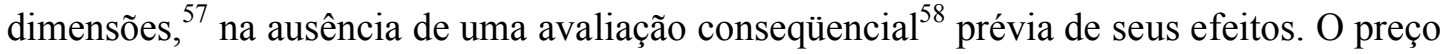
da presunção sem substrato pode ser alto para grupos humanos, que ainda hoje vivem abaixo da linha da pobreza ${ }^{59}$ e para a sobrevivência da humanidade, a qual depende da conservação dos ecossistemas naturais.

A revisão de literatura revelou a inexistência de qualquer proposta no sentido da

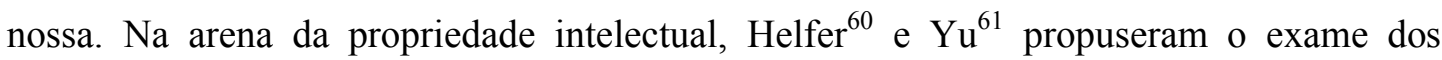
regimes convencionais de proteção da PI vis-à-vis um quadro conceitual de direitos

\footnotetext{
${ }^{55} \mathrm{Cf}$. SCBD, UNEP/CBD/WG8J/5/INF/10, para. 16.

${ }^{56}$ POSEY; DUTFIELD, 1996, p. 95.

${ }^{57}$ Stuart Mill (2001, p. 6) nos lembra de que "[a]1l action is for the sake of some end, and rules of action, it seems natural to suppose, must take their whole character and colour from the end to which they are subservient. When we engage in a pursuit, a clear and precise conception of what we are pursuing would seem to be the first thing we need, instead of the last we are to look forward to".

${ }^{58}$ Cf. SALZBERGER, 2006, p. 31.

${ }^{59}$ Cf. ALARCÓN-CHÁIRES, 2006.

${ }^{60} \mathrm{Cf}$. HELFER, 2007.

${ }^{61} \mathrm{Cf}$. YU, 2007.
} 
humanos, composto basicamente pelos dispositivos do PIDESC. Tais propostas, sem embargo, se aplicadas para a avaliação das propostas de regimes de proteção dos RBIs, seriam inaptas a resguardar suas quatro dimensões.

Em suma, optamos pelo desenvolvimento de um quadro conceitual de desenvolvimento sustentável para a avaliação das propostas de regimes de proteção dos RBIs pelas seguintes razões:

i. Existe uma convergência entre as quatro dimensões do PBI (humana, ambiental, imaterial e cultural) que se busca proteger e os quatro pilares sobre os quais se assenta a concepção de desenvolvimento sustentável (desenvolvimento humano, conservação ambiental, desenvolvimento econômico e diversidade cultural). Ademais, existe uma relação direta entre as referidas dimensões e pilares com objetivos perseguidos pela comunidade internacional, plasmados em normas internacionais, que vinculam tanto países industrializados quanto em desenvolvimento;

ii. O quadro conceitual desempenhará o papel de um mecanismo de avaliação da capacidade das propostas para tutelar as quatro dimensões do PBI e, em paralelo, promover a meta de desenvolvimento sustentável;

iii. O quadro conceitual de desenvolvimento sustentável, por ter como um de seus pilares de sustentação o desenvolvimento econômico, se afasta de propostas ingênuas, que advogam pela conservação de um meio ambiente intocado e de culturas isoladas. A ampliação dos interesses a serem promovidos pelos futuros regimes de proteção viabilizará a superação de confrontações não-construtivas entre países em desenvolvimento e industrializados. Se os regimes propostos lograrem harmonizar os interesses das comunidades locais e países em desenvolvimento com os dos países industrializados, as chances de se identificar um denominador comum se ampliam. ${ }^{62}$ Assim, o quadro conceitual proposto, ao 
harmonizar interesses de grupos diversos, ${ }^{63}$ constrói sinergias, onde usualmente se enxerga conflitos; ${ }^{64}$

iv. O quadro conceitual de desenvolvimento sustentável permite a apresentação de recomendações de ordem normativa, isto é, o desenvolvimento de propostas de arranjo legal e institucional, aptas a tutelar as múltiplas dimensões do PBI e os interesses de seus usuários; e

v. O uso de um quadro conceitual de desenvolvimento sustentável, construído sobre normas internacionais vigentes que vinculam uma parcela importante da comunidade internacional, promove a observância de normas do corpus do direito internacional, dedicadas à proteção da biodiversidade, à realização dos direitos humanos e à promoção da diversidade cultural, que lamentavelmente são desrespeitadas mesmo por seus Estados contratantes. ${ }^{65}$ Assim, é possível se mitigar os custos sociais, ambientais, culturais e econômicos, ${ }^{66}$ que podem decorrer da adoção de regimes internacionais inadequados. ${ }^{67}$

\section{MATÉRIAS EXCLUÍDAS dO ESCOPO DO TRABALHO}

\subsection{INTERPRETAÇÕES DE ECTS}

Excluímos do escopo deste estudo as interpretações de ECTs, tuteladas pelos direitos conexos. Os direitos conexos protegem os "atores, cantores, músicos, bailarinos ou outras pessoas que representem um papel, cantem, recitem, declamem, interpretem ou executem, em qualquer forma, obras literárias, artísticas ou expressões folclóricas". ${ }^{6}$

\footnotetext{
${ }^{63} \mathrm{Cf}$. WIPO, IIM/1/4, para. 40.

${ }^{64}$ Cf., e.g., SANWAL, 2004, p. 20-21; BOYLE, 2003b, p. 52. 65 Cf. HATHAWAY, 2002; SCHRIJVER, 2007, p. 380-381.

${ }^{66} \mathrm{O}$ termo "custo" é empregado no sentido de obstáculo à realização de algum objetivo almejado (OAKERSON, 1992, p. 48).

67 Cf. PANEL OF EXPERTS CONVENED BY THE SECRETARY-GENERAL OF THE UNITED NATIONS CONFERENCE ON THE HUMAN ENVIRONMENT, 2002, p. 56-57.

${ }^{68}$ Cf. art. 2(a), WIPO, WPPT
} 
A Convenção internacional para a proteção dos artistas intérpretes ou executantes, dos produtores de fonogramas e dos organismos de radiodifusão de 1961 (Convenção de Roma) estende proteção legal apenas aos artistas intérpretes de obras literárias e artísticas (art. 3(a)), excluindo do rol de proteção os intérpretes de ECTs. Já o Tratado da OMPI sobre Interpretação ou Execução e Fonogramas de 1996 (WIPO Performances and Phonograms Treaty - WPPT) supre a deficiência da Convenção de Roma, concedendo proteção também aos artistas intérpretes de ECTs (art. 2(1), WPPT). Desde então, qualquer membro de uma comunidade tradicional que interprete ou execute ECTs está investido nos direitos morais de "ser identificado como o artista intérprete ou executante de suas interpretações ou execuções" e no "direito de opor-se a qualquer deformação, mutilação ou outra modificação de suas interpretações ou execuções que cause prejuízo à sua reputação" (art. 5(1)). Os intérpretes de ECTs estão também investidos no direito de receberem benefícios econômicos pela radiodifusão e comunicação ao público de fonogramas, publicados com o fito de lucro (art. 15), e no direito de controlarem: a radiodifusão, a comunicação ao público, a fixação de suas interpretações (art. $6^{\circ}$ ), a reprodução de suas interpretações ou execuções já fixadas em fonogramas, a distribuição comercial do original e dos exemplares de sua interpretação (art. 8(1)), o aluguel de exemplares de suas interpretações fixadas em fonogramas (art. 9(1)) e a colocação à disposição do público de suas interpretações ou execuções em meios eletrônicos, de modo a viabilizar seu acesso por meio de fios ou outros meios sem fio pelo consumidor (art. 10).

O problema dos direitos conexos é que conferem uma proteção indireta ${ }^{69}$ às ECTs. A fruição desta proteção pelas comunidades tradicionais depende da interpretação de suas ECTs por algum de seus membros e da existência de uma obrigação, que imponha ao intérprete o compromisso de exercer seus direitos individuais em consonância com os desígnios da comunidade titular da ECT. ${ }^{70}$ Porquanto os direitos conferidos pelo WPPT são extensíveis a todo e qualquer intérprete de ECTs, seja ele associado ou não a uma comunidade tradicional, é possível que toda a ampla lista de direitos morais e patrimoniais mencionada acima seja conferida a um membro estranho à comunidade, em detrimento dos interesses do titular da ECT interpretada.

\footnotetext{
${ }^{69}$ Cf. WIPO, WIPO/GRTKF/IC/13/4(b) Rev, para. 16.

${ }^{70}$ Cf. VON LEWINSKI, 2003-2004, p. 761-762.
} 
$\mathrm{O}$ objeto de nossa preocupação é a proteção direta das ECTs sujeitas à interpretação. Se as comunidades tradicionais detiverem direitos que incidam diretamente sobre as ECTs, poderão controlar quem as interpreta e o contexto em que serão interpretadas, podendo contornar as dificuldades não resolvidas pelo WPPT.

\subsection{SINAIS DISTINTIVOS}

Excluímos igualmente do escopo do trabalho as palavras, signos, nomes e símbolos, integrantes do patrimônio cultural das comunidades tradicionais, que podem ser registrados como marcas comerciais. A opção pela exclusão não significa que o tema seja irrelevante aos países em desenvolvimento e às comunidades tradicionais. A título de ilustração da importância econômica de que se revestem os sinais distintivos para as comunidades tradicionais podemos citar o caso do registro da marca CUPUAÇU pelo Escritório de Patentes do Japão (JPO). ${ }^{71}$

Em 1998, a empresa de produtos alimentícios Asahi Foods registrou, perante o JPO, o Escritório de Marcas e Patentes dos Estados Unidos (USPTO) e o Escritório de Registro de Marcas, Desenhos e Modelos da União Européia (OAMI), a marca nominativa CUPUAÇU para a classe de produtos comestíveis.

Quatro anos mais tarde, a ONG brasileira Amazonlink foi impedida, pela empresa japonesa, de exportar doces artesanais de cupuaçu para o mercado alemão, elaborados por comunidades da Amazônia brasileira, porquanto ostentavam em suas embalagens o referido sinal distintivo. O registro da marca CUPUAÇU conferiu à Asahi Foods o monopólio de fato para a comercialização de produtos derivados das sementes e frutos do cupuaçu, nos territórios europeu, norte-americano e japonês. Em outras palavras, a marca CUPUAÇU foi utilizada pela Asahi como uma patente nos referidos mercados a fím de impedir a entrada de concorrentes, produtores de alimentos derivados do cupuaçu, nos mercados onde a marca foi registrada.

\footnotetext{
${ }^{71}$ O sumário do caso aqui apresentado baseia-se em RODRIGUES JR.; HEATH, 2006.
} 
Em virtude da distorção comercial estabelecida, no primeiro semestre de 2003, três instituições brasileiras - Amazonlink, o Instituto Brasileiro de Direito do Comércio Internacional, Tecnologia da Informação e Desenvolvimento (CIITED) ${ }^{72}$ e o Grupo de Trabalho Amazônico (GTA) - impugnaram, em Tóquio, a validade da marca cupuaçu, pelo fato dela servir: quando utilizada junto a produtos derivados do cupuaçu, para descrever o produto comercializado ou sua matéria-prima, ao invés de indicar a origem do produto; e quando utilizada junto a produtos que não contivessem em sua formulação a referida matéria-prima, para enganar o público consumidor a respeito das características essenciais do bem comercializado.

Durante o processo administrativo que tramitou no JPO, a Asahi reconheceu explicitamente que o registro da marca objetivou assegurar-lhe um monopólio de comercialização de produtos alimentícios derivados do cupuaçu, a fim de salvaguardar seus investimentos, realizados para produzir e comercializar o produto popularmente conhecido pela denominação "cupulate". 73 Acolhendo todos os argumentos apresentados pelas autoras da ação administrativa, o JPO invalidou a marca em 18 de fevereiro de 2004.

O caso Cupuaçu instigou o governo do Brasil, apoiado pelo setor empresarial local, a elaborar uma lista não-exaustiva de nomes associados à biodiversidade de uso costumeiro no Brasil, a qual foi encaminhada às autoridades estrangeiras, responsáveis pelo registro de marcas comerciais. A referida lista foi divulgada na sexta sessão do Comitê Permanente da OMPI para o Direito das Marcas, dos Desenhos Industriais e das Indicações Geográficas, em novembro de $2006 .^{74}$

Com o objetivo de impedir o uso abusivo do direito marcário, em detrimento dos interesses econômicos e culturais das comunidades tradicionais, o projeto de disposições da OMPI para a proteção das ECTs, inspirado pela experiência legislativa da Nova

\footnotetext{
${ }^{72}$ A atual denominação do CIITED é Instituto de Direito do Comércio Internacional e Desenvolvimento (IDCID).

${ }^{73}$ Entende-se por cupulate uma espécie de chocolate, produzido com manteiga vegetal extraída da semente do cupuaçu. Este produto foi originalmente desenvolvido pelas comunidades tradicionais da Amazônia e posteriormente aprimorado tecnologicamente pela Empresa Brasileira de Pesquisa Agropecuária (EMBRAPA).

${ }^{74}$ Ver WIPO, SCT/16/7. A lista não-exaustiva preparada pelo governo brasileiro está disponibilizada em: $<$ http://www2.mre.gov.br/dipi/ListaBiodivBrasilVer1.pdf $>$.
} 
Zelândia $^{75}$, propõe a investidura nas comunidades tradicionais do direito de oposição, inter alia, ao registro de marcas comerciais compostas por palavras, signos, nomes e símbolos, integrantes de seu patrimônio cultural, desde que as marcas "desacredit[em] ou ofend[am] a comunidade em questão ou sugir[am] uma falsa conexão com ela, ou desprestig[iem] a comunidade.",76

Optamos por excluir essa categoria de ECTs do escopo do trabalho, por julgarmos a solução apresentada pela OMPI despida de maiores controvérsias e apta a reconciliar os interesses das comunidades tradicionais de terem suas sensibilidades culturais respeitadas com a liberdade de terceiros de criar e proteger suas marcas comerciais. ${ }^{77}$

\subsection{RECURSOS MARINHOS FORA DAS JURISDIÇÕES DOS ESTADOS CONTRATANTES DA CONVENÇÃo DA ONU SOBRE DIREITO DO MAR (CDM)}

O presente trabalho se limita a tratar da proteção dos recursos da biodiversidade sujeitos ao regime da CDB. A CDB confere aos seus Estados contratantes soberania sobre os recursos biológicos originados em seus territórios. ${ }^{78}$ Se o Estado parte da CDB também for parte contratante da CDM, o regime da CDB igualmente se estenderá aos recursos biológicos marinhos, situados na Zona Econômica Exclusiva e na Plataforma Continental destes. $^{79}$

Portanto não será objeto de nossa análise o regime de proteção aplicável aos recursos biológicos, localizados em águas internacionais. Contudo, apenas a título de informação, julgamos importante destacar que não existe posição pacífica sobre o regime

\footnotetext{
75 O art. 17(1) (b) (ii) do Trade Marks Act da Nova Zelândia proíbe o registro de marcas comerciais que "would be likely to offend a significant section of the community, including Maori".

76 Cf. art. 3(a)(ii), WIPO, Revised draft provisions for the protection of traditional cultural expressions/expressions of folklore: policy objectives and core principles.

77 Em sentido mais restritivo da liberdade do setor produtivo de proteger suas marcas comerciais, o art. 136(g) da Decisão no. 486 da Comunidade Andina de Nações, que estabeleceu um regime comum de propriedade industrial aos seus Estados Membros, proíbe o registro de marcas comerciais que "consistan en el nombre de las comunidades indígenas, afroamericanas o locales, o las denominaciones, las palabras, letras, caracteres o signos utilizados para distinguir sus productos, servicios o la forma de procesarlos, o que constituyan la expresión de su cultura o práctica, salvo que la solicitud sea presentada por la propia comunidad o con su consentimiento expreso [...]".

${ }^{78} \mathrm{~A}$ CDB, nos termos de seu artigo $2^{\circ}$, entende como país de origem de um determinado recurso biológico aquele que o possui em condições in situ, isto é, "em ecossistemas e habitats naturais"; e caso o recurso seja uma espécie domesticada, se em seu território tiver "desenvolvido suas propriedades características".

${ }^{79}$ Cf. Art. 246(5)(a), CDM.
} 
legal aplicável para disciplinar o acesso e uso destes recursos. Duas são as alternativas possíveis: seu acesso e uso seriam disciplinados pelo regime de liberdade do alto mar, ${ }^{80}$ caracterizado pela liberdade de investigação científica de todas as partes contratantes da $\mathrm{CDM}^{81}$ ou pelo regime de patrimônio comum da humanidade, disciplinado pela parte XI da CDM. O regime de patrimônio comum da humanidade da CDM confere aos Estados contratantes a titularidade compartilhada dos recursos do leito do mar, fundos marinhos e subsolo, nas áreas fora dos limites das jurisdições nacionais; o direito de gestão conjunta destes recursos e de participar equitativamente dos benefícios decorrentes de sua exploração; e a obrigação compartilhada de conservar tais recursos. ${ }^{82}$

Possivelmente, o regime aplicável seja o primeiro, porquanto o regime de patrimônio comum da humanidade, segundo os termos da CDM (art. 133(b), estaria limitado aos recursos minerais. ${ }^{83}$

\subsection{RECURSOS DA AGROBIODIVERSIDADE REGIDOS PELO TIRFAA}

Estão igualmente fora do escopo do presente trabalho, os recursos biológicos regidos pelo Tratado Internacional da FAO sobre Recursos Fitogenéticos para a Alimentação e Agricultura (TIRFAA), bem como os conhecimentos tradicionais a eles conexos. A razão para a exclusão é a existência de um sistema multilateral, operado pela FAO, para a gestão destes recursos e insumos, inexistindo, no presente momento, qualquer proposta política no sentido de substituí-lo.

\section{MÉTODOS DE PESQUISA}

O desenvolvimento do presente trabalho envolveu:

\footnotetext{
${ }^{80}$ Por conta deste princípio, as Partes contratantes (ou seus nacionais) não poderão reivindicar direitos de propriedade intelectual sobre os resultados da pesquisa, pois os direitos de exclusivo afetariam o exercício do direito dos demais Estados parte de usufruir dos benefícios auferidos junto ao recurso acessado. Segundo os termos do art. 244 da CDM, as informações e conhecimentos científicos sobre os recursos marinhos de regiões além da jurisdição dos Estados devem ser amplamente divulgados, especialmente, em benefício da autonomia científica dos países em desenvolvimento (SALPIN; GERMANI, 2007, p.20).

${ }^{81}$ Cf. art. 87(f), CDM, combinado com os arts. 241, 256, 257 da mesma convenção.

${ }^{82}$ Cf. ONWUEKWE, 2004, p. 74-75.

${ }^{83}$ Ver SALPIN; GERMANI, op.cit., p.15
} 
i. Revisão de literatura e dos documentos oficiais, produzidos por, inter alia, CCDB, OMC, OMPI e FAO com o propósito de identificar os elementos que compõem as propostas de regimes internacionais de proteção dos RBIs, em discussão na esfera internacional;

ii. Revisão de literatura, de resoluções da Assembléia Geral das Nações Unidas, de outros documentos produzidos pela Organização das Nações Unidas e de sentenças judiciais com o propósito de desenvolver o quadro conceitual de desenvolvimento sustentável;

iii. Condução de entrevistas, em 2007, junto à professora Eliana Rodrigues (UNIFESP) e Cristina Theodore Assimakopoulos (FAPESP) e revisão de documentos oficiais de órgãos da administração pública brasileira, com o objetivo de colher informações que serviram de base para o desenvolvimento da seção dedicada ao caso UNIFESP-Krahô; e

iv. Condução de entrevistas, em 2007, junto ao pessoal da organização ARTESOL (Helena Sampaio e demais responsáveis pela organização) com o objetivo de colher informações e material a respeito do trabalho da organização, na área de comercialização de produtos que incorporem expressões culturais tradicionais.

\section{Plano do trabalho e as regras utilizadas para citaÇão}

Para indicação das fontes consultadas, nas notas de referência, este trabalho aplicou o sistema autor-data, em conformidade com a ABNT $10520 .^{84}$ No que tange aos documentos de organizações intergovernamentais e de órgãos da Organização das Nações Unidas (ONU), optou-se por empregar a seguinte regra: indicação da sigla ou do nome por extenso da organização ou do órgão responsável pelo documento, seguido pelo número oficial do documento e pelo número da página ou do parágrafo. Quando o documento não conta com um número oficial, foi indicado o ano da publicação. Por fim, os instrumentos legais foram citados por seu nome por extenso e/ou por sua sigla, conforme a lista de abreviações indicada ao início do trabalho.

\footnotetext{
${ }^{84}$ Cf. ASSOCIAÇÃO BRASILEIRA DE NORMAS TÉCNICAS, 2002.
} 
Quanto ao plano do presente trabalho, este se organiza em quatro capítulos. O primeiro deles esclarece a origem do termo patrimônio biocultural imaterial e define, detalhadamente, os RBIs que o compõem (recursos da biodiversidade, CTs e ECTs), bem como suas quatro dimensões comuns (imaterial, humana, ambiental e cultural).

Uma vez identificada a matéria sobre a qual nos debruçaremos ao longo deste estudo, o capítulo seguinte trata de dois aspectos iníquos dos dois principais regimes de proteção de produções intelectuais--o direito das patentes e o direito de autor: sua incapacidade de tutelar os RBIs e seu papel de catalisador da apropriação indébita destes recursos.

O terceiro capítulo se centra na construção do quadro conceitual de desenvolvimento sustentável. Primeiramente, será determinado o conteúdo da concepção de desenvolvimento sustentável utilizada neste estudo. Em seguida, são identificados pontualmente os elementos ideais, que comporão o quadro conceitual de desenvolvimento sustentável (critérios de operacionalização do quadro conceitual). Os critérios de operacionalização servem para revestir de caráter prático a definição teórica de desenvolvimento sustentável, ensejando, assim, sua aplicação como um parâmetro analítico e normativo. ${ }^{85}$

Finalmente, o último capítulo avalia as propostas de regimes internacionais de proteção dos RBIs, em discussão/construção na CCDB, OMC e OMPI, bem como duas propostas acadêmicas, calcadas parcialmente em um regime de responsabilidade, em face do quadro conceitual de desenvolvimento sustentável. A partir dos resultados da contraposição, será identificado um possível arranjo legal e institucional, adequado a proteger o PBI em suas múltiplas dimensões. Por fim, encerraremos o trabalho com uma breve conclusão.

\footnotetext{
${ }^{85}$ Cf. SHIELDS; TAJALLI, 2006, p. 324 et seq.
} 
CAPÍTULO 1 | 43

\section{DEFINIÇÃO DE CONHECIMENTOS TRADICIONAIS, RECURSOS DA BIODIVERSIDADE E EXPRESSÕES CULTURAIS TRADICIONAIS}

\subsection{INTRODUÇÃo: A GÊNESE DO TERMO "PATRIMÔNIO BIOCULTURAL IMATERIAL"}

O termo patrimônio biocultural imaterial (PBI) decorre de uma associação parcial de forma e conteúdo dos termos "patrimônio biocultural", empregado no Código de Ética da Sociedade Internacional de Etnobiologia (SIE) ${ }^{86}$ e "patrimônio cultural imaterial", utilizado pela CSPCI.

O termo "patrimônio biocultural" compreende "o patrimônio cultural (tanto tangível quanto intangível, incluindo [...] folclore, [...] conhecimentos, inovações e práticas) e o patrimônio biológico (diversidade de genes, variedades, espécies [...]) dos povos indígenas, sociedades tradicionais e comunidades locais [...]. Este patrimônio inclui a paisagem como dimensão espacial, em que a evolução do patrimônio biocultural [...] tem lugar." ${ }^{87} \mathrm{O}$ aspecto interessante do escopo do termo é a inclusão do patrimônio artístico (as ECTs) e dos conhecimentos e elementos técnicos (CTs). Contudo, o termo também se estende às paisagens naturais. A proteção das paisagens naturais não é objeto de interesse primário deste estudo, embora decorram da ação das comunidades tradicionais e constituam condições indispensáveis ${ }^{88}$ para a concepção, desenvolvimento contínuo e conservação do PBI.

Com vistas a diferenciar o conteúdo coberto pelo termo "patrimônio biocultural" daquele sobre o qual nos debruçaremos nesse estudo, agregamos-lhe a palavra "imaterial", por influência da terminologia utilizada pela CSPCI. Nos termos desta convenção, o termo "patrimônio cultural imaterial" compreende os "usos, representações, expressões, conhecimentos e técnicas que as comunidades, os grupos e em alguns casos os indivíduos

\footnotetext{
${ }^{86}$ Cf. INTERNATIONAL SOCIETY OF ETHNOBIOLOGY, 2008.

87 Ibid., nota de rodapé no.1. Em sentido similar, Erica-Irene Daes (1997, p. iii) indica que o termo "patrimônio indígena" abrange tanto o patrimônio criativo das comunidades locais, as paisagens naturais e finalmente os despojos humanos de seus antepassados: "Heritage" [...] includes all of those things which contemporary international law regards as the creative production of human thought and craftsmanship, such as songs, music, dances literature, artworks, scientific research and knowledge. It also includes inheritance from the past and from nature, such as human remains, the natural features of the landscape, and naturally occurring species of plants and animals with which a people has long been connected."

${ }^{88}$ Cf. art. 14(c), CSPCI.
} 
reconhecem como parte integrante de seu patrimônio cultural” (art. 2(1)). Esse patrimônio "se manifesta em particular nos seguintes âmbitos: a) tradições e expressões orais; b) artes do espetáculo; c) usos sociais, rituais e atos festivos; d) conhecimentos e usos relacionados com a natureza e o universo; e) técnicas artesanais tradicionais" (art. 2(2)).

A limitação do termo "patrimônio cultural imaterial" decorre da exclusão de seu escopo dos recursos biológicos, que representam uma importante parcela do patrimônio intelectual conservado pelas comunidades tradicionais.

A Declaração das Nações Unidas sobre os Direitos dos Povos Indígenas utiliza o termo "patrimônio cultural, conhecimentos tradicionais e expressões culturais tradicionais" para designar "as manifestações de suas ciências, ${ }^{89}$ tecnologias ${ }^{90}$ e culturas," notadamente, "os recursos genéticos e humanos, sementes, medicamentos, conhecimentos sobre as propriedades da fauna e flora, tradições orais, desenhos, esportes e jogos tradicionais e artes visuais e de interpretação" (art. 31(1)). Duas são as diferenças de abrangência entre o termo empregado na Declaração e o termo PBI: em primeiro lugar, o último exclui de seu bojo o patrimônio genético humano, porquanto este não resulta de qualquer trabalho intelectual por parte de seus detentores. A segunda diferença está na titularidade do PBI: enquanto a Declaração da ONU limita-se a tratar do patrimônio imaterial conservado pelos povos indígenas, o PBI é conservado tanto pelas comunidades indígenas como por outros grupos culturalmente diferenciados.

Para facilitar a abordagem do tema, trataremos, em separado, das três grandes categorias de RBIs, que compõem o PBI: os recursos da biodiversidade; os CTs, e as ECTs. Mas antes, examinaremos as quatro dimensões comuns às três categorias de RBIs.

\footnotetext{
${ }^{89}$ A UNESCO define Ciência como "el proceso en virtud del cual la humanidad actuando individualmente o en pequeños o grandes grupos, hace un esfuerzo organizado, mediante el estudio objetivo de los fenómenos observados, para descubrir y dominar la cadena de causalidades; reúne de forma coordinada los resultantes subsistemas de conocimiento por medio de la reflexión sistemática y la conceptualización, a menudo ampliamente expresada bajo forma de símbolos matemáticos; y con ello se da a sí misma la posibilidad de utilizar, para su propio progreso, la comprensión de los procesos y de los fenómenos que ocurren en la naturaleza y en la sociedad." Ver art. $1^{\circ}$ (a)(i), UNESCO, Recomendación relativa a la situación de los investigadores científicos.

${ }^{90}$ Tecnologia consiste no processo de aplicação dos conhecimentos científicos sobre o funcionamento dos fenômenos naturais para o desenvolvimento ou aprimoramento de bens e serviços. Cf. item 1(b), UNESCO, Recomendación relativa a la situación de los investigadores científicos; WESTERLUND, 2002, p. 37.

91 A UNESCO define cultura como o "conjunto de los rasgos distintivos espirituales y materiales, intelectuales y afectivos que caracterizan a una sociedad o a un grupo social y que abarca, además de las artes y las letras, los modos de vida, las maneras de vivir juntos, los sistemas de valores, las tradiciones y las creencias”. Cf. Preâmbulo, UNESCO, em sua Declaração Universal sobre a Diversidade Cultural.
} 
CAPÍtulo 1 | 45

\subsection{CARACTERÍSTICAS COMUNS ÀS TRÊS CATEgORIAS DE RBIS}

Os RBIs apresentam quatro dimensões comuns, que os unem:

i. $\quad$ Sua natureza informacional (dimensão imaterial);

ii. As fontes humanas que os geraram e conservam (dimensão humana);

iii. $\mathrm{O}$ arcabouço cultural diferenciado, que direciona as comunidades locais a se conduzirem de maneira a desenvolvê-los incessantemente e conservá-los para as futuras gerações (dimensão cultural); e

iv. $\quad$ O substrato natural que sustenta a vida física e cultural das comunidades locais (dimensão ambiental).

As dimensões revelam não apenas aspectos que irmanam bens intelectuais tão diversos; revelam, sobretudo, os aspectos primários que qualquer regime legal, apto a proteger os RBIs, deve resguardar, sob pena de catalisar sua deterioração. ${ }^{92}$

\subsubsection{DIMENSÃO IMATERIAL}

Os recursos biológicos, os CTs e as ECTs compartilham com os bens elegíveis de proteção pelos regimes de PI - e.g. as invenções biotecnológicas e farmacêuticas, obras literárias e artísticas, as cultivares etc. - a natureza imaterial. ${ }^{93}$

Os recursos biológicos ${ }^{94}$ têm como conteúdo imaterial seus recursos genéticos, ${ }^{95}$ i.e. ácido desoxirribonucléico (DNA), seqüências genéticas (polinucleotídeos) e de

\footnotetext{
92 Cf. SCBD, UNEP/CBD/WG8J/3/INF/1, p. 14, 19-20.

${ }^{93}$ Cf. DRAHOS, 1998, p. 2.

${ }^{94}$ É necessário ter claro que há diferenças marcantes entre o recurso genético e o recurso biológico: um grão qualquer cultivado por uma comunidade rural que apresenta, por exemplo, resistência a solos salinizados, tem em seu código genético (genoma) determinada seqüência genética responsável por codificar uma proteína que lhe confere a referida resistência. Para a indústria da agrobiotecnologia o aspecto comercial de interesse não é o grão de per si, mas a seqüência genética que pode ser isolada do genoma do grão e transpôla a qualquer variedade vegetal, com vistas a lhe agregar a mesma característica de resistência. Logo, uma vez identificada a seqüencia genética de interesse industrial, e caracterizada em termos de suas bases
} 
polipeptídios (proteínas) e compostos químicos bioativos. Os CTs e as ECTs figuram como bens intangíveis, já que consistem, respectivamente, em know-how e expressões artísticas, fixadas ou não em um suporte tangível. Em outras palavras, os RBIs configuram bens públicos, no sentido econômico do termo.

Bens públicos são aqueles "cujos benefícios, em forma de utilidade, não podem ser percebidos por seu criador, mas sim pela sociedade em geral", ${ }^{96}$ pois apresentam duas características que obstaculizam a apropriação privada de seus benefícios, a saber, seu consumo é não-rival e não é viável técnica ou economicamente excluir terceiros nãoautorizados de sua fruição (bem não-excludente).

O consumo de um bem é não-rival, quando duas ou mais pessoas possam consumilo simultaneamente, ainda que em altos níveis de consumo, sem limitar a capacidade de outros indivíduos para usufruí-lo simultaneamente. ${ }^{97}$ Um exemplo típico de bem cujo consumo é não-rival é o conhecimento. Um mesmo conhecimento técnico por ser utilizado simultaneamente por um número infinito de pessoas, sem que o uso por uma parte interfira na capacidade de utilização das demais. Thomas Jefferson em carta endereçada a Isaac McPherson, em 13 de agosto de 1813, reconhece claramente a natureza de bem público do conhecimento:

\begin{abstract}
"He who receives an idea from me, receives instruction himself without lessening mine; as he who lights his taper at mine, receives light without darkening me. That ideas should freely spread from one to another over the globe, for the moral and mutual instruction of man, and improvement of his condition, seems to have been peculiarly and benevolently designed by nature, when she made them, like fire, expansible over all space, without lessening their density in any point, and like the air in which we breathe, move, and have our physical being, incapable of confinement or exclusive appropriation." ${ }^{, 98}$
\end{abstract}

\footnotetext{
nitrogenadas (A- Adenina; C-citosina, G-guanina, T-tiamina), o recurso biológico que lhe contém é descartável. Sobre o tema, ver RESNIK, 2004, p. 18-24.

${ }^{95} \mathrm{~A} \mathrm{CDB}$, em seu art. $2^{\circ}$, define material genético como o "material de origem vegetal, animal, microbiana ou outra que contenha unidades funcionais de hereditariedade". Uma definição mais clara de gene é dada pela FAO: "the smallest complete unit of coded information in an organism. This constitutes the 'source code' of the organism, just as sequences of 1 and 0 define a computer file or program" (FAO, 2002, p. 2).

${ }^{96}$ Cf. BANCO INTERNACIONAL DE RECONSTRUCCIÓN Y FOMENT/BANCO MUNDIAL, 19981999 , p. 5, tradução nossa.

${ }^{97}$ Cf. OSTROM, E; OSTROM, V., [19_], p. 3.

${ }^{98}$ JEFFERSON, 1813.
} 
Bens públicos, portanto, são inexauríveis ${ }^{99}$ e se sujeitam ao que Drahos denomina "Lei da Abundância" (Law of Repletion), caracterizada pela multiplicação do valor e da quantidade dos bens públicos, à medida que forem se disseminando publicamente. ${ }^{100}$ Assim sendo, para que uma parte possa usufruir um bem público não é condição que o detenha em regime de propriedade privada, porquanto os usos conjuntos não subtraem do recurso sua capacidade de satisfazer os interesses de todos os potenciais usuários. Diz-se, pois, que o consumo de bens públicos é não-subtraível (nonsubtractible). ${ }^{101}$

Ser não-excludente significa que excluir terceiros não-autorizados da fruição do recurso ou envolve custos demasiadamente altos, ou não é factível tecnicamente. ${ }^{102} \mathrm{CTs}$ e ECTs, uma vez revelados ao público, destroem qualquer pretensão das comunidades tradicionais de controlar sua disseminação e uso por terceiros. Recursos biológicos, por sua vez, sendo naturalmente auto-replicáveis e objeto de trocas comerciais internacionais, ${ }^{103} \mathrm{se}$ disseminam sem controle. ${ }^{104}$

Diferentemente dos bens públicos, os bens privados são excludentes, ou seja, com facilidade o titular de um bem privado pode excluir de sua fruição terceiros nãoautorizados, e seu nível de "subtraibilidade" é alto, uma vez que seu consumo por um indivíduo impacta no quanto terceiros poderão utilizar daquele bem. ${ }^{105} \mathrm{Um}$ exemplo de bens privados são os recursos naturais: o consumo de uma floresta nativa por uma empresa madeireira destituirá terceiros da oportunidade de utilizá-la para fins mais construtivos.

Stiglitz classifica os bens públicos em duas categorias: bens públicos locais, isto é, aqueles cujos benefícios podem ser auferíveis apenas localmente, e bens públicos globais ou internacionais, ou seja, aqueles cujos benefícios são auferíveis por toda a humanidade. ${ }^{106} \mathrm{O}$ conhecimento integra a lista de Stiglitz de bens públicos globais, ${ }^{107}$ pois sua utilidade e geração é transfronteiriça. ${ }^{108}$

\footnotetext{
${ }^{99}$ Cf. BELL; PARCHOMOVSKY, 2003, p. 12.

${ }^{100}$ Cf. DRAHOS, 2006. No mesmo sentido ver BARLOW, 1997, p. 358; MERTON, 1988, p. 620; HARDIN, 1986.

${ }^{101}$ Cf. OSTROM, E.; OSTROM, V., [19_], p. 4.

${ }^{102}$ Cf. STEVENSON, 1991, p. 9, 54-55.

${ }^{103} \mathrm{Cf}$. WTO, IP/C/W/458, para. 23.

${ }^{104}$ Cf. BIBER-KLEMM, 2004, p. 97.

${ }^{105}$ Cf. OSTROM; HESS, 2003, p. 54.

${ }^{106}$ Cf. STIGLITZ, 1999, p. 310.
} 
Entretanto não é qualquer conhecimento que apresenta a natureza de bem público. Aquele apenas se torna um bem público, à medida que for codificado, desde que seus potenciais usuários concentrem o instrumental técnico para operacionalizá-lo. ${ }^{109} \mathrm{Um}$ exemplo de conhecimento codificado é aquele que se apresenta fixado em um substrato tangível - e.g. em um artigo científico, invenção, produto -, podendo, por isso, ser transmitido com facilidade. ${ }^{110} \mathrm{O}$ processo de codificação do conhecimento lhe traz contornos concretos, permitindo sua identificação, diferenciação e aplicação por terceiros, segundo seus interesses.

$\mathrm{O}$ conhecimento não-codificado, em sentido diverso, apresenta fronteiras e conteúdo tão fluído, que sua aquisição por seu potencial usuário depende da realização de investimentos em sua codificação e de contatos interpessoais com o autor do conhecimento. $^{111}$

Em virtude da geração de conhecimentos envolver pesados custos e sua reprodução envolver apenas custos diminutos, ${ }^{112}$ seus produtores, em circunstâncias normais, não têm como extrair uma remuneração por sua contribuição social. A conseqüência previsível desta realidade é a subprovisão de conhecimentos, até que sobrevenha algum meio que permita que seus produtores internalizem, ao menos, alguns dos benefícios fruídos pela sociedade a partir de sua contribuição. ${ }^{113}$ Por esta razão, a geração do conhecimento demanda a intervenção da comunidade internacional, seja por meio da adoção de regimes legais de proteção dos interesses morais e materiais dos autores de produções intelectuais

107 Os demais bens públicos globais que figuram na lista de Stiglitz são: estabilidade econômica internacional, segurança internacional (estabilidade política), meio ambiente ecológico e assistência humanitária internacional.

${ }^{108}$ Cf. THORSTEINSDÓTTIER et al., 2003, p. $891-892$.

${ }^{109}$ Determinadas categorias de conhecimentos técnicos sofisticados, por exemplo, informações genômicas, ainda que estejam disponibilizadas livremente, apenas podem ser utilizadas pelas instituições que detêm recursos materiais, humanos, tecnológicos para convertê-los em inovação científica e produtos. A maioria dos países em desenvolvimento não é portadora deste instrumental técnico e humano. Logo, um recurso que, sob o aspecto teórico, apresenta as características de bem público, na prática, é um "club good", ou seja, um recurso cujo consumo é não-rival, mas que apenas pode ser utilizado por aqueles que detêm os instrumentos para torná-lo útil. Cf. THORSTEINSDÓTTIR, 2003, p. $891-892$.

${ }^{110}$ Cf. MANDERVILLE, 1998, p. 362.

${ }^{111}$ Ver Ibid., p. 360-363; SAMPATH, 2005, p. 115.

112 Cf. VOGEL, 2000c, p. 11.

${ }^{113}$ Cf. SAMPATH, op.cit., p. 108. 
— e.g. por meio da adoção de DPIs -, seja por meio de subvenções oferecidas pelo Estado para a geração de conhecimento. ${ }^{114}$

Os RBIs são bens informacionais, e por isso, bens públicos. Contudo, os recursos que lhe dão sustentação - os ecossistemas naturais - são tangíveis e, por isso, estão sujeitos à degradação.

\subsubsection{DiMENSÃo HUMANA}

As comunidades culturalmente diferenciadas figuram como sustentáculos humanos do PBI. ${ }^{115} \mathrm{O}$ desaparecimento desses grupos é o fato gerador de um efeito dominó de erosão cultural e biológica. Se as comunidades tradicionais perdem sua coesão e se distanciam dos biomas, em que seus RBIs foram concebidos, seus conhecimentos sobre os atributos dos recursos da biodiversidade se perdem permanentemente; e tudo aquilo que não se conhece é considerado descartável pelo homem moderno. O destino das ECTs, na hipótese de desaparecimento dos grupos que as criaram, não é menos dramático: com a perda dos vínculos com a natureza, os grupos humanos deixam de reproduzir suas ECTs, as quais geralmente retratam as relações das comunidades tradicionais com a biodiversidade e o mundo espiritual.

Com o aumento do intercâmbio cultural, facilitado pelos meios de comunicação de massa, as demandas e expectativas das gerações mais jovens das comunidades tradicionais se aproximam dos desejos materialistas presentes nas sociedades ocidentais. ${ }^{116} \mathrm{Na}$ ausência de perspectivas de melhoria de seu padrão de vida, as gerações mais jovens destes grupos estão deixando as áreas rurais e as florestas, em busca de melhores perspectivas nos centros urbanos. A imigração destrói as possibilidades de conservação do PBI; sem o interesse das gerações mais jovens de recebê-lo, conservá-lo e continuamente utilizá-lo e

\footnotetext{
${ }^{114}$ Cf. STIGLITZ, 1999, p. 311-312; BELL; PARCHOMOVSKY, 2003, p. 12.

115 Cf. DENHEZ, 1998, p. 207. Ver também proposta no 40(d), INTERGOVERNMENTAL PANEL ON FORESTS, [200-?].

${ }^{116}$ Balick (2003, p. 13-14) assinala que, no início da década de 80, os membros mais jovens da tribo Apinajé do Nordeste brasileiro participavam freqüentemente de atividades de coleta de castanhas e outros recursos das florestas locais. Nestas oportunidades, conhecimentos lhes eram transmitidos. Dez anos depois, o autor retornou à mesma comunidade e se deparou com uma nova realidade: as crianças da tribo ao redor de um aparelho de televisão.
} 
desenvolvê-lo, os conhecimentos conservados pelas gerações mais velhas se extinguirão, quando de sua morte. ${ }^{117}$

\subsubsection{DimENSÃO CULTURAL}

A dimensão cultural se associa intimamente à dimensão humana. As comunidades tradicionais são portadoras de culturas únicas, que se ocupam com a gestão sustentável dos recursos naturais, sobre os quais foi construído seu PBI. A natureza e a cultura mantêm continuamente uma relação de influência mútua: as culturas são construídas a partir dos elementos da natureza, ao mesmo tempo em que influenciam (positiva ou negativamente) o desenvolvimento e a conservação da natureza. ${ }^{118}$ Não basta assegurar a existência física dos membros de comunidade tradicional para se alcançar a conservação de seu PE; é igualmente indispensável que a cultura destes grupos seja protegida contra práticas de genocídio cultural. ${ }^{119}$

Dentro da dimensão cultural encontram-se os valores religiosos, que são especialmente relevantes para as ECTs. Expressões culturais podem, sob a perspectiva estética da sociedade ocidental, portar um apelo artístico, ao mesmo tempo em que as comunidades locais podem conferir-lhes um caráter sacro. É ilustrativo o caso George $\mathrm{M}^{*}$, Payunka, Marika et al. versus Indofurn, que tramitou perante as cortes australianas nos anos 90. Neste caso, uma empresa australiana importou tapetes manufaturados no Vietnã, que reproduziam uma ECT de uma comunidade aborígene australiana. O problema para a comunidade afetada era o caráter religioso da expressão artística reproduzida indiscriminadamente, em um objeto que servia para ser pisado. Nestas circunstâncias, a reprodução da ECT sacra foi julgada pela comunidade como um ato de blasfêmia. ${ }^{120}$

Em decorrência da contumácia com que os RBIs são apropriados pela sociedade ocidental e da falta de apoio oficial para que estes recursos sejam difundidos e conservados em uso, de maneira culturalmente adequada, ${ }^{121}$ as comunidades tradicionais vêm se

\footnotetext{
${ }^{117}$ Cf. SCBD, UNEP/CBD/WG8J/3/INF/1, p. 22; GUPTA, 2002, p. 385.

${ }^{118}$ Cf. EAGLETON, 2000, p. 4.

${ }^{119}$ Cf. STAVENHAGEN, 1998, p. 11.

${ }^{120}$ Cf. JANKE, 2003, p. 10-19.

${ }^{121}$ Cf. BALICK, 2003, p. 14.
} 
fechando ao intercâmbio cultural com outras comunidades locais e com a sociedade ocidental. ${ }^{122} \mathrm{O}$ efeito colateral deste fechamento está no fato de que o livre intercâmbio de RBIs os conserva em desenvolvimento contínuo; a ruptura com essa tradição conduzirá à sua erosão.

Uma vez determinadas as quatro dimensões comuns a todos RBIs, passaremos a explorar as características específicas das três categorias de RBIs (recursos da biodiversidade, conhecimentos tradicionais e expressões culturais tradicionais).

\subsubsection{DIMENSÃO AMBIENTAL}

Os recursos da biodiversidade têm como sustentáculo os ecossistemas naturais, que os geraram e conservam. Os CTs, por sua vez, foram desenvolvidos e são conservados por comunidades tradicionais em interação direta com a natureza, como forma de superação de seus problemas e desafios diários. Logo, a conservação dos CTs e da biodiversidade depende da conservação dos ecossistemas e do vínculo das comunidades tradicionais com a natureza. As ECTs, por sua vez, refletem as relações simbióticas entre o homem, a natureza e o mundo espiritual; a sobrevivência destas expressões artísticas está igualmente associada à conservação do meio ambiente e do vínculo das comunidades tradicionais aos ecossistemas em que tradicionalmente vivem.

Por ironia, no momento em que as possibilidades de exploração sustentável dos RBIs se ampliam graças à emergência de novas tecnologias, a diversidade cultural e biológica sofre ameaças constantes do modelo econômico corrente, assentado sobre a homogeneização cultural e biológica para a expansão das atividades empresariais. ${ }^{123}$ Neste sentido, é ilustrativo o impacto da agricultura moderna sobre os RBIs: a expansão da agricultura de monocultura, associada ao uso de variedades vegetais homogêneas de alta produtividade, vêm conduzindo à desvalorização e ao desaparecimento dos conhecimentos tradicionais agrícolas e das variedades vegetais tradicionais. ${ }^{124}$

${ }^{122}$ Cf. SCBD, UNEP/CBD/WG8J/3/INF/1, p. 21-30.

${ }^{123}$ Cf. DUTFIELD, 2004a, p. 2-3.

${ }^{124}$ Cf. SCBD, UNEP/CBD/WG8J/3/INF/1, p. 14; SCBD, UNEP/CBD/WG8J/2/5, p. 11. É ilustrativo o efeito da Revolução Verde em Bangladesh: na década de 60, o país asiático conservava cerca de 8500 variedades tradicionais de arroz. 40 anos mais tarde, restaram apenas algumas dezenas de variedades de arroz em uso (AHMED, 2004, p. 186). 
Além das atividades agrícolas insustentáveis, a demanda crescente do setor industrial por recursos naturais ameaçam a sustentabilidade dos ecossistemas naturais, em que se refugiam as comunidades tradicionais. ${ }^{125} \mathrm{O}$ setor farmacêutico, por exemplo, produz um sem-número de produtos farmacêuticos, cujos princípios bioativos são extraídos diretamente de recursos da biodiversidade. A demanda crescente por esses produtos e a falta de compromisso do setor privado para com a conservação do meio ambiente estimulam o uso insustentável de ecossistemas naturais. ${ }^{126}$ Desaparecendo os vínculos que ligam as comunidades locais à natureza, extinguem-se as fontes que alimentam os CTs, os recursos biológicos e as ECTs.

\subsection{RECURSOS DA BIODIVERSIDADE}

\subsubsection{OS RECURSOS BIOLÓGICOS INTANGÍVEIS ${ }^{127}$}

A CDB define recurso genético como um elemento integrante do recurso biológico: o primeiro consiste em "material genético de valor real ou potencial."128 O último compreende "qualquer componente biótico de ecossistemas" que apresente "real ou potencial utilidade ou valor para a humanidade" (art. $\left.2^{\circ}\right)$. Em outras palavras, a expressão recurso biológico contempla os recursos biológicos tangíveis, tal como os encontramos livremente na natureza - plantas, animais, microorganismos -, bem como os recursos biológicos intangíveis - seu genoma (o conjunto de seqüências genéticas que compõem um organismo), proteoma (o conjunto de proteínas que compõem um organismo) e compostos químicos em geral.

O repositório de instruções, capazes de dirigir a construção e o funcionamento de um organismo vivo é chamado de ácido desoxirribonucléico (DNA), o qual se localiza no

\footnotetext{
${ }^{125}$ Cf. Preâmbulo, INTERNATIONAL CONGRESS OF ETHNOBIOLOGY, Declaração de Belém.

${ }^{126}$ Cf. ALVES; ROSA, 2007.

${ }^{127}$ Agrecemos a Joseph Vogel por nos chamar a atenção a respeito da natureza informacional dos recursos biológicos intangíveis.

${ }^{128} \mathrm{O}$ Tratado Internacional sobre Recursos Fitogenéticos para a Alimentação e Agricultura, em seu artigo $2^{\circ}$, entende "material genético" como "qualquer material de origem vegetal [...] que contenha unidades funcionais de herança".
} 
interior nas células dos seres vivos e se organiza em estruturas chamadas cromossomos. O DNA de todo e qualquer ser vivo é composto por seqüências genéticas cujos tijolos constitutivos são apenas quatro nucleotídeos, a saber, adenosina (A), citosina (C), guanina $(\mathrm{G})$ e tiamina $(\mathrm{T}){ }^{129}$ As seqüências genéticas, por sua vez, são responsáveis pela produção de proteínas, ${ }^{130}$ às quais cabe o papel de regular o funcionamento dos organismos vivos (figura 1). Tanto é que o funcionamento do corpo humano depende de mais de dois milhões de proteínas diferentes. ${ }^{131}$

Figura 1: figura indicando a presença do material genético no interior das células dos seres vivos; a composição deste material pelos nucleotídeos $\mathrm{A}, \mathrm{C}, \mathrm{G}$ e T, e seu papel na produção de proteínas, que sustentam os organismos vivos

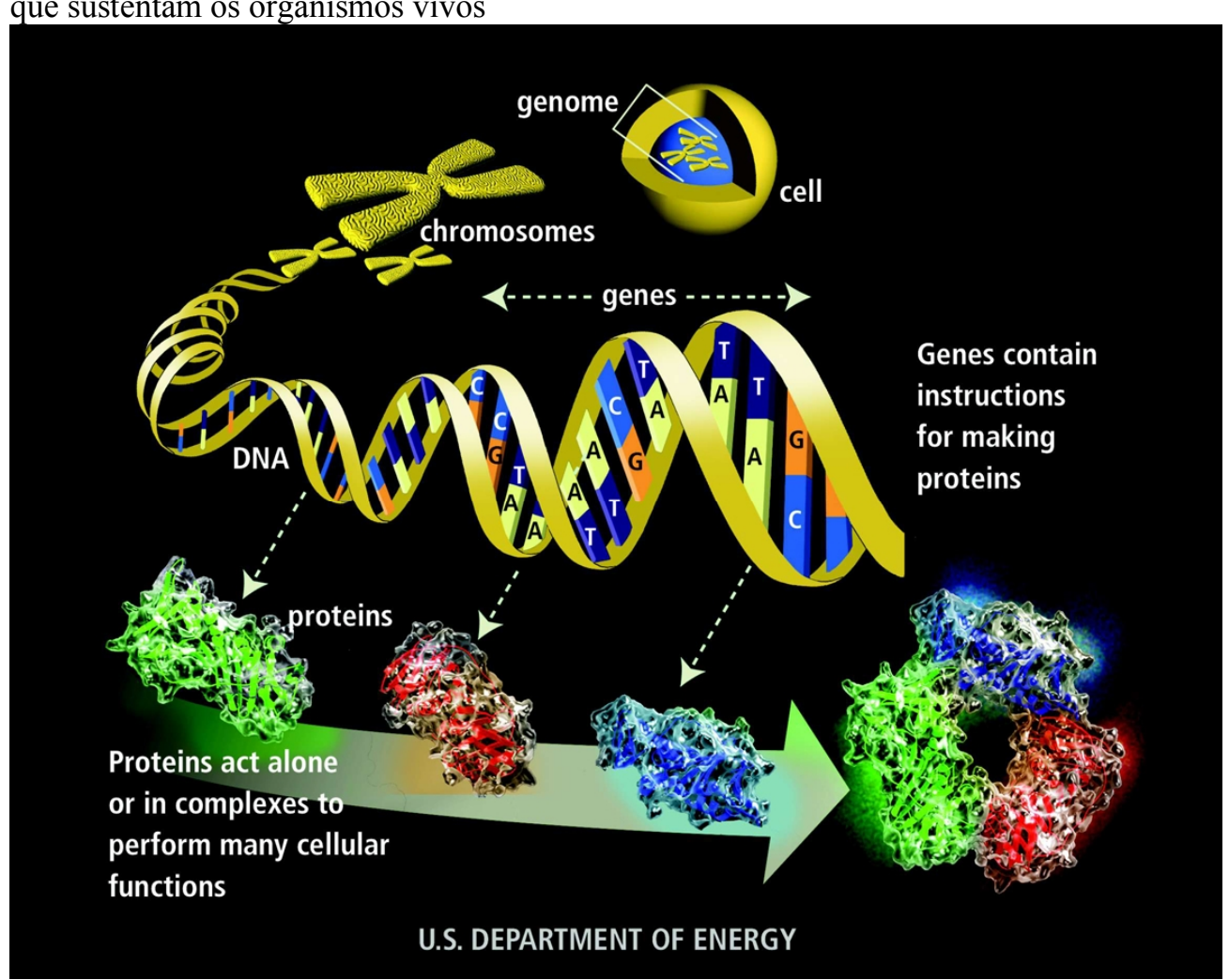

Fonte: Human Genome Program, U.S. Department of Energy, Primer on Molecular Genetics, Washington, D.C., 1992.

O que de fato importa às instituições de pesquisa e industriais são as informações contidas no recurso biológico tangível, descritíveis em termos de estruturas químicas. O uso científico e comercial dos recursos biológicos intangíveis depende apenas inicialmente

\footnotetext{
${ }^{129}$ Cf. RESNIK, 2004, p. 14-15.

${ }^{130}$ Cada três nucleotídeos formam um aminoácido que é o tijolo fundamental na construção de qualquer proteína.

${ }^{131}$ Cf. RESNIK, op.cit., p. 23-24.
} 
do recurso biológico tangível; e mesmo assim, em quantidades mínimas. ${ }^{132}$ Tecnologias de ponta - e.g. DNA recombinante, genômica, proteômica, bioinformática - são hábeis a decompor os recursos biológicos tangíveis em um leque amplo de produtos informacionais - seqüências de DNA e de polipeptídios, compostos bioativos - ${ }^{133}$ que além de se distanciarem do recurso biológico tangível que lhes deu origem, podem ser utilizados independentemente do acesso ao recurso biológico tangível. ${ }^{134}$ Por exemplo, por meio da associação de tecnologia de triagem em alta velocidade (high throughput screening) e da de DNA recombinante é possível identificar uma determinada proteína bioativa, produzida por um microorganismo natural, identificar e isolar a seqüência genética responsável por sua expressão no organismo natural e inseri-la em um organismo hospedeiro, que passará a produzir a proteína de interesse em larga escala. ${ }^{135}$ É por meio desta tecnologia que o hormônio do crescimento humano é produzido por bactérias geneticamente modificadas para fins terapêuticos. ${ }^{136}$

A emergente biologia sintética ${ }^{137}$ igualmente tornará o acesso contínuo aos recursos da biodiversidade dispensável para a consecução de projetos de $\mathrm{P} \& \mathrm{D}$, envolvendo seus elementos intangíveis. A partir de uma amostra diminuta, um recurso biológico, capaz de produzir uma molécula $X$, portadora de qualidades farmacológicas, pode ser seqüenciado descrito em termos de nucleotídeos A, G, C, T. A seqüência de DNA, responsável pela produção da molécula $X$, codificada em termos de nucleotídeos, pode ser armazenada em meios digitais. Uma vez digitalizada a seqüência, ela poderá ser enviada por e-mail a alguma das muitas instituições espalhadas pelo globo, especializadas na construção física de genes sintéticos. O gene sintético reconstruído, idêntico ao gene natural, está pronto a ser inserido em um microorganismo hospedeiro, por meio de técnicas de DNA recombinante, com o objetivo de produzir, em larga escala, a molécula bioativa X. ${ }^{138}$

\footnotetext{
${ }^{132}$ Na cláusula 4 do modelo de memorando de entendimento, utilizado pelo Instituto Nacional de Câncer dos EUA para formalizar acordos de acesso a recursos biológicos com instituições de países em desenvolvimento, há uma referência à quantidade de recurso biológico necessária para a consecução de testes voltados à identificação de algum princípio bio-ativo: $5 \mathrm{mg}$ para compostos puros e $10 \mathrm{mg}$ para compostos crus. Ou seja, uma quantidade próxima a de um comprimido de aspirina. Ver WTO, IP/C/W/341.

${ }^{133}$ Cf. WIPO, 2001, p. 140.

${ }^{134}$ Cf. SOPLÍN; MULLER, 2008, passim.

${ }^{135}$ Cf. GRUBB, 2004, p. 256.

${ }^{136}$ Cf. RESNIK, 2004, p. 29.

137 Campo da ciência resultante da convergência entre a nanotecnologia, a biotecnologia, as tecnologias da informação e as ciências cognitivas, que viabiliza, inter alia, a construção de microorganismos que inexistem na natureza a partir do zero ou a reprogramação de recursos biológicos naturais para novos propósitos.

${ }^{138}$ Cf. ETC GROUP, 2007a, p. 38-39.
} 
Em virtude das dimensões infinitesimais das amostras de recursos biológicos necessárias para a consecução de projetos de $\mathrm{P} \& \mathrm{D}$, da natureza informacional dos recursos biológicos intangíveis e da facilidade com que podem ser transmitidos em escala global, no momento, não é plausível estabelecer o nexo causal entre o recurso biológico natural e um produto final, dele derivado direta ou indiretamente. O processo de P\&D envolve um amplo espectro de insumos informacionais, os quais são associados simbioticamente até se alcançar um produto final. Este geralmente não se confunde com nenhum dos elementos absorvidos, ao longo do processo de $\mathrm{P} \& \mathrm{D} .{ }^{139}$ Se não se conhece mais de $90 \%$ da biodiversidade do planeta, ${ }^{140} \mathrm{o}$ espaço para se burlar qualquer marco legal que se preste a controlar o fluxo de recursos tangíveis e intangíveis da biodiversidade é amplo.

Outro aspecto dos recursos biológicos intangíveis, que confirma sua natureza de bens públicos, é o fato de que os mesmos compostos bioativos e seqüências genéticas, presentes em determinado recurso biológico, podem estar igualmente presentes em outros recursos biológicos, espalhados em diferentes regiões do mundo. ${ }^{141}$ Em outras palavras, existe uma sobreposição genética entre as diferentes espécies (similaridades genéticas ou homologias). Assim, é de se prever que moléculas, compostos bioativos e genes comercialmente valiosos podem existir em diversas espécies, ${ }^{142}$ que não necessariamente são de titularidade de um mesmo Estado nacional.

Além do problema da homologia, outros fatores fazem com que os recursos biológicos dificilmente se encontrem exclusivamente dentro das fronteiras políticas de um único Estado: em decorrência do comércio internacional, das missões científicas internacionais, do compartilhamento de um mesmo ecossistema natural por dois ou mais países, dos fatores naturais, responsáveis por espalhar os recursos biológicos por amplas áreas, ${ }^{143}$ da auto-replicabilidade ${ }^{144}$ dos seres vivos, ${ }^{145}$ raros são os casos de endemismo.

\footnotetext{
${ }^{139}$ Cf. KOOPMAN, 2006, p. 140.

${ }^{140}$ Menos de $1 \%$ das espécies de plantas existentes na Terra já foi pesquisada; um número menor do que este de animais é conhecimento pela ciência. Cf. WORLD COMMISSION ON ENVIRONMENT AND DEVELOPMENT, 1987, cap. 6, para. 2-4.

${ }^{141}$ Cf. SOPLÍN; MULLER, 2008, p. 6.

${ }^{142}$ Cf. OLDHAM, 2005, p. 46.

${ }^{143}$ Cf. ICC, 2008a, p. 2.

${ }^{144}$ Cf. SAFRIN, 2004, p. 664-665.

145 Cf. VOGEL, 2004, p. 229 (cita o caso do quimioterápico de origem natural Paclitaxel (taxol), que é encontrado tanto na árvore Taxus brevifolia, originária do novo mundo, como na Taxus baccata, encontrada no velho mundo).
} 
Assim, não se deve confundir os recursos biológicos tangíveis com os intangíveis. Os últimos são os que apresentam valor aos setores industrial e científico. No entanto, notamos que, nos foros internacionais há uma tendência a não se atentar para estas diferenças. ${ }^{146}$ Essa falta de atenção pode conduzir à negociação de regimes internacionais inadequados para regular a proteção dos recursos biológicos intangíveis.

\subsubsection{O VALOR ECONÔMICO E SOCIAL DA BIODIVERSIDADE MEDICINAL}

As duas principais subcategorias de recursos da biodiversidade são os recursos biológicos medicinais e os recursos da biodiversidade agrícola (agrobiodiversidade). O valor destes recursos está em sua capacidade de sustentar um estoque amplo de fatores de produção, imprescindíveis ao desenvolvimento de novas soluções técnicas para os problemas os médicos, ambientais, agrícolas que afetam a humanidade. ${ }^{147}$

No que tange aos recursos biológicos medicinais, seu valor pode ser ilustrado com os potenciais resultados de alguns projetos de $\mathrm{P} \& \mathrm{D}$ em andamento no Brasil, que poderão culminar no desenvolvimento de novas drogas para o tratamento do mal de Alzheimer e de tipos diversos de tumores ${ }^{148}$ (inclusive para evitar a metástase), ${ }^{149}$ na cura para doenças negligenciadas, como a doença de Chagas, a leishmaniose e a malária; ${ }^{150}$ no desenvolvimento de um analgésico 600 vezes mais poderoso que a morfina ${ }^{151}$ e de um moderno antiasmático. ${ }^{152}$ Em termos de benefícios presentes, com poucos investimentos financeiros, a Universidade Federal do Maranhão, há alguns anos, distribui produtos fitoterápicos, derivados da biodiversidade brasileira, que comprovadamente melhoraram a qualidade de vida de portadores do HIV/AIDS. ${ }^{153}$ Em termos de benefícios futuros, em

\footnotetext{
${ }^{146} \mathrm{Cf}$. WTO, IP/C/W/423. Os países em desenvolvimento tendem a empregar o termo "recurso biológico" com mais freqüência que recurso genético, pois a utilidade industrial do último depende do controle de tecnologias, que muitos deles não dispõem (WTO, IP/C/M/49, para. 139).

${ }^{147}$ Cf. SWANSON; GOESCHL, 2002, p. 497.

${ }^{148}$ Cf. GIRARDI, 2008b.

${ }^{149}$ Cf. DE ALMEIDA, 2008.

${ }^{150} \mathrm{Cf}$. GIRARDI, $2008 \mathrm{a}$.

${ }^{151}$ Id., $2008 \mathrm{~d}$.

${ }^{152}$ Id., 2008c.

${ }^{153}$ Cf. PORTELA, 2004.
} 
2008, o Brasil e a França, objetivando explorar o potencial comercial da biodiversidade da Amazônia brasileira, firmaram um acordo de cooperação científica e tecnológica. ${ }^{154}$

Na economia real, os benefícios dos recursos da biodiversidade já são palpáveis. Estima-se que $40 \%$ da economia mundial tenham por base produtos e processos desenvolvidos a partir da biodiversidade, ${ }^{155}$ e que, se o ritmo presente de deterioração das florestas se mantiver até 2050, a economia mundial encolherá ao menos 5\%. ${ }^{156}$ Entre 1983 e 1994, 62\% das drogas para tratamento do câncer, comercializadas no mundo, originaramse da manipulação de moléculas encontradas na natureza. ${ }^{157} \mathrm{Em} \mathrm{1999}$, o mercado mundial de medicamentos, desenvolvidos a partir de plantas, alcançou a cifra de US\$ 40 bilhões/ano. ${ }^{158}$ Enfim, a biodiversidade, se associada à ciência e tecnologia, pode catalisar o desenvolvimento econômico, ${ }^{159}$ inclusive dos países em desenvolvimento, onde se concentram as maiores parcelas de recursos da biodiversidade. ${ }^{160}$

Os recursos biológicos podem apresentar em sua composição compostos bioativos, úteis ao desenvolvimento de produtos medicinais para o tratamento humano e veterinário. Tais compostos podem ser extraídos diretamente dos recursos biológicos ou sintetizados em laboratório, ou podem ainda servir de base ao desenvolvimento de moléculas diversas. Embora as últimas não se confundam com a molécula natural, esta pode oferecer dicas de como alcançar determinado produto, que a ciência convencional enfrentava dificuldades para desenvolver. Ademais, os recursos biológicos podem conter seqüências genéticas, responsáveis pela expressão de moléculas comercial ou cientificamente interessantes, que

${ }^{154}$ Cf. [BRASIL E FRANÇA] ..., 2008.

${ }^{155}$ Cf. THE CRUCIBLE II GROUP, 2000, p.1.

${ }^{156}$ Cf. EUROPEAN PARLIAMENT et al., 2008 , p. 5.

${ }^{157}$ Ver NEWMAN; CRAGG; SNADER, 2000, p. 226 (todos os compostos mencionados neste estudo são semi-sintéticos ou totalmente sintéticos. Isto significa que, embora tenham como origem uma molécula encontrada na natureza, resultaram de manipulações realizadas em suas estruturas químicas, com vistas a minimizar efeitos tóxicos ou potencializar efeitos terapêuticos ou torná-las solúvel em determinado meio etc. O papel do homem no desenvolvimento destas moléculas sintéticas, no entanto, não minimiza em nada a importância dos compostos naturais: sem o auxílio prestado pelas molécula naturais, o homem não teria alcançado as moléculas semisintéticas ou sintéticas. O estudo confirma a complementaridade que a biodiversidade e a ciência de ponta desempenham no processo de desenvolvimento de novas terapias).

${ }_{158}$ Cf. UNEP, 1999 , p. 167.

${ }^{159}$ Cf. ORGANIZACIÓN DEL TRATADO DE COOPERCIÓN AMAZÓNICA, 2000.

${ }^{160} \mathrm{Em} 18$ de fevereiro de 2002, dezessete países ricos em termos biológicos e culturais formaram o Grupo dos Países Megadiversos (GPM). Os países que formam o GPM são Bolívia, Brasil, China, Colômbia, Costa Rica, República Democrática do Congo, Equador, Índia, Indonésia, Quênia, Madagascar, Malásia, México, Peru, Filipinas, África do Sul, Venezuela. O GPM congrega mais de 70\% de toda a biodiversidade do mundo e $45 \%$ da população mundial. O grupo foi estabelecido para coordenar ações de defesa internacional dos recursos genéticos, conhecimentos tradicionais e assegurar a repartição justa e equitativa decorrente de seu uso. Cf. MINISTRY OF ENVIRONMENT \& FORESTS, GOVERNMENT OF INDIA, 2005. 
podem ser isoladas e inseridas em leveduras para produção industrial das moléculas de interesse. ${ }^{161}$ Enfim, os recursos biológicos são indispensáveis à vida humana, e se tornam cada vez mais relevantes ao desenvolvimento científico e industrial de qualquer país. ${ }^{162}$

A indústria farmacêutica e da biotecnologia são as que mais demandam recursos biológicos para a condução de projetos de P\&D. Existe uma demanda contínua por novos insumos biológicos para o processo de $\mathrm{P} \& \mathrm{D}$, uma vez que estas indústrias sofrem duas ameaças constantes: a chamada "destruição criativa," marcada pela obsolescência gerada por novas alternativas técnicas, superiores em qualidade, introduzidas pela concorrência; e a "destruição adaptativa", isto é, os produtos biotecnológicos e biomédicos perdem mercado, à medida que perdem eficácia no combate a pestes, pragas e enfermidades. ${ }^{163}$

\subsubsection{RECURSOS DA AGROBIODIVERSIDADE}

A agrobiodiversidade inclui "as variedades e a variabilidade de animais, plantas e microorganismos ao nível genético e de espécies."164 Dentre os recursos da agrobiodiversidade de interesse mais destacado estão as variedades agrícolas tradicionais (variedades tradicionais). Entende-se por variedades tradicionais aqueles recursos biológicos, desenvolvidos ao longo dos 10 mil anos de agricultura, geralmente em centros de origem da diversidade biológica, ${ }^{165}$ por uma associação entre fatores ambientais e intensiva intervenção humana. ${ }^{166}$ A última toma a forma de processos de observação, seleção consciente das variedades mais produtivas, nutritivas e resistentes a pragas e

${ }^{161}$ Cf. ICC, 2008a, p. 2.

${ }_{162}$ Cf. BURHENNE-GUILMIN; LEFKOWITZ, 1992, p. 43-44.

${ }^{163}$ Cf. SWANSON; GOESCHL, 2002, p. 479.

${ }^{164} \mathrm{Cf}$. parágrafo $1^{\circ}$ do apêndice, COPCBD, Decision V/5.

${ }^{165}$ Centros de origem da diversidade biológica são regiões que congregam as condições ambientais, climáticas, humanas mais favoráveis ao desenvolvimento de espécies; por conseguinte, concentram as maiores e mais importantes parcelas de diversidade biológica em todo o mundo. Estas regiões encontram-se, em regra, nos países em desenvolvimento. Isto não significa, no entanto, que outras regiões do mundo não tenham contribuído ao desenvolvimento das variedades tradicionais. Nos chamados centros secundários, variedades originadas nos centros de origem ganharam traços diferentes, à medida que foram se adaptando a novas condições ambientais e passaram por processos de intervenção humana. Ver, e.g., FONTES; DA ROCHA; VARELLA, 1999, p. 21-22; BIBER-KLEMM, 2006, p. 165.

166 Neste sentido ver BRUSH, 1994, p. 5; SHIVA, 2001, p. 77; PERSIC; MARTIN, 2008, p.126; HALEWOOD et al, 2006, p. 188; FAO, Resolución 5/89. 
intempéries, cruzamento contínuo com variedades de origens diversas e livre intercâmbio de material de propagação com outras comunidades. ${ }^{167}$

Os recursos da agrobiodiversidade são os recursos biológicos mais relevantes ao homem: enquanto os recursos biológicos medicinais são úteis quando o homem adoece, alimentar-se é uma necessidade, independente de seu estado de saúde. Tais recursos são importantes tanto para regiões materialmente pobres - como é o caso da África, onde 95\% da agricultura dependem de variedades tradicionais $-{ }^{168}$, como em um país super industrializado, como é o caso da Alemanha. ${ }^{169}$ Sua relevância econômica não é desprezível: apenas o setor de sementes movimentou, em 2006, US\$ 22.9 bilhões. ${ }^{170}$ Seu valor social e comercial é confirmado pela tendência recente dos grandes conglomerados industriais de reivindicar patentes sobre seqüências de DNA de variedades tradicionais, que lhes conferem resistência ao estresse resultante das mudanças climáticas e ambientais. $^{171}$

\subsubsection{O PAPEL DAS COMUNIDADES AGRÍCOLAS NO DESENVOLVIMENTO DA AGROBIODIVERSIDADE}

As comunidades de agricultores tradicionais, cientes de que o cultivo de um número reduzido de variedades tradicionais tornaria suas lavouras vulneráveis a pragas e intempéries, buscam minimizar sua fragilidade por meio do intercâmbio contínuo de recursos da agrobiodiversidade com outras comunidades agrícolas. Essas comunidades misturam suas variedades com as de outras procedências a fim de permitir sua autopolinização e o enriquecimento de sua diversidade genética. Da safra resultante, os agricultores selecionam as melhores sementes, segundo as qualidades que valorizam, e posteriormente as intercambiam com outras comunidades, que as cultivarão em novas condições ambientais, o que promoverá a aquisição de novas características ao longo do

\footnotetext{
${ }^{167}$ Ver para 7(a), FAO, 1996a.

${ }^{168}$ Cf. ETC GROUP, 2008b, p. 13-15.

${ }^{169}$ Durante a $2^{\mathrm{a}}$ Guerra Mundial, o regime nazista tinha clara a necessidade de pilhar coleções estrangeiras de recursos da agro-biodiversidade para assegurar novas variedades vegetais para alimentar o povo alemão. Em 1938/39, a SS comandou uma missão ao Tibete e, em 1943, liderou a "Sammelkommando", missão voltada à pilhagem das coleções ex situ de germoplasma da antiga União Soviética, espalhadas pela Ucrânia e Criméia. Os recursos apropriados formaram o acervo do Instituto para Fitogenética da SS, baseado no castelo de Lannach, onde foram conduzidas pesquisas voltadas ao desenvolvimento de novas variedades de grãos, adaptados às características do meio ambiente local (THORNSTRÖM; HOSSFELD, 2002a, 2002b).

${ }^{170}$ Cf. ETC GROUP, $2007 b$.

${ }^{171}$ Id., 2008 b.
} 
tempo. ${ }^{172}$ A troca ocorre tão intensamente que é possível observar que uma determinada variedade tradicional pode se difundir por diversas regiões geográficas, muito distantes do ponto de partida. ${ }^{173}$

O livre intercâmbio de variedades tradicionais entre comunidades agrícolas e seu uso perene por elas são fatores essenciais para a sustentação do ciclo de desenvolvimento de novas variedades tradicionais, ${ }^{174}$ cada vez mais adaptáveis aos novos desafios climáticos e à demanda humana por variedades mais produtivas. ${ }^{175}$ Deve-se também a esta prática milenar, a emergência da indústria do melhoramento vegetal nos países industrializados no início do século XX e, ironicamente, a própria extensão do regime de DPI aos recursos vivos ${ }^{176}$ cuja característica central é a restrição da livre difusão das variedades protegidas.

No entanto, o livre intercâmbio intercomunitário e o fato das variedades tradicionais serem, a um só tempo, um fator de produção e um produto de consumo, ${ }^{177}$ levam à sua dispersão por todo o mundo, ${ }^{178}$ apagando qualquer possível vínculo mais forte entre uma determinada comunidade agrícola e "suas" variedades tradicionais. Ademais, ao longo dos últimos cinco séculos, a ampla disseminação dos recursos da agrobiodiversidade levou-os a adquirir novas características em cada uma das regiões, onde foram introduzidos. ${ }^{179}$ Portanto, seria iníquo reconhecer, em favor de determinada comunidade tradicional, o status de fonte genésica de uma determinada variedade tradicional, quando em seu processo de desenvolvimento participou um grupo indeterminado e indeterminável ${ }^{180}$ de comunidades agrícolas, ainda que de modo não planejado. ${ }^{181}$

Embora as práticas de intercâmbio criem obstáculos à identificação das comunidades e dos Estados de origem desses recursos, a limitação de sua continuidade colocaria em risco à própria agrobiodiversidade. Nos últimos séculos, um processo intenso

\footnotetext{
${ }^{172}$ Cf. HALEWOOD et al., 2006, p. 178-179.

${ }^{173}$ Ibid.

${ }^{174}$ Cf. parágrafo $2^{\circ}$, alíneas (b), (e), (f), apêndice da COPCBD, Decision V/5.

${ }^{175}$ Cf. RAMANNA; SMALE, 2004.

${ }^{176}$ Cf. LOUWAARS et al, 2006, p. 56; SWANSON; GOESCHL, 2007, p. 10.

${ }^{177}$ Cf. SHIVA, 2001, p. 74; CHEN, 2006, p. 9.

${ }^{178}$ Ver FAO, [200-].

${ }^{179}$ Cf. para 7 (c), FAO, 1996a.

${ }^{180}$ Cf. HARDON; VOSMAN; VAN HINTUM, 1994, p. 15-17.

${ }^{181}$ Ver BRAGDON, 2002, p. 448; HALEWOOD et al., op.cit., p. 175-178.
} 
de transferência de variedades tradicionais dos países em desenvolvimento em direção às coleções ex situ $^{182}$ dos países industrializados tomou lugar. No entanto essas coleções estão longe de representar a riqueza genética cultivada pelas comunidades agrícolas. Ainda que no dia de hoje, fossem coletadas amostras de todas as variedades tradicionais existentes na Terra, as coleções ex situ formadas seriam insuficientes para satisfazer as necessidades futuras da humanidade. Com as mudanças climáticas, as variedades tradicionais em depósito podem ser tornar inaptas ao enfrentamento de desafios ambientais e climáticos emergentes. Apenas aquelas variedades cultivadas continuamente estão sujeitas ao livre intercâmbio intercomunitário e à subseqüente introdução em novos ambientes; são essas as mais capacitadas a enfrentar os novos desafios. ${ }^{183}$

Como conseqüência do processo de concentração da atividade agrícola em grandes propriedades de monocultura e da ampla introdução de variedades vegetais homogêneas, desenvolvidas por empresas de agrobiotecnologia, as comunidades agrícolas tradicionais vêm se desmantelando e com elas, a agrobiodiversidade. ${ }^{184}$ No contexto atual marcado pelo prenúncio de hecatombes climáticas, a perda desse patrimônio representa um grande risco à segurança alimentar da humanidade no médio e longo prazo. Nesse contexto, a conservação das variedades tradicionais em processo de constante intercâmbio é de fundamental importância à humanidade.

Em sumários, as variedades tradicionais apresentam características específicas, que as diferenciam dos recursos da biodiversidade medicinais, notadamente: ${ }^{185}$

i. $\quad$ Resultam da intervenção intensiva do homem;

ii. Têm origem em centros de diversidade, localizados nas regiões tropicais e subtropicais, e de lá se dispersaram por todo o planeta;

\footnotetext{
${ }^{182}$ Coleções ex situ são bancos que conservam os componentes da diversidade biológica fora de seus habitats naturais. Pode-se mencionar como exemplos de coleções ex situ os bancos de recursos genéticos e os jardins botânicos.

${ }^{183}$ Cf. BRUSH, 1994, p. 2-3.

184 As comunidades agrícolas de todo o mundo, ao longo dos 10.000 anos de história da agricultura, desenvolveram em torno de 10.000 espécies da plantas diferentes para a alimentação; na atualidade, tãosomente 150 variedades de plantas são responsáveis por alimentar a maior parte da humanidade. A FAO estima que $75 \%$ dos recursos fitogenéticos para a agricultura se perderam apenas no século XX (INTERNATIONAL PLANT [...], 2004).

${ }^{185}$ Cf. LOUWAARS et al., 2006, p. 57.
} 
iii. Devido à sua ampla difusão ao longo da história do homem, que recrudesceu a partir dos séculos XV-XVI, com a expansão das fronteiras do comércio internacional, as variedades tradicionais, originadas em regiões tropicais e subtropicais, passaram a ser cultivadas em todo o mundo. Neste processo, essas variedades ganharam novas características que tornam difícil—se não impossível-a identificação de sua origem;

iv. Todos os países do mundo, mesmo aqueles em que estão localizados os centros de diversidade, dependem de recursos fitogenéticos de múltiplas regiões a fim de conservarem a variabilidade genética indispensável ao enfrentamento de pragas emergentes e mudanças ambientais inesperadas. Assim sendo, o livre intercâmbio de variedades tradicionais é uma condição para a sobrevivência da agricultura; e

v. Uma vez que congregam uma grande diversidade genética em sua composição, as variedades tradicionais não apresentam estabilidade intergeracional e homogeneidade intrageracional. ${ }^{186}$

\subsection{CONHECIMENTOS Tradicionais}

Os conhecimentos tradicionais de maior relevância prática são aqueles que se associam aos recursos da biodiversidade (CTAs), notadamente, os conhecimentos sobre as aplicações medicinais de recursos da biodiversidade e os conhecimentos associados à agrobiodiversidade. $^{187}$

Os CTs de natureza agrícola se integram aos recursos da agrobiodiversidade, sendo impossível separá-los uns dos outros. ${ }^{188}$ A ampla variedade de frutas, grãos, legumes, verduras nutritivos e saborosos que suportam a humanidade é uma decorrência direta dos esforços ingentes empreendidos pelas comunidades tradicionais agrícolas, fundamentalmente baseadas nos países em desenvolvimento. Graças ao seu trabalho diário

${ }^{186}$ Cf. BIBER-KLEMM, 2006, p. 169.

${ }^{187}$ Ibid., p. 160.

${ }^{188}$ Ibid. 
de observação, seleção, melhoramento e cultivo, as gerações presentes herdaram um patrimônio biológico capaz de sustentá-la condignamente. ${ }^{189}$

Já os CTs de natureza médica se associam aos recursos da biodiversidade, sendo deles destacáveis; sem embargo, seu valor deles depende. Tais conhecimentos não ganharam importância apenas com a emergência da indústria da biotecnologia nas últimas três décadas, capacitada a manipular o genoma de recursos vivos para a geração de processos e produtos úteis ao homem. Já ao final do séc. XIX, a Índia tinha em funcionamento um comitê, dedicado a estudar o valor medicinal das plantas indianas, utilizadas pela medicina tradicional deste país. ${ }^{190}$

As duas categorias de CTs apresentam aspectos em comum e peculiaridades. As observações realizadas nesta seção a respeito dos $\mathrm{CT}$ s associados à biodiversidade e à agrobiodiversidade devem ser examinadas em conjunto com os itens supra, onde se analisou as características dos recursos biológicos em geral e dos recursos da agrobiodiversidade.

\subsubsection{CARACTERÍSTICAS GERAIS DOS CONHECIMENTOS TRADICIONAIS ASSOCIADOS À BIODIVERSIDADE}

Não existe consenso internacional sobre quais conhecimentos devam ser concebidos como "tradicionais"; ${ }^{191}$ o único consenso é a respeito de seu caráter técnico. Os conhecimentos desenvolvidos pelas comunidades tradicionais não se limitam àqueles de natureza prática, associados à sua alimentação e à sua sobrevivência. Segundo LéviStrauss, as comunidades tradicionais apresentam uma pré-disposição natural à busca pelo conhecimento do entorno em que vivem. ${ }^{192}$ Do conhecimento dos biomas em que vivem, os membros destes grupos identificam as aplicações e qualidades dos elementos constitutivos destes biomas que podem servir à sua subsistência e à melhoria da qualidade de vida do ser humano em geral.

\footnotetext{
${ }^{189}$ Ver FAO, Resolución 4/89, Resolución 5/89, 1996a. Cf. item 1.3.3.1.

${ }^{190}$ Ver SOME [...], 1909; ARNOLD, 2003.

${ }^{191}$ Cf. WIPO, WIPO/GRTKF/IC/12/5(b), anexo, p. 17-37; SCBD, UNEP/CBD/WG8J/2/7, para. 74.

192 Cf. LÉVI-STRAUSS, 2006, p. 18-24.
} 
Um entendimento recorrente e simplista de CT compreende apenas aqueles conhecimentos técnicos associados aos recursos da biodiversidade, os quais são conservados por comunidades indígenas. Esta definição estabelece difículdades para uma compreensão correta do alcance do termo, pois nem todos os detentores de conhecimentos tradicionais são povos indígenas ${ }^{193}$ e nem todos os CTs se associam à biodiversidade. Os CTs indígenas constituem tão-somente uma categoria de CT, diferenciando-se dos demais pelo grupo que os detêm. ${ }^{194}$

De qualquer forma, a origem étnica e o arcabouço cultural diferenciado dos detentores dos CTs desempenham um papel central na construção de sua definição. Um determinado conhecimento será ou não caracterizado como "tradicional" dependendo, dentre outros fatores, de quem o conserva e exerça titularidade. ${ }^{195}$ CTs são detidos por grupos marginalizados e culturalmente distintos, portadores de estilos de vida "tradicionais", ou seja, seguindo as tradições de seus antepassados, estes grupos extraem seus meios de subsistência do meio ambiente natural ${ }^{196}$ em que vivem, sem lançar mão de recursos e tecnologias modernas. ${ }^{197} \mathrm{O}$ vínculo do tema a grupos social e economicamente marginalizados torna-o de relevância aos direitos humanos. ${ }^{198}$

A OMPI entende por CT, aquele que: apresentar um vínculo com uma comunidade tradicional, responsável por sua preservação e transmissão de geração a geração (1); ter sido criado e preservado em um contexto tradicional (2); ser parte integrante da identidade cultural de uma comunidade que exerce o papel de guardiã dos conhecimentos para suas futuras gerações, por meio da observância de normas sociais, disciplinadoras de seu uso e transmissão (3). ${ }^{199}$

O predicado "tradicional" pode sugerir que os conhecimentos integrantes desta categoria de conhecimentos técnicos são transmitidos em formato "fossilizado", desde

\footnotetext{
${ }^{193}$ Cf. SCBD, UNEP/CBD/WG8J/3/INF/1, p. 9.

${ }^{194}$ Cf. DUTFIELD, 2004a, p. 141.

${ }^{195}$ Cf. SCBD, UNEP/CBD/WG8J/3/INF/1, p. 9 et seq.; WIPO, WIPO/GRTKF/IC/12/5(b), anexo, p.35.

196 Os CTs não foram originalmente gerados para serem comercializados, mas para satisfazerem as necessidades das comunidades que os conservam e utilizam. Ver OMPI, WIPO/GRTKF/IC/12/5(b), anexo, p. 57.

${ }^{197} \mathrm{Cf}$. SCBD, UNEP/CBD/WG8J/2/5, para. 8. Aplicando esse critério para determinar os grupos que detêm CTs, a ONU estima que entre 1.5 e 2 bilhões de pessoas estejam abrangidas na definição de comunidades tradicionais. Ou seja, até um terço da população mundial.

${ }^{198}$ Id., UNEP/CBD/WG8J/3/INF/1, p. 11

${ }^{199}$ Cf. WIPO, WIPO/GRTKF/IC/13/5(b)Rev., para. 20.
} 
tempos imemoriais. De fato, os CTs são difundidos, desde tempos imemoriais, pelas gerações mais velhas às mais jovens, em suas relações diárias. ${ }^{200}$ No entanto, o termo não deixa transparecer a atividade criativa contemporânea dos membros das comunidades tradicionais, que atualizam os conhecimentos antigos em face das demandas presentes. ${ }^{201}$ Deve-se, pois, ter claro que a natureza "tradicional" dos conhecimentos de comunidades tradicionais não implica sua antiguidade. "Tradicional" confere conteúdo cultural aos conhecimentos, interligando-os à identidade cultural de um determinado grupo humano, ${ }^{202}$ ou seja, é tradicional aquele conhecimento gerado e utilizado como parte das tradições de um determinado grupo. ${ }^{203}$ Por conseguinte, novos conhecimentos são desenvolvidos ininterruptamente pela atividade intelectual ${ }^{204}$ dos membros de comunidades tradicionais. $^{205}$ Os CTs contemporâneos apresentam laços com o passado - com o patrimônio cultural acumulado pelo grupo ${ }^{206}$ - e com o futuro, porquanto a sobrevivência do grupo depende da conservação de seu patrimônio intelectual. ${ }^{207}$

Embora nem todo CT se associe aos recursos da biodiversidade, com freqüência com eles conservam uma relação de forte interdependência. ${ }^{208} \mathrm{Sem}$ conhecimento, um elemento da natureza é apenas um recurso desconhecido, despido de valor. ${ }^{209}$ Os recursos biológicos e os conhecimentos constituem para as comunidades tradicionais, respectivamente, uma extensão de sua própria sociedade ${ }^{210}$ e uma emanação do mundo espiritual no mundo material. ${ }^{211}$ A relação de respeito das comunidades tradicionais para

\footnotetext{
${ }^{200}$ Cf. PERSIC; MARTIN, 2008, p. 15.

${ }^{201}$ Cf. NAKASHIMA, 2000, p. 432.

${ }^{202}$ Cf. art. 4(2), CPPDEC.

${ }^{203}$ Cf. HOWELL, [200-?], p. 18.

${ }^{204} \mathrm{Cf}$. WIPO, WIPO/GRTKF/IC/12/5(b), p. 25-26. O sistema de conhecimento tradicional mais importante do Sri Lanka tem como raízes a medicina Ayurveda, originária na Índia. Este sistema sofreu mudanças e adaptações no Sri Lanka. Conhecimentos tradicionais indianos foram adaptados em face da realidade botânica do Sri Lanka; receitas foram modificadas e novas plantas locais tomaram o lugar de plantas indianas, alcançando os mesmos propósitos alcançados pelas receitas originais. Este exemplo comprova, empiricamente, que os sistemas de conhecimentos tradicionais são dinâmicos e inventivos, afinal substituir plantas estrangeiras por locais, às vezes pertencentes a outros grupos taxonômicos, não é uma tarefa mecânica(KUMAR, 2004, p. 299-303). No mesmo sentido, SUNDER, 2006, p. 15; GUPTA, 2006, p. 62; VAN BEEK; JARA, 2002, p. 40.

${ }^{205} \mathrm{O}$ trabalho criativo de um único indivíduo, associado à uma comunidade cultural, pode ser considerado a expressão da criatividade da comunidade, desde que seja construído sobre o patrimônio intelectual acumulado e conservado por ela e expresse suas expectativas (BARSH, 1999, p. 16).

${ }^{206}$ Cf. HARDING, 2003-2004, p.513.

${ }^{207}$ Cf. KALINOE, 2004, p. 42.

${ }^{208}$ Cf. SCBD, UNEP/CBD/COP/6/7, para. 28.

${ }^{209}$ Nas palavras de Atul Kaushik (2004, p. 85) “conhecimentos tradicionais [...] são o componente intangível dos recursos biológicos".

${ }^{210}$ Cf. POSEY, 2004a, p. 125.

${ }^{211}$ Id., 2004i, p. 196.
} 
com a natureza reflete seu sábio entendimento de que, se não os empregarem dentro de sua capacidade de regeneração, seus meios de sobrevivência restarão extintos. ${ }^{212}$

Todo e qualquer sistema de conhecimento tem raízes culturais, inclusive o sistema científico ocidental. A ciência ocidental é apenas uma das formas de saber. ${ }^{213}$ Por isso, não deveria ser uma surpresa à sociedade dominante que outros grupos humanos também tenham desenvolvido um sistema de conhecimentos sofisticado. ${ }^{214}$ Portanto, "os conhecimentos tradicionais devem ser valorizados, respeitados e considerados tão úteis e necessários quanto qualquer outra forma de conhecimento." 215

Os sistemas tradicionais de conhecimentos, tal como a ciência ocidental, são enraizados em visões específicas de mundo. ${ }^{216}$ A ciência ocidental isola o homem do mundo natural e espiritual, enquanto os sistemas tradicionais de conhecimentos valorizam uma perspectiva holística do mundo. ${ }^{217}$ Para muitas comunidades tradicionais, a vida é representada por uma rede de ligações entre o homem, a natureza e a espiritualidade. ${ }^{218}$ Os CTs alimentam uma forte ligação com a natureza, pois resultam da interação entre o homem e o meio ambiente, em busca de soluções para seus problemas cotidianos. Por esta razão, os CTs geralmente se apresentam como instrumentos úteis para a gestão sustentável de ecossistemas naturais.

Outra diferença entre o sistema de conhecimento científico formal e o tradicional está em seu formato de apresentação. O conhecimento científico formal é expresso em formato codificado, i.e. em um formato que viabiliza sua fácil transmissão impessoal ao grande público. O conhecimento científico ocidental é analítico e valoriza o emprego de

212 Cf. POSEY, 2004b, p. 64; SCBD, UNEP/CBD/WG8J/4/INF/14, p.7-8. Sem embargo, há sim comunidades tradicionais que empregam técnicas insustentáveis de manejo da biodiversidade. Neste sentido, $\mathrm{SCBD}, \mathrm{UNEP} / \mathrm{CBD} / \mathrm{WG} 8 \mathrm{~J} / 3 / \mathrm{INF} / 1$, p. 17-18. No entanto, a existência de erros de gestão da biodiversidade por parte de algumas comunidades tradicionais não deveria desmerecer seus acertos.

${ }^{213}$ Cf. item 3(4), SECRETARÍA DE LA CONFERENCIA MUNDIAL SOBRE LA CIENCIA, 1999.

${ }^{214}$ Cf. SCBD, UNEP/CBD/WG8J/4/INF/16, para. 23; NAKASHIMA, 2000, p. 31.

${ }^{215}$ Cf. COPCBD, Decision V/16, para. 24. No mesmo sentido ver preâmbulos COPCBD, Decision III/14 e Decision IV/9.

${ }^{216}$ Agrawal (199-?, p. 3-5) critica tentativas de se separar os conhecimentos tradicionais dos conhecimentos científicos ocidentais, pois estas categorias de conhecimentos são construídas sobre uma base de forte intercâmbio de conhecimentos, não havendo um sistema puramente tradicional ou ocidental. Ademais, se o valor dos conhecimentos tradicionais depende de sua validação pelos métodos científicos formais, não haveria sentido em separá-los. No mesmo sentido, ver HARDING, 2003-2004, p. 518; GUPTA, 2004, p. 49.

217 Cf. INTERNATIONAL COUNCIL FOR SCIENCE, $2002 \mathrm{~b}$.

${ }^{218}$ Cf. SCBD, UNEP/CBD/WG8J/2/6/Add.1, para. 6. 
instrumentos metodológicos que permitem o distanciamento entre o observador e o objeto de seu estudo, sem prejudicar o conteúdo do conhecimento. ${ }^{219}$

O conhecimento tradicional é usualmente tácito, ou seja, ele não está cristalizado em objetos comerciais (e.g. uma invenção) e sua transmissão depende de uma relação próxima com a comunidade que o conserva. ${ }^{220} \mathrm{Na}$ falta de domínio de uma linguagem compreensível universalmente, a transmissão de conhecimentos adquiridos a partir da experiência prática se dá pela via oral. ${ }^{221}$ Graças à existência de publicações internacionais dedicadas ao estudo dos CTs, ${ }^{222}$ com rapidez grandes parcelas de CTs foram codificadas nas últimas décadas, facilitando sua transmissão em escala internacional. ${ }^{223}$

Uma vez que não detém os instrumentos técnicos, típicos da ciência ocidental, para identificar os princípios bioativos e as leis biológicas, que regem a interação entre a aplicação dos recursos biológicos e os resultados técnicos alcançados, o detentor de CTs conduz experimentos de tentativa e erro, guiado por sua intuição ${ }^{224}$ e pela observação minuciosa das características presentes nos recursos biológicos. Seguindo a mesma lógica que dirige a Homeopatia ("o semelhante age sobre o semelhante"), com freqüência, os membros de comunidades tradicionais crêem que os recursos da natureza ocultam em suas características naturais (e.g. odor, textura, coloração, formato) sua potencial função terapêutica. ${ }^{225}$ De fato, não é fantasioso associar a função de um recurso da natureza às suas características naturais: por exemplo, uma fatia de cenoura lembra muito um olho; sabidamente, este legume é rico em beta-caroteno. A metade de uma noz (gênero Juglans), com seu formato e nervuras, nos remete ao cérebro. A ciência ocidental indica que este fruto contém substâncias fundamentais para o bom funcionamento do cérebro. ${ }^{226}$

\footnotetext{
${ }^{219}$ Cf. JOHNSON, 1992.

${ }^{220}$ Cf. STRATHERN, 2004, p. 98-99.

${ }^{221}$ Cf. RAHMAN, 2004, p. 313 et seq.

222 A OMPI identificou cerca de 180 publicações diferentes dedicadas aos CTs. A título de exemplo, podemos mencionar o Journal of Ethnobiology, o Journal of Ethnobiology and Ethnomedicine e o Journal of Ethnopharmacology (SCHIWY-RAUSCH, 2006b).

223 Existem dúvidas se estas publicações são totais substitutos para a interação direta com os grupos detentores de conhecimentos sobre as aplicações medicinais de recursos da biodiversidade. Lewis e ElvinLewis (1995, p. 20) concluíram, ao avaliarem comparativamente a atividade antiviral de plantas indicadas pela literatura especializada (fontes secundárias) e aquelas indicadas diretamente pelos detentores de CTs medicinais (fontes primárias), que as indicações feitas pelas fontes primárias chegam a ser 5 vezes mais eficientes que as derivadas de fontes secundárias.

${ }^{224}$ Cf. JOHNSON, 1992.

${ }^{225}$ Cf. RODRIGUES, 2001, p. 34-35.

${ }^{226}$ Cf. BAGLEY, 2008.
} 
Do mesmo modo que o livre intercâmbio de recursos da agrobiodiversidade é fundamental para sua conservação e desenvolvimento contínuo, o compartilhamento de conhecimentos é outra feição de relevo dos sistemas tradicionais de conhecimentos. ${ }^{227}$ Os detentores de conhecimentos tradicionais igualmente reconhecem, aceitam e adotam os elementos de sistemas de conhecimentos diversos, tal como a sociedade ocidental adota elementos dos sistemas tradicionais de conhecimentos. ${ }^{228}$

\subsubsection{O PAPEL DE GUARDIÃS DAS COMUNIDADES TRADICIONAIS}

As comunidades tradicionais não se vêem como proprietárias dos conhecimentos e recursos biológicos que conservam, mas como suas guardiãs para as futuras gerações. ${ }^{229}$ Estes grupos tendem a ver seus conhecimentos e recursos naturais como dádivas do Criador; e devido à importância dessas dádivas, estabelecem regras para sua transmissão, uso e conservação. Assim aquele que recebe um CT, recebe com ele responsabilidades e não simplesmente direitos de uso. ${ }^{230}$ Neste sentido, a parábola bíblica dos talentos reflete apropriadamente a perspectiva das comunidades tradicionais de que deter conhecimentos e recursos é deter responsabilidades perante a sociedade. ${ }^{231}$

As normas sociais das comunidades tradicionais, reitoras do uso e transmissão dos CTs, variam de comunidade para comunidade, mas seu objetivo essencial é evitar a quebra das responsabilidades de seus membros, assumidas perante o mundo natural e espiritual. ${ }^{232}$ Portanto, os CTs não existem de modo isolado de um contexto social e cultural, ${ }^{233}$ e o processo conduzido pelos criadores e inovadores do ocidente de separação do objetivo do subjetivo e dos aspectos culturais é severamente criticado pelos criadores tradicionais. ${ }^{234}$

Apesar da importância das normas sociais, elas perdem dia-a-dia seu poder disciplinador, à medida que os vínculos sociais que unem os componentes das comunidades se deterioram e com o avanço das pesquisas científicas, que disseminam

${ }^{227}$ Cf. KARBOLO, 2004, p. 274.

${ }^{228}$ Cf. INTERNATIONAL COUNCIL FOR SCIENCE, 2002b, p. 4.

${ }^{229}$ Cf. SCBD, UNEP/CBD/WG8J/5/3/Add.2, para. 28.

${ }^{230} \mathrm{Id} ., \mathrm{UNEP} / \mathrm{CBD} / \mathrm{WG} 8 \mathrm{~J} / 4 / 11$, p. 19.

${ }^{231}$ Mateus, cap. XXV, versículos 14-30.

${ }^{232} \mathrm{Cf}$. SCBD, UNEP/CBD/WG8J/4/INF/9, para. 84.

${ }^{233} \mathrm{Cf}$. WIPO, WIPO/GRTKF/IC/12/7, para. 6 .

${ }^{234}$ Cf. NAKASHIMA, 2004, p. 132. 
amplamente conhecimentos até então restritos às comunidades. Com esta difusão, os usuários destes conhecimentos deixam de estar sob a área de influência das autoridades comunitárias pertinentes, tornando suas normas sociais disfuncionais. ${ }^{235}$

Em síntese, o termo "conhecimento tradicional" compreende inovações, conhecimentos e práticas, altamente especializados, ${ }^{236}$ portadores das seguintes características:

i. Desenvolvidos seqüencialmente ao longo do tempo, por meio do método de tentativa e erro e da observância das características dos recursos da biodiversidade ${ }^{237}$.

ii. Não se vinculam a qualquer campo específico da tecnologia, podendo abranger, inter alia, conhecimentos medicinais, relacionados à biodiversidade, meio ambiente, alimentação e agricultura; ${ }^{238}$

iii. Resultam da atividade criativa de um grupo de indivíduos; ${ }^{239}$

iv. São construídos colaborativamente: as comunidades locais tendem a compartilhar seus conhecimentos tradicionais com outras comunidades; ${ }^{240}$

v. São associados às raízes sociais, históricas, religiosas e espirituais de grupos culturalmente diferenciados; ${ }^{241}$

vi. São transmitidos oralmente;

${ }_{235}^{235}$ Cf. LOSHIN, 2007, p. 26; FAUCHART; VON HIPPEL, 2006, p. 27.

${ }^{236}$ Diferentemente do julgamento precipitado de alguns de que os conhecimentos indígenas apenas seriam úteis para o tratamento de problemas de saúde comezinhos (neste sentido, ver GERAQUE, 2007), apenas a título de ilustração, vale mencionar que um dos sistemas de conhecimentos tradicionais médicos do Sri Lanka- o Desiya Chikitsa - é especializado para tratar uma diversidade de doenças, tais como oculares, fraturas, dermatológicas etc (KUMAR, 2004, p. 299 et seq).

${ }^{237}$ Cf. GUPTA, 2004, p. 29.

${ }^{238}$ Cf. WIPO, 2001, p. 211-212.

${ }^{239}$ Cf. BIBER-KLEMM, 2004, p.96.

${ }^{240} \mathrm{Cf}$. UNEP/CBD/WG8J/4/INF/9, para. 19.

${ }^{241}$ Cf. WIPO, 2001, p. 211-212. 
vii. Seu uso e transmissão intra e intercomunitária são regidos por protocolos culturais $^{242}$

viii. Alimentam uma relação de dependência e respeito com a natureza, ${ }^{243}$ o que resulta em seu uso sustentável e sua conservação para as presentes e futuras gerações; ${ }^{244}$

ix. São factuais e pessoais, ou seja, são colhidos junto às experiências diárias de seus detentores; ${ }^{245}$

x. São essenciais para a subsistência dos grupos tradicionais; ${ }^{246} \mathrm{e}$

xi. Estão em constante mudança.

\subsubsection{CONHECIMENTOS TRADICIONAIS ASSOCIADOS À AGROBIODIVERSIDADE}

Conforme indicado na introdução, o presente estudo não tratará dos recursos da agrobiodiversidade e dos CTs a eles conexos, disciplinados pelo Tratado Internacional sobre Recursos Fitogenéticos para a Alimentação e Agricultura (TIRFAA). No entanto, o tratamento dado à matéria pelo tratado da FAO não será ignorado, por duas razões. Primeiramente, porque o TIRFAA foi construído a partir da natureza peculiar dos recursos da agrobiodiversidade e dos CTs a eles associados. Em segundo lugar, porque a CDB disciplina a proteção daqueles recursos da agrobiodiversidade e CTs conexos excluídos do escopo de proteção do TIRFAA.

Apesar de não-vinculante, o primeiro instrumento internacional que disciplinou o uso dos recursos da agrobiodiversidade foi o Acordo Internacional da FAO sobre Recursos Fitogenéticos (AIFAO) de $1983 .{ }^{247}$ Tal acordo se propunha a estimular e facilitar a coleta, estudo e uso comercial e científico dos recursos da agrobiodiversidade em todo o mundo,

${ }^{242}$ Cf. BIBER-KLEMM, 2004, p. 96.

${ }^{243}$ Ibid.

${ }^{244}$ Cf. POSEY, 2004f, p. 135.

${ }^{245}$ Ver, e.g., VAN BEEK; JARA, 2002, p. 38; RUDDLE, 2000.

${ }^{246} \mathrm{Cf}$. SCBD, UNEP/CBD/TKBD/1/2, para. 85.

${ }^{247}$ O AIFAO foi adotado pela resolução FAO 8/83. 
com o fito de conservá-los e promover a segurança alimentar, notadamente, nos países em desenvolvimento.

Em virtude da crescente apropriação dos recursos biológicos dos países pobres pela indústria do melhoramento vegetal, por meio da reivindicação de DPIs sobre variedades vegetais derivadas destes recursos, ${ }^{248}$ o AIFAO conferiu aos recursos biológicos em geral, inclusive às cultivares melhoradas, o status de patrimônio da humanidade. ${ }^{249}$ A FAO objetivava com isso facilitar a livre disseminação dos recursos biológicos de importância para a agricultura e quebrar o tratamento mais favorável conferido aos recursos biológicos, aprimorados pelos países industrializados. Isto significa que os países industrializados continuariam a gozar de acesso livre aos recursos da agrobiodiversidade dos países pobres, enquanto os últimos estariam investidos no direito de acessar livremente as variedades melhoradas nos países industrializados, ainda que protegidas por DPIs. Sem surpresas, alguns países industrializados ${ }^{250}$ se opuseram ao Acordo, por vê-lo como uma medida de esfacelamento de seus direitos de exclusivo, conferidos essencialmente pelos Tratados da União para Proteção das Obtenções Vegetais (UPOV).

Seis anos mais tarde, por pressão dos países industrializados, a FAO aprovou a Resolução 4/89, a qual excluiu do alcance do AIFAO as variedades melhoradas, protegidas por DPIs. ${ }^{251}$ Em contrapartida ao reconhecimento dos DPIs da indústria do melhoramento vegetal, a Resolução, procurando assegurar um tratamento equânime ao trabalho intelectual dos agricultores dos países em desenvolvimento, ${ }^{252}$ estabeleceu os chamados direitos de agricultor, ${ }^{253}$ com base na "enorme contribuição realizada pelos agricultores de todas as regiões em favor da conservação e desenvolvimento dos recursos fitogenéticos, que constituem a base da produção agrícola em todo o mundo". ${ }^{254}$ Direitos de agricultor resultam "das contribuições passadas, presentes e futuras dos agricultores, associadas à conservação, aprimoramento e disponibilização de recursos fitogenéticos, particularmente, aqueles dos centros de origem/diversidade., ${ }^{, 255}$

\footnotetext{
${ }^{248}$ Cf. BRAGDON, 2002, p. 444.

${ }^{249}$ Cf. art. 10 combinado com o art. 2(1) do AIFAO.

250 Alemanha, Canadá, Estados Unidos, França, Japão, Reino Unido e Suíça.

${ }^{251}$ Cf. itens 1 e 2, FAO, Resolución 4/89.

${ }^{252}$ Ver BRAGDON, 2002, p. 445; DUTFIELD, 2001, p. 265-266.

${ }^{253}$ Cf. item 3, FAO, Resolución 4/89.

254 Ibid.

${ }^{255}$ Cf. FAO, Resolución 5/89.
} 
Os direitos de agricultor visam a recompensar as comunidades agrícolas por suas contribuições intelectuais ao desenvolvimento dos recursos da agrobiodiversidade e a criar incentivos para continuarem a desenvolver novas variedades agrícolas. ${ }^{256}$ Conforme foi tratado no item 1.3.3.1, a conservação dos recursos da agrobiodiversidade demanda intervenção humana contínua. ${ }^{257}$ Considerando o processo de concentração das atividades agrícolas em grandes propriedades monocultoras, que tendem a utilizar cultivares homogêneas, os direitos de agricultor interviriam no processo de substituição de variedades agrícolas tradicionais por cultivares modernas, incentivando as comunidades agrícolas a continuarem a se engajar em práticas de conservação e melhoramento in situ $^{258}$ de recursos da agrobiodiversidade.

Os direitos de agricultor, diferentemente do que poderia sugerir o termo, foram "investidos na comunidade internacional [representada pela FAO], na condição de fideicomissária das gerações presentes e futuras de agricultores, com o propósito de assegurar benefícios integrais aos agricultores". A resolução da FAO investiu na comunidade internacional a titularidade dos direitos de agricultor, em virtude da impossibilidade de se identificar, com segurança, a origem dos recursos da agrobiodiversidade, porquanto são desenvolvidos a partir de um processo colaborativo entre múltiplas comunidades agrícolas. Os direitos de agricultor seriam realizados por meio do financiamento de projetos, dedicados a apoiar as comunidades agrícolas de todo o mundo em seu trabalho de conservação in situ dos recursos da agrobiodiversidade. ${ }^{259}$ Os recursos financeiros necessários adviriam das contribuições realizadas pelos Estados signatários do AIFAO ao Fundo Internacional da FAO para Recursos Fitogenéticos. ${ }^{260}$

Como essas contribuições eram voluntárias, os direitos dos agricultores nunca chegaram a ser efetivos. Tanto é que, em 1992, a Conferência para a Adoção do Texto da Convenção sobre Diversidade Biológica determinou que as partes contratantes deste

\footnotetext{
${ }^{256}$ Cf. MOORE; TYMOWSKI, 2005, p. 66; WTO, IP/C/3/383, para. 78.

${ }^{257}$ Cf. item 7, FAO, 1996a.

${ }^{258}$ A Convenção sobre Diversidade Biológica entende por conservação in situ dos recursos da biodiversidade "a conservação de ecossistemas e habitats naturais e a manutenção e recuperação de populações viáveis de espécies em seus meios naturais e, no caso de espécies domesticadas ou cultivadas, nos meios onde tenham desenvolvido suas propriedades características" (art. $\left.2^{\circ}, \mathrm{CDB}\right)$.

${ }^{259}$ Cf. FAO, Resolución 5/89.

${ }^{260}$ Cf. item 4, Id., Resolución 4/89 e itens 3-5, Id., Resolución 3/91.
} 
instrumento se empenhassem em alcançar um instrumento efetivo de proteção dos direitos dos agricultores. ${ }^{261}$

Entre 1994 e 2001, foi negociado o TIRFAA, ${ }^{262}$ o qual trouxe uma solução frágil ao problema da ineficácia dos direitos de agricultor. Segundo os termos TIRFAA, seus Estados signatários devem observar três obrigações distintas, a saber: ${ }^{263}$

i. Proteger os CTs das comunidades agrícolas associados aos recursos da agrobiodiversidade;

ii. Reconhecer o direito das comunidades agrícolas de receber uma parcela equitativa dos benefícios oriundos da exploração dos recursos da agrobiodiversidade; e

iii. Oferecer às comunidades agrícolas a prerrogativa de participar da tomada de decisões políticas, que impactem na conservação dos recursos da agrobiodiversidade.

A solução trazida pelo TIRFAA é frágil, pois, ao invés de conferir direitos às comunidades agrícolas, conferiu aos Estados contratantes a prerrogativa de decidir se devem ou não implementar os direitos dos agricultores. ${ }^{264} \mathrm{O}$ caráter voluntário dos direitos de agricultor chancelou a manutenção do tratamento discriminatório concedido aos melhoristas dos países industrializados - que continuam a gozar de DPIs assegurados pelo Acordo TRIPS - em face do tratamento conferido às comunidades agrícolas, apesar de suas contribuições indiscutíveis ao desenvolvimento da indústria da agrobiotecnologia. A única obrigação assumida pelos Estados é a de facilitar o acesso aos recursos da agrobiodiversidade regidos pelo TIRFAA para fins científicos e comerciais, contra o depósito de uma taxa de royalties pré-fixada, em um fundo administrado pela FAO. ${ }^{265}$ Ainda que estes recursos biológicos resultem das contribuições intelectuais de comunidades agrícolas tradicionais, os recursos econômicos revertidos em favor da FAO

\footnotetext{
${ }^{261}$ Cf. item 4, FAO, Resolution 3 of the Nairobi Conference for the Adoption of the Agreed Text of the Convention on Biological Diversity.

${ }^{262} \mathrm{Cf}$. SCBD, UNEP/CBD/WG8J/2/7, para. 16.

${ }^{263}$ Cf. art. 9(2), TIRFAA.

${ }^{264} \mathrm{Cf}$. FAO, IT/GB-2/07/Inf.6, para. 11

${ }^{265}$ Cf. UNEP/CBD/WG8J/4/INF/9, para. 43.
} 
podem nunca beneficiar as comunidades agrícolas que genuinamente os conservam e aprimoram. $^{266}$

É nesse espaço deixado pelas “obrigações voluntárias” estabelecidas pelo TIRFAA que os Estados contratantes da CDB atuam, procurando estabelecer um regime obrigatório de proteção dos CTs associados aos recursos da agrobiodiversidade cobertos pela CDB.

\subsubsection{O VALOR SOCIAL E ECONÔMICO DOS CTS}

A importância dos conhecimentos tradicionais para o desenvolvimento da ciência ocidental não é de hoje. A origem da valorização desses conhecimentos remonta ao século XVI, quando da criação dos primeiros jardins botânicos e da publicação das primeiras obras européias sobre ervas exóticas. ${ }^{267}$ Durante o período colonial, as matrizes européias criaram as cadeiras de etnobotânica e etnozoologia em suas universidades a fim de compreender os recursos naturais com que esbarravam em suas colônias. Estas disciplinas e demais ramos da ciência ocidental associados aos recursos da biodiversidade foram desenvolvidos sob forte influência dos conhecimentos das comunidades tradicionais, que habitavam as colônias. ${ }^{268}$ Ao longo dos últimos cinco séculos os sistemas tradicionais de conhecimento realizaram aportes indiscutíveis ao desenvolvimento científico, industrial, agrícola e social das sociedades de todo o mundo. ${ }^{269}$

O papel mais valorizado dos CTs é o de agregar e explicitar o valor dos recursos da biodiversidade. Essa associação transforma matéria-prima barata ou ervas qualificadas como daninhas em produtos biomédicos e agrobiotecnológicos em estado bruto. ${ }^{270} \mathrm{E}$ um engano, no entanto, acreditar que o sistema tradicional de conhecimentos se circunscreva a

\footnotetext{
${ }^{266}$ Nos termos dos artigos 13.3 e 18.5 , TIRFAA, os benefícios colhidos pela FAO deverão ser revertidos prioritariamente para as comunidades agrícolas dos países em desenvolvimento, podendo, portanto, ser canalizados para comunidades agrícolas de países industrializados, que nenhuma relação podem ter com os recursos fitogenéticos providos. Os incentivos tão necessários à sustentabilidade das comunidades pobres podem nunca chegar (MOORE; TYMOWSKI, 2005, p. 73-74).

${ }^{267}$ Cf. INTERNATIONAL COUNCIL FOR SCIENCE, 2002b, p. 6

${ }^{268}$ Cf. NAKASHIMA, 2004, p. 131-132.

269 Cf. WORLD CONFERENCE ON SCIENCE, Declaration on Science and the Use of Scientific Knowledge, para. 26.

${ }^{270}$ Ver, e.g., SCBD, UNEP/CBD/WG8J/5/INF/10, para. 46; MGBEOJI, 2001-2002, p. 164.
} 
aplicações dos recursos biológicos. Os sistemas tradicionais de conhecimentos abarcam temas "como astronomia, meteorologia, geologia, ecologia, botânica, agricultura, fisiologia, psicologia e saúde"; ${ }^{271}$ na Ásia, os conhecimentos indígenas servem para prevenir ou mitigar os efeitos de desastres naturais, como por exemplo, secas, enchentes, terremotos e erosão. ${ }^{272}$

Hoje, é indiscutível que o arcabouço de conhecimentos acumulados pelas comunidades locais, se associado sinergicamente à ciência ocidental, pode conduzir a humanidade a grandes descobertas, ${ }^{273}$ ao mesmo tempo em que incentiva a conservação da diversidade cultural. ${ }^{274}$ Hayek assinala que o sistema ocidental de conhecimento é imperfeito por não compreender os "conhecimentos das pessoas, das condições locais, e das circunstâncias especiais" onde serão aplicados. ${ }^{275} \mathrm{Em}$ virtude da diferença de abordagem dos sistemas tradicionais de conhecimento, estes podem complementar e enriquecer $^{276}$ o sistema ocidental de conhecimento, habilitando-o a alcançar soluções mais efetivas a problemas de variadas naturezas. Para isso, é preciso construir uma relação de respeito mútuo entre culturas diversas, a qual depende da libertação dos preconceitos vigentes na ciência ocidental, a qual freqüentemente desqualifica os conhecimentos das comunidades tradicionais, ao julgá-los não-científicos. ${ }^{277}$

Para o setor biomédico, duas são as contribuições mais importantes dos CTs ao desenvolvimento de novos produtos farmacêuticos: sugerir a eficácia e a segurança de princípios bioativos, extraídos de recursos da biodiversidade, utilizados desde tempos imemoriais por comunidades locais. ${ }^{278}$

Sobre a utilidade concreta dos CTs para a identificação de moléculas bioativas eficazes, a literatura é farta a este respeito. Limitar-nos-emos a mencionar apenas algumas ilustrações do papel destes conhecimentos para o desenvolvimento da indústria biomédica: Farnsworth et al. comprovaram, por meio de em um estudo que examinou 119 substâncias

${ }^{271}$ Cf. SECRETARÍA DE LA CONFERENCIA MUNDIAL SOBRE LA CIENCIA, 1999, para. 36.

${ }^{272}$ Cf. UN ISDR ASIA AND PACIFIC, 2008.

${ }^{273}$ Cf. POSEY, 2004j, p. 60.

${ }^{274}$ Cf. UNESCO, Declaração Universal da UNESCO sobre Diversidade Cultural, anexo, item 14.

${ }^{275}$ HAYEK, 1945, p. 522.

${ }^{276}$ Cf. INTERNATIONAL COUNCIL FOR SCIENCE, $2002 \mathrm{~b}, \mathrm{p} .11$.

${ }^{277}$ Cf. NAKASHIMA, 2004, p. 132; SCBD, UNEP/CBD/WG8J/1/INF/14, p. 5.

${ }^{278}$ Os CTs também são úteis para identificação de novos sintomas para enfermidades já conhecidas no ocidente, facilitando seu diagnóstico (POSEY, 2004b, p. 66). 
químicas, extraídas de 91 espécies de plantas, que 74\% dos medicamentos estudados foram descobertos e desenvolvidos a partir do isolamento de substâncias químicas de plantas, utilizadas por comunidades locais e indígenas para fins medicinais. ${ }^{279}$ Recentemente, graças aos conhecimentos de comunidades locais, um novo antiviral, útil ao tratamento dos portadores do HIV/AIDS, foi desenvolvido a partir de extratos da árvore Homalanthus nutans, originária de Samoa. ${ }^{280} \mathrm{~A}$ importância dos CTs para a identificação de moléculas farmacêuticas resta indiscutível a partir da análise dos termos do contrato-modelo, utilizado pelo Instituto Nacional do Câncer dos EUA para disciplinar o acesso a recursos biológicos, originários de outros países. O contrato demanda de seus parceiros, sempre que possível, a coleta de amostras de recursos biológicos, aplicados por comunidades tradicionais para fins medicinais. ${ }^{281}$

Os CTs são importantes não apenas quando identificam a aplicação de um recurso biológico, posteriormente confirmada por estudos científicos, mas também quando possibilita a descoberta de uma aplicação de um recurso, ainda que o uso tradicional sugira uma aplicação diferente daquela identificada por estudos científicos. Os CTs desempenham, pois, a função de alertar para a bioatividade de um recurso biológico. Por exemplo, o Catharanthus roseus, planta nativa de Madagascar, era utilizada na Jamaica para o tratamento do diabetes; por conta desta alegada aplicação, pesquisadores no Canadá e da Eli Lilly decidiram pesquisá-la. No entanto, testes de laboratório identificaram dois compostos ativos, úteis no tratamento da leucemia infantil. ${ }^{282}$ Apesar da falta de identidade entre as aplicações descobertas em laboratórios e as indicações tradicionais, estas foram fundamentais para o desenvolvimento de novas drogas.

No que tange à segurança ao uso humano, os benefícios trazidos pelos CTs ao setor industrial não devem ser negligenciados. Os medicamentos derivados de recursos biológicos, desenvolvidos a partir de indicações feitas por comunidades tradicionais, apresentam uma menor chance de serem tóxicos. Quando a indústria farmacêutica coleta

\footnotetext{
${ }^{279}$ Cf. FARNSWORTH et al., 1995. No mesmo sentido ver, LEWIS; ELVIN-LEWIS, 1995.

${ }^{280}$ Cf. COX, 2001, p. 33-34.

281 "Should the appropriate agency in [SCG or SCO] have any knowledge of the medicinal use of any plants, microbes and marine macro-organisms by the local population or traditional healers, this information will be used to guide the collection of plants, microbes or marine macro-organisms on a priority basis where possible. Details of the methods of administration (e.g., hot fusion, etc.) used by the traditional healers will be provided where applicable to enable suitable extracts to be made. All such information will be kept confidential by DTP/NCI until both parties agree to publication" (WTO, IP/C/W/341, p. 13-14).

${ }^{282}$ Cf. CHEN, J., 2006, p. 5.
} 
recursos biológicos com potencial farmacêutico a partir de indicações da medicina tradicional (método etnobotânico), a pesquisa se inicia e termina no homem, isto é, a pesquisa coleta e examina plantas tradicionalmente utilizadas para fins medicinais e termina em testes clínicos em seres humanos. Tradicionalmente, a indústria farmacêutica, começa com a avaliação de atividade biológica de recursos naturais in vitro, coletados aleatoriamente, e o ciclo se encerra em testes clínicos. ${ }^{283}$ Neste último caso, muitas moléculas bioativas que chegam à fase de testes clínicos não alcançam o mercado por se mostrarem tóxicas ao organismo humano.

Devido às novas tecnologias, que permitem identificar a potencial aplicação de um grande número de compostos bioativos extraídos de recursos naturais poder-se-ia imaginar que a importância dos CTs, cuja função usual é identificar plantas que apresentam potencial atividade medicinal, estaria perdendo terreno. No entanto, as tecnologias não são capazes de substituir o papel dos CTs de oferecer evidências fundamentadas da segurança das moléculas bioativas identificadas. ${ }^{284}$ Estas evidências são uma fonte de economia à indústria farmacêutica, que vêm incorrendo em gastos cada vez mais vultosos em P\&D de novos produtos farmacêuticos, em parte graças aos maiores gastos em testes clínicos. ${ }^{285}$

CTs desempenham não apenas o papel de insumos para os processos de desenvolvimento industrial e científico dos países já industrializados. Podem servir, se bem empregados, para a gestação de estratégias de desenvolvimento de países pobres a partir de suas fortalezas locais, em substituição às estratégias que impõem modelos estrangeiros, condutores da perda de identidade cultural local ${ }^{286}$ e da independência de tecnologias alienígenas, inadequadas à realidade local. ${ }^{287}$ Estratégias de desenvolvimento, calcadas no uso de RBIs, mitigam a drenagem de recursos nacionais, por meio do envio de royalties

${ }^{283}$ Cf. BIERER; CARLSON; KING, 1996.

${ }^{284}$ Cf. FARNSWORTH et al., 1985, p. 965-968.

${ }^{285}$ Entre 1987 e 2001, o custo estimado para se desenvolver um produto farmacêutico saltou de US\$ 231 milhões para US\$ 802 milhões. A razão do salto está nos custos envolvidos para se conduzir testes clínicos, que atestam a segurança e eficácia dos potenciais produtos farmacêuticos (TUFTS [...], 2001).

${ }^{286}$ Cf. BHATTI, 2004, p. 121.

${ }^{287}$ Em entrevista à revista alemã Spiegel (2005), o economista queniano James Shikwati defende que doação de recursos financeiros, remédios, roupas, alimentos para as populações locais, coloca os pequenos produtores africanos na situação de competirem com produtos disponibilizados gratuitamente. Não sendo possível competirem com o que é gratuito, acabam saindo do mercado produtivo e passam a mendigar ajuda, fortalecendo o ciclo de fome e subdesenvolvimento local. CTs podem auxiliar os setores produtivos dos países em desenvolvimento a gerarem suas próprias armas para alcançar riqueza, ao invés de dependerem de tecnologias externas que entram no domínio público. 
dos países em desenvolvimento aos industrializados. ${ }^{288}$ Desde a década de 1980, agências multilaterais de desenvolvimento valorizam a associação entre ciência e técnicas ocidentais e CTs, em projetos relacionados à gestão ambiental, aumento da produtividade agrícola, melhoria da qualidade de vida de comunidades pobres. ${ }^{289}$ Sem embargo, a aplicação desses insumos intelectuais para o desenvolvimento econômico, tecnológico e social dos países em desenvolvimento ainda é incipiente. ${ }^{290}$ Estes recursos técnicos apresentam muitas vantagens em comparação às tecnologias desenvolvidas nos países industrializados: são adaptados à realidade e ao contexto cultural e ambiental local, envolvem custos baixos para adaptação, são eficazes e não recebem oposição das culturas locais. ${ }^{291}$

Os CTs são igualmente relevantes para a satisfação das necessidades alimentícias e médicas de largas parcelas da humanidade. ${ }^{292} \mathrm{Na}$ Índia, por exemplo, especialistas em medicina tradicional ayurvédica e os curandeiros tribais são responsáveis pelo tratamento médico de $80 \%$ da população indiana - aproximadamente 900 milhões de pessoas. ${ }^{293}$ No Sri Lanka, o governo oferece serviços de saúde, baseados no sistema de medicina tradicional Ayurveda. ${ }^{294} \mathrm{Na}$ década de 80, a Organização Mundial da Saúde (OMS) estimava que $80 \%$ da população mundial dependiam de medicamentos tradicionais, derivados de plantas. ${ }^{295} 85 \%$ das necessidades das parcelas mais pobres da população mundial associadas à alimentação, saúde, roupas, moradia ainda hoje são satisfeitas com recursos extraídos da natureza, graças aos conhecimentos acumulados sobre seu valor. ${ }^{296}$

\subsection{Expressões Culturais Tradicionais}

As ECTs correspondem aos RBIs de natureza artística; ${ }^{297}$ compreendem: ${ }^{298}$

\footnotetext{
${ }^{288}$ Cf. MBEVA, 2004, p. 173.

${ }^{289}$ Cf. INTERNATIONAL COUNCIL FOR SCIENCE, 2002b, p. 5.

${ }^{290} \mathrm{Cf}$. SCBD, UNEP/CBD/WG8J/1/2, para. 64.

${ }^{291}$ Cf. GORJESTANI, 2004, p. 266.

${ }^{292}$ Cf. BIBER-KLEMM, 2004, p. 95.

${ }^{293}$ Cf. SAHAI, 2004, p. 280.

${ }^{294}$ Cf. KUMAR, 2004, p. 299.

${ }^{295}$ Cf. FARNSWORTH, 1985, p. 965-966.

${ }^{296}$ Cf. COOMBE, 2001-2002, p. 278.

${ }^{297}$ Cf. UNESCO; WIPO, 1985, para. 33.

${ }^{298}$ Cf. WIPO, WIPO/GRTKF/IC/12/4(c), para. 14; art. 31, United Nations Declaration on the Rights of Indigenous Peoples.
} 
i. As expressões verbais, e.g. os contos épicos, as lendas, a poesia, os enigmas e outras narrações;

ii. Os signos distintivos, e.g. as palavras, os signos, os nomes e os símbolos;

iii. As expressões musicais, e.g. as canções e a música instrumental;

iv. As expressões corporais: e.g. as danças, representações cênicas, cerimônias, rituais e outras interpretações ou execuções; e

v. As expressões reproduzidas em substratos permanentes, e.g. as obras de arte em geral, os desenhos e pinturas, esculturas, mosaicos, trabalho de cestaria, bordados, tecidos, jóias, cristais, tapetes, artesanato, instrumentos musicais, obras arquitetônicas, entalhamento, bordados, terracota.

Diferentemente dos RBIs de natureza técnica - os CTs e recursos da biodiversidade -, as ECTs não são fundamentais para sustentar a vida física do homem; sem embargo, trazem beleza e qualidade à sua vida mental e espiritual. As ECTs são utilizadas como fonte de inspiração pela indústria da moda, ${ }^{299}$ fonográfica e joalheira, ${ }^{300}$ em esculturas e obras artísticas contemporâneas e em projetos arquitetônicos. ${ }^{301}$

A título de ilustração do aporte das ECTs brasileiras à melhoria da qualidade de vida mental do homem, é digno de nota o projeto de reforma de um condomínio de apartamentos localizado em Hellersdorf, em Berlim. O conjunto habitacional conhecido por "Gelbes Viertel" (Bairro Amarelo), situado na antiga Berlim oriental, era considerado deprimente por seus mais de 12.000 moradores. Após a queda do muro de Berlin e vários anos de pressão, os condôminos conseguiram, da empresa administradora do Bairro Amarelo a aprovação de um projeto multimilionário de reformulação das áreas comuns condominiais, com vistas a criar um ambiente mais alegre e acolhedor. ${ }^{302} \mathrm{O}$ escritório de

\footnotetext{
${ }^{299}$ Cf. THOMÉ, 2009; PACCE, 2008; CHERNIKOFF, 2008.

300 Por exemplo, a coleção Parãngaw da joalheria H.Stern, de 1994, e a coleção de 2004 da Francesca Romana. Ver REGIÃO [...], 2004.

${ }^{301}$ Cf. WIPO, WIPO/GRTKF/IC/13/4(b) Rev, para. 60.

${ }^{302}$ Cf. FREIRE, [200-?].
} 
arquitetura vencedor da concorrência-Brasil Arquitetura---lançou mão, dentre outros recursos, de painéis de azulejos que reproduzem grafismos tradicionais de uma tribo indígena brasileira, elaborados por seus membros. ${ }^{303}$

O termo "expressões" é utilizado para traçar a diferença com a matéria de proteção dos regimes de direitos autorais, ${ }^{304}$ que tutelam obras artísticas e literárias. Dois são os aspectos centrais que diferenciam as ECTs dos objetos de proteção dos regimes de direitos autorais. Em primeiro lugar, em regra, as ECTs não são fixadas em um suporte tangível, sendo transmitidas de geração a geração pela via oral ou por imitação. ${ }^{305} \mathrm{Em}$ segundo lugar, as ECTs resultam de um esforço intelectual comunitário, dissociados de algum membro específico de um grupo humano. ${ }^{306}$ Assim sendo, ainda que uma ECT resulte do trabalho intelectual de um membro identificável de uma comunidade local, ela integrará o patrimônio do grupo ao qual se vincula o artista, desde que a expressão reflita a identidade cultural do grupo. ${ }^{307}$

Mas mesmo quando o é, não cabe ao criador direitos individuais sobre a ECT, porquanto constitui uma composição criativa, que agrega elementos distintos do patrimônio intelectual artístico da comunidade, realizada ou para preservá-la para as presentes e futuras gerações da comunidade, ou com vistas a dar cumprimento a obrigações de natureza espiritual. Isto porque freqüentemente a criação, reprodução e transmissão das ECTs têm fins religiosos, o que não significa que todas as ECTs tenham natureza sacra. ${ }^{308}$ As ECTs sagradas constituem apenas uma subcategoria de ECTs, as quais são regidas por normas sociais que limitam ou proíbem seu uso fora de contextos tradicionais. ${ }^{309}$

Da mesma forma que os CTs e os recursos da biodiversidade podem resultar de atividades criativas contemporâneas, as ECTs não são sinônimo de expressões artísticas antigas. As ECTs podem compreender versões contemporâneas de expressões artísticas antigas, recriadas pelas gerações atuais de uma comunidade tradicional. ${ }^{310} \mathrm{O}$ aspecto comum que permeia as ECTs antigas e as contemporâneas é o fato de refletir a identidade

${ }^{303}$ Cf. BRASIL ARQUITETURA, 2009.

${ }^{304}$ Cf. UNESCO; WIPO, 1985, para. 32.

${ }^{305}$ Cf. WIPO, WIPO/GRTKF/IC/13/4(b) Rev, para. 8.

${ }^{306}$ Cf. FICSOR, 1998, p. 216.

${ }^{307}$ Cf. EUROPEAN COMMUNITY, 2002, p. 1.

${ }^{308}$ Cf. GERVAIS, 2003, p. 474.

${ }^{309}$ Ibid.

${ }^{310}$ Cf. WIPO, WIPO/GRTKF/IC/13/4(b) Rev, para. 6. 
cultural da comunidade tradicional à qual se associa, ao invés de refletir a identidade pessoal dos criadores individuais. ${ }^{311}$

O processo criativo que culmina na criação de uma ECT se protrai durante longos períodos, com pequenas alterações, que são realizadas continuamente. ${ }^{312}$ Como reflexo do processo de transmissão contínua, desde tempos imemoriais, assim como em virtude dos processos migratórios, geralmente as comunidades tradicionais não têm condições de controlar a transmissão de muitas de suas ECTs. Por conseguinte, um sem número de ECTs se disseminou amplamente, por muitas comunidades, regiões e países (ECTs regionais). ${ }^{313}$

Resumidamente, uma expressão artística para ser considerada uma ECT deve cumprir cumulativamente com os seguintes fatores: ${ }^{314}$

i. Resultar da atividade intelectual de um indivíduo ou de um grupo de indivíduos, sejam eles contemporâneos ou não, investidos na responsabilidade cultural ou religiosa de criá-las, reproduzi-las e conservá-las; ${ }^{315}$

ii. É transmitida de geração a geração, podendo neste processo ser agregados novos elementos criativos; ${ }^{316}$

iii. A identificação de seus criadores pode ser impossível ou quando possível, o(s) criador(s) deve estar associado a um grupo culturalmente diferenciado; ${ }^{317}$

iv. Reflete a identidade cultural da comunidade, i.e. a ECT deve ser característica da comunidade e responder às suas expectativas culturais. ${ }^{318}$ Em outras palavras, a ECT deve ser um atributo típico da identidade cultural do grupo ao qual se

${ }^{311}$ Cf. POSEY, 2004k, p. 160.

${ }^{312}$ Cf. VON LEWINSKI, 2003-2004, p. 757.

${ }^{313} \mathrm{Cf}$. WIPO, WIPO/GRTKF/IC/9/INF/4, para. 49

${ }^{314}$ Ibid., para. 47

${ }^{315} \mathrm{Cf}$. WIPO, WIPO/GRTKF/IC/12/4(c), para. 14.

${ }^{316} \mathrm{Id}$., WIPO/GRTKF/IC/13/4(b) Rev, para.8.

${ }^{317}$ Ibid.

${ }^{318}$ Cf. UNESCO, Recomendación sobre la salvaguardia de la cultura tradicional y popular, item "A", anexo I. 
associa, e ser reconhecida por seus membros como parte integrante de sua identidade cultural; ${ }^{319} \mathrm{e}$

v. Geralmente, a transmissão, reprodução e uso das ECTs são disciplinados por protocolos culturais das comunidades pertinentes. A reprodução e transmissão das ECTs de natureza sagrada tendem a estar sujeitas à observância de normas mais rigorosas.

\subsection{CONCLUSÕes}

As três categorias de RBIs que constituem o PBI, embora aparentemente tão diversos, em verdade, compartilham aspectos comuns que os unem. ${ }^{320}$ Em primeiro lugar, os RBIs são geralmente desenvolvidos e/ou conservados por comunidades culturalmente diferenciadas e socialmente marginalizadas. Em segundo lugar, sua transmissão ocorre de geração a geração. Em terceiro lugar, o processo criativo é ininterrupto e se protrai ao longo da história da comunidade pertinente. Em quarto lugar, os ecossistemas naturais oferecem às comunidades tradicionais os recursos sobre os quais desenvolvem seu patrimônio técnico, indispensável para a solução de seus desafios diários de sobrevivência, e a inspiração para a criação de ECTs, que retratam sua relação com o mundo natural e espiritual. Finalmente, os RBIs são reproduzidos, criados e aperfeiçoados por esforços comunitários ou individuais, que refletem a identidade cultural do grupo ao qual se vincula o criador.

A continuidade dos processos criativos e inventivos das comunidades tradicionais depende não somente da proteção da dimensão imaterial dos RBIs contra a prática de atos de apropriação indébita. Depende fundamentalmente da conservação da cultura e do entorno natural, em que tradicionalmente surgiram seus RBIs e se desenvolvem.

Considerando a visão holística das comunidades tradicionais, que vêem cultura, ecossistemas e RBIs como elementos interdependentes, a proteção dos RBIs demanda mais

${ }^{319}$ Cf. WIPO, WIPO/GRTKF/IC/12/4(c), anexo, para. 14.

320 Elementos identificados a partir da decomposição do art. 2(1) da Convenção para a Salvaguarda do Patrimônio Cultural Imaterial. 
que a mera proteção dos recursos em isolamento de suas fontes humanas, culturais e biológicas. ${ }^{321}$ Assim, qualquer regime que se proponha a protegê-los contra erosão deverá atentar para o imperativo de conservar suas fontes humanas - comunidades tradicionais, empobrecidas economicamente e socialmente marginalizadas - para mediatamente conservá-los vivos, em constante aprimoramento, no presente e no futuro. ${ }^{322}$

Além das comunidades humanas, os regimes legais devem salvaguardar outras duas dimensões do PBI: a cultural, pois o PBI reflete os valores culturais, inclusive, espirituais das comunidades tradicionais que os criaram e conservam, ${ }^{323}$ e a ambiental, porquanto os RBIs resultam da interação das comunidades tradicionais com os recursos naturais presentes nas terras e águas, que tradicionalmente ocupam. ${ }^{324}$

${ }_{321}^{321}$ Cf. SCBD, UNEP/CBD/COP/6/7, para. 64; BROWN, M., 1998, p. 195.

${ }^{322}$ Cf. FERNANDO, 2003, p. 56-57.

${ }^{323}$ Ver COPCBD, Decision V/16, para. 16 (reconhece que a conservação dos CTs depende da conservação das identidades culturais das comunidades que os detêm).

${ }^{324} \mathrm{Cf}$. SCBD, UNEP/CBD/WG8J/5/6, para. 16. 


\section{O PAPEL DOS DPIS NA APROPRIAÇÃO INDÉBITA DOS RBIS E A EMERGÊNCIA DO CONTRAMOVIMENTO DOS PAÍSES EM DESENVOLVIMENTO}

\subsection{NOTAS INTRODUTÓRIAS}

O presente capítulo explora a incapacidade genérica dos regimes de patentes e dos de direitos autorais para tutelarem os RBIs, em favor das comunidades tradicionais e dos países detentores de recursos da biodiversidade em condições in situ. Embora este estudo se limite a examinar estes dois regimes, porquanto simbolizam os paradigmas centrais do direito da propriedade intelectual, as observações gerais tecidas a respeito de sua incapacidade para salvaguardar os RBIs contra atos de apropriação indébita são extensíveis aos demais regimes de proteção de produções intelectuais, ${ }^{325}$ uma vez que deles derivam. ${ }^{326}$

Finalmente, este capítulo tratará da contrarresposta dos países em desenvolvimento à iniqüidade instaurada pelos regimes de PI, com o objetivo de resguardar seus recursos biológicos e os RBIs de suas comunidades tradicionais.

\subsection{DEFINIÇÃO DE DIREITOS DE PROPRIEDADE INTELECTUAL}

O termo propriedade intelectual - o qual abrange bens gerados pelo intelecto humano, e.g. signos distintivos, invenções, obras literárias e artísticas, cultivares ${ }^{327}$ ganhou força a partir da criação da OMPI, em 1967. Contudo, a idéia de PI como conhecemos no presente - direitos de exclusivo sobre bens intelectuais - se desenvolveu

\footnotetext{
${ }^{325}$ E.g., os regimes de proteção das variedades de plantas ou cultivares, estabelecido pela UPOV, os de proteção dos modelos de utilidade etc.

${ }^{326}$ Cf. WESTKAMP, 2005, p. 116

${ }^{327}$ O art. 2(viii) da Convenção que estabelece a Organização Mundial da Propriedade Intelectual, assinada em Estocolmo, em 1967, define propriedade intelectual como os direitos relativos a "las obras literarias, artísticas y científicas; a las interpretaciones de los artistas intérpretes y a las ejecuciones de los artistas ejecutantes, a los fonogramas y a las emisiones de radiodifusión; a las invenciones en todos los campos de la actividad humana; a los descubrimientos científicos; a los dibujos y modelos industriales; a las marcas de fábrica, de comercio y de servicio, así como a los nombres y denominaciones comerciales; a la protección contra la competencia desleal, y todos los demás derechos relativos a la actividad intelectual en los terrenos industrial, científico, literario y artístico."
} 
paulatinamente desde o Renascimento ${ }^{328}$ e vem ganhando importância a partir da adoção da Convenção de Berna para a proteção das obras literárias e artísticas (Convenção de Berna ou CB) e da Convenção de Paris para a proteção da propriedade industrial (Convenção de Paris ou CP), ao final do século XIX. ${ }^{329}$

A propriedade intelectual compreende três dimensões, a saber: titulares de direitos; domínio ou escopo dos direitos conferidos, e configuração do objeto de proteção, ${ }^{330}$ sendo que as duas últimas dimensões são interdependentes. ${ }^{331}$ Dois aspectos diferenciam os DPIs dos direitos reais. O primeiro é a natureza ficcional do objeto de proteção, ${ }^{332}$ isto é, este figura como um bem intangível ou informacional. ${ }^{333} \mathrm{O}$ segundo aspecto é o rol de direitos e obrigações investidos nos titulares de direitos; seu alcance é determinado pela natureza intangível do objeto de proteção.

\subsubsection{OBJETO DE PROTEÇÃO}

A res dos DPIs não é simplesmente uma informação bruta, mas a aplicação substantiva de uma informação, desenvolvida pela criatividade e esforços do intelecto humano, ou seja, a "manifestação física da res" ${ }^{334}$ Por exemplo, os regimes de direitos autorais protegem não a idéia artística, mas sua expressão, conservando livremente acessível a idéia que a permeia. $O$ direito de patentes, por sua vez, não tutela a informação técnica de per si, mas um grupo de aplicações concretas deste tipo de informação.

Os DPIs se limitam a tutelar a manifestação palpável de uma informação. Haja vista que os DPIs consistem em um direito impessoal e relacional entre o titular e a sociedade direito válido erga omnes -, é imprescindível que seu objeto de proteção tenha uma vida independente da do seu titular. O grande público goza, por conseguinte, dos meios para identificar o objeto que não deve apropriar sem autorização, assim como da oportunidade de optar conscientemente entre apropriá-lo indebitamente ou respeitar os direitos de

\footnotetext{
${ }^{328} \mathrm{Cf}$. SCBD, UNEP/CBD/WG8J/1/2, para. 5.

${ }^{329}$ Cf. YU, 2005, p. 1-4.

${ }^{330} \mathrm{Cf}$. BELL; PARCHOMOVSKY, 2007.

${ }^{331}$ Cf. LAMETTI, 2004, p. 272-273.

${ }^{332}$ Cf. BELL; PARCHOMOVSKY, 2007, p. 35-36.

${ }^{333} \mathrm{Cf}$. WIPO, WIPO/GRTKF/IC/5/7, para. 6.

${ }^{334}$ Cf. HUGHES, 1997, p. 112-113, 125.
} 
terceiros. Assim, ainda que uma idéia apresente um potencial econômico, enquanto se mantiver abstrata, despida de uma manifestação prática e concreta, que viabilize a identificação segura de seus contornos e limites, não há como protegê-la por meio de um DPI. ${ }^{335}$ É por esta razão que as legislações de proteção de obras literárias e artísticas tendem a proteger apenas as expressões artísticas, fixadas em algum substrato permanente ou semipermanente; os regimes de patentes tutelam as invenções objeto de um pedido formal, que determina a matéria objeto de proteção; e os regimes de proteção de marcas comerciais protegem apenas aquelas registradas ou em uso comercial ostensivo. Em outras palavras, o objeto de proteção do DPI deve ter uma utilidade social objetiva ${ }^{336}$, sendo, pois, identificável por seu titular e pelo grande público (as pessoas obrigadas a respeitar o direito de propriedade de terceiros), independentemente de qualquer relação direta entre eles.

\subsubsection{DIREITOS E OBRIGAÇÕES ABRANGIDOS PELOS DPIS}

Tony Honoré identificou os "elementos essenciais à noção de propriedade", isto é, os direitos e deveres geralmente investidos nas mãos dos proprietários. ${ }^{337}$ Os elementospadrão identificados por Honoré são paradigmáticos; conseqüentemente, a presença simultânea de todos eles não é condição para que um determinado feixe de direitos possa configurar-se como um direito de propriedade. Segundo Honoré, os direitos e obrigaçõespadrão, investidos nos proprietários são:

i. Direito de posse: o direito de controlar o objeto de proteção do direito de propriedade e de permanecer em seu controle. Em outras palavras, o direito de impedir terceiros não-autorizados de se apropriarem do bem protegido; ${ }^{338}$

ii. Direito de usar: direito de usar e gozar da propriedade para benefício pessoal do proprietário; 339

\footnotetext{
${ }^{335}$ Cf., e.g., LAMETTI, 2004, p. 285; BROWN, M., 1998, p. 202.

${ }^{336}$ Cf. LAMETTI, 2004, p. 280.

${ }^{337}$ Cf. HONORÉ, 1987, p. 165.

${ }^{338}$ Ibid., p. 166.

${ }^{339}$ Ibid., p. 168.
} 
iii. Direito de administrar: o poder de autorizar terceiros a utilizar a propriedade e o de definir os limites de seu uso por terceiros; 340

iv. Direito à renda: direito de receber renda, em virtude da exploração da propriedade por terceiros autorizados e o de receber os frutos gerados pelo bem; ${ }^{341}$

v. Direito ao capital: direito de alienar a propriedade, de consumi-la e até mesmo de destruí-la; ${ }^{342}$

vi. Direito à segurança: direito do proprietário de assim permanecer indefinidamente, desde que assim deseje ou se mantenha solvente $;{ }^{343}$

vii. Incidente ${ }^{344}$ de transmissibilidade: a propriedade pode ser transmitida ilimitadamente aos herdeiros;

viii. Incidente de ausência de termo de proteção: o direito de propriedade dura por tempo indeterminado, podendo ser limitado em caso de desapropriação e insolvência de seu titular; 345

ix. Dever de prevenção de danos: o proprietário goza da liberdade de usar e autorizar terceiros a usar sua propriedade, desde que não a empregue nem autorize terceiros a empregá-la, de modo a prejudicar os interesses de terceiros; ${ }^{346}$

x. Sujeição à execução: a propriedade pode ser executada para o pagamento de débitos de seu titular; ${ }^{347} \mathrm{e}$

${ }^{340}$ Cf. HONORÉ, 1987, p. 168.

${ }^{341}$ Ibid., p. 169.

${ }^{342}$ Ibid., p. 170.

${ }^{343}$ Ibid., p. 171.

${ }^{344}$ Cf. Honoré (1987, p. 172-173) não considera a transmissibilidade da propriedade como um direito, porquanto seu exercício independe da vontade do titular do direito; por esta razão, rotula esta característica de "incidente".

${ }^{345}$ Ibid., p. 174.

${ }^{346}$ Ibid.

${ }^{347}$ Cf. HONORÉ, 1987, p. 175. 
xi. Caráter residual: Um direito de propriedade pode ter sua extensão limitada, temporariamente, por outros direitos que recaiam sobre o bem. Por exemplo, o depositário goza, provisoriamente, do direito de posse do bem. Uma vez extintos os direitos de terceiros, que limitam a extensão dos direitos investidos no proprietário, aqueles retornarão ao feixe de direitos do último. ${ }^{348}$

Em virtude das especificidades do objeto de proteção dos DPIs, ${ }^{349}$ estes não são compostos pelos mesmos elementos indicados por Honoré: segundo Schäffle, DPIs conferem temporariamente aos seus titulares um "direito de controle de um mercado para os bens que incorporem uma idéia" protegida, ${ }^{350}$ ou seja, o direito de determinar, com exclusividade, a agenda de aplicações do objeto protegido, segundo seus interesses pessoais. ${ }^{351}$ Assim sendo, o direito à segurança e os incidentes de transmissibilidade e de ausência de termo de proteção não são investidos nos titulares de DPIs, porquanto sua duração é temporalmente limitada. No entanto, os direitos de possuir, usar, administrar, à renda, ao capital, o dever de prevenir danos, a sujeição à execução e o caráter residual geralmente integram o feixe de direitos e obrigações investidos nos titulares de DPIs.

Os direitos de possuir, usar, administrar, de receber renda e o direito ao capital apenas podem ser exercidos pelos titulares de DPIs graças ao poder de excluir terceiros não-autorizados do uso do objeto de proteção. Este direito confere ao seu titular o direito exclusivo de eleger quem pode ou não utilizar seu bem, ${ }^{352}$ independentemente de qualquer intervenção estatal. ${ }^{353}$ Em virtude de sua importância para assegurar aos titulares de DPIs a liberdade de controlar seus bens intangíveis e de deles extrair renda, ${ }^{354}$ o direito de exclusão de terceiros não-autorizados é tratado pela literatura como o atributo fundamental dos DPIs. ${ }^{355}$

Naturalmente, esse direito não é absoluto. Os DPIs, tal qual qualquer direito de propriedade, apresentam uma função social. Por conseguinte, alguns limites lhes são

\footnotetext{
348 Ibid., p. 179.

${ }^{349}$ Cf. LAMETTI, 2003, p. 360 et seq.

${ }^{350}$ Cf. SCHÄFFLE, 1867 apud MACHLUP; PENROSE, 1950, p. 12.

${ }^{351}$ Cf. KATZ, 2008, p. 34-35; FICSOR, 2002, p. 15-16.

${ }^{352}$ Cf. LESSIG, 2002, p. 1789.

${ }^{353}$ Cf. CALABRESI; MELAMED, 1972, p. 1092.

${ }^{354}$ Cf. BOYLE, 2003a, p, 9-10.

355 Ver, por exemplo, GERVAIS, 2005, p. 153; LAMETTI, 2003, p. 335; SMITH, 2007, p. 61-63; SWANSON; GOESCHL, 2007, p. 8.
} 
impostos pelo Estado, a fim de permitir a realização de interesses eminentemente sociais. Tais limites tomam a forma de: exceções aos direitos de exclusivo para fins públicos, que podem ser exercidas independentemente da vontade dos titulares e da obrigação de pagarlhes alguma remuneração; ${ }^{356}$ exclusões do rol de matérias elegíveis de proteção e da limitação temporal do termo de proteção dos DPIs.

\subsubsection{ESTÍMULO À CRIATIVIDADE VERSUS PROTEÇÃO DO PRÉ-EXISTENTE}

A principal justificativa para a concessão de DPIs para a proteção de produções intelectuais está em seu papel de estímulo à geração de bens intelectuais. A teoria do trabalho de John Locke e a justificativa econômica são suas manifestações mais recorrentes.

A justificativa econômica se assenta no fato de que bens informacionais são bens custosos para se produzir, mas reproduzíveis a custos ínfimos. Embora o objeto de proteção dos DPIs sejam bens públicos, os instrumentos necessários para criá-los são escassos, e.g. laboratórios, recursos humanos especializados em geral. Conseqüentemente, os Estados conferem direitos de propriedade sobre bens públicos, tornando-os artificialmente escassos, com vistas a incentivar indivíduos e instituições a alocar bens genuinamente escassos para a geração de bens públicos. ${ }^{357}$ Em outras palavras, a justificativa econômica presume que, se os produtores de bens intelectuais não detiverem os instrumentos para controlar o mercado para suas produções intelectuais, não se engajarão em sua produção. ${ }^{358}$

A teoria do trabalho de Locke, por sua vez, sustenta que cada indivíduo deveria fruir de um direito natural de propriedade, que nasce da agregação de valor social aos recursos comuns da natureza, por meio do trabalho braçal ou intelectual. O direito de propriedade seria um meio para assegurar ao homem sua sobrevivência, pois, ao menos que pudesse privatizar alguns dos recursos comuns, conferidos por Deus à humanidade, estes seriam inúteis. Sob a ótica da teoria de Locke, os DPIs configuram um incentivo aos

\footnotetext{
${ }^{356}$ Cf. BELL; PARCHMOVSKY, 2002, p. 40-41.

${ }^{357}$ Cf., e.g., SMITH, 2007, p. 2-3; NOAM, 2002, p. 52.

${ }^{358}$ Ver, e.g., SWANSON; GOESCHL, 2007, p. 7-8; COLANGELO, 2004, p. 11-12; CONCEIÇÃO et al, 2004, p. 559.
} 
indivíduos e instituições para se engajarem em atividades criativas e de inovação, ao conferir aos responsáveis pela agregação de valor aos bens comuns o direito de reter uma parte dos benefícios sociais, gerados por seu trabalho. ${ }^{359}$

Locke estabelece condições que devem ser observadas para que o homem obtenha um direito de propriedade sobre um determinado bem. ${ }^{360}$ Primeiramente, o bem deve resultar do trabalho útil do homem sobre os bens compartilhados pela humanidade. ${ }^{361}$ Se o bem sobre o qual o homem exerceu seu trabalho for de propriedade de outrem, do seu trabalho não surgirá um direito de propriedade, pois este implicaria na supressão do direito de outrem. A segunda condição é que o ato de apropriação dos recursos comuns conserve aos demais membros da humanidade recursos em qualidade e quantidade adequada para lhes proporcionar uma existência digna. Locke preocupa-se com a realização dos interesses materiais de todos os indivíduos da família humana, a partir de seu trabalho. ${ }^{362}$ A terceira condição fixada por Locke figura como um limite ao direito de propriedade: este se estende até onde o homem possa "retirar uma vantagem qualquer para sua existência sem desperdício [...]. Tudo o que excede a este limite é mais que a sua parte e pertence aos outros." $" 363$

Com base na idéia de que a concessão de DPIs tem como propósito estimular indivíduos e instituições a investirem seu trabalho e recursos escassos na geração de bens intelectuais, os DPIs se mostram, em termos teóricos, inadequados para protegê-los, ${ }^{364}$ porquanto o interesse central dos Estados e das comunidades tradicionais não é obter um incentivo para investirem na geração de RBIs contemporâneos; desejam fundamentalmente obter proteção para bens intelectuais pré-existentes ao regime de proteção.

\subsubsection{FUNDAMENTO COMUM DA OBRIGAÇÃo DE PROTEÇÃO DAS PRODUÇõeS INTELECTUAIS GERADAS NA SOCIEDADE OCIDENTAL E NO ÂMBITO DE COMUNIDADES TRADICIONAIS}

\footnotetext{
${ }^{359}$ Cf. HUGHES, 1997, p. 119-120.

${ }^{360}$ Cf. SHIFFRIN, 2001, p. 147-148.

${ }^{361}$ Cf. LOCKE, 1994, p. 97-99.

${ }^{362}$ Ibid., p. 98.

363 Ibid., p. 100.

${ }^{364}$ Cf. WIPO, WIPO/GRTKF/IC/12/5(b)), anexo, p. 89.
} 
Além das grandes convenções de proteção da PI, em vigor desde o final do séc. XIX (Convenções de Berna e Paris) e daquelas adotados desde então, a proteção internacional conferida aos autores de produções intelectuais tem como raízes o marco internacional de direitos humanos. Há mais de seis décadas, a Declaração Universal dos Direitos do Homem (DUDH), em seu artigo 27(2), reconhece a todo ser humano o "direito à proteção dos interesses morais e materiais decorrentes de qualquer produção científica, literária ou artística da qual seja autor”. Quase duas décadas mais tarde, o Pacto Internacional de Direitos Econômicos, Sociais e Culturais (PIDESC ou Pacto), em seu art. $15(1)(c),{ }^{365}$ reiterou a obrigação insculpida na DUDH. ${ }^{366}$

Embora o Pacto sublinhe que os direitos econômicos, sociais e econômicos estão sujeitos à realização progressiva, seus Estados contratantes estão obrigados a adotar algumas medidas positivas, as quais devem ser realizadas imediatamente ing $^{367}$ apua entrada em vigor. Os Estados contratantes do Pacto devem inclusive reformar seu marco legal doméstico, naquilo que for necessário, para acomodar as obrigações lá previstas, ${ }^{368} \mathrm{e}$ empregar "até o máximo dos recursos de que disponha" para empreender a tarefa de operacionalizar os direitos lá reconhecidos (art. 2(1)).

Em 2005, o Comitê sobre Direitos Econômicos, Sociais e Culturais (CDESC), o órgão do Conselho Econômico e Social da ONU encarregado de monitorar o cumprimento do PIDESC por seus Estados Contratantes, publicou o Comentário Geral no. 17, com o propósito de identificar o conteúdo normativo do art. 15.1(c). ${ }^{369} \mathrm{O}$ CDESC esclareceu que o art. 15.1(c) estende proteção também ao PBI das comunidades locais, ${ }^{370}$ obrigando, pois, a todos os Estados contratantes a reconhecer o direito das comunidades de se beneficiar

\footnotetext{
${ }^{365}$ No mesmo sentido, o art. 13 da Declaração Americana dos Direitos e Deveres do Homem de 1948 ("He likewise has the right to the protection of his moral and material interests as regards his inventions or any literary, scientific or artistic works of which he is the author") e o art. 14(1)(c) do Protocolo Adicional à Convenção Americana sobre Direitos Humanos na área de Direitos Econômicos, Sociais e Culturais ("The States Parties to this Protocol recognize the right of everyone: (c.) To benefit from the protection of moral and material interests deriving from any scientific, literary or artistic production of which he is the author").

${ }^{366}$ É de se notar que países industrializados e usuários de RBIs são partes contratantes deste acordo. Dentre eles, podemos mencionar a Austrália, Áustria, Alemanha, Canadá, Dinamarca, Espanha, Finlândia, França, Itália, Irlanda, Israel, Japão, Reino Unido, Suécia, Suíça. Os EUA assinaram o acordo em 1977, mas nunca o ratificaram. Informações extraídas de: $<$ http://www2.ohchr.org/english/bodies/ratification/3.htm $>$. Acesso em 3 dez. 2008.

${ }^{367}$ Cf. CCPR, CCPR/C/21/Rev.1/Add.13, para. 5.

${ }^{368} \mathrm{O}$ art. 27 da Convenção de Viena sobre o Direito dos Tratados determina que “[u]ma parte não poderá invocar as disposições de seu direito interno como justificação do incumprimento de um tratado".

${ }^{369}$ Cf. CESCR, E/C.12/GC/17.

${ }^{370}$ Ibid., para. 7-8.
} 
"da proteção dos interesses morais e materiais decorrentes de toda a produção científica, literária ou artística" de que sejam autoras. Sem embargo, no presente, raros são os países que contam com regimes legais dedicados à proteção do RBIs. Não porque inexista uma obrigação de tutelar os interesses morais e materiais dos grupos culturalmente diferenciados, mas em virtude do fato das comunidades tradicionais não deterem qualquer poder político, que torne seus interesses visíveis. ${ }^{371}$

Os regimes ocidentais de proteção da PI tratam os RBIs já disseminados na sociedade dominante como elementos pertencentes ao domínio público e, por isso, sujeitos à livre apropriação por terceiros. ${ }^{372}$ Assim, sob a ótica dos regimes ocidentais de proteção da PI, uma vez difundido um RBI para além da comunidade tradicional que o conserva, seus membros perdem o oportunidade de controlá-lo e de extrair quaisquer benefícios econômicos. ${ }^{373}$ Por exemplo, no presente, embora as publicações científicas sejam instrumentos de proteção da liberdade de expressão científica e criativa da sociedade, aquelas especializadas no estudo dos CTAs e recursos biológicos facilitam sua apropriação pelos setores científico e empresarial, que nada compartilham com as fontes dos RBIs utilizados. $^{374}$

O domínio público se estende sobre aqueles bens intelectuais e prerrogativas de uso sobre os quais não recai um DPI e, por isso, podem ser livremente utilizados e exercidos. Em termos concretos, pertencem ao domínio público:

- Aqueles bens intelectuais e informações que não se qualificam para proteção por DPIs, ou porque não preenchem as condições de proteção ou porque integram o rol de matérias não-elegíveis para proteção;

- Todas as produções intelectuais que já foram protegidas por DPIs, cujo termo de proteção já expirou;

\footnotetext{
${ }^{371}$ Cf. POSEY, 2004g, p. 181-182.

${ }^{372}$ Id., 2004f, p. 139-140.

${ }^{373}$ Id., 2004d, p. 170.

${ }^{374}$ Ver, e.g., SAMPATH, 2005, p. 146; DAES, 1997, para. 110.
} 
- Todos os usos de produções intelectuais protegidas por DPIs, autorizados pelos regimes de proteção da PI e jurisprudência, independentemente da obtenção de autorização prévia dos titulares de direitos (as exceções aos DPIs); e

- Aqueles bens intelectuais, tutelados por DPIs cujos usos foram autorizados previamente por seus titulares; e.g. as obras autorais sujeitas às licenças Creative Commons. ${ }^{375}$ Aqui é válido um esclarecimento, ainda que não aprofundado, a respeito das licenças Creative Commons: O mecanismo das licenças Creative Commons oferece aos titulares de direitos autorais um leque de condições préfixadas (condições standardizadas), que podem ser escolhidas para reger o contrato de licenciamento. Por meio das licenças Creative Commons, os titulares de direitos autorais tendem a oferecer amplamente suas obras a terceiros para fins criativos e educacionais, desde que determinadas condições por eles selecionadas sejam observadas (e.g. respeito ao direito moral de atribuição; uso da obra para fins não-comerciais; não modificação da obra protegida etc.). Quando os titulares de direitos autorais elegem uma licença Creative Commons para reger as regras de licenciamento da obra, essa licença é agregada à obra, facilitando, portanto, sua disseminação pública, uma vez que os usuários não precisam negociar acordos de licenciamento, em bases individuais. ${ }^{376}$

Ao rotular os RBIs como recursos em domínio público, os regimes de DPI se colocam em status hierárquico superior às normas comunitárias que regem seu acesso, uso e transmissão na esfera intra e intercomunitária. ${ }^{377}$ As comunidades tradicionais, naturalmente, protestam contra tal tratamento e julgam a figura do domínio público altamente discriminatória, sobretudo porque parcelas substanciais de seu patrimônio intelectual foram disseminadas independentemente de sua vontade, ${ }^{378}$ e porque a difusão e compartilhamento de RBIs é imanente ao seu processo de desenvolvimento e

\footnotetext{
${ }^{375}$ Cf. DEAZLEY, 2007, p. 25-27; CAHIR, 2007, p.36.

376 Para maiores informações a respeito do tema, consultar $<$ http://creativecommons.org/>.

377 Cf. GIBSON, 2007, p. 177.

${ }^{378}$ Ver, e.g., SCBD, UNEP/CBD/WG8J/5/INF/15, p. 9; WIPO, WIPO/GRTKF/IC/12/4(C), anexo, p. 44; TOBIN, 2004, p. 9-10. A intervenção do representante da tribo Tulalipe, na quinta sessão do CIG da OMPI é ilustrativa desta posição: "Its existence (do PBI) in the 'public domain' has not been caused by their failing to take the steps necessary to protect the knowledge in the Western IP system, but from a failure from governments and citizens to recognize and respect the customary law regulating its use" (TULALIPE TRIBES OF WASHINGTON, 2003).
} 
conservação. ${ }^{379}$ As comunidades sustentam que a mera difusão de seus RBIs para além das fronteiras de suas comunidades não deveria esvaziar seu direito de aplicar suas normas consuetudinárias, da mesma forma que uma obra literária, protegida por direitos autorais, pode ser divulgada amplamente no território onde a proteção foi obtida, sem que seu titular perca seus direitos. ${ }^{380}$

Tomando nota que o marco internacional de direitos humanos demanda que todo ser humano tenha sua dignidade respeitada e seja tratado sem discriminação, ${ }^{381}$ marcos legais, voltados à implementação do art. 15(1)(c), não devem se limitar a conferir proteção apenas às produções intelectuais concebidas em conformidade com as normas e práticas vigentes na sociedade ocidental. A aplicação do Pacto de modo a deixar descoberto os RBIs caracteriza uma discriminação racial, ${ }^{382}$ nos termos da Convenção Internacional para a Eliminação de Todas as Formas de Discriminação Racial, ${ }^{383}$ ou simplesmente um ataque ao princípio da igualdade entre pessoas de todas as raças e grupos étnicos, ${ }^{384}$ o que acaba por interferir na realização dos direitos fundamentais dos membros das comunidades tradicionais. ${ }^{385}$

Ainda que se argumente que os regimes de proteção da propriedade intelectual podem ser utilizados pelos membros das comunidades tradicionais, segundo o Comitê das Nações Unidas sobre a Eliminação da Discriminação Racial, tais regimes podem ser qualificados como discriminatórios, se gerarem "um impacto díspar injustificável sobre

\footnotetext{
${ }^{379} \mathrm{Cf}$. SCBD, UNEP/CBD/WG8J/4/INF/9, para. 88(k).

${ }^{380}$ Ver, e.g., SCBD, UNEP/CBD/COP/9/7, para. 41 (a representante da Indigenous Women's Biodiversity Network defende "[...] que seus sistemas de conhecimento não estão sujeitos ao domínio público e que a definição de conhecimentos tradicionais deve respeitar os sistemas jurídicos dos povos indígenas"); SCBD, $\mathrm{UNEP} / \mathrm{CBD} / \mathrm{WG} 8 \mathrm{~J} / 4 / \mathrm{INF} / 9$, para. 12; e declaração conjunta da Indigenous World Association e da Indigenous Media Network (E/CN.4/Sub.2/AC.4/2005/CR).

${ }^{381}$ Cf. NIEC, 1998, p. 182.

${ }^{382} \mathrm{O}$ art. 1(1) desta Convenção define discriminação racial como “[...] toda distinção, exclusão, restrição ou preferência baseada em motivos de raça, cor, descendência, ou origem nacional ou étnica que tenha por objeto ou por resultado anular ou menoscabar o reconhecimento, gozo ou exercício, em condições de igualdade, dos diretos humanos e liberdades fundamentais nas esferas políticas, econômica, social, cultural, social, cultural ou em qualquer outra esfera da vida pública".

${ }^{383}$ A importância prática desta Convenção está no fato de países industrializados como Canadá, EUA, Japão e Estados europeus a terem ratificado. Informações extraídas de: $<$ http://www2.ohchr.org/english/bodies/ratification/2.htm>. Acesso em: 03 dez. 2008.

${ }^{384}$ Cf. CERD, 2004, para. 1-4. O art. $2^{\circ}$ da Declaração das Nações Unidas sobre os Povos Indígenas dispõe: "Os povos e pessoas indígenas são livres e iguais a todos os demais povos e indivíduos e têm o direito de não serem submetidos a nenhuma forma de discriminação no exercício de seus direitos, que esteja fundada, em particular, em sua origem ou identidade indígena".

${ }^{385}$ Cf. art. 5, Convenção Internacional para a Eliminação de Todas as Formas de Discriminação Racial e o art. 2(2) do PIDESC.
} 
grupos distinguidos por raça, cor, descendência ou origem nacional ou étnica." ${ }^{\text {386 }}$ Esta é exatamente a conseqüência de oferecer DPIs às comunidades tradicionais como única alternativa de proteção de seus RBIs: o direito internacional da propriedade intelectual ao mesmo tempo em que possui um caráter universalizante, porquanto objetiva sua aplicação em âmbito global, é discriminatório, ao determinar a elegibilidade das produções intelectuais segundo os padrões ocidentais. ${ }^{387}$ Os regimes convencionais de propriedade intelectual, ao excluírem de seu escopo os RBIs, conferem um status superior às produções intelectuais gestadas segundo os padrões ocidentais. ${ }^{388}$ Este tratamento discriminatório põe em perigo a diversidade de fontes que a alimentam a criatividade humana, instigando a homogeneização cultural. ${ }^{389}$

Cabe aos Estados contratantes do PIDESC suprimir qualquer feição discriminatória de suas políticas e regimes legais, dedicados à proteção de produções intelectuais. É parte de suas responsabilidades monitorar a conduta do setor privado e reprimir aquelas de natureza discriminatória, ${ }^{390}$ inclusive punir empresas e nacionais sob sua jurisdição que infrinjam, localmente ou no exterior, ${ }^{391}$ os direitos materiais e morais assegurados às comunidades locais, resguardados pelo PIDESC. ${ }^{392}$

A adoção de regimes de proteção dos RBIs, que atentem às suas características peculiares, não se qualifica como um ato discriminatório, uma vez que objetiva viabilizar a fruição pelas comunidades locais de seus direitos assegurados pelo art. 15.1(c) do PIDESC, em igualdade de condições com os outros setores da sociedade. ${ }^{393}$ A fim de se alcançar um igualdade substantiva, os grupos culturalmente diferenciados devem gozar não apenas dos mesmos direitos compartilhados pelos membros da sociedade dominante, mas também de

\footnotetext{
${ }^{386}$ Cf. CERD, 1993, para. 2.

387 Paráfrase baseada em um texto de Keal (2003, p. 85) a respeito do caráter discriminatório do direito internacional: "International law can for these reasons, be seen as a 'universalising discourse' that simultaneously sought to include and exclude some but not all non-Europeans. It was universalising because the rules and norms it codified were intended to have universal application, but by seeting the terms for inclusion in international society according to European standards it necessarily excluded many nonEuropeans".

${ }^{388}$ Cf. DAES, 1997, para. 18 e 142.

${ }^{389} \mathrm{Cf}$. art. $7^{\circ}$, UNESCO, Declaração Universal sobre a Diversidade Cultural.

${ }^{390}$ Cf. CERD, 1996, para. 1 - 2.

${ }^{391}$ Cf. COOMBE, 1998-1999, p. 70.

${ }^{392}$ Ver, e.g., KHALFAN; SEGGER, 2004, p. 211; CESCR, E/C.12/2000/4, para. 42.

${ }^{393}$ Cf. artigos 1(4) e 2(2), Convenção Internacional para a Eliminação de Todas as Formas de Discriminação Racial.
} 
direitos específicos, adequados à sua condição e realidade. ${ }^{394}$ Discriminação é obrigar as comunidades locais a se adequarem aos padrões ocidentais, o que pode interferir em suas práticas, costumes e valores culturais.

Sem surpresas, poucos Estados contratantes do PIDESC cumprem integralmente suas obrigações derivadas do art. 15(1)(c), ao focarem apenas na proteção das criações intelectuais geradas no seio da cultura ocidental. Conforme será visto neste capítulo, os regimes de proteção da PI se mostram habilitados a proteger o PBI tão-somente em caráter residual. E mesmo assim, os recursos econômicos e técnicos necessários protegê-los mediante DPIs estão fora do alcance das comunidades tradicionais.

\subsection{A INADEQUAÇÃo dOS DIREITOS AUTORAIS PARA TUTELAR AS ECTS}

O regime internacional de direitos autorais, inaugurado pela Convenção de Berna (CB), por um lado, mostra-se, em regra, inadequado à proteção jurídica das ECTs, essencialmente por refletir as práticas criativas dominantes na sociedade ocidental e as necessidades e demandas dos criadores individuais. ${ }^{395}$ Pelo outro, o regime internacional de direitos autorais facilita grandemente a prática de atos de apropriação cultural por parte dos criadores pertencentes à sociedade dominante, ao tratar ECTs como expressões artísticas integrantes do domínio público. ${ }^{396}$

Os atos de apropriação cultural são caracterizados pela utilização de ECTs fora de contextos culturais, sem a devida autorização das comunidades tradicionais pertinentes e sem o pagamento das retribuições econômicas devidas. Os impactos negativos para as comunidades locais decorrentes desta dupla iniqüidade têm natureza cultural e econômica.

Em termos culturais, o uso de ECTs, em contextos e de modos culturalmente desrespeitosos, infringe as normas sociais das comunidades responsáveis por disciplinar seu uso, conservação e disseminação. Uma obra de arte, grafismo ou escultura criada e conservada por uma comunidade tradicional, apesar de seu apelo estético, pode ter natureza religiosa, ${ }^{397}$ não podendo ser amplamente utilizada.

\footnotetext{
${ }^{394}$ Cf. CERD, 1999, para. 2- 3.

${ }^{395}$ Cf. SCBD, UNEP/CBD/WG8J/5/3/Add.2, para. 33.

${ }^{396}$ Cf. EVATT, 1998, p. 57-80.

${ }^{397}$ Cf. JANKE, 2003, p. 14.
} 
Quanto aos impactos econômicos, a ausência de meios de controle da exploração comercial de produtos derivados de ECTs interfere injustamente nas oportunidades das comunidades de extraírem benefícios de ordem material de suas expressões. ${ }^{398}$ Em resposta, as comunidades se fecham para intercâmbios culturais com outras comunidades e com a sociedade dominante. ${ }^{399}$

O litígio envolvendo a artista plástica Maria Bernadete Conte e a indústria joalheira H. Stern (H. Stern) ilustra o caráter duplamente iníquo do regime de direitos autorais. A artista plástica criou uma linha de jóias inspirada na arte indígena e apresentou-a, em 1988, à H.Stern. A indústria joalheira expressou desinteresse na coleção de Conte. Contudo, seis anos mais tarde lançou no Brasil e no exterior, a coleção de jóias Purãngaw, inspirada na arte de povos indígenas brasileiros. Em 11 de setembro de 1996, Conte propôs uma ação de indenização em face da H.Stern, perante o Poder Judiciário do Estado do Rio Grande do Sul, ${ }^{400}$ com fundamento na suposta infração aos seus direitos autorais. Em primeira instância, a H.Stern venceu; em grau de apelação a decisão foi revertida em favor de Conte. Contra a apelação, a empresa joalheira apresentou embargos infringentes, mas sem sucesso.

A pergunta em que se centrou o litígio foi se a H.Stern havia infringido os direitos autorais da artista plástica. Embora, o voto da relatora dos embargos infringentes assinale que "as jóias idealizadas pela autora [Maria Bernadete Conte] reproduzem modelos das tribos Muiraquitãs (fls. 95, 97, 98, 99), 'Wai-Wai’ (fls. 101-102, 104), ‘Arumã I' (fl. 105), 'Krixaná' (fls. 106, 107), Karajá I (fl. 109, 110, 111, 112, 113, 114, 115), 'Maiongong' (fls. 126, 127), 'Asurini' (fls. 136, 137), 'Apaial' (fl. 141, 142)”, e que "as peças da Coleção Purãngaw traduzem criações artísticas das tribos Ashaninka, Kadiwéu, 'Caiapó', 'Bororó', Nahukuá, 'Kaigang' e 'Ramkokamekra-canela', Tukano, 'Carajás”, 401 em momento algum o litígio tratou da incidência de direitos autorais de titularidade das etnias citadas sobre as ECTs, que serviram de base ${ }^{402}$ às obras das partes litigantes. Muito pelo

\footnotetext{
${ }^{398}$ Cf. BROWN, M., 2005, p. 44; DUTFIELD, Graham Dutfield, 2003, p. 26.

${ }^{399}$ Cf. SCBD, UNEP/CBD/WG8J/1/INF/2, para. 20.

${ }^{400}$ Cf. BRASIL - Tribunal de Justiça do Rio Grande do Sul, 2004.

${ }^{401}$ Cf. voto vencido da desembargadora Mara Larsen Chechi, BRASIL - Tribunal de Justiça do Rio Grande do Sul, 2004.

402 A dissertação de mestrado de Taísa Rodrigues (2006, p. 75-95), apresenta a reprodução fotográfica de inúmeras peças artísticas contemporâneas, criadas sob a inspiração da arte indígena, inclusive a coleções de
} 
contrário, quatro dos votos proferidos sustentaram que as obras artísticas das comunidades indígenas integram o domínio público brasileiro, ${ }^{403}$ apesar dos termos da lei aplicável ao caso, ${ }^{404}$ que determina pertencer ao domínio público, “[a]lém das obras em relação às quais decorreu o prazo de proteção aos direitos patrimoniais [...] [aquelas] "de autor desconhecido, transmitidas pela tradição oral". ${ }^{405}$ As ECTs indígenas que serviram de base para as obras dos litigantes estão fixadas em um suporte permanente - as peças de artesanato e os livros que as reproduzem -, logo, não são transmitidas apenas por tradição oral. Por conseguinte, não se poderia presumir que as ECTs utilizadas pertencem ao domínio público, sem antes examinar se o prazo de proteção, conferido pela lei aplicável às obras de autores desconhecidos, já expirou. ${ }^{406} \mathrm{E}$ ainda que se concluísse que as ECTs indígenas, utilizadas no processo criativo das partes litigantes, pertencem ao domínio público, a lei aplicável ao caso estabeleceu um regime de domínio público pagante, que demanda dos usuários de obras caídas em domínio público, quando “a utilização visar a

jóias da H.Stern. Neste sentido, a desembargadora Larsen Chechi parece reconhecer que o aporte intelectual da H.Stern para a criação da coleção, em relação às obras originais indígenas, é pequeno: "As jóias da coleção designada Purãngaw, produzida pela ré, embora igualmente baseadas no acervo cultural indígena brasileiro, reproduzem com maior fidelidade (pela leveza, cores, harmonia de movimentos e linhas curvas) os padrões adotados como fontes de inspiração." No mesmo sentido o desembargador Adão Sérgio do Nascimento Cassiano, aponta que a H.Stern "[...] alega, sem qualquer sustentável probatório, que se baseou em cópia de livro e exames de livros sobre a cultura indígena". Ver BRASIL-Tribunal de Justiça do Rio Grande do Sul, 2004.

${ }^{403}$ Ver voto da desembargadora Mara Larsen Chechi ("Destarte, se é rigorosamente certo dizer que ambas as partes acessaram um acervo de domínio público para a criação de suas coleções de jóias, também tanto a autora como a ré se valeram da estrutura da arte indígena e desenvolveram o tema em estilos diferentes, produzindo resultados finais estéticos também diferentes, sem nenhuma identidade de estruturação na escolha dos referenciais. E, como cediço, o aproveitamento de idéia preexistente no acervo cultural comum não caracteriza nenhum ilícito"); o voto do desembargador Luís Augustro Coelho Brava ("Para concluir o laudo, diz o perito que não constatou na coleção da $\mathrm{H}$. Stern que existam elementos formais que possam caracterizar cópia ou plágio de modelos, no máximo a inspiração em uma idéia de domínio público."); o voto do desembargador Luiz Ary Vessini de Lima ("Trata-se de um parecer de um especialista em Matemática no sentido de que realmente a coisa não é tão simples assim, que embora a temática indígena seja do folclore, seja do uso comum, a verdade é que [...]"); e o voto do desembargador Paulo Antônio Kretzmann ( "[...] convenci-me da inexistência de plágio, em virtude de que a temática dos indígenas brasileiros constitui patrimônio de domínio público.”). Ver BRASIL-Tribunal de Justiça do Rio Grande do Sul, 2004.

${ }^{404}$ BRASIL. Lei no. 5.988, de 14 de dezembro de 1973.

${ }^{405}$ Cf. caput e inciso II do artigo 48, Lei no. 5.988, de 14 de dezembro de 1973. A lei no. 9.610/98, que substituiu a lei no. 5988/73, retirou do rol de obras que integram o domínio público, as ECTs; seu art. 45, II, dispõe que pertence ao domínio público as obras "de autor desconhecido, ressalvada a proteção legal aos conhecimentos étnicos e tradicionais." Neste dispositivo, a expressão "conhecimentos étnicos e tradicionais" foi utilizada sem tecnicidade. Mas devido à natureza artística da matéria tutelada pela Lei 9610/98, esta expressão refere-se às ECTs. Segundo uma das roupagens do princípio da boa-fé (Ex re sed non ex nomine), o operador do direito deve dar atenção à substância e intenção dos termos legais, ao invés de se apegar a denominações legais (CHENG, B. 1953, p. 122).

${ }^{406} \mathrm{O}$ art. 44 da Lei no. 5.988/73 aplica o prazo de sessenta anos para a proteção dos "direitos patrimoniais sobre obras anônimas. [...], contado de $1^{\circ}$ de janeiro do ano imediatamente posterior ao da primeira publicação." 
lucro [...] [o pagamento de] importância correspondente a cinqüenta por cento da que caberia ao autor da obra," se as ECTs não integrassem o domínio público. ${ }^{407}$

O resultado do litígio corrobora a força da idéia disseminada no ocidente, de que os RBIs pertencem ao domínio público, enquanto os trabalhos intelectuais dos indivíduos integrados à sociedade dominante merecem proteção legal, mesmo quando o marco legal procure salvaguardar os interesses das comunidades tradicionais.

\subsubsection{INAPLICABILIDADE DOS REGIMES DE DIREITOS AUTORAIS ÀS ECTS}

Como regra, os regimes de proteção dos direitos autorais se mostram inaptos para a proteção das ECTs pelas razões tratadas a seguir.

\subsubsection{TitUlaridade E AUTORIA}

As ECT são o resultado de um processo criativo comunitário lento, que se protrai cumulativamente por longos períodos. ${ }^{408}$ No início do processo criativo, a ECT é criada por um indivíduo, mas posteriormente pequenas variações são realizadas, ${ }^{409}$ pouco a pouco por outras gerações da comunidade a fim de refletir sua identidade cultural. ${ }^{410}$ Nas palavras de Barsh, as ECTs "consistem em obras de indivíduos que ganharam significação coletiva". 411 Muitas vezes, não é factível a identificação dos autores individuais responsáveis pela criação de uma ECT, ou os responsáveis pela conservação contemporânea das ECTs podem ter realizado aportes não-substanciais para justificar a obtenção de direitos autorais.

Os regimes de direitos autorais têm o autor-individual como seu centro gravitacional: ${ }^{412}$ a proteção autoral nasce de aporte criativo individual e contemporâneo, ${ }^{413}$

\footnotetext{
${ }^{407}$ Cf. parágrafo único do art. 93, Lei no. 5988/73.

${ }^{408}$ Cf. RICKETSON, 1987, p. 313.

${ }^{409}$ Cf. KUTTY, 2002, p. 9.

${ }^{410}$ Cf. KURUK, 1998-1999, p. 796.

${ }^{411}$ BARSH, 1999, p. 16, tradução nossa.

${ }^{412}$ Cf. FICSOR, 1998, p. 217.

${ }^{413}$ Cf. UNESCO; WIPO, 1985, para. 10.
} 
que conecta uma determinada obra a um ou mais autores identificáveis. Sem embargo, as legislações contemporâneas vêm sendo remodeladas, de modo a permitir que entes coletivos possam ser titulares de direitos autorais, em virtude da realidade atual, caracterizada pela forte atuação dos conglomerados empresariais. ${ }^{414}$ Ainda assim, as legislações contemporâneas não se mostram úteis para a proteção das ECTs. Por exemplo, obras produzidas por uma coletividade, para receberem proteção legal, devem ter um coordenador contemporâneo, responsável por dirigir sua criação. ${ }^{415}$

As comunidades tradicionais consideram que a própria noção de titularidade, adotada pelos regimes de DPIs, não reflete sua concepção mais sofisticada, que não vê a comunidade ou seus membros como titulares de direitos, mas como fideicomissários, investidos na obrigação de observarem determinadas responsabilidades relacionadas à ECT, em benefício do grupo. ${ }^{416}$ As ECTs - e qualquer outro RBI - são um patrimônio comunitário, não sendo adequado um regime dedicado à valorização do indivíduo em detrimento do grupo. ${ }^{417}$ Sob a perspectiva do regime de proteção da PI, um determinado membro da comunidade pode fruir de direitos individuais amplos sobre as ECTs que "criou". Mas sob a ótica da comunidade, estes direitos pertencem ao grupo. Os DPI ignoram o vínculo existente entre o criador e a comunidade, que teria por efeito limitar seus direitos individuais. ${ }^{418}$ Em outras palavras, os direitos autorais podem conferir direitos de controle sobre uma ECT em favor de uma parte diferente da pessoa ou instituição que deveria controlá-la, quando analisamos as normas consuetudinárias da comunidade pertinente. $^{419}$

\subsubsection{DIREITOS MORAIS}

\footnotetext{
${ }^{414}$ Cf. DUTFIELD, 2001, p. 250-251.

${ }^{415}$ Cf. VON LEWINSKI, 2003-2004, p.758.

${ }^{416}$ Cf. WIPO, WIPO/GRTKF/IC/13/4(b)Rev., para. 35(b).

${ }^{417}$ Cf. HANSEN; VANFLEET. 2003, p. 4.

${ }^{418}$ Ver, e.g., DUTFIELD, 2003, p. 24; KURUK, 1998-1999, p. 794.

${ }^{419}$ Cf. VON LEWINSKI, 2004, p. 383; WIPO, WIPO/GRTKF/IC/13/5(b) Rev., para. 86; KALINOE, 2004, p. 43.
} 
Os direitos morais de paternidade e de integridade, reconhecidos pela Convenção de Berna ${ }^{420}$, têm como parâmetro os interesses dos autores individuais e como fundamento os direitos da personalidade. A manifestação de uma idéia pode se dar de inúmeras formas, e o homem, por meio de sua vontade e personalidade única, tem a capacidade expressá-la, segundo a maneira que lhe aprouver. O reconhecimento de direitos morais em relação às manifestações materiais da personalidade do autor configuram o reconhecimento social do vínculo que liga o criador à criatura. ${ }^{421}$

Enquanto as ECTs são criadas constantemente por inúmeros indivíduos, muitos deles não-identificáveis, os quais refletem as expectativas artísticas de um grupo, o sistema de direitos autorais tutela a honra, a reputação, enfim, os interesses de autores identificáveis.

\subsubsection{PROTEÇÃO TEMPORALMENTE LIMITADA}

Enquanto os regimes de direitos autorais concedem proteção temporalmente limitada às obras literárias e artísticas, uma vez que a vida das comunidades ultrapassa a vida de cada um de seus membros, estes grupos consideram que os regimes de direitos autorais inadequados para tutelar ECTs, pois não lhes confeririam proteção perpétua. ${ }^{422}$

\subsubsection{REQUISITO DA FIXAÇÃO EM UM SUBSTRATO PERMANENTE}

Em regra, várias categorias ${ }^{423}$ de ECTs são transmitidas oralmente, por imitação ou por outros meios que dispensam sua fixação em um suporte permanente. ${ }^{424}$ Embora a Convenção de Berna confira aos Estados contratantes a opção de condicionar a proteção

\footnotetext{
${ }^{420} \mathrm{O}$ art. 6(1)bis, $\mathrm{CB}$ confere aos autores o "[...] direito de reivindicar a paternidade da obra e de se opor a qualquer deformação, mutilação ou outra modificação da obra ou a qualquer outro atentado contra a mesma obra, prejudicial à sua honra ou à sua reputação."

${ }^{421}$ Cf. HUGHES, 1997, p. 141-152.

${ }^{422}$ Cf. DUTFIELD, 2001, p. 251.

${ }^{423}$ Nem todas as ECTs sofrem deste problema: peças de artesanato, jóias, esculturas, pinturas, dentre outras ECTs, são fixadas pelas comunidades pertinentes em suportes permanentes.

${ }^{424}$ Cf. DUTFIELD, op. cit., p. 252.
} 
das obras literárias e artísticas à sua fixação em um substrato permanente, ${ }^{425}$ geralmente, os regimes nacionais de direitos autorais condicionam sua proteção à observância desta condição, com vistas a viabilizar a identificação das fronteiras da obra protegida, o momento de sua criação e o momento da expiração da proteção. ${ }^{426}$ ECTs orais, e.g canções não-fixadas em um suporte permanente, pinturas corporais geralmente não são elegíveis de proteção pelos regimes de direitos autorais. O problema poderia ser resolvido com sua fixação em um suporte permanente. Contudo, faltam às comunidades tradicionais os meios econômicos para realizar tal tarefa. Na prática, são os indivíduos e instituições ocidentais que se encarregam de fixar as ECTs em publicações, bancos de dados, e em outros suportes; e com o mero ato de fixação ganham direitos autorais sobre ECTs criadas pelos esforços de outrem. ${ }^{427}$

\subsubsection{ORIGINALIDADE}

A proteção autoral de qualquer obra artística ou literária depende do preenchimento da condição de originalidade, devendo expressar a individualidade de seu criador, ou nas palavras de Lipszyc, a obra deve ter "algo de individual y proprio de su autor". ${ }^{428} \mathrm{O}$ aporte individual do autor, cristalizado em sua obra, pode ser mínimo para que mereça proteção legal, isto é, deve expressar "algún grado de creatividad y ser fruto del esfuerzo personal de su autor." $" 429$

As ECTs são criadas por indivíduos, mas modificadas cumulativamente por um sem número de gerações de uma comunidade tradicional, a fim de expressar as expectativas culturais do grupo. Os autores das modificações realizadas, muita vez não são identificáveis, sendo, portanto, impossível reconhecer-lhes direitos. No mais, em princípio, os aportes criativos individuais podem não ser necessariamente substantivos, ao ponto de afastar a versão contemporânea de uma ECT daquela que lhe deu origem. ${ }^{430}$

\footnotetext{
${ }^{425}$ Cf. art. 2(2), CB.

${ }^{426}$ Cf. GERVAIS, 2005, p. 141-142.

${ }^{427}$ Cf. WIPO, WIPO/GRTKF/IC/13/4(b) Rev., para. 35(c).

${ }^{428}$ Cf. LIPSZYC, 2001, p. 65.

${ }^{429}$ Ibid., p. 67.

${ }^{430}$ Ver, e.g., VON LEWINSKI, 2003-2004, p. 759; KURUK, 1998-1999, p. 796.
} 
Sem bem que os regimes de direitos autorais exigem que as obras protegidas sejam originais, na prática, tal exigência, embora varie em cada jurisdição, é preenchida com alguma facilidade. Basta a comprovação de que o criador contemporâneo empregou habilidades artísticas e esforço intelectual para criar uma versão contemporânea da ECT, que não se confunde com a ECT base. ${ }^{431}$ Em outras palavras, mesmo aportes nãosubstanciais podem ser suficientes para dotar a versão contemporânea de originalidade, para fins de proteção legal, ${ }^{432}$ desde que identificável seu autor. Por conseguinte, apesar da incapacidade dos regimes de direitos autorais para tutelar as ECTs antigas ou simples reproduções de ECTs, suas versões contemporâneas, criadas por indivíduos identificáveis artistas pertencentes ou não a comunidades tradicionais ${ }^{4}{ }^{43}$ são elegíveis de proteção autoral, desde que sejam portadoras de alguma contribuição intelectual em relação à ECT que lhe deu origem. ${ }^{434} \mathrm{O}$ aspecto negativo associado à facilidade com que se preenche $\mathrm{o}$ critério de originalidade está na neutralidade dos regimes de direitos autorais, os quais conferem proteção legal a qualquer pessoa, que criar versões contemporâneas de ECTs. ${ }^{435}$

\subsubsection{DICOTOMIA IDÉIA/EXPRESSÃO}

Os regimes de direitos autorais têm como princípio basilar a dicotomia idéia e expressão, o que significa que estes regimes conferem proteção à expressão de uma idéia, conservando a última em domínio público, em benefício de todos. ${ }^{436}$ Por exemplo, um jurista pode escrever um livro sobre um determinado tema, sem que terceiros percam o direito de escrever sobre o mesmo tema. Ainda que comunidades tradicionais logrem obter proteção autoral para as versões contemporâneas de suas ECTs, seus interesses não estarão

\footnotetext{
${ }^{431}$ Cf. WIPO, WIPO/GRTKF/IC/13/4(b) Rev., para. 44.

${ }^{432}$ Cf. HUDSON, 2006, p. 55.

${ }^{433}$ No caso George M*, Payunka, Marika \& outros v. Indofurn, o Poder Judiciário da Austrália reconheceu a existência de direitos autorais sobre a obra criada pelos artistas indígenas que propuseram a ação. A criatividade e habilidades artísticas empregadas foram consideradas suficientes para conferir direitos autorais sobre obras substancialmente derivadas de ECTs (JANKE, 2003, p. 7).

434 Cf. VON LEWINSKI, 2003-2004, p. 760; LUCAS-SCHLOETTER, 2004, p. 365; WIPO, WIPO/GRTKF/IC/13/4(b)Rev., para. 35(a).

${ }^{435}$ Cf. WIPO, WIPO/GRTKF/IC/13/4(b) Rev., para. 59(a).

${ }^{436}$ Cf. art. 9(2), Acordo TRIPS. Ver também JANKE, 2003, p. 22; WIPO, WIPO/GRTKF/IC/13/4(b) Rev., para. 35(g); GERVAIS, 2003, p. 475.
} 
necessariamente tutelados, se não lhes for conferido o direito de controlar o uso das idéias que permeiam a obra protegida. ${ }^{437}$

\subsubsection{LIMITAÇÕES AOS DIREITOS AUTORAIS}

Os regimes de proteção dos direitos autorais apresentam limitações aos direitos de exclusivo conferidos aos seus titulares, que têm por fim fomentar objetivos públicos, tais como liberdade criativa, direito de acesso à informação para fins educacionais etc. Em virtude destas limitações, mesmo obras protegidas por direitos autorais poderão ser reproduzidas parcialmente, independentemente da vontade dos titulares de direitos, naturalmente dentro da margem fixada por lei. ${ }^{438}$ Algumas limitações aos direitos autorais podem ser contrárias aos interesses das comunidades tradicionais, ${ }^{439}$ sobretudo quando a ECT for portadora de natureza sagrada.

\subsubsection{RESTRIÇÃO DA DIFUSÃO}

DPIs limitam o acesso aos bens por eles protegidos por aqueles que podem por eles pagar. Muitas comunidades tradicionais pobres podem se ver destituídas do direito de acessar ECTs, se forem protegidas por um direito de propriedade intelectual. ${ }^{440}$

Apesar de todas essas dificuldades, os regimes de direitos autorais apresentam alguma utilidade às comunidades tradicionais. Primeiramente, porque muitas ECTs, embora venham sendo criadas e recriadas desde tempos imemoriais, em realidade, são desconhecidas do grande público, pois nunca foram fixadas em um suporte permanente ou

437 O sistema de repressão da concorrência desleal, fundado no art. 10bis da CP, poderia aplicar-se excepcionalmente para proteger um determinado estilo artístico (a idéia de per si, ao invés da aplicação concreta do estilo) conservado por uma comunidade tradicional, se esta tiver adquirido um caráter distintivo, isto é, se o uso do estilo por um terceiro sugerir ao público que a comunidade tradicional endossa a comercialização do produto que ostenta o estilo, ou que o produto foi produzido pela comunidade. As regras de repressão à concorrência desleal seriam aplicáveis apenas para reprimir esta associação ou mensagem fraudulenta. Não havendo indícios que levem o público consumidor a se enganar neste sentido, terceiros podem utilizar livremente o estilos artísticos criados e conservados por comunidades tradicionais (WIPO, WIPO/GRTKF/IC/13/4(b) Rev, para. 59(b)).

${ }^{438}$ Cf. LAMETTI, 2004, p. 284 et seq.

${ }^{439}$ Cf. WIPO, WIPO/GRTKF/IC/13/4(b) Rev., para. 35(f).

${ }^{440}$ Id., 2001, p. 193. 
divulgadas fora dos limites das comunidades que as criaram e conservam. Enquanto estas ECTs não forem fixadas e divulgadas, é como se não existissem para os regimes de direitos autorais. Nesse sentido, as ECTs desconhecidas do grande público se qualificariam como “originais", a partir de sua fixação em um suporte permanente e divulgação pública.

Em segundo lugar, as versões contemporâneas das ECTs são criadas por indivíduos identificáveis. Se as autoridades da comunidade de pertinente determinarem que certos indivíduos sejam os autores das ECTs contemporâneas, para fins de obtenção de proteção autoral, não importará aos regimes de direitos autorais, se eles de fato o são, ou se representam gerações passadas e presentes de uma dada comunidade.

Sem embargo, é relevante reiterar que os direitos autorais são totalmente inúteis para a proteção das informações que permeiam as ECTs. Conseqüentemente, não são um instrumento verdadeiramente adequado ao resguardo dos interesses materiais, morais e religiosos das comunidades tradicionais, que podem ter, dependendo do tipo de ECT, o interesse de controlar tanto a ECT quanto as informações que a permeiam. ${ }^{441}$

\subsubsection{INICIATIVAS INTERNACIONAIS PARA A CORREÇÃO DO CARÁTER DISCRIMINATÓRIO DOS DIREITOS AUTORAIS}

$\mathrm{Na}$ década de 60, os países em desenvolvimento, instigados pelo intenso processo de descolonização que tomou lugar desde o fim da $2^{\text {a }}$ Guerra Mundial, se engajaram em aplacar o caráter discriminatório da Convenção de Berna, durante a Conferência de Revisão de Estocolmo, em 1967. A principal proposta neste sentido foi apresentada pela delegação da Índia, ${ }^{442}$ que propôs a emenda do art. $2^{\circ}$ da CB a fim de inserir as ECTs no rol de obras elegíveis para proteção autoral. O efeito da inserção seria obrigar todos os Estados contratantes a conceder proteção autoral às ECTs, em seus respectivos territórios. A proposta não vingou, pois se chocou com a oposição de alguns países industrializados.

Uma solução, que se mostrou um fracasso na prática, foi aceita pelos Estados participantes da negociação. $\mathrm{O}$ art. 15 da CB foi emendado para permitir a proteção de

\footnotetext{
${ }^{441}$ Cf. POSEY, 2004k, p. 156-157.

${ }^{442}$ Cf. RICKETSON, 1987 , p. 314.
} 
obras literárias e artísticas não-publicadas, ${ }^{443}$ criadas por um autor cuja identidade é desconhecida, desde que fortes indícios o apontem como nacional de um Estado membro da União de Berna (art. 15(4)). O exercício dos direitos morais e patrimoniais ficaria investido em uma autoridade nacional, designada pelo Estado contratante, com a função de exercê-los em nome do autor desconhecido.

Uma das fraquezas da "solução" alcançada é seu caráter opcional; após mais de quarenta anos desde a aprovação da emenda, apenas a Índia designou uma autoridade nacional para exercer os direitos autorais de autores desconhecidos. A segunda fraqueza está em reconhecer direitos autorais sobre obras de autores individuais desconhecidos, quando a regra é que as ECTs resultem do trabalho criativo de uma comunidade tradicional. Dependendo da interpretação que se dê aos termos da CB, um Estado pode se julgar não obrigado a reverter os benefícios econômicos coletados junto aos usuários de uma ECT, tutelada pelo art. 15(4) da CB, na hipótese de uma comunidade tradicional reivindicar, em nome próprio, a titularidade dos direitos autorais exercidos pela autoridade governamental. ${ }^{444}$

Em terceiro lugar, quando os Estados optam por conceder proteção às ECTs não publicadas, a proteção durará por apenas cinqüenta anos, a partir de sua divulgação ao público. ${ }^{445}$ Se um Estado presumir que o criador de uma dada ECT morreu há mais de cinqüenta anos, poderá optar por não protegê-la. ${ }^{446}$

Apesar do insucesso da emenda, o desafio representado pela proteção internacional das ECTs se conservou ininterruptamente na agenda dos países em desenvolvimento até meados da década de 1980: em 1973, a Bolívia solicitou ao Diretor Geral da UNESCO a emenda da Convenção Universal de Direitos Autorais da UNESCO, com vistas a estender proteção autoral às ECTs. ${ }^{447}$ Três anos mais tarde, a OMPI e a UNESCO publicaram a Lei Modelo de Direitos Autorais da Tunísia para Países em Desenvolvimento (Lei Modelo da

\footnotetext{
${ }^{443}$ Os direitos autorais relacionados a obras publicadas de autores desconhecidos são exercidos pelo editor, até que o autor se identifique (art. 15(3), CB).

${ }^{444}$ Cf. DAES, 1997, para. 132.

${ }^{445} \mathrm{O}$ prazo de proteção para obras de autores conhecidos perdura durante sua vida mais cinqüenta anos após a sua morte (art. 5(1), CB)

${ }^{446}$ Cf. art. 7(3), CB.

${ }^{447}$ Cf. HONKO, 2001, p. 8-10.
} 
Tunísia), a título de referência legal aos países em desenvolvimento. ${ }^{448}$ A Lei Modelo da Tunísia além de inserir no rol de matérias elegíveis de proteção autoral as ECTs não fixadas em um suporte permanente, ${ }^{449}$ ainda confere a esta matéria proteção por tempo ilimitado e investe em uma autoridade governamental o poder-dever de exercer os direitos de natureza patrimonial e moral associados às ECTs. ${ }^{450}$

Entre o final da década 70 e início da década de 80, a UNESCO e OMPI trabalharam em conjunto na redação de um projeto de regime sui generis de direitos autorais, dedicado exclusivamente à proteção das ECTs. O resultado final deste trabalho tomou a forma de "Disposições Modelo para a Proteção de Expressões Folclóricas contra Atos de Exploração Ilícita e outras Ações Prejudiciais" (Disposições Modelo), publicadas em 1982. ${ }^{451}$ As Disposições Modelo, da mesma forma que a Lei Modelo da Tunísia, podem ser caracterizadas como uma adaptação do sistema de proteção de direitos autorais, amoldando-o à natureza coletiva do processo criativo ${ }^{452}$ próprio das ECTs. ${ }^{453}$

Após a publicação das Disposições Modelo, as duas agências das Nações Unidas novamente uniram esforços para redigir um projeto de tratado internacional de proteção das ECTs contra atos de exploração ilícita e outras ações prejudiciais, ${ }^{454}$ o qual refletiu substancialmente o conteúdo das disposições Modelo de 1982. Em 1984, a OMPI e a UNESCO reuniram um grupo de especialistas em proteção internacional de ECTs para avaliar a viabilidade de se adotar a minuta de tratado internacional. Àquela época, os participantes julgaram inadequada a adoção de um tratado internacional para a matéria, em virtude das dificuldades para se identificar aquelas ECTs que deveriam ser objeto de proteção e devido à ausência de uma solução para os problemas concernentes às ECTs presentes em dois ou mais países (ECTs regionais). ${ }^{455}$

\footnotetext{
${ }^{448}$ Cf. UNESCO; WIPO, 1976.

${ }^{449} \mathrm{Cf}$. artigos 1(3) e 1(5), UNESCO, WIPO, 1976.

${ }^{450}$ Cf. art. $6^{\circ}$, UNESCO, WIPO, 1976.

${ }^{451}$ Id., 1985.

${ }^{452}$ Cf. POSEY, 2004k, p. 160-161.

453 A configuração das disposições modelo reproduz a estrutura ordinária das leis de direitos autorais. As disposições modelo contêm, dentre outros elementos: (1) uma lista de usos sujeitos à autorização prévia dos titulares de direitos (art. 3), (2) uma lista de exceções aos direito de exclusivo conferidos, notadamente para fins educacionais e criativos (art. 4), (3) direitos morais das comunidades; (4) lista de atos que constituem ofensas culturais que devem ser reprimidas (art. 6); (5) uma lista de sanções civis e penais que poderiam ser aplicadas para dotar o marco legal de efetividade (arts. 6-8).

${ }^{454}$ Cf. UNESCO; WIPO, 1984.

${ }^{455}$ Cf. FISCSOR, 1998, p. 223.
} 
Ao final da década de 80 , o tema é retomado pela UNESCO por intermédio da adoção da Recomendação sobre a Salvaguarda da Cultura Tradicional e Popular. Tal recomendação encoraja os Estados membros da UNESCO a adotarem medidas de preservação das ECTs para as futuras gerações; dentre elas, foi recomendada a adoção de regimes sui generis de proteção das ECTs. ${ }^{456}$

O tema só retornou com força à agenda internacional em 1996, quando da adoção dos novos tratados da OMPI para proteção dos direitos autorais e conexos, no contexto das novas tecnologias da informação. ${ }^{457}$ Nessa época, os países em desenvolvimento lograram persuadir a OMPI e a UNESCO a organizarem, um ano mais tarde, o Fórum Mundial sobre proteção do Folclore. O Fórum adotou um plano de ação para a negociação de um acordo para a proteção das ECTs, o qual nunca saiu do papel. ${ }^{458}$

\subsection{EXPANSÃo DO DIREITO DAS PATENTES SOBRE AS INVENÇÕES BIOTECNOLÓGICAS E SUA INAPTIDÃO PARA TUTELAR OS CTS E OS RECURSOS DA BIODIVERSIDADE}

\subsubsection{O DESENVOLVIMENTO DA BIOTECNOLOGIA E AS MUDANÇAS EMPREENDIDAS NOS REGIMES DE PATENTES}

Desde o final do século XIX, o sistema de patentes procurou se adequar à expansão da capacidade científica e tecnológica da humanidade para manipular seres vivos para fins úteis. Já em 1873, o USPTO concedeu pela primeira vez uma patente para uma invenção composta por um organismo vivo: uma levedura, desenvolvida por Louis Pasteur. Mas alguns anos após a concessão desta patente, o USPTO passou a vetar proteção a pedidos de patentes que reivindicassem organismos vivos. ${ }^{459}$ Quase um século mais tarde, como reflexo dos novos desenvolvimentos científicos empreendidos no setor das ciências biológicas, em 1969, a Suprema Corte da Alemanha, no caso Rote Taube, decidiu favoravelmente pela patenteabilidade de animais, resultantes de alguma intervenção humana, sem a qual o animal-invenção não existiria. ${ }^{460}$

\footnotetext{
${ }^{456}$ Cf. item "F", UNESCO, Recomendación sobre la salvaguardia de la cultura tradicional y popular.

${ }^{457}$ Tratado da OMPI sobre direito de autor (WCT) e Tratado da OMPI sobre Interpretação ou Execução e Fonogramas (WPPT).

${ }^{458}$ Cf. VON LEWINSKI, 2003-2004, p. 755.

${ }^{459}$ Cf. GRUBB, 2004, p. 248 -284.

${ }^{460}$ Cf. WESTERLUND, 2002, p. 27-29.
} 
Apesar desses precedentes, a decisão que mais influenciou a extensão dos regimes nacionais, regionais e internacionais de patentes para tutelar invenções biotecnológicas foi aquela proferida pela Suprema Corte dos EUA, no caso Diamond v. Chakrabarty. ${ }^{461}$ Em 1972, Ananda Chakrabarty, bioquímico da General Electric, depositou perante o USPTO uma patente que reivindicava proteção para uma bactéria não-natural do gênero Pseudomonas, capaz de digerir moléculas de petróleo cru. O USPTO rejeitou as reivindicações relacionadas à bactéria per se, ao considerar seres vivos, em conformidade com a doutrina dos produtos da natureza, ${ }^{462}$ não elegíveis para proteção patentária. $\mathrm{O}$ USPTO receava que, ao estender proteção para um ser unicelular modificado pelas mãos do homem, patentes poderiam ser reivindicadas para seres multicelulares, resultantes da intervenção humana, inclusive sobre seres humanos. ${ }^{463}$

Chakrabarty apelou para a Court of Customs and Patent Appeals, que reverteu a decisão do USPTO. Este, por sua vez, apelou à Suprema Corte dos EUA, com vistas a esclarecer definitivamente a dúvida sobre a patenteabilidade de seres vivos, desenvolvidos por intervenção humana. A Suprema Corte dos EUA interpretou ampliativamente os termos da lei de patentes deste país, e julgou que "qualquer coisa sob o sol produzida pelo homem" seria passível de proteção. Para a Suprema Corte era irrelevante se a invenção era composta por um ser vivo ou um ser inanimado. Nos termos do julgado, é patenteável qualquer invenção resultante do trabalho intelectual humano, desde que não exista previamente no estado da técnica ou livremente na natureza. ${ }^{464}$

A sentença proferida no litígio entre o USPTO e Chakrabarty é o pilar que sustentou a prática das cortes norte-americanas de ampliar continuamente o rol de invenções biotecnológicas patenteáveis. Como reflexo do caso Chakrabarty, o regime de patentes norte-americano passou a proteger invenções constituídas por seres vivos modificados geneticamente, ${ }^{465}$ inclusive mamíferos ${ }^{466}$ e material genético de origem humana.

${ }^{461}$ UNITED STATES OF AMERICA, Supreme Court of United States. DIAMOND, Commissioner of Patents and Trademarks v. CHAKRABARTY (447 U.S. 303).

${ }_{462}$ Desde 1889 , o USPTO não concedia patentes para produtos que ocorrem naturalmente na natureza; concedia proteção apenas aos processos para sua extração.

${ }^{463}$ Cf. KEVLES, 2002, p. 16-17.

${ }^{464}$ Ibid., p. 44.

${ }^{465}$ Ibid., p. $46-47$

${ }^{466}$ Ibid., p. 45-47. 
Conforme já adiantado, a influência do caso Chakrabarty é global. Desde 1980, as políticas, a jurisprudência e os marcos legais dos países industrializados e em desenvolvimento vêem sendo influenciados a seguir o rastro deixado pela jurisprudência norte-americana. Inclusive, a cláusula da biotecnologia do Acordo TRIPS da OMC art.27(3)(b) -, que obriga os Estados membros da OMC a concederem DPIs sobre algumas invenções biotecnológicas, é um reflexo da jurisprudência norte-americana.

A força propulsora da expansão global do escopo de proteção dos regimes de patentes foi a adoção da ficção jurídica de que organismos vivos e seus elementos constitutivos - material genético, polinucleotídeos, polipeptídios etc. - constituem meros compostos químicos. ${ }^{467}$ Igualar materiais biológicos a produtos químicos permitiu a aplicação analógica da experiência legal e administrativa, desenvolvida anteriormente para tutelar invenções químicas, às invenções do setor biotecnológico. ${ }^{468}$ A preocupação central dos países industrializados era - e continua sendo - o de assegurar incentivos econômicos para a expansão dos setores biotecnológico e biomédico.

Perseguir o desenvolvimento científico e industrial local é um objetivo político louvável, desde que esta busca não ocorra à custa dos interesses legítimos de países em desenvolvimento e de comunidades tradicionais. Os desenvolvimentos legislativos e jurisprudenciais ocorridos nas últimas três décadas facilitaram a apropriação dos recursos biológicos e CTAs por parte dos indivíduos e instituições dedicadas a atividades de P\&D, essencialmente baseados nos países industrializados.

\subsubsection{O PROBLEMA DA BIOPIRATARIA}

As matérias-primas básicas utilizadas pela indústria farmacêutica e da biotecnologia são o trabalho humano, os conhecimentos especializados, os recursos

\footnotetext{
${ }^{467}$ Garforth (2005, p. 25) reconhece que, ao nível mais básico, os seres vivos têm como tijolos fundamentais compostos químicos: bases nitrogenadas adenina, guanina, citosina e tiamina, quando associadas à uma molécula de açúcar e outra de fosfato formam um nucleotídeo, que é a unidade básica dos genes. De fato, as partes de um ser vivo podem ser caracterizadas como compostos químicos, mas um organismo vivo não se confunde com a soma de suas partes.

${ }^{468}$ A título de exemplo, as Diretrizes de Patenteabilidade do Instituto Nacional de Propriedade Industrial do Brasil (INPI) para invenções farmo-químicas e biotecnológicas adota a mesma ficção jurídica que serviu de base à expansão do alcance dos regimes de patentes, nos países industrializados. No item que trata sobre a patenteabilidade de polinucleotídeos e polipeptídeos sintéticos, as Diretrizes dispõem: "Cabem as observações acima para compostos químicos, uma vez que, de fato, são compostos químicos [...]" (INPI, 2002, item 2.3.1).
} 
biológicos e o capital; os países em desenvolvimento e suas comunidades contribuem para seu desenvolvimento com CTs e recursos biológicos. ${ }^{469}$ Esses insumos, em sua capacidade de catalisadores do processo de $\mathrm{P} \& \mathrm{D}$ de novos produtos e processos biomédicos e biotecnológicos, criam uma externalidade positiva ${ }^{470} \mathrm{em}$ favor dos setores produtivo e científico. Entretanto, organizações científicas e industriais, movidas pela ambição desmedida, freqüentemente retribuem o bem recebido com a imposição de uma externalidade negativa sobre as comunidades tradicionais e países em desenvolvimento, ao não reconhecerem o papel destas contribuições ao desenvolvimento de sua missão nem beneficiá-las com uma parcela dos lucros auferidos.

A prática de apropriação dos recursos da biodiversidade e dos CTAs é chamada popularmente de biopirataria. ${ }^{471} \mathrm{O}$ termo se refere à obtenção de um DPI sobre uma criação não-inventiva que reproduz ${ }^{472}$ ou se funda substancialmente em um CTA e/ou recurso biológico, ${ }^{473}$ ou à obtenção de um DPI para uma criação nova e inventiva, derivada de um CTA e/ou recurso biológico. Em ambas as situações, ou titular do DPI não reparte quaisquer benefícios econômicos com as comunidades tradicionais e/ou Estados

${ }^{469}$ Cf. KOOPMAN, 2006, p. 132.

${ }^{470}$ Externalidades são ações externas geradoras de efeitos positivos ou negativos sobre a atividade de alguém. Há uma externalidade positiva quando alguém é beneficiado por uma ação de terceiro. A contrario sensu, há uma externalidade negativa, quando a ação de um indivíduo/organização gerar impactos negativos sobre terceiros (EPSTEIN, 1993, p. 558-560).

471 O termo "biopirataria" não é um termo legal, existindo diversas definições. Possivelmente, a mais influente é a do ETC Group (2009), que a define como "[...] a apropriação do conhecimento e recursos genéticos das comunidades agrícolas e indígenas por indivíduos ou instituições que buscam controle exclusivo monopólico (patentes ou propriedade intelectual) sobre estes recursos e conhecimentos". Esta definição exclui de seu escopo a exploração comercial de produtos resultantes da apropriação de recursos da biodiversidade e CTs, mas que não são protegidos por DPIs. Em sentido diverso, para a Câmara de Comércio Internacional (ICC, 1999), há biopirataria quando terceiros, após a entrada em vigor da CDB, em dezembro de 1993, acessarem e utilizarem recursos da biodiversidade e CTs em desrespeito às normas do país onde foram acessados. $\mathrm{O}$ gatilho da biopirataria seria acionado, quando fossem desrespeitadas as normas nacionais que disciplinam o acesso aos recursos da biodiversidade e CTs, pouco importando se o usuário demandará proteção intelectual para o produto/processo que utilizá-los. A definição da CCI é favorável aos países industrializados, haja vista que muitos países biológica e culturalmente diversos não contam com marcos legais que regulam o acesso aos seus RBIs. Neste contexto, apropriá-los seria lícito.

${ }^{472}$ Um caso paradigmático é o da patente norte-americana no. 5,894,079, concedida em 13 de abril de 1999 sobre qualquer variedade de feijão que ostente um determinado tom de cor amarela. $\mathrm{O}$ objeto da patente (feijão "enola"), nada mais é que uma variedade de feijão originária do México, amplamente cultivada há séculos e consumida no mercado americano, pelo menos, desde os anos 30. Em 2000, a FAO impugnou, perante o USPTO, a validade da patente, com fundamento no fato da patente recair sobre uma variedade de feijão idênticas a um tipo de feijão natural, depositado nas coleções ex situ do Grupo Consultivo para Investigação Agrícola (GCIA). Em abril de 2008, o USPTO revogou a patente, mas o titular da patente revogada ainda pode apelar às cortes americanas (ETC GROUP, 2008a, 2002, p.7; RAFI, 2002, p.2).

${ }^{473}$ Um exemplo clássico é a patente concedida para o pesticida agrícola Margosan-O. A empresa titular da patente, a norte-americana W.R.Grace, "desenvolveu" o referido produto por intermédio da apropriação de CTs associados às sementes da árvore Azadirachta indica, em uso ininterrupto pelo povo da Índia há pelo menos dois mil anos (SHIVA, [199-]). 
provedores dos insumos utilizados, ${ }^{474}$ ou reparte benefícios infinitesimais, pagos para debelar possíveis demandas legais. Esta última categoria de casos é classificada como biofraude $^{475}$ e é viabilizada pela existência de múltiplas fontes de um mesmo recurso biológico e CTAs, permitindo que o potencial usuário escolha as fontes provedoras mais facilmente manipuláveis. ${ }^{476}$ A noção de biopirataria funda-se na falha deliberada dos regimes de DPIs em promover o reconhecimento e a compensação material pelos aportes informacionais e intelectuais dos países ricos em termos biológicos e das comunidades tradicionais, absorvidos como insumos gratuitos ou de custo infinitesimal para a geração de produtos e processos valiosos, freqüentemente protegidos por DPIs.

Embora haja quem duvide da existência da biopirataria, ${ }^{477}$ fechando os olhos para todas as evidências, ${ }^{478}$ esta prática de espoliação sistemática impinge perdas surpreendentes aos países em desenvolvimento e a suas comunidades tradicionais: em 1999, o Programa das Nações Unidas para o Desenvolvimento estimou que, se os usuários de recursos da agrobiodiversidade, de plantas medicinais e de CTAs, desenvolvidos e conservados pelas comunidades dos países pobres, estivessem obrigados a pagar-lhes a

${ }^{474}$ KOOPMAN, 2005, p. 528.

${ }^{475}$ Segundo Vogel, não é porque um usuário de recursos biológicos ou CTs assinou um acordo de repartição de benefícios com as comunidades/Estado pertinentes, que este acordo revestirá a transferência com o manto da probidade. Muitos acordos oferecem aos provedores de RBIs benefícios econômicos irrelevantes, com o intuito de debelar acusações de biopirataria (VOGEL, 2007a).

${ }^{476}$ Cf. MOONEY, 2000, p. 37 et seq.

${ }^{477}$ J. Chen (2006, p. 14), inter alia, argumenta que, se os países em desenvolvimento não desempenham com êxito seus direitos soberanos sobre seus recursos biológicos, os usuários destes recursos não deveriam sofrer qualquer tipo de responsabilização. Koopman (2005, p. 531), por sua vez, sustenta que os Estados nacionais gozam de soberania sobre seus recursos biológicos tangíveis, mas não sobre os recursos intangíveis neles contidos. Assim, o autor considera legalmente insustentável considerar que a CDB dê alguma base para os países em desenvolvimento reivindicarem qualquer participação nos benefícios resultantes da exploração comercial de invenções patenteadas, derivadas de recursos biológicos intangíveis. Koopman ignora que a $\mathrm{CDB}$ estende aos Estados contratantes da CDB direitos sobre seus recursos biológicos intangíveis, conforme os termos de seus art. $2^{\circ}$.

${ }^{478}$ Existem inúmeros exemplos na literatura nacional e internacional de casos de biopirataria. Limitar-nosemos a indicar algumas alguns poucos exemplos e referências. Um estudo recente (MCGOWN, 2006) identificou dezenas de patentes, depositadas em países industrializados, sobre invenções desenvolvidas com recursos da biodiversidade terrestre e marinha da África, reivindicadas por empresas como Bayer, Phytopharm, Glaxo SmithKline, Christian Dior, Merck. As patentes reivindicam proteção para produtos farmacêuticos, cosméticos e agrícolas, enzimas microbiológicas usadas em detergentes. O Edmonds Institute (2006) identificou uma variedade de amendoim originária do Brasil, utilizada nos EUA desde a década de 80 , no melhoramento das variedades de amendoim, cultivadas neste país. Estima-se que a variedade brasileira rendeu cerca de US\$ 2 bilhões aos americanos, no período de dez anos. A respeito de um caso de apropriação de recursos biológicos e CTs originários do Sri Lanka, utilizados desde longa data no tratamento do diabetes (KUMAR, 2004). Ver RAFI, 1993 para informações sobre a apropriação de variedades de algodão naturalmente coloridos, conservados originariamente por comunidades indígenas mexicanas e peruanas. Em nenhum dos casos mencionados, as instituições privadas acusadas transferiram quaisquer benefícios econômicos às comunidades e Estados provedores de recursos biológicos e CTs. 
taxa de $2 \%$ por seu uso comercial, ser-lhes-ia devido US\$ 5,3 bilhões/ano. ${ }^{479}$ Mas, na prática, o quantum revertido em benefício das comunidades tradicionais e dos Estados ricos em recursos biológicos gira em torno de $0.001 \%$ do total produzido direta ou indiretamente a partir de seus aportes. ${ }^{480}$

Os regimes contemporâneos de DPI foram organizados para eternizar os países em desenvolvimento e suas populações no papel de provedores de matéria-prima barata e consumidores de produtos industrializados, ${ }^{481}$ bem como para assegurar a privatização dos benefícios oriundos dos RBIs e a socialização dos custos de conservação. Em outras palavras, os DPIs asseguram benefícios econômicos decorrentes dos recursos da biodiversidade e dos CTAs a um número reduzido de indivíduos e instituições, enquanto os custos de conservação de ecossistemas naturais e de criação dos CTAs são suportados por comunidades tradicionais pobres e países em desenvolvimento. ${ }^{482}$ Conforme vimos anteriormente, tal feição dos regimes contemporâneos de PI não é de modo algum chancelada pelo direito internacional, que explicitamente proíbe o exercício de direitos por um indivíduo ou grupo, de modo a prejudicar a realização dos direitos de outrem. ${ }^{483}$

A visão estreita de curto prazo dos regimes de PI ignora as conseqüências nefastas que advirão, inclusive aos países industrializados e suas instituições. No longo prazo, se as comunidades tradicionais continuarem a ser sistematicamente espoliadas, é possível que, em meio à miséria material em que muitas delas vivem, venham a perecer e com elas seu PBI e biomas a ele relacionados. ${ }^{484}$ Neste contexto, os DPIs figuram como uma ferramenta biocolonial, ${ }^{485}$ ao promovem crescimento econômico selvagem, marcado pela busca

\footnotetext{
${ }^{479}$ Cf. UNITED NATIONS DEVELOPMENT PROGRAMME, 1999, p. 71.

${ }^{480}$ Cf. POSEY, 1990, p. 16.

${ }^{481}$ Ver preâmbulo, The Cocoyoc Declaration, 1974.

${ }^{482}$ Cf. VOGEL, 2004, p. 228.

${ }^{483}$ Cf. art. 30, DUDH; art. 5(1), PIDESC.

${ }^{484}$ Ver LECHNER; GUBAYDULLINA; BIZER, 2008, p. 8-10; GUPTA, 2002, p. 386-387. Swanson e Goeschl, (2007, p. 11-14), com base em informações empíricas colhidas após a introdução da lei de cultivares nos EUA, nos anos 70, concluem que foram realizados investimentos maciços em P\&D na área de melhoramento vegetal e em capacitação de cientistas. Mas notam que não foram canalizados investimentos para a conservação das fontes primárias dos insumos informacionais empregados pela indústria da agrobiotecnologia: ecossistemas naturais. Como resultado dessa omissão, entre 1960 e 1990, notou-se um aumento de mais de $30 \%$ na taxa de conversão das áreas naturais prístinas em campos agrícolas na África, América Latina e Ásia, o que certamente diminui as fontes de insumos ao desenvolvimento da indústria da biotecnologia.

${ }^{485}$ Cf. WHITT, 1998, p. 214-125.
} 
incessante do lucro pelos grandes conglomerados e instituições dos países industrializados às expensas dos grupos marginalizados e da gestão sustentável da natureza. ${ }^{486}$

A biopirataria figura como uma categoria de pirataria intelectual, ${ }^{487}$ tão combatida pelos países industrializados, quando se vêem na posição de vítimas de atos infratores de seus DPIs, supostamente praticados por organizações e indivíduos dos países em desenvolvimento. ${ }^{488}$ Quando as instituições dos países desenvolvidos ocupam a posição de autores de atos de apropriação de RBIs, podem se valer de artifícios legais hábeis a legitimar e apoiar suas práticas de usurpação. ${ }^{489}$ Ironicamente, enquanto os países em desenvolvimento e suas comunidades detêm recursos intelectuais e biológicos, que são tratados pelos regimes de propriedade intelectual como res nullius, as instituições dos países industrializados, ao desenvolverem criações intelectuais derivadas destes mesmos RBIs, podem gozar de DPIs altamente eficazes internacionalmente. ${ }^{490}$

A doutrina da terra nullius (terras livres de ônus) foi utilizada pelos impérios europeus como justificativa legal para a apropriação das terras do novo mundo. Esta doutrina parte do pressuposto de que os povos indígenas inexistem e não detêm qualquer direito sobre as terras que habitaram desde tempos imemoriais. ${ }^{491} \mathrm{Na}$ década de 70 , a Corte Internacional de Justiça (CIJ) elaborou um parecer, a pedido da Assembléia Geral da ONU (AGONU), em que examinou se um determinado território, localizado na parte ocidental do Saara, àquela época sob o jugo espanhol, era à época de sua colonização terra nullius. A CIJ concluiu que as terras ocupadas pela Espanha, em 1884, não eram terra nullius, pois

\footnotetext{
${ }^{486}$ Cf. SACHS, 2007g, p. 294.

487 Segundo Dutfield (2001, p. 237-238), o termo "biopirataria" foi cunhado por Pat Mooney, ETC Group, para servir como uma contraforça retórica à argumentação recorrente dos países industrializados de que os países em desenvolvimento se apropriam da PI dos nacionais dos países industrializados. Tal argumentação serviu de base para a inserção do tema PI na agenda de negociação da Rodada Uruguai do GATT. O termo biopirataria contribuiu para esclarecer que a indústria farmacêutica e biotecnológica dos países industrializados, ao se apropriarem dos CTs e recursos da biodiversidade, igualmente merecem a alcunha de piratas.

488 Id., 2004, p. 145.

${ }^{489}$ Por exemplo, EUA e Japão defendem que não há biopirataria, quando uma invenção é desenvolvida a partir de recursos legalmente adquiridos no comércio. Tendo em vista que muitos recursos da biodiversidade são comercializados em todo o mundo, raros seriam os casos de biopirataria (WTO, IP/C/W/469, para. 13; WTO, IP/C/W/368/Rev.1, para. 106). Esta posição sumariza a posição da maioria dos países industrializados. Mas não seria correto generalizar. A Noruega é um bom exemplo de país industrializado que busca, na arena internacional, compatibilizar os interesses de seu setor produtivo com os dos países em desenvolvimento e das comunidades tradicionais.

${ }^{490}$ Cf. BRAGDON, 2002, p. 446. No mesmo sentido ver VON LEWINSKI, 2004, p. 383; THE CRUCIBLE II GROUP, 2000, p. 22; CLOATRE, 2006, p. 348.

${ }^{491}$ Cf. ECOSOC, E/CN.4/Sub.2/2001/21, para. 31.
} 
pertenciam às tribos que as ocupavam e administravam à época da conquista. ${ }^{492}$ Apesar do progresso empreendido no direito internacional, tacitamente a doutrina da terra nullius ainda sobrevive, quando os regimes de PI classificam os RBIs como recursos do domínio público, à espera de serem apropriados pelos criadores ocidentais. ${ }^{493}$

Os DPIs permitem "àquele que colocou o último tijolo na parede"494 reivindicar a parede inteira, ignorando a contribuição dos demais partícipes da construção. ${ }^{495}$ Os DPIs equivocadamente pressupõem a idéia de que os criadores intelectuais constroem suas produções intelectuais a partir do nada. ${ }^{496} \mathrm{O}$ trabalho de John Locke, freqüentemente citado como uma justificação filosófica da PI, poderia igualmente prestar-se para atacar a excessiva valorização das contribuições intelectuais dos criadores ocidentais sobre as das comunidades tradicionais e dos países ricos em termos bioculturais:

"Não são somente o esforço do trabalhador, a labuta do ceifador e do debulhador, o suor do padeiro, que devem ser levados em conta no pão que comemos; o trabalho daqueles que domesticaram os bois, que forjaram o ferro e lavraram as pedras, que abateram as árvores e serraram a madeira empregada no arado, no moinho, no forno e em quaisquer outros utensílios, que são em grande número requisitados para este grão, desde a semente a ser semeada até sua transformação em pão, devem ser considerados na avaliação do trabalho e tomados como um efeito dele."497

A essência da noção da biopirataria, marcada pelo caráter discriminatório dos DPIs, pode ser melhor apreendida com a decisão da Suprema Corte da Califórnia em Moore v. Regents of the University of California. ${ }^{498}$ Em outubro de 1976, John Moore, diagnosticado com leucemia, passou em consulta com o Dr. David Golde para ouvir uma segunda opinião médica. Golde colheu materiais corporais de Moore para a realização de exames diagnósticos, que acabaram por confirmar o parecer anterior. Golde recomendou a Moore uma cirurgia de retirada de seu baço, que foi realizada em 20 de outubro de 1976.

${ }^{492}$ Cf. WESTON, 1976, p. 616; INTERNATIONAL COURT OF JUSTICE, 1992, p. 101.

${ }^{493}$ Ver, e.g., SHIVA, 2001, p. 26-27.

${ }_{494}^{49}$ ROSS, 2000 apud GOLD; CARBONE, 2008, p. 44. No mesmo sentido, STIGLITZ, 1999, p. 320-321.

${ }^{495}$ Cf. HAMILTON, C., 2006, p. 97-98.

${ }^{496}$ Cf. SHIVA, 2001, p. 89.

${ }^{497}$ Cf. LOCKE, 1994, p. 108.

${ }^{498}$ UNITED STATES OF AMERICA: Supreme Court of California. Moore v. Regents of the University of Califórnia, 1990. 
Golde havia identificado, nos exames pré-operatórios, características únicas nas células do baço de Moore. Por conta destas peculiaridades, Golde instruiu o médico responsável pela cirurgia a encaminhar parte do material retirado para uma unidade de pesquisa da Universidade Califórnia em Los Angeles (UCLA). Seguindo a praxe médica, antes da cirurgia de extração do baço, Moore assinou um termo de consentimento prévio e informado, onde autorizou a retirada do baço. No entanto, o termo era omisso quanto ao uso de seu material para fins de pesquisa científica e comercial.

Em 1979, Golde e sua parceira de pesquisa, Dr. Quan, isolaram uma linha celular dos linfócitos $\mathrm{T}$ de Moore e lograram produzir em laboratório linfoquinas, substâncias secretadas pelas células $\mathrm{T}$, que exercem importante papel no funcionamento do sistema imunológico humano. Em 1981, a UCLA depositou uma patente, onde reivindicou proteção para a referida linha celular e para as linfoquinas por ela produzida, a qual foi concedida em 20 de março de $1984{ }^{499}$

Golde e Quan foram nomeados como os inventores, cabendo-lhes, com fundamento na política da UCLA, receber uma parcela dos benefícios financeiros auferidos pela exploração comercial da invenção. A patente foi licenciada para as empresas Genetics Institute e Sandoz, e o acordo de licenciamento trouxe benefícios econômicos consideráveis aos coinventores e à UCLA.

Moore, quando descobriu o ocorrido, processou Golde, Quan, a UCLA e as licenciadas, levando o caso até a Suprema Corte da Califórnia. Moore reivindicava o reconhecimento de seu direito de propriedade sobre seu material biológico empregado na pesquisa científica e, com fundamento na infração ao seu direito de propriedade, reivindicava participação nos lucros oriundos da exploração da patente. Em poucas palavras, Moore sustentou que, porquanto a jurisprudência norte-americana confere uma espécie de direito de propriedade sobre a imagem e o nome dos seres humanos, por extensão, também reconheceria um direito de propriedade sobre as unidades biológicas que sustentam a vida humana.

${ }^{499}$ Patente norte-americana no. 4438032. 
Sem embargo, a Suprema Corte da Califórnia, em um julgado não unânime, considerou que, diferentemente de um nome ou imagem, os materiais em litígio (células $\mathrm{T}$ e linfoquinas) são comuns e presentes em todo e qualquer corpo humano, não cabendo a Moore um direito de exclusivo sobre eles. ${ }^{500}$ Em outras palavras, a Suprema Corte julgou que, independentemente se um determinado material biológico é acessado com ou sem autorização de seu detentor, este não goza de qualquer direito de propriedade sobre ele, após dele ser separado. ${ }^{501}$

A argumentação da Corte é despida de lógica. Quando se trata de reconhecer a Moore um direito de propriedade sobre seu material biológico, o material é considerado trivial e livremente apropriável por terceiros. Este mesmo material "trivial" é digno de proteção por uma patente, conferida pelo USPTO em favor da UCLA, devido ao investimento intelectual da UCLA. Este raciocínio desconsidera a contribuição fundamental realizada pelo material de Moore ao sucesso do projeto de pesquisa da Universidade. $^{502}$ A posição majoritária justifica tamanha iniqüidade no interesse de assegurar a liberdade de iniciativa do complexo industrial farmo-biotecnológico norteamericano.

A feição discriminatória dos regimes correntes de proteção da PI promove a sobrevalorização do papel dos cientistas formais no desenvolvimento científico e industrial e a reflexa desvalorização das contribuições dos provedores de CTAs e recursos biológicos para os processos de P\&D. Esta característica é chamada por Robert Merton de efeito

\footnotetext{
${ }^{500}$ Dois votos vencidos (os dos juízes Broussard e Mosk) criticaram o não reconhecimento de um direito de propriedade em favor de Moore sobre seu material biológico. Broussard concorda que os pacientes, após a remoção de partes de seu corpo, não mais têm um direito de propriedade sobre seus órgãos, desde que concordem que os materiais removidos possam ser aplicados para fins científicos e comerciais. Segundo Brossard, a Suprema Corte da Califórnia praticou um ato imoral, ao permitir que terceiros se beneficassem de materiais obtidos de modo não-apropriado, sem recompensar o provedor da matéria-prima da inovação. Mosk igualmente julga a posição vencedora irracional e considera Moore o "parceiro silente" do empreendimento, que culminou no desenvolvimento das invenções patenteadas; considerou também que não compartilhar benefícios com este parceiro é iníquo e imoral. Cf. UNITED STATES OF AMERICA, Supreme Court of Califórnia. Moore v. Regents of the University of California, 1990.

${ }^{501}$ Cf. SKLOOT, 2006, p. 2-3.

${ }^{502}$ Apesar do não reconhecimento de um direito de propriedade em favor de Moore, a Suprema Corte da Califórnia the conferiu o direito de reivindicar danos materiais pelo uso comercial de seu material biológico, pois Golde teria infringido seu dever médico de informá-lo sobre aspectos que poderiam interferir em sua tomada de decisão. Embora um dos objetivos pretendidos por Moore tenha sido alcançado (compensação financeira), se não tivesse comprovado o interesse comercial sub-reptício de Golde, já no momento da cirugia de retirada do basso, nenhuma compensação seria devida. Aplicando o resultado deste litígio para os casos de biopirataria, se os Estados e comunidades não tiverem como comprovar a quebra de algum compromisso tácito ou explícito por parte dos usuários de recursos biológicos e CTAs, possivelmente suas reivindicações de indenização não teriam êxito.
} 
Mateus. ${ }^{503}$ Merton identificou que a comunidade científica sobrevaloriza as contribuições científicas realizadas pelos cientistas de renome e desvaloriza as contribuições, de igual importância, realizadas por cientistas desconhecidos. Em projetos e publicações conjuntos, em que um dos participantes tem prestígio, os louros são canalizados para este, ainda que as contribuições centrais sejam realizadas por outros co-participantes, pouco ou nada conhecidos. ${ }^{504}$ Uma das conseqüências negativas que deflui do efeito Mateus é a perda de incentivos sofrida pela parte desvalorizada para continuar em atividades de pesquisa, o que a obrigará a deixar o campo de pesquisa, já que os benefícios, que lhe seriam de direito, são canalizados para outrem. No caso dos recursos da biodiversidade e CTAs, as contribuições das comunidades e países ricos em recursos biológicos não são reconhecidas pela ciência e pelos DPIs. Estes grupos e países, empobrecidos e sem incentivos para conservarem seus "laboratórios naturais", podem não ver outra alternativa senão destruílos, em busca de alternativas mais rentáveis.

Além das brechas legais oferecidas pelos regimes de PI, a apropriação indébita dos RBIs é facilitada por sua qualidade de bens públicos. ${ }^{505}$ Com freqüência, recursos biológicos estão espalhados por regiões que compreendem vários países e são utilizados por um grande número de comunidades locais, que acabam desenvolvendo conhecimentos similares sobre os recursos compartilhados. ${ }^{506}$ Para tornar o quadro ainda mais complexo, faz-se necessário rememorar que no período pré-CDB, o fluxo de recursos genéticos era liberado, e muitas organizações privadas e públicas organizaram bancos de recursos biológicos de todo o mundo (coleções ex situ). Portanto, os usuários de recursos biológicos e CTAs podem identificar como sua fonte provedora o país cujo marco regulatório lhes oferecer as condições mais favoráveis. ${ }^{507}$

\footnotetext{
503 A expressão "efeito Mateus" foi cunhada por influência da parábola dos talentos, descrita no Evangelho de Mateus (Mateus 25:29), que pode ser sumarizada com o seguinte versículo "[p]orque a todo o que tem se lhe dará, e terá em abundância; mas ao que não tem, até o que tem lhe será tirado.”

${ }^{504}$ Cf. MERTON, 1968, 1988.

${ }^{505}$ Cf. item 1.3.1 supra.

${ }^{506}$ RAFI e a Indigenous Peoples' Biodiversity Network (1994) realizaram uma avaliação de 150 espécies de plantas e 1000 usos diferentes destas, e concluíram que a maior parte das espécies estudadas são utilizadas para o mesmo fim por duas ou mais comunidades; e 35\% das plantas pesquisadas são utilizadas ao menos em dois países.

${ }^{507}$ Cf. RAFI; INDIGENOUS PEOPLE'S BIODIVERSITY NETWORK, 1994, p. 6.
} 


\subsubsection{PAPEl do DIREITO DAS PATENTES NA APROPRIAÇÃo dOS CTS E DOS RECURSOS DA BIODIVERSIDADE}

Embora desde a década de 90, o direito das patentes venha passando por um profundo processo de harmonização internacional, iniciado com a adoção do Acordo TRIPS e intensificado com os acordos de livre comércio celebrados entre países industrializados e em desenvolvimento, ainda hoje, os Estados nacionais gozam de uma limitada liberdade para definir os critérios substantivos de patenteabilidade. ${ }^{508}$ Esta liberdade é utilizada para superproteger as produções intelectuais dos inventores ocidentais e pilhar os RBIs das comunidades tradicionais e países em desenvolvimento.

Os tópicos seguintes examinarão as interpretações legais correntes nos países industrializados - e que estão se disseminando por todo o mundo sob sua direção - que, inter alia, apagam as fronteiras que separam as noções de invenção e de descoberta e rebaixam as condições substantivas de patenteabilidade (novidade, inventividade e aplicação industrial).

Preliminarmente, é necessário esclarecer que o processo de exame da patenteabilidade de um determinado produto ou processo tem duas fases. Em um primeiro momento, o examinador de patentes avalia se o objeto é ou não uma invenção, i.e. se há alguma limitação legal que exclua o objeto do pedido da patente do rol de matérias elegíveis de proteção. Se o objeto for uma invenção, em um segundo momento, será avaliado o cumprimento das condições substantivas de patenteabilidade. Logo, podemos afirmar que todo produto/processo patenteado é uma invenção, mas nem toda invenção é passível de proteção patentária.

\subsubsection{INVENÇÃO E DESCOBERTA}

Todas as legislações de patentes apresentam um rol de matérias elegíveis para proteção patentária. As descobertas não são elegíveis para proteção, enquanto as invenções

\footnotetext{
${ }^{508} \mathrm{O}$ art. 27(1), Acordo TRIPS dispõe "Sem prejuízo do disposto nos parágrafos $2^{\circ}$ e $3^{\circ}$ abaixo, qualquer invenção, de produto ou de processo, em todos os setores tecnológicos, será patenteável, desde que seja nova, envolva um passo inventivo e seja passível de aplicação industrial.” Em outros termos, qualquer invenção para ser patenteável deverá preencher cumulativamente três condições substantivas de patenteabilidade, a saber, novidade, passo inventivo e aplicação indústria.
} 
o são. No sentido ordinário, entende-se por descoberta um produto ou processo que préexista na natureza antes de vir a público, enquanto a invenção envolve um produto ou processo não pré-existente, desenvolvido pelo intelecto humano. ${ }^{509}$ As fronteiras que separam as noções de invenção e descoberta se enfraqueceram dramaticamente, especialmente a partir da emergência da indústria da biotecnologia.

Já em 1911, as cortes norte-americanas passaram a permitir o patenteamento da versão isolada e purificada de uma molécula bioativa, extraída de uma fonte natural, ainda que idêntica à uma molécula natural. ${ }^{510}$ Décadas mais tarde, a perspectiva dos tribunais norte-americanos se globalizou. Hoje, um número importante de países ${ }^{511}$ autoriza o patenteamento de moléculas naturais ${ }^{512}$ artificialmente isoladas de seu entorno natural, desde que caracterizadas estruturalmente e desconhecidas do público, no momento de sua divulgação. ${ }^{513}$ Assim, um produto que um homem de bom senso acreditaria ser uma mera descoberta é tratada pelo direito das patentes de muitos países como uma invenção, apenas porque seu isolamento de seu meio natural se deu por intermédio de um processo técnico, que traz a público um produto pré-existente em uma nova forma de apresentação, que inexistiria sem a intervenção do homem.

Westerlund define "invenção", no contexto do direito das patentes, como "uma solução técnica [...] que utiliza uma lei da natureza ou forças naturais controláveis, que não poderia ser obtida sem a interferência da inteligência humana"514 e que também deve ser previsível e replicável, em escala comercial. ${ }^{515}$ No direito das patentes, a diferenciação entre descoberta e invenção não guarda qualquer relação com sua novidade, no sentido de pré-existência. Um produto ou processo será uma invenção ou uma descoberta dependendo do papel que a intervenção humana desempenhou para a sua revelação. ${ }^{516}$ Uma descoberta

\footnotetext{
${ }^{509}$ Cf. WESTERLUND, 2002, p. 24.

${ }^{510}$ Ver o voto do juiz Hand em UNITED STATES OF AMERICA. Circuit Court for the Southern District of New York. Parke-Davis \& Co. v. H.K. Mulford. Co., 1911.

511 Dentre outros, os membros da União Européia, Austrália, Bielorússia, Canadá, Cazaquistão, China, Coréia do Sul, Equador, Federação Russa, Filipinas, El Salvador, Hong Kong, Islândia, Madagáscar, Malásia, México, Nova Zelândia, EUA, Noruega, Suíça, Tailândia, Japão (WIPO, WIPO/GRTKF/IC/1/6; WTO, IP/C/W/273/Rev.1).

512 Moléculas bioquímicas, seqüências de polinucleotídeos e de polipeptídios etc.

${ }^{513}$ Cf. WESTERLUND, 2002, p. 32-35; GRUBB, 2004, p. 255-256.

${ }^{514}$ Cf. WESTERLUND, 2002, p. 56, tradução nossa.

515 Ibid., p. 56.

${ }^{516}$ Ibid., p. 49-50.
} 
existe independentemente da intervenção intelectual do homem; a invenção depende direta ou indiretamente da ação humana.

Em outras palavras, enquanto um recurso da natureza, em sua forma bruta, não é elegível para proteção patentária, uma molécula natural, isolada de seu entorno natural o é, ainda que homem não tenha realizado qualquer atividade de modificação da molécula natural. ${ }^{517}$ Os produtos naturais medicinais desenvolvidos por comunidades tradicionais, sem qualquer intervenção tecnológica, pertencem à categoria de produtos da natureza, porquanto não é identificável, com segurança, a associação de moléculas e suas estruturas moleculares, responsáveis pelos efeitos técnicos alcançados, ainda que o trabalho intelectual das comunidades seja muito mais palpável, porquanto realizaram pesquisas científicas, sem lançarem mão de qualquer instrumento técnico facilitador.

Alguns países ricos em RBIs, dentre eles o Brasil, ${ }^{518}$ excluem do rol de matérias elegíveis de proteção patentária moléculas naturais, isoladas de seu meio natural. Esta proibição, sem embargo, é de fácil sobreposição. Com as tecnologias disponíveis atualmente, é possível se realizar a modificação das moléculas naturais em um curtíssimo espaço de tempo. Tais modificações podem ser cosméticas, sem que a função original seja alterada. ${ }^{519}$ Após esta modificação, é improvável que se consiga comprovar a origem natural da molécula sintética modificada.

\subsubsection{AUTORIA DA INVENÇÃO}

Argüi-se comumente que o sistema de patentes é incapaz de proteger as inovações tradicionais, pois estas têm natureza comunitária, enquanto o direito das patentes tutela as invenções individuais. Esta observação não é correta. Em verdade, os processos de desenvolvimento de novas invenções envolvem grandes grupos, formados por técnicos especializados de várias áreas; o processo de desenvolvimento de novas invenções na área

\footnotetext{
${ }^{517}$ Ver, e.g., YANO, 1993-1994, p. 453-454; WTO, IP/C/W/369/Rev.1, para. 37; WTO, IP/C/W/273/Rev.1, p. 26-29.

${ }_{518} \mathrm{O}$ art. 10(IX) da Lei 9279/96 considera um descobrimento "o todo ou parte de seres vivos naturais e materiais biológicos encontrados na natureza, ou ainda que dela isolados, inclusive o genoma ou germoplasma de qualquer ser vivo natural e os processos biológicos naturais."

${ }^{519}$ Cf. HUIZENGA; PABST, 1999, p. 287.
} 
biomédica e biotecnológica é tão coletivo quanto o processo criativo das comunidades tradicionais. ${ }^{520}$

Adequando-se a esta realidade, as legislações de patentes autorizam pessoas jurídicas a reivindicarem proteção patentária para suas invenções. Uma organização, representativa de uma comunidade tradicional que conserva ou desenvolveu uma invenção tradicional, poderia ser a titular de uma patente que a reivindica. ${ }^{521}$ Mas esta solução não é despida de problemas. O sistema tradicional de conhecimentos é marcado pela ampla troca de conhecimentos e recursos biológicos entre comunidades. Conseqüentemente, a concessão de uma patente em favor de uma comunidade ou indivíduo poderia estimular competições intercomunitárias. ${ }^{522}$

A Convenção de Paris ${ }^{523}$ determina que o inventor de uma invenção tem o direito de ser citado como tal na carta patente, ainda que não seja o titular da patente. Se uma invenção se fundar substancialmente ${ }^{524} \mathrm{em}$ um CTA, na hipótese da patente que a proteger omitir o nome de seu coinventor (comunidade ou indivíduo), a patente conferida poderá ser revogada em países como Austrália e EUA. ${ }^{525}$ Estas normas não são necessariamente úteis para a proteção dos titulares de CTAs, pois cabe a cada Estado determinar quem deve ser indicado como inventor de uma invenção. ${ }^{526}$ Ademais, não existe um entendimento consolidado sobre o que seja uma contribuição inventiva "substancial".

Um CTA será caracterizado como uma contribuição substancial se houver uma identidade entre alguma das reivindicações presentes na patente e a contribuição intelectual das comunidades, e se as comunidades pertinentes e o inventor trabalharam em um processo colaborativo. Uma patente pode reivindicar proteção para um composto bioativo, para seu processo de isolamento e purificação e para os usos do composto reivindicado. As comunidades podem desempenhar um papel importante na identificação das aplicações técnicas dos recursos da biodiversidade. Assim, se houver identidade entre os usos de um

${ }^{520}$ Cf. MGBEOJI, 2001-2002, p. 182.

${ }^{521}$ Cf. DUTFIELD, 2001, p. 254.

${ }_{522}$ Cf. SANTILI, 2005, p. 222.

${ }_{523} \mathrm{Cf}$. art. 4ter, CP.

${ }^{524}$ As contribuições realizadas pelos detentores de CTAs, para se qualificarem como contribuições substanciais, devem ser centrais para o desenvolvimento da invenção. Em outras palavras, a invenção não teria sido realizada sem o aporte da comunidade (HUFT, 1994-1995).

${ }_{525} \mathrm{Cf}$. WIPO, WIPO/GRTKF/IC/12/7, para. 43; WIPO, WIPO/GRTKF/IC/13/5(b) Rev, para. 90.

${ }^{526}$ Id., WIPO/GRTKF/IC/12/7, para. 45. 
recurso biológico, comunicados por uma comunidade tradicional aos pesquisadores e os usos reivindicados pela patente, que recai sobre a invenção por eles desenvolvida, haveria uma contribuição substancial, desde que os inventores tenham obtido as informações diretamente das comunidades tradicionais pertinentes. Se o acesso aos CTAs se deu por meio de publicações científicas, não há que se falar em trabalho colaborativo entre o inventor e as comunidades. ${ }^{527}$ Para que haja processo colaborativo não é necessário que as contribuições intelectuais dos coinventores tenham as mesmas dimensões ou que trabalhem no processo de $\mathrm{P} \& \mathrm{D}$ simultaneamente e sob um mesmo teto. O que é imprescindível é que os coinventores deliberadamente trabalhem em conjunto para um mesmo fim. ${ }^{528}$ Raros são os casos em que comunidades tradicionais trabalham em conjunto com cientistas para um fim comum. E quando isto ocorre, as comunidades teriam de percorrer o caro caminho dos tribunais para comprovar sua relação colaborativa com o inventor que fraudulentamente não lhes atribuiu o título de coinventor.

\subsubsection{AS TRÊS CONDIÇões SUbSTANTIVAS DE PATENTEABILIDAdE E A APROPRIAÇÃo DOS CTS E RECURSOS BIOLÓGICOS}

\subsection{NOVIDADE E ESTADO DA TÉCNICA}

Uma invenção será nova não se inexistir previamente à data de sua divulgação, mas se não houver meios de se aferir sua existência anteriormente à data de sua divulgação. ${ }^{529}$ Para que uma invenção seja considerada nova, ela não deve existir no estado da técnica. Não existe uma definição uníssona de estado da técnica, pois cada Estado goza de liberdade para defini-lo.

O marco legal de patentes dos EUA $^{530}$ considera pertencer ao estado da técnica informações objeto de publicações, disponibilizadas em território americano e no

${ }^{527}$ Cf. HUFT, 1994-1995, p. 1724-1725.

${ }^{528}$ Cf. USPTO, 2008, para. 605.07.

${ }^{529}$ Cf. WESTERLUND, 2002, p. 43.

${ }^{530}$ De acordo com o $\S 102,35$ United States Code, 35: "A person shall be entitled to a patent unless(a) the invention was known or used by others in this country, or patented or described in a printed publication in this or a foreign country, before the invention thereof by the applicant for patent, or (b) the invention was patented or described in a printed publication in this or a foreign country or in public use or on sale in this country, more than one year prior to the date of the application for patent in the United States, or $[\ldots] "$. 
exterior $^{531}$ e aquelas informações utilizadas ou disseminadas oralmente apenas em território norte-americano. ${ }^{532}$ Em outras palavras, a lei de patentes dos EUA considera "nova" aquela invenção utilizada ou disseminada oralmente em outro país, quando não houver documentação a seu respeito. ${ }^{533}$ Por conseguinte, uma invenção derivada substancialmente de um CTA, que não for objeto de publicações, pode ser qualificada como nova e merecer proteção nos EUA, se as demais condições de patenteabilidade forem cumpridas. $^{534}$

Segundo o marco legal de patentes vigente na Europa, ${ }^{535}$ integra o estado da técnica as informações técnicas objeto de publicações e aquelas disseminadas exclusivamente por via oral ou em uso. O uso anterior de um CTA pode servir de base para impugnar a validade de uma patente que recaia sobre ele. No entanto, é fundamental que o CTA seja comunicado ao público, de modo suficientemente informativo, i.e. o modus operandi da invenção tradicional apropriada indebitamente deve ser divulgado ao público com um nível de detalhamento tal que terceiros inevitavelmente chegariam à ela. ${ }^{536} \mathrm{O}$ argumento de que a invenção objeto da patente impugnada é "inerente" aos CTAs publicamente disponibilizados não é apto a impugnar sua validade. ${ }^{537}$

${ }^{531}$ Os examinadores de patentes não estão obrigados a consultar toda e qualquer publicação sobre o tema técnico pertinente ao pedido examinado; geralmente, analisam um rol pré-determinado de publicações técnicas. Assim, muitas publicações sobre CTAs podem ser ignoradas no processo de exame, pois não integram este rol. Existe a necessidade de se formatar as publicações sobre CTAs, tornando-as facilmente acessíveis pelos examinadores de patentes. Este trabalho envolve investimentos vultosos e retorno duvidoso aos países em desenvolvimento e comunidades tradicionais (SCBD, UNEP/CBD/WG8J/2/7, paras. 77 e 92 93).

${ }^{532}$ Cf. COOMBE, 2001-2002, p. 281-283.

${ }^{533}$ Cf. SCBD, UNEP/CBD/WG8J/2/7, para. 80.

${ }^{534}$ Cf. WIPO, 2001, p. 109.

${ }^{535} \mathrm{O}$ art. 54, parágrafos 10 e 2o, Covenção da Patente Européia dispõem: “(1) An invention shall be considered to be new if it does not form part of the state of the art. (2) The state of the art shall be held to comprise everything made available to the public by means of a written or oral description, by use, or in any other way, before the date of filing of the European patent application."

${ }^{536}$ Cf. REINO UNIDO. House of Lords. Merrell Dow Pharmaceuticals Inc. and others v. H.N. Norton \& Co. Limited, para. 36, 46, 48.

537 O Escritório Europeu de Patentes já decidiu que uma "composição ou estrutura interna do produto integrará o estado da arte, se for possível descobri-la e reproduzi-la sem ônus indevido" (REINO UNIDO. House of Lords. Merrell Dow Pharmaceuticals Inc. and others v. H.N. Norton \& Co. Limited, 1995, para. 42). Em outras palavras, a estrutura molecular de um princípio bioativo, presente em um recurso biológico utilizado por comunidades tradicionais para fins terapêuticos, integrará o estado da técnica, quando sua identificação, isolamento e reprodução, a partir das instruções dadas pelas comunidades tradicionais, não envolver "ônus indevido". Possivelmente, a indústria biomédica teria sucesso em patentear uma molécula bioativa cujo uso foi inspirado por um CTA, pois os investimentos em recursos humanos e técnicos para identificá-la, isolá-la, purificá-la e testar sua eficiência seriam suficientemente altos para considerá-los um ônus indevido. 
Devido à impossibilidade prática encontrada pelos examinadores de patentes de encontrar informações claras e completas sobre CTAs ignorados pela literatura técnica, na prática, pouca diferença ${ }^{538}$ faz se a legislação aceita, como estado da técnica, informações disseminadas oralmente ou em uso. ${ }^{539}$ A mudança das leis de patentes, com vistas a permitir que CTs disponibilizados oralmente sem suficiência descritiva sejam hábeis a impugnar a novidade de patentes poderia trazer insegurança jurídica aos usuários do regime. ${ }^{540}$ A brecha aberta poderia ser empregada por empresas desleais, comprometidas em revogar patentes de concorrentes idôneos.

Ainda que existam publicações acessíveis pelos examinadores de patentes, ${ }^{541}$ tratando de um CTA utilizado no processo de desenvolvimento de uma invenção para a qual se busca proteção, a linguagem utilizada para descrever o CTA e aquela empregada para descrever a invenção é diversa; ${ }^{542}$ os CTs são descritos em termos comuns, enquanto as invenções são descritas segundo o jargão técnico do sistema de conhecimento ocidental. Na prática, a invenção apenas integrará o estado da técnica se descrito em termos técnicos. Além do mais, muitas publicações científicas contemporâneas sobre CTAs não são suficientemente específicas e completas, para serem consideradas hábeis a introduzir o conhecimento nelas descrito no estado da técnica. ${ }^{543}$ E por fim, muitas publicações técnicas

${ }^{538}$ A Índia apenas conseguiu revogar a patente concedida pelo Escritório Europeu de Patentes para uma invenção derivada substancialmente de um CT do povo indiano associado às sementes do neem, porque apresentou provas escritas a respeito do estado da técnica (DUTFIELD, 2001, p. 247-248).

${ }_{539}$ Cf. SCBD, UNEP/CBD/WG8J/2/7, para. 77 e 92.

${ }^{540}$ Cf. WIPO, WIPO/GRTKF/IC/12/7, para. 37.

541 Alguns projetos vêm organizando bancos de dados acessíveis pelos examinadores de patentes, com o objetivo de impedir a concessão de patentes que se apropriem de CTAs. São dignos de nota o Traditional Ecological Knowledge Prior Art Database, organizado pela American Association for the Advancement of Science; o Indigenous Knowledge Database, organizado pelo Banco Mundial; e o Traditional Knowledge Digital Library (TKDL), organizado pelo governo da Índia, que compreende conhecimentos tradicionais das medicinas Ayurveda, Unani e Siddha. Em 2009, a Índia assinou um acordo com o Escritório Europeu de Patentes (EEP), por meio do qual este se comprometeu a consultar o TKDL para identificar o estado da técnica, com o objetivo de prevenir o patenteamento de invenções que se apropriem dos CTs do povo indiano (PANDEYA; KOSHY, 2009). No mesemo sentido, também em 2009, o EEP firmou um acordo com um dos centros de pesquisa do Grupo Consultivo para a Investigação Agronômica Internacional (GCIAI), com o objetivo de integrar à base de consultas do EEP as variedades vegetais desenvolvidas pelo GCIAI (CAS-IPCGIAR, 2009). Um ano antes, o EEP já havia se comprometido a consultar o banco de dados do Escritório Chinês de Patentes sobre medicina tradicional chinesa (EPO, 2009) e vem se empenhando, há alguns anos, a integrar, paulatinamente, publicações científicas que tratem conhecimentos tradicionais em geral ao sistema de consulta dos examinadores do EEP (SCHIWY-RAUSCH, 2006a).

${ }^{542}$ Ver, e.g., WIPO, 2001, p. 109; SCBD, UNEP/CBD/WG8J/4/INF/9, para. 55 - 56.

${ }^{543}$ Para que uma publicação tenha o poder de introduzir um CTA ao estado da técnica, é indispensável sua descrição com tal detalhamento, que um técnico da área possa reproduzi-lo a partir do exame da publicação. Esta deve ainda tratar das possíveis aplicações do CTA e das possíveis alternativas de recursos biológicos que poderiam ser utilizados para se alcançar o mesmo objetivo. Em outras palavras, a publicação deve ser tão específica quanto seria um pedido de patente que reivindica proteção para um CTA. É improvável que 
são disponibilizadas em uma língua não compreensível pelos examinadores de patentes. ${ }^{544}$ Em todos estes casos, as associações entre CTs e recursos da biodiversidade continuam a se qualificar como novas para fins de proteção patentária. E é por conta de sua novidade que os CTAs e recursos biológicos intangíveis são apropriados com freqüência e facilidade por meio de DPIs. ${ }^{545}$ No fim, as publicações, ao invés de prevenirem a concessão de patentes sobre invenções derivadas de CTAs, facilitam o processo. Nos EUA, por exemplo, é possível reivindicar proteção para a combinação de CTAs e recursos da biodiversidade, já integrados ao estado da técnica, desde que a combinação final seja desconhecida. As chamadas patentes de combinação conferem novidade a invenções, que isoladamente não o são. ${ }^{546}$

$\mathrm{Na}$ falta de conhecimento público sobre seus CTAs, as comunidades tradicionais poderiam reivindicar patentes para suas invenções tradicionais. ${ }^{547}$ Contudo, a realidade é que estes grupos não dispõem dos meios técnicos e econômicos ${ }^{548}$ para utilizar patentes estrategicamente. ${ }^{549} \mathrm{E}$ mesmo que detivessem os meios para obtê-las, não teriam os recursos para defendê-las em múltiplos mercados, ou os recursos para obter as autorizações sanitárias, sem as quais não poderiam ser comercializados os produtos derivados de seus CTAs. ${ }^{550}$ Enfim, suas patentes não teriam um valor prático.

Embora seja injusto conferir direitos de exclusivo àquele que isolar tecnicamente uma molécula bioativa, guiado por meio CTs, a patente conferida sobre a molécula isolada, em princípio, não gera o efeito de limitar a continuidade do uso do recurso biológico de onde foi extraída nem do CT conexo. Isto porque não há identidade entre a matéria objeto da patente - uma molécula identificada por sua estrutura molecular - e os insumos e conhecimentos que lhe serviram de fonte. E na hipótese de um indivíduo obter uma patente

antropólogos e outros cientistas sociais dominem os instrumentos necessários para descrever tecnicamente os CTAs que estudaram, de forma a preencher todas essas exigências (WIPO, WIPO/GRTKF/IC/12/7, para. 50 e $52(\mathrm{~d}))$.

${ }^{544}$ Cf. WTO, IP/C/W/458, para. 23.

${ }^{545}$ Cf. SUBBIAH, 2004, p. 545.

${ }^{546}$ Cf. COTTIER; PANIZZON, 2006, p. 225.

${ }^{547}$ Cf. MGBEOJI, 2001-2002, p. 174-179.

${ }^{548}$ Em 2000, Vogel (2000c, p. 18) estimou em US\$ 10,000,00 o custo para a obtenção de uma patente nos EUA. Considerando que as patentes têm validade territorial, para se proteger uma invenção em várias jurisdições é necessário obter uma patente em cada um dos territórios de interesse. Além dos custos envolvidos na obtenção das patentes serem altos, é igualmente custoso o monitoramento de usos nãoautorizados da invenção e a propositura de ações judiciais para se impedir a continuidade de infrações.

${ }_{549}$ Cf. MBEVA, 2004, p. 170. No mesmo sentido, ver DUTFIELD, 2001, p. 255.

${ }^{550}$ Cf. HEATH, WEIDLICH, 2003, p. 84. 
para uma invenção idêntica àquela utilizada por uma comunidade tradicional, as comunidades poderão defender-se com sucesso de acusações de infração, desde que comprovem que a utilização prévia do objeto da patente se fazia publicamente e de maneira informativa. ${ }^{51} \mathrm{Na}$ prática, a realidade é outra: o processo administrativo de revogação da patente norte-americana concedida sobre a variedade de feijão "enola", cultivada tradicionalmente por comunidades agrícolas do México, levou oito anos para ser concluído e consumiu em torno de US\$200,000,00. Neste longo período, as exportações mexicanas de feijão enola aos EUA foram barradas, ${ }^{552}$ em prejuízo das comunidades agrícolas mexicanas.

\subsection{PASSO INVENTIVO}

O examinador de patentes, quando checa se a invenção para a qual se busca proteção envolve um passo inventivo, conduz um teste que envolve as seguintes etapas: a contraposição da invenção frente ao estado da técnica pertinente; a determinação da distância que separa o estado da técnica da invenção reivindicada; a verificação se o nível técnico empregado para percorrer esta distância era óbvio para um técnico especializado na matéria pertinente à invenção, ${ }^{553}$ à época da divulgação da invenção. Por fím, o examinador observa o sucesso comercial da invenção - quando o produto já estiver no mercado -, o histórico da demanda pelo desenvolvimento de uma solução técnica para o problema solucionado pela invenção e os resultados inesperados alcançados pela aplicação da invenção. ${ }^{554}$

A figura do técnico especializado na matéria pertinente à invenção vem perdendo importância à medida que os escritórios de patentes concedem proteção a invenções que, embora novas, úteis e desejáveis, foram desenvolvidas com técnicas previsíveis e ordinárias, dominadas por qualquer técnico médio. ${ }^{555}$ No mais, em regra, os escritórios de patentes não empregam técnicos especializados em CTAs para examinar o passo inventivo envolvido em invenções que os incorporam. Uma exceção é o Escritório de Patentes da

${ }^{551}$ Ibid., p. 77-78. Shiva (2007, p. 312-313) se equivoca, ao generalizar que o patenteamento de invenções derivadas de recursos da biodiversidade e CTs criaria a situação absurda de impedir as comunidades continuarem a utilizá-los.

${ }^{552}$ Cf., e.g., ETC GROUP, 2001, 2002, 2008a; RAFI, 2002.

${ }^{553} \mathrm{O}$ técnico na matéria é uma pessoa com conhecimentos técnicos medianos no setor.

${ }^{554}$ Cf.YANO, 1993-1994, p. 456.

${ }^{555}$ Cf. GRUBB, 2004, p. 247 e 256. 
China, que conta com uma equipe de expertos em medicina tradicional chinesa, encarregada de examinar os pedidos de patentes relacionadas a este campo da técnica. A vantagem principal oferecida por esta prática é garantir a qualidade das patentes concedidas e minorar as chances de apropriação indébita de CTs. Mas esta prática não é factível em um país culturalmente tão mais diverso como é o caso do Brasil, onde vivem mais de 200 etnias indígenas, algumas delas totalmente isoladas da sociedade, sem contabilizarmos as demais comunidades tradicionais, que vivem no território brasileiro. Esperar que um técnico conheça os CTs de todos esses grupos é uma quimera. ${ }^{556}$

Recordando as dificuldades para se introduzir os CTs no estado da técnica e em virtude da inexistência de técnicos especializados em todos os CTs conservados pelas inúmeras comunidades tradicionais, é previsível que os escritórios de patentes concedam patentes a invenções que, embora pareçam envolver um passo inventivo para um técnico médio do ocidente, são óbvias para um técnico que atua no sistema tradicional de conhecimentos. ${ }^{557}$

Por outro lado, ainda que os examinadores de patentes identificassem os CTs que serviram de pontapé ao desenvolvimento da invenção reivindicada, considerando que o nível de inventividade exigido pelos escritórios de patentes em todo o mundo cai dia a dia, ${ }^{558}$ a mera alteração da forma de apresentação da associação entre um CTA e um recurso da biodiversidade seria suficiente para qualificá-la como inventiva. ${ }^{559}$ Os produtos tradicionais, desenvolvidos por comunidades tradicionais a partir de recursos da biodiversidade, não são caracterizados por elas em termos de estruturas químicas, moleculares, como é a prática da indústria biotecnológica e farmacêutica. O principal problema que os examinadores de patentes enfrentam é comparar uma invenção composta pela combinação de recursos da biodiversidade, não definida em termos moleculares, com os elementos que integram o estado da técnica, definidos em termos moleculares. Como comparar, por exemplo, composições de ervas com fórmulas químicas? ${ }^{560}$ O Escritório de Patentes da China, por conta destas dificuldades, permite apenas a concessão de patentes para reivindicações do tipo produto-por-processo, isto é, a reivindicação recai sobre o

\footnotetext{
${ }^{556} \mathrm{Cf}$. WIPO, WIPO/GRTKF/IC/12/7, anexo, para. 60.

${ }^{557}$ Cf. HANSEN, VANFLEET, 2003, p. 24.

${ }^{558}$ Cf. MGBEOJI, 2001-2002, p. 180.

${ }^{559}$ Cf., e.g., RESNIK, 2004, p. 56; NUFFIELD COUNCIL ON BIOETHICS, 2002a, p. 86.

${ }^{560}$ Cf. LI; LI, 2007, p. 139-140.
} 
produto resultante de um determinado processo, que envolve, por exemplo, a associação entre diversos recursos da biodiversidade, em quantidades pré-fixadas etc. Este tipo de reivindicação não confere proteção real ao CTA e aos recursos da biodiversidade. Uma empresa com capacidade tecnológica elevada pode identificar os princípios ativos responsáveis pela ação farmacológica da fórmula da medicina tradicional, reivindicar proteção para os compostos químicos isolados e em combinação e suplantar o produto manufaturado a partir das prescrições tradicionais patenteadas, sem que os titulares destas patentes se dêem conta.

Se as comunidades tradicionais não forem capazes de identificar a estrutura química dos compostos bioativos responsáveis pela atividade farmacológica de uma determinada composição da medicina tradicional, a organização que identificar, caracterizar e isolar a referida molécula terá desenvolvido uma invenção, apta a ser patenteada. Isso porque, um dos objetivos do direito das patentes é o enriquecimento do estado da técnica, o que apenas ocorre com a divulgação detalhada do passo-a-passo a ser seguido para se alcançar um determinado efeito técnico. Nesse sentido, a United States Court of Appeals invalidou a patente da Amgen, que reivindicava seqüências genéticas do genoma humano, responsáveis pela produção de proteínas análogas à eritropoietina, proteína presente no corpo humano responsável pelo tratamento de anemia, capazes de produzir o mesmo efeito técnico da eritropoietina natural. A razão para a revogação foi a incapacidade da Amgen de identificar, com segurança, o objeto da patente, porquanto reivindicava amplamente toda e qualquer seqüência genética capaz de produzir moléculas análogas à eritopoietina e com a mesma função, sem identificá-las e indicar meios técnicos que viabilizassem sua identificação por terceiros. ${ }^{561}$

\subsection{APLICABILIDADE INDUSTRIAL}

Uma invenção terá aplicação industrial se lhe for atribuída uma aplicação útil ao homem (solução técnica a um problema), e se ela for passível de reprodução repetitiva. ${ }^{562}$ Para que um produto decorrente da aplicação de um CTA preencha esta condição, é necessário que o efeito técnico gerado seja estável e replicável, o que raramente ocorre,

${ }^{561}$ Cf. UNITED STATES, United States Court of Appeals for the Federal Circuit, Amgen Inc. v. Chugai Pharmaceutical.

${ }^{562}$ Cf. MGBEOJI, 2001-2002, p. 182. 
pois as composições envolvendo recursos da biodiversidade apresentam variações de concentrações de princípios ativos e, por isso, os efeitos não são sempre replicáveis. ${ }^{563}$

Demais disso, se uma fórmula tradicional apenas puder ser produzida em escala artesanal, uma vez que os produtos que a compõe não estão largamente disponíveis, o requisito de aplicação industrial igualmente não será cumprido. ${ }^{564}$ Finalmente, muitos CTAs, sobretudo os de caráter medicinal, são aplicados de modo customizado em face do paciente, não sendo possível sua generalização automática. ${ }^{565}$

\subsubsection{SEGREDOS COMERCIAIS: UM INSTRUMENTO ÚTIL PARA TUTELAR OS CTS?}

Por conta das dificuldades identificadas para se utilizar o sistema de patentes, a literatura ${ }^{566}$ sugere que o regime de proteção dos segredos comerciais, instaurado pelo Acordo TRIPS da OMC, pode ser um instrumento útil de proteção dos conhecimentos tradicionais associados à biodiversidade, que ainda não se disseminaram pela sociedade dominante. ${ }^{567}$ Em virtude dos países industrializados estarem obrigados a reprimir, em seus territórios, a apropriação de segredos comerciais por meio de práticas desonestas, como resultado de sua associação à $\mathrm{OMC}$, e considerando que as negociações internacionais para a criação de um regime internacional de proteção do PBI caminham sofregamente, a exploração deste mecanismo de proteção parece atraente.

\footnotetext{
${ }^{563}$ Cf. LI; LI, 2007, p. 141.

${ }^{564}$ Cf. LI; LI, 2007, p. 141.

${ }^{565}$ Cf. ONWUEKWE, 2004, p. 67.

${ }^{566}$ Ver, e.g., WIPO, WIPO/GRTKF/IC/12/5(b), anexo, p. 120; WIPO, WIPO/GRTKF/IC/9/INF/4, anexo I, para. 62; WTO, IP/C/W/434; WTO, IP/C/W/257; WTO, IP/C/W/30, para. 154; VOGEL, 2004. Em 2002, Portugal estabeleceu, por meio do Decreto-lei no. 118/2002, um regime jurídico que disciplina a proteção de material vegetal autóctone com interesse para a atividade agrária, agro-florestal e paisagística, que autoriza os detentores de CTs associados a estes materiais vegetais a protegê-los como segredos comerciais (ver art. 3.3). No Equador, tentou-se, sem sucesso, colocar em funcionamento um projeto de transformação de CTAs em segredos comerciais. No entanto, parece não ter havido apoio suficiente para levar o projeto adiante (informações prestadas por Malki Sáenz por meio de correspondência pessoal datada de 27 de outubro de 2008).
}

${ }^{567}$ Cf. VOGEL, 2000d, p. 105. 
Diferentemente das invenções, os segredos comerciais não precisam preencher critérios substantivos rígidos de proteção. ${ }^{568}$ Qualquer CT estará protegido contra atos de apropriação contrários às práticas honestas, se preencher três condições cumulativas. ${ }^{569}$

\section{Condição 1: As informações devem ser secretas}

Uma informação será secreta para fins de proteção legal, se apenas os membros da comunidade que a conserva conhecê-la, ${ }^{570}$ se não a compartilharem abertamente com outros indivíduos, ${ }^{571}$ e se o conhecimento não for facilmente acessível por meios honestos. Em outras palavras, o conhecimento será secreto desde que "não seja em geral conhecido ou prontamente acessível pelas pessoas de círculos que normalmente lidam com” com esse tipo de informação técnica. ${ }^{572}$

Dependendo das dimensões da comunidade, que pode compreender um número expressivo de membros, espalhados por amplas regiões, os CTs dificilmente se qualificarão como secretos, ${ }^{573}$ já que as chances de vazamento são altas. Quando um CT escapa das fronteiras de uma comunidade para outras comunidades tradicionais, conquanto não tenha sido disseminado pela sociedade dominante, seu caráter secreto pode se quebrar facilmente, pouco importando ao DPI o quão importante configura esta disseminação intercomunitária para a conservação do conhecimento e das próprias comunidades. ${ }^{574} \mathrm{Na}$ prática, a proteção conferida aos segredos comerciais se mostra útil apenas quando for possível mantê-los distante do público, ${ }^{575}$ o que não é algo simples de ser alcançado por parte das comunidades tradicionais, que têm como costume o compartilhamento amplo de boa parte de seu PBI.

Para se ter certeza de que um determinado CT é secreto, é necessário, após sua identificação junto à comunidade tradicional que o conserva, realizar buscas em bancos de dados, publicações nacionais e estrangeiras, internet etc. ${ }^{576}$ a fim de se verificar sua

\footnotetext{
${ }^{568}$ Cf. LAMETTI, 2004, p. 284.

${ }^{569}$ Cf. SCHECHTER, 2003, p. 529.

${ }^{570}$ Cf. LEISTNER, 2004, p. 135.

${ }^{571}$ Cf. SCBD, UNEP/CBD/WG8J/4/INF/9, p. 22.

${ }^{572}$ Cf. WIPO, 1996, para. 6.18, tradução nossa.

${ }^{573}$ Id., WIPO/GRTKF/IC/13/4(b) Rev, para. 66.

${ }^{574}$ Cf. LOSHIN, 2007, p. 23-25.

${ }^{575}$ Cf. FAUCHART; VON HIPPEL, 2006, p. 8.

${ }^{576}$ Cf. VOGEL, 2000b, p. 31.
} 
acessibilidade fora dos domínios da comunidade. Esta tarefa além de cara e morosa, nem sempre conseguirá aferir com segurança o caráter secreto de um determinado $\mathrm{CT}$, pois as opções de sua disseminação são amplas.

\section{Condição 2: As informações devem apresentar um valor comercial}

O valor comercial de uma informação não-divulgada é aferido por sua importância comercial para os setores em que ela pode ser aplicada; ${ }^{577}$ e no caso de conhecimentos técnicos, também por sua superioridade em relação ao estado da técnica. ${ }^{578} \mathrm{Nem}$ todos os CTs apresentam um valor comercial; há aqueles que são conservados em segredo por suas comunidades devido a compromissos religiosos assumidos por seus membros. Assim, os CTs secretos, que não ostentam um valor comercial, sob a ótica da sociedade dominante, não são elegíveis para proteção. ${ }^{579}$

\section{Condição 3: O titular dos conhecimentos deve adotar medidas razoáveis para protegê-los contra acesso não-autorizado}

Seu detentor deve tomar medidas que tornem a informação não-divulgada identificável, a fim de estabelecer uma prova material de sua pré-existência a qualquer ato de apropriação desleal. Para isso, é recomendável seu registro em um banco de dados privado. ${ }^{580}$

O detentor de informações não-divulgadas deve tomar todas as medidas necessárias para prevenir sua apropriação em situações previsíveis, ${ }^{581}$ não incluídas medidas extravagantes, economicamente inviáveis. Igualmente, não se faz necessário que o detentor de uma informação secreta obrigue todo terceiro, que tomar contato com ela, a assinar um acordo de confidencialidade. Seu detentor, ao contatar pessoas que possam apropriá-lo, deve informá-las, de maneira clara e indubitável, de que a informação acessada é confidencial e que sua disseminação apenas pode ocorrer com a autorização do titular. ${ }^{582}$

\footnotetext{
${ }^{577}$ Cf. WIPO, 1996, para. 6.20.

${ }^{578}$ Cf. SCHECHTER, 2003, p. 532.

${ }^{579}$ Cf. WIPO, WIPO/GRTKF/IC/13/4(b) Rev, para. 65.

${ }^{580}$ Id., 1996, para. 6.20.

${ }^{581}$ Cf. SCHECHTER, 2003, p. 531.

${ }^{582}$ Cf. HENNING-BODEWIG; RUIJSENAARS,1994, para. 98.
} 
Porquanto inexista a presunção de que uma informação valiosa esteja protegida por um segredo comercial, ${ }^{583}$ e devido às dificuldades para se comprovar que seu receptor tinha ciência de que a informação deveria ser conservada secreta, os acordos de confidencialidade são os instrumentos mais eficazes para se comprovar a obrigação do receptor de não utilizar e disseminar as informações secretas. ${ }^{584}$

\subsubsection{FRAQUEZAS DOS SEGREDOS COMERCIAIS}

Segredos industriais configuram um instrumento fraco de proteção para conhecimentos tradicionais. O Acordo TRIPS obriga os Estados Membros da OMC a concederem proteção para os segredos comerciais contra atos de apropriação, praticados em afronta às práticas comerciais honestas, ${ }^{585}$ e.g., apropriação por meio de "violação ao contrato, abuso de confiança, indução à infração, e inclui a obtenção de informação confidencial por terceiros que tinham conhecimento, ou desconheciam por grave negligência, que a obtenção dessa informação envolvia tais práticas. ${ }^{~} 586$ Isto significa que a proteção conferida pelo Acordo TRIPS não investe seu detentor em um direito de exclusão erga omnes, mas apenas em um direito de prevenir terceiros de os utilizarem ou disseminarem, quando os tiver acessado por meios desonestos. ${ }^{587}$ Caso a parte que desonestamente adquiriu um CT secreto o dissemine, por exemplo, na internet, as demais pessoas poderão utilizá-lo livremente, independente da vontade da comunidade que o conservava em segredo. ${ }^{588}$ A comunidade prejudicada poderá demandar perdas e danos e, dependendo da jurisdição, requerer a aplicação de remédios criminais em face daquele que disseminou o CT secreto sem autorização. A grande dificuldade será identificar o infrator $^{589}$ e comprovar a prática de apropriação por meios desonestos, que dependerá da instauração de um processo judicial até mesmo em uma corte estrangeira. ${ }^{590}$

\footnotetext{
${ }^{583}$ Cf. UNITED STATES OF AMERICA - United States District Court, S.D., Florida, Miami division. Greenberg v. Miami Children's Hospital Research Institute, Inc., Miami, 29 de maio 2003.

${ }^{584}$ Cf. HENNING-BODEWIG; RUIJSENAARS,1994, para. 99.

${ }^{585}$ Cf. SCHECHTER, 2003, p. 529.

${ }^{586}$ Nota no. 10, art. 39(2), Acordo TRIPS.

${ }^{587}$ Ver, e.g., STIGLITZ, 1999, p. 314; SAMPATH, 2005, p. 122; MILLIKIN, 2000, p. 936; LOSHIN, 2007, p. 22-23.

${ }^{588}$ Cf. MILLIKIN, 2000, p. 936 et seq.

${ }^{589}$ Ibid., p. 951.

${ }^{590}$ Ver, e.g., HANSEN; VANFLEET, 2003, p. 18; SCBD, UNEP/CBD/WG8J/2/7, para. 83.
} 
No mais, um criador independente que desenvolva uma invenção substancialmente similar a um CTA ou que, por meio de engenharia reversa, descubra o conhecimento secreto que permeia um determinado produto tradicional, poderá utilizá-lo livremente e inclusive, se preencher os critérios de patenteabilidade, poderá patenteá-lo, transformando legítimos detentores de CTs em potenciais infratores de uma patente. ${ }^{591}$

Embora possa parecer positivo que a proteção dos segredos comerciais perdura enquanto se conservarem em segredo, a proteção por tempo indeterminado pode ser um golpe contra as comunidades tradicionais. ${ }^{592}$ A restrição da difusão dos CTs segredos pode quebrar o ciclo de difusão intra e intercomunitário e ameaçar a própria sobrevivência cultural das comunidades: ${ }^{593}$ a restrição da difusão do conhecimento embarga a difusão de informações que podem auxiliar muitas comunidades a resolverem problemas cotidianos que as afetam; impede as gerações mais jovens de cultivarem o interesse pela conservação do PBI de seu grupo e obstaculiza o aprimoramento do PBI através de sua disseminação e uso paralelo em vários contextos. ${ }^{594}$ Além disso, a conservação da prática costumeira de livre disseminação de conhecimentos e recursos constitui uma obrigação assumida pelos Estados Signatários da CDB. ${ }^{595}$

Tendo em vista estas considerações de ordem prática e legal, os segredos comerciais podem ser um instrumento útil para a proteção de CTAs, apenas quando a restrição de sua disseminação não colocar em risco seu desenvolvimento e as práticas consuetudinárias das comunidades tradicionais de livre intercâmbio de seus RBIs.

Por fim, considerando que um mesmo CT secreto pode ser compartilhado por duas ou mais comunidades, existe a possibilidade de que uma comunidade o considere sagrado e, por isso, opte por não disseminá-lo, e outra o considere laico, não se opondo à sua ampla disseminação. Nesta hipótese, a proteção conferida pelo Acordo TRIPS será despida de qualquer importância. Além do mais, se um CT secreto for compartilhado por duas ou mais comunidades, ainda que todas as comunidades estejam de acordo sobre a necessidade de

${ }^{591}$ Cf. SCHECHTER, 2003, p. 536.

${ }^{592}$ Cf. HETTINGER, 1997, p. 31-34.

${ }^{593}$ Cf. WIPO, WIPO/GRTKF/IC/12/5(b), anexo, p. 131; POSEY, 2004h, p. 139.

${ }^{594}$ Cf. GUPTA, 2002, p. 386-387.

${ }^{595} \mathrm{O}$ art. 10(c), CDB dispõe: "Cada Parte Contratante deve, na medida do possível e conforme o caso:(c) Proteger e encorajar a utilização costumeira de recursos biológicos de acordo com práticas culturais tradicionais compatíveis com as exigências de conservação ou utilização sustentável. 
restringir sua disseminação, se todas elas não se unirem para fixar as condições de acesso, elas poderão concorrer entre si por acordos de licenciamento. O resultado final será o achatamento dos benefícios materiais que poderiam ser extraídos do conhecimento licenciado. ${ }^{596}$

\subsection{A emergênCia da CDB E SEU esvaziamento pela OMC E pelos aCordos BILATERAIS DE COMÉRCIO}

O crescimento econômico e industrial dramático que tomou lugar na segunda metade do século XX interferiu negativamente no equilíbrio ambiental do orbe terrestre, colocando em risco a própria sobrevivência do homem, no longo prazo. Partindo desta realidade, em 1972, a ONU reuniu países industrializados e em desenvolvimento, sob os auspícios da Conferência das Nações Unidas sobre Meio Ambiente Humano para formalizar o reconhecimento da essencialidade de um meio ambiente saudável e produtivo ao desenvolvimento material da humanidade ${ }^{597}$ Onze anos mais tarde, a Assembléia Geral da ONU (AGONU), procurando dar concreção aos Princípios da Declaração de Estocolmo, adotou resolução que aprovou a preparação de um estudo, por uma comissão independente - Comissão Mundial sobre Meio Ambiente e Desenvolvimento ou Comissão -, que apresentaria à comunidade internacional recomendações de medidas de enfrentamento de desafios ambientais globais. ${ }^{598}$

Em 1987, veio a público o estudo encomendado pela ONU, o qual é conhecido popularmente como relatório Brundtland, em referência à primeira ministra da Noruega, Gro Harlem Brundtland, presidente da Comissão encarregada pela elaboração do estudo. $\mathrm{O}$ relatório Brundtland trouxe contribuições, que permitiram melhor compreender a origem dos problemas ambientais enfrentados àquela época e que se arrastam até os dias atuais. No que concerne a biodiversidade, o relatório reconheceu a importância dos ecossistemas naturais e dos serviços ambientais por eles prestados à humanidade e as contribuições dos recursos da biodiversidade ao desenvolvimento industrial e científico dos países industrializados. ${ }^{599}$ Os ecossistemas naturais oferecem ao homem, ao menos, 17 serviços diferentes, e.g. suprimento de água potável, regulação climática, absorção de carbono,

\footnotetext{
${ }^{596}$ Cf. VOGEL, 2004.

${ }^{597}$ Cf. WORLD COMMISSION ON ENVIRONMENT AND DEVELOPMENT, 1987, p. 13.

${ }^{598}$ Cf. item 8, alíneas (a), (b), (c), (d), UNGA, Resolution 38/161.

${ }^{599}$ Cf. WORLD COMMISSION ON ENVIRONMENT AND DEVELOPMENT, op.cit., cap. 6, para. 7, 9 e 11.
} 
matérias-primas, regulação de pragas, polinização, conservação do ciclo hidrológico. As florestas especificamente oferecem "produtos madeireiros, água, alimentos, matériasprimas, medicamentos, combustível, habitação, trabalho, recreação, habitats para a vida selvagem, diversidade de paisagens naturais, reservas e retentores de carbono, dentre outros". ${ }^{600}$ Estes serviços, se fossem pagos, custariam à humanidade entre US\$ 16 e 54 trilhões/ano. ${ }^{601}$

O relatório notou, por outro lado que, apesar da importância social, econômica e científica da biodiversidade e de seu uso intensivo pelos países industrializados, estes recursos vêm se deteriorando rapidamente nos países em desenvolvimento, em virtude da falta de recursos econômicos para conservá-los. ${ }^{602}$

Como solução para essa contradição, o relatório plantou a semente do que, mais tarde, se tornaria a Convenção sobre Diversidade Biológica, ao recomendar a negociação de uma convenção internacional dedicada à conservação das espécies e de ecossistemas naturais, ${ }^{603}$ estruturada de maneira a conjugar esforços dos países industrializados e dos em desenvolvimento em prol da realização desta tarefa. ${ }^{604}$ A cooperação entre países em desenvolvimento e industrializados se daria pela exploração de suas melhores capacidades e recursos: os países em desenvolvimento, ricos em termos de diversidade biológica e de ecossistemas naturais e pobres em recursos econômicos, se comprometeriam em conserválos em troca de benefícios econômicos e apoio tecnológico, a serem transferidos pelos países industrializados, que poderiam continuar a explorar e transformar a biodiversidade em produtos e processos socialmente úteis e economicamente rentáveis. ${ }^{605} \mathrm{~A}$ idéia que permeia a proposta cristalizada no relatório Brundtland se funda na visão pragmática de que, na ausência de recursos financeiros, a conservação da biodiversidade é inalcançável. ${ }^{606}$

\footnotetext{
${ }^{600}$ Cf. princípio 2(b), UNGA, A/CONF.151/26, vol.III

${ }^{601}$ Cf. COSTANZA et al., 1997.

${ }^{602}$ Cf. WORLD COMMISSION ON ENVIRONMENT AND DEVELOPMENT, 1987, cap. 6, para. 22-23.

${ }^{603}$ Ibid., para. 58.

${ }^{604}$ Cf. BRUSH, 1994, p. 5

${ }^{605}$ Cf. WORLD COMMISSION ON ENVIRONMENT AND DEVELOPMENT, op.cit., cap. 6, para. 60.

${ }^{606}$ Ibid., para. 51; WTO, WT/CTE/W/139, para. 1. Em sentido contrário, criticando que o uso de mecanismos comerciais para a conservação da biodiversidade, pois as instituições de mercado estariam na raiz da deterioração ambiental ver THE ECOLOGIST, 1993, p. 95, 99, 170.
} 
Em resposta ao relatório Brundtland, na $14^{\mathrm{a}}$ reunião do Conselho de Governo do Programa das Nações Unidas para o Meio Ambiente (PNUMA), os EUA sugeriram a elaboração de uma convenção global sobre diversidade biológica, que figuraria como uma convenção guarda-chuva, competente para trazer coerência aos acordos multilaterais de proteção do meio ambiente. ${ }^{607} \mathrm{O}$ Conselho de Governo do PNUMA apoiou a idéia norteamericana e recomendou ao seu Diretor Executivo o estabelecimento de um grupo de trabalho, encarregado de investigar a conveniência de uma convenção dedicada à conservação da biodiversidade e os temas que deveriam ser por ela disciplinados. ${ }^{608}$ Em 25 de maio de 1989, o Conselho de Governo do PNUMA autorizou o estabelecimento de um grupo de trabalho, investido na tarefa de redigir um instrumento legal internacional para a proteção da biodiversidade da Terra. ${ }^{609}$

No período que se seguiu, emergiu uma forte dissensão entre países industrializados e em desenvolvimentos a respeito das obrigações que deveriam ser assumidas por cada parte, no contexto da tarefa comum de conservação da biodiversidade em seus lugares de origem. Os países em desenvolvimento viram na negociação da CDB a oportunidade para corrigir o tratamento iníquo dado pelos regimes de DPI aos recursos da biodiversidade e CTAs. ${ }^{610}$ Por isso, advogaram pela adoção de medidas que obrigassem os países industrializados a internalizarem os custos associados aos aportes de CTAs e recursos biológicos absorvidos gratuitamente por suas empresas e instituições científicas. ${ }^{611} \mathrm{~A}$ internalização se daria por meio da transferência de tecnologia e benefícios econômicos aos países em desenvolvimento e suas comunidades tradicionais. ${ }^{612}$

Os EUA e Japão, por sua vez, se opuseram à adoção de qualquer medida que pudesse obstaculizar o desenvolvimento da indústria da biotecnologia ou diminuir sua lucratividade. ${ }^{613}$ Assim, se mostraram contrários ao estabelecimento de qualquer medida que obrigasse os países usuários de recursos da biodiversidade e CTs a repartirem benefícios com os países e comunidades pertinentes. Em posição reconciliadora, os países nórdicos, Canadá, Austrália e Nova Zelândia se mostraram favoráveis a um acordo que

\footnotetext{
${ }^{607}$ Cf. MCCONNELL, 1996, p. 5.

${ }^{608}$ Cf. UNEP, Decision 14/26.

${ }^{609}$ Id., Decision 15/12, para. 6.

${ }^{610}$ Cf. SOUTH CENTRE, 2002, p. 128-129.

${ }^{611}$ Cf. BURHENNE-GUILMIN; CASEY-LEFKOWITZ, 1992, p. 54; BOYLE, 2000b, p. 72.

${ }^{612}$ Cf. MCCONNELL, 1996, p. 20 e 25.

${ }^{613}$ Ibid., p. 47, 54, 72-73.
} 
permitisse recompensar os provedores de recursos da biodiversidade e CTs, quando novas tecnologias derivadas destes recursos fossem exitosas. Formalmente, a União Européia se mostrou pronta a apoiar medidas de repartição de benefícios financeiros com os provedores de recursos da biodiversidade, desde que elas não pusessem em risco os DPI de seus nacionais. ${ }^{614}$ Sem embargo, seu verdadeiro interesse estava na adoção de medidas que regulassem o comércio internacional de organismos geneticamente modificados. ${ }^{615}$

Após anos de intensos conflitos Norte-Sul, que permearam todo o processo negociador da CDB, em maio de 1992, em Nairóbi, foi concluída sua redação. A CDB introduziu grandes mudanças no direito internacional. A CDB é o primeiro e único tratado internacional que persegue a conservação da diversidade biológica em seus três níveis diversidade genética, de espécies e ecossistemas. Esta meta é perseguida a partir de um enfoque holístico (enfoque por ecossistemas), ${ }^{616}$ fundado na conservação sustentável da diversidade genética e de espécies junto dos ecossistemas, em que se originaram. ${ }^{617} \mathrm{O}$ enfoque por ecossistema considera cada elemento que compõe um ecossistema e suas relações entre si, com vistas a conservá-los em plena saúde e funcionamento; portanto, não visa simplesmente a conservar os elementos que o compõem de maneira isolada. ${ }^{618} \mathrm{Em}$ outras palavras, os Estados contratantes da CDB assumiram a obrigação de gerir, de modo integrado "terras, extensões de águas e recursos vivos para que se promova a conservação e utilização sustentável [da biodiversidade] de modo equitativo."619

\footnotetext{
${ }^{614}$ Cf. MCCONNELL, 1996, p. 47 e 54

${ }^{615}$ Ibid., p. 66.

${ }^{616} \mathrm{O}$ enfoque por ecossistemas é uma ferramenta de gestão efetiva da biodiversidade em seus três níveis. Sobre os princípios reitores do enfoque por ecossistemas ver SCBD, 2004a, 2004b.

${ }^{617}$ Cf. PERSIC; MARTIN, 2008, p. 45; BURHENNE-GUILMIN; CASEY-LEFKOWITZ, 1992, p. 45.

${ }^{618}$ A CCDB alçou o enfoque por ecossistemas ao papel de principal marco de atividades da CDB: sua decisão II/8 (COPCBD, Decision II/8, para. 1, tradução nossa) "reafirma que a conservação e uso sustentável da diversidade biológica e de seus componentes deve ser dirigida de maneira holística, tomando em consideração os três níveis de diversidade biológica e considerando em sua completude fatores sócioeconômicos e culturais. [...] [O] enfoque por ecossistemas deve ser o marco de ação primário a ser adotado pela Convenção". No mesmo sentido, ver COPCBD, Decision II/9, para. 12. Dessas decisões, pode-se inferir que o fim último da $\mathrm{CDB}$ não é a conservação dos componentes isolados que integram o patrimônio biológico, mas sua conservação em seus contextos naturais. Iniciativas como a "arca de Noé", que se constitui em um banco de germoplasma composto por 268 mil variedades vegetais de todo o mundo, armazenado em uma área próxima ao Pólo Norte (ACHER, 2008), seriam suficientes para substituir ecossistemas naturais inteiros, se a CDB objetivasse tão-somente a conservação da diversidade genética em isolamento de contextos naturais.

${ }^{619}$ Cf. SCBD, Decision V/6, parte "A", para. 1.
} 
A CDB reconhece que a conservação da diversidade genética, de espécies e de ecossistemas de modo associado ${ }^{620}$ é dependente da conservação da diversidade cultural, ${ }^{621}$ haja vista que os verdadeiros responsáveis pelo patrimônio natural fruído pelas gerações presentes são as comunidades culturalmente diferenciadas cujo arcabouço de conhecimentos e práticas as capacita a viver em harmonia com a natureza. ${ }^{622}$ Para as comunidades tradicionais, a natureza e o homem são membros de uma mesma família, dependendo o bem-estar do último da conservação da natureza. Por esta razão, freqüentemente, estes grupos pautam seu viver por uma conduta conservacionista. ${ }^{623}$

Considerando que comunidades tradicionais freqüentemente vivem em condições de pobreza material, o artigo $8(\mathrm{j})$ da $\mathrm{CDB}$ encoraja ${ }^{624}$ suas partes contratantes a lhes conferir um direito de propriedade sobre seus CTAs, ${ }^{625}$ com o objetivo de, por um lado, fomentar seu amplo uso produtivo ${ }^{626}$ e, pelo outro, gerar benefícios econômicos a partir de seu uso a serem repartidos com as comunidades. ${ }^{627}$ A CDB busca criar condições materiais para a erradicação da pobreza ao nível local ${ }^{628} \mathrm{e}$, por conseguinte, para a conservação dos ecossistemas onde vivem as comunidades tradicionais e de seu patrimônio cultural. ${ }^{629}$

${ }^{620}$ Id., 2002, para. 22 e 48.

${ }^{621}$ Cf. COOMBE, 2001-2002, p. 276; KOOPMAN, 2006, p. 137; SHIVA, 2001, p. 114.

${ }^{622}$ Cf. POSEY, 2004b, p. 63.

${ }^{623}$ Cf. SOLOMON, 2004, p. 155-156.

${ }^{624}$ Os termos empregados pela CDB são tíbios e deixam à discricionariedade dos Estados contratantes a opção de reconhecê-lo ou não: nos termos do art 8(j): “[c]ada Parte Contratante deve, na medida do possível e conforme o caso: (j) [...]respeitar, preservar e manter o conhecimento, inovações e práticas das comunidades locais e populações indígenas com estilo de vida tradicionais relevantes à conservação e à utilização sustentável da diversidade biológica e incentivar sua mais ampla aplicação com a aprovação e a participação dos detentores desse conhecimento, inovações e práticas; e encorajar a repartição eqüitativa dos benefícios oriundos da utilização desse conhecimento, inovações e práticas.” Dutfield (2001, p. 237) assinala que os termos são fracos em comparação com os utilizados no reconhecimento do direito soberano dos Estados sobre seus recursos da biodiversidade, pois a inserção do art. 8(j) na CDB resultou do empenho de organizações não governamentais.

${ }^{625} \mathrm{Cf}$. SCBD, UNEP/CBD/WG8J/1/INF/14, p. 5-6. No mesmo sentido, ver item 26(4)(b) da Agenda 21 (UNCED, 1992).

${ }^{626}$ Cf. POSEY, 2004f, p. 139.

${ }^{627}$ A Declaração de Belém, adotada pelos participantes do Primeiro Congresso da Sociedade Internacional de Etnobiologica, figura como o primeiro documento internacional a demandar compensação justa às comunidades tradicionais pelo uso comercial e científico de seus RBIs (INTERNATIONAL CONGRESS OF ETHNOBIOLOGY, 1988). O art. 8(j) da CDB é uma resposta à esta demanda (POSEY, 1990, p. 14).

${ }^{628}$ Em consonância com o art. 20(4), CDB, a erradicação da pobreza é um dos objetivos centrais perseguidos pelos Estados parte países em desenvolvimento. No mesmo sentido, ver princípios 5(a), 7(b), 9(b) e 9(c), UNGA, A/CONF.151/26 (vol.III).

${ }^{629}$ Cf. UNGA, Resolution 62/98; princípio 12 das Diretrizes de Adis Abeba (SCBD, 2004b); POSEY, 2004h, p. 146. 
Partindo da premissa de que, historicamente, o livre acesso aos recursos da biodiversidade não gerou quaisquer incentivos econômicos para sua conservação, ${ }^{630} \mathrm{a}$ CDB igualmente alterou o regime jurídico destes recursos, que passaram de um regime de patrimônio comum da humanidade ${ }^{631}$ para um regime de soberania dos Estados, ${ }^{632}$ uma espécie de direito de propriedade investido nos Estados, que os autoriza a condicionar o acesso aos seus recursos da biodiversidade à negociação de acordos comerciais com os potenciais usuários. ${ }^{633}$ A mudança do status jurídico da biodiversidade objetivou constituir uma associação construtiva ${ }^{634}$ entre os setores usuários de recursos da biodiversidade e os países em desenvolvimento, com o fito de canalizar recursos econômicos dos países industrializados para os em desenvolvimento para apoiá-los na tarefa de conservação da biodiversidade para as presentes e futuras gerações. ${ }^{635}$

Representa, portanto, uma premissa da CDB que a meta de conservação da biodiversidade não conflita com a de desenvolvimento comercial. Muito pelo contrário. A conservação da biodiversidade apenas se faz possível com a quebra do ciclo de pobreza, que leva os grupos humanos a explorá-la de modo insustentável para a satisfação de suas necessidades. ${ }^{636}$ A conservação da natureza apenas será um fím factível, se existirem mecanismos que capitalizem a conservação ambiental, ${ }^{637}$ tornando-a uma fonte de renda para as populações dos países em desenvolvimento. Tanto é que um dos três objetivos da CDB é a "repartição justa e equitativa dos benefícios derivados da utilização dos recursos genéticos" (art. $\left.1^{\circ}\right)$. Assim sendo, a repartição de benefícios não é um objetivo final da $\mathrm{CDB}$, mas um objetivo instrumental.

Embora inexista um conflito inerente entre a conservação da biodiversidade e o desenvolvimento comercial a partir dela, a CDB reconhece que os DPIs podem interferir

${ }^{630}$ Cf. COOMBE, 1998-1999, p. 92-93; TOBIN, [20--], p. 1.

${ }^{631} \mathrm{Cf}$. art. 1(1) combinado com os parágrafos $1^{\circ} \mathrm{e} 2^{\circ}$ do art. 2 do AIFAO.

${ }^{632}$ Ao menos três resoluções da AGONU (UNGA, Resolution (XVII), para. 1; UNGA, Resolution 3201 (SVI), para. 4(c); UNGA, Resolution 41/128, preâmbulo) reconhecem o direito soberano dos Estados sobre seus recursos naturais. A FAO (FAO, Resolución 3/91, para. 1(1)) reconheceu o direito soberano dos Estados sobre seus recursos fitogenéticos. Uma vez que estas resoluções não têm natureza vinculante, coube à CDB (art. 15) a mudança do regime legal dos recursos da biodiversidade.

${ }^{633}$ Cf. BRAGDON, 2002

${ }^{634}$ Cf. BIBER-KLEMM, 2004, p. 98-99; KOOPMAN, 2005, p. 532.

${ }^{635} \mathrm{Cf}$. POSEY, 2004k, p. 163

${ }^{636}$ Ver, e.g., COOMBE, 1998-1999, p. 90; POSEY, 2004i, p. 204-205; UNGA, Resolution 62/98, para. 6 (y).

${ }^{637}$ Cf. PANEL OF EXPERTS CONVENED BY THE SECRETARY-GENERAL OF THE UNITED NATIONS CONFERENCE ON THE HUMAN ENVIRONMENT, 2002, p. 41. No mesmo sentido, ver a Diretrizes de Bonn da Conferência das Partes da CDB (SCBD, 2002, para. 51). 
negativamente em sua implementação. Por isso, chama seus Estados contratantes à responsabilidade de adotar regimes domésticos e internacionais de proteção da propriedade intelectual, de maneira que os DPIs se "apóiem e não se oponham aos objetivos" da CDB (art. 16(2) e (5)). A compatibilização entre a CDB e os DPIs demanda dos Estados contratantes da CDB, além do reconhecimento do direito soberano dos Estados sobre seus recursos da biodiversidade e das comunidades tradicionais sobre seus CTAs, a facilitação da transferência de tecnologias aos países em desenvolvimento, ${ }^{638}$ com o propósito de capacitá-los a explorar sustentavelmente seu patrimônio natural e, por conseguinte, a exercer real soberania sobre sua biodiversidade. ${ }^{639}$ Os EUA interpretaram as referidas obrigações como uma autorização para se atacar os DPIs incidentes sobre invenções biotecnológicas, na hipótese dos países industrializados não efetivarem voluntariamente a transferência de tecnologia e de outros benefícios econômicos aos países de origem dos recursos da biodiversidade. ${ }^{640}$ Por esta razão, até o presente, não ratificaram a CDB.

Na prática, apesar de vinculante, a CDB mostrou-se um acordo tremendamente fraco, não só como resultado da oposição norte-americana, ${ }^{641}$ mas também porque a CDB é uma convenção quadro. Conseqüentemente, muitos de seus dispositivos não contam com substância suficiente para serem autoaplicáveis, ${ }^{642}$ o que certamente serve de justificativa para os países industrializados não agirem.

Se esses problemas já não fossem suficientes para ameaçar o sucesso da CDB, menos de um ano após sua entrada em vigor internacional, ${ }^{643}$ em 15 de abril de 1994, foi encerrada a Rodada Uruguai do Acordo Geral sobre Tarifas e Comércio (GATT), que

\footnotetext{
${ }^{638}$ Cf. art. 19(2), combinado com o art. 22(1) da CDB.

${ }^{639}$ Cf. THOMPSON, C.B., 2004, p. 854-855.

${ }^{640}$ Cf. RITCHIE; DAWKINS, VALLIANATOS, 1995-1996, p. 445. A interpretação norte-americana sobre as obrigações decorrentes da CDB vão ao encontro da demanda dos Estados membros da Organização para o Tratado de Cooperação Amazônica (OTCA). Em 1992, no período de negociações da CDB, os membros da OTCA demandaram que o acesso aos seus recursos da biodiversidade estivesse condicionado ao acesso às biotecnologias e cultivares desenvolvidas nos países industrializados (OTCA, 1992, para. 9-10).

${ }^{641}$ Os recursos biológicos presentes em território americano são regidos pelo princípio do patrimônio comum da humanidade, podendo as instituições lá localizadas utilizá-los livremente. Recordando que os EUA congregam uma ampla gama de ecossistemas, os recursos lá presentes podem ser substitutos dos recursos de ecossistemas de países megadiversos. A não-ratificação da CDB pelos EUA também significa que este país não se comprometeu a perseguir potenciais instituições americanas, envolvidas em atividades de apropriação indébita de recursos da biodiversidade e CTs, praticadas nos territórios dos Estados parte da CDB (VOGEL, 2000a, p. 6).

${ }^{642}$ Cf. BURHENNE-GUILMIN; CASEY-LEIFKOWITZ, 1992, p. 56-57; MOORE; TYMOWSKI, 2005, p. 13.

${ }^{643}$ A CDB entrou em vigor internacional em 29 de dezembro de 1993.
} 
culminou na criação da Organização Mundial do Comércio (OMC), ${ }^{644}$ bem como na adoção do Acordo TRIPS. Uma das funções centrais deste acordo é obrigar os 153 Estados Membros da $\mathrm{OMC}$ a adotarem regimes de proteção da PI, similares àqueles em vigor nos países industrializados. ${ }^{645}$ Tais regimes, conforme examinado anteriormente, promovem a apropriação sistemática dos RBIs seja por meio da expansão do rol de matérias elegíveis para proteção seja pelo afrouxamento das condições de proteção. ${ }^{646} \mathrm{O}$ Acordo TRIPS não objetiva apenas criar um ambiente previsível e homogêneo para a atuação das organizações empresariais; ${ }^{647}$ seu propósito central é perpetuar a posição hegemônica dos países industrializados frente aos países menos desenvolvidos. ${ }^{648}$

\subsubsection{ACORDO TRIPS E O ESVAZIAMENTO DA CDB}

Em 1967, foi criada a OMPI com o objetivo de desempenhar o papel de motor propulsor do desenvolvimento de regimes internacionais de proteção da PI. Como resultado do grande número de Estados membros países em desenvolvimento, entre as décadas de 70 e 90, o regime internacional de proteção da PI não sofreu qualquer grande desenvolvimento. ${ }^{649}$ A Rodada Uruguai do GATT (1986-1994) foi a responsável por reintroduzir a temática na agenda internacional, bem como pelo mais importante desenvolvimento do sistema internacional de proteção da PI, desde o final do século XIX. ${ }^{650} \mathrm{O}$ grande sucesso do Acordo TRIPS se deve ao fato de que aderir a ele é uma condição para a participação no sistema multilateral de comércio. ${ }^{651}$

O Acordo TRIPS substituiu o princípio do tratamento especial e preferencial concedido aos países em desenvolvimento, estabelecido pela Conferência das Nações Unidas para o Comércio e Desenvolvimento, nos anos 60, pela noção de equalização de tratamento. Isto implica que os países em desenvolvimento passaram a estar obrigados a proteger as produções intelectuais dos países industrializados nos termos fixados por estes,

\footnotetext{
${ }^{644}$ Cf. WTO, Marrakesh Declaration of 15 April 1994.

${ }^{645}$ Cf. SHIVA, 2001, p. 130.

${ }^{646}$ Cf. MENESCAL, 2005a, p. 789.

${ }^{647}$ Cf. THOMPSON, C.B., 2004, p. 851.

${ }^{648}$ Cf. RIBEIRO, 2007, p. 61.

${ }^{649}$ Cf. GROSHEIDE, 2002, p. 16.

${ }^{650}$ Cf. AOKI, K., 1998, p. 19-20.

${ }^{651}$ Cf. BARLOW, 1997, p. 355.
} 
apesar de tais regimes os prejudicarem. ${ }^{652}$ Os interesses e objetivos perseguidos pelos países em desenvolvimento - dentre eles, a proteção do PBI - não foram albergados pelo Acordo TRIPS. Isto porque sua redação e negociação foram dirigidas pelos grandes conglomerados empresariais dos países industrializados ${ }^{653}$ e pelas associações comerciais representativas de seus interesses, dentre elas, a Câmara de Comércio Internacional (CCI) e a Associação Internacional para a Proteção da Propriedade Intelectual (AIPPI). ${ }^{654}$

Até a criação da $\mathrm{OMC}$, os RBIs eram sistematicamente apropriados pelas instituições dos países industrializados de maneira localizada. Em outras palavras, a apropriação ocorria por meio da obtenção de DPIs sobre criações intelectuais derivadas de RBIs apenas nos territórios dos países industrializados, porquanto um número substancial de países em desenvolvimento ou não contava com legislações de proteção da PI, ou seus termos viabilizavam a exclusão das produções intelectuais derivadas de RBIs do rol de proteção das legislações.

Com a criação da $\mathrm{OMC}$, os países em desenvolvimento tiveram de assumir a obrigação de disciplinar a proteção da PI em termos similares àqueles presentes nos marcos legais dos países industrializados, realidade esta que os conduziu a legalizar localmente práticas de apropriação indébita dos RBIs. A substância da Convenção de Berna $^{655}$ cujos termos permitem a apropriação das ECTs e do regime norte-americano de proteção das produções biotecnológicas se transformaram no padrão mínimo, que os marcos legais de PI dos países em desenvolvimento devem observar.

É indiscutível que o Acordo TRIPS gera impactos negativos tanto sobre as ECTs quanto sobre os recursos da biodiversidade e CTs. Sem embargo, a chamada "cláusula da biotecnologia", ${ }^{656}$ cristalizada em seu art. 27(3)(b), que permite a apropriação dos recursos da biodiversidade e CTAs é vista como um de seus dispositivos mais polêmicos, recebendo atenção diferenciada das organizações da sociedade civil, academia e políticos de países em desenvolvimento. Diferentemente da seção dedicada aos direitos autorais, que basicamente globaliza os termos da Convenção de Berna, a cláusula da biotecnologia vai

\footnotetext{
${ }^{652}$ SOUTH CENTRE, 2002, p. 4-6.

${ }^{653}$ Sobre o papel da indústria farmacêutica na elaboração do Acordo TRIPS ver DRAHOS, 2003.

${ }^{654}$ Cf. MENESCAL, $2005 b$.

${ }^{655}$ Seção I, parte II do Acordo TRIPS disciplina a proteção dos direitos autorais e conexos.

${ }^{656}$ Cf. UNCTAD-ICTSD, 2005, p. 891.
} 
além dos termos dos acordos internacionais vigentes em meados da década de 90 - e.g., Convenção de Paris. Tal "atualização" do padrão vigente à época de sua adoção conduziu ao esvaziamento da CDB.

$\mathrm{O}$ art. 27(3)(b) do TRIPS demanda dos Estados membros da OMC a concessão de patentes de invenção para microorganismos e processos microbiológicos ${ }^{657}$ e nãobiológicos e lhes autoriza a excluir do rol de matérias patenteáveis plantas, animais e processos essencialmente biológicos ${ }^{658}$ para a sua produção. No que tange às variedades vegetais, os Estados membros da OMC são obrigados a protegê-las, mas gozam da liberdade de eleger o meio de proteção, podendo optar por protegê-las por patentes ou por um sistema sui generis eficaz ou por uma combinação de ambos. O Acordo TRIPS não determina o que seja um sistema "sui generis eficaz", mas necessariamente deverá apresentar as características comuns a todo regime de proteção da PI: (i) definir a matéria de proteção e a matéria excluída de proteção; (ii) determinar os titulares de direitos; (iii) estabelecer as limitações aos direitos conferidos; (iv) estabelecer as condições que as variedades vegetais devem observar para ganharem proteção; (v) determinar o mecanismo para obtenção de direitos; (vi) fixar o termo de proteção e, por fim, (vii) os remédios disponíveis para defesa dos direitos. ${ }^{659}$

A definição de plantas e animais não envolve polêmicas. Plantas são seres vivos multicelulares, auto-replicáveis, capazes de produzir seu próprio alimento por meio da fotossíntese (seres autótrofos). ${ }^{660}$ Animais, por sua vez, são seres vivos multicelulares, também auto-replicáveis, dotados de mobilidade, incapazes de produzirem autonomamente seu alimento (heterótrofos). ${ }^{661}$ No que tange a estas duas matérias, os Membros da OMC gozam da opção de não protegê-las.

As dificuldades começam com o alcance do termo variedade vegetal. Variedade de planta consiste numa planta modificada tecnicamente, portadora de características especiais

\footnotetext{
${ }^{657}$ A Diretiva européia 98/44/CE entende por processo microbiológico aquele "que utilize uma matéria microbiológica, que inclua uma intervenção sobre uma matéria microbiológica ou que produza uma matéria microbiológica" (art. 2(1)(b)). Matéria microbiológica é qualquer material biológico invisível ao olho nu.

${ }^{658}$ Processos essencialmente biológicos consistem em fenômenos integralmente naturais para a obtenção de vegetais ou de animais; por exemplo, os processos de cruzamento ou seleção (art. 2(2), Diretiva européia 98/44/CE).

${ }^{659} \mathrm{Cf} . \mathrm{IP} / \mathrm{C} / \mathrm{W} / 369 /$ Rev.1, para. 51.

${ }^{660}$ Cf. ADCOCK; LLEWELYN, 2000, p. 15

${ }^{661}$ Ibid., p. 15.
} 
que não se apresentam na versão natural da planta da qual derivou, que se conservam intergeracionalmente. ${ }^{662}$ Os países industrializados sustentam que, apesar da omissão do Acordo TRIPS, a definição de variedade vegetal deveria compreender apenas aquelas resultantes de atividades de melhoramento comercial. ${ }^{663}$ Também defendem que o TRIPS não impede - tampouco obriga - suas partes a estabelecerem regimes de proteção para variedades vegetais tradicionais. Se o objetivo do Acordo TRIPS é proteger criações intelectuais a fim de suprimir distorções no comércio internacional, seria contrário aos fins do acordo excluir do escopo do termo variedade vegetal aquelas desenvolvidas pelo trabalho intelectual de comunidades agrícolas. Uma vez que o TRIPS não fixou as condições substantivas que as variedades vegetais devem observar para serem elegíveis para proteção legal, não é lícito aos membros da OMC excluir de seu escopo obrigatório as variedades tradicionais. Tal exclusão estimula sua apropriação indébita pelos melhoristas vegetais formais, o que nada mais é do que um tipo de distorção comercial. Isto posto, o Acordo TRIPS demanda que países industrializados e em desenvolvimento definam variedades vegetais elegíveis para proteção de maneira a abranger tanto as variedades vegetais obtidas pelos melhoristas industriais quanto aquelas desenvolvidas por comunidades agrícolas. ${ }^{664}$

O Acordo TRIPS igualmente oferece aos seus Estados parte a prerrogativa de definir o que sejam microorganismos. ${ }^{665}$ Dependendo da definição deste termo, um maior ou menor número de organismos vivos será elegível para proteção legal. Definir microorganismos não é uma tarefa simples. Em primeiro lugar, em virtude de sua importância comercial, está é a única categoria de seres vivos para a qual todos os Estados membros da OMC estão obrigados a conceder proteção patentária. ${ }^{666}$ Logo, existe pressão pela expansão de sua definição. Em segundo lugar, porque inexiste uma definição internacional pacífica do que seja microorganismo. ${ }^{667}$

Os organismos vivos podem ser divididos em cinco reinos: animal, vegetal, monera, protista e fungos. Em regra, microorganismos abarcam organismos dos reinos monera (e.g.

\footnotetext{
${ }^{662}$ Cf. UNCTAD-ICTSD, 2005, p. 389.

${ }^{663}$ Ver WTO, IP/C/W/284.

${ }^{664}$ Em sentido diverso, Oviedo, Gonzáles e Maffi (2004, p. 79) defendem que o artigo 27(3)(b) seja objeto de uma declaração, em que se esclareça que o sistema pode ser utilizado para proteção do patrimônio imaterial das comunidades tradicionais.

${ }^{665}$ Cf. WTO, IP/C/3/383, p. 1 .

${ }^{666}$ A importância dos microorganismos para a indústria pode ser medida pelos mais de 299,000 pedidos de patentes publicados entre 1990-2003, que reivindicam proteção para microorganismos (OLDHAM, 2004).

${ }^{667}$ Cf. ADCOCK; LLEWELYN, 2000, p. 7.
} 
arquebactérias, eubactérias e cianobactérias), protista (e.g. algas, protozoários), fungos unicelulares (microscópicos). ${ }^{668}$ Os Escritórios de Patentes dos EUA, Europa e Japão adotam uma definição mais inclusiva e tratam como microorganismos células de plantas e de animais, já que lhes interessa ampliar continuamente o rol de matérias elegíveis para proteção. ${ }^{669}$ Isto não implica que os Estados parte países em desenvolvimento não possam excluir da definição de microorganismos células de plantas e animais. Naturalmente, esta prerrogativa não interfere na liberdade dos países industrializados de definir microorganismos. Contudo, ao menos permite que os países em desenvolvimento evitem a situação de se verem obrigados a protegerem invenções biotecnológicas, desenvolvidas a partir de recursos da biodiversidade apropriados indebitamente.

A obrigatoriedade pura e simples de conceder DPIs sobre invenções e criações biotecnológicas cria um conflito entre a CDB e o TRIPS. A existência deste conflito não é pacífica, mas foi reconhecido, ainda que veladamente, pela $\mathrm{CCDB}^{670}$ que encorajou a $\mathrm{OMC}$ a examinar meios de harmonizar o Acordo TRIPS com a CDB, quando da revisão do artigo 27.2.b do TRIPS. ${ }^{671}$

Muitos países em desenvolvimento ${ }^{672}$ e mesmo alguns países industrializados - e.g. Holanda, Itália e Noruega ${ }^{673}$ - sustentam que a CDB e o TRIPS conflitam. O conflito central giraria em torno da titularidade da propriedade dos recursos biológicos e CTs. Ambos os acordos apresentam um ponto em comum: conferem direitos de propriedade sobre recursos biológicos e CTAs. ${ }^{674}$ Enquanto a CDB confere aos Estados e às comunidades tradicionais, respectivamente, um direito de propriedade sobre seus recursos biológicos e CTAs, o Acordo

\footnotetext{
${ }^{668}$ Ibid., p. $6-10$.

${ }^{669}$ Cf. ADCOCK, LLEWELYN, 2000, p. 3-4.

${ }^{670} \mathrm{Cf}$. COPCBD, Decision V/26, item "B", para. 2.

671 O Acordo TRIPS obriga seus Estados contratantes a revisarem as obrigações insculpidas no do art. 27(3)(b), em 1999. Em dez anos de revisão, o processo não chegou a lugar algum. Além da revisão prevista no dispositivo mencionado, o art. 71(1) determina que o TRIPS seja revisto a cada dois anos, a partir de $1^{\circ}$ de janeiro de 2000.

672 Posição sustentada por, dentre outros, o Grupo Africano, Brasil, Colômbia, Equador, Índia, Indonésia, Tailândia, Turquia, Venezuela (WTO, IP/C/W/368/Rev.1, para. 15).

${ }^{673}$ A Holanda, com o apoio da Itália e da Noruega, ajuizou um recurso, perante o Tribunal de Justiça das Comunidades Européias, contra o Parlamento Europeu e o Conselho da União Europeia. O recurso legal tinha por fim anular a diretiva européia 98/44/CE, que disciplina a proteção jurídica das invenções biotecnológicas. Os proponentes do recurso defenderam que a Diretiva 98/44/CE viola a CDB, por “[...] privar um país em desenvolvimento da capacidade de controlar os seus recursos biológicos e de ter acesso aos seus conhecimentos tradicionais", por "favorecer a monocultura" e por "desencorajar os esforços nacionais e internacionais de conservação da biodiversidade" (UNIÃO EUROPÉIA - Tribunal de Justiça das Comunidades Européias. Processo C-377/98., para. 65). O Tribunal julgou o recurso improcedente.

${ }^{674}$ Ver, e.g., DUTFIELD, 2001, p. 260; THOMPSON, C.B., 2004, p. 850; GRAIN, 1998.
} 
TRIPS reconhece direitos amplos de propriedade sobre invenções biotecnológicas, biomédicas, agrobiotecnológicas em favor de instituições privadas. ${ }^{675}$ Durante as negociações da $\mathrm{CDB}$, os países industrializados desejavam que os recursos biológicos continuassem a ser regidos pelo regime de patrimônio comum da humanidade, enquanto demandavam dos países em desenvolvimento a adoção de medidas de proteção da PI de seus nacionais. No fim, a posição dos países industrializados venceu: apesar dos termos da CDB, os recursos biológicos e CTAs conservam de fato o status de patrimônio comum da humanidade, enquanto as criações intelectuais dos países industrializados ganharam o status de propriedade privada. ${ }^{676}$ Isto se deve à opção daqueles países industrializados, que são partes contratantes de ambos os acordos, de observarem as obrigações derivadas do Acordo TRIPS e negligenciarem a CDB.

Uma segunda faceta do conflito está no não-estabelecimento pelo TRIPS da obrigação dos titulares de DPIs de repartirem os benefícios econômicos auferidos, resultantes do uso comercial de recursos biológicos e CTAs, com as comunidades tradicionais e Estados pertinentes. ${ }^{677}$ As únicas partes habilitadas a extrair benefícios destes RBIs são os titulares de DPIs, que obviamente não se confundem com os guardiões da diversidade biológica e cultural. ${ }^{678}$ Para o TRIPS é irrelevante o papel das comunidades tradicionais na conservação dos ecossistemas, geradores dos RBIs absorvidos nos processos de inovação industrial.

Uma terceira faceta do conflito se assenta no fato do TRIPS se limitar a proteger produtos biológicos homogêneos geneticamente, incentivando a substituição das variedades vegetais tradicionais, ricas em termos de biodiversidade, ${ }^{679}$ por variedades geneticamente homogêneas, pobres em termos biológicos. Essa prática conduz à erosão da diversidade biológica e dos conhecimentos associados a ela. ${ }^{680}$

Para um grande número de países industrializados ${ }^{681}$ e organizações empresariais inexiste qualquer conflito entre a CDB e o TRIPS, pois cada qual persegue objetivos diversos,

${ }^{675}$ Cf. NATURE, 1998, p. 525.

${ }^{676}$ Cf. SOUTH CENTRE, 2002, p. 128.

${ }^{677} \mathrm{Cf}$. WTO, IP/C/W/459, para. 1.

${ }^{678}$ Cf. BIBER-KLEMM, 2004, p. 100.

${ }^{679}$ Cf. GRAIN, 1998.

${ }^{680}$ Cf. THOMPSON, C.B., 2004, p. 853.

${ }^{681}$ Posição defendida por, inter alia, Austrália, Canadá, Cingapura, Coréia do Sul, Japão, EUA, Nova Zelândia (WTO, IP/C/W/368/Rev.1, para. 7-11) e União Européia (WTO, IP/C/3/383, para. 36-37). A Noruega e a Suíça defendem a adoção de medidas que harmonizem os dispositivos do Acordo TRIPS concernentes ao direito de patentes com as obrigações derivadas da CDB (WTO, IP/C/W/368/Rev.1, para. 13). 
inexistindo a necessidade de adoção de qualquer medida, no âmbito do Acordo TRIPS, dedicada a harmonizá-lo com a CDB. Segundo a perspectiva destes países, o Acordo TRIPS não estabelece obstáculos para que os benefícios decorrentes da exploração dos DPIs sejam compartilhados com os Estados e comunidades provedoras de RBIs. ${ }^{682}$ E apesar da CDB dispor que os DPIs devam ser implementados de maneira a apoiar a CDB, segundo o Tribunal de Justiça das Comunidades Européias, esta não "prevê como condições para a atribuição de uma patente para invenções biotecnológicas que sejam tidos em conta os interesse dos países dos quais os recursos genéticos são originários ou a existência de medidas de transferência tecnológica."

Em conformidade com o entendimento dos países industrializados, os DPIs são catalisadores da realização dos objetivos da $\mathrm{CDB}$, ao maximizarem os benefícios econômicos decorrentes do uso de recursos da biodiversidade e CTAs, bastando o uso de contratos para assegurar a repartição de benefícios em favor das comunidades e Estados provedores destes insumos. ${ }^{684}$ Tal visão omite que a indústria dos países industrializados voluntariamente optou por não observar a CDB, e por conta da falta de instrumentos que garantam respeito aos seus termos nos países usuários, os países provedores e suas comunidades não contam com os meios de reivindicar seus direitos assegurados pela CDB.

O TRIPS conflita com a CDB não por obstaculizar a adoção de regimes de proteção da PI harmônicos com a CDB, ou por permitir o patenteamento de microorganismos, plantas e animais, mas por ser omisso quanto aos direitos dos Estados e das comunidades sobre seus recursos biológicos e CTAs, ${ }^{685}$ notadamente o direito de receberem uma compensação justa e equitativa por seu uso produtivo. ${ }^{686} \mathrm{Na}$ esfera do dever-ser, uma vez que muitos dos Estados parte da CDB são igualmente membros da OMC, em consonância com os termos do art. 31(3)(c) da Convenção de Viena sobre Direitos dos Tratados, é prescindivel que o TRIPS faça referência explícita à $\mathrm{CDB}$ para que os Estados contratantes de ambos os acordos estejam obrigados a implementar o TRIPS de maneira a apoiar a CDB. ${ }^{687}$ Mas em um cenário em que o lucro é o valor reinante nas relações humanas e interestatais, a omissão do TRIPS

\footnotetext{
${ }^{682}$ Ver, e.g., WTO, IP/C/3/383, para. 33; WTO, IP/C/W/472, para. 6.

${ }^{683}$ Cf. UNIÃO EUROPÉIA - Tribunal de Justiça das Comunidades Européias. Processo C-377/98., para. 65.

${ }^{684}$ Ver WTO, IP/C/3/383, para. 38-41; GUPTA, 2004, p. 120.

${ }^{685} \mathrm{Id} ., \mathrm{IP} / \mathrm{C} / \mathrm{W} / 470$, para. 2.

${ }^{686} \mathrm{Id} ., \mathrm{IP} / \mathrm{C} / \mathrm{W} / 459$, para. 1.

687 Cf. UNITED NATIONS DEPARTMENT FOR POLICY COORDINATION AND SUSTAINABLE

DEVELOPMENT, 1996, para. 9.
} 
equivale a oferecer aos membros da OMC a discricionariedade para implementá-lo de maneira a interferir negativamente na observância da CDB, o que certamente constitui um conflito.

A CCI, ${ }^{688}$ em nome do setor empresarial dos países industrializados, defende que, emergindo algum conflito entre o Acordo TRIPS e a CDB, o primeiro deveria prevalecer, pois, segundo os termos da Convenção de Viena sobre Direito dos Tratados, o tratado mais recente deve revogar o anterior, se tratarem de um mesmo tema, e o tratado mais específico revoga o geral. Na perspectiva da CCI, o art. 16(5) da CDB, que demanda que os DPIs devam ser observados de maneira a apoiar a CDB, seria uma norma de PI e por isto, se conflitar com o TRIPS, este prevaleceria, porquanto mais recente. Contudo, se o conflito for examinado sob a ótica do desenvolvimento sustentável, a CDB é a norma mais específica e por isso, em caso de conflitos, se sobreporia ao TRIPS.

\subsubsection{FLEXIBILIDAdES OFERECIDAS PELO ACORDO TRIPS PARA MITIGAR SEU CONFLITO COM A CDB}

Os países em desenvolvimento, dado que não podem obrigar os países industrializados a definir as condições de patenteabilidade de modo a impedir a apropriação de seus RBIs, ${ }^{689}$ ao menos podem moldar seu conteúdo, ou com o objetivo de dificultar ou facilitar a concessão de patentes sobre invenções que neles se baseiam substancialmente.

A opção por condições de patenteabilidade mais rigorosas-condições de mais difícil cumprimento--pode ser adequado para países que já detêm indústrias tecnologicamente desenvolvidas, capazes de desenvolver invenções aptas a cumprir estas condições. Já os setores menos desenvolvidos do país terão difículdades para alcançar o nível tecnológico necessário para desenvolver invenções patenteáveis. A adoção de critérios de proteção mais baixos pode facilitar a obtenção de patentes sobre CTAs e recursos da biodiversidade, mas igualmente facilitará a obtenção de patentes sobre todo e

\footnotetext{
${ }^{688}$ Cf. ICC, 1999.

${ }^{689}$ A União Européia (WTO, IP/C/M/43, para. 40) já expressou total oposição a mudanças que limitem a liberdade dos países industrializados para definir o rol das matérias elegíveis de proteção por patentes e as condições de patenteabilidade.
} 
qualquer tipo de invenção trivial, o que limitará o espaço em que as empresas nacionais poderão atuar. ${ }^{690}$

Uma segunda opção de correção paliativa do regime de patentes é excluir do rol de matérias elegíveis para proteção, invenções que compreendam CTAs e recursos biológicos intangíveis isolados de seus meios naturais. ${ }^{691}$ Esta opção é igualmente equivocada. Em primeiro lugar, conforme visto anteriormente, é freqüentemente difícil identificar a origem de uma invenção derivada de CTAs e recursos da biodiversidade. E na hipótese de ser possível identificá-la, a exclusão de invenções derivadas de CTAs e recursos biológicos do rol de matérias patenteáveis pode limitar as oportunidades dos detentores destes RBIs de reivindicar benefícios, derivados da exploração comercial destas invenções. Sem patentes, é compreensível que as instituições comerciais tenham menor interesse em investir em projetos de $\mathrm{P} \& \mathrm{D}$ que envolvam CTs e recursos da biodiversidade.

Os países em desenvolvimento membros da OMC podem ainda mitigar o potencial conflito entre o Acordo TRIPS e a CDB, em seus territórios, por meio da limitação das matérias elegíveis de proteção patentária (exclusão de plantas e animais do rol de matérias patenteáveis e limitação da definição de microorganismos), bem como por meio do emprego da flexibilidade oferecida pelo art. 27(2) do TRIPS. Este dispositivo autoriza os Estados membros da OMC a denegarem proteção patentária a invenções cuja exploração contraria a ordem pública ou à moralidade. Deve-se ter claro que na hipótese de uma invenção puder ser explorada no território onde a proteção for reivindicada, sem conflitar com os valores morais e a ordem pública local, a não-concessão da patente, com fundamento no art. 27(2), infringirá o Acordo TRIPS. ${ }^{692}$

Um exemplo de implementação deste dispotivo com o objetivo de harmonizar o Acordo TRIPS com a CDB está presente na primeira versão do projeto de emenda da lei de patentes da Bélgica, que objetivava adequá-la aos termos da Diretiva 98/44/CE, bem como compatibilizá-la com a CDB, de maneira a impedir a biopirataria. ${ }^{693}$ Esta proposta proibia a

\footnotetext{
${ }^{690}$ Cf. LIU, 2003, p. 85-97.

${ }^{691}$ Posição defendida pela delegação sul-africana na OMPI (WIPO, WIPO/GRTKF/IC/12/5(b), anexo, p. 124).

${ }^{692}$ Cf. GRUBB, 2004, p. 281-282.

693 "La biopiraterie est une question cruciale qui mérite, par son importance, d'être traitée afin de lutter contre le pillage des ressources biologiques des pays du tiers monde ou en voie de développement. C'est pourquoi, il convient également, dans le cadre de la transposition de la directive, de prendre en considération la
} 
proteção de invenções contrárias à ordem pública e à moral, tratando como contrária à ordem pública e à moral qualquer invenção que utilizasse CTs e recursos genéticos, acessados em violação dos artigos 3, 8(j), 15 e 16 da CDB. ${ }^{694}$ Para que esta proposta fosse compatível com os termos do Acordo TRIPS, o marco legal belga teria de prever a suspensão da exploração comercial da invenção contrária à ordem pública e à moral. E para transformá-la em um incentivo para a regularização de situações ilegais, poder-se-ia pensar em oferecer ao depositante do pedido de patente não concedida ou ao titular da patente revogada a opção de repartir benefícios com o Estado e/ou comunidades provedores dos recursos biológicos e/ou CTAs apropriados, com vistas a recuperar seus direitos. A suspensão provisória do processamento do pedido de patente ou da validade da patente, enquanto o titular do pedido depositado ou da patente não compartilhar os benefícios econômicos devidos, seria um meio mais efetivo de transformar o TRIPS em uma ferramente de exigibilidade da $\mathrm{CDB},{ }^{695}$ do que simplesmente proibir o processamento do pedido ou revogar a patente.

Naturalmente, todos os países em desenvolvimento ricos em RBIs teriam razões para transpor o art. 27(2) do TRIPS aos seus marcos legais domésticos seguindo o modelo belga. Contudo, é importante salientar que o uso desta flexibilidade apenas seria hábil a transformar o Acordo TRIPS em uma ferramenta de exigibilidade da CDB naqueles países que contam com grandes mercados consumidores, por exemplo, Brasil, China e Índia. Isto porque a proibição da comercialização de uma invenção biotecnológica ou farmacêutica nesses mercados apresenta potencial de gerar grandes prejuízos aos titulares de patentes. Em mercados diminutos, as instituições que se apropriam de RBIs não têm incentivos para lá buscarem proteção. A fim de cooperar com os países que não dispõem de mercados suficientemente atraentes, os países em desenvolvimento mais ricos poderiam permitir a revogação/suspensão da validade de patentes que recaem sobre invenções derivadas de RBIs de qualquer origem. Neste caso, tomariam para si a função de fiscais do cumprimento global

Convention de Rio sur la diversité biologique, notamment en ce qui concerne le droit souverain des États d'exploiter leurs ressources génétiques (article 3 Convention de Rio), ainsi que le droit des communautés autochtones et locales sur leurs connaissances et à un partage équitable des avantages découlant de l'utilisation de ces connaissances (article 8J) ». Cf. CHAMBRE DES REPRÉSENTANTS DE BELGIQUE, 2002, p. 13.

${ }^{694}$ A proposta original de art. 4o, $\S 4^{\circ}$ da Lei de Patentes da Bélgica dispõe: "L'exploitation commerciale d'une invention est contraire à l'ordre public et aux bonnes mœurs notamment lorsqu'il est établi que l'invention a été développée dans des conditions contraires à l'ordre public et aux bonnes mœurs. Tel est le cas par exemple: - lorsqu'une invention est développée à partir de matière biologique prélevée ou exportée en violation des dispositions des articles 3,8 j), 15 et 16 de la Convention de Rio sur la diversité biologique du 5 juin 1992. » Cf. CHAMBRE DES REPRÉSENTANTS DE BELGIQUE, 2002, p. 13.

${ }^{695}$ Cf. GOLD; CAULFIELD, 2002, p. 2268-2270. 
da $\mathrm{CDB}$, ao mesmo tempo em que ganhariam experiência de grande valia, quando da criação de regimes internacionais de proteção dos RBIs.

Em sentido diverso, mas com efeitos similares, a Nova Zelândia elaborou um projeto de lei de patentes que, se aprovado, estabelecerá um comitê composto por representantes Maoris, investido na missão de avaliar se determinados pedidos de patentes envolvem ou não CTs e recursos genéticos conservados pelo povo Maori. Se o comitê identificar casos de uso não-autorizado de CTs e recursos da biodiversidade, deverá avaliar se a exploração comercial da invenção feriria os valores do povo Maori. O parecer seria levado em conta pelo Escritório de Patentes da Nova Zelândia, que poderia deixar de conceder a patente, não estando obrigado a assim proceder. ${ }^{696}$

\subsubsection{OS ACORDOS DE LIVRE COMÉRCIO E A SUPRESSÃO DAS FLEXIBILIDADES DO ACORDO TRIPS}

Apesar de o Acordo TRIPS ter trazido mudanças substantivas em relação à Convenção de Paris, as mudanças realizadas já não pareciam suficientes a muitos países industrializados, à época da Rodada Uruguai. A proposta de redação da cláusula da biotecnologia, patrocinada pelos EUA, Japão, países nórdicos e Suíça, demandava proteção irrestrita para organismos vivos, ${ }^{697}$ de certa forma reproduzindo os desenvolvimentos jurisprudenciais norte-americanos. Os termos do art. 27(3)(b) foram mais suaves que a proposta original, devido à ofensiva da UE e de alguns países em desenvolvimento. ${ }^{698}$ Mas o Acordo TRIPS foi estruturado para ser atualizado sem dificuldades: primeiramente, o adota o princípio da proteção mínima, o que significa que os membros da OMC poderão conceder proteção à PI mais robusta que a exigida pelos termos do TRIPS. Em segundo lugar, o princípio do tratamento da nação mais favorecida, disciplinado pelo art. $4^{\circ}$ do TRIPS, permite

\footnotetext{
${ }^{696}$ Artigos 283, 284, 285, 286, NOVA ZELÂNDIA, Patents Bill.

${ }^{697}$ Cf. UNCTAD-ICTSD, 2005, p. 891.

${ }^{698}$ Os países em desenvolvimento que participaram da negociação do Acordo TRIPS propuseram a seguinte redação do art. 27.3(b), visando a prevenir a patenteabilidade de invenções biotecnológicas: "Parties may also exclude from patentability [...] [p]lants and animals, including microorganisms, and parts thereof and processes for their production. As regards biotechnological inventions, further limitations should be allowed under national law" (GERVAIS, 1145-147).
} 
a extensão automática a todos os membros da OMC das vantagens concedidas por um membro da organização a outro. ${ }^{699}$

As flexibilidades oferecidas pelo Acordo TRIPS ensejam a adoção pelos países em desenvolvimento de regimes de proteção das invenções biotecnológicas e variedades vegetais adequados à sua realidade socioeconômica. E embora estes países não tenham como impedir os países industrializados de concederem DPIs para produções intelectuais derivadas de RBIs apropriados indebitamente, as flexibilidades do TRIPS lhes oferecem espaço para prevenir a concessão de muitos destes direitos em seus territórios. No entanto, esta discricionariedade está em processo de franca erosão, em virtude dos chamados acordos bilaterais de comércio, celebrados entre países em desenvolvimento e industrializados.

No período pós-OMC, os EUA e a UE, e em menor medida, o Japão e outros países industrializados, passaram a investir intensamente em estratégias bilaterais, em resposta à oposição dos países em desenvolvimento à reforma do Acordo TRIPS para a supressão de suas flexibilidades, a partir do início do processo de revisão do art. 27(3)(b) do Acordo TRIPS, em 1999. Outro motor propulsor da estratégia bilateral foi a aprovação pelos membros da OMC da Declaração de Doha sobre o Acordo TRIPS e Saúde Pública, em 2001. Este instrumento permite a interpretação dos termos do TRIPS, de modo apoiar a superação das crises de saúde pública enfrentadas pelos países em desenvolvimento. Estes dois fatos representaram obstáculos aos ímpetos dos países industrializados de soerguerem multilateralmente os patamares de proteção previstos no TRIPS, atacando, em particular, as demandas das indústrias farmacêutica e da biotecnologia. ${ }^{700}$

Os acordos bilaterais, celebrados entre países industrializados e em desenvolvimento impõem aos últimos, em troca de acesso preferencial aos mercados dos primeiros, a desistência das liberdades oferecidas pelo Acordo TRIPS. ${ }^{701}$ E como estes acordos tendem a ser negociados secretamente, a opinião pública não é capaz de influenciar sua negociação. ${ }^{702}$ Em termos mais específicos, os acordos bilaterais obrigam os países em desenvolvimento a

\footnotetext{
${ }^{699}$ Cf. HEATH, 2007.

${ }^{700}$ Cf. DRAHOS, 2003, p. 10.

${ }^{701}$ Para uma lista atualizada dos mais recentes acordos bilaterais entre países industrializados e países em desenvolvimento ver GRAIN, 2008b.

${ }^{702}$ Cf. GRAIN, 2008a.
} 
harmonizarem seus regimes de PI com os dos países industrializados. ${ }^{703}$ Isto significa a aceitação da obrigação de conceder patentes para microorganismos tal qual existentes na natureza, ${ }^{704}$ plantas e animais; de aderir ao regime da UPOV 1991 para proteção de variedades de plantas; ${ }^{705}$ de restringir ao máximo o uso da flexibilidade oferecida pelo art. 27(2) do TRIPS; ${ }^{.06}$ de não adotar qualquer medida que possa facilitar a prevenção de biopirataria (e.g. adoção da obrigação de divulgação da origem dos recursos biológicos e CTs utilizados em uma invenção, sujeita à um pedido de patente). ${ }^{707}$

Existem, no entanto, alguns acordos de livre comércio que obrigam ou encorajam suas partes contratantes a protegerem determinadas categorias de RBIs contra atos de apropriação indébita. Neste sentido, é digno de nota o Acordo de Livre Comércio entre Taiwan e o Panamá, que os obriga a proteger CTs e ECTs e recursos biológicos por meio de um mecanismo de propriedade intelectual sui generis $;{ }^{708}$ o Acordo de Parceria Econômica entre Brunei, Chile, Nova Zelândia e Singapura, que encoraja suas partes contratantes a adotarem medidas de proteção de CTs $;{ }^{709}$ a terceira minuta do capítulo de PI da proposta de Acordo de Livre Comércio das Américas, que propõe a adoção de regimes legais de proteção dos recursos biológicos, CTs e ECTs contra atos de apropriação. ${ }^{710}$ Sem embargo, os acordos em vigor têm um alcance restrito, o que certamente limita sua efetividade.

Em sumário, no espaço de menos de duas décadas, a discricionariedade dos países em desenvolvimento para determinar o alcance de seus regimes de PI foi restringida dramaticamente. Enquanto a Convenção de Paris obrigava a concessão de patentes de processo (art. 5quater), o art. 27 do TRIPS obriga a concessão de patentes para produtos e processos de todos os setores tecnológicos, inclusive para invenções biotecnológicas;

\footnotetext{
${ }^{703}$ Cf. KOOPMAN, 2005, p. 532.

${ }^{704}$ No Agreement between the Kingdom of Thailand and Japan for an Economic Partnership, a Tailândia contraiu a obrigação de não rejeitar pedidos de patentes que reivindiquem proteção para microorganismos naturais. Isto significa que recursos da biodiversidade tailandesa poderão ser patenteados, mesmo na ausência de qualquer intervenção humana. Nos termos dos art. 130(3) do acordo, "Each Party shall ensure that any patent application shall not be rejected solely on the grounds that the subject matter claimed in the application is related to a naturally occurring micro-organism." Ver também GRAIN, 2007.

${ }^{705}$ Cf. GRAIN, 2001.

${ }^{706}$ Por exemplo, ver art. 15(9), capítulo 15, Central America-Dominican Republic-United States Free Trade Agreement.

${ }^{707}$ Cf. GRAIN; CERVANTES, 2006.

${ }^{708}$ Artigos 16.05, 16.06, 16.07, Free trade Agreement between The Republic of China (Taiwan) and the Republic of Panama.

${ }^{709}$ Ver art. 10(3) (3) (d), Trans-Pacific Strategic Economic Partnership Agreement between Brunei Darussalam, Chile, New Zealand and Singapore. Para outros acordos de livre comércio que disciplinam a proteção de RBIs, ver GRAIN; CERVANTES, 2006.

${ }^{710}$ Subseções (B) (2)(d) e (B)(2)(f), capítulo XX, terceira Minuta do Acordo ALCA.
} 
contudo, oferece algumas flexibilidades que permitem mitigar a prática de apropriação indébita de RBIs. Os acordos bilaterais de comércio, que passaram a ser negociados com maior freqüência no período pós-OMC, vêm minando a reduzida liberdade oferecida pelo TRIPS, impondo aos países em desenvolvimento a obrigação de concederem irrestritamente DPIs sobre produções biotecnológicas, ainda que os recursos biológicos e CTAs empregados no processo de $\mathrm{P} \& \mathrm{D}$ tenham sido acessados ilegalmente. ${ }^{711}$

\subsection{A CONTRARRESPOSTA DOS PAÍSES EM DESENVOLVIMENTO}

Os países em desenvolvimento não assistem passivamente as articulações dos países industrializados voltadas à intensificação do processo de apropriação dos RBIs. Desde o final dos anos 90, articulam processos na CCDB, OMC e OMPI, que podem culminar na adoção de regimes internacionais dedicados à proteção dos CTs, recursos da biodiversidade e ECTs contra atos de apropriação indébita.

No marco da CDB, em 2002, a comunidade internacional comprometeu-se a negociar "um regime internacional para promover e salvaguardar a repartição justa e equitativa dos benefícios decorrentes da utilização dos recursos genéticos." ${ }^{~} 712$ Procurando dar efetividade a este compromisso, dois anos mais tarde, os Estados contratantes da CDB conferiram ao Grupo de Trabalho ad hoc sobre Acesso e Repartição de Benefícios, ${ }^{713}$ em colaboração ${ }^{714}$ com o Grupo de Trabalho ad hoc sobre o artigo 8(j) e dispositivos conexos, ${ }^{715}$ o mandato para negociar o referido regime internacional. ${ }^{716}$ Nos termos do plano original, o regime internacional será adotado na $10^{\mathrm{a}} \mathrm{CCDB}$, em $2010 .^{717}$ Não existe ainda consenso quanto à

711 Cf. US-Peru Trade Promotion Agreement; US-Dominican Republic-Central America Free Trade Agreement (US-DR-CAFTA) (Dominican Republic , Guatemala, El Salvador, Honduras, Nicaragua, Costa Rica, USA).

${ }_{712}^{71}$ Cf. WORLD SUMMIT ON SUSTAINABLE DEVELOPMENT, 2002, para. 44, (o), tradução nossa.

713 A $5^{\mathrm{a}}$ CCDB (SCBD, Decision V/26, item 11) criou o Grupo de Trabalho ad hoc sobre Acesso e Repartição de Benefícios, com a missão de apoiar os Estados contratantes da CDB na tarefa de implementar os dispositivos da CDB relacionados ao acesso aos recursos da biodiversidade e repartição de benefícios decorrentes de seu uso.

${ }^{714}$ Cf. SCBD, Decision VIII/5, item C.

${ }^{715}$ A $4^{\text {a }}$ CCDB estabeleceu o Grupo de Trabalho ad hoc sobre artigo 8(j) e disposições relacionadas da CDB (SCBD, Decision IV/9). Seu mandato de trabalho inclui, inter alia, a preparação de diretrizes para a elaboração de mecanismos legais, que assegurem às comunidades tradicionais benefícios justos e equitativos, derivados da aplicação de seus CTAs; a elaboração de normas e diretrizes para a prevenção da apropriação indébita de CTAs e recursos biológicos intangíveis (SCBD, Decision V/16, para. 9).

716 Cf. COPCBD, Decision VII/19, item D.

${ }^{717}$ Cf. UNGA, Resolution A/63/414/Add.6, para 8(a). 
natureza jurídica do instrumento a ser adotado no marco da $\mathrm{CDB}$, podendo ser tanto um regime voluntário quanto um acordo internacional vinculante. ${ }^{718}$

No âmbito da OMC, em 2001, os países em desenvolvimento lograram inserir na Declaração Ministerial de Doha o mandato para que o Conselho para o Acordo TRIPS examine "a relação entre o Acordo TRIPS e a Convenção sobre Diversidade Biológica, a proteção dos conhecimentos tradicionais e folclore". ${ }^{719}$ Em termos concretos, isto significa um mandato para negociar um mecanismo de proteção dos recursos da biodiversidade, CTs e ECTs contra atos de apropriação indébita. Desde então, um grupo importante de países em desenvolvimento apresentou uma proposta de proteção dos recursos da biodiversidade e CTs, a qual, se adotada, obrigará todo depositante de patente a divulgar a origem dos recursos genéticos e de CTAs utilizados no desenvolvimento da invenção reivindicada e a apresentar provas de que os RBIs utilizados foram acessados em consonância com as legislações nacionais pertinentes. ${ }^{720}$

Finalmente, no marco da OMPI, em 2000, a Assembléia Geral desta organização aprovou a criação do Comitê Intergovernamental sobre Propriedade Intelectual, Recursos Genéticos, Conhecimentos Tradicionais e Folclore (CIG), órgão dedicado a tratar da proteção dos CTs associados ou não aos recursos da biodiversidade, recursos da biodiversidade e ECTs. ${ }^{721}$ Desde sua criação, já ocorreram treze reuniões do CIG; atualmente, discute informalmente dois projetos de regimes de proteção - um dedicado à proteção dos CTs e outro que trata especificamente das ECTs -, elaborados pelo Secretariado da OMPI para melhor direcionar seu trabalho. Contudo, os projetos ainda não foram formalmente adotados com o status de propostas de instrumentos internacionais, como reflexo da oposição dos países industrializados. $\mathrm{O}$ mandato do $\mathrm{CIG}$ esclarece que seu trabalho pode culminar na adoção de: ${ }^{722}$ um ou mais acordos internacionais vinculantes sobre a proteção dos CTs e ECTs; uma declaração política não vinculante, que fixa os objetivos e princípios fundamentais dos regimes de proteção dos CTs e ECTs; uma lei-tipo não vinculante; um documento interpretativo oficial de normas de PI vigentes na esfera internacional, guiando

\footnotetext{
${ }^{718}$ Cf. SCBD, Decision IX/12, para. 3.

${ }^{719}$ Cf. WTO, WT/MIN(01)/DEC/1, para. 19.

${ }^{720} \mathrm{Id} ., \mathrm{IP} / \mathrm{C} / \mathrm{W} / 474$.

721 Cf. WIPO, WO/GA/26/6, WO/GA/26/10, para. 71.

${ }^{722}$ Id., WIPO/GRTKF/IC/12/5(c), para. 26.
} 
seus Estados contratantes a aplicá-las de maneira a também estender proteção aos CTs e ECTs.

Os termos das propostas para proteção dos RBIs apontam que os instrumentos eleitos para sua proteção foram fortemente influenciados pelos regimes de proteção da PI. Em termos concretos, no âmbito da $\mathrm{CDB}$ e da $\mathrm{OMC}$, os documentos de negociação deixam claro que o direito de propriedade seria o mecanismo de proteção mais adequado para tutelar os recursos da biodiversidade e CTs. Na OMPI, mecanismos calcados em direitos de propriedade, regras de repressão da concorrência desleal e, residualmente, um regime de responsabilidade foram sugeridos como instrumentos adequados para a proteção dos CTs e ECTs.

Os DPIs vêm se expandindo e se adaptando às demandas dos setores produtivos desde o final do séc. XIX. Por esta razão, embora não sejam geralmente aplicáveis à proteção dos RBIs, são vistos como passíveis de serem adaptados para tutelá-los na esfera internacional. ${ }^{723}$ Recordando que os RBIs não se confundem com as criações intelectuais tuteladas pelos regimes de PI, porquanto são portadores de três dimensões específicas (ambiental, humana e cultural), faz-se necessário avaliar se as propostas em negociação estão habilitadas a tutelar simultaneamente suas múltiplas dimensões.

O próximo capítulo concentrar-se-á no desenvolvimento do quadro conceitual de desenvolvimento sustentável, que congrega os elementos fundamentais que um regime de proteção do PBI deve conter a fim de salvaguardar, simultaneamente, suas quatro dimensões. No quarto capítulo, o quadro conceitual de desenvolvimento sustentável funcionará como o parâmetro contra o qual serão avaliadas centralmente as propostas em discussão na CCDB, OMC e OMPI para a proteção dos RBIs.

\subsection{CONCLuSÕes}

Os DPIs se mostram inaptos para a proteção dos RBIs e discriminatórios. Inaptos porque, em regra, os RBIs não preenchem as duas condições fundamentais para a obtenção de

\footnotetext{
${ }^{723}$ Cf. SCBD, UNEP/CBD/WG8J/2/7, p. 2.
} 
um DPI — identificação do autor e da produção intelectual a ser protegida -, e o rol de direitos investidos nos titulares de direitos divergem das demandas de seus detentores. ${ }^{724}$ Naturalmente, em alguns casos, os DPIs podem servir para proteger os RBIs. Mas a grande desvantagem de se procurar aplicar normas gerais para a sua proteção é que o operador do direito precisa se valer de lacunas legais e ambigüidades. ${ }^{725}$ Esta empreitada é louvável, mas seu êxito depende de uma série de fatores, e.g. a visão do Poder Judiciário do local onde a proteção é perseguida, os recursos econômicos e o poder da comunidade e da parte contrária, em caso de litígios.

Os DPIs se mostram discriminatórios, porquanto ao mesmo tempo em que são pouco úteis para proteger os RBIs, são altamente eficazes para a proteção de criações intelectuais deles derivadas, geralmente desenvolvidas pelos setores produtivos da sociedade dominante. $^{726}$ Nos casos excepcionais em que os RBIs são formalmente elegíveis para proteção por DPIs, a carência de recursos por parte das comunidades tradicionais e países em desenvolvimento para demandarem sua proteção em todos os territórios, onde possam ser explorados ilegalmente, despe a idéia teórica de sentido prático.

A obtenção de patentes drena altas somas para: a contratação de técnicos habilitados a redigir os pedidos em termos adequados; o pagamento das taxas de processamento dos pedidos nas jurisdições de interesse; o monitoramento de infrações às patentes conferidas; ${ }^{727}$ a contratação de assistência legal especializada na defesa das patentes contra infratores e, por fim, para a contratação de assessoria especializada no licenciamento das patentes.

Os direitos autorais não drenam tantos recursos para a proteção de ECTs. Contudo, o monitoramento de infrações em múltiplos mercados, a contratação de assessoria especializada em licenciamento, a defesa administrativa e judicial, em múltiplas jurisdições, dependem de recursos vultosos para o padrão de vida de muitas comunidades tradicionais.

\footnotetext{
${ }^{724}$ Cf. GERVAIS, 2005, p. 141-142. No mesmo sentido ver WIPO, WIPO/GRTKF/IC/6/4.

${ }^{725}$ Cf. TORSEN, 2006, p. 288.

${ }^{726}$ Cf. WIPO, WIPO/GRTKF/IC/12/5(b), anexo, p. 28.

${ }^{727} \mathrm{O}$ governo peruano criou a Comissão Nacional de Combate à Biopirataria, investida na responsabilidade de identificar potenciais casos de uso não-autorizado de recursos biológicos originários do Peru em invenções biotecnológicas. A Comissão enfrentou sérios problemas para monitorar a concessão de patentes supostamente ilegais pelo JPO: muitos pedidos estão disponibilizados apenas em japonês; em muitos outros casos, o site do JPO disponibiliza traduções literais para o inglês dos pedidos de patentes, restando impossível examiná-los apropriadamente; houve casos em que a invenção reivindicada não era descrita de modo suficientemente claro (WTO, IP/C/W/458, para. 23).
} 
Os segredos comerciais, finalmente, podem ser úteis para a proteção de CTs secretos, a custos muito baixos. No entanto, gera como efeito colateral restringir a disseminação dos CTs não divulgados, colocando em risco sua perpetuação para as futuras gerações.

Os países em desenvolvimento não assistiram ao processo de apropriação de seu PBI pacificamente: entre as décadas de 60 e 80, sem sucesso, se empenharam na negociação de um instrumento internacional para a proteção das ECTs. Entre a segunda metade dos anos 80 e início dos anos 90, lograram negociar a $\mathrm{CDB}$, que confere aos Estados e às comunidades tradicionais direitos de propriedade sobre seus recursos da biodiversidade e CTAs. Contudo, os países industrializados, por meio do Acordo TRIPS e acordos bilaterais de comércio, transformaram a CDB em um tigre de papel.

Sem esmorecer, nos últimos dez anos, os países em desenvolvimento se articulam em três foros-CCDB, OMC e OMPI--com o fito de finalmente alcançar um pacote de acordos internacionais que, se aprovados, assegurarão proteção global aos RBIs. Resta saber se as propostas apresentadas são de fato adequadas para a proteção do PBI, em suas múltiplas dimensões. 
CAPÍ́TULO 3 | 160

\section{CONSTRUÇÃO DO QUADRO CONCEITUAL DE DESENVOLVIMENTO SUSTENTÁVEL}

\subsection{A CONCEPÇÃO DE DESENVOLVIMENTO SUSTENTÁVEL E UM BREVE HISTÓRICO DE SEU DESENVOLVIMENTO NO DIREITO INTERNACIONAL CONTEMPORÂNEO}

Ao longo da segunda metade do século XX, a concepção vigente de desenvolvimento alterou-se paulatinamente. Inicialmente, crescimento econômico era tratado como sinônimo de desenvolvimento; o meio ambiente era tratado simplesmente como uma fonte de recursos a ser superexplorada para a satisfação dos desejos consumistas de uma parcela da humanidade e como uma lixeira para os excrementos produzidos por este grupo. ${ }^{728}$ Com fundamento na teoria da percolação, presumia-se que a expansão econômica automaticamente promoveria bem-estar social. ${ }^{729}$ Neste contexto, o crescimento do Produto Interno Bruto (PIB) figurava como o indicador de desenvolvimento por excelência. $^{730}$

Na raiz do problema do subdesenvolvimento certamente está a má distribuição de riqueza, ${ }^{731}$ que se evidencia como um obstáculo à realização dos direitos fundamentais de parcelas substantivas da população mundial. $^{732} \mathrm{O}$ crescimento econômico configura condição para se alcançar a meta de desenvolvimento humano, essencialmente porque a realização dos direitos econômicos, sociais e culturais depende da adoção de medidas positivas onerosas. ${ }^{733}$ Não é factível erradicar a pobreza, realizar direitos humanos e dotar o homem de autonomia para trilhar o caminho de sua escolha, em um cenário marcado pela ausência de recursos econômicos e atividade empresarial. ${ }^{734}$ Isto não significa que

${ }^{728}$ Cf. BITTAR, 2009, p. 480 et seq.

${ }^{729}$ Cf. SACHS, 2007b, p. 261.

${ }^{730}$ Id., 2007 c, p. 123.

731 O parágrafo 1, Resolução UNGA 3201 (S-VI) reconhece que "[t]he developing countries, which constitute 70 per cent of the world's population, account for only 30 per cent of the worlds income. It has proved impossible to achieve an even and balanced development of the international community under the existing international economic order."

${ }^{732} \mathrm{Em}$ 2007, a AGONU reconheceu que "si bien la globalización ofrece grandes oportunidades, el hecho de que sus beneficios se compartan de forma muy desigual y sus costos se distribuyan desigualmente es un aspecto del proceso que afecta el pleno disfrute de todos los derechos humanos, particularmente en los países en desarrollo" (UNGA, Resolution 62/151, para. 5). No mesmo sentido ver SACHS, $2007 \mathrm{~g}$, p. 289.

${ }^{733}$ Cf. SACHS, 2007e, p. 354-355. É por esta razão que o Pacto Internacional sobre Direitos Econômicos, Sociais e Culturais, em seu art. 2(1), autoriza seus Estados contratantes a implementarem os direitos nele reconhecidos de maneira progressiva, dentro de suas possibilidades econômicas.

${ }^{734}$ Cf. UNGA, Resolution 48/180 (reconhece que o fortalecimento da capacidade empresarial é essencial para se lograr crescimento econômico e desenvolvimento sustentável). No mesmo sentido ver para. 27 , 
CAPÍTULO 3 | 161

crescimento econômico seja condição suficiente para se promover desenvolvimento humano. ${ }^{735}$

Atenta à esta realidade, em 1969, a AGONU aprovou a Declaração sobre Progresso e Desenvolvimento Sociais, ${ }^{736}$ que encoraja a adoção de uma nova concepção de desenvolvimento, pautada na realização integral dos direitos humanos ${ }^{737}$ de todos os povos, sobretudo das populações dos países em desenvolvimento, ${ }^{738}$ com o objetivo central de garantir-lhes "a contínua elevação de [seu] nível de vida tanto material como espiritual."739 Ainda que timidamente, a Declaração assinalou a conservação do meio ambiente como um limite às políticas e atividades voltadas ao desenvolvimento material e social. $^{740}$

A Declaração marca a substituição da concepção de expansão do PIB como fim último das políticas de desenvolvimento pela de realização do bem comum. O bem comum, nas palavras de Cançado Trindade, "é o bem de todos (inclusive daqueles marginalizados), e não apenas de alguns. Com isto, retornamos às origens históricas tanto do Estado nacional, que existe para o ser humano, - e não vice-versa - como do próprio Direito Internacional, o qual não era em suas origens um direito estritamente interestatal, mas o direito das gentes. A realização do bem comum pressupõe a garantia, por todos os Estados, de condições de vida digna a todos os indivíduos em suas respectivas jurisdições." 741

TERCERA CUMBRE MUNDIAL DE LAS NACIONES UNIDAS SOBRE AMBIENTE Y DESARROLLO, Declaración de Johannesburgo sobre el Desarrollo Sostenible.

${ }^{735}$ Cf. SACHS, 2007g, p. 294. No mesmo sentido, ver OIT, ILO Declaration on fundamental principles and rights at work; em seu preâmbulo assinala que o "crescimento econômico é essencial, mas não suficiente para se assegurar equidade, progresso social e erradicação da pobreza " (tradução nossa).

${ }^{736}$ UNGA, Resolution 2542.

737 Em termos mais específicos, a Declaração estabeleceu como fins das políticas de desenvolvimento a erradicação da pobreza, por meio da garantia do direito ao trabalho digno, livre de exploração de qualquer natureza; o direito à alimentação, ao melhor padrão possível de saúde e de acesso universal aos bens culturais e instrução. Cf. artigos. $6^{\circ}$ e 10, alíneas (a), (b), (c), (d), (e) e (f), UNGA, Resolution 2542.

738 Artigos 2(b) e 18(a), UNGA, Resolution 2542. Tomando em consideração o abismo que separa as populações dos países industrializados e em desenvolvimento, a Declaração assinala que às populações dos países em desenvolvimento devem ser oferecidas "oportunidades iguais [àquelas presentes nos países industrializados] de progredir social e economicamente, com o objetivo de alcançar uma sociedade efetivamente integrada" (art 5(e), UNGA, Resolution 2542, tradução nossa).

${ }^{739}$ Cf. UNGA, Resolution 2542, parágrafo introdutório a parte II.

${ }^{740}$ UNGA, Resolution 2542, artigos $4^{\circ}, 13$ (c) e 25(a).

${ }^{741}$ Cf. CORTE INTERAMERICANA DE DERECHOS HUMANOS, 2006b, para. 27, tradução nossa. 
Pouco tempo depois, em 1971, a ONU reuniu, em Founex, Suíça, um grupo de especialistas com a missão de preparar um estudo de base para a Conferência das Nações Unidas sobre Meio Ambiente Humano, que tomaria lugar em 1972, em Estocolmo (relatório Founex). O relatório reconheceu a relação de causa e efeito entre, de um lado, desenvolvimento industrial indisciplinado nos países industrializados e subdesenvolvimento econômico nos países pobres e, do outro, a degradação de seus ecossistemas. No caso específico dos países em desenvolvimento, foi identificado o nexo causal entre pobreza e superexploração dos recursos naturais. ${ }^{742} \mathrm{Em}$ um quadro de estagnação econômica e faltando-lhes meios de vida dignos, a população crescente dos países pobres não goza de outra alternativa senão utilizar insustentavelmente os recursos naturais a fim de alcançarem um nível de vida minimamente adequado, ${ }^{743}$ ainda que assim se conduzindo, minem suas oportunidades de sobrevivência no longo prazo.

Tendo esse pano de fundo, o relatório Founex advogou pelo descarte definitivo da concepção de desenvolvimento baseada na idéia simplista de expansão econômica e pelo aprofundamento da dimensão ambiental da concepção de desenvolvimento, introduzida pela Declaração sobre Progresso e Desenvolvimento Sociais. A nova concepção proposta é conhecida por ecodesenvolvimento ${ }^{744}$ ou desenvolvimento sustentável. ${ }^{745}$

Desenvolvimento sustentável consiste tanto em um fim quanto em um processo para alcançá-lo. Como fim, consiste na expansão da autonomia do ser humano e de grupos humanos de perseguirem seu projeto de vida por meio da realização integral de seus direitos fundamentais e da simultânea proteção da base de recursos naturais de que depende sua sobrevivência. Desenvolvimento como expansão da autonomia humana não envolve a imposição de um modelo pré-concebido de cima para baixo, mas a garantia ao ser humano das liberdades fundamentais para determinar seu próprio destino. ${ }^{746}$ Amartya Sen indica como liberdades substantivas essenciais para o homem perseguir livremente seu projeto de vida "ter condições de evitar privações como a fome, a subnutrição, a morbidez

\footnotetext{
${ }^{742}$ Cf. UNGA, Resolution 2849, preâmbulo.

${ }^{743}$ Cf. Preâmbulo, The Cocoyoc Declaration.

${ }^{744}$ DASMANN, 2002, p. 79-80.

745 Cf. PANEL OF EXPERTS CONVENED BY THE SECRETARY-GENERAL OF THE UNITED NATIONS CONFERENCE ON THE HUMAN ENVIRONMENT, 2002, p. 37.

${ }^{746}$ Ver, e.g., SEN, 2000, p. 26, 33 e 39; SACHS, 2007f, p. 101.
} 
evitável e a morte prematura, bem como as liberdades associadas a saber ler e fazer cálculos aritméticos, ter participação política e liberdade de expressão etc."747

Desenvolvimento sustentável como processo constitui uma estratégia de crescimento econômico de longo prazo, ${ }^{74}$ caracterizada pela a integração das dimensões humana e ecológica ao processo econômico. Seu fim último é a dignificação de todos os seres humanos e povos através da erradicação da pobreza ${ }^{749}$ e da realização de seus direitos fundamentais. ${ }^{750} \mathrm{Tem}$ como limites aqueles impostos pela natureza a fim de assegurar às presentes e futuras gerações um desenvolvimento perene. ${ }^{751}$ Ademais, o crescimento econômico para ser apto a promover desenvolvimento sustentável deve ser autônomo e, portanto, apoiado nas fortalezas humanas, naturais e materiais de cada povo, ao invés de se assentar sobre soluções importadas, responsáveis pela perpetuação da dependência externa $^{752}$ e geradoras de homogeneização cultural. ${ }^{753}$

Cinco são as premissas que permeiam a concepção de desenvolvimento sustentável: em primeiro lugar, a relação de interdependência entre a vida humana e a conservação da natureza. Em segundo lugar, a constatação de que a Terra está enferma e a restauração de sua saúde depende da harmonização das atividades humanas com as leis da natureza. ${ }^{754} \mathrm{Em}$ terceiro lugar, a degradação ambiental limita a capacidade de desenvolvimento econômico da humanidade como um todo. Em quarto, o desenvolvimento econômico é condição sine qua non para se alcançar desenvolvimento sustentável, porquanto a pobreza material gera maior pressão sobre a base de recursos naturais do planeta, tornando-o mais vulnerável a catástrofes. ${ }^{755}$ Finalmente, o desenvolvimento econômico deve ter como fim último a satisfação das necessidades da família humana, especialmente das populações marginalizadas dos países mais pobres. ${ }^{756}$

\footnotetext{
${ }^{747}$ Cf. SEN, 2000, p. 52.

${ }^{748}$ Cf. WORLD COMMISSION ON ENVIRONMENT AND DEVELOPMENT, 1987, capítulo 1, para. 48.

${ }^{749}$ Cf. KHALFAN; SEGGER, p. 2 e 7.

${ }^{750}$ Cf. Preâmbulo, INTERNATIONAL LAW ASSOCIATION. New Delhi Declaration of Principles of International Law relating to Sustainable Development; UNITED NATIONS DEPARTMENT FOR POLICY COORDINATION AND SUSTAINABLE DEVELOPMENT, para. 12.

${ }^{751}$ Ver, e.g., SACHS, 2007g, p. 286; SCHRIJVER, 2007, 374.

${ }^{752}$ Cf. DAG HAMMARSKJÖLD FOUNDATION, 1975, p. 34-35.

${ }^{753}$ Cf. SHIVA, 2001, p. 134.

${ }^{754}$ Cf. WORLD COMMISSION ON ENVIRONMENT AND DEVELOPMENT, capítulo 2, para. 9.

755 Ibid., capítulo 1, para. 49.

${ }^{756}$ Ibid., capítulo 2, para. 6 .
} 
A concepção de desenvolvimento sustentável trouxe dois grandes progressos em relação à concepção anterior. $\mathrm{O}$ primeiro foi o reconhecimento de que crescimento econômico, desenvolvimento humano e proteção ambiental interagem e se influenciam mutuamente, ${ }^{757}$ sendo contraproducentes políticas estanques. O segundo se relaciona à adoção da ética ecológica ou da posteridade, que se assenta sobre a salvaguarda das oportunidades de autodeterminação das gerações futuras. ${ }^{758}$ A ética ecológica respalda-se no fato de que toda ação individual gera múltiplas reações que podem se tornar palpáveis apenas no longo prazo; por essa razão, não se satisfaz com avaliações superficiais das conseqüências de curto prazo de propostas políticas. ${ }^{759}$ A concepção tradicional de desenvolvimento ignora que ações dirigidas para atingir um determinado objetivo geram um largo espectro de impactos futuros e inesperados, que podem afetar a capacidade futura da humanidade de realizar outros interesses socialmente relevantes. Em sumário, a ética ecológica ensina que em um cenário composto por múltiplas variáveis interdependentes, a alteração de uma delas, a fim de alcançar um determinado objetivo desejável, pode gerar efeitos colaterais, quando ignoradas todas as conseqüências futuras que podem dela advir. $^{760}$

Em outras palavras, o ideal de desenvolvimento sustentável funda-se sobre o tripé expansão econômica; observância de certos limites internos e externos. ${ }^{761}$ Os limites externos são representados pelo meio ambiente e seus recursos finitos. Respeitar os limites impostos pela natureza significa utilizar seus recursos "de modo e em ritmo tais que não levem, no longo prazo, à diminuição" da diversidade genética, de espécies e de ecossistemas, "mantendo assim seu potencial para atender as necessidades e aspirações das gerações presentes e futuras." ${ }^{, 762}$ Os limites internos, por sua vez, são representados pelas necessidades fundamentais do ser humano, tuteladas pela Carta Magna dos Direitos Humanos. $^{763}$

\footnotetext{
${ }^{757}$ Cf. WORLD SUMMIT ON SUSTAINABLE DEVELOPMENT, item 2.

${ }^{758}$ Cf. HARDIN, 1975.

${ }^{759}$ Id., 2001 b, p. 21.

${ }^{760}$ Cf. BROWN, M., 2005, p. 42.

${ }^{761}$ Cf. SACHS, 2007g, p. 287; preâmbulo, The Cocoyoc Declaration.

${ }^{762} \mathrm{Cf}$. Art. $2^{\circ}, \mathrm{CDB}$.

763 A Carta Magna dos Direitos Humanos é composta pela Declaração Universal de Direitos do Homem de 1948, o Pacto Internacional de Direitos Civis e Políticos e o Pacto Internacional de Direitos Econômicos, Sociais e Culturais, ambos de 1966 (OFFICE OF THE HIGH COMMISSIONER FOR HUMAN RIGHTS, 1996).
} 
Quadro 2: Tipos de Crescimento

\begin{tabular}{|l|l|l|l|}
\hline \multicolumn{1}{|c|}{$\begin{array}{c}\text { Tipo de } \\
\text { crescimento }\end{array}$} & \multicolumn{1}{c|}{ Econômico } & \multicolumn{1}{c|}{ Humano } & Ecológico \\
\hline Selvagem & Efeitos positivos & Efeitos negativos & Efeitos negativos \\
\hline $\begin{array}{l}\text { Socialmente } \\
\text { benigno }\end{array}$ & Efeitos positivos & Efeitos positivos & Efeitos negativos \\
\hline Estável & Efeitos positivos & Efeitos negativos & Efeitos positivos \\
\hline $\begin{array}{l}\text { Desenvolvimento } \\
\text { sustentável }\end{array}$ & Efeitos positivos & Efeitos positivos & Efeitos positivos \\
\hline
\end{tabular}

Fonte: Ignacy Sachs ${ }^{764}$

O quadro 2 sobre tipos de crescimento explicita o tripé de sustentação da concepção de desenvolvimento sustentável e a diferença entre este e outros tipos de desenvolvimento, facilitando a compreensão de que desenvolvimento sustentável não se confunde com a idéia de desenvolvimento a qualquer custo ou com a de conservação pura e simples do meio ambiente. ${ }^{765}$ No entanto, o quadro não deixa claro que as políticas promotoras de desenvolvimento sustentável devem gerar efeitos positivos em escala global. ${ }^{766}$ Assim, é insustentável uma política que localmente promova desenvolvimento econômico, proteção dos direitos humanos e conservação ambiental e, ao mesmo tempo, gere como efeito colateral, em outros Estados, degradação ambiental e iniqüidade social. ${ }^{767}$

Retornando ao histórico do desenvolvimento da concepção de desenvolvimento sustentável, em 1972, a Declaração de Estocolmo, adotada na Conferência das Nações Unidas sobre o Meio Ambiente Humano, tomou para si as diretivas plasmadas no relatório Founex, lançando as bases da noção de desenvolvimento sustentável. A Declaração confere ao homem a responsabilidade pela conservação dos recursos naturais para as presentes e futuras gerações, ${ }^{768}$ porquanto um meio ambiente de qualidade é condição para a realização dos direitos fundamentais. ${ }^{769} \mathrm{O}$ crescimento econômico perdeu o status de fim

\footnotetext{
${ }^{764}$ Baseado em tipologia desenvolvida por Ignacy Sachs (2007d, p. 269).

${ }^{765}$ Cf. DAG HAMMARSKJÖLD FOUNDATION, 1975, p. 25.

${ }^{766}$ Cf. SACHS, 2007g, p. 295. No mesmo sentido UNGA, Resolution A/RES/56/226, para. 5.

${ }^{767}$ Cf. SOUTH CENTRE, 2002, p. 111.

768 Os princípios 2, 3 e 7 da Declaração de Estocolmo (UNITED NATIONS CONFERENCE ON THE HUMAN ENVIRONMENT, 1972) tratam da obrigação dos Estados e sociedades de bem administrar os recursos naturais para as presentes e futuras gerações. E para isso, a Declaração demanda a observância da capacidade dos ecossistemas de regenerar seus recursos naturais, para que as futuras gerações tenham as mesmas oportunidades de desenvolvimento que aquelas fruídas pelas gerações presentes.

769 Princípio $1^{\circ}$, Declaração de Estocolmo (UNITED NATIONS CONFERENCE ON THE HUMAN ENVIRONMENT, 1972). Ver também UNEP; OFFICE OF THE HIGH COMMISSIONER FOR HUMAN RIGHTS, 2002, para. 12, 13 e 18. No mesmo sentido, o Comitê de Direitos Econômicos, Sociais e Culturais identificou a relação entre proteção do meio ambiente e realização do "direito de toda pessoa de desfrutar o mais elevado nível possível de saúde física e mental", quando reconhece a obrigação dos Estados contratantes do PIDESC de "adoptar medidas contra los peligros que para la salud representan la
} 
último das políticas de desenvolvimento, mas ganhou o relevante papel de instrumento de geração das condições materiais indispensáveis para a realização de direitos fundamentais e conservação da natureza. ${ }^{770}$

Dando seguimento aos progressos introduzidos pela Declaração de Estocolmo, em 1982, a AGONU adotou a Carta Mundial para a Natureza, cujos princípios sugerem a integração da dimensão ecológica às políticas de desenvolvimento. ${ }^{771} \mathrm{~A}$ Carta, em termos gerais, determina que os ecossistemas e organismos, terras, recursos marinhos e atmosféricos devem ser empregados pelo homem, dentro de sua capacidade de regeneração. ${ }^{772}$ Outrossim, encoraja os Estados membros da ONU, quando da implementação de políticas e atividades desenvolvimento econômico, a tomarem em consideração seus efeitos sobre conservação da natureza. ${ }^{773}$ Nessa resolução, contudo, ainda não é clarividente todos os pilares de sustentação da noção de desenvolvimento sustentável, porquanto não há qualquer indicação de que as políticas de desenvolvimento econômicos devem se voltar à realização dos direitos fundamentais.

Em 1986, a AGONU adotou a Declaração sobre o Direito ao Desenvolvimento. ${ }^{774}$ Desenvolvimento foi por ela definido como "um amplo processo econômico, social, cultural e político, que visa à melhoria constante do bem-estar de toda a população e indivíduos cuja base é sua participação ativa, livre e significativa no desenvolvimento e na distribuição de benefícios dele resultantes." 775 A Declaração trouxe a marcante inovação de conferir o status de direito humano ao direito ao desenvolvimento, ${ }^{776}$ o qual investe em "todo ser humano e em todos os povos [...] [o] direito a participar, contribuir, e gozar de

contaminación del medio ambiente [....] Con tal fin, los Estados deben formular y aplicar políticas nacionales con miras a reducir y suprimir la contaminación del aire, el agua y el suelo, incluida la contaminación causada por metales pesados tales como el plomo procedente de la gasolina" (CESCR, E/C.12/2000/4, para. 35).

${ }^{770}$ Ver princípios 9 e 12 da Declaração de Estocolmo (UNITED NATIONS CONFERENCE ON THE HUMAN ENVIRONMENT, 1972).

${ }^{771}$ Cf. UNGA, Resolution 37/7.

${ }^{772}$ Ibid., item 1.

${ }^{773}$ Cf. UNGA, Resolution 37/7, item 7.

${ }^{774}$ Cf. UNGA, Resolution 41/128.

${ }^{775}$ Ibid., preâmbulo.

${ }^{776}$ O direito ao desenvolvimento foi reafirmado na Declaração e Programa de Ação de Viena (WORLD CONFERENCE ON HUMAN RIGHTS, A/CONF.157/23, para. 10), adotada na Conferência Mundial de Direitos Humanos, em 1993, "como derecho universal e inalienable y como parte integrante de los derechos humanos fundamentales". 


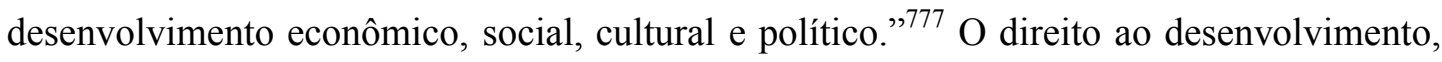
nas palavras de Sengupta,

"[...] no es un concepto global ni la suma de un conjunto de derechos. La integridad de estos derechos significa que si se transgrede cualquiera de ellos se transgrede también el derecho al desarrollo en todas sus facetas. El experto independiente describe esta realidad [o direito ao desenvolvimento] como un "vector" de derechos humanos compuesto de varios elementos que representan los diferentes derechos económicos, sociales y culturales, así como los derechos civiles y políticos. La realización del derecho al desarrollo exige perfeccionar este vector de manera de mejorar algunos de estos derechos, o por lo menos uno de ellos, sin transgredir los demás.",778

"Probablemente es mucho mejor describir el derecho al desarrollo como el derecho a un proceso de desarrollo, denominándolo un "derecho básico" [...] Derecho básico es aquél cuyo disfrute es esencial para el disfrute de todos los demás derechos. Un derecho básico no es necesariamente superior o preferible a otros derechos, pero para que los seres humanos puedan "disfrutar" o "ejercer" otros derechos, "los derechos básicos deben cimentarse firmemente antes de que se puedan garantizar los demás derechos". [...] Efectivamente, en ese sentido el derecho a un proceso de desarrollo puede describirse como un derecho básico con respecto a todos los demás derechos civiles, políticos, económicos, sociales y culturales. Sin la realización del derecho básico no podrá disfrutarse efectivamente y de manera sostenida ninguno de los demás derechos. ${ }^{779}$

O direito ao desenvolvimento não se compõe somente de direitos civis, políticos, econômicos, sociais e culturais. Sendo ele eminentemente pragmático, compreende também o crescimento econômico. Mas não qualquer crescimento econômico; apenas aquele dirigido firmemente a realizar, ao menos, alguns dos direitos que integram o conjunto de direitos humanos, sem prejudicar a observância dos demais. ${ }^{780}$ A principal contribuição do direito ao desenvolvimento ao respeito da dignidade humana é fomentar a integração das diferentes categorias de direitos humanos ${ }^{781}$ às políticas de desenvolvimento

\footnotetext{
${ }^{777}$ Cf. art. 1(1), UNGA, Resolution 41/128.

${ }^{778}$ Cf. ECOSOC, E/CN.4/2002/WG.18/6, para. 6.

${ }^{779}$ Ibid., nota de rodapé no. 4 (grifo nosso).

${ }^{780}$ Cf. ECOSOC, E/CN.4/2002/WG.18/6, para. 8-12.

${ }^{781}$ Cf. SCHRIJVER, 2007, p. 272.
} 
econômico e dar uma feição mais equânime e humana ao comércio internacional e ao processo de globalização. ${ }^{782}$

A Declaração sobre Direito ao Desenvolvimento ao mesmo tempo em que pôs o ser humano "como sujeito central e beneficiário do desenvolvimento", ${ }^{7}$ não absorveu os avanços introduzidos pelo relatório Founex, pela Declaração de Estocolmo e pela Carta Mundial da Natureza. Felizmente, um ano mais tarde, em, 1987, a AGONU corrigiu o equívoco praticado, ao revigorar o conceito de desenvolvimento sustentável. Nesse ano, a Assembléia Geral reafirmou que a degradação ambiental é uma ameaça ao futuro da humanidade ${ }^{784}$ e identificou como suas principais forças propulsoras o desequilíbrio econômico entre os povos; ${ }^{785}$ a desvalorização do papel de um meio ambiente sadio no desenvolvimento econômico e social da humanidade; a falta diálogo e coordenação entre as instituições nacionais, regionais e internacionais, competentes pelo delineamento de políticas econômica, social e ambiental. ${ }^{786}$

Partindo dessas constatações, a AGONU encorajou a comunidade internacional a priorizar políticas de desenvolvimento hábeis a promoverem simultaneamente erradicação da pobreza, realização dos direitos fundamentais e a conservação dos recursos naturais, ${ }^{787}$ ou seja, políticas capazes de engendrar desenvolvimento sustentável. Este foi definido pela ONU como aquele tipo de desenvolvimento competente a satisfazer "as necessidade do presente sem comprometer a habilidade das futuras gerações de satisfazer suas próprias necessidades." O que é mais relevante é que a AGONU alçou o desenvolvimento sustentável ao patamar de princípio diretivo dos programas e organizações que integram a família das Nações Unidas ${ }^{788}$ e de meta a ser perseguida pela comunidade internacional. ${ }^{789}$

\footnotetext{
${ }^{782}$ Cf. MARKS, 2004, p. 141.

${ }^{783}$ Cf. UNGA, Resolution 63/178, preâmbulo.

${ }^{784}$ Cf. UNGA, Resolution 42/186, item 3(d).

785 Ibid., item 3 (b) e (c).

${ }^{786}$ Cf. WORLD COMMISSION ON ENVIRONMENT AND DEVELOPMENT, capítulo 1, para. 8, 21, 40, capítulo 2, para. 17,34 .

${ }^{787}$ Cf. preâmbulo da UNGA, Resolution 42/187.

788 A Resolução 42/187 da AGONU chamou "todos os órgãos, organizações e programas da ONU a revisarem suas políticas, programas e atividades com vistas a fomentar desenvolvimento sustentável" (para. 8; tradução nossa). Em 2002, a AGONU decidiu "adotar o desenvolvimento sustentável como elemento fundamental do marco general das atividades das Nações Unidas" (UNGA, Resolution 57/253, para. 3; tradução nossa).

${ }^{789}$ Cf. preâmbulo da UNGA, Resolution 42/187.
} 
Em 1992, a Conferência da ONU sobre Meio Ambiente e Desenvolvimento (CONUMAD ou Rio-92) deu passos concretos no sentido de tornar o ideal de desenvolvimento sustentável em realidade. Durante a Conferência, a comunidade internacional adotou uma série de instrumentos vinculantes e não-vinculantes, onde cristalizaram seu compromisso de perseguir o ideal de desenvolvimento sustentável. ${ }^{790}$ Dentre eles, podemos mencionar, a CDB; ${ }^{791}$ a Convenção-Quadro das Nações Unidas sobre Mudança do Clima (CQMC); ${ }^{792}$ a Agenda 21; a Declaração oficial não-vinculante de princípios para um consenso global sobre a gestão, conservação e desenvolvimento sustentável de todos os tipos de florestas; ${ }^{793}$ e a Declaração do Rio sobre Meio Ambiente e Desenvolvimento (Declaração do Rio). Essa última fixou, com maior clareza, os pilares de sustentação da concepção de desenvolvimento sustentável, a saber:

i. A realização da dignidade da pessoa humana como fim último do desenvolvimento sustentáveli; ${ }^{794}$

ii. A erradicação global da pobreza como condição sine qua non para se alcançar desenvolvimento sustentáveli ${ }^{795}$

iii. O direito de todos os grupos sociais e países de usufruir, em bases equitativas e não discriminatórias, os benefícios do crescimento $^{796}$ (equidade intrageracional ${ }^{797}$ ). Sem embargo, aos grupos que vivem em situação de miséria lhes caberia "maior acesso aos recursos produtivos;"

\footnotetext{
${ }^{790}$ Em 2002, na Cúpula da Terra sobre Desenvolvimento Sustentável, a Declaração de Johannesburgo sobre Desenvolvimento Sustentável igualmente reconheceu o desenvolvimento econômico, social e a proteção ambiental como pilares interdependentes e sinérgicos do desenvolvimento sustentável. Ver, TERCERA CUMBRE MUNDIAL DE LAS NACIONES UNIDAS SOBRE AMBIENTE Y DESARROLLO, para. 5.

${ }^{791}$ Ver, inter alia, os artigos $1^{\circ}, 5^{\circ}, 6^{\circ}, 8(\mathrm{c}),(\mathrm{e}),(\mathrm{i}),(\mathrm{j}), 1^{\circ}, 11,12(\mathrm{a}),(\mathrm{b}),(\mathrm{c}), 16(1), 17(1), 18(1)$ e 19(3), CDB.

${ }^{792}$ A CQMC, em diversos momentos, reafirma como seu fim último o desenvolvimento sustentável de todos os países: "Afirmando que as medidas para enfrentar a mudança do clima devem ser coordenadas, de forma integrada, com o desenvolvimento social e econômico, de maneira a evitar efeitos negativos neste último [...]" (CQMC, preâmbulo). Ver também artigos 2º art. 3(4), 3(5), 4(2)(a), CQMC.

${ }^{793}$ UNGA, A/CONF.151/26, vol. III, para. 13, alíneas (c) e (d).

${ }^{794}$ Cf. UNCED, Declaração do Rio de Janeiro sobre Meio Ambiente e Desenvolvimento, princípio 1.

795 Ibid., princípio 5.

796 Cf. item 8, WORLD SUMMIT for SOCIAL DEVELOPMENT, Programme of Action of the World Summit for Social Development. Ver também princípio 6, Programa de Ação da Cúpula Mundial sobre Desenvolvimento Social (A/CONF. 166/9); e princípio 6, UNCED, Declaração do Rio de Janeiro sobre Meio Ambiente e Desenvolvimento.

797 Cf. item 2(1), INTERNATIONAL LAW ASSOCATION, New Delhi Declaration of Principles of International Law relating to Sustainable Development.
} 
iv. Promoção do desenvolvimento econômico a partir do uso intensivo de tecnologias, especialmente, aquelas desenvolvidas com capacidade tecnológica endógena; ${ }^{798}$

v. Integração da dimensão ecológica e social às políticas voltadas ao desenvolvimento econômico. ${ }^{799}$ A fim de evitar políticas desastrosas sob a perspectiva ambiental, os Estados se comprometeram a adotar uma abordagem de precaução, ou seja, de não apoiarem políticas que possam impactar negativamente sobre o meio ambiente e a saúde humana, sempre que houver riscos; ${ }^{800} \mathrm{e}$

vi. A satisfação das necessidades sociais e econômicas das gerações presentes, sem comprometer a capacidade das gerações futuras de satisfazer suas próprias aspirações e necessidades (equidade intergeracional). ${ }^{801}$ A geração presente tem o dever de conservar a qualidade do planeta e o de conservar a diversidade de opções de recursos naturais e culturais para as futuras gerações. ${ }^{802}$

Um ano mais tarde, a Conferência Mundial sobre Direitos Humanos, ocorrida em Viena, associou os progressos insculpidos na Declaração sobre Direito ao Desenvolvimento de 1986 àqueles introduzidos pelas Declarações de Estocolmo e do Rio, ao reafirmar o direito ao desenvolvimento como um "direito universal e inalienável e parte integral dos direitos fundamentais humanos", ${ }^{803}$ o qual deve ser "observado com vistas a satisfazer as necessidades de desenvolvimento e ambientais das presentes e futuras gerações." 804

Às vésperas do início do século XXI, em 2000, a AGONU adotou a Declaração do Milênio das Nações Unidas, ${ }^{805}$ que indica como valores fundamentais a reger as relações internacionais, no novo século, o direito de homens e mulheres de viverem condignamente, a igualdade entre indivíduos e nações, a solidariedade entre os povos que detêm maiores recursos para com aqueles mais vulneráveis, o respeito e a tolerância para com as

\footnotetext{
${ }^{798}$ Cf. UNCED, Declaração do Rio de Janeiro sobre Meio Ambiente e Desenvolvimento, princípio 9.

${ }^{799}$ Ibid., princípios 1,3 e 4.

800 Cf. item 4(1), INTERNATIONAL LAW ASSOCATION, New Delhi Declaration of Principles of International Law relating to Sustainable Development.

${ }^{801}$ Cf. UNCED, Declaração do Rio de Janeiro sobre Meio Ambiente e Desenvolvimento, princípio 3.

802 Cf. UNITED NATIONS DEPARTMENT FOR POLICY COORDINATION AND SUSTAINABLE DEVELOPMENT, para.43-48.

${ }^{803}$ Cf. WORLD CONFERENCE ON HUMAN RIGHTS, A/CONF.157/23, para. 10, (tradução nossa).

${ }^{804}$ Ibid. para. 11 (tradução e grifo nossos).

${ }^{805}$ Cf. UNGA, Resolution A/RES/55/2.
} 
diferenças culturais, o respeito pela natureza, e a responsabilidade compartilhada de todas as nações pela construção de uma sociedade materialmente próspera, pacífica e justa. ${ }^{806}$ Com o propósito de operacionalizar tais valores, a Declaração do Milênio estabeleceu, dentre os fins a serem perseguidos pela comunidade internacional, aqueles que servem de sustentação da concepção de desenvolvimento sustentável, a saber: erradicação da pobreza e o desenvolvimento de todas as nações, ${ }^{807}$ conservação do meio ambiente ${ }^{808}$ e a promoção do conjunto de direitos humanos. ${ }^{809}$

No ano de 2005, a AGONU, como resultado da Cúpula Mundial de 2005, adotou resolução, em que reconhece incontestavelmente o desenvolvimento sustentável como meta a ser perseguida pela comunidade internacional, bem como seus pilares de sustentação:

"Reafirmamos nuestro compromiso de alcanzar el objetivo relativo al desarrollo sostenible, entre otras cosas, mediante la aplicación del Programa 2110 y el Plan de Aplicación de las Decisiones de Johannesburgo3. Con tal fin, nos comprometemos a emprender acciones y medidas concretas a todos los niveles y fomentar la cooperación internacional, teniendo en consideración los principios de Río11. En ese esfuerzo también se promoverá la integración de los tres componentes del desarrollo sostenible - desarrollo económico, desarrollo social y protección del medio ambiente - como pilares interdependientes que se refuerzan mutuamente." ${ }^{810}$

É importante notar que a influência da concepção de desenvolvimento sustentável vai além das fronteiras da ONU e já alcançou o criticado sistema multilateral de comércio. O Acordo Constitutivo da OMC reconhece explicitamente o compromisso de seus Estados contratantes de promoverem o livre comércio com o fito de alcançar um desenvolvimento sustentável. ${ }^{811}$ Uma das medidas adotadas pela OMC para promovê-lo foi a Decisão sobre

\footnotetext{
${ }^{806}$ Ibid., para. 6.

${ }^{807}$ Cf. UNGA, Resolution A/RES/55/2, para. 11.

${ }^{808}$ Ibid., para. 23.

${ }^{809}$ Ibid., para. 25.

${ }^{810}$ Cf. UNGA, Resolution A/RES/60/1, para. 48 (grifo nosso).

${ }^{811}$ O primeiro parágrafo do preâmbulo do Acordo Constitutivo da OMC dispõe: "Reconhecendo que as suas relações na esfera da atividade comercial e econômica devem objetivar a elevação dos níveis de vida, o pleno emprego e um volume considerável e em constante elevação de receitas reais e demanda efetiva, o aumento da produção e do comércio de bens e serviços, permitindo ao mesmo tempo a utilização ótima dos recursos mundiais em conformidade com o objetivo de um desenvolvimento sustentável e buscando proteger e preservar o meio ambiente".
} 
Comércio e Meio Ambiente, que estabeleceu o Comitê da OMC sobre Comércio e Meio Ambiente (CCMA). Seu objetivo geral é o de auxiliar a organização na tarefa de compatibilização de suas regras comerciais com as dos acordos multilaterais de proteção do meio ambiente. O CCMA tem como princípio a inexistência de "contradição política entre a defesa e salvaguarda de um sistema multilateral de comércio aberto, nãodiscriminatório e equitativo, de um lado, e medidas de proteção do meio ambiente e de promoção de desenvolvimento sustentável, do outro." ${ }^{\text {} 812}$

A concepção de desenvolvimento sustentável, em algumas ocasiões, foi tratado, ainda que tacitamente, como princípio reitor da interpretação das normas do marco legal da OMC: o Órgão de Apelações da OMC, nos casos United States-Standards for Reformulated and Conventional Gasoline e United States-Import Prohibition of Certain Shrimp and Shrimp Products, deu mostras de que é possível integrar normas de acordos ambientais ao marco legal da OMC. ${ }^{813}$

Ainda na esfera da OMC, a Declaração Ministerial de Doha ${ }^{814}$ estabeleceu o mandato negociador da Rodada Doha de liberação comercial. Ao menos formalmente, a OMC colocou as necessidades e interesses dos países em desenvolvimento em seu centro $^{815}$ a fim de capacitá-los a erradicar a pobreza e a dotar seus povos dos meios essenciais para se autodeterminarem ${ }^{816} \mathrm{e}$, assim, promover um sistema multilateral de comércio que efetivamente viabilize o desenvolvimento sustentável de todos os seus membros. ${ }^{817}$ É de se notar que esta é a primeira vez que uma rodada de negociações

812 Preâmbulo, WTO, Decisión sobre comercio y medio ambiente. O Comitê sobre Comércio e Meio Ambiente tem um mandato amplo que inclui, inter alia, a responsabilidade de (i) examinar a relação existente entre medidas comerciais e medidas ambientais com o fim de promover o desenvolvimento sustentável; (ii) preparar recomendações sobre a necessidade de reformar regras do sistema multilateral de comércio, desde que compatíveis com o caráter não-discriminatório do sistema; (iii) evitar medidas comerciais protecionistas; e (iv) avaliar a necessidade de adoção de mecanismos multilaterais eficazes que garantam a capacidade de resposta do sistema multilateral de comércio aos objetivos ambientais enunciados na Agenda 21 e na Declaração do Rio.

${ }^{813}$ Cf. ZARRILLI, 2000, p. 22-23.

${ }^{814} \mathrm{Cf}$. WTO, WT/MIN(01)/DEC/1.

${ }^{815}$ A AGONU reconhece que as questões de desenvolvimento e as necessidades e demandas dos países em desenvolvimento figuram no centro da Agenda de Trabalho de Doha, e exorta os membros da OMC "[...] a que respondan al mandato de desarrollo de la Declaración Ministerial de Doha, la decisión del Consejo General de la Organización Mundial del Comercio de $1^{\circ}$ de agosto de 2004 (documentoWT/L/579) y la Declaración Ministerial de Hong Kong, que sitúa el desarrollo en el centro del sistema multilateral de comercio" (UNGA, Resolution A/RES/62/184).

${ }^{816}$ Cf. WTO, WT/MIN(01)/DEC/1, para. 2.

${ }^{817}$ Ibid., para. 6: "Reafirmamos decididamente nuestro compromiso con el objetivo del desarrollo sostenible, enunciado en el preámbulo del Acuerdo de Marrakech. Estamos convencidos de que los objetivos de respaldar y salvaguardar un sistema multilateral de comercio abierto y no discriminatorio y de actuar para la 
comerciais se compromete a harmonizar a meta de liberação e expansão do comércio internacional com o ideal de desenvolvimento sustentável. ${ }^{818}, 819$

\subsubsection{O PILAR CULTURAL DA CONCEPÇÃO DE DESENVOLVIMENTO SUSTENTÁVEL}

O desenvolvimento sustentável busca a dignificação do homem por intermédio da realização integral de seus direitos humanos; dentre eles, inclui-se o direito à conservação e ao desenvolvimento de sua cultura.

Existe uma multiplicidade de concepções de cultura, mas tomaremos apenas três delas. Segundo Williams, o termo pode ser utilizado para descrever "um processo geral de desenvolvimento intelectual, espiritual e estético," ou para se referir "às obras e práticas resultantes da atividade intelectual, especialmente, a artística”. E, por fim, o termo cultura pode "indicar um modo de vida particular, seja de um povo, um período, um grupo, ou da humanidade em geral." ${ }^{820} \mathrm{Na}$ prática, essas definições se inter-relacionam. O processo de desenvolvimento intelectual, espiritual e estético (definição 1) gera como frutos as produções artísticas e científicas (definição 2), que refletem os modos de vida particulares de um determinado agrupamento humano (definição 3). Por exemplo, enquanto os CTAs são um reflexo dos modos de vida dos grupos indígenas e de outras comunidades tradicionais, as invenções, produzidas em laboratórios mediante a aplicação de tecnologias de ponta, refletem os modos de vida da cultura ocidental contemporânea. As duas produções - CTs e invenções - são científicas. Contudo, resultam de processos de desenvolvimento intelectual associados a culturas diversas.

Nenhuma das concepções indicadas de cultura nos parece completa. Aquela que nos parece mais adequada foi introduzida pela Declaração Universal sobre a Diversidade Cultural da UNESCO, dado que logrou fundir as três concepções referidas de cultura. Cultura, segundo a Declaração, consiste no "conjunto dos traços distintivos espirituais e materiais, intelectuais e afetivos que caracterizam uma sociedade ou um grupo social e que

protección del medio ambiente y la promoción del desarrollo sostenible pueden y deben apoyarse mutuamente."

${ }^{818} \mathrm{Cf}$. WTO, WT/MIN(01)/DEC/1, para. 19, 31-33.

${ }^{819}$ Pascal Lamy (2007) considera que a harmonização inconteste entre o sistema multilateral de comércio e meio ambiente depende do sucesso da Rodada Doha.

${ }^{820}$ WILLIAMS, 1983, p. 90-91. 
abrange, além das artes e das letras, os modos de vida, as maneiras de viver juntos, os sistemas de valores, as tradições e as crenças". ${ }^{821}$ A definição adotada pela UNESCO explicita alguns elementos essenciais para a compreensão da concepção de cultura, a saber: a cultura é um processo social, resultante da interação entre os seres humanos; portanto, é parte integrante da própria essência social do homem. ${ }^{822}$ Sua função primária é "habilitar os seres humanos a conservar e perpetuar a vida". ${ }^{823}$ Assim sendo, cada cultura disponibiliza os meios sem os quais a vida humana seria inviável.

$\mathrm{Na}$ base de cada sociedade se encontra um conjunto de valores diferenciados, que informa suas tradições, modos de vida, línguas, instituições sociais, econômicas e religiosas e suas produções intelectuais peculiares. É mediante este conjunto que o homem e grupos humanos "expressa[m] sua humanidade e os significados que [...] [dão] à sua existência e ao seu desenvolvimento". ${ }^{824}$ Uma determinada cultura não se distingue das demais em virtude das práticas reproduzidas por seus membros ou pela localidade por eles habitada, mas por seu sistema de significação próprio, que habilita seus membros a interpretarem um conjunto de signos da mesma maneira e, conseqüentemente, a se engajarem em relações mutuamente significativas. ${ }^{825}$

Embora coexistam na Terra mais de 6000 culturas diferentes, ${ }^{826}$ a DUDH de 1948 foi construída como se a humanidade fosse homogênea, ao não conceder qualquer proteção à cultura das minorias étnicas. ${ }^{827}$ Logo após a aprovação da Declaração, a American Anthropological Association desafiou sua adequação e legitimidade em face de um mundo culturalmente complexo, ao questionar publicamente como uma declaração de direitos pretensamente universais poderia ser calcada "nos valores prevalecentes nos países da Europa ocidental e América?" ${ }^{\circ 28}$ A DUDH, refletindo unicamente a perspectiva ocidental, limitou-se a tutelar os direitos básicos do homem individualmente considerado, ignorando o homem como integrante de grupos sociais, portadores de valores culturais não

\footnotetext{
821 Ver preâmbulo, UNESCO, Declaração Universal sobre a Diversidade Cultural. No mesmo sentido, UNESCO, Recommendation on Participation by the People at Large in Cultural Life and their Contribution to it, para. 3(a).

${ }^{822}$ Cf. UNESCO, STATEMENT ON CULTURAL RIGHTS AS HUMAN RIGHTS, para. II.

${ }^{823}$ Cf. UNESCO, STATEMENT ON CULTURAL RIGHTS AS HUMAN RIGHTS, para. II.

${ }^{824}$ Cf. GRUPO DE FRIBURGO, Os Direitos Culturais - Declaração de Friburgo, art. 2(A).

${ }^{825}$ Cf. SEWELL JR, 1999, p. 48-51; STAVENHAGEN, 1998, p. 5.

${ }^{826} \mathrm{Cf}$. SCBD, UNEP/CBD/WG8J/2/5, para. 10.

${ }^{827}$ Cf. SZABÓ, 1974, p. 45.

${ }^{828}$ Cf. AMERICAN ANTHROPOLOGICAL ASSOCIATION, 1947, p. 539, tradução nossa.
} 
necessariamente equivalentes àqueles do ocidente. ${ }^{829} \mathrm{O}$ único grupo humano protegido pela Declaração é a família. ${ }^{830}$ A Declaração negligenciou que a realização plena da dignidade da pessoa humana passa pelo respeito às distintas comunidades em que se insere o homem e, por conseguinte, pelo respeito à diversidade de culturas. ${ }^{831}$

Também em 1948, a Convenção para a Prevenção e a Repressão do Crime de Genocídio (CPRCG), seguindo a linha da DUDH, ignorou a necessidade de se proteger as culturas diferenciadas das minorias culturais. Em sua fase de redação, o projeto de convenção previa a punição de três categorias de crimes de genocídio: ${ }^{832}$ o genocídio físico (o assassinato dos membros de um grupo humano com o objetivo de exterminá-lo), o genocídio biológico (práticas voltadas à redução das taxas de natalidade de um grupo, com o objetivo de aniquilá-lo no médio e longo prazo), e o genocídio cultural ou etnocídio (destruição da cultura de um grupo, i.e. língua, práticas culturais, instituições religiosas, bibliotecas, bens culturais, obras literárias e artísticas e a prevenção do desenvolvimento e transmissão de culturas e línguas ${ }^{833}$ ). Ao final do processo de redação da Convenção, optou-se por excluir o genocídio cultural de seu escopo, deixando a identidade cultural dos grupos humanos sujeita a práticas e políticas etnocidas. Nersessian, com perspicácia, sublinha que nosso "entendimento presente de genocídio preserva o corpo físico do grupo, mas permite a destruição de sua alma." ${ }^{834}$ Assim, ao mesmo tempo em que a CPRCG dá um passo adiante em relação à DUDH, ao reconhecer o direito dos étnicos, raciais e religiosos de existirem como coletividades, ${ }^{835}$ rechaça qualquer proteção à sua identidade cultural. $^{836}$

Menos de duas décadas depois, com a adoção do Pacto Internacional de Direitos Civis e Políticos de 1966 (PIDCP), o direito internacional começou a substituir seu enfoque individualista e culturalmente uniformizante pelo da valorização e respeito ao

${ }^{829}$ Ibid., p. 541.

${ }^{830}$ Cf. STAVENHAGEN, 1998, p. 12 (artigos 12, 16, 23, 25, DUDH).

${ }^{831}$ Cf. AMERICAN ANTHROPOLOGICAL ASSOCIATION, 1947, p. 541; AMERICAN ANTHROPOLOGICAL ASSOCIATION, 1999, preâmbulo.

${ }^{832}$ Cf. NERSESSIAN, 2005.

${ }^{833}$ Cf. ALRU, 1985.

${ }^{834}$ Cf. NERSESSIAN, 2005. Ver art. 2 ${ }^{\circ}$, Convenção para a Prevenção e a Repressão do Crime de Genocídio. ${ }^{835}$ Cf. STAVENHAGEN, 1998, p. 2.

${ }^{836}$ O termo "identidade cultural" é utilizado neste trabalho no sentido dado pela Declaração de Friburgo, que a define como "[...] o conjunto de referências culturais pelo qual uma pessoa, individualmente ou em coletividade, se define, se constitui, se comunica e se propõe a ser reconhecida em sua dignidade" (GRUPO DE FRIBURGO, 2007, art. 2(b)). 
multiculturalismo, ${ }^{837}$ ao conferir direitos culturais aos membros de minorias étnicas, religiosas e lingüísticas. ${ }^{838}$

Tradicionalmente, direitos culturais compreendem "aqueles [direitos] que melhor protegem a participação e o acesso de todo ser humano à vida cultural: a liberdade de se envolver em atividades criativas e em pesquisa científica, o direito à educação, o direito de acesso às formas de expressão artística e ao conhecimento científico e tecnológico," o direito de beneficiar-se dos avanços científicos, as liberdades de expressão, informação e comunicação. ${ }^{839} \mathrm{Em}$ outras palavras, tradicionalmente, os direitos culturais asseguram ao ser humano o direito individual de consumir e o de produzir bens culturais. ${ }^{840}$

O PIDCP agregou novos direitos ao rol de direitos culturais resguardados pelo direito internacional. Especificamente, o art. 27 do PIDCP confere aos integrantes de minorias étnicas, religiosas e lingüísticas o "direito de ter, conjuntamente com outros membros de seu grupo, sua própria vida cultural, de professar e praticar sua própria religião e usar sua própria língua”. Considerando que a cultura é um fenômeno social e, por isto, dependente da interação entre seres humanos, ${ }^{841}$ o PIDCP assegura aos integrantes de grupos culturalmente diferenciados um direito individual, cujo exercício se dá em conjunto com os demais membros da coletividade. ${ }^{842} \mathrm{O}$ Pacto assegura ainda às minorias culturais a liberdade de conservarem, reproduzirem, modificarem, transmitirem, inter alia, suas instituições, tradições, valores, modos de vida, línguas, enfim, sua cultura. ${ }^{843}$

A viga mestra deste dispositivo do Pacto Internacional de Direitos Civis e Políticos é a investidura nos integrantes de comunidades culturais, individual e comunitariamente considerados, do direito de "produzir, reproduzir e alterar as condições e formas de sua existência física, pessoal e social", ${ }^{844}$ e de ter o arcabouço cultural de seu grupo respeitado por terceiros (indivíduos, grupos e Estados), independentemente se os compartilham ou

${ }^{837} \mathrm{Cf}$. SCBD, UNEP/CBD/WG8J/5/INF/10, para. 13 e 15.

${ }^{838} \mathrm{Cf}$. CCPR, CCPR/C/21/Rev.1/Add.5, para. 7.

${ }^{839}$ Cf. UNESCO, $166 \mathrm{EX} / 28$, para. 20.

${ }^{840}$ Cf. SZABÓ, 1974, p. 46.

${ }^{841}$ Ver, e.g., ANAYA, 2004, p. 22; SZABÓ, 1974, p. 53; UNESCO, Recommendation on Participation by the People at Large in Cultural Life and their Contribution to it, preâmbulo e item (a).

${ }^{842} \mathrm{Cf}$. CCPR, CCPR/C/21/Rev.1/Add.5, para. 1.

${ }^{843}$ Ver, e.g., OEA, OEA/Ser.L/VII.108; Doc. 62, capítulo III, item 6(b); ANAYA, 2004, p.22-29; CERD, 1997, para. 4(e); UNESCO, Recommendation on Participation by the People at Large in Cultural Life and their Contribution to it, para. 4(f).

${ }^{844}$ Cf. AMERICAN ANTHROPOLOGICAL ASSOCIATION, 1999a. 
não. ${ }^{845}$ Em outras palavras, o Pacto tutela a capacidade dos membros de minorias e de coletividades para a cultura, ${ }^{846}$ seu direito de serem culturalmente diferentes e de assim se conservarem. ${ }^{847}$

Em virtude do art. 27 do PIDCP, seus Estados contratantes devem adotar medidas de proteção da autonomia cultural das minorias; ${ }^{848}$ e quando da proposição e adoção de políticas de desenvolvimento social e econômico, devem atentar para as possíveis conseqüências sobre a fruição destes direitos, dado que o conjunto de direitos humanos é indivisível e interdependente. Conseqüentemente, "a promoção, o respeito e a fruição de certos direitos humanos e liberdades fundamentais [...] [não justifica] a negação de outros direitos humanos e liberdades fundamentais." ${ }^{849}$ No sentido de reforçar este entendimento, a Declaração Universal sobre a Diversidade Cultural destaca que "a defesa da diversidade cultural é [...] inseparável do respeito da dignidade da pessoa humana [...] [e] implica o compromisso de respeitar os direitos humanos e as liberdades fundamentais, em particular os direitos das pessoas que pertencem a minorias e aos povos indígenas."

De 1966 em diante, a adoção de um número não-desprezível de instrumentos internacionais dedicados à proteção da diversidade cultural confirmam a mudança do enfoque do direito internacional em favor do multiculturalismo. Podemos mencionar como representativos dessa mudança de rumo a Declaração da UNESCO sobre os Princípios da Cooperação Cultural Internacional de $1966,{ }^{851}$ a Recomendação da UNESCO sobre Participação Ampla do Povo na Vida Cultural e sua Contribuição para ela de $1976,{ }^{852}$ a Convenção no. 169 da OIT sobre povos indígenas de $1989,{ }^{853}$ a Declaração das Nações Unidas sobre os Direitos das Pessoas Pertencentes a Minorias Nacionais ou Étnicas,

${ }^{845}$ Cf. STAVENHAGEN, 1998, p. 8.

${ }^{846} \mathrm{Cf}$. AMERICAN ANTHROPOLOGICAL ASSOCIATION, op. cit.

${ }^{847}$ Cf. arts. 1(2) e 5(1), UNESCO, Declaration on Race and Racial Prejudice.

${ }^{848} \mathrm{Cf}$. CCPR, CCPR/C/21/Rev.1/Add.5, para. 6(2) e 7.

${ }^{849}$ Ver preâmbulo, UNGA, Resolution A/41/128.

${ }^{850}$ Cf. art. $4^{\circ}$, UNESCO, Declaração Universal sobre a Diversidade Cultural. No mesmo sentido, ver UNITED NATIONS COMMISSION ON HUMAN RIGHTS, Resolution 2005/20, para. 11.

${ }^{851}$ Cf. UNESCO, Declaration on the Principles of International Cultural Cooperation, art. 1, parágrafos (1) e (3) (reconhece que todas as culturas são valiosas e integram o patrimônio comum da humanidade, devendo ser protegidas e respeitadas).

${ }^{852}$ Cf. art. 4(f), UNESCO, Recommendation on Participation by the People at Large in Cultural Life and their Contribution to it (reconhece a igualdade de todas as culturas, incluindo as culturas das minorias nacionais e estrangeiras e confere às minorias o direito a participar da vida cultural dos países em que vivem e o direito de preservarem sua identidade cultural).

${ }^{853}$ Cf. art. 8(3), Convenção OIT no. 169 (confere aos povos indígenas e tribais o direito à integridade de suas culturas, desde que estas não infrinjam os direitos humanos de terceiros). 
Religiosas ou Lingüísticas de $1992,{ }^{854}$ a Declaração Universal sobre a Diversidade Cultural de 2001, a Convenção sobre a Proteção e a Promoção da Diversidade das Expressões Culturais de 2005 e a Declaração das Nações Unidas sobre os Povos Indígenas de $2007 .{ }^{855}$ É importante ter presente que é nesse contexto de valorização e promoção do multiculturalismo pelo direito internacional que ocorrem as negociações internacionais orientadas à construção de regimes de proteção dos RBIs.

Tacitamente, o reconhecimento dos direito culturais das minorias pelo PIDCP de 1966 tem por efeito introduzir a dimensão cultural à concepção de desenvolvimento sustentável já a partir da Declaração de Estocolmo de 1972, uma vez que, por meio dela, a comunidade internacional indicou, ainda que tacitamente, a realização dos direitos humanos como meta das políticas de desenvolvimento. ${ }^{856}$ Contudo, o reconhecimento explícito do pilar cultural da concepção de desenvolvimento apenas se deu em 1986, quando a Assembléia Geral da ONU proclamou o período entre 1988 e 1997 como a Década Mundial para o Desenvolvimento Cultural. ${ }^{857}$ Neste interregno, durante a Cúpula Mundial sobre Desenvolvimento Social, que tomou lugar em Copenhague, em $199^{858}$ os Estados lá representados assumiram, dentre outros compromissos, o de reconhecer "a importância da dimensão cultural do desenvolvimento," ${ }^{859}$ mediante o respeito da "diversidade cultural, étnica e religiosa" ${ }^{\text {"860 }}$ e o de criar um entorno adequado à promoção do desenvolvimento social, assentado sobre o crescimento econômico e o respeito aos direitos humanos, à diversidade cultural e ao meio ambiente. ${ }^{861}$

Em 2002, a Cúpula Mundial sobre Desenvolvimento Sustentável (Johanesburgo), dando seguimento aos compromissos assumidos em Copenhague, reconheceu como uma das condições "essenciais para se alcançar desenvolvimento e assegurar que o

\footnotetext{
${ }^{854}$ Adotada pela Resolução 47/135 da AGONU (resolução reitera os direitos previstos no art. 27 do PIDCP).

${ }^{855}$ Adotada pela Resolução A/61/L.67 da Assembléia Geral das Nações Unidas (reconhece aos povos indígenas, inter alia, direitos coletivos à integridade de suas culturas, de conservá-las, revitalizá-las, desenvolvê-las continuamente. Cf. artigos 11(1), art. 13(1), 15(1), 15(2), $20,34$.

${ }^{856}$ Cf. CONFERENCE ON THE HUMAN ENVIRONMENT, 1972, para. 4-6; princípios 1 e 8.

${ }^{857}$ Cf. BEAT-GRABER, 2006, p. 4.

${ }^{858}$ Cf. WORLD SUMMIT for SOCIAL DEVELOPMENT, Copenhagen Declaration on Social Development, para. 26(d), 28, 29.

${ }^{859}$ Ibid., item (t) do sexto compromisso.

${ }^{860} \mathrm{Ibid}$., item (i) do quarto compromisso.

${ }^{861}$ Cf. WORLD SUMMIT ON SUSTAINABLE DEVELOPMENT, 2002, para. 8.
} 
desenvolvimento sustentável beneficie a todos", inter alia, o respeito à diversidade de culturas. ${ }^{862}$

Três anos mais tarde, a UNESCO cristalizou na Convenção sobre a Proteção e a Promoção da Diversidade das Expressões Culturais (CPPDEC) o compromisso assumido pela comunidade internacional em Copenhague e em Johanesburgo de integrar o respeito à diversidade cultural à concepção de desenvolvimento sustentável. A CPPDEC reconheceu "como condições essenciais para um desenvolvimento sustentável em benefício das gerações presentes e futuras [...] [a] proteção, a promoção e a manutenção da diversidade cultural" (art. 2(6)). Seus Estados contratantes se comprometeram a envidar esforços "para integrar a cultura em suas políticas de desenvolvimento, em todos os níveis," inclusive em foros internacionais, (art. 21) "a fim de criarem condições propícias ao desenvolvimento sustentável” (art. 13).

A agregação da dimensão cultural à concepção de desenvolvimento sustentável tem por conseqüência o imperativo de tratar as necessidades do homem, visto em seu contexto social e cultural. ${ }^{863}$ Nos termos da Declaração Universal sobre a Diversidade Cultural, desenvolvimento não deve ser entendido apenas em termos de satisfação das necessidades materiais do indivíduo, mas "como meio de acesso à uma existência intelectual, afetiva, moral e espiritual satisfatória." ${ }^{, 864}$ Para isso, políticas de desenvolvimento devem trabalhar para mitigar a homogeneização cultural, aprovisionar todos os grupos humanos dos meios para alimentar, manter e desenvolver continuamente suas culturas ${ }^{865}$ e, por fim, atenuar os conflitos interculturais que podem resultar da promoção da diversidade cultural.

\subsubsection{AS RELAÇÕES CONSTRUTIVAS ENTRE AS DIVERSIDADES CULTURAL E BIOLÓGICA}

Por um longo período, as políticas de conservação ambiental procuraram se dissociar de qualquer relação com o ser humano, porquanto o tratavam como inatamente

\footnotetext{
862 Ibid., para. 5.

${ }^{863}$ Cf. UNGA, Resolution 32/130, para. 1(d).

${ }^{864} \mathrm{Cf}$. art. $3^{\circ}$, UNESCO, Declaração Universal sobre a Diversidade Cultural.

${ }^{865}$ Cf. UNGA, Resolution 62/155, para. 2 e 5.
} 
destrutivo. A cultura ocidental, em termos gerais, é dirigida à satisfação dos ímpetos materialistas de curtíssimo prazo de seus membros, dando pouca importância aos efeitos futuros das ações presentes.

De modo diverso, as culturas tradicionais mantêm uma relação simbiótica com a natureza. ${ }^{866}$ A natureza, para grande parte das comunidades tradicionais, não configura um obstáculo ao desenvolvimento a ser eliminado; opera como sustentáculo de sua identidade cultural e de sua sobrevivência material. ${ }^{867}$ Para elas, a proteção da integridade de sua cultura passa obrigatoriamente pela conservação da natureza. ${ }^{868}$

$\mathrm{Na}$ atualidade, é tida como inconteste a relação de interdependência e de coevolução entre a diversidade biológica e cultural. ${ }^{869}$ Deve-se ao trabalho intensivo das comunidades tradicionais ricas paisagens naturais, que a ciência ocidental julgava resultarem do trabalho das forças da natureza; ${ }^{870}$ variedades de plantas de importância ímpar para a alimentação e agricultura; ${ }^{871}$ a gestão sustentável da diversidade biológica fruída pela humanidade nos dias atuais; o desenvolvimento de aplicações inovadoras dos recursos da natureza. ${ }^{872}$ Evidências estimam que em torno de $90 \%$ da biodiversidade de todo o mundo tenha sido desenvolvida e conservada nos territórios habitados por comunidades tradicionais. ${ }^{873}$ Ainda hoje, as florestas com as taxas mais altas de biodiversidade são as habitadas por estes grupos. ${ }^{874}$

O ideal de desenvolvimento sustentável, que encontra tantas dificuldades para se incorporar verdadeiramente às agendas políticas dos Estados, é um princípio diretivo de

${ }^{866}$ Cf. SACHS, $2007 \mathrm{c}$, p. 136.

${ }^{867}$ Cf. PERSIC; MARTIN, 2008, p. 20.

${ }^{868}$ Cf. POSEY, 1998, p. 43.

${ }^{869}$ Ver, e.g., POSEY; DUTFIELD, 1996, p. 95; COOMBE, 2001-2002, p. 279; SACHS, 2007d, p. 264; PERSIC; MARTIN, 2008, p. 7; preâmbulo, CSPCI.

${ }^{870}$ Cf. POSEY, 2004b, p. 64.

${ }^{871}$ Cf. BRUSH, 1994, p. 6-9.

${ }^{872}$ Cf. POSEY, 2004i, p. 197.

${ }^{873} \mathrm{Cf}$. SCBD, UNEP/CBD/COP/5/5, para. 20.

${ }^{874}$ Cf. POSEY, 2004f, p. 133. As regiões com as maiores taxas de diversidade lingüística (i.e. com maior diversidade cultural) contam com as taxas mais elevadas de diversidade biológica (SCBD, $\mathrm{UNEP} / \mathrm{CBD} / \mathrm{WG} 8 \mathrm{~J} / 3 / \mathrm{INF} / 1$, p. 23). Treze dos dezessete países mais ricos em termos de diversidade biológica estão listados entre os 25 países, que conservam o maior número de línguas endêmicas. O Brasil, por exemplo, ocupa a oitava posição no ranking mundial de línguas endêmicas, a terceira posição no ranking de vertebrados endêmicos e a primeira posição no ranking plantas endêmicas com flores (OVIEDO; GONZALES; MAFFI, 2004, p. 71). 
muitas comunidades tradicionais. ${ }^{875}$ Não é possível generalizar os princípios que regem as normas consuetudinárias de todas elas; no entanto, há alguns princípios comuns, identificados com freqüência no arcabouço de suas normas costumeiras, que guardam forte relação com o ideal de desenvolvimento sustentável, a saber: ${ }^{876}$

i. Aqueles investidos no poder decisório devem exercê-lo com o objetivo de servir àqueles por quem é responsável;

ii. Os seres humanos devem trabalhar em conjunto para alcançar objetivos comuns;

iii. O ser humano é um mero administrador do meio ambiente e de seus recursos, devendo geri-los com respeito, responsabilidade para com as gerações futuras e tendo sempre em vista a inter-relação entre os seres humanos e a natureza;

iv. Tudo aquilo que o homem extrair/receber da natureza deve devolver na mesma medida a fim de conservar sua capacidade de satisfação de suas necessidades futuras;

v. O ser humano não deve se conduzir egoisticamente; deve avaliar previamente as conseqüências de seus atos sobre a natureza e sobre o bem-estar do outro; e

vi. Os bens e serviços prestados pela natureza devem ser fruídos por todos de maneira equitativa e proporcional às suas necessidades, capacidades, responsabilidades, contribuições e/ou esforços.

Frente à relação íntima entre a diversidade cultural e a biológica, não é factível lograr a conservação da primeira, sem a manutenção da última. A imigração das gerações mais jovens das comunidades locais, em busca de melhores condições de vida; as invasões das terras tradicionais por agricultores, garimpeiros e madeireiras; a expansão da agricultura de monocultura sobre florestas e outros ecossistemas naturais; a execução de projetos de "desenvolvimento" em terras ocupadas por comunidades tradicionais ou em seu entorno interferem na capacidade de sobrevivência física e cultural destes grupos. Essas dificuldades conduzem à erosão das bases de sustentação das comunidades tradicionais, que acabam por se desagregar e abandonar suas terras. A extinção das

\footnotetext{
${ }^{875}$ Ver,e.g., SCBD, UNEP/CBD/WG8J/3/INF/1, p. 13; SCBD, UNEP/CBD/WG8J/5/INF/15, p. 20.
}

${ }^{876}$ Id., UNEP/CBD/WG8J/5/6, para. 30, 35 e 37. 
comunidades leva consigo o arcabouço de conhecimentos associados aos elementos naturais do meio em que vivem; ${ }^{877}$ e tudo aquilo que não é conhecido, é subvalorizado pela sociedade dominante. ${ }^{878} \mathrm{O}$ abandono de terras ricas em diversidade biológica igualmente torna-as ainda mais vulneráveis a intervenções destrutivas e pode ainda conduzir ao desaparecimento de paisagens naturais, cuja conservação depende diretamente da intervenção contínua pelo homem. ${ }^{879}$

Ainda que nem o crescimento demográfico das comunidades tradicionais nem seu vínculo com as terras e águas que seus antepassados ocuparam estivessem sob ameaça, se suas culturas forem destroçadas, a biodiversidade também poderá perecer. As tradições destes grupos, suas normas costumeiras, tabus e instituições sociais desempenham o papel - consciente ou não - de conservação da biodiversidade. Por exemplo, o caráter sagrado de determinadas áreas naturais, ocupadas por comunidades tradicionais, desempenha o papel de censor de sua degradação. ${ }^{880}$ Quando as culturas são homogeneizadas, as instituições que limitam a exploração desordenada dos recursos naturais desaparecem. As próprias comunidades, cujos antepassados se conduziram como administradores prodigiosos da herança natural da humanidade, podem passar a utilizá-los destrutivamente.

A CDB e a Declaração do Rio de Janeiro não explicitam, com a mesma clareza que a UNESCO, o pilar cultural da concepção de desenvolvimento sustentável, mas admitem a relação de interdependência entre as diversidades biológica e cultural e a inter-relação entre desenvolvimento sócio-econômico e diversidade cultural e biológica. A CDB admite que a sobrevivência das comunidades tradicionais depende da conservação dos recursos biológicos ${ }^{881}$ e reconhece a relevância de seu patrimônio cultural para a conservação da biodiversidade, a geração de incentivos econômicos para sua conservação e, por fim, para a ampliação de seu uso sustentável pela humanidade. ${ }^{882}$ Com fundamento nessas razões, seus Estados contratantes se comprometeram a "respeitar, preservar e manter o conhecimento, inovações e práticas" destas comunidades; ${ }^{883}$ a "incentivar sua mais ampla aplicação [por

\footnotetext{
${ }^{877}$ Cf. PERSIC; MARTIN, 2008, p. 12-14.

${ }^{878}$ Cf. THE CRUCIBLE II GROUP, 2000, p. 9-10.

${ }^{879}$ Cf. PERSIC; MARTIN, op.cit., p. 12.

${ }^{880}$ Cf. SCBD, UNEP/CBD/WG8J/3/INF/1, p. 15.

${ }^{881}$ Cf. preâmbulo, CDB.

${ }^{882}$ Cf. art. 18(4) combinado com o art. $1^{\circ}, \mathrm{CDB}$.

${ }^{883}$ Cf. art. 8(j), CDB.
} 
toda a humanidade] com a aprovação e a participação [...] [de seus] detentores";,;84 e a encorajar as comunidades tradicionais a continuarem a utilizar os recursos da biodiversidade "de acordo com [suas] práticas culturais tradicionais compatíveis com as exigências de conservação ou utilização sustentável." 885

A Declaração do Rio igualmente destaca o papel das comunidades tradicionais "na gestão do meio ambiente e no desenvolvimento, em virtude de seus conhecimentos e práticas tradicionais" e encoraja a comunidade internacional a "reconhecer e apoiar de forma apropriada a identidade, cultura e interesses dessas populações e comunidades, bem como habilitá-las a participar efetivamente da promoção do desenvolvimento sustentável." ${ }^{886}$

Mais recentemente, em 2002, a Declaração de Johanesburgo sobre Desenvolvimento Sustentável reafirmou o papel vital das populações indígenas no processo para se alcançar um desenvolvimento sustentável; ${ }^{887}$ e, em 2005, a AGONU reafirmou que o respeito e conservação do patrimônio intelectual associado à biodiversidade das comunidades tradicionais é indispensável para se alcançar o almejado desenvolvimento sustentável. ${ }^{888}$

\subsubsection{O STATUS LEGAL DA CONCEPÇÃO DE DESENVOLVIMENTO SUSTENTÁVEL}

Desenvolvimento sustentável é uma inequívoca aspiração da comunidade internacional, figura como meta dos Estados membros da OMC e da ONU e serve de princípio reitor do trabalho dos programas e agências das Nações Unidas. Contudo, não devemos confundir "aspiração" com natureza não-vinculante. Sob a ótica jurídica, desenvolvimento sustentável figura como um princípio do direito internacional contemporâneo, que obriga os Estados nacionais a interpretarem e aplicarem as normas internacionais pertinentes ao desenvolvimento econômico de modo a harmonizá-las com as normas internacionais relacionadas aos direitos humanos, respeito à diversidade cultural

\footnotetext{
${ }^{884}$ Cf. art. 8(j), CDB.

${ }^{885}$ Cf. art. 10 (c), CDB

${ }^{886}$ Cf. princípio 22, UNCED, Declaração do Rio de Janeiro sobre Meio Ambiente e Desenvolvimento.

887 Cf. TERCERA CUMBRE MUNDIAL DE LAS NACIONES UNIDAS SOBRE AMBIENTE Y DESARROLLO, 2002, para. 25

${ }^{888}$ Cf. UNGA, Resolution A/RES/60/1, item 56(e).
} 
e proteção do meio ambiente, ${ }^{889}$ com o propósito de dar fiel cumprimento a todas suas obrigações contraídas. ${ }^{890}$

O princípio do desenvolvimento sustentável é um filho do pacta sunt servanda, ${ }^{891} \mathrm{o}$ qual configura o princípio basilar do direito internacional. ${ }^{892}$ Ora, se os Estados não puderem confiar na palavra empenhada pelos demais com que se relacionam, é impossível a construção de relações internacionais pacíficas e previsíveis. Todo e qualquer Estado tem o dever legal de observar com boa-fé os termos dos acordos de que é parte, não podendo exercer seus direitos e liberdades, de modo a ignorar suas obrigações assumidas em face de terceiros. ${ }^{893}$ Para se prevenir a perda da legitimidade do direito internacional, acordos internacionais diversos devem ser vistos como "ilhas interconectadas," 894 que compõem uma unidade coerente, ${ }^{895}$ cujas partes se apóiam mutuamente, ao invés de conflitarem. ${ }^{896}$ Logo, existe a presunção de que as normas internacionais não conflitam, salvo se houver sobreposição de normas "ratione materiae, personae e temporis". ${ }^{897} \mathrm{Se}$ as normas não forem mutuamente excludentes, os Estados devem interpretá-las e aplicá-las de maneira a assegurar a integridade de suas obrigações, ${ }^{898}$ conforme exigido pelo princípio da efetividade (ut res magis valeat quam pereat). ${ }^{899}$

Em sumário, embora normas de proteção e promoção dos direitos humanos, da diversidade cultural, do meio ambiente e as de natureza comercial tendam a ser negociadas sem se atentar para as suas relações mútuas, tendo em vista o princípio do pacta sunt servanda, a concepção de desenvolvimento sustentável ganha o status legal de metaprincipio vinculante, competente a orientar os Estados a aplicarem normas potencialmente conflitantes, de maneira a coexistirem pacificamente e a se apoiarem mutuamente. ${ }^{900}$ Neste sentido, a opinião do juiz Weeramantry, no litígio envolvendo o

\footnotetext{
${ }^{889}$ Cf. UNGA, Resolution 62/151, para. 2.

${ }^{890}$ Em sentido contrário, sustentando que a meta de desenvolvimento sustentável é política e, portanto, não vinculante (SCHRIJVER, 2007, p. 383-386).

${ }^{891}$ Cf. art. 26, Convenção de Viena sobre o Direito dos Tratados determina que "[t]odo tratado em vigor obriga as partes e deve ser cumprido por elas de boa fé".

${ }^{892}$ Cf. CHENG, B., 1953, p. 105.

${ }^{893}$ Cf. CHENG, B., 1953, p. 117.

${ }^{894}$ Cf. PAUWELYN, 2004, p. 915.

${ }^{895}$ Cf. FRANCIONI et al., [200-?], p. 56.

${ }^{896}$ Ver, e.g., WTO, WT/CTE/W/139, para. 5; WTO, WT/CTE/W/168, para. 6.

${ }^{897}$ Cf. KHALFAN; SEGGER, 2004, p. 51.

${ }^{898} \mathrm{Cf}$. WTO, TN/TE/W/58, para. 17.

${ }^{899}$ Cf. CAMERON; GRAY, 2001, p. 256

${ }^{900}$ Cf. KHALFAN; SEGGER, op.cit., p. 50- 53.
} 
projeto de hidroelétrica Gabcíkovo-Nagymaros (Hungria e Eslováquia), julgado pela Corte Internacional de Justiça, em 1997, vai ao encontro à posição adotada neste estudo:

\footnotetext{
"The problem of steering a course between the needs of development and the necessity to protect the environment is a problem alike of the law of development and of the law of the environment. Both these vital and developing areas of law require, and indeed assume, the existence of a principle which harmonizes both needs.
}

To hold that no such principle exists in the law is to hold that current law recognizes the juxtaposition of two principles which could operate in collision with each other, without providing the necessary basis of principle for their reconciliation. The untenability of the supposition that the law sanctions such a state of normative anarchy suffices to condemn a hypothesis that leads to so unsatisfactory a result.

Each principle cannot be given free rein, regardless of the other. The law necessarily contains within itself the principle of reconciliation. That principle is the principle of sustainable development." 901

"The components of the principle [of sustainable development] come from wellestablished areas of international law - human rights, State responsibility, environmental law, economic and industrial law, equity, territorial sovereignty, abuse of rights, good neighbourliness - to mention a few. It has also been expressly incorporated into a number of binding and far-reaching international agreements, thus giving it binding force in the context of those agreements. It offers an important principle for the resolution of tensions between two established rights." $" 902$

O único aspecto criticável da opinião de Weeramantry está em considerar que a concepção de desenvolvimento sustentável se assenta apenas sobre dois pilares desenvolvimento econômico e conservação ambiental - quando, em verdade, no presente, a comunidade internacional considera quatro os pilares que a sustentam. Possivelmente, esse equívoco se deu em virtude do litígio examinado envolver fundamentalmente um conflito entre questões econômicas e ambientais.

Inspirados pelo papel pacificador do princípio do desenvolvimento sustentável, desde o final da década de 80 , alguns instrumentos internacionais explicitam a obrigação

\footnotetext{
${ }^{901}$ Cf. WEERAMATHY, 1997, p. 99 (grifo nosso).

902 Ibid., p. 95.
} 
dos Estados de observarem acordos internacionais potencialmente conflitantes de maneira a harmonizá-los. ${ }^{903}$ Esta obrigação está insculpida no princípio da potenciação mútua (principle of mutual suppotiveness), também conhecido por princípio da inter-relação ou integração $^{904}$ ou obrigação de potenciação mútua, complementaridade e nãosubordinação. ${ }^{905} \mathrm{O}$ princípio da potenciação mútua se confunde com o princípio do desenvolvimento sustentável, configurando nada além de uma nova roupagem para o pacta sunt servanda. A obrigação de potenciação mútua está prevista, inter alia, na Convenção 169 da OIT; ${ }^{906} \mathrm{CDB} ;{ }^{907}$ Declaração de Copenhagen sobre Desenvolvimento Social; ${ }^{908}$ Resolução 2000/7 da Subcomissão de Direitos Humanos sobre Direitos de Propriedade Intelectual e Direitos Humanos; ${ }^{909}$ Declaração de Doha sobre o Acordo TRIPS e Saúde Pública da OMC; $;^{910}$ Declarações Ministeriais da OMC de Singapura e Doha; ${ }^{911}$ TIRFAA $;{ }^{912}$ CSPCI $;{ }^{913}$ CPPDEC $;{ }^{914}$ Diretrizes de Bonn da CDB sobre acesso aos recursos

903 Cf. FRANCIONI et al., [200-?], p. 56; UNITED NATIONS DEPARTMENT FOR POLICY COORDINATION AND SUSTAINABLE DEVELOPMENT, 1996, para. 18.

904 Cf. UNITED NATIONS DEPARTMENT FOR POLICY COORDINATION AND SUSTAINABLE DEVELOPMENT, 1996, para. 15-18.

${ }^{905}$ Cf. art. 20, CPPDEC.

906 A Convenção 169 da OIT, em seu art. 7(3), obriga suas partes contratantes, quando da preparação de políticas globais de desenvolvimento econômico das regiões, em que vivem os povos indígenas e tribais, a avaliarem a incidência "social, espiritual e cultural" e ambiental destas políticas.

907 O art. 16(5) da CDB demanda de seus Estados contratantes a implementação de regimes de proteção da propriedade intelectual de maneira a "[...] garantir que esses direitos (DPIs) apóiem e não se oponham aos objetivos [...]" da CDB. No mesmo sentido ver o art. 22(1), CDB.

${ }^{908}$ Cf. WORLD SUMMIT for SOCIAL DEVELOPMENT, A/CONF.166/9, para. 26(d).

${ }^{909}$ Cf. UNITED NATIONS SUB-COMMISSION ON HUMAN RIGHTS, Resolution 2000/7, para. 6, 8, 13 (a Subcomissão recomenda que a OMC, organizações intergovenamentais e inclusive a Conferência das Partes da CDB integrem, em seu trabalho relacionado à elaboração de novas regras de proteção de bens intelectuais, princípios e normas protetoras dos direitos humanos).

${ }^{910}$ Nessa declaração, os Estados Membros da OMC reconhecem seu direito de adotarem medidas de reconciliação de suas obrigações de proteção das invenções por meio das patentes com seu dever de assegurar aos seus nacionais acesso a medicamentos: "afirmamos que dicho Acuerdo [TRIPS] puede y deberá ser interpretado y aplicado de una manera que apoye el derecho de los Miembros de la OMC de proteger la salud pública y, en particular, de promover el acceso a los medicamentos para todos" (WTO, WT/MIN(01)/DEC/2, para. 4).

911 A Declaração Ministerial de Doha reafirmou o compromisso assumido na Conferência Ministerial de Singapura, em 1996, de "respeitar as normas fundamentais do trabalho internacionalmente reconhecidas", fundamentalmente aquelas adotadas no seio da OIT (WTO, WT/MIN(01)/DEC/1, para. 8 combinado com WTO, WT/MIN(96)/DEC, para. 4). A Declaração de Doha igualmente reafirma o compromisso da OMC e de seus membros de compatibilizar as regras do sistema multilateral de comércio com o objetivo de alcançar desenvolvimento sustentável (WTO, WT/MIN(01)/DEC/1, para. 6).

912 O preâmbulo do Tratado da FAO dispõe: "[r]econhecendo que o presente Tratado e outros acordos internacionais pertinentes devem respaldar-se mutuamente com vistas a conseguir uma agricultura e uma segurança alimentar sustentáveis". Ver também os artigos 12.3(f), 13.2(b)(i) e 13.2(b)(ii) do TIRFAA

${ }_{913} \mathrm{O}$ art. 3(b) da Convenção estabelece a necessidade de sua aplicação em harmonia com as obrigações assumidas pelos Estados, associadas à proteção da propriedade intelectual e dos recursos biológicos: "Ninguna disposición de la presente Convención podrá ser interpretada de tal manera que: (b) afecte los derechos y obligaciones que tengan los Estados Partes en virtud de otros instrumentos internacionales relativos a los derechos de propiedad intelectual o a la utilización de los recursos biológicos y ecológicos de los que sean Partes." 
genéticos e repartição justa e equitativa dos benefícios resultantes de sua utilização; ${ }^{915}$ Protocolo de Cartagena sobre Biossegurança; ${ }^{916}$ Diretrizes de Adis Abeba para a utilização sustentável da diversidade biológica; $;{ }^{917}$ Diretrizes de Akwén:Kon para a condução de estudos de impacto ambiental cultural e social de projetos de desenvolvimento ${ }^{918}$ e na Declaração da ONU sobre Direitos dos Povos Indígenas. ${ }^{919}$

Muitos dos Estados envolvidos nas negociações voltadas à proteção dos RBIs são signatários de acordos relacionados às áreas que dão sustentação à concepção de desenvolvimento sustentável. Por conseguinte, as propostas de regime de proteção de RBIs não devem ser concebidas como se as negociações ocorressem em um vácuo legal, onde inexistem limites do que pode ou não ser adotado. ${ }^{920}$ No contexto das negociações em curso, a realização da meta de desenvolvimento sustentável depende da avaliação prévia dos potenciais impactos presentes e futuros, locais e transfronteiriços de políticas e medidas legislativas de natureza econômica, social, cultural e ambiental. ${ }^{921}$

Negligenciando os compromissos internacionais assumidos, nem os Estados nem as organizações envolvidos na negociação de regimes internacionais de proteção dos RBIs examinaram as propostas em debate, sob a perspectiva de sua capacidade de promover o respeito aos instrumentos legais internacionais associados à proteção das quatro dimensões

\footnotetext{
914 O art. 20 da CPPDEC dispõe que: "1. Las Partes reconocen que deben cumplir de buena fe con las obligaciones que les incumben en virtud de la presente Convención y de los demás tratados en los que son Parte. En consecuencia, sin subordinar esta Convención a los demás tratados: a) fomentarán la potenciación mutua entre la presente Convención y los demás tratados en los que son Parte; b) cuando interpreten y apliquen los demás tratados en los que son Parte o contraigan otras obligaciones internacionales, tendrán en cuenta las disposiciones pertinentes de la presente Convención. 2. Ninguna disposición de la presente Convención podrá interpretarse como una modificación de los derechos y obligaciones de las Partes que emanen de otros tratados internacionales en los que sean parte."

${ }^{915} \mathrm{O}$ item 10 das Diretrizes de Bonn (SCBD, 2002) sublinha que "[t]he guidelines should be applied in a manner that is coherent and mutually supportive of the work of relevant international agreements and institutions".

916 O preâmbulo do Protocolo de Cartagena sobre Segurança da Biotecnologia reconhece "que los acuerdos relativos al comercio y al medio ambiente deben apoyarse mutuamente con miras a lograr el desarrollo sostenible".

${ }_{917}$ Cf. SCBD, 2004b, princípio prático 10.

${ }^{918}$ Id., 2004c, para. 5.

919 O art. 46(2) da Declaração dispõe que os direitos lá enunciados devem ser observados, de maneira a se harmonizarem com os direitos fundamentais de todos os grupos que compõem a sociedade humana: "2. In the exercise of the rights enunciated in the present Declaration, human rights and fundamental freedoms of all shall be respected."

${ }_{920}$ Ver, e.g., COTTIER; PANIZZON, 2006, p. 208; SCBD, UNEP/CBD/WG8J/2/INF/1, para. 9.

${ }^{921}$ Ver, e.g., VERSCHUUREN, 2003, p. 21; SACHS, 2007 a, p. 384; KHALFAN; SEGGER, 2004, p. 1-5.
} 
do $\mathrm{PBI} .{ }^{922}$ Se as negociações em andamento não alterarem seu rumo, existe, portanto, a possibilidade de que venham a ser adotados acordos internacionais, que obstaculizarão a proteção das múltiplas dimensões do PBI.

\subsection{A relaÇão entre as dimensões do PBI E os Pilares de SUSTENTaÇão da CONCEPÇÃO DE DESENVOLVIMENTO SUSTENTÁVEL}

Conforme visto no capítulo 1, o PBI encerra quatro dimensões interdependentes (imaterial, ambiental, humana e cultural), as quais se inter-relacionam com os pilares de sustentação da concepção de desenvolvimento sustentável (desenvolvimento econômico e social, conservação ambiental e diversidade cultural).

A dimensão imaterial do PBI é a mais visível, porquanto é freqüentemente apropriada pelos setores científico, cultural e produtivo, na condição de conjunto de matérias-primas, que alimenta o processo de desenvolvimento de novos produtos e processos comerciais. Existe, portanto, uma relação entre a dimensão imaterial do PBI e o pilar de desenvolvimento econômico da concepção de desenvolvimento sustentável.

Sob a ótica da dimensão imaterial do PBI, faz-se necessária a adoção de medidas legais que previnam sua apropriação indébita e, conseqüentemente, assegurem às comunidades tradicionais e Estados os meios de extrair renda de seus RBIs. Ademais, os futuros regimes internacionais para a matéria não devem replicar os equívocos praticados pelos regimes de proteção da PI, que protegem excessivamente os interesses de um grupo (autores de produções intelectuais desenvolvidas no contexto da cultura ocidental) em detrimento dos interesses de outros grupos. Isso significa, primeiramente, que a proteção dos RBIs deve se harmonizar com o imperativo de facilitar seu uso amplo pela sociedade dominante, com vistas a fomentar seu desenvolvimento material, ao mesmo tempo em que

\footnotetext{
${ }^{922}$ A $9^{\text {a }}$ Conferência das Partes da CDB (COPCBD, Decision IX/12, para. 13(c)) limitou-se a encomendar estudos independentes, que avaliaram as alternativas que os negociadores do regime internacional de acesso a recursos genéticos e conhecimentos tradicionais associados poderiam considerar para estabelecer um regime harmônico com outros acordos internacionais, que governam a proteção de recursos genéticos, notadamente, o TIRFAA, as convenções da UPOV e o Acordo TRIPS da OMC, e com o processo em curso na OMPI. Ver MEDAGLIA, 2009; BULMER, 2009.
} 
gera benefícios econômicos em favor do bem-estar das comunidades tradicionais e da conservação da biodiversidade.

A dimensão imaterial do PBI e o pilar de desenvolvimento econômico da concepção de desenvolvimento sustentável se apóiam sobre o artigo 15(1)(c) do PIDESC e os artigos 8(j), 15(1) da CDB, os quais tutelam os interesses econômicos das comunidades tradicionais e dos Estados sobre seus RBIs, bem como sobre os artigos 15(2), 15(3) do PIDESC e os artigos 15(2), 17(2) e 18(4) da CDB, os quais resguardam o direito de todos à liberdade científica e criativa.

A diversidade genética, de espécies e ecossistemas serve de esteio ao desenvolvimento e conservação do PBI, correspondendo à sua dimensão ambiental, a qual se relaciona com o pilar de conservação ambiental da concepção de desenvolvimento sustentável. Salvo se a biodiversidade for conservada em seus três níveis, o PBI que com ela se relaciona direta ou indiretamente se deteriorará. A proteção da dimensão ambiental do PBI somente será factível, se forem canalizados recursos econômicos em prol da biodiversidade. Considerando que o uso produtivo dos RBIs é um fato-gerador de recursos econômicos, subsiste uma relação de interdependência entre, de um lado, a dimensão ambiental e o pilar de conservação ambiental e, do outro, a dimensão imaterial e o pilar de desenvolvimento econômico.

O principal acordo internacional a tutelar tanto a dimensão ambiental quanto o pilar de conservação ambiental é a CDB.

As comunidades tradicionais que desenvolvem e conservam o PBI e a biodiversidade que o alimenta constituem a dimensão humana do PBI. Esta, por sua vez, se relaciona com o pilar de desenvolvimento humano da concepção de desenvolvimento sustentável. Freqüentemente, as comunidades tradicionais vivem em condições de miséria material, faltando-lhes o mínimo para uma existência digna, apesar do potencial econômico de seus RBIs. Se a qualidade de vida destas comunidades não sofrer uma melhoria dramática, elas continuarão a se desmantelar. ${ }^{923} \mathrm{O}$ efeito colateral de seu

${ }^{923}$ Estimativas conservadoras calculam que, ao longo do séc. XX, apenas na região amazônica, um grupo indígena foi extinto ao ano (POSEY, 2004e, p. 149). 
desaparecimento é a extinção de seu patrimônio intelectual e a fragilização da biodiversidade que lhe dá suporte. O desaparecimento da biodiversidade, por sua vez, coloca em risco a sustentabilidade dos setores produtivos da sociedade dominante, notadamente, as indústrias biomédica, agrobiotecnológica e criativa, cuja sobrevivência depende do fluxo regular de insumos informacionais e biológicos de múltiplas fontes. Com a erosão do PBI e da biodiversidade, decairá o ritmo de desenvolvimento de bens indispensáveis para a qualidade de vida da humanidade, e.g. novas cultivares agrícolas, medicamentos, tecnologias e produtos criativos.

A salvaguarda tanto da dimensão humana do PBI quanto do pilar de desenvolvimento social da concepção de desenvolvimento sustentável depende da proteção das dimensões ambiental e imaterial do PBI e, reflexamente, da efetivação dos pilares de conservação ambiental e desenvolvimento econômico da concepção de desenvolvimento sustentável. Afinal, sem recursos materiais que assegurem os meios para as comunidades tradicionais viverem condignamente junto à natureza, seu futuro e o da natureza não serão nada promissores.

A dimensão humana e o pilar de desenvolvimento humano têm como principal base de sustentação legal o PIDESC e o PIDCP.

A própria existência do PBI e o estado de conservação dos ecossistemas naturais em que vivem as comunidades tradicionais são o reflexo das escolhas realizadas pelos membros destes grupos, guiados por seu arcabouço cultural diferenciado. Sua cultura constitui a dimensão cultural do PBI; a ela se associa o pilar diversidade cultural da concepção de desenvolvimento sustentável.

A preservação e o desenvolvimento das culturas das comunidades tradicionais é uma das condições fundamentais para se conservar o PBI e a biodiversidade que o alimenta. $\mathrm{O}$ respeito à cultura das comunidades tradicionais se dá pela continuidade do uso costumeiro do PBI; pelo reconhecimento público por parte da sociedade dominante do valor do PBI, o que pode estimular as comunidades tradicionais a continuarem com seu trabalho ingente de desenvolvimento e conservação de RBIs; e pela investidura nas comunidades do direito de prevenirem usos culturalmente desrespeitosos de seus RBIs, fundamentalmente daqueles portadores de valor religioso. 
A dimensão cultural do PBI e o pilar diversidade cultural da concepção de desenvolvimento sustentável se embasam, inter alia, sobre o art. 10(c) da CDB, o art. 27 do PIDCP, o art. 15(1)(a) do PIDESC, a CPPDEC e a CSPCI.

A partir da associação das dimensões do PBI com os pilares de sustentação da concepção de desenvolvimento sustentável é possível a identificação dos fins que um regime internacional de proteção do PBI deve simultaneamente promover: a proteção de sua dimensão imaterial contra atos de apropriação indébita; a conservação da diversidade biocultural; a erradicação da pobreza nas comunidades tradicionais e a realização integral dos direitos fundamentais de seus membros, considerados em sua condição de seres humanos e de membros de comunidades culturalmente diferenciadas. $\mathrm{O}$ atendimento a esses objetivos depende da transferência de recursos financeiros generosos, em caráter perene (no curto, médio e longo prazo) aos países ricos em recursos biológicos e às comunidades tradicionais. A geração destes recursos está subordinada à capacidade dos futuros regimes de facilitar o uso produtivo dos RBIs pelos setores produtivos da sociedade dominante. A ampliação do uso dos RBIs catalisará a expansão dos setores produtivo, científico e cultural tanto de países industrializados quanto dos em desenvolvimento, bem como a geração de novos produtos socialmente relevantes.

Contudo, não basta facilitar e ampliar o uso dos RBIs; há muito estes recursos são utilizados pela sociedade dominante, inclusive de maneira insustentável, ${ }^{924}$ sem beneficiar nem os países em desenvolvimento e seus ecossistemas nem suas comunidades tradicionais. Assim, é fundamental que os futuros regimes internacionais sejam funcionais (exigíveis) em escala global, sobretudo nos países usuários do PBI. Devem ainda assegurar a reversão de parcelas dos benefícios derivados do uso produtivo dos RBIs, em favor da melhoria da qualidade de vida das comunidades tradicionais e da conservação da biodiversidade.

\footnotetext{
924 A exploração dos recursos da biodiversidade, incentivados pela disseminação dos conhecimentos tradicionais a eles associados, vem sendo realizada sem respeitar os limites impostos pela natureza, uma vez que o setor privado se ocupa tende a se ocupar exclusivamente com a maximização de seus lucros (BUCKLEY, 2005). No mesmo sentido SAHAI, 2004, p. 283. (a árvore Taxus baccata, fonte natural do princípio ativo da lucrativa droga anticancerígena Taxotere ${ }^{\circledR}$ da Sanofi-Aventis, quase foi extinta na Ásia em virtude do aumento da demanda comercial pela matéria-prima natural).
} 
Finalmente, os futuros regimes devem proporcionar às comunidades tradicionais o direito de: serem publicamente reconhecidas por seus aportes ao desenvolvimento material da sociedade dominante; de conservarem suas práticas de livre intercâmbio de RBIs e o de controlarem as condições e contextos, em que poderão ser utilizados seus RBIs de natureza sagrada, a fim de prevenirem aplicações culturalmente desrespeitosas.

Da combinação das dimensões do PBI com os pilares da concepção de desenvolvimento é possível inferir quatro critérios de operacionalização, que comporão o quadro conceitual de desenvolvimento sustentável, a saber:

i. Geração de benefícios econômicos no curto, médio e longo prazo, derivados do uso produtivo dos RBIs, a serem revertidos obrigatoriamente em favor da conservação da biodiversidade e da melhoria da qualidade de vida das comunidades tradicionais;

ii. Direito de uso amplo e facilitado dos RBIs pelos setores produtivo, científico e criativo da sociedade dominante, assim como pelas comunidades tradicionais, em consonância com suas práticas costumeiras;

iii. Assegurar às comunidades tradicionais o direito de atribuição e de oposição aos usos culturalmente desrespeitosos; e

iv. Efetividade dos regimes de proteção em escala global.

As próximas seções tratarão de cada um dos quatro critérios de operacionalização do quadro conceitual de desenvolvimento sustentável.

\subsubsection{CRITÉRIOS DE OPERACIONALIZAÇÃO DO QUADRO CONCEITUAL DE DESENVOLVIMENTO SUSTENTÁVEL}

3.2.1.1 CRITÉRIO DE OPERACIONALIZAÇÃo 1: GERAÇÃo DE BENEFÍ́CIOS ECONÔMICOS DERIVADOS DOS RBIS E SUA REVERSÃO OBRIGATÓRIA EM FAVOR DA CONSERVAÇÃO DA BIODIVERSIDADE E DA MELHORIA DA QUALIDADE DE VIDA DAS COMUNIDADES TRADICIONAIS 
O art. 8(j) da CDB é tratado como a principal justificativa legal para se negociar um regime internacional de proteção dos interesses materiais das comunidades tradicionais sobre seus CTAs. Sem embargo, tal dispositivo pode ser limitado para esta função: A CDB limita-se a conferir aos Estados partes a prerrogativa de adotar medidas protetoras dos interesses materiais das comunidades sobre seus CTAs. ${ }^{925}$

Todavia, o art. 15(1)(c) do PIDESC indiscutivelmente assegura às comunidades tradicionais o direito à uma remuneração justa ${ }^{926}$ pelo uso de seus RBIs, a fim de proporcionar-lhes um nível de vida adequado ${ }^{927}$ e incentivos para preservarem suas instituições culturais. ${ }^{928}$ Indiretamente, a efetivação do direito econômico reconhecido neste dispositivo figura como condição material, para que as comunidades tradicionais continuem a alimentar a diversidade biocultural. ${ }^{929}$

O Pacto oferece às partes contratantes a liberdade de escolha dos mecanismos legais para cumprirem o art. 15(1)(c). Não há nada na história da redação deste dispositivo indicando que os DPIs sejam o único meio para cumpri-1o. ${ }^{930}$ Disto pode-se concluir que o PIDESC não confere às comunidades tradicionais e seus membros um DPI sobre seus RBIs. $^{931}$

Em situação diversa estão os recursos intangíveis da biodiversidade. A CDB conferiu aos seus Estados contratantes um direito de propriedade sobre seus recursos da biodiversidade, inclusive sobre os recursos intangíveis neles contidos, ${ }^{932}$ mas também lhes ofereceu a discricionariedade para eleger outros meios legais para protegê-los contra atos de apropriação indébita. ${ }^{933}$ Para aqueles Estados que também são partes da Convenção no. 169 da OIT, o direito de controle reconhecido pela CDB é limitado, porquanto a convenção da OIT conferiu às comunidades tradicionais o direito de receber benefícios resultantes da

\footnotetext{
925 Cf. item 2.5 .

${ }^{926}$ Cf. YU, 2007, p. 1087-1088.

${ }^{927} \mathrm{Cf}$. art. 11(1), PIDESC

${ }_{928}$ Cf. art. 15(1)(c), PIDESC combinado com o art. 27, PIDCP. Cf. CESCR, E/C.12/GC/17, para. 33.

${ }^{929}$ Cf. $\operatorname{artigos} 6(1)(g), 7(1)(a)$, CPPDEC.

${ }^{930} \mathrm{Cf}$. YU, 2007, p. 1072, 1079, 1143.

${ }^{931}$ Cf. CESCR, E/C.12/GC/17, para. 1. e. 2.

${ }^{932}$ Cf. art. 15(1), (4), (5), CDB.

${ }^{933} \mathrm{Cf}$. art. 15(5), in fine, CDB.
} 
exploração comercial dos recursos biológicos presentes em suas terras. ${ }^{934}$ Cabe ainda aos Estados parte da Convenção da OIT o dever de assegurar às comunidades indígenas e tribais as condições materiais necessárias para viverem condignamente, sem que precisem explorar insustentavelmente os recursos naturais de suas terras. ${ }^{935}$

Em sumário, o artigo 15(1)(c) do PIDESC em associação com os artigos 8(j) da CDB, 7(4) e 15(2) da Convenção no. 169 da OIT garantem às comunidades tradicionais recursos econômicos, ${ }^{936}$ que lhes proporcionem desenvolvimento social harmônico com o imperativo de conservação da biodiversidade ${ }^{937}$ e de suas peculiaridades culturais. ${ }^{938} \mathrm{O}$ art. 15 da CDB, por sua vez, confere aos Estados detentores de recursos da biodiversidade o direito de controlar seu uso, a fim de extraírem recursos econômicos essenciais ao financiamento de medidas de conservação e recuperação da biodiversidade.

A comunidade internacional reconhece que a realização dos direitos humanos dos membros das comunidades culturalmente diferenciadas é um garante da "paz e [da] estabilidade política e social e enriquece a diversidade cultural e o patrimônio da sociedade." ${ }^{939}$ Reconhece igualmente que a realização destes direitos está subordinada à garantia a estes grupos do direito de autodeterminação. ${ }^{940}$

A Convenção no. 169 da OIT confere às comunidades indígenas e tribais a liberdade para fixarem e perseguirem seus projetos de desenvolvimento econômico, social e cultural (direito de autodeterminação). ${ }^{941}$ A medida da autonomia das comunidades é

\footnotetext{
934 Cf. art. 15(2), Convenção no. 169 da OIT. Esta obrigação subsiste apenas para os 20 Estados signatários da convenção. São eles: Argentina, Bolívia, Brasil, Chile, Colômbia, Costa Rica, Dinamarca, Equador, Espanha, Fiji, Guatemala, Holanda, Honduras, México, Nepal, Noruega, Paraguai, Peru, República Dominicana e Venezuela.

${ }_{935}$ Cf. art. 7(4), Convenção no. 169, OIT.

${ }^{936} \mathrm{O}$ art. 15(1)(c), PIDESC relaciona-se intimamente com o art. 6(1) do mesmo instrumento (o direito ao trabalho livremente escolhido ou aceito) e com o art. 7(a)(i) (direito à uma remuneração justa e adequada ao trabalho realizado); art. 11(1) (o direito a um nível de vida adequado para si próprio e sua família). Cf. CESCR, E/C.12/GC/17, para. 4.

${ }^{937}$ Cf. KARBOLO, 2004, p. 273.

${ }^{938}$ Cf. CERD, 1997, para. 4(b).

${ }^{939}$ Cf. UNGA, Resolution A/RES/60/1, para. 130.

${ }^{940}$ Cf. UNGA, Resolution 62/144, para. 1.

${ }^{941}$ Cf. art. 7(1), Convenção 169 da OIT; ANAYA, 2004, p. 50. A Declaração da ONU sobre os Direitos do Povos Indígenas, em seu art. $3^{\circ}$, igualmente reconhece aos povos indígenas o direito à autodeterminação, "em virtude do qual os povos indígenas determinam livremente sua condição política e perseguem livremente seu desenvolvimento econômico, social e cultural."
} 
proporcional à disponibilidade de recursos econômicos para alcançarem as metas eleitas; ${ }^{942}$ mais vastos forem os recursos econômicos sob seu controle, maior será a autonomia para elegerem as metas que podem ser de fato alcançadas. ${ }^{943}$

$\mathrm{O}$ direito de autodeterminação reconhecido às comunidades tradicionais não se confunde com o direito unilateral de secessão do Estado (direito de autodeterminação externa). ${ }^{944} \mathrm{O}$ que o direito internacional reconhece às comunidades tradicionais é o direito de autodeterminação interna ou de etnodesenvolvimento, ${ }^{945}$ i.e. o direito de "perseguir livremente seu desenvolvimento econômico, social e cultural, sem interferência externa [...] [e o] de conservar e reforçar suas próprias instituições políticas, jurídicas, econômicas, sociais e culturais, $", 946$ dentro dos limites territoriais da comunidade. ${ }^{947} \mathrm{O}$ direito de autodeterminação interna autoriza as comunidades tradicionais a conservarem pacificamente todos os elementos que compõem e alimentam sua identidade cultural diferenciada ${ }^{948}$ (língua, religião, tradições e costumes), ${ }^{949}$ sem o risco de serem assimiladas forçadamente pela sociedade dominante..$^{950}$

Sem embargo, os direitos econômicos, sociais e culturais (e.g. direito ao trabalho e à remuneração justa e não-discriminatória, à educação, à saúde, à nutrição adequada, à

942 Ver, e.g., POSEY, 1990, p. 15; UNGA, Resolution A/RES/40/114, preâmbulo; UNGA, Resolution 32/130, para. 1(f). A Declaração das Nações Unidas sobre os Direitos dos Povos Indígenas, em seu art. $4^{\circ}$, dispõe que "[o]s povos indígenas, no exercício do seu direito à autodeterminação, têm direito à autonomia ou ao autogoverno nas questões relacionadas a seus assuntos internos e locais, assim como a disporem dos meios para financiar suas funções autônomas".

${ }^{943}$ Cf. KATZ, 2008, p. 61.

${ }^{944}$ Ver, e.g., OIT, 2003, p. 9; CERD, 1996, para. 1 e 6. Contudo, é importante notar que a separação é possível, desde que em bases mutuamente acordadas. Neste sentido, a Declaração das Nações Unidas sobre os Direitos dos Povos Indígenas, ao mesmo tempo em que reconhece o direito de autodeterminação dos povos indígenas (art. $3^{\circ}$ ), proíbe qualquer interpretação deste direito "[...] no sentido de autorizar ou de fomentar qualquer ação direcionada a desmembrar ou a reduzir, total ou parcialmente, a integridade territorial ou a unidade política de Estados soberanos e independentes" (art. 46(1)).

945 Cf. UNESCO, Declaration of San José, para. 3.

${ }^{946}$ Cf. art. 5o, Declaração das Nações Unidas sobre Direitos dos Povos Indígenas.

${ }^{947}$ Cf. CERD, 1996, para. 4.

${ }_{948}$ Cf. STAVENHAGEN, 1998, p. 16.

949 Cf. art. 4(2), Declaration on the Rights of Persons Belonging to National or Ethnic, Religious and Linguistic Minorities (adotada pela resolução 47/135, da Assembléia Geral das Nações Unidas).

950 A principal mudança introduzida pela Convenção no. 169 da OIT em relação à sua antecessora Convenção no. 107 da OIT, de 1957 - está no reconhecimento do direito das comunidades indígenas e povos tribais de escolher se desejam ou não ser assimiladas à sociedade dominante. A Convenção no. 107 perseguia a assimilação destes povos à cultura ocidental, desrespeitando sua liberdade de traçar seu próprio destino e conservar sua identidade cultural. No mesmo sentido, vide o arts. 7(2) e 8(1), Declaração das Nações Unidas sobre os Direitos dos Povos Indígenas. 
moradia, à vestimenta) das comunidades tradicionais ${ }^{951}$ ainda não são observados a contento. As condições de vida das comunidades indígenas ilustram os desafios enfrentados pelas comunidades tradicionais em geral, em todo o mundo: os povos indígenas figuram como um dos grupos mais marginalizados e empobrecidos do mundo ${ }^{952}$ e certamente apresentam os piores índices de saúde, ${ }^{953}$ mesmo quando baseados em países desenvolvidos. ${ }^{954}$ A expectativa de vida ao nascer de um indígena é de 10 a 20 anos menor que a da população do Estado em que vive; a mortalidade infantil nestes grupos chega a ser três vezes maior que a taxa aplicável à sociedade envolvente. $\mathrm{O}$ alcoolismo, o suicídio e o abuso de drogas grassam nestes grupos. ${ }^{955}$ Faltam às crianças indígenas oportunidades de desenvolvimento pleno; estão mais sujeitas à exploração sexual e trabalhista e sofrem discriminação de todo tipo, o que conduz à deterioração de sua autoestima. ${ }^{956}$

Mesmo no Brasil, país cujo marco legal tutela especificamente os direitos dos povos indígenas, a situação não é diferente. No Vale do Javari, no extremo da Amazônia brasileira, casa dos povos indígenas mais isolados de todo o mundo, os índices de subnutrição, malária, febres tropicais, hepatite alcançaram níveis tão alarmantes, que colocam em risco sua sobrevivência. ${ }^{957}$ A crise de saúde pública por que passam as comunidades lá baseadas não pode mais ser respondida apenas com o emprego dos conhecimentos medicinais dos pajés, realidade que ataca frontalmente os incentivos para conservá-los.

\subsection{A RELAÇÃO ENTRE O DIREITO À TERRA E O DIREITO À AUTODETERMINAÇÃO DAS COMUNIDADES TRADICIONAIS}

\footnotetext{
951 O preâmbulo da Convenção no. 169 da OIT anota "que em muitas partes do mundo estes povos não podem gozar dos direitos humanos fundamentais no mesmo grau que o resto da população dos Estados em que vivem e que suas leis, valores, costumes e perspectivas sofrem com freqüência a uma erosão."

${ }^{952}$ Cf. SECRETARIAT OF THE PERMANENT FORUM ON INDIGENOUS ISSUES, PFII/2005/WS.2/14; OIT, 2003, p. 59.

953 Cf. STEPHENS et al., 2006, p. 2022.

954 Ver ANDERSON; LOFF, 2004 (em 2001, a expectativa de vida ao nascer de um homem aborígine australiano era de apenas 56 anos, enquanto a de um homem australiano "comum" era de 77 anos. O estudo indica que as populações aborígenes da Austrália estão também mais sujeitas à morte decorrente de enfermidades crônicas, como diabetes, doenças circulatórias, hepatite B).

${ }^{955}$ Cf. KAPP, 1999.

${ }_{956}$ Cf. BOSCH, 2004, p. 789.

${ }^{957}$ Cf. BRANDT, 2008.
} 
Apesar da diversidade de comunidades tradicionais, a maioria delas mantém uma relação simbiótica com as terras em que vivem. ${ }^{958}$ Vandana Shiva bem coloca que a terra é por elas concebida como "terra mater": 959 a terra não lhes oferece apenas os meios de vida econômica (i.e. moradia, trabalho, alimento, recursos medicinais), mas também o "espaço geográfico necessário para a reprodução cultural e social do grupo", ${ }^{960}$ pois serve de palco para a reprodução de suas instituições sociais, culturais e religiosas, modos de vida e PBI. ${ }^{961}$

A Corte Interamericana de Direitos Humanos, no caso Yakye Axa vs. Paraguay, já julgou que o direito à vida garante aos seus titulares "condições mínimas de vida, compatíveis com a dignidade da pessoa humana." 962 Em conformidade com o princípio da efetividade, é necessário dar cumprimento ao direito à vida dos membros das comunidades tradicionais tomando nota de sua realidade fática e cultural. ${ }^{963}$ Isto significa, em termos concretos, que a realização deste direito passa necessariamente pela garantia às comunidades tradicionais do direito de propriedade sobre as terras que tradicionalmente ocupam. ${ }^{964}$

$\mathrm{Na}$ mesma sentença, a Corte Interamericana de Direitos Humanos assinala que a ruptura do vínculo entre as comunidades tradicionais e suas terras coloca em risco a vida física, bem-estar espiritual e a identidade cultural destes grupos, ${ }^{965}$ a integridade de seu patrimônio cultural (PBI, línguas, costumes, modos de vida) ${ }^{966} \mathrm{e}$, recordando a interdependência entre a diversidade cultural e a biológica, a própria biodiversidade. ${ }^{967}$

\footnotetext{
958 Ver, e.g., FAGAN, 2001, p. 634; ANAYA, 2004, p. 36.

${ }^{959}$ Cf. SHIVA, 2001, p. 70.

${ }^{960}$ Ver, e.g., OEA, OEA/Ser.L/VII.108; Doc. 62, capítulo 3, item “A”; ECOSOC, E/CN.4/Sub.2/2001/21, para. 16

${ }_{961}$ O projeto da ONU de Princípios e Diretrizes para a proteção do patrimônio dos povos indígenas conta com um princípio (princípio no. 6), que reconhece a relação entre a conservação e o desenvolvimento do PBI com as terras ocupadas pelas comunidades: "A descoberta, uso e ensino dos conhecimentos, artes e culturas dos povos indígenas estão intimamente vinculados às terras tradicionais de cada povo. Controle dos territórios tradicionais e dos recursos é essencial para a contínua transmissão do patrimônio dos povos indígenas para as futuras gerações, e para sua integral proteção" (COMMISSION ON HUMAN RIGHTS, E/CN.4/Sub.2/1994/31, anexo; tradução nossa).

${ }_{962}$ Cf. CORTE INTERAMERICANA DE DERECHOS HUMANOS, 2005, para. 162.

${ }^{963}$ Cf. CESCR, E/C.12/40/4, p. 14-15.

${ }^{964}$ Cf. CORTE INTERAMERICANA DE DERECHOS HUMANOS, 2006b, OEA - Corte Interamericana de Derechos Humanos, 2006c.

965 Ver, e.g., CORTE INTERAMERICANA DE DERECHOS HUMANOS, 2005, para. 166; CESCR, E/C.12/2000/4, para. 27; OIT, 2003, p. 29.

${ }_{966}$ Ver, e.g., SCBD, UNEP/CBD/WG8J/3/INF/1, p. 23-24; SCBD, UNEP/CBD/WG8J/1/INF/14, p. 5.

${ }^{967}$ Cf. UNESCO, 2006, p. 300; BARSH, 1999, p. 18-20.
} 
Sem a garantia do direito de propriedade, as comunidades tradicionais não detêm as condições mínimas para conservarem sua individualidade cultural em face da sociedade dominante, ${ }^{968}$ nem para manterem a biodiversidade em contínuo desenvolvimento. Ao menos que a biodiversidade possa interagir continuamente com o homem e em novas condições climáticas e ambientais, deixará de adquirir novas características que a torna apta a satisfazer as necessidades da humanidade. ${ }^{969}$

Exatamente pela importância central da terra na vida social, cultural e espiritual das comunidades tradicionais, as Convenções no. 107 e 169 da OIT $^{970}$ e a Declaração da ONU sobre Direitos dos Povos Indígenas ${ }^{971}$ tutelam o direito de comunidades indígenas e tradicionais sobre os territórios por elas utilizados, para fins de subsistência física, cultural, social e espiritual. ${ }^{972}$

Os efeitos devastadores gerados pela expulsão do povo San, originário da África austral, de suas terras tradicionais ilustram seu papel na sobrevivência física e cultural das comunidades tradicionais: com a expulsão, o povo San perdeu a liberdade de viver da caça e da coleta de frutos. Com isso, veio a mudança na dieta e as doenças associadas às mudança de hábitos, a perda de conhecimentos medicinais associados à biodiversidade $\mathrm{e}$ de outros conhecimentos ecológicos. O empobrecimento cultural tornou os San dependentes da assistência governamental. Em virtude das condições de pobreza em que vivem, a prostituição tornou-se uma alternativa de meio de vida, na região do globo com as taxas mais expressivas de contaminação pelo HIV. ${ }^{973}$

O desenraizamento das comunidades tradicionais de suas terras também desencadeia a perda do patrimônio lingüístico da humanidade. A UNESCO estima que as comunidades tradicionais conservem a maioria esmagadora das mais de 6000 línguas

\footnotetext{
968 Cf. ECOSOC, E/CN.4/Sub.2/2001/21, para. 13.

${ }^{969}$ Cf. BRUSH, 1994, p. 6-9.

${ }^{970}$ Ver, e.g., artigos. 11-14, Convenção no. 107 da OIT; e artigos 13(1), 14(1), 15(1), Convenção no. 169 da OIT.

${ }^{971}$ Cf. artigos 10, 12(1), 25, 26, 27, 28, 29, 30, 32, Declaração da ONU sobre Direitos dos Povos Indígenas.

972 O art. 25 da Declaração da ONU sobre Direitos dos Povos Indígenas possivelmente é o dispositivo que reconhece com maior clareza a importância espiritual das terras e seus recursos para os povos indígenas: "Os povos indígenas têm o direito de manter e de fortalecer sua própria relação espiritual com as terras, territórios, águas, mares costeiros e outros recursos que tradicionalmente possuam ou ocupem e utilizem, e de assumir as responsabilidades que a esse respeito incorrem em relação às gerações futuras."

${ }^{973}$ Cf. PERSIC; MARTIN, 2008, p. 18.
} 
faladas em todo o mundo. ${ }^{974}$ Deste total, $90 \%$ deve desaparecer até o final do presente século; ${ }^{975} 2500$ línguas podem ser extintas de imediato e um número ainda mais elevado está perdendo os contextos ecológicos que as mantêm vivas. ${ }^{976}$ As línguas, fundamentalmente para os grupos humanos que transmitem oralmente seu patrimônio intelectual, constituem o "armazém"977 de seu PBI. Com a perda das línguas tradicionais, as gerações mais jovens das comunidades tradicionais deixam de receber os RBIs conservados pelas gerações antigas. ${ }^{978}$ A conservação dos laços das comunidades tradicionais com suas terras é uma condição para conservarem vivo seu patrimônio lingüístico ${ }^{979}$ e, conseqüentemente, suas culturas. ${ }^{980}$

Além do valor inconteste da manutenção das comunidades tradicionais em suas terras para a manutenção da diversidade biocultural, estudos recentes confirmam que estes grupos podem ainda desempenhar ${ }^{981}$ o papel de gestores de um dos mais importantes reservatórios naturais de carbono - as florestas - cuja conservação é indispensável para a reversão da tendência de aquecimento global. ${ }^{982}$ Atualmente, as atividades de desflorestamento contabilizam $20 \%$ das emissões anuais de gás carbônico, já ocupando a terceira posição no ranking das fontes que mais liberam gases de efeito estufa. A conservação das florestas prístinas é uma arma poderosa em favor do equilíbrio climático da Terra e da sobrevivência de 1.6 bilhões de pessoas. ${ }^{983}$

\footnotetext{
${ }^{974}$ Cf. SCBD, UNEP/CBD/WG8J/2/5, para. 10.

975 Cf. ICTSD, 2007, p.9.

${ }^{976} \mathrm{Cf}$. SCBD, UNEP/CBD/WG8J/2/5, para. 10.

${ }^{977}$ Cf. POSEY, 2004f, p. 134.

${ }^{978}$ Cf. OVIEDO; GONZALES; MAFFI, 2004, p. 73; SCBD, UNEP/CBD/WG8J/1/INF/14, p. 5.

979 Cf. UNGA, Declaration on the Rights of Persons Belonging to National or Ethnic, Religious and Linguistic Minorities, art. 4(3); Convenção no. 169 da OIT, art. 28(3).

980 Ver anexo II, para. 5 e 6, UNESCO, Declaração Universal sobre a Diversidade Cultural; preâmbulo, CPPDEC.

${ }^{981}$ Um estudo brasileiro, que avaliou a variação nas taxas de desmatamento da Amazônia, apontou que o desmatamento chega a $19 \%$ nas áreas públicas, $2 \%$ nas áreas no interior de parques nacionais e apenas $1.1 \%$ nas terras indígenas (RIGHTS AND RESOURCES INITIATIVE; RAINFOREST FOUNDATION NORWAY, 2008). Ostrom e Hess (2003, p. 58) sublinham que, embora muitas das florestas públicas dos países em desenvolvimento sejam governadas de jure por um regime de propriedade governamental, são governadas de facto por um regime de acesso aberto - que confere a todos os indivíduos a liberdade de explorar os recursos florestais até sua extinção -, em virtude da falta de recursos financeiros e humanos por parte dos Estados para monitorar e administrar grandes extensões de florestas. O compromisso das comunidades tradicionais com a gestão sustentável dos recursos naturais como forma de assegurar sua sobrevivência é a razão principal para a baixíssima taxa de degradação ambiental das áreas em que habitam.

982 Os participantes da Conferência Internacional sobre Direitos, Florestas e Mudança Climática, que tomou lugar em outubro de 2008, em Oslo, chegaram à conclusão que, ao menos que sejam assegurados direitos de propriedade às comunidades tradicionais, as florestas continuarão a ser destruídas em todo o mundo (RIGHTS AND RESOURCES INITIATIVE; RAINFOREST FOUNDATION NORWAY). No mesmo sentido ver, MORRISON, 2008; GREENPEACE, 2008.

${ }^{983}$ Cf. EUROPEAN PARLIAMENT et al, 2008.
} 


\section{§ 1 A FRAGILIDADE DO DIREITO DAS COMUNIDADES TRADICIONAIS E O IMPERATIVO DE SE GERAR RENDA EM SEU FAVOR}

Em virtude da pobreza material, da dependência dos recursos naturais, de sua distribuição aleatória e da incerteza trazida pela produtividade irregular dos recursos naturais, as populações rurais e das florestas historicamente se associam em comunidades com o objetivo de administrar territórios e seus recursos, mediante um regime de propriedade comum (common property). ${ }^{984}$ Antes de identificarmos as características básicas de um regime de propriedade comum, é válido assinalar que o uso de territórios ricos em recursos naturais pode ser governado por um regime de acesso aberto (open access), propriedade privada, propriedade governamental ou de propriedade comum. ${ }^{985}$

No regime de acesso aberto, múltiplos usuários gozam do privilégio de explorar ilimitadamente um recurso exaurível e nenhum deles conta com um direito de exclusão, que permitiria controlar quem o explora e em que medida. ${ }^{986}$ Como resultado da inexistência de regras vinculantes de boa governança, que garantiriam a todos a oportunidade de extraírem benefícios perenes do recurso compartilhado, ${ }^{987}$ seus múltiplos usuários, cientes de que apenas auferirão benefícios à medida que dele se apropriarem, competem pela maximização de seu bem-estar individual, ${ }^{988}$ apropriando-o tanto quanto possível até sua total exaustão. ${ }^{989}$ Cada indivíduo, ao buscar isoladamente o melhor para si, ignora que sua ação individualmente benéfica, quando associada às dos demais usuários, ultrapassa a capacidade de recuperação do recurso. O resultado final das ações individuais benéficas é a degradação do recurso comum. ${ }^{990}$ Este efeito socialmente nefasto, resultante da disjunção entre direitos de uso e responsabilidade para com os demais usuários e com as futuras gerações ${ }^{91}$ foi chamado por Hardin de tragédia dos recursos comuns (tragedy of the commons). ${ }^{992}$

\footnotetext{
${ }^{984}$ Cf. RUNGE, 1992, p. 19-20.

${ }^{985}$ Cf. OSTROM et al., 1999.

${ }_{986}$ Ver, e.g., PARISI; SCHULZ; DEPOORTER, 2004, p. 175.

${ }^{987}$ Cf. HARDIN, 1998.

${ }^{988}$ Ver, e.g., PARISI; SCHULZ; DEPOORTER, op.cit., p. 3.

${ }^{989}$ Cf. STEVENSON, 1991, p. 63.

${ }^{990}$ Cf. HELLER, 1998, p. 677; HARDIN, [197-?].

${ }^{991}$ Cf. HARDIN, 2001a.

${ }^{992}$ Id., 1968.
} 
Um exemplo de regime de acesso aberto são as terras devolutas da Amazônia. Como a União não detém a capacidade de monitorar e de impedir a exploração insustentável de uma área que legalmente lhe pertence, na prática, os recursos naturais dispostos nestas terras podem ser livremente explorados por quem quer que seja, até seu total desaparecimento. ${ }^{993}$

No regime de propriedade privada, cabem a um ou mais indivíduos ou instituições os direitos de usar, fruir e gozar do bem e o de excluir terceiros não-autorizados. O regime de propriedade governamental é idêntico ao regime de propriedade privada, com a diferença de que o feixe de direitos está investido na figura do Estado. ${ }^{994}$ Os regimes de propriedade privada e governamental geralmente são tratados como uma solução legal para o problema da tragédia dos recursos comuns, porquanto o titular de direitos teria incentivos para geri-lo sustentavelmente, em seu próprio benefício. ${ }^{995}$ No entanto, a prática demonstra que não é suficiente o reconhecimento de direitos de propriedade para se prevenir a degradação dos recursos naturais. Isto porque, geralmente, os regimes de direito de propriedade não obrigam os titulares de direitos a gerirem sustentavelmente os recursos naturais presentes em suas terras. ${ }^{996}$ Com freqüência, direitos de propriedade são alocados para empresas mineradoras, pesqueiras para explorarem insustentavelmente recursos naturais e poluírem o meio ambiente. ${ }^{997}$

Finalmente, no regime de propriedade comum, um recurso normalmente passível de sobre-exploração e que apresenta produtividade difusa ${ }^{998}$ (e.g. uma floresta) é administrado cooperativamente por um grupo determinado de indivíduos, em consonância com normas sociais de governança, que especificam quais deles podem explorá-lo e em quais condições, com o objetivo de prevenir a emergência da tragédia dos recursos comuns. ${ }^{999}$ Os participantes de arranjos de propriedade comum abrem mão de perseguir seu bem-estar egoisticamente, em nome da realização do bem-comum da comunidade.

\footnotetext{
${ }^{993}$ Cf. OSTROM; HESS, 2003, p. 57.

994 Cf. HELLER, 2001, p. 85.

995 Ver, e.g., COLANGELO, 2004, p. 84; HELLER, 1998, p. 678; BOYLE, 2003b, p. 35.

${ }^{996}$ Cf. KIRSCH, 2004, p. 31.

${ }^{997}$ Ibid.

${ }^{998}$ Cf. THE ECOLOGIST, 1993, p. 8.

${ }^{999}$ Ver, e.g., STEVENSON, 1991, p. 46; OAKERSON, 1992, p. 47; BELL; PARCHOMOVSKY, 2007, p. 26; BELL; PARCHOMOVSKY, 2003, p. 44; GUPTA, 2004, p.15; SMITH, 2007, p. 46.
} 
Perante o mundo exterior, o recurso sujeito ao regime de propriedade comum se apresenta como uma propriedade privada tradicional, no sentido de que a comunidade deteria o poder (não necessariamente assegurado por lei) de excluir do gozo do recurso qualquer indivíduo estranho à comunidade. ${ }^{1000} \mathrm{Na}$ esfera interna da comunidade, seus integrantes estão investidos no direito de utilizá-lo, desde que observem as normas sociais, fixadas por um órgão ou membro da comunidade, competente para delinear as regras de boa gestão, controlar seus níveis de exploração, ${ }^{1001}$ monitorar seu cumprimento e sancionar os infratores. ${ }^{1002} \mathrm{Na}$ falta destas normas, todos os integrantes da comunidade consumiriam excessivamente o recurso compartilhado, em nome da maximização de seu bem-estar, já que aqueles que assim não se conduzissem, assumiriam o risco de perecer. ${ }^{1003}$

Para que o regime de propriedade comum funcione apropriadamente, a comunidade que governa o uso de um recurso natural precisa se manter coesa, o que ocorre normalmente em comunidades menores, onde cada membro reconhece que sua sobrevivência depende da sustentabilidade dos recursos naturais compartilhados. ${ }^{1004}$ Quando o tecido social da comunidade se rompe e seus membros deixam de se solidarizar com os interesses dos demais, ${ }^{1005}$ as normas sociais do grupo perdem sua força vinculante, aumentando as chances de degradação do recurso compartilhado. ${ }^{1006} \mathrm{O}$ mesmo ocorre quando indivíduos externos à comunidade passam a explorar o bem comunitário, de maneira desrespeitosa para com as determinações da comunidade, porquanto nada têm a perder, se degradá-lo. Em face destes indivíduos e organizações, as normas sociais das comunidades tradicionais nada podem. E como apenas raramente possuem títulos de propriedade, as comunidades não podem contar com o Poder Judiciário para excluírem os invasores de suas terras.

\footnotetext{
${ }^{1000}$ Cf. OSTROM; HESS, 2003, p. 59-61.

${ }^{1001}$ Cf. OSTROM et al., 1999.

${ }^{1002}$ Ver, e.g., STEVENSON, 1991, p. 40, 41, 51; THE ECOLOGIST, 1993, p. 9-12.

${ }^{1003}$ Cf. HARDIN, 1968, p. 1247.

${ }^{1004}$ Cf. THE ECOLOGIST, op.cit., p. 17-19.

1005 Cf. LIU, 2003, p. 83-84.

1006 Ver, e.g., STEVENSON, op.cit., p. 72; OAKERSON, op.cit., p. 50; BELL; PARCHOMOVSKY, 2003, p. 47-48.
} 
Com freqüência, as comunidades tradicionais são expulsas de suas terras ou têm seu espaço reduzido dramaticamente, ${ }^{1007}$ em nome de atividades agrícolas e extrativas e construção de represas, que impulsionam a degradação dos recursos de que depende sua sobrevivência. ${ }^{1008}$ Em vista da insegurança legal das comunidades tradicionais em relação às terras que ocupam, a garantia do direito de propriedade sobre elas é uma das condições para que gozem de uma vida digna em harmonia com a natureza. Caso contrário, tenderão a aviltá-las, já que podem ser expulsas a qualquer momento. ${ }^{1009}$

A fim de que as comunidades tradicionais gozem de um padrão de vida adequado em bases perenes, além da garantia da propriedade sobre os territórios que ocupam, é preciso assegurar-lhes uma fonte de renda satisfatória e regular, que lhes permitirá viver em permanente harmonia com a natureza. Mesmo as comunidades mais humildes e isoladas precisam de recursos que não podem ser adquiridos fora do mercado. ${ }^{1010} \mathrm{Sem}$ recursos econômicos, as comunidades se desmantelarão, à medida que as gerações mais jovens imigrarem para os centros urbanos, ${ }^{1011}$ em busca da libertação do cativeiro da miséria, ou se engajarão em atividades degradantes de seus territórios para garantir sua sobrevivência no curto prazo. ${ }^{1012}$ Um estudo recente encomendado pelo governo da GrãBretanha confirma esta última assertiva, ao identificar como uma das causas centrais da degradação das florestas dos países pobres a falta de incentivos econômicos para conserválas de pé. Enquanto um hectare da floresta amazônica brasileira, se cultivado com soja ou palma ou utilizado como pasto para gado de corte, produz, respectivamente, US\$ 3.275, US\$ 3.340 e US\$ 413, a mesma área, se utilizada para extração sustentável de madeira, produz US\$ 128. Neste último caso, como a área apenas poderia ser objeto de novas extrações após 30 anos, a rentabilidade anual do hectare cai para alguns poucos dólares. ${ }^{1013}$

\footnotetext{
${ }^{1007} \mathrm{Na}$ Colômbia, com a presença de empresas petroleiras em terras indígenas, no espaço de trinta anos, a extensão das terras ocupadas pelos povos indígenas locais reduziu-se em 90\%; e com a restrição das áreas, houve também um incremento substancial nas taxas de migração destes povos (DE LA CRUZ, 2005).

${ }^{1008}$ Cf. STEPHENS et al., 2006, p. 2021.

${ }^{1009}$ Ver, e.g., AGRAWAL, 2008; OFFICE OF CLIMATE CHANGE, 2008, p. 36.

${ }^{1010}$ Cf. POSEY, 2004e, p. 153.

${ }^{1011}$ Id., 2004h, p. 144.

1012 Ver, e.g., RIGHTS AND RESOURCES INITIATIVE; RAINFOREST FOUNDATION NORWAY, 2008; GUPTA, 2004, p. 15-16; SAHAI, 2004, p. 283.

1013 Cf. OFFICE OF CLIMATE CHANGE, 2008, p.41. No mesmo sentido, na Etiópia, na década de 60, as terras mais férteis foram degradadas para dar lugar à produção de algodão para exportação e, no Zimbábue, as terras mais ricas, em termos biológicos, deram lugar a pastagens para a produção de gado de corte para o mercado europeu (THE ECOLOGIST, 1993, p. 28-30). Na região Amazônia, desde a década de 70, os governos locais passaram a implementar projetos de "desenvolvimento" da região, i.e. projetos agrícolas, industriais, extrativistas não-sustentáveis, de mineração, construção de rodovias, pecuária. Esses projetos impulsionaram sua rápida degradação (POSEY, 2004a, p. 71-72).
} 
As negociações em curso na $\mathrm{CCDB}$, OMC e OMPI deveriam enfocar no estabelecimento de regimes, que tornem a conservação da biodiversidade em seus três níveis (genética, de espécies e de biomas) tão lucrativa quanto a sua destruição. ${ }^{1014}$ Para isso, os regimes de proteção dos RBIs devem viabilizar o uso comercial ético dos RBIs, ${ }^{1015}$ obrigando seus usuários a internalizar, em seus custos operacionais, o valor comercial dos insumos empregados e os custos suportados pelas comunidades tradicionais e países em desenvolvimento para conservá-los e desenvolvê-los. ${ }^{1016}$

Em outras palavras, é preciso obrigar os usuários de RBIs a pagar os custos associados à conservação de ecossistemas naturais, indispensáveis à manutenção e desenvolvimento dos RBIs, incluindo aqueles necessários a proporcionarem às comunidades, que habitam nestas áreas, condições de vida digna. Apenas assim, os Estados terão incentivos para conservarem a diversidade biológica, e as comunidades tradicionais terão os meios para viverem em harmonia com a natureza e adquirirem e/ou defenderem legal e politicamente as terras por elas ocupadas, indispensáveis à sua sobrevivência física e cultural.

\subsection{O PAPEL DAS ECTS NA GERAÇÃO DE BENEFÍCIOS ECONÔMICOS NO CURTO PRAZO}

Com vistas a permitir que as comunidades tradicionais alcancem um nível de vida adequado a partir dos benefícios derivados das aplicações comerciais de seu PBI, os regimes internacionais em negociação precisam ser estruturados de maneira a viabilizar a geração de recursos econômicos no curto, médio e longo prazo. A literatura, a mídia e as negociações internacionais em curso enfocam majoritariamente na importância comercial dos recursos da biodiversidade e CTAs, ignorando ou tratando com timidez o potencial econômico das ECTs. É inconteste o potencial comercial ínsito aos recursos da biodiversidade e aos CTAs; uma única droga desenvolvida a partir da associação entre

\footnotetext{
${ }^{1014}$ Ver, e.g., BRUSH, 2004, p. 8 e 14; POSEY, 2004j, p. 62.

1015 Ver, e.g., DAES, 1997, para. 67. Em sentido contrário, VAN BEEK; JARA (2002, p. 56-57) consideram que a promoção da comercialização do PBI equivale à uma prática neocolonial.

${ }^{1016}$ Ver, e.g., BRUSH, 1994, p. 14; COSTANZA et al., 1997, p. 253; TWAROG, 2004, p. 100; LATTIF; ZAKIR, 2004, p. 307-308; BIBER-KLEMM, 2004, p.97.
} 
CAPÍTULO 3 | 205

cultura tradicional e biodiversidade pode gerar dividendos da ordem de US\$ 1 bilhão/ano. ${ }^{1017}$

Sem embargo, o processo de transformação de recursos da biodiversidade e CTAs em produtos eficazes e seguros ao uso humano consome, em média, de dez a quinze anos $^{1018}$ e centenas de milhões de dólares. ${ }^{1019}$ Sem contar que nem toda boa promessa de produto biomédico se confirma após a realização dos testes pré-clínicos (em animais) e clínicos (em seres humanos). A empresa farmacêutica norte-americana Napo Pharmaceuticals, contabilizando o tempo investido por sua antecessora, a Shaman Pharmaceuticals, ${ }^{1020}$ já investiu mais de 18 anos no processo de P\&D de uma nova droga para o tratamento dos portadores do HIV/AIDS ${ }^{1021}$ (crofelemer), extraída do látex da árvore Croton lechleri, nativa da floresta Amazônica. Até o ano de 1999, o laboratório havia investido mais de US\$ 90 milhões. Atualmente, a empresa está na rodada final de testes de comprovação da segurança e eficácia da nova droga. ${ }^{1022}$

Mesmo quando as comunidades tradicionais recebem alguma compensação pela transferência de CTs e recursos da biodiversidade ao setor produtivo, antecipadamente à existência de um produto pronto para o mercado, os benefícios de grande monta geralmente são pagos a partir da comercialização do novo produto. ${ }^{1023} \mathrm{E}$ o que farão as comunidades tradicionais no período de dez, quinze ou vinte anos, se despidas de recursos econômicos que lhes proporcionem os meios para viverem condignamente?

As comunidades podem seguir três caminhos: podem conservar seus recursos naturais, mas morrerem prematuramente pelas péssimas condições de vida vigentes (i); a pressão imposta pelas dificuldades materiais conduzi-las-á a explorar insustentavelmente os recursos naturais de seus territórios (ii); seus membros imigrarão para outras regiões, em

\footnotetext{
${ }^{1017}$ O Taxotere ${ }^{\circledR}$ (docetaxel), produzido pela empresa Sanofi-Aventis, é extraído da árvore Taxus Baccata e gerou, em 2005, lucro da ordem de US\$ 1.6 bilhões (SAINI, 2006).

1018 Cf. INTERNATIONAL FEDERATION OF PHARMACEUTICAL MANUFACTURERS \& ASSOCIATIONS, 2005, p. 3; MARSHALL, 2004.

${ }^{1019} \mathrm{O}$ setor industrial estima que o desenvolvimento de um novo produto farmacêutico, apto a ser introduzido no mercado, consume em torno de US\$ 800 milhões (TUFTS[...], 2001).

${ }^{1020}$ Shaman Pharmaceuticals foi à falência em 1999, tendo sido o ápice de seu problema, o insucesso para obter aprovação no Food and Drugs Administration, a agência de vigilância sanitária norte-americana, para a comercialização de uma nova droga para o tratamento dos efeitos do HIV/AIDS (ABATE, 1999).

$1021<$ http://www.napopharma.com/products/sustainability.html $>$. Acesso em: 23 jan. 2009.

$1022<$ http://www.napopharma.com/clinicaltrials.html $>$. Acesso em: 23 jan. 2009.

${ }^{1023}$ Cf. SAMPATH, 2005, p. 153.
} 
busca de melhores condições de vida (iii). No ritmo em que a biodiversidade está sendo destruída, se os benefícios econômicos demorarem a chegar, quando finalmente aportarem, poderá ser tarde demais para as comunidades e para a natureza.

Diferentemente dos recursos da biodiversidade e dos CTAs, as ECTs apresentam um potencial comercial que pode ser traduzido em produtos de grande apelo comercial no curtíssimo prazo, sem a necessidade de investimentos de grande monta. Os resultados alcançados pelos projetos conduzidos pelas organizações Artesanato Solidário (ARTESOL) $^{1024}$ e Amigos do Bem Contra a Fome e a Miséria no Sertão Nordestino (Amigos do Bem) e as experiências da Grendene e do estilista brasileiro Walter Rodrigues atestam tal potencial.

Em 1998, as populações do Nordeste brasileiro e do norte do Estado de Minas Gerais foram castigadas pela fome, como resultado de uma longa estiagem. Dra. Ruth Cardoso, ex-professora de antropologia da Universidade de São Paulo e então presidente do Conselho do Programa Comunidade Solidária, tinha a difícil missão de propor um projeto de geração imediata de renda para populações marginalizadas, com pouca escolaridade, baseadas em regiões com baixo Índice de Desenvolvimento Humano (IDH). ${ }^{1025}$ Dra. Cardoso, em sua capacidade de antropóloga, e sua equipe multidisciplinar identificaram um capital social valioso, peculiar a estas populações e que, se bem explorado, poderia auxiliá-las a quebrar o ciclo de pobreza, em que se viam presas desde tempos imemoriais: o artesanato de tradição. ${ }^{1026}$ Neste mesmo ano, foi estabelecido o Programa Artesanato Solidário cujo objetivo, nas palavras de Helena Sampaio, diretora da organização sucessora do programa, é "revitalizar o artesanato tradicional como uma manifestação da cultura popular brasileira e, por meio desta revitalização, gerar renda."1027

À época, seis projetos-piloto emergenciais de geração de trabalho e renda foram colocados em teste. Em cada projeto, uma equipe de técnicos ficou encarregada de identificar ECTs típicas das comunidades beneficiárias, aptas a serem reproduzidas para

1024 As informações sobre os trabalhos da organização ARTESOL foram obtidas no site $<$ www.artesol.org.br> e em entrevistas realizadas em 30 de julho e em 11 de setembro de 2007, com Helena Sampaio, diretora responsável pela organização desde a sua fundação.

${ }^{1025} \mathrm{IDH}$ até 0,499 .

1026 A ARTESOL define artesanato de tradição como "o saber fazer compartilhado por grupos sociais específicos, que transmitem determinadas técnicas e repertório de geração a geração"(ARTESOL. 2008).

${ }^{1027}$ SAMPAIO, 2003, p. 45. 
fins comerciais, bem como artesãos locais, dispostos a capacitar outros membros da comunidade. O projeto envolveu, igualmente, o aprimoramento técnico dos antigos artesãos a fim de melhorar a qualidade e a variedade de suas produções artesanais. Os projetos foram além das expectativas iniciais; quatro anos mais tarde, 42 projetos haviam sido desenvolvidos com sucesso em diversas regiões do Brasil.

A maturidade do Programa foi brindada com sua desvinculação do Governo Federal, em 2002. Neste ano foi criada a Artesanato Solidário: programas de apoio ao artesanato e à geração de renda (ARTESOL), organização da sociedade civil de interesse público (OSCIP), sem finalidade lucrativa cujo objetivo é "a promoção do diálogo (entre artesãos tradicionais e o mercado consumidor), a formação de recursos humanos e a ampliação do acesso ao mercado, mediante a sensibilização do público consumidor de

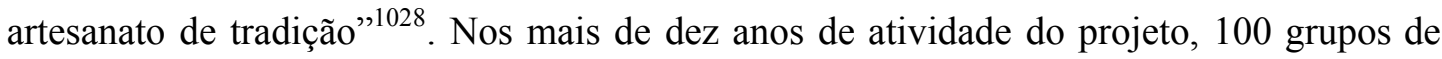
artesanato de tradição foram formados em 17 Estados do Brasil, em benefício de mais de 5.000 artesãos, baseados em regiões materialmente pobres.

No mesmo sentido do projeto ARTESOL, a ONG Amigos do Bem, há mais de 16 anos, auxilia mensalmente milhares de famílias vitimadas pela seca no sertão, com alimentos, remédios, roupas e educação. Nos últimos cinco anos, a organização passou a investir em projetos auto-sustentáveis, que envolvem os sertanejos em atividades produtivas. Um dos projetos, em fase de implementação, é uma vila agrícola, em Pernambuco, que já conta com 100.000 cajueiros plantados. O resultado financeiro do cultivo será integralmente revertido em favor dos projetos da organização. Enquanto os cajueiros crescem e amadurecem - o que ainda pode consumir vários anos - a organização vem fomentando a produção local e a comercialização de peças de artesanato de tradição, a fim de satisfazer as demandas sociais dos sertanejos, no curto e médio prazo. ${ }^{1029}$

No ano 2000, o estilista Walter Rodrigues visitou a Associação de Rendeiras do Morro da Mariana, localizada em uma região materialmente empobrecida do Estado do Piauí. ${ }^{1030}$ As artesãs associadas são especializadas na produção de renda de bilro, ofício

\footnotetext{
1028 Cf. SAMPAIO, 2003, p. 49-50.

1029 Informações extraídas do site: $<$ http://www.amigosdobem.org/ > .

${ }^{1030}$ Cf. LAGES, [200-].
} 
transmitido de geração em geração às mulheres da região. ${ }^{1031}$ Rodrigues capacitou as rendeiras a trabalharem com fios nobres e tecnológicos, como a seda e a lycra, para a produção de rendas que foram incorporadas a peças de alta costura, comercializadas no Brasil e na Europa. ${ }^{1032}$ Desde então, a exposição na mídia aumentou a demanda comercial pelos produtos da associação e, reflexamente, o faturamento das rendeiras e o número de artesãs associadas. Com o sucesso comercial renasceu o interesse das filhas das rendeiras em aprender e/ou se aperfeiçoar no ofício de suas mães, como forma de ganharem o pão de cada dia e perpetuarem o patrimônio cultural de suas ancestrais.

No período 1995-2005, as taxas de desmatamento nas áreas de nascentes do rio Xingu dobraram, colocando em risco a sobrevivência de um rio de mais de $2.700 \mathrm{~km}$ de extensão, a biodiversidade e os povos indígenas da região e outras 250 mil pessoas que dele dependem para sobreviver. ${ }^{1033}$ Em 2007, a indústria calçadista Grendene lançou a linha de sandálias Ipanema Gisele Bündchen Y Ikatu Xingu, as quais reproduzem grafismos indígenas, criados com exclusividade por artistas da tribo Kisedjê, baseada na região do rio Xingu, na Amazônia brasileira, durante uma oficina criativa, que ocorreu em 2006. Com o objetivo de melhorar a qualidade de vida dos povos indígenas da região, a Grendene reverteu um percentual dos lucros auferidos com a comercialização das sandálias para o projeto Y Ikatu Xingu, conduzido pelo Instituto Socioambiental, dedicado ao reflorestamento das matas ciliares das nascentes do Xingu. ${ }^{1034}$

As experiências da ARTESOL, que logrou retirar milhares de famílias da miséria por meio do uso comercial de ECTs; da Grendene, que transformou, em um curto espaço de tempo, grafismos indígenas em produtos éticos de grande lucratividade ${ }^{1035}$; dos Amigos do Bem, que vem gerando renda para a satisfação das necessidades imediatas das vítimas da centenária seca no sertão; e de Walter Rodrigues, que trouxe um mundo de novas oportunidades às rendeiras do Piauí ensinam que as ECTs podem se tornar um forte aliado da conservação da diversidade biocultural e da melhoria da qualidade de vida de comunidades tradicionais, com poucos investimentos e em um curto espaço de tempo.

\footnotetext{
${ }^{1031}$ Cf. MAGALHÃES, 2006.

1032 Cf. PIONER, 2009.

${ }^{1033}$ Cf. PACCE, 2006.

$1034<$ http://www.yikatuxingu.org.br/a-campanha> . Acesso em: 23 jan. 2009.

1035 Segundo informações da Grendene, a coleção Ipanema Giselle Bündchen Y Ikatu Xingu vendeu 40\% a mais que a coleção anterior (NAIDITCH, 2007).
} 
A geração de benefícios econômicos no curto, médio e longo prazo depende da adoção de regimes internacionais que protejam o PBI como um todo, ao invés de tratar os CTs e a biodiversidade com as jóias da coroa, relegando as ECTs a um segundo plano. A proteção das ECTs permite gerar incentivos econômicos naqueles momentos, em que a biodiversidade e os CTs são inaptos, em virtude do longo e complexo processo pelo qual precisam passar até serem transformados em produtos prontos ao mercado. Em outras palavras, a adoção de regimes de proteção das ECTs é um complemento indispensável aos regimes de proteção de CTs e recursos da biodiversidade, se de fato a comunidade internacional buscar um marco legal promotor do bem-estar das comunidades tradicionais.

O crescimento do bolo de benefícios derivados do uso comercial do PIB é fundamental para financiar medidas de proteção das comunidades tradicionais e de preservação da diversidade biocultural. No entanto, para alcançar essas metas é igualmente indispensável dirigir sua aplicação. Os setores produtivos tendem a se concentrar em maximizar seus lucros, sem se importar com o destino dos benefícios pagos a título de repartição de benefícios. Não havendo uma garantia legal de que os benefícios pagos pelos usuários de RBIs serão revertidos em benefícios das comunidades tradicionais e da conservação da biodiversidade, as partes receptoras - por exemplo, uma agência governamental - podem desperdiçá-los em atividades burocráticas inúteis e dispendiosas ou em projetos dissociados das fontes ambientais e humanas do RBI utilizado. E ainda que os recursos sejam revertidos em favor das comunidades tradicionais, na falta de diretrizes de aplicação, as autoridades das comunidades podem empregá-los discriminatoriamente e.g. em detrimento das mulheres e crianças ${ }^{1036}$ - ou na realização de projetos prejudiciais à biodiversidade, e.g., na compra de moto serras para viabilizar a extração de madeiras nobres em seus territórios.

Um marco internacional de proteção do PBI não deve objetivar simplesmente a geração de recursos materiais a partir de sua exploração comercial; deve se ocupar em gerar recursos materiais dirigidos à dignificação das fontes humanas e conservação das fontes ecológicas que o sustenta. ${ }^{1037} \mathrm{O}$ recebimento dos benefícios derivados do PBI pelas

\footnotetext{
${ }^{1036}$ Não podemos ignorar que embora as comunidades tradicionais possam gozar de autonomia para gestão de assuntos de interesse interno, sua autonomia é limitada pelos direitos humanos universalmente reconhecidos para cada um de seus membros. Neste sentido ver art. 5(1), PIDESC; art. 5(1), PIDCP; art. $5^{\circ}$ in fine, Declaração Universal sobre a Diversidade Cultural.

${ }^{1037}$ Cf. SHIVA, 2001, p. 100; GAIA/GRAIN, 1998.
} 
comunidades tradicionais e, dependendo do caso, pelos Estados deve ser condicionado à sua aplicação em projetos associados à conservação ambiental e recuperação de áreas naturais degradadas, ${ }^{1038}$ bem como em projetos dedicados à melhoria da qualidade de vida de todos os membros das comunidades tradicionais, sem discriminação.

\subsubsection{CRITÉRIO DE OPERACIONALIZAÇÃO 2: DiREITO DE ACESSO AMPLO E FACILITAdO AO PBI}

Ao mesmo tempo em que a $\mathrm{CDB}$ confere aos Estados nacionais e às comunidades tradicionais, respectivamente, um direito de propriedade sobre os recursos biológicos que conservam em condições in situ e sobre seus conhecimentos tradicionais associados à biodiversidade, também determina que os Estados contratantes facilitem o acesso a estes recursos e conhecimentos para fins produtivos que se harmonizem com a conservação da natureza. ${ }^{1039}$ Assim sendo, a própria CDB reconhece que os interesses dos Estados nacionais e das comunidades tradicionais deve ser harmonizado com os interesses da sociedade de aplicar produtivamente os recursos da biodiversidade e os conhecimentos tradicionais conexos.

Exatamente no mesmo sentido da CDB, o art. 15(1)(a) do PIDESC não só assegura às comunidades tradicionais a proteção de seus interesses econômicos relacionados aos RBIs que desenvolvem e conservam, mas igualmente determina que a proteção concedida a estes interesses se harmonize com o direito de todos a participar da vida cultural. Esse direito assegura a todo ser humano, inter alia, a liberdade de se engajar em atividades criativas "com o objetivo de [promover] o desenvolvimento integral de sua personalidade; uma vida harmoniosa e o progresso cultural [e científico] da sociedade". ${ }^{1040}$ Diferentemente da maioria dos direitos reconhecidos pelo PIDESC, o direito de participar

${ }^{1038}$ Cf. SCBD, 2002, para. 22, 48 e 51(d) (estes dispositivos das Diretrizes de Bonn encorajam a reversão dos recursos econômicos derivados do uso comercial da biodiversidade em favor de sua conservação).

${ }^{1039}$ Cf. artigos 15(2), 17(2), 18(4), CDB. O art. 15(2) determina que "[e]ach Contracting Party shall endeavour to create conditions to facilitate access to genetic resources for environmentally sound uses by other Contracting Parties and not to impose restrictions that run counter to the objectives of this Convention" (grifo nosso). É surpreendente que a tradução da CDB para a língua portuguesa suprima o termo "facilitar" de seu texto: "Cada Parte Contratante deve procurar criar condições para permitir o acesso a recursos genéticos para utilização ambientalmente saudável por outras Partes Contratantes e não impor restrições contrárias aos objetivos desta Convenção."

${ }^{1040}$ Cf. UNESCO, Recommendation on Participation by the People at Large in Cultural Life and their Contribution to It, para. 2(b); art. 15(3), PIDESC. 
da vida cultural, entendido como liberdade de conduzir pesquisas científicas e atividades criativas, é considerado um direito auto-executável pelo Comitê de Direitos Econômicos, Sociais e Culturais. ${ }^{1041}$

O exercício do direito de participar da vida cultural tem como condição necessária o direito de acesso à cultura, o qual compreende o direito de obter livremente, inter alia, “informação, treinamento, conhecimento [...] e de gozar dos valores culturais e da propriedade cultural. ${ }^{, 1042} \mathrm{O}$ direito de acesso à cultura não visa simplesmente a satisfazer a necessidade humana de consumir bens culturais para sua autosatisfação; tem, em verdade, por fim último munir o ser humano das ferramentas, que o capacite a participar, na condição de agente, da melhoria do bem-estar da humanidade, por intermédio do desenvolvimento ininterrupto da ciência, cultura e educação. ${ }^{1043}$

Sem a garantia do direito de acesso à cultura, o direito de cada indivíduo e comunidade de "beneficiar-se da proteção dos interesses morais e materiais decorrentes de toda a produção científica, literária ou artística de que seja autor" ${ }^{\text {"1044 }}$ restaria esvaziado de substância, uma vez que os potenciais autores e criadores não disporiam dos instrumentos para se envolverem em atividades criativas e inventivas. ${ }^{1045}$

Em reconhecimento à importância liberdade de científica e criativa, os Estados contratantes do PIDESC, quando implementarem o art. 15(1)(c), devem adotar medidas garantidoras da difusão científica e cultural ${ }^{1046}$ e da "liberdade indispensável à pesquisa científica e à atividade criadora." ${ }^{~} 1047$ Preocupados com os impactos dos resultados das negociações internacionais relacionadas à proteção dos RBIs sobre a liberdade científica e

\footnotetext{
${ }^{1041}$ Cf. CESCR, 1990, para. 5.

1042 UNESCO, Recommendation on Participation by the People at Large in Cultural Life and their Contribution to It, para. 2(a). Este direito é assegurado pelos parágrafos 20 e 30 do art. 15, PIDESC.

${ }^{1043}$ Cf. UNESCO, Recomendación relativa a la situación de los investigadores científicos, para. 14(d). O parágrafo 26 desta mesma recomendação retrata o livre "intercâmbio de idéias e de informação entre os investigadores científicos do mundo inteiro [...] [como] condição indispensável” para a liberdade científica (tradução nossa). No mesmo sentido, a Declaração do Conselho Internacional para a Ciência de 1995 afirma "[a]s the intrinsic nature of science is universal, its success depends on co-operation, interaction and exchange, often beyond national boundaries. Therefore, ICSU strongly supports the principle that scientists must have free access to each other and to scientific data and information. It is only through such access that international scientific co-operation flourishes and science thus progresses" (INTERNATIONAL COUNCIL FOR SCIENCE, 1995).

${ }^{1044}$ Cf. art. 15(1)(c), PIDESC.

${ }^{1045}$ Cf. CESCR, E/C.12/GC/17, para. 29.

${ }^{1046}$ Cf. art. 15(2), PIDESC.

${ }^{1047}$ Cf. art. 15(3), PIDESC.
} 
criativa, países industrializados ${ }^{1048}$ e organizações representativas dos interesses do setor produtivo $^{1049}$ se mostram contrários à adoção de qualquer medida que restrinja excessivamente o acesso ao PBI para fins produtivos.

A relação entre direito de acesso à cultura e o direito de participar ativamente da vida cultural foi igualmente explicitada na Convenção sobre a Proteção e a Promoção da Diversidade das Expressões Culturais. Com vistas a promover a diversidade de expressões culturais, a convenção da UNESCO demanda a adoção de medidas que incitem indivíduos e grupos a "criar, produzir, difundir e distribuir suas próprias expressões culturais"1050 e que propiciem o acesso às “diversas expressões culturais procedentes de seu território e dos demais países do mundo."1051

O acesso livre ao conhecimento propicia, pois, o aprimoramento mais acelerado das capacidades científicas, industriais e culturais dos indivíduos e organizações públicas e privadas $^{1052} \mathrm{e}$, indiretamente, o fortalecimento da capacidade de investimentos dos Estados em serviços públicos, suportado pelo incremento de sua renda tributária resultante da expansão das atividades comerciais. No mais, a livre circulação de idéias e de conhecimento é um dos garantes da diversidade cultural. ${ }^{1053}$

Por conta de sua importância instrumental para a realização de outros direitos, historicamente, os regimes de proteção da propriedade intelectual salvaguardaram o direito de acesso à cultura mediante a proteção do domínio público. Mas, na atualidade, o domínio

\footnotetext{
${ }^{1048}$ Cf. WIPO, WIPO/GRTKF/IC/12/5(b) anexo, p. 23 e 30.

1049 Ver, e.g., ICC, 2008a (a CCI critica que as negociações em curso tratem "desproporcionalmente" sobre o tema repartição de benefícios e negligenciem as condições de acesso ao PBI e as necessidade dos usuários); ROBERTS, 2004, p. 93-94 (assinala que os círculos industriais não se colocam contrários à adoção de um regime internacional de proteção do PBI, mas à adoção de regimes que coloquem em risco as atividades do setor empresarial, relacionadas à geração de novos produtos e que impeçam o uso de DPIs para protegê-los). No mesmo sentido, a posição da organização Intellectual Property Owners Association (IPO), (WIPO, WIPO/GRTKF/IC/12/5(b), anexo, p. 99).

${ }^{1050}$ Cf. art. 7(1)(a), CPPDEC.

${ }^{1051}$ Cf. art. 7(1) (b), CPPDEC.

1052 Ver, por exemplo, UNGA, Resolution 1713 (afirma que o acesso ao conhecimento científico e tecnológico é essencial para acelerar o desenvolvimento econômico dos países subdesenvolvidos e para ampliar a produtividade total de suas economias).

${ }^{1053} \mathrm{Cf}$. art. $6^{\circ}$, UNESCO, Declaração Universal da UNESCO sobre a Diversidade Cultural. A CPPDEC reconhece, em seu preâmbulo, "que a diversidade cultural se fortalece mediante a livre circulação de idéias e se nutre dos intercâmbios e das interações constantes entre as culturas". Inclusive, é de se notar, que esta convenção tem como um de seus objetivos promover a diversidade cultural por meio da ampliação do intercâmbios culturais. Cf. art. 1(a), (b), (c), CPPDEC.
} 
público se encontra em processo de franca erosão, em razão da concepção de desenvolvimento sustentável ainda ser tratada como um ideal retórico.

\subsection{O DOMÍNIO PÚBLICO, OS DPIS E O DIREITO DE ACESSO AO CONHECIMENTO}

Os processos de inovação e criação têm natureza social e cumulativa, ${ }^{1054}$ assentando-se sobre a associação de informações e conhecimentos diversos e complementares, ${ }^{1055}$ originários de múltiplas fontes. ${ }^{1056} \mathrm{~A}$ capacidade de indivíduos e organizações de gerar novos bens intelectuais não depende simplesmente da engenhosidade dos envolvidos nos processos de criação e inovação; subordina-se substancialmente às oportunidades de acessar, compartilhar e processar artefatos intelectuais pré-existentes (i.e. idéias e informações ${ }^{1057}$ ), desenvolvidos por outrem. ${ }^{1058} \mathrm{~A}$ veracidade desta afirmação é ilustrada pelas práticas da indústria do melhoramento vegetal: novas variedades vegetais são desenvolvidas a partir da combinação de recursos fitogenéticos pré-existentes. A combinação de diversos recursos produz uma variedade vegetal até então inexistente no mercado. A nova variedade lança, por sua vez, novos pontos de partida para os processos futuros de melhoramento vegetal. ${ }^{1059}$

Nenhum indivíduo ou organização envolvida em atividades de criação e desenvolvimento detém a capacidade para explorar todas as possibilidades de aprimoramento e aplicação de suas produções intelectuais. Sem embargo, outros competidores podem congregar informações, conhecimentos e expertise não controlados pelo criador originário. A diversidade natural de habilidades, associada à liberdade de acesso às criações e inovações pretéritas enseja a perenidade dos ciclos de inovação e criatividade. $^{1060}$

Portanto, qualquer insumo informacional apresenta uma natureza dual: é ao mesmo tempo uma commodity, pronta a ser consumida, e uma matéria-prima, assimilável em

\footnotetext{
1054 Cf. SCOTCHMER, 1991, p. 29-30.

${ }^{1055}$ Cf. FELDMAN, 2002, p. 52.

${ }^{1056}$ Cf. MANDERVILLE, 1998, p. 360.

${ }^{1057}$ Cf. SAMUELSON, 2006, p. 13.

${ }^{1058}$ Ver, e.g., VAN CAENEGEN, 2003, 3, p. 248; BARTON, [200-].

${ }^{1059}$ Cf. WEITZMAN, 1998, p. 336.

${ }^{1060}$ Cf. BESSEN; MASKIN, 2006, p.19-20.
} 
novos processos de criação e inovação. ${ }^{1061}$ Um produto aplicado como matéria-prima em um processo de criação resultará em um novo bem, que servirá de ponto de partida para novos processos criativos. Cada ciclo de criação e inovação expande incrementalmente a base de conhecimentos da sociedade. ${ }^{1062}$ A velocidade deste ciclo e a qualidade de seus resultados dependem da robustez do domínio público ${ }^{1063}$ e de sua acessibilidade. ${ }^{1064}$ Portanto, embora o domínio público venha servindo de justificação para a livre apropriação dos RBIs, apresenta ainda uma função produtiva que não deve ser ignorada. $^{1065}$

O domínio público é um espaço estabelecido em virtude de lei, onde indivíduos e organizações podem livremente ${ }^{1066}$ buscar e explorar recursos informacionais, em sua capacidade de bens de consumo (e.g. imprimir um livro de Machado de Assis, disponível na internet) ou de fator de produção (e.g. publicar uma coletânea das obras de Machado de Assis com o objetivo de lucro). ${ }^{1067}$ Em razão dos elementos que compõem o domínio público terem a natureza de bens públicos, ${ }^{1068}$ seu uso por diversos indivíduos e instituições conduz à geração de novos bens intelectuais que, imediata ou mediatamente, acabarão por enriquecer o domínio público. ${ }^{1069}$

A existência e os contornos do domínio público dependem dos termos dos regimes de DPI de cada país. ${ }^{1070}$ Cabe aos regimes domésticos determinar o que pertence ao domínio privado e o que permanece em domínio público. ${ }^{1071}$ Por conseguinte, os contornos e conteúdo do domínio público variam no tempo, no espaço e de acordo com o público. ${ }^{1072}$

\footnotetext{
${ }^{1061}$ Ver, e.g., DINWOODIE; DREYFUSS, 2006, p. 200-201; SAMUELSON, 2003, p. 107; BOYLE, 2003b, p.43 (nas palavras breves e claras de Boyle, “[y]our information output is someone else's information input”); INTERNATIONAL EXPERT GROUP ON BIOTECHNOLOGY, INNOVATION AND INTELLECTUAL PROPERTY, 2008, p. 4.

1062 Cf. KUNDNANI, 1998-1999, p. 56.

1063 Cf. LECHNER; GUBAYDULLINA; BIZER, 2008, p. 8.

${ }^{1064}$ Cf. CUMBRE MUNDIAL DE LA SOCIEDADE DE LA INFORMACIÓN , WSIS-03/GENEVA/4-S, para. 25-26.

${ }_{1065}$ Sobre a definição de domínio público ver item 2.2.4 supra.

1066 Ver, e.g., DEAZLEY, 2007, p.23; THOMPSON, B., 2007, p.134; OZDEMIR et al., 2006, p. 942; BOYLE, 2003a, p.8.

${ }^{1067}$ Cf. SALZBERGER, 2006, p. 31-32.

${ }^{1068} \mathrm{Cf}$. item 1.2.1 supra.

${ }^{1069}$ Cf. MERTON, 1988, p. 620; TREIGER-BAR-AM, 2007, p. 12.

${ }^{1070}$ Ver, e.g., MACMILLAN, 2007, p.109; SHERMAN; WISEMAN, 2006, p. 272

${ }^{1071}$ Cf. GIBSON, 2007, p. 178.

1072 Cf. DEAZLEY, 2007, p. 25-29.
} 
Em termos espaciais, uma vez que os DPIs são territoriais, cada Estado goza de discricionariedade para estabelecer o domínio privado elegível para proteção mediante DPIs e, reflexamente, seu domínio público. Cada Estado possui um domínio público próprio cuja extensão é um reflexo das opções legais realizadas e dos desenvolvimentos jurisprudenciais na matéria. ${ }^{1073}$ Em termos temporais, o domínio público varia ao longo do tempo, podendo ser alterado mediante decisões legislativas e judiciais, que o restringem ou ampliam, à medida que os direitos dos titulares de DPI são mais ou menos expandidos. ${ }^{1074}$ Finalmente, o conteúdo do domínio público varia de acordo com o público. Por exemplo, a legislação de direitos autorais de um país pode liberar a reprografia de obras protegidas por instituições de ensino e proibir sua prática por instituições empresariais.

Inexiste, pois, um domínio público internacional, previsível e facilmente aferível. Segundo Taubman, o domínio público internacional compreende o "conjunto dos domínios públicos nacionais, que, por sua vez, compreendem a soma daqueles elementos que possuem o status de domínio público em face das leis nacionais."1075

Os tratados internacionais, apenas em caráter excepcional, estabelecem as matérias que obrigatoriamente deverão ser conservadas em domínio público. ${ }^{1076}$ Isto porque a força propulsora por detrás destes instrumentos são os interesses dos criadores de produções intelectuais. Em regra, os acordos internacionais de PI circunscrevem-se a fixar o conteúdo mínimo do domínio privado, ao estipular as matérias que obrigatoriamente devem receber proteção legal, o alcance máximo das limitações e exceções aos direitos conferidos, a duração mínima da proteção conferida. ${ }^{1077}$ Uma vez que estes acordos estabelecem apenas os patamares mínimos de proteção, cada Estado poderá optar por reconhecer proteção mais extensiva que aquela a que se obrigou.

${ }^{1073}$ Cf. TAUBMAN, 2007, p. 70.

1074 Esse exemplo é claro no campo dos produtos farmacêuticos: o Brasil e muitos outros países em desenvolvimento, não concediam proteção a produtos farmacêuticos e alimentícios até a criação da $\mathrm{OMC}$, que veio acompanhada pela adoção do Acordo TRIPS, que passou a obrigar a todos seus membros a conceder proteção patentária a "qualquer invenção, de produto ou de processo, em todos os setores tecnológicos" (art. 27(1), TRIPS).

1075 Cf. TAUBMAN, 2007, p. 70, tradução nossa.

1076 Ver, por exemplo, o art. 9(2) do Acordo TRIPS, que pró́be os Estados membros da OMC de reconhecerem direitos autorais sobre as idéias que permeiam as expressões artísticas objeto de proteção autoral.

${ }^{1077}$ Cf. TAUBMAN, 2007, p. 81-82. 
Da mesma forma que a vida humana depende de fontes de energia para se conservar em atividade e se expandir para além de seu estado presente, ${ }^{1078}$ a criatividade humana igualmente depende de fontes de energia para expandir as fronteiras da criatividade e da ciência. O domínio público figura como este reservatório de energia. Sem ele, o desenvolvimento humano e sua capacidade de satisfação de suas necessidades e desejos se deterioram. ${ }^{1079}$ A Declaração de Princípios da Cúpula Mundial da Sociedade da Informação defende a proteção de um domínio público robusto a fim de fomentar expansão da Sociedade da Informação, porquanto viabiliza a instrução do público, a criação de "novos empregos, inovação, oportunidades comerciais e o avanço das ciências." 1080

As legislações de PI reconhecem, ainda que tacitamente, a importância do domínio público para o processo de inovação e criação ao: limitar a duração dos DPIs conferidos; excluir determinadas matérias do rol de matérias elegíveis de proteção; estabelecer limitações aos direitos de exclusivo investidos nos titulares de DPIs; impedir a obtenção de DPIs sobre criações e inovações já de conhecimento público, ${ }^{1081}$ a fím de afastar obstáculos permanentes ao processo de aprimoramento dos bens protegidos. ${ }^{1082}$

O fato de o domínio público ser tratado como um mero espaço residual composto por tudo aquilo que não é tutelado pelos DPIs ${ }^{1083}$ figura como seu calcanhar de Aquiles. Drahos define o domínio público como um recurso comum negativo, ou seja, aquele sobre o qual ninguém detém um direito de propriedade, mas todos detêm uma prerrogativa de utilizá-lo livremente e inclusive de apropriá-lo, em detrimento dos interesses gerais. ${ }^{1084}$

Em posição diversa, estão os recursos comuns positivos, isto é, aqueles compartilhados por um grupo pré-determinado, e.g. uma comunidade tradicional (recursos

\footnotetext{
1078 Cf. HARDIN, 1968.

${ }^{1079}$ Cf. SHERMAN; WISEMAN, 2006, p. 260.

${ }^{1080}$ Cf. CUMBRE MUNDIAL DE LA SOCIEDAD DE LA INFORMACIÓN, WSIS-03/GENEVA/4-S, para. 26. No mesmo sentido consultar SAMUELSON, 2006, p. 22

${ }^{1081}$ Cf. WESTERLUND, 2002, p. 42.

1082 Cf. DINWOODIE; DREYFUSS, 2006, p. 196.

${ }^{1083}$ Cf. SHERMAN; WISEMAN, op.cit., p. 260. Um exemplo interessante de como o domínio público é maltratado está em um documento da Câmara de Comércio Internacional, que, ao mesmo tempo em que reconhece que o processo de inovação é construído incrementalmente sobre inovações anteriores de fontes diversas, defende o patenteamento de inovações incrementais (inovações triviais; inovações menores, mas que são tecnicamente úteis). A CCI não enfrenta quais seriam os efeitos que resultariam da extensão inadvertida das patentes para inovações incrementais sobre a acessibilidade das matérias-primas técnicas (ICC, 2005b, p. 5).

${ }^{1084}$ Cf. DRAHOS, 2006. No mesmo sentido, ver CAHIR, 2007, p.37-41.
} 
comuns positivos exclusivos) ou indistintamente por todos os membros da humanidade (recursos comuns positivos inclusivos). Os recursos comuns positivos conferem aos seus cotitulares um direito de uso, que apenas poderá ser limitado com a anuência de todos eles. Um exemplo de recurso comum positivo são as obras literárias e artísticas objeto das licenças Creative Commons. À medida que seus usuários observarem rigorosamente as condições fixadas pelos titulares de direitos, o uso das obras se conservará livre. $\mathrm{Na}$ hipótese dos usuários quebrarem as condições fixadas pela licença, sem a anuência do licenciador, este poderá lançar mão de seus direitos de exclusivo para impedir ou neutralizar os atos de apropriação. Já os bens em domínio público (e.g. RBIs em muitas jurisdições) podem ser livremente apropriados e privatizados, ainda que a despeito da vontade das comunidades que os conservam.

\section{§1 OS DPIS E A LIMITAÇÃo GLOBAL DO DIREITO DE ACESSO AO DOMÍNIO PÚBLICO INFORMACIONAL}

Nas últimas três décadas, julgando a conservação do domínio público uma política social e economicamente ineficiente, ${ }^{1085}$ a comunidade internacional, sob a batuta dos países industrializados, vêm expandindo horizontal e verticalmente os regimes nacionais e internacionais de PI. Esta expansão é marcada, respectivamente, pelo inchamento do escopo de direitos conferidos aos titulares de DPIs e do rol de matérias elegíveis de proteção por DPIs, o qual é acompanhado pela reflexa supressão de limitações aos direitos de exclusivo. ${ }^{1086}$

Historicamente, os DPIs tutelavam apenas criações e invenções que se apresentavam prontas ou quase prontas a serem introduzidas no mercado. No presente, os DPIs chegaram às fundações informacionais, que sustentam os produtos, ou seja, passaram a tutelar fatos e dados fundamentais para a criação e desenvolvimento de qualquer produção intelectual. Por exemplo, a Diretiva européia de proteção de bancos de dados não-originais ${ }^{1087}$ protege os dados de per si, contidos nos bancos de dados e não somente sua expressão; o direto das patentes, em muitas jurisdições, vem autorizando a concessão de patentes para seqüências de DNA, a partir do momento que for identificada sua função

\footnotetext{
${ }^{1085}$ Cf. BOYLE, 2003b, p. 39-40.

${ }^{1086}$ Cf. MACMILLAN, 2007, p.98.

${ }^{1087}$ Diretiva 96/9/EC do Parlamento e do Conselho Europeu de 11 de março de 1996.
} 
natural no corpo humano ou no organismo de onde foram extraídas. $\mathrm{O}$ efeito perverso da proteção destes tijolos do conhecimento é restringir os ciclos de inovação e criatividade, em todos os setores que poderiam deles precisar.

O processo de maximização dos DPIs tem por base a idéia equivocada de que os indivíduos e organizações dedicados à criação e desenvolvimento de novos bens intelectuais atuam isolada e autonomamente, independendo de qualquer aporte intelectual de terceiros para a consecução de seus projetos, ${ }^{1088}$ quando em verdade, toda criação intelectual tem raízes sobre idéias e criações prévias. ${ }^{1089} \mathrm{O}$ papel do domínio público no processo de inovação e criatividade foi minimizado, enquanto os interesses dos titulares de DPI ganham uma relevância cada vez maior. ${ }^{1090} \mathrm{O}$ efeito adverso deste equívoco está na degradação das fontes intelectuais que alimentam o ciclo de inovação e criatividade.

No cenário estático, que trata o processo de inovação e criação como um processo individual e isolado, é justificável a existência de regimes de proteção que limitam a disseminação e a reprodução de produções intelectuais, pois os imitadores interfeririam na capacidade dos criadores de recuperarem seus investimentos. No entanto, o cenário adequado para se avaliar o melhor regime de proteção para produções intelectuais é o dinâmico, o qual reconhece que as inovações decorrem do emprego intensivo de aportes intelectuais anteriores. Portanto, a liberdade de acesso a estes aportes incrementa as oportunidades de criação e desenvolvimento de novas idéias, conhecimentos e produtos, enquanto a restrição desta liberdade ceifa a criatividade. ${ }^{1091}$

Além dos regimes contemporâneos de proteção dos DPIs, os contratos também vêm apoiando a tendência de esvaziamento do domínio público, por meio do emprego de cláusulas contratuais que revogam os direitos dos usuários de produções intelectuais protegidas de gozarem das limitações legais, oferecidas pelos regimes de PI. Haja vista que discutir a legalidade de uma cláusula contratual é um processo custoso, lento e imprevisível, no fim, os usuários e sua fonte de recursos intelectuais - o domínio público acabam enfraquecidos. ${ }^{1092}$

\footnotetext{
${ }^{1088}$ Cf. SAMPATH, 2005, p. 113.

${ }^{1089}$ Cf. WIPO, WIPO/GRTKF/IC/5/3, para. 26.

${ }^{1090} \mathrm{Cf}$. The Bellagio Declaration.

${ }^{1091}$ Cf. BESSEN; MASKIN, 2006, p. 34.

${ }^{1092}$ Cf. THOMPSON, 2007, p.136-137.
} 
Em resumo, a tendência de privatização do domínio público diminuiu o fluxo de insumos informacionais em todo o mundo, em particular nos países em desenvolvimento, onde a disponibilidade de recursos financeiros para a aquisição de novas tecnologias e outros insumos informacionais é limitada. ${ }^{1093}$ A título de ilustração, a seção seguinte tratará brevemente dos impactos decorrentes do inchamento dos regimes de patentes sobre a liberdade científica e industrial de indivíduos e instituições. Deve-se ter claro que a expansão dos DPIs afetou a liberdade científica e criativa em todos os setores que dependem de recursos por eles tutelados, e.g. setores cultural, agrícola, biomédica e educacional.

\section{§1.1 AS PATENTES E O ESVAZIAMENTO DO DOMÍNIO PÚBLICO}

$\mathrm{Na}$ década de 40, Robert Merton identificou, dentre as normas sociais que regiam as atividades do setor científico, o "comunismo", ${ }^{1094}$ que vigorou até os primórdios da década de 80. Até então, a ciência era construída fundamentalmente sobre uma base compartilhada e pública de conhecimentos científicos, livremente acessíveis por todo aquele comprometido em utilizá-los para compreender e expandir as fronteiras da ciência.

Até então, os cientistas se sentiam moralmente obrigados a compartilhar amplamente seus sucessos com a comunidade científica e a sociedade em geral, por meio de publicações e apresentações públicas. Esta prática era calcada no reconhecimento de que qualquer avanço científico decorre da "colaboração de gerações passadas e presentes." 1095 A única recompensa que cabia aos cientistas era o prestígio obtido por suas contribuições ao estoque da ciência, ${ }^{1096}$ cujo gozo dependia da disseminação pública de seus trabalhos científicos.

No contexto da norma em apreço, configurava uma infração a reivindicação de um DPI sobre os desenvolvimentos científicos realizados na academia ou conservá-los em

\footnotetext{
${ }^{1093}$ Cf. BARTON, [200-].

${ }^{1094}$ O termo "comunismo" é empregado por Merton em referência ao termo da língua inglesa commons, que pode ser traduzido para o português como recursos comuns, recursos compartilhados por todos.

${ }_{1095}$ MERTON, 1977b, p. 365, tradução nossa.

${ }^{1096}$ Cf. MERTON, 1977b, p. 363.
} 
segredo. ${ }^{1097}$ As patentes tinham presença restrita ao setor empresarial. ${ }^{1098}$ Foi graças a um ambiente livre de DPIs, que Baruch Blumberg, laureado com o Prêmio Nobel em 1976, logrou descobrir um antígeno que leva à produção de anticorpos protetores contra a hepatite B, que se mostrou a chave ao desenvolvimento de uma vacina contra este vírus. ${ }^{1099}$

Nas últimas três décadas, à medida que a ciência passou a desempenhar um papel cada vez mais central no desenvolvimento econômico dos países, a competição pelo uso comercial dos conhecimentos científicos incentivou a mudança do paradigma da ciência e a conseqüente erosão das práticas de livre difusão de conhecimentos. ${ }^{1100} \mathrm{O}$ paradigma da ciência livre cedeu lugar à ciência comercial, marcada pela substituição: da cooperação científica pela competição entre cientistas e centros de investigação; do livre fluxo e intercâmbio de informações e conhecimentos por seu represamento, mediante obtenção de DPIs, conservação em segredo de projetos de pesquisa e retardamento da velocidade com que os novos desenvolvimentos científicos são publicados. ${ }^{1101}$

Parcelas crescentes da comunidade científica contemporânea não mais buscam, como recompensa primária, a estima social por seus aportes ao estoque da ciência; patentes e royalties se tornaram as novas moedas de ascensão profissional, mesmo para os cientistas públicos. ${ }^{1102}$ A ciência comercial rompeu com a tradição ocidental, inaugurada no Renascimento, fundada na troca da confidencialidade dos desenvolvimentos científicos pelo prestígio e estima pública. ${ }^{1103}$

A mudança do paradigma se deu a partir de duas importantes mudanças legais, introduzidas nos EUA e que se difundiram paulatinamente por todo o mundo: a decisão da Suprema Corte dos EUA, proferida em 1980, no caso Diamond v. Chakrabarty, que legalizou o patenteamento de organismos vivos, e a aprovação do Bayh-Dole Act, aprovado no mesmo ano pelo congresso norte-americano, que autoriza universidades e outras instituições norte-americanas a patentearem inovações financiadas com recursos

\footnotetext{
1097 Ibid., p. 364-365.

${ }^{1098}$ Cf. HANSEN et al., 2006, p. 10.

${ }^{1099}$ Cf. SKLOOT, 2006.

${ }^{1100}$ Cf. STIGLITZ, 1995, p. 8.

${ }^{1101}$ Cf. BACA, 2006; CAULFIELD et al, 2006, p. 1091-1093.

1102 Ver, e.g., BACA, 2006; DINWOODIE; DREYFUSS, 2006, p. 206-207.

${ }^{1103}$ Ver, e.g., MERTON, 1988, p. 622; CONCEIÇÃO et al., 2004, p. 561.
} 
públicos. ${ }^{1104} \mathrm{O}$ Bayh-Dole Act tinha por fim estimular a introdução de novos produtos comerciais, desenvolvidos com recursos públicos. No entanto, na prática, ao permitir também o patenteamento conhecimentos científicos básicos, inapropriados para serem introduzidos no mercado, acabou por erigir barreiras ao progresso da ciência e da economia. $^{1105}$

Em razão do sucesso econômico dos EUA nos anos 90, os países membros da Organização para a Cooperação e Desenvolvimento Econômico (OCDE) - e mesmo países em desenvolvimento, como Brasil ${ }^{1106}$ e Índia ${ }^{1107}$ - passaram a ser influenciados pela política norte-americana de privatização do domínio público por intermédio da maximização dos DPIs. ${ }^{1108} \mathrm{O}$ que estes países ignoram é que a explicação por detrás do sucesso comercial norte-americano é muito mais sofisticada que a simples escolha entre ciência livre ou comercial.

A verdade é que os EUA puderam adotar com sucesso a estratégia de privatização do domínio público como instrumento de incentivo à inovação, porquanto, durante o século XX, o governo deste país foi o grande financiador das atividades de ciência e tecnologia. Apenas ao final da década de 1990, os investimentos privados cumulativos superaram os investimentos realizados por agências públicas e, ainda hoje, os investimentos públicos se mantêm em níveis altíssimos em comparação com a capacidade de investimentos dos países em desenvolvimento. ${ }^{1109}$ Graças aos investimentos governamentais em ciência livre por décadas, a sociedade americana acumulou uma capacidade científica e tecnológica ímpar, sobre o qual a iniciativa privada hoje tem condições de continuar a inovar, ainda que o domínio público esteja em franca erosão. Tal paralelo inexiste nos países em desenvolvimento.

\footnotetext{
1104 Cf. BACA, 2006, p. 5-7.

${ }^{1105}$ Cf. RAI; EISENBERG, 2003, p. 157.

1106 No Brasil, a Lei no. 10.973, de 2 de dezembro de 2004 (a chamada "lei da inovação"), permite que instituições de pesquisa, financiadas com recursos públicos, obtenham DPIs sobre suas produções intelectuais.

1107 A Índia publicou recentemente um projeto de lei que figura como uma espécie de Bayh-Dole Act. (INDIA, Bill No. LXVI of 2008).

1108 Cf. CONCEIÇÃO et al., 2004, p. 558.

1109 Ibid., p. 568-569.
} 
As políticas de maximização dos DPIs em todo o mundo além de restringirem o fluxo de insumos informacionais ${ }^{1110} \mathrm{e}$, conseqüentemente, o espaço para a condução de projetos científicos e tecnológicos, alteraram as prioridades do setor científico. Aqueles projetos voltados à satisfação de necessidades públicas e não-lucrativas cederam lugar para os projetos de caráter comercial. ${ }^{111}$ Assim, o ritmo de desenvolvimento científico das áreas sem viés mercantil decaiu dramaticamente; e os produtos introduzidos no mercado estão muito além do poder de compra de grande parte da população mundial.

Os impactos negativos decorrentes da mudança das prioridades dos setores científicos foram majorados pela expansão do setor privado sobre áreas estratégicas ao bem-estar humano. Entre 1994 e 1999, a participação do setor privado no volume total investido em P\&D no setor agrobiotecnológico saltou de 65\% para 80-85\%. ${ }^{112}$ Dados atualizados apontam que os conglomerados empresariais, baseados nos países industrializados, controlam os setores farmacêutico, biotecnológico, veterinário, sementeiro e de insumos agrícolas. As dez maiores empresas sementeiras do mundo controlam quase $50 \%$ do mercado mundial de sementes comerciais; as dez maiores empresas de praguicidas controlam $84 \%$ do setor; as dez maiores empresas farmacêuticas do mundo controlam 59\% do setor; as dez maiores empresas produtoras de produtos veterinários controlam 55\% do setor; e as dez maiores empresas de biotecnologia controlam $72 \%$ do setor. ${ }^{1113}$

\subsection{A IMPORTÂNCIA DA LIBERDADE DE ACESSO AO PBI PELAS COMUNIDADES TRADICIONAIS E PELA SOCIEDADE DOMINANTE}

\section{§1 A RELEVÂNCIA DO ACESSO AMPLO E FACILITADO PELAS COMUNIDADES TRADICIONAIS AO PBI DE OUTRAS COMUNIDADES}

O amplo compartilhamento de CTs e recursos da biodiversidade entre comunidades pobres capacita-as a superar, com maior destreza, problemas já solucionados por outros

\footnotetext{
${ }^{1110}$ Nos EUA, em duas décadas, houve um aumento de 2.5 vezes no número de patentes concedidas anualmente pelo USPTO (COLANGELO, 2004, p. 22). Evidências também apontam uma queda na taxa de difusão de conhecimentos técnicos e material fitogenético do setor privado norte-americano para o público, com a concessão de DPIs sobre estes materiais (GRAIN, 1998).

${ }^{1111}$ Ver, e.g., WALLACE; MAYER, 2007; ROYAL SOCIETY, 2003, p. 5.

${ }^{1112}$ Cf. KOWALSKI; KRYDER, 2002, p. 50.

${ }^{1113}$ Cf. ETC GROUP, 2005.
} 
grupos, que vivem em contextos ecológicos e sociais semelhantes. ${ }^{114}$ A difusão intercomunitária destes RBIs enseja sua independência de soluções importadas de outros meios culturais e naturais e estimula a aplicação e aprimoramento contínuo dos RBIs. ${ }^{1115}$ Sem a difusão intercomunitária dos RBIs, seus desafios diários são majorados. E dependendo da dimensão dos desafios, na falta de conhecimentos para melhorar sua qualidade de vida, as comunidades podem se desestruturar e desaparecer.

Nesse sentido, é digno de nota o trabalho realizado pela rede Honey Bee, da Índia, que há mais de vinte anos realiza pesquisas de campo neste país, documentando CTs de comunidades pobres e disseminando-os por meio de um boletim de notícias. A fim de facilitar o acesso ao conhecimento, o boletim é publicado em sete línguas locais, ampliando assim o acesso a conhecimentos-chave para a melhoria da capacidade das comunidades locais para superarem problemas diários pertinentes às áreas agrícolas, medicinal, veterinária etc. ${ }^{1116}$

Gorjestani assinala que, tal qual qualquer recurso informacional, os RBIs "precisam ser constantemente aplicados, desafiados e adaptados aos novos contextos locais" para se conservarem aptos à satisfação das necessidades contemporâneas da sociedade. ${ }^{1117} \mathrm{~A}$ limitação dos usos tradicionais e das práticas de intercâmbio intra e intercomunitário de RBIs conduz à sua erosão e obsolescência. ${ }^{1118}$ No caso dos conhecimentos conexos à biodiversidade, uma vez perdidos, os próprios recursos da biodiversidade perderão sua utilidade para as comunidades e com ela, os incentivos para sua conservação. ${ }^{1119} \mathrm{E}$ cada recurso da biodiversidade que desaparece, compromete a sobrevivência de outros recursos que com ele se associam. ${ }^{1120}$

\footnotetext{
${ }^{1114}$ Cf. GUPTA, 2006, p. 50; KIMBRELL, 2008.

1115 Cf. GUPTA, 2002, p. 386.

${ }^{1116}$ Id., 2006, p. 49-50. Corroborando a importância da disseminação intercomunitária de RBIs, o projeto da ONU Princípios e Diretrizes para a Proteção da Herança dos Povos Indígenas encoraja "[g]overnos, organizações internacionais e instituições privadas [...] [a] apoiar o desenvolvimento de redes regionais e globais para o intercâmbio de informações e experiências entre povos indígenas nos campos da ciência, cultura, artes, incluído apoio para sistemas eletrônicos de informação e comunicação em massa" (COMMISSION ON HUMAN RIGHTS, E/CN.4/Sub.2/1994/31, anexo, para. 17).

${ }^{1117}$ Cf. GORJESTANI, 2004, p. 270.

${ }^{1118}$ Cf. SAHAI, 2004, p. 279.

${ }_{1119}$ Cf. SCBD, 2004c, para. 29.

${ }^{1120}$ Cf. SHIVA, 2001, p. 92.
} 
Com o objetivo de proteger esses interesses, os Estados contratantes da CDB se comprometeram a adotar medidas de incentivo à "utilização costumeira de recursos biológicos de acordo com práticas culturais tradicionais compatíveis com as exigências de conservação ou utilização sustentável" ${ }^{, 121}$ e afastar obstáculos ao uso sustentável dos recursos da biodiversidade e de CTs por todos os setores da sociedade, ${ }^{1122}$ com vistas a "contribuir para a mitigação da pobreza e transformar em realidade a segurança alimentar, a saúde humana e a integridade cultural, em particular, nos países em desenvolvimento". 1123

No mesmo sentido, a FAO, por meio de seu Plano de Ação Mundial sobre os Recursos Zoogenéticos, encoraja seus Estados membros a incentivarem as comunidades tradicionais a conservarem em uso e em desenvolvimento contínuo a diversidade de recursos zoogenéticos de importância para a alimentação. ${ }^{1124}$ Em sentido complementar, a Convenção para a Salvaguarda do Patrimônio Cultural Imaterial determina aos seus Estados contratantes, com o objetivo de promover a conservação e o desenvolvimento contínuo de seu patrimônio cultural imaterial, que adotem medidas promotoras da "transmissão deste patrimônio nos foros e espaços destinados à sua manifestação e expressão." 1125

\section{§2 A RELEVÂNCIA do ACESSO AMPLO AO PBI PELA SOCIEDAdE dOMINANTE}

O livre acesso à informação e ao conhecimento foi reconhecido reiteradamente pela comunidade internacional ${ }^{1126}$ e científica ${ }^{1127}$ como a "força vital"1128 do desenvolvimento

${ }^{1121}$ Cf. art. 10(c), CDB.

${ }_{1122}$ Cf. SCBD, 2002, para. 51(a).

${ }^{1123}$ Ibid., para. 11(k).

${ }^{1124}$ Cf. FAO, 2007b, prioridade estratégia 6, medida 2.

${ }^{1125}$ Cf. art. 13(d)(i), CSPCI.

${ }^{1126}$ Ver, e.g., UNGA, Resolution 62/201, para. 1(b), 2 e 8; UNGA, Resolution A/RES/60/209, para. 22; UNGA, Resolution A/RES/35/56, para. 117, 118, 121; UNGA, Resolution 62/194, para. 4; UNGA, Resolution A/RES/44/14; UNGA, Resolution 3201, para 4(q); UNGA, Resolution, 3202, para.2; UNGA, Resolution 62/98, para. 7 (k) e (o); CONFERENCE ON THE HUMAN ENVIRONMENT. Declaration of the United Nations Conference on the Human Environment 1972, princípios 18 e 20; WIPO, 2007, recomendações nos. 23, 25, 28 e 45; UNESCO, Declaration on the Principles of International Cultural Cooperation, art. 7(1).

1127 Cf. INTERNATIONAL COUNCIL FOR SCIENCE, 2000, 2002c; WORLD CONFERENCE ON SCIENCE, Declaration on Science and the Use of Scientific Knowledge, para. 38. Com objetivos mais amplos que aqueles defendidos pelos círculos científicos, um grupo de intelectuais se reuniu, em 2005, para traçar os princípios que políticas de proteção de bens intelectuais devem comportar. O resultado do trabalho do grupo é a Adelphi Charter on creativity, innovation and intellectual property, adotada em Londres, em 13 
científico, criativo, industrial, social e ambiental ${ }^{129}$ de todos os grupos e nações, notadamente, dos países na retaguarda do desenvolvimento. ${ }^{1130} \mathrm{E}$ a essencialidade do conhecimento ao processo de desenvolvimento sustentável não se limita àqueles gerados no seio da sociedade dominante. Com freqüência, o patrimônio intelectual enraizado nas comunidades tradicionais se mostra mais adequado à satisfação das necessidades dos países em desenvolvimento que aqueles desenvolvidos em outros contextos e realidades, ${ }^{1131}$ pois melhor se adaptam à realidade ambiental, cultural e social local e envolvem custos mais baixos para serem adaptados e aplicados produtivamente. ${ }^{1132}$

A falta de acesso ao conhecimento por parte das populações dos países em desenvolvimento é um dos fatores preponderantes para a pobreza material e baixa qualidade de vida nestas regiões. Enquanto em 1950, Gana e Coréia do Sul tinham em comum seu PIB per capita, quatro décadas depois, o PIB per capita do país asiático se tornou seis vezes maior que o do país africano, graças, dentre outros fatores, às políticas de valorização da aquisição, utilização e geração de conhecimento. ${ }^{1133}$

Sem que o direito de acesso aos RBIs seja assegurado aos setores produtivos, o fato-gerador de recursos econômicos e materiais não será acionado. ${ }^{1134}$ Mais facilitado é o acesso aos RBIs, maiores serão as oportunidades de pesquisa, desenvolvimento e criação de novos produtos. E, por conseguinte, benefícios econômicos e materiais poderão ser gerados, em prol da conservação das bases humanas e ambientais do PBI. ${ }^{1135}$ Portanto, embora o RBIs apresentem um valor intrínseco que por si só já justificaria sua proteção,

de outubro de 2005 (ROYAL SOCIETY OF THE ARTS, 2005). Em poucas palavras, a carta defende a proteção do direito de acesso mais livre possível aos bens intelectuais a fim de fortalecer a capacidade de todos os setores de se desenvolver.

${ }_{1128}$ Cf. INTERNATIONAL COUNCIL FOR SCIENCE, 2000.

${ }^{1129} \mathrm{O}$ art. 20(4) da CDB incorpora o reconhecimento de que a conservação da biodiversidade, nos países em desenvolvimento, depende do acesso a recursos financeiros e tecnologia.

${ }^{1130}$ Cf. UNGA, A/61/382, para. 4 e 8.

${ }^{1131}$ Cf. UNITED NATIONS COMMISSION ON HUMAN RIGHTS, Resolution 1994/12, para. 7.

${ }_{1132}$ Cf. GORJESTANI, 2004, p. 266.

${ }^{1133}$ Cf. BANCO INTERNACIONAL DE RECONSTRUCCIÓN Y FOMENTO, 1998-1999, p.1.

${ }^{1134}$ Ver, e.g., BIBER-KLEMM et al., 2006, p. 269 ; MEDAGLIA, 2004a, p. 119; CESCR, E/C.12/GC/17, para. 4. Os Estados membros da Organização do Tratado de Cooperação Amazônica, em um documento de 1992, adotado às vésperas da Conferência da ONU sobre Meio Ambiente e Desenvolvimento, fixou a posição de negociação destes países em relação à $\mathrm{CDB}$. Um dos pontos tratados na declaração, é a necessidade de se "[...] dar más énfasis a la utilización y al desarrollo sustentable de estos recursos [recursos da biodiversidade] que a su simple conservación, a fin de maximizar y difundir sus beneficios" (OTCA, 1992, para. 4). Esta observação deixa transparecer o reconhecimento por parte destes países de que o acesso produtivo à biodiversidade é essencial para a geração de recursos a fim de conservá-la.

${ }_{1135}$ Ver, por exemplo, UNGA, Resolution A/RES/42/100 (reconhece que a disseminação facilitada dos conhecimentos científicos acelara o desenvolvimento econômico e social dos países em desenvolvimento). 
em termos pragmáticos, ao menos no presente, sua proteção integral apenas se dará se for econômica e socialmente viável. E para isso, é essencial colocá-lo também a serviço do desenvolvimento sustentável da sociedade dominante, gerando assim divisas, que apoiarão as comunidades tradicionais e os Estados na desincumbência de suas tarefas de conservação da diversidade biocultural. ${ }^{1136}$

Quando a comercialização do PBI se tornar um meio de vida digno às comunidades tradicionais, haverá incentivos para que as gerações mais jovens destes grupos se comprometam em conhecê-lo, conservá-lo e desenvolvê-lo e continuem a viver sustentavelmente junto à natureza. ${ }^{1137}$ Esta lógica está plasmada na CDB que, ao mesmo tempo em que confere aos Estados um direito de controle de seus recursos biológicos tangíveis e intangíveis, ${ }^{1138}$ os obriga a facilitar o acceso a estes recursos "para utilizações ambientalmente adequadas" e a não impôr "restrições contrárias aos objetivos" da $\mathrm{CDB},{ }^{1139}$ quais sejam, "conservação da diversidade biológica, a utilização sustentável de seus componentes e a repartição justa e equitativa dos benefícios derivados da utilização dos recursos" da biodiversidade. ${ }^{1140}$

A transição dos países em desenvolvimento de uma economia calcada na exploração insustentável de recursos naturais finitos para a economia do conhecimento depende, dentre outros fatores, da criação de comunidades do conhecimento ${ }^{1141}$ cuja função é promover a "criação, difusão e uso de novos conhecimentos [social e] economicamente úteis."1142 Quatro são as condições para a emergência destas comunidades: a construção de redes de indivíduos e instituições com capacidades técnicas e conhecimentos diversos e complementares, dirigidas a um objetivo comum (i) ${ }^{1143}$ a criação de um espaço livre de intercâmbio e circulação do conhecimento (ii); ${ }^{1144}$ uso intensivo de tecnologias da informação para facilitar esta circulação (iii); ${ }^{145}$ e a associação

${ }^{1136}$ Cf. PETERSMANN, 2002, p. 629.

1137 Cf. GUPTA, 2006, p. 50.

${ }^{1138} \mathrm{Cf}$. art. $15(1), \mathrm{CDB}$.

${ }^{1139}$ Cf. art. 15(2), CDB.

${ }^{1140} \mathrm{Cf}$. art. 1o, CDB.

1141 Cf. CUMBRE MUNDIAL DE LA SOCIEDAD DE LA INFORMACIÓN, WSIS-03/GENEVA/4-S, para. 34.

${ }_{1142}$ Cf. THORSTEINDÓTTIER, 2004a, p. 5.

${ }^{1143}$ Cf. FELDMAN, 2002, p. 48.

1144 Ver, e.g., UNGA, Resolution 56/182, para. 3; UNGA, A/61/382, para. 8.

${ }^{1145}$ Cf. DAVID; FORAY, 2002, p. 14. 
entre as comunidades científica, empresarial e governamental, com vistas a construir sinergias (iv). ${ }^{1146}$

A transformação do PBI em um catalisador do desenvolvimento dos setores criativo, industrial e científico dos países em desenvolvimento dependerá do afastamento das amarras que impedem a aproximação sinérgica entre a comunidade científica formal, os detentores de RBIs e os setores produtivos, ${ }^{1147}$ bem como a livre difusão de conhecimentos e insumos informacionais entre estes grupos. ${ }^{1148}$ Em outras palavras, é fundamental fomentar a associação construtiva das fortalezas destes grupos com vistas a desenvolver novos produtos e serviços, aptos à satisfação das demandas locais. ${ }^{1149}$

O desenvolvimento focado nas necessidades locais favorece o fortalecimento dos setores produtivos dos países pobres e, no médio e longo prazo, a livre concorrência, ${ }^{1150}$ ao dispensá-los da necessidade de competirem nos mercados dos países industrializados. Ademais, ao enfocarem nas necessidades locais, estes três grupos canalizarão suas energias para resolverem problemas e demandas específicas dos países em desenvolvimento, ${ }^{1151} \mathrm{em}$ regra negligenciados pelos setores de P\&D dos países industrializados. ${ }^{1152}$

Muitas instituições dos países em desenvolvimento não detêm a capacidade para investir no desenvolvimento e criação de novos produtos tecnológicos e bens culturais, se tiverem que seguir o mesmo modelo dispendioso, adotado por seus pares baseados nos países industrializados, sofrendo com a estagnação resultante da falta de transferência de tecnologia de ponta, desenvolvidas nos países industrializados. É terreno comum na literatura defensora da maximização dos DPIs, justificá-los com base em seu suposto papel

${ }^{1146}$ Cf. THORSTEINSDÓTTIER et al., 2004b, p. 50.

1147 Cf. GUPTA, 2002, p. 389.

1148 Dois estudos de caso sobre os avanços da indústria da biotecnologia no Brasil e Egito concluíram que os avanços foram limitados graças à falta de colaboração entre a comunidade científica destes países e seus setores industriais (THORSTEINSDÓTTIER et al., op.cit., p. 51).

${ }^{1149}$ Nesse sentido, o art. 18(2), CDB: “[a]s Partes Contratantes devem, em conformidade com sua legislação e suas políticas nacionais, elaborar e estimular modalidades de cooperação para o desenvolvimento e utilização de tecnologias, inclusive tecnologias indígenas e tradicionais, para alcançar os objetivos desta Convenção. Com esse fim, as Partes Contratantes devem também promover a cooperação para a capacitação de pessoal e o intercâmbio de técnicos."

${ }^{1150}$ Cf. UNGA, Resolution 62/151, preâmbulo.

1151 Ver, e.g., FAO, 2007b, item 13; INTERNATIONAL COUNCIL FOR SCIENCE, 2002b, p. 11-12; SCBD, UNEP/CBD/WG8J/1/INF/14, recomendação no. 4; ECOSOC, E/CN.17/2004/10/Add.3; SCBD, $\mathrm{UNEP} / \mathrm{CBD} / \mathrm{WG} 8 \mathrm{~J} / 4 / \mathrm{INF} / 9$, para. 42.

${ }^{1152}$ Cf. THORSTEINSDÓTTIER et al., op.cit., p. 49. 
de catalisador da transferência de tecnologia dos países industrializados aos em desenvolvimento. ${ }^{153} \mathrm{Um}$ estudo recente do Programa das Nações Unidas para o Desenvolvimento (PNUD) contraria esta presunção, ao apontar que, entre 1992 e 2001, foram identificados apenas três casos de transferência de tecnologia de empresas estrangeiras ao Brasil, uma das economias mais vibrantes do mundo. ${ }^{1154}$ Esta tendência não chega a ser uma surpresa, quando recordamos que entre 1974 e 1995, a comunidade internacional, sob os auspícios da Conferência das Nações Unidas para o Comércio e Desenvolvimento, tentou, sem êxito, negociar um Código Internacional de Conduta para Transferência de Tecnologia, como resultado da oposição sistemática dos países industrializados. ${ }^{1155}$ Este tipo de obstáculo, limitador das oportunidades dos países em desenvolvimento para adentrarem ou consolidarem sua economia da informação, evidencia a necessidade de que estes países reconheçam que a responsabilidade pelo seu próprio desenvolvimento está primariamente em suas mãos ${ }^{1156}$ e passa pela exploração de suas fortalezas intelectuais, culturais e naturais, de maneira inovadora e criativa.

A facilitação do uso do PBI pode abrir os caminhos para que instituições públicas e privadas dos países em desenvolvimento compitam em novos nichos de mercado, porquanto o PBI reduz os custos de desenvolvimento e criação de novos produtos e serviços, ${ }^{1157}$ ao mesmo tempo em que rompe com o ciclo de dependência de recursos humanos e tecnológicos importados. ${ }^{1158}$ Os produtos derivados do PBI serão possivelmente mais acessíveis, em termos econômicos, pelas populações de baixa renda, o que permitirá a melhoria de sua qualidade de vida. ${ }^{1159}$

Partindo desta realidade, o projeto LINKS (Local and Indigenous Knowledge Systems) da UNESCO ${ }^{1160}$ e o Programa sobre Conhecimentos Indígenas do Banco

${ }^{1153}$ Cf. BANCO INTERNACIONAL DE RECONSTRUCCIÓN Y FOMENTO, 1998-1999, p. 9 (o Banco Mundial, por exemplo, defende que os países em desenvolvimento abram seus mercados para investimentos estrangeiros, fortaleçam seus regimes de propriedade intelectual, para fomentar transferência de tecnologia por meio de investimentos estrangeiros diretos e acordos de licenciamento).

${ }_{1154}$ Cf. CASSIOLATO; ELIAS; ZUCOLOTO, 2008, p.212-213.

${ }^{1155}$ Em 1993, a Assembléia Geral da ONU (UNGA, A/RES/48/167) reconheceu a falta de condições para se alcançar consenso sobre dar continuidade às negociações para o código.

${ }^{1156}$ Cf. UNGA, Resolution 2542, preâmbulo.

${ }^{1157}$ Ver, e.g., GUPTA, 2006, p. 50; DAVID; FORAY, 2002, p. 15.

${ }^{1158}$ Cf. ECOSOC, Resolution 1995/54, para. 3(f).

${ }^{1159}$ Cf. THORSTEINSDÓTTIER, 2004b, p. 49.

${ }^{1160}$ Cf. NAKASHIMA, 2007, p. 20-23. 
Mundial $^{1161}$ se propõem facilitar o intercâmbio de CTs entre comunidades tradicionais e a comunidade científica, governos e agentes responsáveis pelo delineamento de políticas de desenvolvimento, com o objetivo de facilitar a conservação da biodiversidade e a melhoria da qualidade de vida nos países pobres. Um exemplo de sucesso do projeto do Banco Mundial é a disseminação das práticas do grupo Tanga AIDS Working Group (TAWG), composto por curandeiros e médicos de Tanzânia, especializados no tratamento das enfermidades oportunistas resultantes da infecção pelo HIV/AIDS. Seus conhecimentos e práticas serviram de base para a produção e distribuição de medicamentos preparados com ervas pelos programas de saúde pública de Burundi, Gana, Guiné e Etiópia. ${ }^{1162}$

A ampla disseminação dos RBIs relacionados ao uso sustentável dos recursos naturais pode ainda contribuir para capacitar a sociedade dominante a extrair maiores benefícios da natureza, sem degradá-la, ${ }^{1163}$ e a reverter os danos já causados. ${ }^{1164}$ Com este propósito, os Estados contratantes da CDB assumiram o compromisso de promover o intercâmbio de informações científicas, inclusive de CTAs, que podem viabilizar o uso sustentável e/ou a conservação da biodiversidade. ${ }^{1165}$ Assegurar o acesso amplo e facilitado aos RBIs pela sociedade dominante ensejará a canalização das energias criativas e naturais dos países em desenvolvimento a serviço da aceleração de seu desenvolvimento sustentável, ${ }^{1166}$ ao mesmo tempo em que colabora com o desenvolvimento de toda a humanidade. ${ }^{1167}$

${ }^{1161}$ Cf. WORLD BANK, 2009b.

1162 Id., 2009a.

1163 A Carta Mundial para a Natureza encoraja os Estados membros das Nações Unidas a disseminarem amplamente os conhecimentos sobre a natureza e a empreenderem esforços contínuos para aprimorá-los e difundi-los, sem qualquer restrição (UNGA, Resolution 37/7, para. 15 e 18). Ver também SCBD, $\mathrm{UNEP} / \mathrm{CBD} / \mathrm{COP} / 9 / 7$, para. 4.

${ }^{1164}$ Ver, e.g., GUPTA, 2004, p. 31; SACHS, 2007f, p. 104; SACHS, 2007c, p. 143.

1165 Cf. art. 17(2), CDB; SCBD, 2004b, princípio 6; INTERGOVERNMENTAL PANEL ON FORESTS, [200-?], propostas 40(i), (j), (k), (l) e (m) (propostas dirigidas a incentivar os encarregados de políticas a associarem os conhecimentos tradicionais relacionados à gestão de recursos florestas com a ciência formal para promover a conservação das florestas); UNGA, A/CONF.151/26, vol.III, princípio 12(d).

${ }_{1166}$ A Declaração de Cocoyoc, há mais de trinta anos, já sublinhava a urgência dos países em desenvolvimento canalizarem suas energias criativas para seu desenvolvimento econômico endógeno: "Science and technology must be responsive to the goals we are pursuing. Present research and development patterns do not effectively contribute to them. We call on universities, other institutions of higher learning, research organizations and scientific associations all over the world to reconsider their priorities. Mindful of the benefits deriving from free and basic research, we underline the fact that there is a reservoir of underutilized creative energy in the whole scientific community of the world, and that is should be more focused on research for the satisfaction of fundamental needs."

${ }^{1167}$ Cf. GUPTA, 2006, p. 50. 
Em virtude da tendência global de homogeneização não só biocultural, promovida pela globalização econômica, a Declaração Universal sobre a Diversidade Cultural e a CPPDEC propõem apartar os obstáculos que dificultam a livre difusão e intercâmbio de expressões culturais de outras culturas, a fim de enriquecer o cenário cultural presente, eminentemente ocidentalizado, e promover o desenvolvimento de todas as culturas. Para isso, estes instrumentos legais encorajam os países em desenvolvimento a criar ou consolidar uma indústria cultural fortalecida, ${ }^{1168}$ facilitando assim a disseminação nacional e internacional de seus bens culturais. ${ }^{1169}$

Naturalmente, a criação de uma indústria cultural apenas é viável se for assegurado aos setores produtivos o acesso facilitado à informação, ao conhecimento e às expressões culturais. É importante salientar que o acesso amplo e facilitado aos RBIs por todos os indivíduos e setores não gera "apenas" incentivos econômicos para a conservação da diversidade biocultural. ${ }^{1170}$ Serve, antes de qualquer coisa, para assegurar a própria sobrevivência e o desenvolvimento das mais de 6000 culturas espalhadas pelo mundo. ${ }^{1171}$ Nenhuma cultura surge e se desenvolve de maneira estanque; sua própria existência e desenvolvimento se devem à permeabilidade das fronteiras que as separam umas das outras, o que viabiliza o livre intercâmbio entre elas, ${ }^{1172}$ sua remodelação e atualização em face das novas demandas e expectativas de seus membros. ${ }^{1173} \mathrm{O}$ intercâmbio intercultural serve, ademais, para promover o entendimento entre culturas diversas; ${ }^{1174}$ para romper visões preconceituosas, baseadas na ignorância; ${ }^{1175}$ para sensibilizar a sociedade sobre a importância e o valor do $\mathrm{PBI}^{1176}$ e para cultivar a auto-estima das comunidades tradicionais, que passam a valorizar sua cultura, ao testemunharem a ampliação de suas aplicações por outras culturas. ${ }^{1177}$

Se já não fossem suficientes as razões elencadas, o fato da realização do direito supremo do homem - o direito à vida - depender da facilitação do acesso aos RBIs,

\footnotetext{
1168 Cf. art. 10, UNESCO, Declaração Universal sobre a Diversidade Cultural; art. 14(a)(iii), CPPDEC.

1169 Cf. Declaração Universal sobre a Diversidade Cultural, anexo II, para. 17.

${ }^{1170}$ Cf. art. 14, CPPDEC.

${ }^{1171}$ Cf. SCBD, UNEP/CBD/WG8J/2/5, para. 10.

1172 Ver, e.g., SWELL JR., 1999, p. 54-55; BROWN, M., 1998, p. 196.

1173 Cf. STAVENHAGEN, 1998, p. 6.

${ }^{1174} \mathrm{Cf}$. art. 14(a)(i) e (iv),CSPCI.

1175 Cf. UNITED NATIONS COMMISSION ON HUMAN RIGHTS, Resolution 2005/20.

${ }^{1176}$ Cf. UNESCO, Recomendación sobre la salvaguardia de la cultura tradicional y popular, item (g).

${ }^{1177}$ Id., Recommendation on Participation by the People at Large in Cultural Life and their Contribution to It, para. $18(\mathrm{c})$ e $(\mathrm{d})$.
} 
confirma que assegurar o acesso amplo e facilitado a estes recursos pelos setores científico, cultural e produtivo não figura como uma mera alternativa, que pode ou não ser acolhida pela comunidade internacional. Esta, especialmente os países em desenvolvimento, deve envidar esforços para criar as condições de liberdade necessárias, sem as quais os RBIs não poderão ser colocados a serviço da realização do direito à vida. ${ }^{1178}$ Neste sentido, a Corte Interamericana de Direitos Humanos assinalou que "[u]ma das obrigações que indiscutivelmente deve assumir o Estado [...] com o objetivo de proteger e garantir o direito à vida, é a de gerar as condições de vida mínimas compatíveis com a dignidade da pessoa humana, e a não produzir condições que a dificultem ou impeçam."1179

O direito à saúde, disciplinado pelo PIDESC, demanda de suas partes contratantes, dentre outras obrigações, a disponibilidade às suas populações de bens de saúde, notadamente, medicamentos de boa qualidade sob a perspectiva científica e médica, em bases não-discriminatórias. Isto significa que devem ser, dentre outras coisas, economicamente acessíveis às populações mais pobres. ${ }^{1180}$

Muitos dos medicamentos demandados pelas populações dos países pobres estão sob a proteção de patentes, de titularidade de empresas baseadas em países industrializados. Tais patentes freqüentemente são empregadas de maneira abusiva por seus detentores, com o objetivo de manter os preços dos medicamentos artificialmente altos e impedir a entrada de novos concorrentes no mercado. ${ }^{181}$ As necessidades médicas das populações dos países em desenvolvimento que poderiam ser satisfeitas pelos desenvolvimentos científicos já realizados, permanecem negligenciadas. Assim sendo, os

1178 Cf. UNGA, Resolution A/RES/42/99, para. 4 (esta resolução chama os Estados a colocar o potencial intelectual e criativo da humanidade em benefício da realização de seus direitos). No mesmo sentido, ver, e.g., UNGA, Resolution 3384, para. 3,7 e 9 (chama os Estados a colocarem os frutos do desenvolvimento científico e tecnológico a trabalho da dignificação do ser humano); UNITED NATIONS COMMISSION ON HUMAN RIGHTS, Resolution 1993/91, preâmbulo; UNGA, Resolution A/RES/35/130, preâmbulo; WORLD SUMMIT FOR SOCIAL DEVELOPMENT, A/CONF.166/9, para. 8.

${ }^{1179}$ Cf. CORTE INTERAMERICANA DE DERECHOS HUMANOS, 2005, para. 162. No mesmo sentido, Cf. CORTE INTERAMERICANA DE DERECHOS HUMANOS, 2006a, para. 152.

${ }^{1180}$ Cf. CESCR, E/C.12/2000/4, para. 12 (a), (b) e (d).

1181 Dutfield (2007, p. 211-225) afirma que o direito das patentes esvaziou o domínio público técnico e restringiu o acesso a medicamentos essenciais: em virtude das patentes, a indústria farmacêutica organizou cartéis farmacêuticos, que lograram estabelecer obstáculos para a entrada de novos competidores em mercados socialmente importantes, como o de antibióticos. O lobby da indústria farmacêutica, outrossim, influenciou a reforma dos regimes de patentes em vários países, de modo a permitir a proteção de inovações de pouca valia em termos de bem-estar humano (as inovações 'mee-too', i.e., aquelas que ostentam modificações de segunda ordem em drogas já conhecidas, e.g., no seu modo de uso, dosagem, combinação com outras drogas, diminuição dos efeitos colaterais), com o objetivo de estender a duração de seus monopólios sobre produtos farmacêuticos. 
países em desenvolvimento não podem contar com a boa-vontade do setor empresarial dos países industrializados para sanar suas demandas sociais.

Outras muitas necessidades médicas das populações pobres não podem ser satisfeitas, sob o ponto de vista do estado técnico atual. As doenças que afetam as populações pobres são invisíveis aos laboratórios dos países industrializados. Enfermidades como a doença do sono, ${ }^{1182}$ a doença de Chagas, a malária, a leishmaniose matam 35 mil pessoas ao dia nos países em desenvolvimento, por falta de soluções terapêuticas, tecnicamente adequadas e economicamente acessíveis. ${ }^{1183}$ Ao menos por enquanto, a indústria farmacêutica e instituições científicas de todo o mundo pautam a seleção de suas prioridades de pesquisa não de acordo com as enfermidades que comprometem a qualidade de vida das maiores parcelas da população do mundo, mas com o fito de satisfazer as demandas imediatas das populações mais afluentes. ${ }^{1184}$ Neste contexto, 90\% dos US\$ 50-60 bilhões gastos anualmente em P\&D na área biomédica são dedicados ao desenvolvimento de drogas para as necessidades de apenas $10 \%$ da população da Terra. ${ }^{1185},{ }^{1186}$ Como resultado deste foco estreito, das 1223 novas entidades químicas comercializadas mundialmente entre as décadas de 70 e 90 , menos de $1 \%$ eram aplicáveis para doenças tropicais. ${ }^{1187}$

Tendo em vista esta realidade, o Comitê de Direitos Econômicos, Sociais e Culturais esclarece que, o cumprimento pleno das obrigações previstas no art. 12 do PIDESC depende, inter alia, do fomento de pesquisas biomédicas pelos Estados contratantes do Pacto. ${ }^{1188}$ Considerando que as comunidades tradicionais, em associação com a biodiversidade, possivelmente guardam a chave para a solução das muitas enfermidades, que imprimem sofrimento na humanidade, bem como o descaso dos países industrializados para com as necessidades dos mais pobres, o compromisso assumido pelos Estados contratantes do PIDESC de assegurar a todo ser humano "o direito de [...]

\footnotetext{
1182 Cf. MCNEIL JR, 2008.

1183 Cf. DNDI, 2006.

${ }^{1184}$ Cf. SACHS, 2007 d, p. 250.

${ }^{1185}$ Cf. NUFFIELD COUNCIL ON BIOETHICS, 2002b, p. 22.

${ }^{1186}$ Ver UNGA, Resolution A/RES/62/180, para. 16 e 21 (tacitamente, esta resolução reconhece o descaso do setor produtivo dos países industrializados para com as necessidades prementes dos países pobres, ao chamar a comunidade internacional para assumir o compromisso de desenvolver e transferir tecnologias de prevenção, imunização e tratamento dos doentes de malária e para transferir aos países em desenvolvimento a tecnologia de produção de mosquiteiros impregnados com repelentes de longa duração).

${ }^{1187}$ Cf. TROUILLER; OLLIARO,1999.

${ }^{1188}$ Cf. CESCR, E/C.12/2000/4, para. 36.
} 
desfrutar o mais elevado nível possível de saúde física e mental"1189 depende para sua realização da facilitação e ampliação do uso dos recursos da biodiversidade e CTs pelos setores científico e industrial.

O direito de acesso amplo e facilitado aos CTAs e recursos biológicos configura igualmente condição fundamental para a realização do direito à alimentação adequada, assegurado pelo art. 11 do PIDESC. O Comitê de Direitos Econômicos, Sociais e Culturais esclarece que "[o] direito à alimentação adequada é exercido quando todo homem, mulher ou criança, seja só ou com outros, tem acesso físico e econômico, a todo o momento, à alimentação adequada ou aos meios para obtê-la." 1190 O direito à alimentação demanda que os Estados contratantes do Pacto garantam uma alimentação adequada em face das “condições sociais, econômicas, culturais, climáticas, ecológicas” vigentes em cada país, e acessível ininterruptamente às presentes e futuras gerações. ${ }^{1191}$

As terras aráveis do planeta são limitadas quantitativamente, enquanto sua população cresce sem descanso, sobretudo nas regiões mais empobrecidas. Também não se deve ignorar que as mudanças climáticas e a degradação dos recursos naturais criaram novos desafios para a agropecuária, cujos instrumentos de trabalho - insumos químicos, sementes melhoradas, linhagens especiais de animais úteis à alimentação - estão sujeitos a um processo de rápida obsolescência em face das novas condições de estresse hidrológico e climático. Salvo se for possível o desenvolvimento tecnológico do setor agrobiotecnológico dos países em desenvolvimento, dirigido ao desenvolvimento de novas tecnologias agrícolas e variedades vegetais, acessíveis economicamente pelas populações mais vulneráveis, o direito de todo ser humano a estar protegido contra a fome será letra morta para as presentes e futuras gerações. ${ }^{192}$

Para viabilizar o desenvolvimento agrotecnológico dos países em desenvolvimentos, o próprio PIDESC determina que seus Estados contratantes promovam a "plena utilização dos conhecimentos técnicos e científicos [...] de maneira que se assegurem a exploração e a utilização mais eficazes dos recursos naturais" (art. 12(2)). Isto implica na obrigação de fomentar o uso amplo e facilitado dos recursos da biodiversidade

\footnotetext{
${ }^{1189}$ Cf. art. 12(1), PIDESC.

${ }^{1190}$ CESCR, E/C.12/1999/5, para. 6, tradução nossa.

${ }^{1191}$ Ibid., para. 7.

${ }^{1192}$ Cf. UNGA, Resolution 62/190, para. 1-2.
} 
relevantes para a alimentação e agricultura, bem como dos conhecimentos que lhe são conexos a fim de assegurar a harmonização do direito humano à alimentação com o imperativo de uso sustentável dos recursos da natureza. ${ }^{1193}$

É interessante notar que, a essencialidade do livre fluxo de recursos da biodiversidade para a sustentabilidade da agricultura é tão verdadeira que mesmo alguns acordos internacionais de proteção da propriedade intelectual - freqüentemente criticados por sua capacidade de restringir excessivamente a livre disseminação dos insumos informacionais - asseguram o livre fluxo de germoplasma (recursos fitogenéticos), em apoio à sustentabilidade da indústria do melhoramento vegetal. ${ }^{1194}$ As Convenções da UPOV de 1978 e 1991 estabeleceram como limitação ao feixe de direitos de exclusivo conferidos ao obtentor vegetal, o uso de cultivares protegidas como material de base ao desenvolvimento de novas cultivares, desde que a cultivar protegida não precise ser empregada sistematicamente para a produção comercial da nova cultivar, ${ }^{1195}$ nem a nova variedade seja essencialmente derivada daquela utilizada como ponto de partida. ${ }^{1196}$

Para encerrar, é importante ter claro que, com a tendência de maximização dos DPIs, o direito de acesso livre a materiais biológicos, reagentes, ferramentas de pesquisa e bens culturais pelos setores público e privado decaiu dramaticamente. ${ }^{1197}$ As instituições públicas e organizações industriais dos países em desenvolvimento naturalmente são mais frágeis que seus concorrentes, baseados nos países industrializados. Na falta de outras fontes de insumos intangíveis, possivelmente o destino dos setores científico, cultural e industrial dos países em desenvolvimento dependerá grandemente de sua liberdade de acessar RBIs.

\footnotetext{
${ }^{1193}$ Cf. FAO, Declaración de Interlaken.

1194 Cf. MEDAGLIA, 2009, para. 45.

${ }^{1195}$ Cf. art. 5(3), UPOV, International Convention for the Protection of New Varieties of Plants, 1978.

1196 Cf. art. 15(1), UPOV, International Convention for the Protection of New Varieties of Plants, 1991. Variedade essencialmente derivada é aquela substancialmente similar à variedade da qual derivou. Nos termos do art. 14(b) da Convenção UPOV de 1991, variedade essencialmente derivada é aquela que "i) se deriva principalmente de la variedad inicial, o de una variedad que a su vez se deriva principalmente de la variedad inicial, conservando al mismo tiempo las expresiones de los caracteres esenciales que resulten del genotipo o de la combinación de genotipos de la variedad inicial; ii) se distingue claramente de la variedad inicial, y iii) salvo por lo que respecta a las diferencias resultantes de la derivación, es conforme a la variedad inicial en la expresión de los caracteres esenciales que resulten del genotipo o de la combinación de genotipos de la variedad inicial."

${ }^{1197}$ Ver, e.g., DOVE, 2002; CAMPBELL et al., 2002; BACA, 2006.
} 


\subsubsection{CRITÉRIO DE OPERACIONALIZAÇÃO 3: DiREITOS MORAIS}

A garantia de acesso amplo e facilitado ao PBI resguarda a liberdade científica e criativa da sociedade, ao mesmo tempo em que promove os interesses econômicos das comunidades tradicionais, ao lhes proporcionar independência econômica, sem a qual seria mais difícil resistir à força homogeneizante das culturas dominantes. Contudo, essa mesma garantia benéfica, se ilimitada, abre brechas para usos culturalmente desrespeitosos dos RBIs por parte da sociedade dominante.

O PIDESC reconhece às comunidades tradicionais a proteção de seus interesses morais decorrentes de suas produções intelectuais (art. 15(1)(c)), com o fito tanto de proteger o laço cultural que as vincula ao seu PBI quanto de "preservar a natureza distinta das culturas minoritárias", ${ }^{1198}$ quando de sua disseminação para além das fronteiras comunitárias. Embora o Pacto seja omisso quanto ao escopo dos direitos morais das comunidades tradicionais em relação aos RBIs, o Comitê de Direitos Econômicos, Sociais e Culturais sugeriu que o art. 15(1)(c) lhes asseguraria os mesmos direitos previstos no art. 6bis da Convenção de Berna, ${ }^{1199}$ a saber, o direito moral de atribuição e o de integridade.

\subsection{DiREITO MORAL DE ATRIBUIÇÃO}

O direito moral de atribuição confere aos criadores de obras literárias e artísticas o direito de reivindicar a autoria das obras de que seja autor, isto é, de ser reconhecido publicamente como o criador de suas obras, em toda e qualquer forma de disseminação pública, tenha ela natureza comercial ou não. ${ }^{1200}$

As comunidades tradicionais buscam o reconhecimento público de suas portentosas e ignoradas contribuições ao desenvolvimento material e cultural da sociedade dominante, ${ }^{1201}$ como forma de corrigir preconceitos históricos, que ainda hoje perduram, sobre a capacidade intelectual destes grupos e a (inexistente) superioridade da cultura

\footnotetext{
${ }^{1198}$ Cf. CESCR, E/C.12/GC/17, para. 2 e 33.

${ }^{1199}$ Ibid., para. 2 e 30.

1200 Cf. WIPO, 2003, p. 44.

${ }^{1201} \mathrm{Cf}$. princípio no.16 em INTERNATIONAL SOCIETY OF ETHNOBIOLOGY, 2008.
} 
ocidental. ${ }^{1202} \mathrm{O}$ reconhecimento público de tais aportes pode figurar ainda como um estímulo de ordem moral para que as comunidades tradicionais conservem seu PBI, bem como para a construção de uma sociedade mais pacífica, pois efetivamente calcada na valorização e no respeito da herança cultural dos múltiplos povos, que a compõem. ${ }^{1203}$

Ainda que o reconhecimento público das fontes comunitárias dos RBIs não exercesse qualquer incentivo concreto junto aos seus detentores, o princípio da igualdade impõe o reconhecimento público das fontes dos RBIs utilizados nos processos de criação e inovação, já que assim nos conduzimos, quando empregamos insumos conexos originados no âmbito da sociedade ocidental.

Considerando que o PBI de cada comunidade é uma construção intelectual coletiva, que encerra as contribuições de múltiplas gerações de integrantes de uma ou mais comunidades tradicionais, não seria respeitoso para com elas investir o direito de atribuição em seus integrantes individualmente considerados. A postura culturalmente mais adequada seria conferi-lo às comunidades tradicionais, onde se passam os processos de criação, inovação ou conservação dos RBIs utilizados. ${ }^{1204}$

O reconhecimento do direito de atribuição em favor das comunidades tradicionais lhes investiria no direito de reivindicar seu reconhecimento público como a fonte dos RBIs que refletem sua identidade cultural, quando utilizados direta ou indiretamente por terceiros. ${ }^{1205}$ Mesmo quando os RBIs tivessem servido apenas de inspiração ou ponto de partida para alguma produção artística ou científica, caberia aos usuários atribuir créditos às comunidades pertinentes. Excepcionalmente, o direito de atribuição poderia ser investido em Estados, na hipótese do RBI não se atrelar à identidade cultural de uma determinada comunidade tradicional, mas sim ao patrimônio cultural de uma nação ou de uma macro-região, compartilhada por dois ou mais Estados, e.g. a Amazônia.

\footnotetext{
1202 Cf. WHITT, 1998.

1203 Cf. UNGA, Resolution A/RES/60/1, par. 14.

1204 Ver, e.g., COMMISSION ON HUMAN RIGHTS, E/CN.4/Sub.2/1994/31, anexo, para. 27; KURUK, 1998-1999, p. 829-830.

1205 Ver, e.g., HANSEN; VANFLEET, 2003, p. 29-30; UNESCO; OMPI, 1985, para. 56 e 61; INTERNATIONAL SOCIETY OF ETHNOBIOLOGY, 2008, princípio no. 16.
} 


\subsection{DIREITO MORAL DE INTEGRIDADE}

O direito moral de integridade, tal como disciplinado pela Convenção de Berna, confere ao autor de obras literárias e artísticas o direito de "se opor a toda deformação, mutilação ou outra modificação dessa obra, ou a qualquer dano à mesma obra", desde que "prejudiciais à sua honra ou à sua reputação" (art. 6bis). Esse direito resguarda a honra do autor (a perspectiva do autor sobre ele mesmo) ${ }^{1206}$ e sua reputação (imagem pública do autor, bem como a do ser humano destacado do autor), ${ }^{1207}$ mediante a salvaguarda de sua autonomia artística, ${ }^{1208}$ expressa no conteúdo e na forma de apresentação de suas obras. ${ }^{1209}$

Os termos "distorção", "mutilação" e "modificação" denotam a realização de alguma alteração não-autorizada na forma de apresentação e no conteúdo da obra que possa lhe trazer um prejuízo de ordem moral. Já a expressão "qualquer dano à mesma obra" não é suficientemente clara quanto ao seu significado. A versão oficial em língua inglesa da CB utiliza a expressão "other derogatory action" (“outra ação prejudicial”). Tal expressão deixa transparecer que o direito moral alcança também usos não-transformativos das obras literárias e artísticas, em contextos prejudiciais à honra ou à reputação do autor, ${ }^{1210}$ isto é, o autor tem a prerrogativa de se opor ao uso de sua obra, ainda que sua forma de apresentação e conteúdo sejam preservados, na hipótese de terceiros utilizá-la em contextos prejudiciais à honra ou reputação do autor.

O direito moral de integridade não constitui um direito de propriedade, porquanto não confere aos seus titulares, inter alia, um direito de usar, gozar e de dispor das prerrogativas associadas ao direito de integridade. ${ }^{1211}$ Sem embargo, seus titulares retêm o poder mais característico a compor o direito de propriedade: o de excluir terceiros nãoautorizados que utilizarem suas obras de maneira a pôr em risco sua dignidade e/ou reputação. Haja vista que os parâmetros de avaliação dos prejuízos à honra e à reputação de um autor são eminentemente subjetivos, o direito moral de integridade acabar por conferir aos seus titulares um amplo poder de controle de suas obras. Tal prerrogativa, ao

\footnotetext{
${ }^{1206}$ Cf. WIPO, 2003, p.44-45.

${ }^{1207}$ Cf. DELMANTO et al, 2000, p. 279 e 281.

${ }^{1208}$ Cf. TREIGER-BAR-AM, 2007, p. 5, 15; HUGHES, 1997, p. 162.

${ }^{1209}$ Ver, e.g., TREIGER-BAR-AM, 2007, p. 20; LYPSZYC, 2001, p. 168.

${ }^{1210}$ Cf. RICKETSON, 1987, p. 469.

${ }^{1211}$ Cf. LAMETTI, 2004, p. 288-289.
} 
mesmo tempo em que protege a liberdade de expressão dos autores, também interfere no direito da sociedade de acesso à informação e ao conhecimento e em sua liberdade de expressão artística. $^{1212}$

Sob a ótica das comunidades tradicionais, o reconhecimento do direito moral de integridade teria a função de resguardar seus RBIs contra alterações e aplicações que se mostrem prejudiciais à sua reputação e aos valores que informam sua cultura. ${ }^{1213} \mathrm{~A}$ fím de prevenir alterações e usos culturalmente desrespeitosos, estes grupos demandam a liberdade de condicionar toda forma de uso de seus RBIs à observância de suas normas consuetudinárias e tradições. ${ }^{1214}$

O PBI encerra bens portadores da identidade e de valores culturais diferenciados e desconhecidos pela sociedade dominante, podendo ser desrespeitoso tratá-los irrestritamente como produções intelectuais comuns. ${ }^{1215}$ Muitos RBIs, especialmente as ECTs, embora possam apresentar um apelo artístico ou comercial sob a ótica ocidental, guardam um forte vínculo com as crenças religiosas das comunidades que os conservam. ${ }^{1216} \mathrm{O}$ emprego destes recursos por indivíduos que não compartilham a mesma base cultural das comunidades pertinentes pode ferir sensibilidades culturais, especialmente religiosas e configurar uma blasfêmia. ${ }^{1217}$ Um exemplo dos absurdos que podem resultar da ausência de um direito moral de integridade para o PBI é um CD de canções de comunidades de Papua Nova Guiné, lançado pela Rounder Records, em 1999, composto por canções sagradas cuja execução deveria ser restrita a contextos comunitários. $^{1218}$

O reconhecimento de um direito moral de integridade poderia servir como uma ferramenta de exigibilidade do respeito aos valores culturais das comunidades tradicionais por terceiros, ${ }^{1219}$ notadamente seus valores religiosos. No entanto, é preciso ter claro que o

1212 Cf. WIPO, WIPO/GRTKF/IC/13/5(b) Rev., para. 107.

${ }^{1213}$ Cf. UNESCO, WIPO, 1984, art. 8(iv).

1214 Cf. VON LEWINSKI, 2003-2004, p. 767.

1215 Cf. art. 8o, UNESCO, Declaração Universal sobre a Diversidade Cultural; art. 4(2), CPPDEC. Ver também, BROWN, M., 2005, p. 46.

${ }^{1216}$ Cf. POSEY, 2002.

1217 Cf. GERVAIS, 2003, p. 469-473; DAES, 2001, p. 144.

${ }^{1218}$ Cf. KALINOE, 2004, p. 47-49.

${ }^{1219}$ Ver, e.g., princípio no. 9 (princípio do respeito), INTERNATIONAL SOCIETY OF ETHNOBIOLOGY, 2008; HUDSON, 2006, p. 76. 
direito internacional reconhece às comunidades tradicionais a liberdade de pensamento, de consciência e de religião (liberdade de religião) ${ }^{1220}$ cujo núcleo normativo engloba dentre outras liberdades:

i. "A de ter ou adotar uma religião ou uma crença de sua escolha";

ii. "A de praticar cultos ou de celebrar reuniões associadas à religião ou às convicções, e a de fundar e manter lugares para estes fins";

iii. "A de confeccionar, adquirir e utilizar, em quantidades suficientes, os artigos e materiais necessários para os ritos ou costumes de uma religião ou convicção;" ${ }^{1223}$

iv. "A de escrever, publicar e difundir publicações pertinentes a estas esferas"; ${ }^{1224}$

v. "A de ensinar religião ou convicções em lugares aptos para estes fins"; ${ }^{225}$

vi. "A de observar dias de descanso e de celebrar festividades e cerimônias de conformidade com os preceitos de sua religião ou convicção"; ${ }^{1226} \mathrm{e}$

vii. "A de estabelecer e manter comunicações com indivíduos e comunidades acerca de questões de religião ou convicções em âmbito nacional e internacional". ${ }^{127}$

O direito internacional consente que as comunidades tradicionais adotem, conservem e manifestem suas crenças religiosas e seus valores culturais, mas não as autoriza a impor suas crenças e valores a terceiros. ${ }^{1228}$ Da mesma forma que as comunidades desfrutam da liberdade de expressar seus valores e opiniões, os demais membros da sociedade gozam do mesmo direito.

1220 Cf. art. 18(1), PIDCP combinado com seu art. 27. O mesmo direito é reconhecido pelo: art. 18, Declaração Universal dos Direitos do Homem; art. $1^{\circ}$ da Declaração da ONU sobre a Eliminação de Todas as Formas de Intolerância e Discriminação baseada em Religião ou Credo (UNGA, Resolution 36/55); art. 5 (vii), Convenção Internacional sobre a Eliminação de Todas as Formas de Discriminação Racial.

${ }^{1221}$ Cf. art. 18(1), PIDCP.

1222 Cf. art. 6(a), Declaração da ONU sobre a Eliminação de Todas as Formas de Intolerância e Discriminação baseada em Religião ou Credo.

1223 Cf. art. 6(c), Declaração da ONU sobre a Eliminação de Todas as Formas de Intolerância e Discriminação baseada em Religião ou Credo.

${ }^{1224}$ Cf. art. 6(d), Declaração da ONU sobre a Eliminação de Todas as Formas de Intolerância e Discriminação baseada em Religião ou Credo.

1225 Cf. art. 6(e), Declaração da ONU sobre a Eliminação de Todas as Formas de Intolerância e Discriminação baseada em Religião ou Credo.

${ }^{1226}$ Cf. art. 6(h), Declaração da ONU sobre a Eliminação de Todas as Formas de Intolerância e Discriminação baseada em Religião ou Credo.

${ }^{1227}$ Cf. art. 6(i), Declaração da ONU sobre a Eliminação de Todas as Formas de Intolerância e Discriminação baseada em Religião ou Credo.

${ }^{1228}$ Cf. art. 18(2), PIDCP. 
Há muitas comunidades tradicionais, que demandam o reconhecimento internacional de um direito moral de integridade sobre seus recursos biológicos e conhecimentos conexos, porquanto se opõem ao uso científico e industrial transformativo destes recursos com fundamento em suas crenças religiosas. ${ }^{1229}$ Antes que a comunidade internacional decida por apoiar irrestritamente tais demandas, é preciso compreender que um mesmo recurso pode ter múltiplas aplicações e formas de apresentação, que coexistem pacificamente. As comunidades tradicionais podem empregar um determinado recurso da biodiversidade em rituais religiosos, enquanto cientistas empregam-no para extrair uma proteína bioativa, útil ao desenvolvimento de uma nova terapia médica. $\mathrm{O}$ uso científico e comercial desta molécula não interfere na autonomia das comunidades tradicionais de utilizar o recurso-fonte da molécula, em contextos religiosos. ${ }^{1230}$ Identificar identidade onde há diversidade, a fim de reconhecer às comunidades tradicionais o direito de embargar usos social e comercialmente úteis de RBIs, despirá países em desenvolvimento e mesmo estes grupos de oportunidades de desenvolvimento social, científico e econômico. ${ }^{1231}$

Este raciocínio, contudo, não se aplica às ECTs. Uma canção sagrada que integra o patrimônio cultural de uma determinada comunidade indígena conservará tal natureza, quando entoada em um ritual religioso ou utilizada como música de fundo em uma propaganda publicitária. Isto porque as ECTs ostentam uma forma de apresentação mais próxima a de um produto final que os recursos da biodiversidade e seus conhecimentos conexos. Logo, sua descontextualização, ainda que realizadas alterações em sua forma de apresentação, não resultará em sua dessacralização, uma vez que as ECTs originais e suas derivações sempre guardarão algum grau de identidade entre si.

$\mathrm{Na}$ seara dos direitos autorais, o direito moral de integridade pode conferir aos seus titulares um direito de exclusão amplo, porque este direito recai apenas sobre a expressão criativa de uma idéia, conservando em domínio público as idéias que permeiam a obra. Um artista pode ser proibido de alterar uma determinada obra artística, pois, na perspectiva de seu titular, o projeto proposto infringiria sua dignidade. Contudo, o autor terá a liberdade

\footnotetext{
${ }^{1229}$ Ver, e.g., SOLOMON, 2004, p. 163; WHITT, 1998, p. 238.

${ }^{1230}$ Cf. ALARCÓN; MORALES, 2000, p. 86.

${ }^{1231}$ Cf. SOPLÍN; MULLER, 2008, p. 11.
} 
de se inspirar nas idéias a ela incorporadas e em outras fontes criativas para criar sua própria obra.

As áreas técnicas do direito da propriedade intelectual (e.g., o direito das patentes) investem em seus titulares apenas o direito moral de atribuição. ${ }^{1232}$ Em comparação com as produções literárias e artísticas, nas produções técnicas, a presença da personalidade de seus autores é mínima, pois as limitações técnicas restringem o espaço, em que pode ser expressa sua personalidade. ${ }^{1233}$ Uma determinada seqüência de DNA, responsável pela produção de uma dada proteína medicinal, não pode ter sua função natural alterada ao bel prazer dos cientistas. Naturalmente, pode haver um espaço de manobra para alterá-la ou para ampliar o leque de aplicações da proteína, mas este espaço é fixado pelas leis da natureza e instrumentos técnicos disponíveis e não pela personalidade dos cientistas.

Por outro lado, uma obra artística pode ser manipulada e transformada em uma infinidade de produtos. Se existisse um direito moral de integridade em relação às produções científicas, seus titulares poderiam impedir o acesso da humanidade aos inventos protegidos, sob a justificativa de que os usos e alterações realizadas por terceiros afrontariam sua dignidade ou reputação. O desenvolvimento científico e comercial da humanidade seriam reféns do bom-senso dos titulares de direitos morais.

O Comitê de Direitos Econômicos, Sociais e Culturais recomenda aos Estados parte do PIDESC que garantam às comunidades tradicionais um direito moral de integridade inclusivo, estendido a todas as categorias de RBIs. ${ }^{1234}$ O Comitê ignorou a diferenciação do escopo dos direitos morais reconhecidos pelos marcos de direitos autorais e pelos de patentes, que se presta a resguardar a liberdade científica e criativa da sociedade. Se o próprio PIDESC determina que seus Estados contratantes, quando do estabelecimento de regimes de proteção dos interesses morais de comunidades tradicionais sobre suas produções intelectuais, adotem medidas voltadas "à difusão da ciência e da cultura" (art. 15(2)) e ao respeito da "liberdade indispensável à pesquisa científica e à atividade criadora" (art. 15(3)), não há espaço legal para se delinear o conteúdo normativo dos

\footnotetext{
${ }^{1232}$ Cf. art. 4ter, CP ("O inventor tem o direito de ser mencionado como tal na patente.").

${ }^{1233}$ Cf. HUGHES, 1997, p. 152.

${ }^{1234}$ Cf. CESCR, E/C.12/GC/17, para. 32 e 33.
} 
direitos morais das comunidades tradicionais às expensas dos interesses dos usuários de RBIs.

O direito à liberdade de expressão e de pensamento, tutelado, inter alia, pelo PIDCP (art. 19(2)), ${ }^{1235}$ igualmente estabelece uma limitação ao reconhecimento às comunidades tradicionais de um direito moral de integridade amplo. O Pacto assegura a todo ser humano "a liberdade de procurar, receber e difundir informações e idéias de qualquer natureza, independentemente de considerações de fronteiras, verbalmente ou por escrito, em forma impressa ou artística, ou por qualquer outro meio de sua escolha." O direito à liberdade de expressão e de pensamente compreende o direito de formar uma opinião, o qual tem como condição essencial a conservação de uma variedade de fontes de informação e conhecimento, acessíveis pelo público. ${ }^{1236}$ Naturalmente, este direito não é absoluto, podendo ser limitado, a fim de "assegurar o respeito dos direitos e da reputação das demais pessoas; proteger a segurança nacional, a ordem, a saúde ou a moral públicas" (art. 19(3)). O reconhecimento de um direito de controle absoluto dos RBIs em favor das comunidades tradicionais, ao encerrar fontes de conhecimentos e informações úteis à humanidade, constitui, acima de tudo, segundo a perspectiva da Corte Interamericana de Direitos Humanos, um ataque a um dos elementos fundamentais da democracia. ${ }^{1237}$

Portanto, a proteção reconhecida pelo PIDESC aos interesses morais das comunidades tradicionais em relação às suas produções intelectuais não é absoluta. $\mathrm{O}$ conteúdo normativo dos direitos reconhecidos deve ser estabelecido de modo a harmonizálos com outros direitos humanos e liberdades fundamentais que com eles possam conflitar. ${ }^{1238}$ Os direitos conferidos às minorias étnicas, religiosas e lingüísticas em normas gerais ou específicas são construídos sobre as fundações do direito internacional, não gozando de uma vida independente. ${ }^{1239}$ Qualquer interpretação e aplicação dos direitos

\footnotetext{
${ }^{1235}$ Esse direito também é reconhecido pela Declaração Universal dos Direitos do Homem (art. 19) e pela Declaração Americana dos Direitos e Deveres do Homem (art. 13).

${ }^{1236}$ Cf. BEAT-GRABER, 2006, p. 10.

${ }^{1237}$ Cf. CORTE INTERAMERICANA DE DERECHOS HUMANOS, 2006d, para. 85.

1238 Ver, e.g., UNITED NATIONS SUB-COMMISSION ON HUMAN RIGHTS, Resolution 2001/21, preâmbulo e para. 5; UNITED NATIONS COMMISSION ON HUMAN RIGHTS, Resolution 2005/20, preâmbulo; UNGA, Resolution 36/55, art. $8^{\circ}$; art. 31(1) combinado com o art. 46(2), Declaração das Nações Unidas sobre os Direitos do Povos Indígenas, (a Declaração reconhece a estes grupos o direito à proteção de seu PBI, mas limita seu exercício na medida necessária para se respeitar os direitos humanos de todos os outros setores da sociedade); art. $2^{\circ}$, CPPDEC; artigos $2^{\circ}$ e $5^{\circ}$ in fine, Declaração Universal sobre a Diversidade Cultural; artigos 5(1), 18(3) PIDCP; art. 8(2), Convenção no. 169 da OIT.

${ }^{1239}$ Ver, e.g., CHEN, L. 1989; CHEN, L. 1987; ANAYA, 2004, p. 25.
} 
reconhecidos às comunidades tradicionais, de maneira a infringir os direitos garantidos aos demais membros da sociedade, não passa pelo crivo do direito internacional. ${ }^{1240}$

A fim de prevenir que direitos morais inclusivos impactem na liberdade científica, criativa e de expressão de terceiros, à primeira vista, seria uma alternativa fixar o escopo dos direitos morais relativos aos RBIs em consonância com a abordagem adotada pelo marco legal de proteção da PI: garantir às comunidades tradicionais um direito amplo de atribuição em relação a todas as categorias de RBIs e limitar o reconhecimento do direito moral de integridade aos RBIs de natureza artística (ECTs).

Contudo, o reconhecimento de um direito moral de integridade que se estendesse para toda e qualquer ECT obstaculizaria a liberdade criativa da humanidade e, mais importante, interferiria no ritmo de geração de recursos econômicos derivados das ECTs, em prol da manutenção das fontes humanas e ambientais do PBI. Faz-se necessária, pois, limitar o escopo do direito moral de integridade em relação às ECTs, na medida necessária a torná-lo compatível com a proteção dos interesses materiais das comunidades tradicionais e com a liberdade criativa dos demais membros da sociedade. ${ }^{1241}$

A opção pela supressão do direito moral de integridade não se mostra legalmente adequada, pois abriria as comportas para usos contrários aos valores espirituais e à reputação das comunidades pertinentes. Mantê-lo amplo, por outro lado, conforme já mencionado, poderia esvaziar a liberdade criativa e de expressão da sociedade.

A alternativa mais equilibrada é estender o direito moral de integridade tão-somente às ECTs de natureza sagrada ou culturalmente sensíveis, cabendo às comunidades tradicionais a competência para identificar quais ECTs são laicas e quais são sagradas. Da mesma forma que o homem médio se opõe ao emprego público de iconografia sacra, enraizada em sua cultura, fora de determinados contextos, as comunidades tradicionais também devem gozar do direito de controlar as alterações e contextos, em que são utilizadas suas ECTs sagradas. O uso desenfreado de ECTs sagradas pela sociedade

${ }^{1240}$ Cf. MCDOUGAL; LASSWELL, CHEN, 1969, p.269. Ver também art. 30, Declaração Universal de Direitos do Homem; art. 5(1), PIDESC; art. 5(1), PIDCP; CESCR, E/C.12/40/15, p. 10-11.

${ }^{1241}$ Ver, e.g., CESCR, E/C.12/2000/4, para. 29; CESCR, E/C.12/40/15, p. 10-11; art. 4º, PIDESC; art. 29(2), Declaração Universal dos Direitos do Homem; CORTE INTERAMERICANA DE DERECHOS HUMANOS, 2006d, para. 91; CCPR, CCPR/C/21/Rev.1/Add.13, para. 6. 
dominante pode dar lugar a tensões e conflitos, como os que assistimos com a publicação pelo jornal dinamarquês Jyllands-Posten de charges do profeta Maomé, de maneira a ofender a religião Islâmica; ${ }^{1242}$ com a publicação de um ensaio erótico pela revista Playboy, em que uma atriz seminua ${ }^{1243}$ aparece portando um terço, um dos símbolos do Cristianismo; ${ }^{1244}$ e com a divulgação dos filmes Je vous salue Marie, de Jean-Luc Godard, e A Última Tentação de Cristo, de Martin Scorcese, em que imagens e histórias sagradas aos seguidores do Cristianismo foram associadas a imagens com apelo sexual.

Restringir o reconhecimento do direito moral de integridade das comunidades tradicionais apenas às ECTs de natureza sacra corresponde ao desejo de seus membros de vê-las protegidas contra alterações e aplicações profanas e ao compromisso dos Estados de compatibilizar o respeito à dignidade das diversas culturas, que compõem a humanidade, com a liberdade científica, criativa e de expressão de terceiros, satisfazendo, assim, "as justas exigências da moral, da ordem pública e do bem-estar de uma sociedade democrática”. 1245

\subsubsection{CRITÉRIO DE OPERACIONALIZAÇÃO 4: EFETIVIDADE DOS REGIMES DE PROTEÇÃo} EM ESCALA GLOBAL

Drahos e Daes chamam a atenção para o fato de que ainda que as negociações em curso culminem na adoção de regimes internacionais vinculantes, fundados sobre as três condições já tratadas neste capítulo, a proteção real do PBI somente será alcançada, se os novos regimes forem exigíveis em escala global, sobretudo nas jurisdições dos países usuários de RBIs (países industrializados). ${ }^{1246} \mathrm{~A}$ garantia formal às comunidades tradicionais e aos Estados de mundos e fundos em acordos não auto-executáveis, sem lhes

1242 Com a publicação, o cartunista recebeu ameaças de morte; escritórios diplomáticos da Dinamarca foram atacados na Síria e no Líbano; e protestos ocorridos na Nigéria, Líbia e Paquistão resultaram em mortes. Cf. JORNAIS [...], 2008.

${ }^{1243}$ Cf. JANSSEN, 2009, p. 13-15.

1244 Cf. PORTAL IMPRENSA, 2008.

1245 Cf. art. 29(2), Declaração Universal dos Direitos do Homem (esse dispositivo da DUDH determina que "No exercício de seus direitos e liberdades, toda pessoa estará sujeita apenas às limitações determinadas pela lei, exclusivamente com o fim de assegurar o devido reconhecimento e respeito dos direitos e liberdades de outrem e de satisfazer às justas exigências da moral, da ordem pública e do bem-estar de uma sociedade democrática."

${ }^{1246}$ Cf. DRAHOS, 2007, p. 386; DAES, 2001, p. 146; SCBD, UNEP/CBD/WG8J/1/2, para. 83. 
aprovisionar com os meios para efetivamente reivindicá-los, ${ }^{1247}$ transformará acordos legalmente vinculantes em "regulações simbólicas", ${ }^{1248}$ incapazes de trazer qualquer alívio aos problemas por eles enfrentados.

Conquanto os direitos econômicos, sociais e culturais estejam sujeitos à realização progressiva, já que sua realização depende da alocação de recursos que os Estados podem não dispor, ${ }^{1249}$ com o objetivo de dotar de efetividade os direitos assegurados às comunidades tradicionais pelo art. 15(1)(c) do PIDESC, suas partes contratantes devem cumprir de imediato com algumas obrigações mínimas. ${ }^{1250}$ Tais obrigações apenas podem deixar de ser observadas, se a parte contratante comprovar que envidou seus melhores esforços e empregou todos os recursos de que dispunha para realizá-los. ${ }^{1251}$ Recordando que o problema da apropriação sistemática de RBIs se dá pela omissão de países materialmente ricos, é improvável que logrem justificar sua omissão na adoção de medidas, para tornar exigíveis os direitos econômicos e morais das comunidades locais. Segundo o Comitê de Direitos Econômicos, Sociais e Culturais, as obrigações mínimas associadas ao art. 15(1)(c), que devem ser cumpridas pelos Estados contratantes do Pacto compreendem: ${ }^{1252}$

i. Adoção de medidas legislativas e disponibilização de remédios judiciais às comunidades locais, que viabilizem a reivindicação de proteção aos seus interesses materiais e morais, resultantes de suas produções intelectuais; ${ }^{1253}$

ii. Tutela dos interesses materiais e morais das comunidades tradicionais de maneira a reconciliá-los com outros direitos humanos, dentre eles, o direito à alimentação, à saúde, à educação, ao acesso à cultura, à participação na vida cultural da sociedade; e

\footnotetext{
${ }^{1247}$ Ver, e.g., SCBD, UNEP/CBD/WG8J/3/INF/1, p. 38; SCBD, UNEP/CBD/WG8J/5/INF/15, p. 14.

${ }^{1248}$ Cf. DRAHOS, 2007, p. 386.

${ }^{1249}$ Cf. CESCR, E/1991/23, para. 9-10.

${ }^{1250}$ Ibid., para. 10.

1251 Ibid.

${ }^{1252}$ Cf. CESCR, E/C.12/GC/17, para. 39.

${ }^{1253}$ Id., E/C.12/1998/24, para. 2.
} 
iii. Em razão das condições especiais em que vive a maioria das comunidades tradicionais, os Estados contratantes devem tomar medidas especiais que as habilite de fato a reivindicar proteção aos seus interesses morais e materiais.

Embora inexista um comentário oficial que indique as obrigações mínimas a serem cumpridas imediatamente pelos Estados contratantes da CDB, o conteúdo das obrigações mínimas associadas ao art. 15(1)(c) do PIDESC seriam aplicáveis mutatis mutandis aos Estados partes da CDB: primeiramente, porque este é um acordo vinculante e, portanto, regido pelo princípio pacta sunt servanda. Em segundo lugar, porque a realização dos direitos das comunidades tradicionais em relação aos seus RBIs (CTs e ECTs) é dependente da conservação e restauração da biodiversidade que os sustenta direta (CTAs) ou indiretamente (ECTs). Em terceiro lugar, porque o art. 8(j) da CDB nada mais é do que uma derivação do art. 15(1)(c) do PIDESC, com a diferença que ele se presta a proteger exclusivamente os interesses morais e materiais das comunidades tradicionais sobre seus conhecimentos tradicionais associados à biodiversidade, enquanto o Pacto tutela os conhecimentos tradicionais em geral (ainda que não-associados à biodiversidade) e as expressões culturais tradicionais.

Retornando às obrigações mínimas assumidas pelos Estados contratantes do PIDESC e da CDB, a terceira obrigação merece especial atenção. Exatamente por conta das dificuldades materiais enfrentadas pelos detentores de RBIs, mesmo que os países industrializados saíam da inércia e finalmente adotem regimes de proteção do PBI, ainda assim persistirá uma assimetria pronunciada de poder e recursos entre os titulares de direitos sobre RBIs e seus usuários. ${ }^{1254}$

É fato que, em regra, as comunidades tradicionais e muitos países em desenvolvimento não detêm a expertise necessária para negociar acordos de licenciamento de seus RBIs e para defender seus interesses perante tribunais nacionais e estrangeiros. ${ }^{1255}$ Assim sendo, suas debilidades materiais abrem espaço para a apropriação contínua de seu PBI; seja porque celebram acordos de licenciamento de seus RBIs em termos que lhes são desfavoráveis; seja porque sobrevalorizam seu potencial econômico e acabam impondo

\footnotetext{
${ }^{1254}$ Ver, e.g., WIPO, WIPO/GRTKF/IC/12/5(b), anexo, p. 163; SCBD, UNEP/CBD/WG8J/4/INF/16, para. 32.

${ }^{1255}$ Ver, e.g., JANKE, 2003, p. 94; SCBD, UNEP/CBD/WG8J/5/INF/10, para. 40.
} 
condições tão irreais que espantam potenciais usuários; seja porque lhes faltam os recursos econômicos ${ }^{1256}$ e técnicos, para perseguir os responsáveis por uma quebra de contrato ou pela apropriação pura e simples de seus recursos, em âmbito local ou em outras jurisdições.

A correção dessa assimetria de pode ser realizada, se os futuros regimes internacionais incorporarem um pacote de medidas especiais de assistência, endereçadas sobretudo às comunidades tradicionais, que os tornarão verdadeiramente exigíveis, em âmbito global. ${ }^{1257}$

Uma primeira medida que se afigura necessária é o oferecimento aos detentores de RBIs de apoio técnico especializado para a negociação de acordos de licenciamento e repartição de benefícios com os potenciais usuários. ${ }^{1258}$ Uma assessoria especializada em licenciamento, capacitada a avaliar adequadamente o valor comercial destes recursos e a realidade dos mercados em que serão aplicados, impedirá que as comunidades tradicionais e países em desenvolvimento caiam vítimas de contratos leoninos, ou de seu desconhecimento, o que poderia lhes conduzir ao equívoco de condicionar a celebração de um acordo à observância de condições distanciadas da realidade dos mercados.

Considerando as dificuldades enfrentadas por qualquer titular de direitos sobre produções intelectuais para monitorar possíveis infrações e demandar proteção em todos os mercados, onde possa desfrutar proteção, ${ }^{1259}$ uma segunda medida de assistência seria a organização de uma estrutura institucional competente para, inter alia, monitorar globalmente $^{1260}$ sua exploração por terceiros; identificar eventuais infrações aos direitos conferidos; propugnar ações judiciais perante tribunais locais e estrangeiros, em defesa dos direitos conferidos; receber e distribuir os benefícios econômicos devidos aos titulares de RBIs, em virtude de seu uso comercial.

Uma estrutura especialmente capacitada para monitorar continuamente infrações aos direitos conferidos é fundamental, sobretudo quando recordamos que produtos desenvolvidos a partir da associação entre recursos da biodiversidade e CTs, geralmente, se

\footnotetext{
${ }^{1256}$ Cf. TWAROG, 2004, p. 65.

${ }^{1257}$ Cf. artigos 3(1), 4(1), 33(1), 12, Convenção no. 169 da OIT.

1258 Ver, e.g., CARNEIRO DA CUNHA, 2004, p. 92; SCBD, UNEP/CBD/WG8J/5/INF/10, para. 47(m); INTERGOVERNMENTAL PANEL ON FORESTS, [200-?], proposta 40(g).

${ }^{1259}$ Cf. KANSA; SCHULTZ; BISSELL, 2005, p. 16.

${ }^{1260}$ Cf. SCBD, UNEP/CBD/WG8J/2/7, para. 83.
} 
distanciam das matérias-primas brutas, utilizadas no processo de $\mathrm{P} \& \mathrm{D},{ }^{1261}$ bem como pelo fato do processo de inovação consumir muitos anos até culminar no lançamento de um novo produto.

É relevante destacar que a importância de se dar atenção à efetividade dos futuros regimes internacionais de proteção do PBI é corroborada pela motivação que impulsionou a negociação do Acordo TRIPS. Os países industrializados (e seus conglomerados empresariais) advogaram em seu favor não porque inexistisse àquela época um marco legal internacional de proteção da PI, mas porque o marco legal então vigente, composto essencialmente pelos acordos administrados pela OMPI, não estava munido de mecanismos legais que os dotasse de exigibilidade internacional. ${ }^{1262}$ Até a adoção do Acordo TRIPS, os Estados contratantes dos acordos de proteção da PI fruíam de uma ampla discricionariedade para observarem suas obrigações, em conformidade com seus interesses nacionais. Tal liberdade poderia, inclusive, ser utilizada para desrespeitar abertamente as obrigações contraídas. No presente, um Estado membro da OMC que desrespeitar as obrigações mínimas fixadas pelo Acordo TRIPS, estará sujeito a pesadas sanções comerciais, aplicáveis pelas partes prejudicadas. ${ }^{1263}$

Ainda hoje, preocupados com o desrespeito à PI de seus nacionais, países industrializados continuam a pressionar países em desenvolvimento a adotarem medidas relacionadas à melhoria da efetividade dos DPIs conferidos. São ilustrativas da importância dada pelos países industrializados ao tema a iniciativa conjunta dos EUA, Japão e União Européia de negociar o acordo Anti-Counterfeiting Trade Agreement, que, se aprovado, obrigará suas partes a adotarem medidas rígidas assecuratórias da exigibilidade de DPIs em seus territórios; a legislação modelo da Organização Mundial Aduaneira relacionada à adoção de medidas de fronteira, voltadas a embaraçar a circulação internacional de produtos infratores aos DPIs; e a criação pela International Criminal Police Organization (INTERPOL) de uma unidade especializada em crimes relacionados à infração aos DPIs. $^{1264}$

\footnotetext{
${ }^{1261}$ Cf. DUTFIELD, 2004a, p. 145.

${ }^{1262}$ Ver, e.g., DREYFUSS; LOWENFELD, 1996-1997, p. 275- 284; BASSO, 2000, p. 147-160.

${ }^{1263}$ Cf. HENNING-BODEWIG, 2006, p. 21.

${ }^{1264}$ Cf. BIADGLENG; TELLEZ, 2008, p. 17-27.
} 


\subsection{OGCDS E OGDS}

Para dotar de efetividade os direitos conferidos aos detentores de RBIs é fundamental que os futuros regimes internacionais se apóiem obrigatoriamente em organizações de gestão coletiva de direitos (OGCDs) ou em organizações de gestão de direitos (OGDs) (genericamente, organizações de gestão de direitos). ${ }^{1265}$ Freqüentemente, essas instituições são utilizadas, no marco dos direitos autorais e conexos, para dotar de efetividade os direitos dos autores, intérpretes e empresas fonográficas, em escala global. A determinação de qual das duas organizações seria a mais adequada para a gestão dos RBIs depende, dentre outros fatores, do mecanismo legal utilizado para sua proteção (e.g. direito de propriedade, regras de repressão da concorrência desleal, regime de responsabilidade etc.), o que apenas será possível indicar, após a avaliação das propostas em debate e construção na $\mathrm{CCDB}, \mathrm{OMC}$ e $\mathrm{OMPI}$, em face dos demais critérios de operacionalização que compõem o quadro conceitual de desenvolvimento sustentável.

No marco de direitos autorais e conexos, as OGCDs são competentes para, em nome dos titulares de direitos: (i) celebrar acordos de licenciamento com terceiros cujas cláusulas e taxas de royalties são pré-estabelecidos para cada categoria de uso possível, com o objetivo de tornar o processo de licenciamento rápido e barato, porquanto standardizado; (ii) monitorar possíveis infrações aos direitos sobre as obras geridas e perseguir supostos infratores; (iii) recolher a remuneração devida pelos usuários e repassála aos titulares de direitos. ${ }^{1266}$ Enfim, as OGCDs representam os interesses dos titulares de direitos autorais e conexos, ao mesmo tempo em que facilitam a vida dos potenciais usuários de obras literárias, artísticas e musicais, ao lhes disponibilizar um amplo portfólio de produções intelectuais, rapidamente acessíveis mediamente a assinatura de contratospadrão e o pagamento de taxas de licenciamento, previamente fixadas pela organização. ${ }^{1267}$

\footnotetext{
1265 Nesse sentido, cf. WIPO, WIPO/GRTKF/IC/9/INF/4, anexo I, p. 37, 149; WIPO, WIPO/GRTKF/IC/3/10, anexo I, p. 42-45.

${ }^{1266}$ Cf. FICSOR, 2002, p. 17.

${ }^{1267}$ Informações prestadas por Tarja Koskinen-Olsson, em comunicação pessoal datada de 14 de setembro de 2006.
} 
Em sentido diverso, no sistema de gestão individual, os direitos autorais e conexos são geridos diretamente por seus titulares, cabendo-lhes, dentre outras funções, negociar individualmente acordos de licenciamento com os potenciais usuários de suas obras, ${ }^{1268} \mathrm{o}$ que certamente consome tempo e energia de todos os envolvidos na negociação e, dependendo do conhecimento dos titulares de direitos sobre o funcionamento dos mercados em que serão aplicadas suas obras, as negociações podem ser infrutíferas.

A diferença fundamental entre o sistema de gestão coletiva de direitos, operado por OGCDs, e os de gestão individual está no fato do primeiro operar um sistema de gestão homogêneo para todos os titulares de direitos e usuários. Ou seja, a fixação das tarifas pelo uso das obras, as condições de licenciamento, a administração do sistema de solução de disputas e do sistema de coleta e distribuição de royalties cabem à OGCD. ${ }^{1269}$ As OGCDs, ao tornarem o processo de licenciamento transparente e previsível para os usuários e titulares de direitos, reduz sensivelmente os custos de transação ${ }^{1270}$ e diminuem as chances que negócios deixem de ser realizados, em virtude da inabilidade dos titulares de direitos para negociar acordos de licenciamento e fixar condições condizentes com a realidade dos mercados.

Nos domínios dos direitos autorais e conexos, as OGCDs são tratadas como imprescindíveis ao seu exercício, sempre que obras literárias, artísticas e musicais forem utilizadas em massa e seus titulares não detiverem o instrumental técnico e os meios econômicos para: monitorarem o respeito aos seus direitos, em todos os mercados onde forem protegidas; negociarem acordos de licenciamento com os potenciais usuários; e cobrarem os royalties resultantes de sua exploração comercial. ${ }^{1271}$ Por exemplo, embora os regimes de direitos autorais confiram aos autores de composições musicais o direito de controlar sua execução pública, na prática, o exercício individual desse direito é impossível. Nenhum individuo está capacitado a monitorar 24 horas/dia a execução pública de suas composições em todas as emissoras de rádio e TV locais e estrangeiras. Por essa razão, criaram OGCDs, competentes para controlar sua comercialização e exploração. ${ }^{1272}$

\footnotetext{
1268 Cf. CLARK; KOSKINEN-OLSSON, 1998, p.233.

${ }^{1269}$ Cf. FICSOR, op.cit., p. 12 e 157.

${ }^{1270}$ Cf. GRAFF; ZILBERMAN, 2001b, p. 6.

1271 Ver, e.g., FICSOR, 2002, p. 13, 19; FICSOR, 2006, p. 45.

1272 Cf. BELL; PARCHOMOVSKY, 2007, p. 16-17.
} 
As OGCDs também são utilizadas por aqueles indivíduos e instituições que, embora detenham a capacidade para gerir individualmente seus direitos, optam por se unir a outros indivíduos, sob o amparo de uma mesma instituição, a fim de fortalecerem seu poder de negociação em face de instituições poderosas. ${ }^{1273}$ Portanto, as OGCDs resultam do esforço cooperativo de titulares de direitos autorais e conexos, que se reconhecem incapazes de gerir isoladamente seus direitos; estes organismos atuam nos espaços inalcançáveis aos titulares de direitos, individualmente considerados.

As organizações de gestão de direitos (OGDs), por sua vez, diferentemente das OGCDs, preservam a discricionariedade dos titulares de direitos de fixar a remuneração pelo uso de seus RBIs e os termos dos acordos de licenciamento. As OGDs são geralmente dotadas de três bancos de dados: um que compreende as obras protegidas e informações específicas para cada uma delas a respeito dos usos proibidos e os autorizados e as condições a serem cumpridas pelos potenciais usuários. O segundo banco de dados indica a identidade do titular(s) de direitos e, em caso de titularidade compartilhada, o percentual da remuneração que caberá a cada um. Um terceiro banco de dados conta com informações de identificação a respeito dos licenciados. ${ }^{1274}$ As OGDs limitam-se, pois, a assegurar que a vontade dos titulares de direitos será integralmente refletida nos acordos de licenciamento e efetivamente cumprida pelos licenciados, a emitir faturas, receber os royalties contratados e repassá-los às partes pertinentes. ${ }^{1275}$

Independentemente de qual seja o tipo de instituição mais adequada para a gestão de RBIs (uma espécie de OGCD ou de OGD ou, ainda, uma organização sui generis, resultante da fusão das duas) frente aos demais critérios que integram o quadro conceitual de desenvolvimento sustentável, ${ }^{1276}$ ela deverá encerrar, ao menos, dois elementos fundamentais: um registro obrigatório dos RBIs protegidos e uma rede de organizações científicas.

\footnotetext{
${ }^{1273}$ Cf. FICSOR, op.cit., p. 131.

${ }^{1274}$ Informações prestadas por Tarja Koskinen-Olsson, em comunicação pessoal datada de 12 de setembro de 2006.

${ }^{1275}$ Cf. FICSOR, op.cit., p. 12.

${ }^{1276}$ Somente será possível identificar o tipo de organização mais adequada para a gestão internacional do PBI no capítulo 4, quando for constatado o mecanismo legal ou associação de mecanismos legais mais apropriados para tutelar os diversos tipos de RBIs (direitos de propriedade, regras de repressão da concorrência desleal e/ou regime de responsabilidade).
} 


\section{§1 REGISTRO OBRIGATÓRIO DOS RBIS PROTEGIDOS E UMA REDE DE INSTITUIÇÕES CIENTÍFICAS}

Recursos informacionais, diferentemente dos recursos tangíveis, apresentam fronteiras fluídas que podem ser manipuladas com facilidade tanto em favor quanto em detrimento dos interesses de seus titulares. Qualquer regime legal que se preste a proteger com efetividade recursos intelectuais deve ser capaz de determinar, com segurança, aquilo que é protegido, ${ }^{1277}$ de maneira a demarcar as diferenças entre recursos similares e a fronteira que separa o domínio privado do público. É exatamente para trazer segurança aos titulares de direitos e ao público em geral que os regimes de proteção da PI condicionam a proteção de bens intangíveis ao seu registro (e.g. regimes de proteção de marcas, patentes, cultivares, desenhos industriais) ou à sua fixação em um substrato permanente ou semipermanente (i.e. regime de direitos autorais), ao trazer visibilidade e concretude. ${ }^{1278}$

O mesmo caminho deve ser seguido pelos regimes de proteção de RBIs. ${ }^{1279}$ Sobretudo porque uma das razões centrais que conduziu ao fracasso das negociações de 1984, voltadas à adoção do Tratado para a Proteção das Expressões Folclóricas contra Exploração Ilícita e outras Ações Prejudiciais, foi a ausência de um mecanismo que viabilizasse a identificação das ECTs que seriam objeto de proteção. ${ }^{1280}$ Não seria sábio ignorar as lições do passado e dispensar a necessidade de integrar, à estrutura dos futuros regimes de proteção, um mecanismo que traga publicidade e visibilidade aos RBIs protegidos.

O registro prévio de RBIs seria benéfico tanto aos interesses dos titulares de direitos quanto aos do público em geral. ${ }^{1281}$ Os titulares de direitos sobre RBIs gozariam de maior facilidade para substanciar, a um custo baixo, reivindicações de direitos em face de potenciais infratores. ${ }^{1282}$ Com provas frágeis sobre a existência do RBI, ações judiciais ou administrativas, fundadas na alegada apropriação de um RBI cujo conteúdo é desconhecido, podem não prosperar.

\footnotetext{
1277 Ver, e.g., GERVAIS, 2005, p.164; AOKI, 1998, p. 34; SMITH, 2007, p. 14-15; KATZ, 2008, p. 12-13.

${ }^{1278}$ Cf. HUGHES, 1997, p. 112.

1279 Cf. KIRSCH, 2004, p. 35.

${ }^{1280}$ Cf. WIPO, WIPO/GRTKF/IC/3/10, para. 167.

${ }^{1281}$ Cf. THOMPSON, B., 2007, p.142.

1282 Cf. WIPO, WIPO/GRTKF/IC/9/INF/4, anexo 1, para. 76.
} 
A acessibilidade pública ao registro de RBIs protegidos ofereceria ao público a oportunidade de optar conscientemente por respeitar ou infringir os direitos reconhecidos. ${ }^{1283}$ Sem a identificação pública da matéria protegida, um usuário de boa-fé poderia ser surpreendido com uma ação indenizatória pelo uso não-autorizado de, digamos, uma aplicação de um recurso da biodiversidade, que julgava pertencer ao domínio público. Portanto, a inexistência de um registro que inequivocamente identifique as fronteiras das matérias protegidas coloca em risco a liberdade de expressão criativa e inventiva do público, que pode ser restringida pelos arroubos dos titulares de RBIs, ao disporem da liberdade para ampliar o escopo de seus direitos. ${ }^{1284}$

De mais a mais, não se deve ignorar que, na ausência de um registro, o direito de defesa, assegurado pelo Pacto Internacional de Direitos Civis e Políticos, seria colocado em perigo (art. 14). Se o registro for dispensado, é natural que o regime assegure aos titulares de direitos a prerrogativa de propor ações judiciais, mesmo sem provas inequívocas a respeito da existência do RBI supostamente apropriado e de suas fronteiras. Ora, se empresas e indivíduos vierem a ser processados e condenados por infrações a direitos conexos a recursos intelectuais desconhecidos, será aberto um amplo caminho para a prática de arbitrariedades em detrimento dos potenciais usuários de RBIs.

Em síntese, um regime destituído da obrigação de registrar previamente os RBIs permitiria a movimentação da fronteira que separa os objetos protegidos do domínio público, tanto para beneficiar injustificadamente seus titulares (que poderiam ter reconhecidos direitos sobre bens que se assemelham aos seus, mas que com eles não se confundem), quanto para prejudicá-los, mediante a limitação equivocada do alcance de seus direitos.

Contudo, o registro de RBIs não é sempre uma tarefa simples. Naturalmente, a fixação de ECTs em um substrato permanente ou semipermanente e a acessibilidade pública ao registro seriam suficientes para trazer segurança a todas as partes, uma vez que o registro indicaria os traços fundamentais das ECTs protegidas, que estarão presentes em novas aplicações realizadas por terceiros. Assim, por exemplo, mesmo que uma jóia indígena, originalmente produzida com penas e caroços de frutos, venha a ser reestilizada e

${ }^{1283}$ Cf. SMITH, 2007, p. 56.

${ }^{1284}$ Cf. BARLOW, 1997, p. 353. 
produzida com metais e pedras preciosas, seria possível a um perito e mesmo a uma pessoa leiga identificar a origem da peça contemporânea, a partir do exame do registro público.

\section{§ 1.1 REDE DE INSTITUIÇÕES CIENTÍFICAS}

Sem embargo, a situação é diferente para os recursos biológicos e os CTAs. Ainda que um Estado e uma comunidade tradicional registrem e depositem, respectivamente, uma amostra de um dado recurso biológico e o CT a ele associado, tal registro não asseguraria a identificação exitosa de episódios de apropriação indébita. Esses RBIs, quando incorporados a novos produtos, ganham novas apresentações que, muitas vezes, se distanciam dramaticamente de sua forma original. Por exemplo, uma nova cultivar de soja produzida por engenharia genética, resistente a determinadas pragas, em virtude da introdução em seu genoma de uma seqüência genética, extraída de um dado microorganismo, não guarda qualquer identidade com o microorganismo de per si, sendo difícil (quando não impossível) identificar a fonte do gene especial.

Um mesmo recurso biológico pode encerrar uma grande diversidade de recursos intangíveis bioativos, que não só são desconhecidos pelo homem, mas também nãoidentificáveis até que sejam dele isolados e caracterizados estruturalmente. No mesmo sentido, um determinado recurso da agrobiodiversidade pode enganar os olhos humanos que o julgam ordinário, mas que, quando examinado cientificamente e em conjunto com o histórico de usos tradicionais, pode revelar características e elementos valiosos.

Portanto, ao menos que o registro indique claramente as moléculas bioativas contidas em um recurso biológico bruto e suas possíveis aplicações, e as associe aos CTs pertinentes (e.g. recursos biológicos medicinais); bem como indique as características morfológicas, vantagens agrícolas e nutricionais e possíveis genes responsáveis por elas (recursos da agrobiodiversidade), os episódios de apropriação indébita continuarão a ocorrer. 
Em vista das peculiaridades dos CTAs e dos recursos biológicos, a organização de gestão de direitos deveria ser respaldada por uma rede de instituições científicas, investidas na competência de: ${ }^{285}$

i. Realizar estudos taxonômicos dos recursos biológicos depositados para registro. A taxonomia é o campo da ciência responsável pela identificação de cada um dos recursos da biodiversidade (plantas, animais, microorganismos, fungos etc.) e descrição de suas características peculiares e por nomear estes recursos. Atualmente, apenas 1.7 milhões, de um possível total de 100 milhões de espécies de espécies, foram nomeadas. Tanto países industrializados quanto países em desenvolvimento sofrem com a falta de conhecimento sobre a diversidade biológica e com a falta de iniciativas taxonômicas. Sem se conhecer cada um dos elementos da biodiversidade e as interações entre os organismos, é uma tarefa impossível conservá-la apropriadamente. ${ }^{1286}$ No presente, inexiste um inventário internacional atualizado, que conte com informações taxonômicas sobre as espécies já estudadas. Em virtude destas deficiências, a Secretaria da CDB está implementando uma Iniciativa Global de Taxonomia, com o propósito de estimular a comunidade internacional a investir em projetos de taxonomia. ${ }^{1287} \mathrm{O}$ futuro regime internacional de proteção do PBI poderia fazer sua contribuição ao estudo da biodiversidade, se as instituições científicas de apoio da organização de gestão de direitos contarem com especialistas em taxonomia, e se a organização se comprometer a organizar um inventário publicamente acessível, com informações a respeito das espécies depositadas nas coleções da organização de gestão;

ii. No que tange aos recursos biológicos com aplicações medicinais, preparar extratos a partir deles e conduzir testes de bioatividade, com o objetivo de identificar suas possíveis aplicações ou confirmar cientificamente as indicações trazidas pelas comunidades tradicionais. Sempre que os testes indicassem ou confirmassem a bioatividade do recurso biológico testado, os laboratórios isolariam a molécula responsável pela bioatividade e a caracterizariam estruturalmente. A partir dos resultados dos testes, os laboratórios elaborariam um

\footnotetext{
1285 As tarefas (i), (ii) e (iv) se basearam em VOGEL, 2000b.

${ }^{1286}$ Cf. SCBD, [2009?].

1287 Informações sobre a Iniciativa Global de Taxonomia podem ser encontradas em: $<$ http://www.cbd.int/gti/>. Acesso em: 27 de maio de 2009.
} 
arquivo para cada composto químico, proteína ou seqüência genética identificada, com informações taxonômicas sobre sua fonte natural, possíveis lugares onde o recurso exista em condições in situ, composição química etc. ${ }^{1288} \mathrm{E}$ caso as aplicações identificadas se confundissem ou fossem similares às indicações realizadas por comunidades tradicionais, o registro indicaria, outrossim, a(s) comunidade(s) tradicional(s) que conserva o referido CTA; os modos de preparo das fórmulas tradicionais desenvolvidas com o recurso biológico bruto; os modos de aplicação; o tempo médio de ação da fórmula; e os efeitos esperados e possíveis efeitos colaterais.

iii. No que tange aos recursos da agrobiodiversidade, a rede de laboratórios realizaria uma descrição de suas características morfológicas e agronômicas, com base nas informações prestadas por comunidades agrícolas (quando pertinente) e confirmadas por testes de campo. Realizariam, outrossim, a identificação dos genes responsáveis pelas características agronômicas especiais (e.g. resistência a pragas e à estiagem, melhor valor nutricional etc.), os isolaria e caracterizaria estruturalmente; e

iv. Sempre que a rede de laboratórios recebesse recursos biológicos, já previamente depositados, originários de outras fontes que os conservam em condições in situ, agregaria ao banco de dados da organização informações sobre a identidade dos outros codetentores do recurso. E assim também se conduziria, sempre que identificasse moléculas bioativas, que embora derivadas de fontes biológicas diferentes, fossem idênticas ou similares estruturalmente e idênticas funcionalmente a compostos que já integram o registro da organização de gestão. $^{1289}$

A idéia aqui apresentada está longe de ser fantasiosa e inexeqüível por países em desenvolvimento: no Brasil, a empresa Extracta Moléculas Naturais S.A. organizou, com a autorização do governo deste país, um banco de biodiversidade química, composto por mais de 40.000 amostras de "extratos e compostos naturais puros, prontos para testes de

\footnotetext{
${ }^{1288}$ Cf. GUPTA, 2002, p. 399.

${ }^{1289}$ Conforme visto anteriormente, uma mesma sequência genética, molécula bioativa pode estar presente em recursos biológicos diversos. Cf. item 1.3.1.
} 
triagem na descoberta de novas substâncias de interesse industrial. ${ }^{\text {"1290 }}$ A Extracta oferece também ao setor privado serviços tecnológicos, que incluem: "Caracterização estrutural e química medicinal de compostos naturais bioativos; validação de novos alvos biológicos em doenças cardiovasculares, neurológicas e imunológicas; bioensaios inovadores e tecnologias de avaliação pré-clínica in vitro;caracterização de compostos naturais bioativos; desenvolvimento de tecnologias de produção e controle de qualidade de fitoterápicos, cosméticos e produtos agro-ativos; novos materiais biológicos de interesse industrial; aplicações de nanotecnologias à bioatividade de produtos naturais." ${ }^{\prime 291}$

Os serviços tecnológicos oferecidos pela Extracta são providos com o apoio técnico de instituições públicas (e.g. Universidade Federal do Pará, Universidade do Estado do Rio de Janeiro) e consultores que integram o corpo de profissionais de instituições públicas de ensino e pesquisa do Brasil (e.g. Universidade Federal do Rio de Janeiro, Universidade Estadual do Rio de Janeiro, FIOCRUZ). ${ }^{1292}$

No mesmo sentido da Extracta, o Centro de Biotecnologia da Amazônia (CBA), organização de $\mathrm{P} \& \mathrm{D}$ do governo brasileiro, localizada em Manaus, oferece ao setor público e privado, os seguintes serviços tecnológicos, em relação a recursos da biodiversidade brasileira: “Aplicação genômica, proteômica e metabolômica à inovação biotecnológica; análise de DNA (animal e vegetal); análise e determinação estrutural de proteínas; atividade biológica de micro e macromoléculas; manipulação de cosméticos, alimentos funcionais e fitoterápicos em escala pré-piloto e piloto; ensaios toxicológicos; análises bioquímicas; ensaios farmacológicos; análises físico-químicas; produção, padronização e certificação de extratos, insumos e produtos acabados."

O processo de agregação de valor científico e econômico aos recursos biológicos e CTAs facilitaria o controle de sua exploração comercial pela organização de gestão de direitos, porquanto estes recursos seriam transferidos a terceiros em uma forma de apresentação mais ou menos próxima àquela de um produto ou processo comercial final.

\footnotetext{
${ }^{1290}$ Informações extraídas de: $<\underline{\text { http://www.extracta.com.br/estrategia.htm> }}$. Acesso em: 14 abr. 2009.

${ }^{1291}$ Informações extraídas de: http://www.extracta.com.br/parceiros.htm. Acesso em: 14 abr. 2009.

${ }^{1292}$ Informações extraídas de: http://www.extracta.com.br/parceiros.htm. Acesso em: 14 abr. 2009.

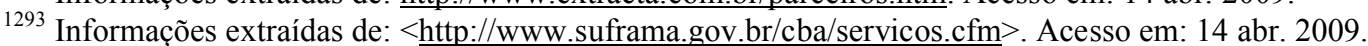


Naturalmente, sempre há espaço para que instituições de pesquisa e organizações empresariais realizem modificações cosméticas no genoma de recursos naturais e nas estruturas de compostos químicos, objetivando fraudar a obrigação de compartilhar royalties com os provedores destes recursos. No entanto, a partir do momento em que recursos biológicos e CTs tiverem passado pelo crivo da rede de instituições científicas proposta neste estudo, as referidas alterações serão mais facilmente detectáveis e as fraudes reprimidas.

\section{§1.2 OUTRAS RAZÕes PARA O CONDICIONAMENTO DA PROTEÇÃo dos RBIS AO SEU REGISTRO}

\section{§1.2.1 IDENTIFICAÇÃO DOS COTITULARES DE RBIS}

O registro obrigatório facilita a identificação dos grupos que compartilham um mesmo RBI. A autoridade competente pelo registro poderia realizar o cruzamento de dados dos registros e identificar as comunidades que compartilham um mesmo RBI. A identificação de todos cotitulares favorece o desenvolvimento de esquemas inclusivos de repartição de benefícios, ao invés de beneficiar apenas um único provedor.

\section{§1.2.2 PROMOÇão do USO AMPLO E FACILITADO AOS RBIs ${ }^{1294}$}

O registro público dos RBIs protegidos traria ao conhecimento público recursos até então desconhecidos, o que certamente promoveria seu uso mais amplo para fins produtivos, científicos e culturais e, naturalmente, sua comercialização. ${ }^{1295} \mathrm{Se}$ os regimes internacionais de proteção dos RBIs não forem capazes de atrair a atenção dos potenciais usuários de RBIs, ${ }^{1296}$ estes se conservarão como riquezas inexploradas, incapazes de gerar incentivos econômicos. ${ }^{1297}$

\footnotetext{
${ }^{1294}$ Cf. SCBD, UNEP/CBD/WG8J/5/6, para. 61.

${ }^{1295}$ Ver, e.g., WIPO, WIPO/GRTKF/IC/9/INF/4, anexo I, para. 76; SCBD, UNEP/CBD/WG8J/4/INF/9, para. 53.

${ }^{1296}$ Cf. BRUSH,1994, p. 27.

${ }^{1297}$ Cf. BIBER-KLEMM et al., 2006, p.269.
} 
Embora os regimes de patentes sejam calcados na divulgação pública das invenções protegidas, ainda assim seus titulares enfrentam dificuldades para licenciá-las para empresas capacitadas a explorá-las comercialmente. A fim de suprir essa deficiência de comunicação entre os autores de produções técnicas e os usuários comerciais, a rede iBridge Network oferece a universidades de todo o mundo um espaço público na internet, onde podem divulgar e oferecer suas invenções (notadamente, da área biomédica) a terceiros. $^{1298}$

Os registros públicos permitiriam também disseminar RBIs para além das fronteiras dos grupos que usualmente os utilizam, facilitando seu acesso por todos aqueles que deles precisam, o que vai desde membros de outras comunidades tradicionais até instituições encarregadas de implementar projetos de desenvolvimento. ${ }^{1299}$ Com a disseminação dos RBIs para círculos que os desconhecem, ampliam-se as oportunidades de desenvolvimento de aplicações até então desconhecidas. ${ }^{1300}$

\section{§1.2.3 CONSERVAÇÃo DOS RBIS PARA AS FUTURAS GERAÇÕES ${ }^{1301}$}

Os RBIs estão se perdendo em virtude do rápido processo de urbanização e ocidentalização dos países em desenvolvimento. ${ }^{1302}$ Porquanto não seria nem lícito nem ético impor às comunidades tradicionais a obrigação de viverem segundo estilos de vida tradicionais, a organização de inventários extensivos sobre os RBIs é a única solução viável para conservá-los para as futuras gerações, ainda que seus titulares optem por ocidentalizar seus estilos de vida.

Se no passado a Empresa Brasileira de Pesquisa Agropecuária (EMBRAPA) não tivesse organizado um importante banco de germoplasma, composto por amostras de variedades vegetais cultivadas por comunidades tradicionais brasileiras, talvez a etnia indígena Krahô já não mais existisse. Nos anos 70, a instituição brasileira iniciou a formação do referido banco de germoplasma. No mesmo período, o governo brasileiro

\footnotetext{
1298 Cf. $<$ http://www.ibridgenetwork.org/info/about $>$. Acesso em: 13 fev. 2009.

1299 Cf. RAHMAN, 2004, p. 314.

${ }^{1300}$ Cf. GUPTA, 2006, p.50.

${ }^{1301}$ Cf. WIPO, 2001, p. 128.

${ }^{1302}$ Cf. SCBD, UNEP/CBD/WG8J/3/INF/1, para. 26.
} 
estimulou os índios da etnia Krahô a cultivar arroz para fins comerciais. Para isso, lhes ofereceu recursos técnicos e insumos para capacitá-los a administrar autonomamente suas plantações. Com o passar do tempo, os índios Krahô perderam o hábito de cultivar suas variedades tradicionais e substituíram suas variedades tradicionais de arroz por variedades híbridas, em busca de maior produtividade. ${ }^{1303}$

$\mathrm{Na}$ década seguinte, a produtividade do arroz caiu vertiginosamente nas terras Krahô. Como já não mais cultivavam suas variedades tradicionais, os índios se viram sem os meios de subsistência. Lamentavelmente, a estratégia do governo brasileiro, ao invés de trazer prosperidade e autonomia à etnia Krahô, trouxe a fome e a dependência de apoio governamental. ${ }^{1304}$ Nos anos 90, os índios da etnia Krahô, com o auxílio da Fundação Nacional do Índio (FUNAI), descobriram que o banco de germoplasma da EMBRAPA tinha em depósito amostras das variedades vegetais, originalmente cultivadas pelos índios Krahô. Decidiram recorrer a ele em busca dessas amostras. Desde 1995, apoiados pela EMBRAPA, os Krahô reintroduziram sementes, que julgavam terem se perdido no tempo (variedades de milho, amendoim, abóbora, mandioca etc.). Com as sementes, retornaram os hábitos alimentares tradicionais e culturais associados às variedades reintroduzidas (rituais, festejos, canções). ${ }^{1305}$ Retomaram também os costumes antigos de trocar conhecimentos e variedades vegetais com comunidades de outras etnias indígenas que vivem na mesma região geográfica, com o objetivo de se apoiarem na busca por um melhor padrão de vida. ${ }^{1306}$

A Índia, como resultado da Revolução Verde, sofreu uma perda maciça de CTs agrícolas e de variedades vegetais. No mesmo sentido do projeto da EMBRAPA, atualmente ONGs e instituições governamentais da Índia estão envolvidas na criação de um grande inventário de técnicas tradicionais relacionadas à agricultura sustentável, com o objetivo de reverter a tendência de erosão biocultural. ${ }^{1307}$

As iniciativas brasileira e indiana deixam a mensagem de que regimes legais que não se assentem sobre inventários de RBIs não alcançarão a meta de preservá-los para as

\footnotetext{
${ }^{1303}$ Cf. SANTOS, 1999.

${ }^{1304}$ Ibid.

${ }^{1305}$ Cf. SEEDQUEST, 2005.

${ }^{1306}$ Cf. CIPRIANO, 2004.

${ }^{1307}$ Cf. SAHAI, 2004, p. 279.
} 
futuras gerações, inclusive, em benefício das futuras gerações das comunidades tradicionais, que os conservam no presente.

Se as comunidades tradicionais forem os únicos pontos de conservação dos RBIs, corre-se o risco de sofrer uma perda similar àquela associada à queima da biblioteca de Alexandria. Seu desaparecimento levou consigo os conhecimentos exclusivos por ela centralizados. ${ }^{1308}$ Preocupadas com a perpetuação do conhecimento para as futuras gerações, mesmo bibliotecas de grandes universidades estão envolvidas em projetos de conservação do conhecimento. Vale mencionar como ilustração a iniciativa LOCKSS (Lots of Copies Keep Stuff Safe) da Universidade de Stanford, da qual participam bibliotecas espalhadas por todo o mundo, que se dedica à conservação de acervos de obras científicas disponibilizadas em meios eletrônicos. ${ }^{1309} \mathrm{Na}$ mesma direção do projeto de Stanford, a Faculdade de Direito da Universidade de São Paulo, com o apoio da Microsoft, se prepara para digitalizar todo seu acervo bibliográfico. ${ }^{1310}$

Em outras palavras, o registro obrigatório de RBIs permitiria transformar conhecimentos tácitos, cuja existência se vincula à memória e às praticas dos membros de comunidades tradicionais, em conhecimentos codificados, que podem ser divulgados ampla e fidedignamente, permitindo, assim, a expansão da base de conhecimentos da sociedade a partir dos novos RBIs disseminados.

Diferentemente do que pensam alguns, registros de RBIs não representariam "mausoléus para o conhecimento". ${ }^{1311}$ A existência de um registro não seria um substituto mais barato para medidas de promoção da conservação dos RBIs junto às comunidades. Apenas serviriam como uma imagem fotográfica da base de RBIs em um dado momento histórico, podendo ser atualizado mediante novos registros, sempre que novos RBIs forem desenvolvidos ou RBIs já registrados forem atualizados. Portanto, o registro obrigatório de RBIs fomenta a liberdade científica e criativa e o avanço da base de conhecimentos da humanidade, ${ }^{1312}$ sem interferir na capacidade das comunidades de os aprimorarem continuamente.

\footnotetext{
${ }^{1308}$ Ver, e.g., OSTROM; HESS, 2003, p. 73; GUPTA, 2002, p. 385.

${ }^{1309} \mathrm{Ver}<$ http://www.lockss.org/lockss/Home> . Acesso em: 13 fev. 2009.

${ }^{1310}$ Cf. RODAS, 2009.

${ }^{1311}$ Cf. AGRAWAL, [199-?].

1312 Cf. DAVID; FORAY, 2002, p. 13.
} 


\section{§1.2.4 PRoteção DAS ECTS SAgRAdas CONTRA USOS CULTURALMENTE DESRESPEITOSOS}

Os registros podem divulgar as ECTs sagradas, sem com isso liberar seu uso por terceiros. Registros podem determinar as condições sob as quais pode se dar seu uso, permitindo que as comunidades indiretamente controlem seu uso por terceiros. Se as condições de uso forem públicas, será uma tarefa muito mais simples para as comunidades comprovarem que o infrator estava ciente do caminho que deveria ter percorrido. Facilitará também a observância pelos potenciais usuários de ECTs das normas culturais das comunidades que conservam as ECTs de interesse, prevenindo a emergência de conflitos interculturais desnecessários.

Se existisse um registro público para ECTs sagradas, casos como Yumbulul v. Aboriginal Artists Agency não ocorreriam. Nesse litígio, o artista aborígene australiano Terry Yumbulul autorizou a agência Aboriginal Artists Agency (agência) a representá-lo em acordos de licenciamento envolvendo sua obra Morning Pole Star. A agência celebrou um acordo de licenciamento da obra de Yumbulul com o Banco Central da Austrália, que a reproduziu em notas de 10 dólares australianos. Os Galpu, etnia a que se vincula Yumbulul, criticaram-no pela transferência à agência de mais direitos do que possuía. Segundo as autoridades da etnia, Yumbulul estava autorizado a expor publicamente sua obra para difundir a cultura aborígene, mas não poderia reproduzi-la em papel moeda. ${ }^{1313}$ Certamente, se a agência estivesse a par das condições que os usuários teriam de observar, o Banco Central da Austrália não teria infringindo as normas culturais dos Galpu.

\section{§1.2.5 COMPROMISSOS INTERNACIONAIS}

Ao menos quatro convenções internacionais determinam que suas partes contratantes organizem inventários públicos de diferentes categorias de RBIs, como forma de alcançar seus objetivos específicos.

${ }^{1313}$ Ver, e.g., KALINOE, 2004, p. 43; JANKE, 2003, p. 61. 
A Convenção para a Salvaguarda do Patrimônio Cultural Imaterial determina que seus Estados contratantes adotem medidas de identificação, documentação, investigação, preservação, valorização e transmissão do patrimônio cultural imaterial das comunidades, grupos e indivíduos baseados em sua jurisdição, com o objetivo de salvaguardá-lo. ${ }^{1314}$ Como medida de salvaguarda, a convenção explicitamente obriga suas partes contratantes a organizar inventários do patrimônio cultural imaterial presente em seu território. ${ }^{1315}$

Tanto a Convenção sobre Diversidade Biológica ${ }^{1316}$ quanto o Tratado Internacional sobre Recursos Fitogenéticos para a Alimentação e Agricultura ${ }^{1317}$ requerem de suas partes contratantes a coleta e a organização de inventários, compostos por seus recursos biológicos e CTAs, com o objetivo de promover sua identificação, caracterização, documentação, investigação de suas aplicações e conservação.

A Convenção das Nações Unidas de Combate à Desertificação (CNUCD), com o propósito de facilitar a aplicação de CTs úteis ao combate da desertificação, ao enfrentamento da seca e à melhoria na gestão de terras agrícolas e recursos hídricos das regiões afetadas pelo processo de desertificação ou seca, obriga seus Estados contratantes a organizarem inventários dessas "tecnologias, conhecimentos gerais, conhecimentos técnicos e práticas e [d]as respectivas utilizações potenciais”, e disseminá-los amplamente. $^{1318}$

\subsection{CONCLUSÕES}

Encerraremos o presente capítulo com um breve sumário do conteúdo dos quatro critérios de operacionalização do quadro conceitual de desenvolvimento sustentável.

\footnotetext{
${ }^{1314}$ Cf. art. 1o, alíneas (a) e (b), combinado com os artigos 2(3), 11(b), CSPCI.

1315 Cf. artigos 12(1) e 13(d)(iii), CSPCI.

${ }^{1316}$ Cf. Artigos 7o (a), (b), (d) e $9^{\circ}$ (b),(d), (e), CBD. Ainda na esfera da CDB, a decisão V/16, adotada em sua $5^{\text {a }}$ Conferência das Partes, encorajou às suas partes a apoiarem a "criação de registros nacionais de conhecimentos, inovações e práticas tradicionais das comunidades indígenas e locais que entranhem estilos de vida tradicionais" (COPCBD, Decision V/16, para. 17).

${ }_{1317}$ Cf. art. 5(1) (a), (b), (e), (f), TIRFAA.

${ }^{1318}$ Cf. art. 18(2) (a), CNUCD.
} 
Critério de operacionalização 1: Geração de benefícios econômicos em bases perenes, derivados do uso produtivo dos RBIs, e sua reversão obrigatória em favor da conservação da biodiversidade e da melhoria da qualidade de vida das comunidades tradicionais

A realização dos direitos humanos das comunidades tradicionais vincula-se à erradicação da pobreza ${ }^{1319}$ e à garantia de seu direito de propriedade sobre os territórios que tradicionalmente ocupam. Porquanto a sociedade ocidental trata as comunidades tradicionais como obstáculos ao seu desenvolvimento econômico, ${ }^{1320}$ e a maioria dos Estados é omissa em face das demandas sociais destes grupos, é imperioso assegurar-lhes os meios econômicos que viabilizem, com o menor nível de dependência da assistência dos Estados, a melhoria contínua de sua qualidade de vida em harmonia com a natureza e a aquisição das terras, em que habitam e/ou o financiamento de embates políticos e judiciais, em prol da observância de seus direitos sobre os territórios que ocupam.

Para tanto, é preciso operacionalizar o direito das comunidades tradicionais de receber uma remuneração justa pelo uso produtivo de seu RBIs. Considerando que os direitos humanos são interdependentes e se reforçam mutuamente, ${ }^{1321}$ a não-realização dos direitos econômicos das comunidades tradicionais interfere na realização de outros direitos, inter alia, no direito de seus membros à saúde, à educação, à alimentação e à melhoria constante de suas condições de vida, em sua autonomia para perseguirem seu desenvolvimento cultural, social e econômico ${ }^{1322}$ e, por fim, no estado de conservação da diversidade biológica e cultural.

Da mesma forma que as comunidades tradicionais dependem de recursos econômicos para alcançarem um padrão de vida que lhes assegure as condições para conservarem seu PBI, os Estados nacionais dependem de recursos econômicos para investirem em projetos de conservação da biodiversidade.

Um regime internacional apto a gerar incentivos econômicos para a proteção dos RBIs, em bases perenes, deve: (i) dar igual atenção à proteção dos recursos da

\footnotetext{
${ }^{1319}$ Ver, e.g., UNGA, Resolution 62/151, preâmbulo; UNITED NATIONS COMMISSION ON HUMAN RIGHTS, Resolution 1994/12, preâmbulo e para. 3 .

${ }^{1320}$ Cf. STEPHENS et al., 2006, p 2025.

${ }^{1321}$ Ver, e.g., UNGA, Resolution A/RES/60/1; UNGA, Resolution 62/147, preâmbulo.

${ }^{1322}$ Cf. SEN, 2000, p. 21-30, 409.
} 
biodiversidade, CTs e ECTs, e (ii) reverter obrigatoriamente os benefícios auferidos em favor da dignificação dos membros das comunidades tradicionais e da conservação da biodiversidade.

Critério de operacionalização 2: direito de acesso amplo e facilitado ao PBI

Apesar do processo de inchamento dos DPIs, o PBI é conservado com o status de domínio público na maioria dos países, em desconsideração dos interesses das comunidades tradicionais e dos Estados de verem seus RBIs protegidos contra atos de apropriação indébita e de obterem uma nova fonte de recursos, que viabilize a conservação da diversidade biocultural. A conservação do PBI em domínio público não é uma resposta ao imperativo de salvaguardar o domínio público em prol do desenvolvimento material da humanidade, mas o reflexo dos desejos dos setores produtivos, notadamente dos países industrializados, de continuar a utilizá-los gratuitamente. ${ }^{1323}$ A conservação do domínio público, neste ponto, serve a um interesse iníquo.

Assim sendo, apesar da importância social e econômica de se revitalizar e nutrir o domínio público, a proteção legal do PBI contra atos de apropriação indébita implicará em sua retirada do domínio público, o que não desembocará necessariamente na limitação do direito de acesso e uso destes recursos pelas comunidades tradicionais e sociedade em geral. Contudo, dependendo do regime legal escolhido para tutelá-lo, mais um reservatório de insumos intangíveis poderá desaparecer, em detrimento, sobretudo, das necessidades dos países em desenvolvimento, que já sofrem com as limitações impostas pelos acordos multilaterais, regionais e bilaterais dedicados à proteção da propriedade intelectual.

Sob a perspectiva do quadro conceitual de desenvolvimento sustentável, as negociações em curso na CCDB, OMC e OMPI têm o difícil desafio de estabelecer regimes de proteção que tutelem as demandas das comunidades tradicionais e dos Estados de serem recompensados pelos aportes realizados ao desenvolvimento material da sociedade dominante, sem interferir negativamente sobre a capacidade das presentes e futuras gerações de utilizar ampla e sustentavelmente os RBIs. ${ }^{1324}$

\footnotetext{
${ }^{1323}$ Cf. CHANDER; SUNDER, 2004, p. 1336.

${ }^{1324}$ Ver, e.g., YU, 2005, p. 16; BROWN, M., 2005, p. 51.
} 
Alcançar o objetivo de proteção multidimensional do PBI depende de uma associação sinérgica de esforços das comunidades tradicionais, Estados e setores produtivos, ${ }^{1325}$ calcada na valorização da relação entre facilitação do uso sustentável do PBI por todos os setores da sociedade e sua conservação. ${ }^{1326}$ Não é suficiente preservar exclusivamente o direito das comunidades tradicionais de usar e compartilhar livremente seu PBI com outras comunidades, pois, na falta de recursos materiais, o PBI e suas bases humanas e naturais se conservarão em risco de extinção. Tampouco é suficiente conferir aos setores produtivos da sociedade a prerrogativa de uso amplo e facilitado aos RBIs, sem a paralela proteção das fontes humanas e biológicas destes recursos, uma vez que a sociedade dominante tende a valorizar a homogeneização cultural e biológica. ${ }^{1327}$ A chave para a proteção do PBI está em reconciliar o dever de conservá-lo junto às suas raízes culturais e biológicas com a necessidade de aplicá-lo produtivamente, satisfazendo assim demandas sociais. $^{1328}$

Diferentemente das discussões acadêmicas e políticas a respeito da reforma dos regimes de proteção da PI, que se alternam em torno de posições pró autores de produções intelectuais ou pró domínio público, ${ }^{1329}$ sob a perspectiva do quadro conceitual de desenvolvimento sustentável, as negociações internacionais dedicadas à proteção do PBI devem resguardar duas esferas distintas de criatividade: ${ }^{1330}$ uma representada pelas comunidades tradicionais, que se opõem a conservação de seu PBI em domínio público, e a outra representada pelos usuários do $\mathrm{PBI},{ }^{1331}$ que, em regra, se opõem à sua privatização, em virtude das limitações à sua liberdade científica e criativa que poderiam dela emergir.

A tendência de sobrevalorização do domínio privado pelos acordos internacionais de proteção da PI, em detrimento do domínio público pode estar com os dias contados: a Agenda do Desenvolvimento, adotada em 2007 pela OMPI, determina que os trabalhos desta organização considerem o papel da "preservação do domínio público [...] [em seus] processos normativos e aprofunde a análise das conseqüências e benefícios de um domínio

${ }^{1325}$ Cf. FAO, 2007b, para. 15.

${ }^{1326}$ Ver, e.g., FAO, 1996b, para. 6, 8 e 9; FAO, 1996a, item 7(e).

${ }^{1327}$ Cf. SHIVA, 2001, p. 115, 125, 142.

1328 Cf. UNESCO, Recommendation on Participation by the People at Large in Cultural Life and their Contribution to it, para. 4(p).

${ }^{1329}$ Cf. CHANDER; SUNDER, 2004, p. 1334.

${ }^{1330}$ Cf. HOWKINS, 2007, p.118-124.

1331 E.g., a posição dos Austrália, EUA e Japão defendida na OMPI (WIPO, WIPO/GRTKF/IC/12/5(b), anexo, p. 23, 30, 68). 
público abundante e acessível," e fomentem "atividades normativas em matéria de PI que contribuam para conservar um sólido domínio público [...]."1332 $\mathrm{Da}$ mesma forma que o regime convencional de proteção da PI está revendo seus retrocessos, para assegurar que o sistema verdadeiramente promova desenvolvimento científico e cultural, os regimes de proteção do PBI devem igualmente atentar para a importância de se preservar um reservatório intelectual robusto.

Em sumário, conforme as palavras da resolução 2005/20 do Alto Comissariado da ONU para Direitos Humanos, "a ampla difusão das idéias e dos conhecimentos, baseada no intercâmbio e na confrontação mais livres é essencial para a atividade criadora, a busca da verdade e o desenvolvimento da personalidade de todos e da identidade de todos os povos." ${ }^{1333}$ Considerando a facilidade com que o domínio público é esfacelado mediante o uso de DPIs, o imperativo de salvaguardar o direito de acesso amplo e facilitado da sociedade ao PBI não pode ser satisfeito com a sua conservação em domínio público. ${ }^{1334}$ Ademais, mantê-lo com este status atacaria frontalmente as demandas legítimas dos países em desenvolvimento e das comunidades tradicionais, apoiadas pelo corpus do direito internacional. Portanto, as negociações internacionais em curso devem procurar alternativas legais que ensejem a transformação dos RBIs de recursos comuns negativos (recursos em domínio público) em recursos comuns positivos, protegendo-os assim contra a apropriação indébita, ao mesmo tempo em que assegura o livre intercâmbio intercomunitário de RBIs e a liberdade científica e criativa da humanidade.

Critério de operacionalização 3: direitos morais de atribuição e de integridade

As comunidades tradicionais buscam o reconhecimento internacional de dois direitos morais em relação aos RBIs: o direito de atribuição e o direito de integridade. $\mathrm{O}$ reconhecimento de um direito de atribuição inclusivo não gera grandes problemas, pois não interfere com nenhum outro direito de outros setores da sociedade. Por outro lado, o reconhecimento de um direito de integridade pode interferir na liberdade científica e artística dos potenciais usuários de RBIs.

${ }^{1332}$ Cf. WIPO, 2007, respectivamente recomendações no. 16 e 20.

1333 Cf. UNITED NATIONS COMMISSION ON HUMAN, Resolution 2005/20, para. 12.

1334 Em 2005, organizações da sociedade civil redigiram uma proposta de Tratado sobre Acesso ao Conhecimento. Esta proposta objetiva transformar o domínio público de bens comuns negativos em bens comuns positivos. Para isto, na minuta do acordo estão previstas matérias e prerrogativas mínimas, que deveriam ser conservadas em domínio público. Cf. Treaty on Access to Knowledge (Draft), 2009. 
Para as comunidades tradicionais, o problema que mereceria a proteção conferida pelo direito moral de integridade resulta da divergência entre os valores culturais dos usuários de RBIs e os valores de que são portadoras as comunidades tradicionais. A partir do momento que um RBI se dissemina para além das fronteiras humanas da comunidade que lhe deu origem, os membros de outras culturas interpretá-lo-ão à luz de seu sistema de significação. A diversidade de sistemas de significação pode dar lugar a conflitos interculturais. Enquanto uma comunidade tradicional julga dado RBI como sacro, um membro da sociedade ocidental pode considerá-lo portador tão-somente de apelo comercial e, assim, utilizá-lo em contextos que firam os valores espirituais da comunidade pertinente.

Reconhecer às comunidades tradicionais um direito moral de integridade amplo e inclusivo, estendido a todos os recursos de seu PBI, lhes permitiria fruir de um amplo direito de controle. Seu efeito colateral seria restringir a liberdade criativa e científica da sociedade dominante. A fim de harmonizar o interesse das comunidades de prevenir usos culturalmente desrespeitosos com as liberdades indispensáveis para a consecução de atividades científicas e artísticas, o alcance ideal para o direito moral de integridade é estendê-lo apenas às ECTs sagradas.

Critério de operacionalização 4: Efetividade dos regimes de proteção em escala global

$\mathrm{O}$ sucesso dos futuros regimes internacionais dedicados à proteção do PBI dependerá da capacidade econômica e institucional dos novos titulares de direitos de assegurar o cumprimento de seus direitos em escala global. ${ }^{1335}$

Tendo em mente realidade dos países em desenvolvimento e das comunidades tradicionais, a efetividade dos futuros regimes internacionais dependerá não só da disponibilidade de remédios judiciais para os titulares de direitos, mas também da operação de organizações, apoiadas por instituições científicas, competentes para defender o direito das comunidades tradicionais e dos Estados em relação aos seus RBIs. Na ausência de uma estrutura institucional de apoio, os novos regimes internacionais serão natimortos.

1335 Cf. BARLOW, 1997, p. 355. 
No próximo capítulo, serão examinadas as principais propostas de proteção dos RBIs, em debate na esfera internacional contra o conjunto de condições sumarizadas no quadro a seguir (quadro 3), que indica os critérios de operacionalização do quadro conceitual de desenvolvimento sustentável e as evidências buscadas para atestar seu cumprimento pelas referidas propostas.

Quadro 3: Critérios de operacionalização que integram o quadro conceitual de desenvolvimento sustentável

\begin{tabular}{|c|c|}
\hline $\begin{array}{l}\text { Critérios de operacionalização do } \\
\text { quadro conceitual de desenvolvimento } \\
\text { sustentável }\end{array}$ & $\begin{array}{l}\text { Evidências buscadas para se confirmar } \\
\text { a observância dos critérios de } \\
\text { operacionalização }\end{array}$ \\
\hline $\begin{array}{l}\text { Geração de benefícios econômicos no } \\
\text { curto, médio e longo prazo, derivados do } \\
\text { uso produtivo de RBIs e sua reversão } \\
\text { obrigatória, em favor da conservação da } \\
\text { biodiversidade e da melhoria da qualidade } \\
\text { de vida das comunidades tradicionais }\end{array}$ & $\begin{array}{l}\text { Os regimes propostos devem: } \\
\text { (i) Dar igual atenção à proteção dos } \\
\text { recursos da biodiversidade, CTs e ECTs; } \\
\text { (ii) Reverter obrigatoriamente os } \\
\text { benefícios repartidos, em favor da } \\
\text { dignificação dos membros das } \\
\text { comunidades tradicionais e da } \\
\text { conservação da biodiversidade. }\end{array}$ \\
\hline $\begin{array}{l}\text { Direito de acesso amplo e facilitado ao } \\
\text { PBI pelas comunidades tradicionais e } \\
\text { sociedade em geral }\end{array}$ & $\begin{array}{l}\text { Os regimes propostos devem assegurar: } \\
\text { (i) Direito de acesso amplo e facilitado } \\
\text { aos RBIs às comunidades tradicionais; } \\
\text { (ii) Direito de acesso amplo e facilitado } \\
\text { aos RBIs para fins produtivos (comercial, } \\
\text { industrial, cultural, científico) a todos os } \\
\text { setores da sociedade dominante. }\end{array}$ \\
\hline Direitos morais & $\begin{array}{l}\text { Os regimes propostos devem: } \\
\text { (i) Reconhecer às comunidades } \\
\text { tradicionais um direito de atribuição } \\
\text { amplo e inclusivo para todas as categorias } \\
\text { de RBIs, em todas as formas de uso direto } \\
\text { e indireto; } \\
\text { (ii) Reconhecer às comunidades } \\
\text { tradicionais um direito moral de } \\
\text { integridade em relação às ECTs sagradas. }\end{array}$ \\
\hline $\begin{array}{l}\text { Efetividade do marco legal internacional } \\
\text { de proteção do PBI }\end{array}$ & $\begin{array}{l}\text { Os regimes propostos devem estabelecer } \\
\text { uma organização de gestão de RBIs } \\
\text { (OGCDs, OGDs ou uma organização } \\
\text { híbrida), competente e tecnicamente } \\
\text { capacitada para, inter alia: registrar RBIs; } \\
\text { estudar e agregar valor aos recursos }\end{array}$ \\
\hline
\end{tabular}


CAPÍTULO 3 | 270

biológicos e CTAs; redigir e celebrar acordos de licenciamento; monitorar possíveis infrações, em escala global; perseguir infratores; receber royalties decorrentes da exploração comercial de RBIs e repassá-los aos titulares de direitos. 


\section{AVALIAÇÃO DAS PROPOSTAS DE MECANISMO DE PROTEÇÃO INTERNACIONAL DO PBI EM FACE DO QUADRO CONCEITUAL DE DESENVOLVIMENTO SUSTENTÁVEL}

\subsection{NOTAS INTRODUTÓRIAS}

O capítulo final do presente estudo será dedicado a examinar a adequação das principais propostas de regimes internacionais de proteção dos RBIs, em negociação na CCDB, OMC e OMPI, em face do quadro conceitual de desenvolvimento sustentável, cujos critérios de operacionalização foram sumarizados no quadro 3 supra (capítulo 3). As propostas serão examinadas em separado, segundo a seguinte ordem:

i. Propostas calcadas em esquemas de direito de propriedade;

ii. Propostas calcadas em regras de repressão à concorrência desleal (direito de quase-propriedade);

iii. Propostas calcadas em um regime de responsabilidade. Cabe aqui um esclarecimento preliminar. Optamos por examinar também duas das únicas propostas acadêmicas calcadas em regimes de responsabilidade, em virtude da falta de propostas que lançam mão deste mecanismo.

É importante ter claro que as propostas examinadas em separado não configuram necessariamente propostas independentes. Em termos mais claros, enquanto no marco da $\mathrm{CDB}$, a proposta de criação de um regime internacional para a proteção dos recursos da biodiversidade e CTAs se funda integralmente em direitos de propriedade, as propostas em discussão na OMPI para a proteção de CTs e ECTs associam direitos de propriedade, direitos de quase-propriedade e regimes de responsabilidade. Já a proposta de emenda do art. 29 do Acordo TRIPS, patrocinada pelos países em desenvolvimento, confere aos Estados e comunidades tradicionais um direito de propriedade sobre seus recursos biológicos e CTAs; no entanto, os detalhes do mecanismo proposto apenas podem ser apreendidos após a avaliação do conteúdo dos regimes propostos, no âmbito da CCDB e da OMPI. Por conseguinte, a avaliação das propostas que envolvem a associação de mecanismos legais diversos (OMC e OMPI) dependerá da leitura conjunta das diversas partes deste capítulo, dedicadas a avaliar separadamente seus dispositivos, segundo sua pertença à uma das três categorias de mecanismos de proteção de recursos intelectuais. 


\subsection{PROPOSTAS FUNDADAS EM DIREITO DE PROPRIEDADE}

\subsubsection{RELAÇÃO ENTRE CPLI E DIREITO DE PROPRIEDADE}

As características básicas do direito de propriedade foram identificadas previamente, ao início do capítulo $2 .{ }^{1336} \mathrm{O}$ que importa recordar para a realização do exame das propostas de regimes legais, fundadas em direito de propriedade é que o atributo fundamental do direito de propriedade é o poder, investido em seu titular, de excluir terceiros não-autorizados do gozo de seu bem.

Nos últimos anos, uma profusão de declarações públicas, patrocinadas por representantes de comunidades tradicionais e países em desenvolvimento, advogam pela adoção de regimes internacionais de proteção dos RBIs, que os invistam no direito de condicionar o acesso e uso de seus recursos por terceiros à obtenção de seu consentimento prévio, livre e informado (CPLI), com fundamento, inter alia, nos artigos 8(j), 15(5) da CDB, artigos $6^{\circ}$ e $8^{\circ}$ da Convenção no. 169 da OIT, art. 32(2) da Declaração das Nações Unidas sobre os Direitos dos Povos Indígenas e art. 13(d) (ii) CSPCI. ${ }^{1337}$ As comunidades tradicionais e Estados demandam que o acesso aos seus RBIs seja condicionado ao seu CPLI para que assim possam controlar suas aplicações e receber uma compensação econômica pelo uso produtivo destes recursos. ${ }^{1338}$

A obtenção de um consentimento verdadeiramente prévio, livre e informado depende da instauração pelos potenciais usuários de RBIs de um processo de consultas e negociações junto às comunidades e Estados pertinentes, cujo resultado não poderá serlhes imposto. ${ }^{1339}$ A obrigação ${ }^{1340}$ dos potenciais usuários de oferecer às comunidades tradicionais e aos Estados um espaço para expressar suas opiniões e desejos e de respeitálos é tratado como uma condição para a realização de seu direito de autodeterminação. ${ }^{1341}$

\footnotetext{
${ }^{1336} \mathrm{Cf}$. itens $2.2,2.2 .1$ e 2.2 .2 .

${ }^{1337} \mathrm{Cf}$. SCBD, UNEP/CBD/WG8J/2/INF/1, para. 43-44.

${ }^{1338}$ Id., 2002, para. 34-35.

1339 Cf. SECRETARIAT OF THE PERMANENT FORUM ON INDIGENOUS ISSUES, PFII/2005/WS.2/14

${ }^{1340}$ Ver, e.g., art. 15, CSPCI; art. $7^{\circ}$ (1), (2), Convenção no. 169 da OIT; INTERNATIONAL LAW ASSOCIATION, Declaration of Principles of International Law relating to Sustainable Development, princípio no. 5 .

${ }^{1341}$ Cf. WESTON, 1976, p. 618.
} 
Para que o consentimento seja prévio, o processo de consulta deve ser instaurado pelos potenciais usuários de RBIs previamente à sua obtenção e/ou uso (se a parte interessada já tivê-lo em seu poder). ${ }^{1342}$

O consentimento será livre, se inexistir qualquer força ou circunstância que obrigue a comunidade e/ou Estado pertinente a consentir com usos que, em verdade, não deseja. Os potenciais usuários devem identificar e consultar as autoridades representativas ${ }^{1343}$ das comunidades e/ou Estados pertinentes, que gozarão da liberdade de fixar os procedimentos pelos quais deve passar as solicitações de acesso. ${ }^{1344}$ Exatamente pela liberdade de negociação conferida tanto aos potenciais usuários quanto aos detentores de RBIs, o processo para a obtenção do CPLI pode consumir muitos anos, pois seu sucesso depende do estabelecimento de uma relação de confiança entre as partes envolvidas. ${ }^{1345}$

Para que o consentimento seja informado, uma vez instaurado o procedimento de consultas, os potenciais usuários devem informar os titulares de RBIs sobre, dentre outros aspectos, os usos e contextos, em que planejam empregá-los; a existência de propósitos comerciais; as possíveis conseqüências sobre seu bem-estar que decorrerão do uso; as instituições envolvidas no projeto; dependendo da natureza do projeto, o prazo estimado para se receber algum benefício econômico; os riscos envolvidos no projeto. Os proponentes devem ainda se assegurar de que as comunidades tradicionais e/ou Estados compreendam integralmente todas as informações transmitidas ${ }^{1346}$ para que possam conscientemente deliberar sobre o assunto. ${ }^{1347}$ Em outras palavras, os potenciais usuários devem ser transparentes e compartilhar com os detentores de RBIs todas as informações de que disponham, que possam ser essenciais ao processo de tomada de decisão.

Engana-se quem acredita que o processo para obtenção de CPLI se encerra com a formalização de um acordo entre as partes envolvidas na negociação. O processo, em verdade, se protrai até que os objetivos do projeto proposto sejam alcançados, fruindo as

1342 Cf. HANSEN; VANFLEET, 2003, p. 26.

1343 Cf. OIT, 2003, p. 16.

1344 Cf. SECRETARIAT OF THE PERMANENT FORUM ON INDIGENOUS ISSUES, FPII/2005/WS.2/10.

${ }^{1345}$ Ver, e.g., POSEY, 2004j, p. 59; CARLINI; RODRIGUES, 2005, p. 17.

${ }^{1346}$ Cf. OIT, 2003, p. 44.

1347 Cf. SECRETARIAT OF THE PERMANENT FORUM ON INDIGENOUS ISSUES, FPII/2005/WS.2/6. 
comunidades tradicionais e os Estados da prerrogativa de monitorar de perto o destino dado aos seus RBIs; ${ }^{1348}$ de interferir no andamento e nos resultados dos projetos aprovados a fim de assegurar que suas normas e condições sejam fielmente observadas; ${ }^{1349}$ e, sempre que julgarem que suas normas culturais foram feridas, de retirar seu consentimento, a qualquer momento.

A origem do princípio do CPLI remonta aos julgamentos dos crimes de guerra perpetrados durante a $2^{\mathrm{a}}$ Guerra Mundial pelo regime nazista alemão, realizados pelo Tribunal Internacional de Nuremberg (Tribunal Internacional). Em resposta aos abusos praticados pela "ciência médica" em detrimento da dignidade da pessoa humana, em 1947, o Tribunal Internacional adotou o Código de Nuremberg, que encerra dez princípios reitores das pesquisas envolvendo seres humanos, que hoje são considerados princípios bioéticos universais. Dentre os princípios do Código de Nuremberg figura o do CPLI, que introduz a obrigação dos responsáveis por pesquisas médicas, envolvendo seres humanos, de instaurar um processo para a obtenção do CPLI dos sujeitos de pesquisa. ${ }^{1350}$

Segundo o Código de Nuremberg, a realização de qualquer pesquisa científica que envolva o homem, na condição de sujeito de pesquisa, deve ser condicionada à obtenção de seu CPLI. Para que o consentimento seja informado, o potencial sujeito de pesquisa deve ter sido esclarecido, em linguagem acessível, sobre as condições em que se realizará a pesquisa, as possíveis conseqüências benéficas e maléficas ao seu bem-estar físico e mental, a duração da pesquisa e os métodos a serem aplicados. ${ }^{1351}$ Para que seja livre, o potencial sujeito de pesquisa deve ser dotado da capacidade para expressar conscientemente seu consentimento; não pode ser sujeitado a qualquer condição que limite sua capacidade para expressar livremente sua vontade (e.g. fraude, mentira, coação, astúcia); e por fim, deve ser informado da sua autonomia para retirar seu consentimento a qualquer momento, ainda que após o início do desenvolvimento das pesquisas. ${ }^{1352}$

1348 CF. SECRETARIAT OF THE PERMANENT FORUM ON INDIGENOUS ISSUES, PFII/2005/WS.2/15, para. 10.

${ }^{1349}$ Cf. CANADA INSTITUTES OF HEALTH RESEARCH, 2007, p. 6 (art. 14).

${ }^{1350}$ O princípio do CLPI foi mais tarde insculpido na Declaração de Helsinki de 1964, adotada pela World Medical Organization e na Declaração Universal sobre Bioética e Direitos Humanos, adotada pela UNESCO $\left(\operatorname{artigos} 6^{\circ}\right.$ e $7^{\circ}$ ).

${ }^{1351}$ Cf. Nuremberg Code, para. 1.

${ }^{1352}$ Id., para. 9. 
Os propósitos do princípio do CPLI no contexto dos regimes legais de proteção do PBI é naturalmente diverso dos perseguidos na esfera das pesquisas biomédicas. Na última, o CPLI é um processo dedicado a assegurar o respeito à dignidade e à autonomia do ser humano. ${ }^{1353}$ No âmbito da proteção do PBI, a exigência da obtenção do CPLI dos titulares de RBIs objetiva assegurar-lhes renda e prevenir aplicações culturalmente desrespeitosas de RBIs sagrados. ${ }^{1354} \mathrm{Na}$ seara dos RBIs, o princípio do CPLI nada mais é que uma denominação diversa para o direito de propriedade, ao investir em seus titulares um direito de exclusão de terceiros não-autorizados do gozo destes recursos. ${ }^{1355}$

O reconhecimento internacional do princípio do CPLI seria um meio de realizar um desejo antigo das comunidades tradicionais: o de poder exigir o respeito transfronteiriço de suas normas consuetudinárias e valores culturais que regem o acesso e a aplicação de seus RBIs, ${ }^{1356}$ independentemente de seu reconhecimento explícito por parte dos Estados e de suas instituições. ${ }^{1357}$ Comunidades tradicionais podem até compartilhar alguns valores e normas consuetudinárias, mas a verdade é que cada uma detém um arcabouço cultural próprio. ${ }^{1358} \mathrm{O}$ reconhecimento pelos regimes internacionais em construção do princípio do CPLI criaria um espaço, nas instituições legais da sociedade dominante, para o reconhecimento do pluralismo jurídico das comunidades tradicionais, ao menos no que tange à proteção de seu PBI; ${ }^{1359} \mathrm{e}$, ao estender o alcance territorial da vigência das normas comunitárias, alteraria o status de domínio público dos RBIs.

A opção por um mecanismo institucional de proteção dos RBIs assentado sobre o respeito ao CPLI dos Estados e comunidades tradicionais (i.e., regime de propriedade) é de longe a mais influente e aceita ${ }^{1360}$ nos círculos acadêmicos ${ }^{1361}$ e políticos ${ }^{1362}$ internacionais.

\footnotetext{
1353 Cf. WIPO, 2006a.

1354 Ver, e.g., SCBD, UNEP/CBD/WG8J/4/7, anexo II; INTERNATIONAL CONGRESS OF ETHNOBIOLOGY, The Declaration of Belém, item (2); CARNEIRO DA CUNHA, 1998, p. 93-94; FLETCHER, 2005, p. 545-547.

${ }^{1355}$ Ver a definição de CPLI presente em, e.g., INTERNATIONAL SOCIETY OF ETHNOBIOLOGY, 2008, princípios no. 7 e 8; WIPO, WIPO/GRTKF/IC/9/INF/4, para. 20.

${ }_{1356}$ Ver, e.g., SOLOMON, 2004, p. 160-161; ANAYA, 2004, p. 49-52; TAMANG, 2005, para. 51.

1357 Ver, e.g., SCBD, UNEP/CBD/WG8J/2/6/Add.1, para. 10; WIPO, 2001, p. 57-58; COMMISSION ON HUMAN RIGHTS, E/CN.4/Sub.2/1994/31, para. 15.

${ }_{1358}$ Ver, e.g., SCBD, UNEP/CBD/WG8J/5/INF/15, p. 18; SCBD, UNEP/CBD/WG8J/5/INF/10, para. 23 e 28; SCBD, UNEP/CBD/WG8J/4/INF/9, para. 86.

${ }^{1359}$ Ver, e.g., DAES, 1997, para. 27; SECRETARIAT OF THE PERMANENT FORUM ON INDIGENOUS ISSUES, FPII/2005/WS.2/4, para. 4; TOBIN, 2004, p. 23-24; VON LEWINSKI, 2003-2004, p. 768; GROSHEIDE, 2002, p. 13; GIBSON, 2007, p. 183.

${ }^{1360}$ Ver, e.g., BROWN, M., 2005, p. 49; LEISTNER, 2004, p. 138-139.
} 
Veremos neste capítulo que as propostas em discussão e negociação na CCDB, OMC e OMPI priorizam a proteção dos RBIs por meio de direitos de propriedade. O que nos resta averiguar é se os mecanismos propostos são adequados para promover a proteção do PBI em suas quatro dimensões e, reflexamente, auxiliar no alcance da almejada meta de desenvolvimento sustentável.

\subsubsection{EXAME DAS PROPOSTAS EM NEGOCIAÇÃO NA CCDB, OMC E OMPI, SUSTENTADAS EM DIREITOS DE PROPRIEDADE}

\subsubsection{CCDB}

\subsubsection{ELEMENTOS DA PROPOSTA DA CCDB PARA A PROTEÇÃO DOS RECURSOS DA BIODIVERSIDADE}

A proposta-base para a negociação de um regime internacional, a ser adotado no marco da CDB, competente para disciplinar o acesso e o uso dos recursos da biodiversidade e dos CTAs (regime internacional ou RI) ainda não se encontra tão bem elaborada e detalhada quanto as propostas da OMPI para proteção dos CTs e das ECTs e a de emenda do Acordo TRIPS para proteção dos CTAs e recursos biológicos, que serão

\footnotetext{
${ }^{1361}$ Para propostas fundadas, explicita ou tacitamente, em direitos de propriedade (i.e. em direitos de exclusão de terceiros não-autorizados), consultar, e.g., SAMPATH, p. 143-157; AGRAWAL, [199-?]; SUNDER, 2006, p. 9; SHERMAN; WISEMAN, 2006, p. 272-277; GUPTA, 2004, p. 14-16, 28, 32; GUPTA, 2002, p. 393; ZERDA-SARMIENTO; FORERO-PIÑEDA, 2002; SANTILI, 2005; LECHNER; GUBAYDULLINA; BIZER, 2008; VON LEWINSKI, 2004, p. 388; COTTIER; PANIZZON, 2006; CORREA, 2001, p. 18-19; ONWUEKWE, 2004; CHANDER; SUNDER, 2004, p. 1364-69; CARRIZOSA, 2004, p. 297; POSEY; DUTFIELD, 1996, p. 95; POSEY, 2004g, p. 193; GERVAIS, 2005, p. 139-140, 160, 163-166; The Bellagio Declaration; QUIGGIN, 2002; JANKE, 2002A, 2002b, 2002c, 2002d.

${ }^{1362}$ Ver, por exemplo, COPCBD, Decision IX/13, anexo, para. 10-13, 22; UNESCO, Recomendación sobre la salvaguardia de la cultura tradicional y popular, item (f); DAES, 1997, para. 26; DAES, 2001, p. 146-147; art. XX, OEA, Proposed American Declaration on the Rights of Indigenous Peoples; WIPO, WIPO/GRTKF/IC/13/9, anexo, p. 4 (posição do Grupo Africano); WTO, IP/C/W/404 (proposta do Grupo Africano de proteção dos RBIs apresentada no Conselho para o Acordo TRIPS); SCBD UNEP/CBD/COP/9/7, para. 85 (posição do Brasil); INDIGENOUS PEOPLE'S CÁUCUS, 2008; ORGANIZACIÓN DEL TRATADO DE COOPERCIÓN AMAZÓNICA, Declaración de Lima, preâmbulo; ORGANIZACIÓN DEL TRATADO DE COOPERCIÓN AMAZÔNICA, Declaración de CARACAS, item sobre meio ambiente; UNCED, Agenda 21, capítulo 26; UNGA, A/61/382, para. 8; COMMISSION ON HUMAN RIGHTS, E/CN.4/Sub.2/1994/31, anexo, para. 4, 9 e10; CPPDEC (um dos parágrafos preambulares da Convenção sublinha"la importancia de los derechos de propiedad intelectual para sostener a quienes participan en la creatividad cultural"); Terceira minuta do Acordo de Livre Comércio das Américas, capítulo XX, subseção (B)(2)(f), art. 20.
} 
analisadas mais adiante. ${ }^{1363}$ Ainda assim, algumas decisões e documentos oficiais da CCDB permitem a identificação de seus elementos fundamentais, notadamente a Decisão IX/12 da $9^{\text {a }}$ Conferência das Partes da CDB e as Diretrizes de Bonn sobre Acesso aos Recursos Genéticos e Participação nos Benefícios Provenientes de sua Utilização (Diretrizes de Bonn). ${ }^{1364}$

Conforme assinalado anteriormente, a CDB confere aos seus Estados contratantes um direito de propriedade sobre seus recursos biológicos e, embora os termos do art. 8(j) da CDB não sejam tão claros quanto os utilizados em seu art. 15, nos círculos políticos e acadêmicos, a posição preponderante é que a CDB igualmente reconhece às comunidades tradicionais um direito de propriedade sobre seus CTAs. Em outras palavras, os Estados e comunidades tradicionais podem condicionar o acesso aos seus recursos biológicos e CTAs à obtenção de seu CPLI, o que se dá por meio da negociação de um contrato, que disciplinará o uso de seus RBIs e a repartição dos benefícios resultantes. Essencialmente, é sobre esses pilares que se assentará o RI da CDB.

Primeiramente, serão avaliados os elementos centrais da proposta de RI pertinentes à proteção dos recursos da biodiversidade e, em seguida, os elementos relacionados à proteção dos CTAs. Indispensável destacar que, sempre que for examinado algum elemento do futuro RI, que se aplicará tanto para a proteção dos recursos biológicos quanto dos CTAs, far-se-á uma referência explícita a este respeito, a fim de se evitar repetições desnecessárias.

\section{§1 OBJETIVOS POLÍTICOS GERAIS}

Tendo em vista que o RI terá como marco a CDB, ele objetivará a promoção dos três objetivos deste instrumento internacional, a saber, conservação da biodiversidade em seus três níveis (intra-espécies, entre espécies e de ecossistemas), utilização sustentável de

\footnotetext{
1363 Os elementos estão indicados em COPCBD, Decision IX/12, anexo. Identificamos igualmente o conteúdo da proposta-base de regime internacional de proteção dos recursos da biodiversidade em COPCBD, Decision VIII/4, anexo, que identifica, com mais detalhamento, os elementos presentes na decisão IX/12.

${ }^{1364} \mathrm{O}$ anexo I da decisão IX/12 da CCDB estabeleceu a base sobre a qual será negociado o futuro regime internacional; este documento determina que os negociadores do futuro regime internacional tomem nota das Diretrizes de Bonn e que se empenhem em aprimorar sua aplicação pelos futuros Estados contratante do regime internacional (cf. preâmbulo e item 2(6), parte III(A), anexo I, COPCBD, Decision IX/12).
} 
seus componentes e a repartição justa e equitativa dos benefícios derivados de sua utilização $\left(\operatorname{art} .1^{\circ}\right)$. Contudo, o objetivo fundamental que o RI pretende alcançar é o de tornar a CDB em um acordo plenamente exigível, especialmente nos países usuários de recursos biológicos, i.e., países industrializados que, embora sejam partes contratantes da $\mathrm{CDB}$, nunca se movimentaram para cumpri-la. ${ }^{1365}$

\section{§2 MATÉRIA DE PROTEÇão}

Vem sendo discutida a possibilidade de se incluir no escopo do RI, além dos recursos da biodiversidade sobre os quais os Estados contratantes da CDB já exercem soberania (os recursos originados em seus territórios e águas territoriais ou que nele adquiriram suas características distintivas, quando originados em outros territórios), também os recursos disciplinados pelo TIRFAA; aqueles presentes na área coberta pelo Tratado da Antártida de 1959 e os recursos da biodiversidade marinha, localizados em áreas além da jurisdição dos Estados contratantes da Convenção sobre Direito do Mar. ${ }^{1366}$ A única matéria que, com segurança, será disciplinada pelo futuro RI são os recursos da biodiversidade, tutelados no presente pela CDB.

Os países em desenvolvimento ricos em recursos da biodiversidade reivindicam direitos não somente sobre seus recursos biológicos brutos, mas, sobretudo, sobre: os recursos biológicos intangíveis deles isolados, quando utilizados diretamente por terceiros, ou quando influenciaram, de alguma forma, no desenvolvimento de invenções. Tendo como parâmetro a práxis do Instituto Nacional do Câncer dos EUA, relacionada à repartição de benefícios pelo uso produtivo de recursos da biodiversidade, originários de inúmeros países, os países em desenvolvimento possivelmente reivindicam direitos econômicos, sempre que uma invenção for "estruturalmente baseada em um produto isolado de um material natural”; ou for composta por um princípio ativo isolado de um recurso natural; ou se uma invenção sintética ou um método de síntese foi desenvolvido a partir de uma "uma dica-chave", oferecida pelo recurso natural. ${ }^{1367}$

\footnotetext{
${ }^{1365}$ Cf. COPCBD, Decision IX/12, anexo, item I.

1366 Ibid., item II.

${ }^{1367}$ Cf. WTO, IP/C/W/341, cláusula 12; WTO, IP/C/W/393, p. 6.
} 


\section{§3 FORMALIDADES PARA OBTENÇÃO DA PROTEÇÃO}

Não foi encontrada qualquer referência à obrigatoriedade de depósito de amostras dos recursos biológicos, conservados em condições in situ pelos Estados contratantes de um possível regime internacional, como condição para o gozo e exercício de direitos.

\section{§4 TITULARIDADE}

Se o RI apenas regular o acesso e uso dos recursos biológicos sob jurisdição dos Estados parte da CDB, estes serão os titulares de direitos e as autoridades competentes para autorizar seu acesso e uso.

\section{§5 DIREITOS CONFERIDOS}

O futuro RI planeja reafirmar o direito dos Estados de controlar o acesso e todo e qualquer uso de seus recursos biológicos e o direito de condicionar o acesso e uso destes recursos ao pagamento de benefícios pecuniários e de outra natureza (e.g. transferência de tecnologia). ${ }^{1368} \mathrm{O}$ aspecto inovador que o RI pretende introduzir é o direito dos Estados de controle transfronteiriço de seus recursos da biodiversidade. Esta prerrogativa os habilitaria a impedir a concessão de títulos de PI sobre produções intelectuais derivadas de seus recursos biológicos, na hipótese do autor da produção não ter observado as normas legais do país de origem do recurso utilizado, ou em caso de quebra de acordo celebrado com o país de origem do recurso.

\section{§6 LIMITAÇÕES AOS DIREITOS CONFERIDOS}

A única limitação aos direitos de exclusivos dos Estados seria o uso dos recursos da biodiversidade por comunidades tradicionais, segundo suas práticas consuetudinárias. ${ }^{1369}$ No mais, a julgar pelos termos do mandato negociador do RI, é possível que venham a ser

\footnotetext{
${ }^{1368}$ Cf. COPCBD, Decision IX/12, 4o parágrafo preambular combinado com SCBD, 2002, apêndice 1, item B(3); SCBD, 2002, para. 16.

${ }^{1369}$ Cf. SCBD, 2002, para. 43(b); 44(g).
} 
fixadas regras facilitadoras do acesso a recursos biológicos, para fins científicos e pesquisas taxonômicas (sem fins comerciais). ${ }^{1370}$

\section{§7 DURAÇÃo dOS DIREITOS}

Direitos de duração perpétua.

\section{§8 ORGANIZAÇÃo DE APOIO AOS ESTADOS PARA ASSEGURAR A OBSERVÂNCIA DOS DIREITOS}

As Diretrizes de Bonn encorajam os Estados contratantes da CDB a estabelecerem uma autoridade nacional, investida na competência de, inter alia, autorizar o acesso aos recursos da biodiversidade e conhecimentos tradicionais conexos; monitorar usos lícitos e ilícitos destes RBIs; monitorar o cumprimento de acordos de acesso e repartição de benefícios; auxiliar os Estados e comunidades na tarefa de negociação de acordos equilibrados de repartição de benefícios; assegurar a sustentabilidade do uso da biodiversidade para fins produtivos. ${ }^{1371}$ Nos termos das Diretrizes de Bonn, o acesso aos recursos da biodiversidade pode ser condicionado à obtenção de diversas autorizações de autoridades Estatais. ${ }^{1372}$

Ademais, com o objetivo de assegurar o cumprimento da CDB e do futuro regime internacional que a complementará, a decisão IX/12 da CCDB indica várias medidas que, se adotadas, facilitariam o respeito dos direitos de exclusivo dos Estados sobre seus recursos da biodiversidade e os das comunidades tradicionais sobre seus CTAs. ${ }^{1373}$

Certamente, o principal mecanismo proposto seria um certificado internacional de origem dos recursos biológicos e CTAs acessados (certificado de origem), cujo objetivo central seria o de viabilizar o exercício transfronteiriço do direito de propriedade dos

${ }^{1370}$ Cf. SCBD, 2002, para. 43(e); COPCBD, Decision IX/12, item III(B), para. 2(5); COPCBD, Decision VIII/4, anexo, item "Participación Justa y Equitativa en los Beneficios", para. 10.

${ }^{1371}$ Cf. SCBD, 2002, para. 14-15.

1372 Ibid., para. 29.

${ }^{1373}$ Cf. COPCBD, Decision IX/12, item E. 
Estados e das comunidades tradicionais sobre seus RBIs. O certificado de origem seria expedido pelo Estado de origem do recurso biológico e CTAs acessados e serviria como um passaporte, ${ }^{1374}$ a acompanhá-los a partir do momento de sua transferência dos Estados ou comunidades provedoras. ${ }^{1375}$ Esse passaporte teria de ser apresentado pelo usuário, quando desejasse reivindicar algum DPI sobre uma produção intelectual derivada, ou fosse registrar produtos derivados destes RBIs, perante agências de vigilância sanitária ou outros órgãos responsáveis pela emissão de autorizações de comercialização. ${ }^{1376} \mathrm{O}$ certificado atestaria internacionalmente que o acesso ao recurso biológico e/ou CTA nele indicado ocorreu de maneira lícita. ${ }^{1377}$ Mais especificamente, o certificado indicaria o recurso biológico e/ou CTA acessado; seus provedores (Estado e/ou comunidades tradicionais pertinentes); a existência de um acordo de repartição de benefícios; os usos autorizados e proibidos dos RBIs. ${ }^{1378}$

A relevância prática do certificado de origem depende da reforma dos marcos legais de PI, notadamente, dos marcos de patentes e de proteção de cultivares dos Estados membros da OMC, bem como da reformulação das legislações nacionais e regionais que disciplinam a concessão de registros sanitários, considerando que nem todos os produtos que fazem uso de recursos biológicos e CTAs são objeto de DPIs. Se os regimes nacionais, regionais e internacionais não condicionarem a concessão de DPIs e de autorizações de comercialização à apresentação do certificado de origem, este não terá qualquer relevância prática.

Conforme será visto mais adiante, no âmbito da OMC, os países em desenvolvimento demandam que os demais Estados membros da organização condicionem a concessão de patentes, incidentes sobre invenções derivadas de recursos biológicos e CTAs, à divulgação de sua origem pelos depositantes de patentes, à obtenção do CPLI das comunidades e Estados pertinentes e à assinatura de um acordo de repartição de benefícios. ${ }^{1379} \mathrm{O}$ certificado internacional poderia facilitar a observância desta obrigação pelas autoridades de patentes, ao liberá-las da responsabilidade de examinar documentação

${ }^{1374}$ Cf. TOBIN, 2004, p. 18.

1375 Cf. SCBD, UNEP/CBD/WG8J/5/INF/10, para. 33.

${ }^{1376}$ Cf. CUNNINGHAM; TOBIN; WATANABE, 2004.

${ }^{1377}$ Cf. COPCBD, Decision IX/12, item C, para. 2(a); item D, para. 2(3).

${ }^{1378}$ Cf. TOBIN, [20--], p. 7.

1379 No âmbito da OMC, os países em desenvolvimento patrocinam uma emenda ao Acordo TRIPS neste sentido. Cf. item 4.2.5. 
e legislações que não dominam. ${ }^{1380}$ No entanto, ao menos no presente, a proposta de reforma do Acordo TRIPS, apresentada pelo Brasil e outros países em desenvolvimento, não contém qualquer referência ao certificado internacional de origem, o que certamente ataca sua importância prática.

\section{§9 VINCULAÇÃO DOS BENEFÍCIOS RECEBIDOS AO SEU INVESTIMENTO NA MELHORIA DA QUALIDADE DE VIDA DAS COMUNIDADES E NA CONSERVAÇÃO DA NATUREZA}

Em seu estado atual, o RI proposto pretende estabelecer mecanismos para encorajar (e não obrigar) a reversão dos benefícios econômicos, coletados pela exploração de recursos biológicos, em projetos de conservação da natureza e erradicação da pobreza. ${ }^{1381}$

\subsection{1 ELEMENTOS DA PROPOSTA DA CCDB PARA A PROTEÇÃo DE CONHECIMENTOS TRADICIONAIS ASSOCIADOS À BIODIVERSIDADE (CTAS)}

No anexo da decisão VII/16 H da $7^{\mathrm{a}} \mathrm{CCDB}$, há a indicação de doze elementos que possivelmente serão incluídos no futuro RI, com vistas a proteger especificamente os CTAs contra atos de apropriação indébita. Recentemente, o Grupo de Trabalho sobre o art. 8(j) e dispositivos conexos da CDB (Grupo 8(j) ou Grupo) divulgou um estudo, em que explora o conteúdo destes elementos, ${ }^{1382}$ o qual é tratado pela CCDB como um guia para a elaboração do RI, no que tange à proteção dos CTAs. ${ }^{1383}$ Embora inexista, no momento, uma proposta bem formatada de regime legal para a proteção de CTAs, as diretrizes traçadas nesses documentos, certamente, configuram o ponto de partida de qualquer futuro acordo, a ser negociado no marco da CDB.

\section{§1 MATÉRIA DE PROTEÇão}

1380 Cf. COPCBD, Decision VIII/4, anexo, item "[Declaración [de procedencia legal] [origen] [consentimiento fundamentado previo y participación en los beneficios]", para. 1-3.

${ }^{1381}$ Id., Decision IX/12, item III.A, para. 10.

${ }^{1382}$ Cf. SCBD, UNEP/CBD/WG8J/5/6.

${ }^{1383}$ Cf. COPCBD, Decision IX/13, item (f). 
O Grupo recomenda que todos os CTAs, indiscriminadamente, sejam elegíveis para proteção, inclusive aqueles em "domínio público"1384 (publicamente acessíveis), desde que vinculados culturalmente a alguma comunidade tradicional. ${ }^{1385}$ Sugere, contudo, caso os Estados julguem necessário restringir o alcance do RI, que reconheçam proteção, ao menos, às seguintes categorias de CTAs: ${ }^{1386}$ CTAs vinculados à identidade cultural das comunidades tradicionais (i); CTAs suscetíveis de aplicação comercial (ii); CTAs úteis para fins acadêmicos (iii); CTAs aptos a promover práticas ambientalmente sustentáveis (iv).

A extensão de proteção legal aos CTAs publicamente acessíveis (e a qualquer RBI publicamente acessível) é fundamental para se assegurar a funcionalidade e equidade do futuro regime. Em virtude das tradições das comunidades tradicionais de livre compartilhamento de seu PBI, das publicações científicas sobre o tema e das modernas tecnologias da informação, RBIs em geral estão se disseminando publicamente com uma velocidade cada vez maior. ${ }^{1387}$ Se apenas os CTs secretos forem elegíveis para proteção, com o passar do tempo, restaria muito pouco a se tutelar. E aqueles que se conservassem em segredo sofreriam concorrência desleal dos seus pares em domínio público. ${ }^{1388}$ No fim, os titulares de direitos sobre os CTs ou não encontrariam partes interessadas em licenciálos, ou se veriam obrigados a transferi-los em troca de uma remuneração simbólica.

\section{§2 FORMALIDAdes PARA A OBTENÇÃo DE PROTEÇÃo}

O Grupo assinala que a proteção dos CTAs poderia ser condicionada ao seu registro prévio. Mas ao considerar a miséria material em que vivem muitas comunidades tradicionais, seu distanciamento geográfico dos grandes centros e a possível desconfiança que teriam em registrá-los em bancos de dados fora de seu controle, o Grupo recomenda a proteção dos CTAs, a partir do momento em que se encerrou o processo de seu

\footnotetext{
1384 Cf. SCBD, UNEP/CBD/WG8J/5/6, para. 47.

${ }^{1385}$ Cf. art. 8(j), CDB.

${ }^{1386}$ Cf. SCBD, op.cit., para. 49.

${ }^{1387}$ Cf. HUFT, 1994-1995, p. 1704-1705.

${ }^{1388}$ Cf. MOUCHET, 1983-1984, p. 140-143.
} 
desenvolvimento, ou do momento em que vier a público, independentemente de qualquer registro. $^{1389}$

\section{§3 TITULARIDADE}

As comunidades tradicionais seriam sempre as titulares de direitos de propriedade sobre os CTAs, ainda que alguns poucos indivíduos, integrantes da comunidade os conservem. ${ }^{1390} \mathrm{Na}$ hipótese de um mesmo recurso da biodiversidade existir em dois ou mais países, ou um mesmo CTA for compartilhado por duas ou mais comunidades, estejam elas baseadas em um mesmo país ou em jurisdições diversas, o Grupo recomenda que o RI condicione seu uso à obtenção do CPLI de todos os múltiplos codetentores. ${ }^{1391}$

\section{§4 DIREITOS CONFERIDOS}

O Grupo recomenda que o RI invista nas comunidades tradicionais os direitos de: ${ }^{1392}$ transferir e licenciar seus CTAs; se opor a qualquer tipo de reprodução, utilização ou exploração não autorizada; transmitir conhecimentos e direitos às gerações futuras das comunidades. $^{1393}$ Enfim, o Grupo recomenda o reconhecimento de um direito de propriedade às comunidades tradicionais. Ademais, o Grupo sugere que os Estados confiram às comunidades tradicionais direitos diferenciados em relação aos CTAs já publicamente acessíveis; no entanto, não chega a especificar que direitos seriam esses. ${ }^{1394}$

\section{§5 LIMITAÇÕES AOS DIREITOS CONFERIDOS}

As comunidades tradicionais estariam investidas na liberdade de compartilhar livremente seus CTAs e os recursos biológicos associados com outras comunidades

\footnotetext{
${ }^{1389}$ Cf. SCBD, UNEP/CBD/WG8J/5/6, para. 47-52, 62.

1390 Ibid., para. 19.

1391 Ibid., para. 21.

1392 Ibid., alíneas (a), (b), (c), (d) e (f).

1393 Ibid., para. 57.

${ }^{1394}$ Ibid., para. 54(e).
} 
tradicionais, com o objetivo de fomentar o desenvolvimento contínuo de sistemas de tradicionais de conhecimento e melhor conservar a biodiversidade. ${ }^{1395}$

\section{§6 DURAÇÃo dos DIREITOS}

A recomendação principal é que os direitos durem perpetuamente. Uma segunda sugestão é que, em caso de opção por um termo de proteção limitado, a proteção comece a fluir da prática do primeiro ato de exploração comercial do CTA protegido. ${ }^{1396}$

\section{§7 ORgANIZAÇÃO DE APOIO ÀS COMUNIDADES TRADICIONAIS PARA ASSEGURAR A OBSERVÂNCIA DE SEUS DIREITOS}

Foi sugerido o estabelecimento de uma organização nacional, com o objetivo de compensar a assimetria de poder entre as comunidades tradicionais e os potenciais usuários de CTAs. Esta organização seria competente para, inter alia: ${ }^{1397}$ processar pedidos de acesso a CTAs; facilitar a obtenção do CPLI das comunidades pertinentes; assegurar a distribuição equitativa dos benefícios decorrentes da utilização dos CTAs; prestar assessoria jurídica às comunidades tradicionais para assegurar a defesa de seus direitos; promover o uso e o desenvolvimento dos CTAs nas esferas comunitária e extracomunitária; apoiar pesquisas envolvendo CTAs; garantir que os direitos das comunidades tradicionais sejam observados por terceiros.

\subsubsection{OMPI}

Entre 2001 e 2008, o CIG se reuniu treze vezes, e, desde sua segunda sessão, os trabalhos já foram se encaminhando em direção à redação de um projeto de disposições

\footnotetext{
${ }^{1395}$ Cf. SCBD, UNEP/CBD/WG8J/5/6, para. 57.

${ }^{1396}$ Ibid., para. 53.

${ }^{1397}$ Ibid., para. 66, 69.
} 
para a proteção dos CTs e das ECTs, que serviria de base para um futuro acordo internacional sobre a matéria.

Em dezembro de 2001, na segunda sessão do CIG, as delegações do Grupo Africano, Venezuela, Brasil, Equador e Egito solicitaram ao Comitê a preparação de um estudo, que identificasse os elementos que um regime sui generis de proteção de CTs deveria conter. Na sessão seguinte, a delegação da Noruega, embora julgasse precipitado discutir o conteúdo de um possível acordo internacional para a matéria, recomendou que o artigo 10bis da Convenção de Paris fosse tomado como ponto de partida para a elaboração de um futuro regime sui generis internacional. ${ }^{1398}$

Anos mais tarde, absorvendo as recomendações trazidas pela delegação norueguesa e por estudos de direito comparado, o CIG redigiu dois projetos de disposições: um dedicado à proteção dos CTs e outro dedicado à proteção das ECTs ${ }^{1399}$, cujas primeiras versões foram apresentadas e debatidas em sua sétima sessão. ${ }^{1400}$

Tanto o projeto de disposições da OMPI para a proteção de CTs quanto o projeto para a proteção das ECTs adotam uma estratégia de associação de mecanismos legais diversos para a proteção de categorias específicas de CTs e ECTs (e.g. CTs publicamente acessíveis, sagrados; ECTs laicas, sagradas, secretas). ${ }^{1401}$ Mais especificamente, os projetos da OMPI propõem a proteção destas categorias de RBIs mediante a associação de direitos de propriedade, regras de repressão da concorrência desleal e regime de responsabilidade.

\subsection{PROJETO DE DISPOSIÇÕES DA OMPI PARA A PROTEÇÃo DE CTS ${ }^{1402}$}

\footnotetext{
${ }^{1398}$ Cf. WIPO, WIPO/GRTKF/IC/3/17, para. 227.

1399 Cf. OMPI, Disposiciones revisadas para la protección de las expresiones culturales tradicionales/expresiones del folclore: objetivos políticos y principios fundamentales (WIPO, $\mathrm{WIPO} / \mathrm{GRTKF} / \mathrm{IC} / 9 / \mathrm{INF} / 4)$.

${ }^{1400} \mathrm{Cf}$. WIPO, WIPO/GRTKF/IC/7/5, anexo I.

${ }^{1401}$ Cf. WIPO, WIPO/GRTKF/IC/6/4, para. 33.

1402 Cf. WIPO, Revised provisions for the protection of traditional knowledge (WIPO, $\mathrm{WIPO} / \mathrm{GRTKF} / \mathrm{IC} / 12 / 5(\mathrm{c}))$.
} 
A presente seção limitar-se-á a examinar aqueles dispositivos do projeto da OMPI que conferem um direito de propriedade aos titulares de CTs, bem como alguns aspectos que são comuns a todos os direitos conferidos às comunidades tradicionais, sejam eles tutelados por direitos de propriedade ou por regras de concorrência desleal ou por um regime de responsabilidade, e.g. objetivos e princípios do projeto, matéria de proteção, titulares de direitos, limitações aos direitos conferidos, mecanismo de gestão de direitos. Nas seções seguintes, a análise do projeto de disposições da OMPI para a proteção de CTs será encerrada, a partir do exame dos dispositivos que tutelam os CTs por meio de regras de repressão da concorrência desleal e regime de responsabilidade.

\section{§1 OBJETIVOS POLÍTICOS GERAIS}

O projeto de disposições estabeleceu como objetivos políticos gerais, a serem perseguidos por um regime internacional, inter alia: ${ }^{1403}$

- Reconhecimento do valor e dos aportes realizados pelos CTs ao bem-estar da sociedade em geral;

- Promoção do respeito ao livre-arbítrio das comunidades, no que concerne ao uso de seu PBI;

- Satisfação das verdadeiras necessidades dos titulares de CTs;

- Conservação e salvaguarda dos CTs;

- Fortalecimento dos detentores de CTs e reconhecimento do caráter distintivo dos sistemas tradicionais de conhecimento;

- Apoio aos sistemas tradicionais de conhecimento;

${ }^{1403}$ Cf. WIPO, WIPO/GRTKF/IC/12/5(c), anexo, p. 3-6. 
- Prevenção dos atos de apropriação indébita de CTs;

- Coexistência harmônica do projeto de disposições com os acordos e processos internacionais pertinentes, especialmente, aqueles relacionados à regulação do acesso aos recursos da biodiversidade;

- Promoção da inovação e criatividade intra- e intercomunitária, com vistas à perpetuação dos ciclos de inovação comunitária;

- Garantia às comunidades tradicionais de que o uso de seus CTs dará lugar à uma repartição justa e equitativa de benefícios, mesmo quando os CTs forem publicamente acessíveis e as comunidades detentoras não forem identificáveis;

- Promoção do desenvolvimento material e cultural das comunidades titulares de CTs e de atividades comerciais legítimas, conduzidas pelas próprias comunidades;

- Prevenção da concessão de DPIs sobre produções intelectuais derivadas de CTs apropriados indebitamente;

- Construção de relações de confiança e respeito entre comunidades e usuários de CTs; e

- Complementação da proteção reconhecida às ECTs.

\section{§2 PRINCÍPIOS REITORES GERAIS}

A seção II do projeto de disposições estabelece os princípios, que dirigirão a aplicação das disposições propostas, de maneira a realizar os objetivos políticos indicados anteriormente. ${ }^{1404}$ Os dez princípios reitores são indicados a seguir: ${ }^{1405}$

\footnotetext{
${ }^{1404}$ Cf. WIPO, WIPO/GRTKF/IC/12/5(c), anexo, p. 9.
}

${ }^{1405}$ Ibid., anexo, p. 8 


\section{Princípio da receptividade às necessidades e expectativas dos titulares de CTs}

Os regimes de proteção devem ser aptos a satisfazer as demandas e necessidades das comunidades tradicionais em relação aos CTs, i.e. devem ser capazes de impedir sua apropriação e usos culturalmente desrespeitosos e oferecer um espaço, para que as normas consuetudinárias das comunidades possam ser efetivamente observadas por terceiros. ${ }^{1406}$

\section{Princípio do reconhecimento dos direitos dos detentores de CTs a tê-los efetivamente protegidos}

Os Estados membros de um possível acordo internacional devem reconhecer, em seus ordenamentos jurídicos, os direitos das comunidades tradicionais sobre seus CTs. ${ }^{1407}$

\section{Princípio da efetividade e acessibilidade da proteção}

Os regimes de proteção dos CTs devem ser delineados de maneira a permitir a exigibilidade dos direitos conferidos às comunidades tradicionais. Isto significa que não é suficiente disponibilizar às comunidades remédios judiciais e administrativos que, em termos técnicos, ensejem a defesa de seus direitos. Tomando nota do contexto social, cultural e econômico em que vivem as comunidades tradicionais, os regimes devem igualmente assegurar-lhes o apoio material e técnico, indispensável ao exercício concreto de seus direitos, nas esferas local e internacional. ${ }^{1408}$

\section{Princípio da concordância com os regimes jurídicos vigentes, aplicáveis ao acesso aos recursos genéticos conexos}

O projeto de disposições deve ser observado de maneira a não interferir no direito soberano dos Estados sobre seus recursos biológicos. ${ }^{1409}$ Isso significa que o CPLI dado por uma comunidade tradicional, para que um terceiro acesse e utilize um determinado CT associado à biodiversidade, não autoriza o acesso ao recurso biológico conexo. ${ }^{1410}$

\footnotetext{
${ }^{1406}$ Cf. WIPO, WIPO/GRTKF/IC/12/5(c), anexo, p. 9.

${ }^{1407}$ Ibid., anexo, p. 9.

1408 Ibid., anexo, p. 9.

${ }^{1409}$ Ibid., anexo, p. 10-11.

${ }^{1410} \mathrm{Cf}$. WIPO, Revised provisions for the protection of traditional knowledge, art. 12.
} 


\section{Princípio da flexibilidade e exaustividade}

O projeto de disposições oferece aos Estados um amplo espaço de manobra para a escolha dos mecanismos de proteção dos CTs, tendo em vista sua realidade econômica, social e política, as categorias de conhecimentos a serem protegidos e os objetivos a serem perseguidos. $^{1411}$

\section{Princípio da equidade e repartição nos benefícios}

As disposições devem ser implementadas de modo a reconciliar os interesses das comunidades tradicionais sobre seus CTs com outros interesses, notadamente, aqueles dos usuários e os tutelados por políticas públicas. Ademais, os regimes de proteção de CTs devem assegurar às comunidades tradicionais uma repartição justa de benefícios, a título de contraprestação pelo uso de seus CTs. ${ }^{1412}$

\section{Princípio do respeito a outros instrumentos e processos internacionais e regionais e cooperação com os mesmos}

Os regimes de proteção dos CTs devem observar os limites fixados pelas normas do direito internacional e por outros processos regionais e internacionais relacionados à proteção dos CTs. $^{1413}$

\section{Princípio do respeito ao uso e à transmissão consuetudinários dos conhecimentos tradicionais}

As disposições devem ser realizadas de modo a conservar as tradições das comunidades tradicionais de compartilhamento de seus RBIs em âmbito intra e intercomunitário. ${ }^{1414}$

\footnotetext{
${ }^{1411}$ Cf. WIPO, WIPO/GRTKF/IC/12/5(c), anexo, p. 10.

${ }^{1412}$ Ibid., anexo, p. 10.

1413 Ibid., anexo, p. 11.

${ }^{1414}$ Ibid., anexo, p. 11.
} 


\section{Princípio do reconhecimento das características específicas dos conhecimentos tradicionais}

Os regimes de proteção dos CTs devem respeitar os valores culturais das comunidades tradicionais que os conservam, o caráter intergeracional de seus CTs e os processos comunitários de constante desenvolvimento de seu PBI. ${ }^{1415}$

\section{Princípio da prestação de assistência para atender às necessidades dos titulares de conhecimentos tradicionais}

A OMPI reconhece que os detentores de CTs necessitam de apoio técnico para exercer os direitos conferidos. ${ }^{1416}$ Em termos de substância, este princípio se sobrepõe aos princípios do reconhecimento de direitos dos detentores de CTs a tê-los efetivamente protegidos e o da efetividade e acessibilidade da proteção.

\section{§3 MATÉRia de PROTEÇÃo}

Quaisquer formas de CTs resultantes de atividades intelectuais, conduzidas na esfera de comunidades culturais, independentemente das áreas técnicas a que se vinculam. Portanto, o projeto da OMPI não se limita a tutelar os conhecimentos tradicionais associados à biodiversidade.

O projeto da OMPI determina que, ao menos, os CTs que preencherem as seguintes condições deverão receber proteção legal:

i. Foram criados e são preservados no contexto de comunidades tradicionais; ${ }^{1417}$

\footnotetext{
${ }^{1415}$ Cf. WIPO, WIPO/GRTKF/IC/12/5(c), anexo, p. 11.

${ }^{1416}$ Ibid., anexo, p. 11

${ }^{1417}$ Cf. WIPO, Revised provisions for the protection of traditional knowledge, art. 4(i).
} 
ii. Integram a identidade cultural de uma comunidade tradicional, cujas normas consuetudinárias a investe na obrigação de salvaguardá-lo, conservá-lo e administrá-lo; ${ }^{1418}$

iii. São transmitidos de geração em geração. ${ }^{1419}$ É dado que CTs não são, necessariamente, conhecimentos antigos, mas conhecimentos que evoluem incessantemente. Essa condição deveria ser interpretada de maneira a permitir a proteção daqueles CTs contemporâneos, que refletem a identidade cultural das comunidades que o desenvolvem. No entanto, como a extensão de proteção a esta categoria de CTs seria facultativa, os Estados membros de um possível acordo de proteção de CTs, que se limitasse a reproduzir os termos da proposta da OMPI, poderiam excluir de seu escopo de proteção os CTs contemporâneos.

Apesar desse equívoco, o projeto da OMPI acertou ao não fixar a inacessibilidade pública dos CTs como condição de proteção. Assim sendo, CTs publicamente acessíveis (os chamados CTs em "domínio público") são elegíveis para proteção, desde que preencham as três condições de proteção referidas.

\section{§4 FORMALIDADES PARA OBTENÇÃO DA PROTEÇÃO}

O projeto da OMPI não condiciona a proteção dos CTs ao cumprimento de qualquer formalidade, mas oferece aos Estados a discricionariedade para estabelecerem registros a fim de assegurar transparência, segurança e conservação dos CTs ou como condição para que as comunidades obtenham proteção legal. ${ }^{1420}$

\section{§5 TITULARIDADE}

\footnotetext{
${ }^{1418} \mathrm{Cf}$. WIPO, Revised provisions for the protection of traditional knowledge, art. 4, incisos (ii)e (iii).

${ }^{1419}$ Ibid., art. 4(i) e (ii).

${ }^{1420}$ Ibid., art. 11 .
} 
Aquelas comunidades tradicionais que conservam ou desenvolvem CTs que preencherem as três condições de proteção mencionadas acima. ${ }^{1421}$ Pelos termos amplos utilizados no projeto, é possível inferir que, na hipótese de duas ou mais comunidades compartilharem um mesmo CT elegível para proteção legal, todas elas teriam direitos sobre o mesmo CT. ${ }^{1422}$

\section{§6 DIREITOS CONFERIDOS}

$\mathrm{O}$ artigo $2^{\circ}$ do projeto da OMPI assinala que os Estados gozam de ampla liberdade para elegerem os mecanismos legais que julgarem mais adequados para a proteção dos CTs contra atos de apropriação indébita e usos culturalmente desrespeitosos, podendo protegêlos, inter alia, mediante normas de concorrência desleal, direitos de propriedade e um regime de responsabilidade. Apesar da flexibilidade oferecida, é interessante notar que o projeto de disposições é estruturado de modo a sobrevalorizar a opção por um regime de direito de propriedade.

Corroborando o que ora se afirma, nota-se que uma das disposições substantivas do projeto determina que os Estados nacionais reconheçam às comunidades tradicionais o direito de condicionar todo e qualquer acesso aos seus CTs à obtenção de seu CPLI ${ }^{1423}$ ou à uma autorização, concedida por uma organização, investida pelas comunidades tradicionais titulares de direitos nesta competência. ${ }^{1424}$ Conforme já indicado, condicionar o acesso e uso dos CTs à obtenção do CPLI das comunidades tradicionais equivale a reconhecer-lhes um direito de propriedade sobre seus CTs.

Uma possível razão para a OMPI priorizar um regime de propriedade para a proteção dos CTs se deve ao fato do projeto de RI, negociado no marco da CDB,

${ }^{1421} \mathrm{Cf}$. WIPO, Revised provisions for the protection of traditional knowledge, art. $5^{\circ}$.

${ }^{1422}$ Essa interpretação se coaduna com os resultados da pesquisa de campo, conduzida pela OMPI, entre 1998 e 1999, que sublinhou o interesse de diversas comunidades pesquisadas de que aquelas, que compartilham um mesmo RBI, recebam benefícios por sua exploração comercial ou de outra natureza (WIPO, 2001, p. 71, 88). No mais, deve-se sublinhar o compromisso do projeto da OMPI de se harmonizar com os processos, em negociação, em outras esferas (CCDB e OMC). Conforme já indicado, o projeto de regime internacional, em negociação no marco da $\mathrm{CDB}$, ao menos em sua forma atual, pretende condicionar $\mathrm{o}$ acesso a recursos da biodiversidade e CTAs compartilhados por duas ou mais partes à obtenção do CPLI de todos os codetentores (cf. Cf. item 4.2.2.1.2, §3).

${ }^{1423} \mathrm{Cf}$. WIPO, Revised provisions for the protection of traditional knowledge, art. 7(1).

${ }^{1424}$ Ibid., art. 7(2). 
igualmente se estruturar sobre direitos de propriedade. Para dar concreção ao objetivo político de ensejar a coexistência harmônica do projeto da OMPI com os demais acordos e processos internacionais pertinentes, é natural que a OMPI dê guarida à proposta em construção no marco da CDB.

\section{§7 DIREITOS MORAIS}

O projeto de disposições da OMPI confere às comunidades tradicionais um direito moral de atribuição, que obriga todo usuário de CTs a reconhecer publicamente a comunidade-fonte dos conhecimentos direta ou indiretamente empregados. ${ }^{1425}$

O projeto confere ainda um direito moral de integridade, que poderia ser oposto contra qualquer uso ou alteração dos CTs protegidos, capaz de ferir seus valores culturais (inclusive espirituais), a moral e a ordem pública. ${ }^{1426}$ Os valores centrais contra os quais seria avaliado o suposto ato de desrespeito são aqueles conservados pelas comunidades tradicionais pertinentes. ${ }^{1427}$ Portanto, os usuários de CTs teriam de observar as normas e valores culturais das comunidades tradicionais titulares de direitos, com o propósito de não praticarem atos culturalmente desrespeitosos. Neste diapasão, os direitos morais conferem às comunidades uma justificativa de ordem cultural para controlarem os usos e alterações de seus CTs e possíveis contextos, em que serão aplicados.

\section{§8 EXCEÇÕES AOS DIREITOS CONFERIDOS}

O projeto da OMPI prevê duas exceções aos direitos de exclusivo conferidos às comunidades tradicionais: ${ }^{1428}$ intercâmbio intercomunitário de CTs, em consonância com as práticas costumeiras das comunidades pertinentes (i); e o uso de CTs medicinais na esfera doméstica, em hospitais públicos ou para outros fins de saúde pública (ii).

\footnotetext{
${ }^{1425} \mathrm{Cf}$. WIPO, Revised provisions for the protection of traditional knowledge, art. 6(3).

${ }^{1426}$ Ibid., artigos 1(3)(v) e 6(3) in fine.

${ }^{1427}$ Ibid., art. 1(5).

${ }^{1428}$ Ibid., art. 8 (1).
} 


\section{§9 DURAÇÃo DOS DIREITOS}

Nos termos do projeto da OMPI, a proteção perdurará, enquanto os CTs preencherem as três condições de proteção, isto é, enquanto mantiverem um forte vínculo com a identidade cultural das comunidades titulares de direitos, que os geraram e conservam. ${ }^{1429}$ É igualmente possível que os Estados optem por conceder proteção mais extensiva aos CTs, ${ }^{1430}$ e.g. proteção perpétua.

\section{§10 ORGANIZAÇÃo DE APOIO ÀS COMUNIDADES TRADICIONAIS PARA ASSEGURAR A OBSERVÂNCIA DOS DIREITOS}

Com o objetivo de dar concreção aos princípios da efetividade e acessibilidade da proteção e da prestação de assistência para atender às necessidades dos titulares de conhecimentos tradicionais, o projeto da OMPI prevê a criação de organismos nacionais ou regionais, investidos em um amplo leque de responsabilidades. Essas autoridades desempenhariam funções muito similares àquelas geralmente exercidas por organizações de gestão de direitos. Nos termos do 13(1)(a), os organismos nacionais ou regionais seriam competentes para: ${ }^{1431}$

i. Distribuir informação acerca da proteção dos conhecimentos tradicionais e realizar campanhas de conscientização dos titulares de conhecimentos tradicionais e de outros setores interessados sobre a disponibilidade, o alcance, o uso e o cumprimento da proteção dos conhecimentos tradicionais;

ii. Determinar se dado ato envolvendo conhecimentos tradicionais constitui ou não uma apropriação indébita ou ato de concorrência desleal;

iii. Determinar se o consentimento fundamentado prévio foi ou não outorgado em relação ao uso de conhecimentos tradicionais protegidos;

iv. Determinar se direitos sobre conhecimentos tradicionais foram ou não infringidos e estabelecer os recursos e compensações aplicáveis; e

\footnotetext{
${ }^{1429} \mathrm{Cf}$. WIPO, Revised provisions for the protection of traditional knowledge, art. 9(1). ${ }^{1430}$ Ibid., art. 9(2).

1431 Cf. WIPO, Revised provisions for the protection of traditional knowledge, art. 13; WIPO/GRTKF/IC/12/5(c), anexo, p. 43.
} 
v. Prestar assistência, quando possível e de maneira adequada, aos titulares de conhecimentos tradicionais, a fim de adquirirem, exercitarem e fazerem valer seus direitos sobre seus conhecimentos tradicionais.

\section{§11 VINCULAÇÃO DOS BENEFÍCIOS RECEBIDOS À SUA APLICAÇÃO NA MELHORIA DA QUALIDADE DE VIDA DAS COMUNIDADES TRADICIONAIS E NA CONSERVAÇÃO DA NATUREZA}

O projeto da OMPI propõe que os benefícios resultantes do uso de CTs protegidos sejam revertidos em favor das comunidades titulares de direitos. ${ }^{1432}$

\subsection{PROJETO DE DISPOSIÇÕES DA OMPI PARA A PROTEÇÃO DAS ECTS}

O projeto de disposições da OMPI dedicado à proteção das ECTs compartilha os mesmos objetivos políticos gerais e princípios reitores do projeto de disposições para a proteção dos CTs. Assim, estes aspectos não voltarão a ser tratados aqui.

Da mesma forma que o projeto de disposições para a proteção dos CTs, o projeto de disposições para ECTs se assenta sobre a associação de diferentes mecanismos de proteção, aplicáveis a categorias específicas de ECTs: o projeto confere às comunidades tradicionais um direito de propriedade sobre ECTs portadoras de um valor cultural ou espiritual singular, bem como para ECTs secretas, inacessíveis publicamente. Para aquelas ECTs que não são nem objeto de um registro público nem são conservadas em segredo, o projeto as tutela por meio de um regime de responsabilidade. A presente seção tratará apenas da proteção conferida às ECTs por intermédio de direitos de propriedade.

Vale aqui a mesma observação feita anteriormente, quando tratamos do projeto de disposições da OMPI para a proteção dos CTs: alguns dos elementos aqui tratados - e.g. titularidade, limitações aos direitos, duração dos direitos, organização de apoio à gestão de direitos - permeiam integralmente a proposta da OMPI para as ECTs, independentemente do mecanismo de proteção aplicado. Assim sendo, apenas será possível compreender integralmente o projeto em comento, a partir de uma análise conjunta das seções dedicadas

${ }^{1432} \mathrm{Cf}$. WIPO, Revised provisions for the protection of traditional knowledge, art. 5o. 
a examinar, especificamente, os dispositivos calcados em direitos de propriedade e em um regime de responsabilidade.

\section{§1 MATÉRIA DE PROTEÇão}

O projeto da OMPI confere às comunidades tradicionais direitos de propriedade sobre aquelas ECTs referidas no item 1.5 do capítulo 1, portadoras de valor cultural, espiritual ou de importância singular (ECTs singulares) para as comunidades que as criaram e/ou conservam, sejam elas publicamente acessíveis ou secretas, bem como sobre ECTs secretas, independentemente se portam ou não um valor espiritual ou cultural singular.

\section{§2 FORMALIDADES PARA OBTENÇÃO DA PROTEÇÃO}

A proteção das ECTs singulares depende de seu registro em um órgão designado pelo Estado para este fim. A proteção das ECTs secretas independe de qualquer registro prévio; a proteção surge no momento de sua criação.

\section{§3 TITULARIDADE}

A titularidade dos direitos de propriedade cabe àquelas comunidades tradicionais, cujas normas consuetudinárias determinam sua obrigação de "custódia, cuidado e salvaguarda das ECTs" protegidas, e que as "mantêm, utilizam ou desenvolvem [...] como elementos característicos de sua identidade cultural e social e de seu patrimônio cultural". 1433

No que tange às ECTs registradas, na hipótese de duas ou mais comunidades reivindicarem a titularidade de uma mesma ECT, a autoridade responsável pelo registro será competente para decidir qual delas é a verdadeira titular de direitos, podendo chegar à conclusão de que todas elas devem ocupar o papel cotitulares de direitos. ${ }^{1434}$

\footnotetext{
1433 Cf. WIPO, Disposiciones revisadas para la protección de las expresiones culturales tradicionales/expresiones del folclore: objetivos políticos y principios fundamentales, art. $2^{\circ}$.

${ }^{1434}$ Ibid., art. 7(iv).
} 


\section{§4 DIREITOS CONFERIDOS (INCLUINDO DIREITOS MORAIS)}

Nos termos do projeto, as comunidades seriam investidas no direito de condicionar as seguintes atividades à obtenção de seu CPLI: ${ }^{1435}$

(i) “a reprodução, publicação, adaptação, radiodifusão, interpretação ou execução pública, comunicação ao público, distribuição, aluguel, colocação à disposição do público e fixação (incluída fotografia estática) das expressões culturais tradicionais $[\ldots]$ ou $[\mathrm{d}]$ as obras derivadas das mesmas."

Ademais, o projeto confere às comunidades tradicionais o direito de excluir terceiros não-autorizados da prática dos seguintes atos: ${ }^{1436}$

(ii) "todo uso das expressões culturais tradicionais [...] ou adaptação das mesmas que não reconheça devidamente a comunidade como fonte das expressões culturais tradicionais";

(iii) "toda deformação, mutilação ou outra modificação das expressões culturais tradicionais $[\ldots]$ ou atentado às mesmas; $\mathrm{e}^{\prime}$

(iv) "a aquisição ou exercício de direitos de propriedade intelectual sobre as expressões culturais tradicionais [...] ou adaptações das mesmas".

Nos termos do projeto, as comunidades tradicionais titulares de ECTs registradas contariam com um direito moral de atribuição e um amplo direito de integridade, podendo este último ser exercido contra qualquer forma alteração da ECT que desagradar às comunidades titulares de direitos. O escopo do direito moral de integridade, reconhecido no projeto da OMPI, segue o modelo Francês de droit au respect de l'oeuvre, ${ }^{1437}$ assegurado no Código de Propriedade Intelectual deste país, o qual caracteriza como uma

1435 Cf. WIPO, Disposiciones revisadas para la protección de las expresiones culturales tradicionales/expresiones del folclore: objetivos políticos y principios fundamentales, art. 3(a)(i). ${ }^{1436}$ Ibid., art. 3(a)(i).

1437 Cf. art. L.121-1, França, Code de la propriété intellectuelle. Agredecemos à professora Mira Sundara Rajan, Universidade de British Columbia, por trazer à nossa atenção este dispositivo. 
infração ao direito moral dos autores qualquer alteração da obra protegida, ainda que esta não produza qualquer prejuízo à honra e à reputação dos autores. ${ }^{1438}$

Estes grupos contam, ainda, com um direito de adaptação, isto é, a prerrogativa de controlar as obras derivadas de suas ECTs, realizadas por terceiros sem sua autorização, ainda que resultantes de grande esforço criativo. $O$ direito de adaptação oferece às comunidades tradicionais o poder de impedir a disseminação, comercial ou não, de obras derivadas de suas ECTs que desrespeitem seus valores culturais, espirituais. Esta prerrogativa lhes oferece também a oportunidade de extrair renda pela exploração comercial indireta de suas ECTs. ${ }^{1439}$

O lado negativo do direito de adaptação é que a "liberdade" de expressão de terceiros, que desejarem utilizar ECTs registradas, passaria às mãos das comunidades tradicionais, que teriam o direito de vida e morte sobre as obras derivadas de suas ECTs singulares. ${ }^{1440} \mathrm{Na}$ prática, o direito de adaptação confere às comunidades o direito de controlar as informações que permeiam suas ECTs. Tais "tijolos" informacionais são conservados em domínio público pelos regimes de direitos autorais exatamente para salvaguardar a liberdade de expressão de terceiros.

No que tange às ECTs secretas, o projeto de disposições confere às comunidades tradicionais o direito de se oporem à divulgação não-autorizada de suas ECTs e, na hipótese de serem divulgadas sem autorização, o direito de impedirem qualquer uso subseqüente por terceiros e a aquisição e o exercício de DPIs sobre elas. ${ }^{1441}$ Como o conteúdo dos direitos conferidos em relação às ECTs secretas é delineado com o objetivo de impedir sua disseminação pela sociedade, o projeto não reconhece às comunidades

\footnotetext{
${ }^{1438}$ Cf. HEIDE, 1996, p. 245-246.

${ }^{1439}$ Cf. WIPO, WIPO/GRTKF/IC/13/4(b) Rev, para. 100.

${ }^{1440} \mathrm{O}$ direito de adaptação vai ao encontro as reivindicações de alguns povos indígenas de obterem maior poder de controle sobre as aplicações de suas ECTs. O site da National Indigenous Arts Advocacy Association (NIAAA), uma organização da Austrália dedicada à proteção dos direitos dos povos aborígenes deste país em relação às suas ECTs, ecoa críticas ao uso de estilos e expressões artísticas indígenas, amplamente divulgadas por artísticas não indígenas, pois tais atos seriam contrários ao direito de autodeterminação dos indígenas. A NIAA defende que apenas as populações indígenas estariam autorizadas a utilizar estilos e padrões artísticos aborígenes. Cf. texto no site $<$ http://www.culture.com.au/exhibition/niaaa/about.htm>. Acesso em: 25 set. 2008.

1441 Cf. WIPO, Disposiciones revisadas para la protección de las expresiones culturales tradicionales/expresiones del folclore: objetivos políticos y principios fundamentales, art. 3(c).
} 
direitos morais, já que a divulgação pública das ECTs é um pressuposto para o exercício destes direitos.

Contraditoriamente, ao mesmo tempo em que o projeto aparentemente confere um direito de propriedade amplo às comunidades tradicionais, esvazia-o, ao determinar que o direito de exclusão conferido às comunidades sobre suas ECTs secretas não se estende sobre obras derivadas. Assim, na hipótese de uma ECT secreta for disseminada publicamente, sem a autorização da comunidade pertinente, terceiros não poderão reproduzi-la sem autorização, mas poderão criar obras nela inspiradas. ${ }^{1442}$

Sem embargo, o projeto oferece um mecanismo de correção deste equívoco: haja vista que as comunidades tradicionais gozam da liberdade para determinar quais ECTs são ou não singulares, se inicialmente optarem por conservar secretas aquelas ECTs inacessíveis publicamente, sempre poderão alterar o regime de proteção aplicável mediante seu registro a fim de obterem direitos mais amplos de controle. Assim sendo, se uma ECT secreta for divulgada publicamente a despeito da vontade das comunidades titulares, estas poderão registrá-la para obterem a proteção legal oferecida às ECTs singulares.

\section{§5 LIMITAÇÕES AOS DIREITOS CONFERIDOS}

O projeto da OMPI excepciona da obrigação de obter o CPLI das comunidades detentoras de ECTs singulares ou secretas, os atos de compartilhamento intra- e intercomunitário conduzidos por seus membros, desde que realizados em consonância com as normas consuetudinárias das comunidades pertinentes.

Igualmente estão fora do alcance dos direitos de exclusivo das comunidades tradicionais o uso de ECTs protegidas por terceiros não-associados às comunidades titulares, em contextos não tradicionais, praticados com o propósito de (a) "ilustração para ensino e aprendizagem; (b) pesquisa não-comercial ou estudo privado; (c) crítica ou exame; (d) transmissão de notícias ou acontecimentos da atualidade; (e) utilização em procedimentos judiciais; (f) registros e outras reproduções de ECTs para sua inclusão em

1442 Cf. WIPO, Disposiciones revisadas para la protección de las expresiones culturales tradicionales/expresiones del folclore: objetivos políticos y principios fundamentales, p. 26. 
um arquivo ou inventário, com fins não-comerciais de salvaguarda do patrimônio cultural; e (g) utilização incidental."

A liberdade conferida pelo projeto da OMPI apenas pode ser exercida, se o uso proposto por terceiros não tiver fins comerciais, não ofender a comunidade titular de direitos e, sempre que possível, o uso reconhecer publicamente a comunidade-fonte da ECT utilizada. ${ }^{1443}$

\section{§6 DURAÇÃo dos DireITos}

A proteção perdura enquanto as ECTs se conservarem como um elemento característico da identidade cultural e social da comunidade titular e continuarem a ser conservadas, utilizadas ou desenvolvidas, ao menos, por alguns dos integrantes do grupo. Além destas condições, as ECTs singulares deverão permanecer registradas e as ECTs secretas deverão se conservar publicamente inacessíveis. ${ }^{1444}$

\section{§7 ORGANIZAÇÃO DE APOIO ÀS COMUNIDADES TRADICIONAIS PARA ASSEGURAR A OBSERVÂNCIA DOS DIREITOS}

O projeto da OMPI determina a criação de uma agência competente para assessorar as comunidades tradicionais em temas relacionados à gestão e proteção das ECTs, bem como para atuar como sua procuradora legal. ${ }^{1445}$ Esta agência seria uma espécie de OGD. $\mathrm{Na}$ qualidade de representante legal das comunidades, a agência teria a competência para receber solicitações de acesso e uso de ECTs, negociar acordos de licenciamento, receber royalties e repassá-los às comunidades.

É importante esclarecer que a agência apenas atuaria a pedido das comunidades tradicionais e de acordo com seus desígnios. Naturalmente, uma vez que agência não atua autonomamente, as comunidades tradicionais teriam a liberdade de optar por exercer diretamente seus direitos ou de retirar, a qualquer momento, a procuração conferida.

1443 Cf. WIPO, Disposiciones revisadas para la protección de las expresiones culturales tradicionales/expresiones del folclore: objetivos políticos y principios fundamentales, art. 5 (ii) e (iii).

${ }^{1444}$ Ibid., art. 60.

1445 Ibid., art. 4 o. 


\section{§8 VINCULAÇÃO DOS BENEFÍCIOS RECEBIDOS AO INVESTIMENTO NA MELHORIA DA QUALIDADE DE VIDA DAS COMUNIDADES E NA CONSERVAÇÃO DA NATUREZA}

O projeto de disposições da OMPI determina que a proteção conferida às ECTs deve "redundar em benefício dos povos indígenas, das comunidades tradicionais e demais comunidades culturais", o que parece vincular os benefícios a serem pagos, a título de repartição de benefícios, às comunidades tradicionais que as desenvolvem e conservam em contextos tradicionais. ${ }^{1446}$

\subsubsection{ELEMENTOS E PROBLEMAS COMUNS DAS PROPOSTAS}

As propostas de regimes internacionais para a proteção de ECTs, CTs, associados ou não à biodiversidade, e recursos da biodiversidade, em discussão/construção no âmbito da CCDB e OMPI, compartilham as seguintes características:

i. Obrigatoriedade de obtenção do CPLI das comunidades tradicionais ou Estados pertinentes, previamente ao acesso e uso de ECTs, CTs e recursos biológicos;

ii. Reivindicações de direitos de largo alcance, ou seja, os projetos geralmente conferem aos Estados e comunidades tradicionais direitos sobre produções literárias, artísticas e científicas derivadas de RBIs; ${ }^{1447}$

iii. A obtenção e o exercício de direitos independem do cumprimento de formalidades por parte das comunidades tradicionais e Estados, e.g. registro prévio dos RBIs protegidos. A única exceção recai sobre as ECTs singulares; os demais RBIs são protegidos desde o momento de sua criação; e

iv. Os direitos de exclusivo conferidos sofrem limitações mínimas. A principal limitação é aquela que resguarda a prerrogativa dos integrantes das comunidades

\footnotetext{
${ }^{1446} \mathrm{Cf}$. Disposiciones revisadas para la protección de las expresiones culturales tradicionales/expresiones del folclore: objetivos políticos y principios fundamentales, art. $2^{\circ}$.

1447 Essa observação não é aplicável às ECTs secretas.
} 
tradicionais de continuarem a compartilhar seus RBIs nas esferas intra e intercomunitária.

As referidas propostas compartilham também problemas, ignorados pelos negociadores e pela literatura especializada, a serem abordados a seguir.

\subsubsection{PROBLEMA I: A FRAGMENTAÇÃO DA TITUlARIDADE E A TRAGÉDiA dOS ANTICOMUNS}

\subsection{TITULARIDADE COMPARTILHADA ENTRE COMUNIDADES OU ESTADOS}

Conforme visto no capítulo 2, uma das críticas mais comuns ao regime de proteção da PI é a investidura de direitos em indivíduos, enquanto os RBIs são, freqüentemente, desenvolvidos e conservados por entes coletivos (comunidades tradicionais). As propostas de regimes, em construção na CCDB e OMPI, procuram superar a inadequação dos regimes convencionais de PI mediante a investidura de direitos de exclusivo nas comunidades tradicionais e nos Estados. Em outras palavras, os regimes propostos se centram na figura de comunidades tradicionais e Estados, na qualidade de titulares de direitos, em substituição à figura do autor individual. ${ }^{1448}$ Esta alteração, no entanto, seria suficiente para viabilizar a proteção dos RBIs por meio de um direito de propriedade?

De fato, existem RBIs que pertencem exclusivamente à uma comunidade tradicional (CTs e ECTs), ${ }^{1449}$ ou a um único Estado (recursos biológicos endêmicos). No entanto, as negociações em curso negligenciam que um mesmo RBI pode ser compartilhado (e geralmente o é) por duas ou mais comunidades tradicionais ou Estados, ${ }^{1450}$ podendo se disseminar por regiões vastas e múltiplos países, ${ }^{1451}$ o que certamente cria grandes embaraços para a identificação de todas as comunidades ou Estados que o compartilham. ${ }^{1452}$

\footnotetext{
${ }^{1448}$ Cf. GERVAIS, 2003, p. 483-489; TORSEN, 2005, p. 308.

${ }^{1449}$ Cf. GUPTA, 2004, p. 31.

${ }^{1450}$ Ver, e.g., KAUSHIK, 2004, p. 86; KOOPMAN, 2005, p. 535.

${ }^{1451}$ Cf. SANTILI, 2005, p. 223.

${ }^{1452}$ Cf. DESCOLA, 1998, p. 182-183.
} 
Comunidades locais que vivem em contextos naturais e culturais similares tendem a compartilhar os mesmos RBIs, ${ }^{1453}$ seja por conta de suas tradições de livre intercâmbio de informações, conhecimentos e recursos, ${ }^{1454}$ seja em virtude de descenderem de um tronco étnico comum, ${ }^{1455}$ seja porque os desenvolveram de modo independente, mas em paralelo. $^{1456}$

Inúmeras comunidades tradicionais, despidas de recursos para cuidarem da saúde e alimentação de seus membros, vivendo em regiões inóspitas, são compelidas a agirem como cientistas em busca da satisfação de suas necessidades diárias, sendo as florestas e os ecossistemas naturais seus laboratórios. Um grande número de "cientistas da terra", atuando em contextos similares em busca de soluções para desafios parecidos acabam por realizar descobrimentos múltiplos, tal como ocorre na ciência ocidental. ${ }^{1457}$ Tendo em vista esta realidade, é difícil a identificação, com alguma segurança, de todas as comunidades que compartilham um mesmo RBI. ${ }^{1458}$

Da mesma maneira que os CTs e as ECTs raramente são exclusivos de uma comunidade, os recursos biológicos freqüentemente se espalham por regiões que não respeitam as fronteiras políticas dos Estados nacionais, os quais são empregados por um número substancial de comunidades tradicionais. ${ }^{1459}$ Para dificultar ainda mais a identificação dos titulares de um determinado recurso biológico, não se deve ignorar que no período pré-CDB, o livre fluxo de recursos biológicos era lícito, o que levou à ampla disseminação internacional de recursos de todas as origens.

Recursos da agrobiodiversidade especificamente são desenvolvidos por meio da colaboração - ainda que inconsciente - de um grande número de comunidades agrícolas, que se empenham em intercambiar entre si suas variedades vegetais, visando a ampliar a

${ }^{1453}$ Cf. itens 1.3.1, 1.3.3, 1.3.3.1, 1.4.1.

${ }^{1454}$ Ver, e.g., COOMBE, 1998-1999, p. 82; SHIVA, 2001, p. 35; WIPO, WIPO/GRTKF/IC/12/4(C)), anexo, p. 10.

${ }_{1455}$ Cf. RODRIGUES, 2001, p. 82.

${ }^{1456}$ Cf. LÉVI-STRAUSS, 2006, p. 29-30.

${ }^{1457}$ Merton (1977 a, p. 454, 460, 469) sustenta que, na ciência, a regra são os descobrimentos múltiplos, e a exceção os descobrimentos únicos. Merton, com base em uma ampla revisão bibliográfica e histórica do desenvolvimento da ciência durante o século XIX e o início do século XX, assinala que a partir do momento em que a ciência se institucionalizou e um número cada vez maior de pessoas passou a se dedicar a atividades científicas, as chances de que um mesmo descobrimento ocorra, de maneira independente, mais de uma vez, são cada vez maiores, sobretudo quando sua necessidade é destacada pelas demandas sociais.

${ }^{1458}$ Cf. PACÓN, 2004, p. 175.

${ }^{1459}$ Cf. RAFI; INDIGENOUS PEOPLE'S BIODIVERSITY NETWORK, 1994, p. 6. 
diversidade biológica das sementes que cultivam e, por conseguinte, sua capacidade de adaptação a novos contextos naturais. ${ }^{1460} \mathrm{O}$ intercâmbio de variedades vegetais torna nãorazoável qualquer reivindicação de direito de exclusivo sobre elas, porquanto é impossível a identificação das comunidades envolvidas em seu desenvolvimento.

Segundo o nosso conhecimento, o Marco Regional do Pacífico para a Proteção dos Conhecimentos Tradicionais e Expressões Culturais (Lei Modelo do Pacífico), ${ }^{1461}$ redigido pela Secretaria da Comunidade do Pacífico em colaboração com a UNESCO, ${ }^{1462}$ é possivelmente o único projeto legislativo a enfrentar a questão das ECTs e CTs compartilhados por duas ou mais comunidades tradicionais.

Nos termos da Lei Modelo do Pacífico, sempre que um indivíduo desejar acessar determinado CT ou ECT de titularidade de uma comunidade tradicional, baseada em um dos Estados membros da Comunidade do Pacífico, deveria apresentar uma solicitação de acesso e uso perante a autoridade local competente. Uma vez recebido o pedido, a autoridade publicá-lo-ia na imprensa, oferecendo o prazo de 28 dias a possíveis comunidades tradicionais que compartilham o RBI objeto do pedido, para se identificarem como cotitulares de direitos. A autoridade, se acreditar que identificou todas as comunidades cotitulares do RBI pertinente, divulgará nota, em que indicará a identidade das comunidades tradicionais. ${ }^{1463} \mathrm{Na}$ hipótese da autoridade não ter identificado qualquer titular do RBI, ou se suspeitar que não identificou todos os possíveis cotitulares, ou se surgirem conflitos intercomunitários a respeito da titularidade do RBI, nas duas últimas hipóteses, a autoridade permitirá que as comunidades envolvidas resolvam autonomamente estes impasses. ${ }^{1464}$ Quando as comunidades chegarem a um consenso, a autoridade publicará uma nota sobre a solução alcançada. ${ }^{1465} \mathrm{Na}$ hipótese das comunidades não chegarem a um denominador comum ou se nenhum titular do RBI tiver sido identificado, a autoridade estatal poderá assumir o papel de titular de direitos sobre o RBI. ${ }^{1466}$

\footnotetext{
${ }^{1460}$ Cf. item 1.3.3.1.

${ }^{1461}$ Cf. SECRETARIAT OF THE PACIFIC COMMUNITY, 2002.

1462 A Lei Modelo do Pacífico foi preparada como referência legislativa para os 26 países que integram a Comunidade do Pacífico (22 ilhas do Pacífico mais Austrália, Nova Zelândia, França e EUA).

${ }^{1463}$ Cf. artigos 16-17, SECRETARIAT OF THE PACIFIC COMMUNITY, 2002.

${ }^{1464} \mathrm{Cf}$. art. 18, SECRETARIAT OF THE PACIFIC COMMUNITY, 2002.

${ }^{1465}$ Cf. art. 18(3), SECRETARIAT OF THE PACIFIC COMMUNITY, 2002.

${ }^{1466}$ Cf. art. 19, SECRETARIAT OF THE PACIFIC COMMUNITY, 2002.
} 
Se, por um lado, esta solução beneficiaria aos potenciais cotitulares de um mesmo RBI e ainda lhes permitiria exercitar sua autonomia decisória, pelo outro, as comunidades poderiam não chegar a um consenso, e a autoridade estatal, dependendo da pressão recebida, poderia chancelar a decisão (ou a falta de consenso) das comunidades sobre o tema, bloqueando o uso dos RBIs.

Ademais, com a divulgação de informações sobre os RBIs protegidos, através dos meios de comunicação, aqueles recursos, cujo valor comercial depende de sua inacessibilidade pública, perderiam relevância comercial, já que as instituições, baseadas fora do território onde se dá o litígio, poderiam utilizá-los gratuitamente. Assim, os interessados em utilizar, digamos, um CT até então secreto, poderiam se desinteressar em dar continuidade à negociação.

A solução proposta pela Lei Modelo do Pacífico é igualmente inadequada para a identificação de cotitulares de um mesmo RBI, domiciliados em países diversos: seria implausível economicamente aplicá-la em múltiplas jurisdições para a identificação dos cotitulares de um mesmo RBI. Não haveria segurança se as jurisdições onde foram publicados os comunicados são efetivamente aquelas, onde se encontram os possíveis cotitulares de um RBI.

Em face dessa realidade, as negociações em curso podem optar por desrespeitar essas peculiaridades do PBI e privilegiar impropriamente uma determinada comunidade tradicional ou Estado, conferindo-lhes o status de titular único de um determinado RBI, compartilhado por duas ou mais comunidades tradicionais ou Estados. ${ }^{1467}$

A sociedade ocidental, reconhecendo tacitamente que um mesmo conhecimento pode ser desenvolvimento, de maneira independente, por dois ou mais criadores, estrutura o sistema de proteção da PI de maneira a beneficiar aquele indivíduo ou instituição, que tornar público, em primeiro lugar, o novo conhecimento, por meio do depósito, por exemplo, de um pedido de patente. ${ }^{1468} \mathrm{O}$ sistema é assim estruturado para evitar as dificuldades que surgiriam, se todos os autores de uma mesma produção intelectual tivessem de ser reconhecidos como cotitulares de direitos. A solução trazida pelos regimes

${ }^{1467}$ Cf. MACHLUP; PENROSE, 1950, p. 18.

1468 Cf. MERTON, 1977a, p. 466. 
de PI é prática, mas socialmente iníqua. A aplicação dessa política para a proteção dos RBIs teria como efeito colateral a emergência de conflitos entre, de um lado, a comunidade e o Estado privilegiado e, do outro, as comunidades e os Estados excluídos. Em busca de benefícios materiais e/ou morais, as partes não contempladas não aceitarão passivamente deixar de ser reconhecidos como cotitulares de recursos que integram sua identidade cultural ou patrimônio natural. ${ }^{1469}$

Outra opção seria conferir a cada Estado e comunidade um direito de propriedade autônomo sobre seus RBIs compartilhados, que poderia ser exercido sem a necessidade de obtenção do CPLI de todos os codetentores de um mesmo RBI. ${ }^{1470}$ Essa opção traz segurança jurídica aos usuários de RBIs e maior autonomia às comunidades tradicionais $\mathrm{e}$ Estados, mas terá como efeito colateral a instauração de uma competição entre as comunidades e Estados que compartilham um mesmo RBI. ${ }^{1471} \mathrm{O}$ resultado da concorrência seria o achatamento dos benefícios a serem pagos às comunidades e aos Estados, o que minimizaria as oportunidades de geração de recursos em favor da melhoria da qualidade de vida das comunidades tradicionais e da conservação da biodiversidade. Naturalmente, as comunidades e Estados poderiam se unir com os demais codetentores de seus RBIs para fixarem um valor mais atraente pelo uso de seus RBIs. Mas como a participação neste esquema seria opcional, esse caminho dificilmente seria viável.

Uma terceira opção seria conferir, em caso de RBIs compartilhados por duas ou mais comunidades ou Estados, um direito de propriedade àquela parte que efetivamente prover o RBI e um direito de remuneração às demais partes que compartilham o recurso. Nesse sentido, no Brasil, o Conselho de Gestão do Patrimônio Genético (CGEN) promoveu uma enquete junto a organizações da sociedade civil, comunidades tradicionais, agências governamentais, academia e empresas, que investigou, inter alia, como poderiam ser repartidos os benefícios resultantes da exploração comercial de um CTA compartilhado por duas ou mais comunidades. Uma agência governamental sugeriu que o usuário do CTA compartilhado pagasse $60 \%$ dos benefícios negociados à comunidade tradicional que de fato proveu o CTA, e repartisse o valor restante com as demais codetentoras. ${ }^{1472}$ Essa

\footnotetext{
1469 Ver, e.g., PACÓN, 2004, p. 176; YUPARI et al., 2004, p. 333.

${ }^{1470}$ Ver, e.g., WIPO, WIPO/GRTKF/IC/13/4(b) Rev, para. 39; COTTIER; PANIZZON, 2006, p. 220-222.

1471 Ver, e.g., VOGEL, 2000b, p. 48; MOONEY, 2000, p. 37-38; WIPO, WIPO/GRTKF/IC/9/INF/4, anexo 1, para. 17.

${ }^{1472}$ Cf. MEDEIROS et al. 2008, p. 14
} 
alternativa de solução ofereceria um tratamento assimétrico a partes que compartilham uma mesma situação: a comunidade ou Estado provedor de RBI gozaria do direito de condicionar o acesso ao RBI e de negociar as condições para o acesso, enquanto os demais cotitulares apenas poderiam receber um benefício menor que aquele pago ao provedor do recurso. O provedor teria a discricionariedade de usar de seu poder de uma forma positiva (i.e. negociando um bom acordo comercial para todos os cotitulares) ou não, ao concordar em licenciar o RBI compartilhado em condições prejudiciais a todos.

Uma quarta alternativa seria reconhecer a todas as comunidades e Estados, que compartilham um mesmo RBI, o status de cotitular do direito de propriedade, ${ }^{1473}$ i.e. as partes que compartilham um mesmo RBI apenas poderiam autorizar seu uso por terceiros, se assim decidissem conjuntamente. Essa parece ser a opção preferida pelos Estados envolvidos nas negociações na $\mathrm{CCDB}$ e OMPI, das comunidades tradicionais e organizações da sociedade civil, pois colocaria todas as comunidades e Estados em pé de igualdade. Ademais, tal alternativa seria economicamente mais atraente, ao prevenir a emergência de concorrência entre codetentores de RBIs e o reflexo achatamento dos benefícios materiais que lhes caberiam. Contudo, potenciais usuários apenas poderiam utilizar um RBI compartilhado após identificarem todos os cotitulares e obterem uma autorização unânime de todos eles. Esse tipo de esquema, embora pareça equânime, pode dar azo a um efeito conhecido na teoria de direito de propriedade como tragédia dos anticomuns (tragedy of the anticommons), tema este que será tratado mais adiante.

\subsection{RBIS COMPARTILHADOS POR GRANDES CONTINGENTES HUMANOS}

Se não fosse suficientemente desafiador lidar com o fato de múltiplas comunidades ou Estados poderem compartilhar um mesmo RBI, as propostas em negociação fixam como condição de proteção que os RBIs sejam criados, desenvolvidos e conservados por comunidades tradicionais. A imagem tácita que as propostas alimentam é que os titulares de CTs e ECTs são minorias étnicas e lingüísticas que vivem em organismos sociais, cujos limites são facilmente identificáveis. ${ }^{1474}$

${ }^{1473}$ Cf. WIPO, WIPO/GRTKF/IC/13/4(b) Rev, para. 39.

${ }^{1474} \mathrm{Cf}$. art. 8(J), CDB; art. $4^{\circ}$, WIPO, Revised provisions for the protection of traditional knowledge; art. $2^{\circ}$, WIPO, Disposiciones revisadas para la protección de las expresiones culturales tradicionales/expresiones del folclore: objetivos políticos y principios fundamentales. 
Este, no entanto, não é sempre o caso. A titularidade de CTs e ECTs pode caber a minorias étnicas e lingüísticas, organizadas em entidades sociais fluídas e dinâmicas, ${ }^{1475}$ que se identificam com nossa visão mítica de um pequeno núcleo social estável, cujos membros comungam naturalmente dos mesmos interesses e perseguem objetivos comuns, de maneira conjunta. ${ }^{1476}$ Contudo, a titularidade também pode caber a grandes contingentes humanos, que indiscutivelmente não se organizam em pequenos organismos sociais.

Darcy Ribeiro propõe uma classificação dos povos extraeuropeus, que nos auxilia a compreender que os RBIs podem ser compartilhados por grandes contingentes humanos, que claramente não se confundem com comunidades tradicionais. Os quatro tipos étniconacionais, que integram a classificação de Ribeiro seguem:

(i) Povos-testemunho: Estes povos são representados pelos "sobreviventes de altas civilizações autônomas que sofreram o impacto da expansão européia. São resultantes modernos da ação traumatizadora daquela expansão e dos seus esforços de reconstituição étnica como sociedades nacionais modernas. Reintegradas em sua independência, não voltaram a ser o que eram, porque se haviam transfigurado profundamente, não só pela conjunção das suas tradições com as européias, mas pelo esforço de adaptação às condições que tiveram de enfrentar como integrantes subalternos de sistemas econômicos de âmbito mundial e também pelos impactos diretos e reflexos que sofreram da Revolução Mercantil e Industrial". ${ }^{1477}$

Apesar da influência européia sobre o arcabouço cultural dos povos-testemunho, estes lograram conservar "línguas, costumes, formas de organização social, corpos de crenças e de valores profundamente arraigados em vastas camadas da população, além de um patrimônio de saber vulgar e de estilos artísticos peculiares", ${ }^{1478}$ que já existiam "naquelas células iniciais e ainda hoje sobreviventes no seu modo de ser de povos modernos". ${ }^{1479}$ Como exemplo de povos-testemunho, Ribeiro aponta os povos da China, Coréia, Índia, Japão, países islâmicos, México, Guatemala e países andinos. ${ }^{1480}$

\footnotetext{
${ }^{1475}$ Cf. ANDERSON, 2004, p. 600.

${ }^{1476}$ Informações prestadas por Helena Sampaio, Diretora da ONG ARTESOL, em entrevista realizada em 11 de setembro de 2007.

${ }^{1477}$ Cf. RIBEIRO, 2007, p. 79.

1478 Ibid., p. 80, grifo nosso.

1479 Ibid., p. 99.

${ }^{1480}$ Ibid., p. 80.
} 
Com exceção de China e Japão, como resultado do rápido crescimento econômico e tecnológico sofrido na segunda metade do século XX, os demais povos-testemunho se apresentam bipartidos "em um estamento dominante mais europeizado [...] oposto a amplas massas marginalizadas — sobretudo camponesas — por seu apego a modos de vida arcaicos e resistentes à modernização". ${ }^{1481}$ Os grandes contingentes de camponeses são os principais mantenedores e desenvolvedores do PBI desses povos.

(ii) Povos novos: resultam da "conjunção e da deculturação e caldeamento de matrizes étnicas africanas, européias e indígenas. São aqui designados como povos novos em atenção à sua característica fundamental de species novae, enquanto entidade étnica distinta de suas matrizes formadoras e porque representam antecipações do que virão a ser, provavelmente, os grupos humanos de um futuro remoto, cada vez mais mestiçados e aculturados e, desse modo, uniformizados racial e culturalmente."1482

Em virtude do amplo processo de fusão das matrizes culturais e étnicas africana, ameríndia e européia, os povos novos compartilham um PBI, originalmente desenvolvido e conservado em especial pelos povos indígenas, mas que pouco a pouco se transferiu destes grupos para a sociedade dominante, passando a permear o arcabouço cultural de um povo, e não apenas de alguma determinada etnia indígena. $\mathrm{O}$ principal representante de povo novo identificado por Ribeiro é o Brasil.

(iii) Povos transplantados: correspondem "às nações modernas criadas pela migração de populações européias para novos espaços mundiais, onde procuraram reconstituir formas de vida essencialmente idênticas às de origem. Cada um deles se estruturou segundo modelos de vida econômica e social da nação de que provinha, levando adiante, nas terras adotivas, processos de renovação que já operavam nos velhos contextos europeus."1483

Em termos étnico-culturais, as características fundamentais dos povos transplantados é a "homogeneidade cultural que mantiveram desde o início, pela origem

\footnotetext{
${ }^{1481}$ Cf. RIBEIRO, 2007, p. 80.

1482 Ibid., p. 82.

1483 Ibid., p. 84.
} 
comum de sua população, ou que plasmaram pela assimilação dos novos contingentes"1484 e "sua 'modernidade' enquanto sincronização com os modos de vida e as aspirações das sociedades capitalistas pré-industriais de que foram desgarrados". ${ }^{1485}$ Ribeiro menciona como exemplos de povos transplantados a Argentina, Austrália, Canadá, EUA e Nova Zelândia.

(iv) Povos emergentes: são aqueles que emergiram da condição tribal à de nação. As nações africanas e, em certa medida, as asiáticas representam os povos emergentes da atualidade. $^{1486}$

Os povos indígenas das Américas, apesar de sua expressividade numérica inicial, devido à brutalidade do processo colonizador que tomou lugar na região, não conseguiram emergir da condição tribal à vida nacional. Mas existe a possibilidade de que alguns contingentes ameríndios, devido às suas dimensões populacionais, ascendam à vida nacional, e.g., os milhões de índios das etnias Quéchua e Aymara, originários dos Andes e os Mapuche, do Chile. ${ }^{1487}$

No seio desses quatro tipos étnico-nacionais ainda é possível a identificação de minorias étnicas e lingüísticas, que se organizam em comunidades, cujas fronteiras física e humana são visíveis, ao não se confundirem com a sociedade dominante. Mas, fundamentalmente, nos Estados formados por povos novos, testemunho e emergentes é possível a identificação de CTs e ECTs compartilhados não simplesmente por duas ou mais comunidades tradicionais, mas sim por parcelas substanciais de suas populações, que não necessariamente se organizam em pequenas comunidades, nem limitam sua presença ao território de um único Estado. Isto porque o patrimônio cultural dos grupos que deram origem a esses tipos étnico-nacionais se disseminou amplamente, passando a integrar o patrimônio cultural desses povos, e não mais de grupos reduzidos, em termos numéricos. Tais RBIs podem ser denominados CTs e ECTs populares.

\footnotetext{
1484 Ibid., p. 85.

1485 Ibid., p. 85.

${ }^{1486}$ Cf. RIBEIRO, 2007, p. 86.

${ }^{1487}$ Ibid., p. 87.
} 
Esse é o caso nos países africanos, asiáticos e alguns países sul-americanos. ${ }^{1488}$ Nesses países, é de se presumir que uma parcela expressiva de seus RBIs seja amplamente compartilhada pela população local. Na Bolívia, por exemplo, 55\% de sua população é ameríndia. Apenas os indígenas da etnia Quéchua correspondem a mais de 16\% de uma população total, que gira em torno de 10 milhões de habitantes. ${ }^{1489} \mathrm{O}$ Peru, país vizinho da Bolívia, igualmente é casa de parcelas significativas de indígenas da etnia Quéchua. ${ }^{1490} \mathrm{Se}$ uma corporação desejasse utilizar os CTs médicos dos índios Quéchua, precisaria negociar um acordo com mais de 1.6 milhões de bolivianos, bem como com os membros desta etnia, domiciliados no Peru? Expandir a figura das comunidades tradicionais para abarcar grandes contingentes populacionais pode simplesmente inviabilizar qualquer uso produtivo dos RBIs, ao invés de tornar o sistema mais justo e favorável às minorias étnicas e lingüísticas.

Outro exemplo, baseado na realidade do Sri Lanka, ilustra as dificuldades de se operar um regime de proteção para RBIs que condicione seu acesso e uso à obtenção do CPLI dos detentores. O sistema público de saúde do Sri Lanka utiliza amplamente os CTs originados no sistema médico Ayurveda, da Índia. Conhecimentos originalmente indianos foram disseminados e absorvidos pelo povo do Sri Lanka e adaptados à realidade botânica local, sem que com isso fossem alteradas suas raízes indianas. ${ }^{1491}$ Imaginemos a hipótese de uma companhia se interessar em pesquisar e desenvolver uma nova droga derivada de um dado CT medicinal cingalês, cuja origem remonta à medicina Ayurveda. Nesse caso, qual grupo teria a autoridade para conceder o CPLI à companhia? O povo indiano ou cingalês? Alguma comunidade indiana ou cingalesa? O quão praticável será um regime legal que condiciona o acesso e uso de um RBI à obtenção do CPLI de um povo?

Graças à uma interpretação ampliativa sobre quais indivíduos e autoridades seriam competentes para autorizar o acesso e uso de determinados RBIs, não foi finalizada a negociação de um acordo entre, de um lado, o International Cooperative Biodiversity Groups (ICBG), a Universidade da Geórgia, El Colégio de la Frontera Sur e a empresa britânica Molecular Nature e, do outro, comunidades maias, baseadas em Chiapas, México.

\footnotetext{
${ }^{1488}$ Cf. KURUK, 1998-1999, p. 840.

1489 Informações extraídas da enciclopédia eletrônica Wikipedia (http://es.wikipedia.org/wiki/Bolivia). Acesso em: 07 fev. 2009.

1490 No Peru, 3,2 milhões de indivíduos falam a língua Quéchua (http://en.wikipedia.org/wiki/Quechua). Acesso em: 07 fev. 2009.

${ }^{1491}$ Cf. KUMAR, 2004, p. 299.
} 
Após três anos de trabalhos intensos e a obtenção pelas partes interessadas do CPLI de 47 comunidades mexicanas, uma campanha internacional, promovida por organizações da sociedade civil, conseguiu embargar as negociações. Essas organizações basicamente defenderam que o termo de CPLI obtido pelo ICBG e seus parceiros apenas seria válido, se estas instituições obtivessem o consentimento de cada um dos dois milhões de indígenas maias, que vivem no México e na Guatemala. ${ }^{1492}$

Com o processo acelerado de urbanização dos países em desenvolvimento, a tendência de disseminação cada vez mais ampla do PBI ganha fôlego. ${ }^{1493}$ Em 2007, a população urbana do globo excedeu, pela primeira vez na história, a população rural, ou seja, atualmente mais de 3 bilhões de pessoas vivem em cidades. A ONU estima que 95\% do crescimento urbano, que ocorrerá no planeta nas próximas duas décadas, se dará nas cidades do mundo em desenvolvimento, mediante o processo de favelização. ${ }^{1494}$ Esse inchamento urbano dos países periféricos tem com uma de suas origens o desaparecimento, paulatino, das chamadas comunidades tradicionais, que, em busca de autosustentabilidade ou simplesmente dos meios para uma sobrevivência digna, optam por deixar sua "casa natural", herdada de seus antepassados.

Em suma, a fim de evitar a negociação de acordos internacionais distanciados da realidade que pretendem disciplinar, urge que os negociadores atentem para o fato de que RBIs, segundo sua titularidade, podem ser detidos: ${ }^{1495}$

i. No que tange aos recursos biológicos, por dois ou mais Estados;

ii. No que tange aos CTs e ECTs, por uma ou mais comunidades tradicionais, que podem viver em um mesmo país ou em dois ou mais países distintos; e

iii. Ainda no que tange aos CTs e ECTs, por um grande contingente humano, i.e. uma etnia, um povo, que se espalha pelo território de um único Estado ou de dois ou mais Estados (CTs e ECTs populares).

\footnotetext{
${ }^{1492}$ Cf. ROSENTHAL, 2006, p. 124.

${ }^{1493}$ Cf. DUTFIELD, 2003, p. 22.

${ }^{1494}$ Cf. UN-HABITAT, 2006.

${ }^{1495}$ Ver, e.g., COOMBE, 1998-1999, p. 109; WIPO, WIPO/GRTKF/IC/12/5(b), anexo, p. 32; WIPO, WIPO/GRTKF/IC/12/7, para. 17; WIPO, WIPO/GRTKF/IC/9/INF/4, anexo I, para. 49; BIBER-KLEMM, 2004, p.96; GUPTA, 2004, p. 11; HUFT, 1994-1995, p. 1701-1705.
} 
Ignorar a questão da titularidade dos RBIs pode levar ou à exclusão do escopo dos futuros marcos legais internacionais de um volume impressionante de RBIs, ou à sua total ineficácia, caso os regimes condicionem o acesso aos RBIs compartilhados por grandes contingentes humanos à obtenção do CPLI de todos os codetentores.

Para que os futuros regimes de proteção dos RBIs sejam funcionais, devem se assentar sobre a realidade que se propõem a disciplinar. Para isso, é recomendável que os RBIs compartilhados por grandes contingentes humanos sejam incluídos no escopo dos acordos em negociação, bem como que os Estados pertinentes sejam investidos na competência para exercer os direitos a eles relacionados. No entanto, os recursos recebidos a título de exploração comercial destes RBIs não lhes pertenceriam, mas lhes seriam transferidos sob a condição de revertê-los integralmente em projetos relacionados à proteção e promoção da diversidade biocultural. Em outras palavras, o Estado seria um mero depositário dos recursos.

É surpreendente que as negociações internacionais em curso não tenham enfrentado, até o momento, a questão dos RBIs compartilhados por duas ou mais comunidades ou Estados e os RBIs amplamente disseminados. ${ }^{1496}$ Surpreendente porque, em 1984, quando a OMPI e a UNESCO reuniram um grupo de expertos para debater a conveniência de se adotar um tratado internacional de proteção de ECTs, uma das razões, que levou os participantes a se oporem à adoção da proposta de tratado, foi a ausência de um mecanismo apto a proteger ECTs disseminadas em mais de um país. ${ }^{1497}$

\subsection{A TRAGÉDIA DOS ANTICOMUNS}

O direito de propriedade encerra três dimensões inter-relacionadas: os titulares de direitos; o domínio ou escopo dos direitos conferidos, e a configuração do objeto de proteção (dimensão espacial; natureza tangível ou intangível do bem). ${ }^{1498}$ No mundo ideal, o feixe de direitos associados ao bem protegido por um direito de propriedade é investido

${ }^{1496}$ O Grupo Africano é um dos poucos que reconhece o problema, mas em uma intervenção recente na OMPI, limitou-se a assinalar que "[o]wnership of transnational TK should be treated as a special category as it is not a norm[...]", sem enfrentar o problema (WIPO, WIPO/GRTKF/IC/13/9, anexo, p. 3).

${ }^{1497}$ Ver, e.g., FICSOR, 1998, p. 223; WIPO, WIPO/GRTKF/IC/3/10, para. 167.

${ }^{1498}$ Cf. BELL; PARCHOMOVSKY, 2007. 
em um único indivíduo ou instituição (notadamente, os direitos de uso e de exclusão) a fim de facilitar sua alocação aos fins mais produtivos. ${ }^{1499}$

Com o objetivo de conceder um tratamento equitativo a todas comunidades e Estados, que compartilham um mesmo RBI, ${ }^{1500}$ os regimes de propriedade, propostos no âmbito da CCDB, OMC e OMPI, tendem a fragmentar a titularidade dos direitos, mediante o compartilhamento entre duas ou mais partes (comunidades tradicionais ou Estados) do direito de propriedade sobre um mesmo RBI. ${ }^{1501}$ Isso significa que todos os coproprietários de um RBI gozariam de um direito de exclusão de terceiros não-autorizados, mas nenhum desfrutaria do direito de autorizar terceiros a utilizá-lo, sem o consentimento dos demais cotitulares. ${ }^{1502}$ A referida configuração do direito de propriedade é conhecida como anticomuns.

O termo anticomuns é uma tradução literal do termo inglês anticommons, cunhado por Michael Heller como uma contraposição ao termo commons, ${ }^{1503}$ que pode ser traduzido como "recurso comum", no sentido de um recurso disciplinado por um regime de propriedade comum, ${ }^{1504}$ o qual autoriza terceiros a explorá-lo ao seu bel prazer (todos gozam de um direito de uso), enquanto ninguém goza de um direito de exclusão de terceiros. Já no regime de propriedade anticomuns, um recurso por ele disciplinado apenas poderá ser explorado, quando obtida a autorização de todos os cotitulares do direito de exclusão, que sobre ele incide. Ou seja, dois ou mais indivíduos compartilham um direito de exclusão sobre um dado recurso, mas nenhum deles goza de um direito de uso; logo, o recurso apenas poderá ser utilizado por qualquer um deles ou por terceiros, quando todos os cotitulares do direito de exclusão anuírem. Em outras palavras, anticomuns é uma configuração atípica do direito de propriedade, marcada pela não-centralização dos direitos de uso e de exclusão nas mãos de uma mesma parte. ${ }^{1505}$

Em virtude da falta de coordenação entre os cotitulares de um direito de exclusão, cada um age autonomamente, tomando decisões individuais com o propósito de maximizar

\footnotetext{
${ }^{1499}$ Cf. MICHELMAN, 2004, p. 666.

${ }^{1500}$ Cf. SAFRIN, 2004, p. 652.

${ }^{1501}$ Ver, e.g., SCBD, UNEP/CBD/WG8J/5/6, para. 21.

${ }^{1502}$ Ver, e.g., MUNZER, 2005, p. 148; HELLER, 1998, p. 624.

${ }^{1503}$ Cf. HELLER, 1998.

${ }^{1504}$ Cf. item 3.2.1.1.1 supra.

${ }^{1505}$ Ver, e.g., PARISI; SCHULZ; DEPOORTER, 2001, p. 21; MICHELMAN, 2004, p. 666.
} 
seus próprios benefícios, sem tomar nota dos efeitos cumulativos das decisões individuais. Um cotitular pode ser a favor de autorizar um terceiro a utilizar seu recurso para fins produtivos contra o pagamento de uma determinada compensação, enquanto os demais cotitulares podem simplesmente se opor a qualquer uso do recurso, ou podem fixar condições irreais, que o potencial usuário será incapaz de cumprir.

O resultado da fragmentação da titularidade do direito de propriedade é o aumento vertiginoso dos custos de transação associados ao processo de obtenção das autorizações, indispensáveis para se utilizar o bem protegido por um regime de anticomuns. Tais custos, em termos globais, podem superar de longe os benefícios que o potencial usuário auferiria. ${ }^{1506} \mathrm{Na}$ prática, regimes de anticomuns são aptos a promover o uso apenas daqueles RBIs que tiverem o potencial de gerar produtos de grande apelo comercial, pois serão suficientemente atraentes para incentivar potenciais usuários a passar por um pesado e caro processo burocrático. ${ }^{1507}$ A conseqüência mais importante que deflui da fragmentação do direito de propriedade é a subutilização dos recursos protegidos (isso quando o uso não é totalmente bloqueado). Tal efeito é conhecido como tragédia dos anticomuns. $^{1508}$

Existe uma simetria entre a tragédia dos recursos comuns e a tragédia dos anticomuns ${ }^{1509}$ : na tragédia dos recursos comuns dois ou mais agentes são titulares do direito de usar um determinado recurso, e nenhum deles conta com um correspondente direito de exclusão. Como resultado disso, os titulares do direito de uso podem explorá-lo ilimitadamente, até sua total exaustão (tragédia dos recursos comuns). Já na tragédia dos anticomuns, dois ou mais agentes são titulares do direito de excluir terceiros nãoautorizados do uso de um determinado recurso, e nenhum deles goza do direito de usá-lo e/ou de autorizar terceiros a explorá-lo. Assim sendo, o recurso apenas poderá ser explorado, quando todos os titulares do direito de exclusão chegarem a um consenso neste sentido. Em virtude da fragmentação do direito de exclusão entre duas ou mais partes, o recurso sujeito a um regime de propriedade anticomuns pode vir a ser subutilizado ou nãoutilizado (tragédia dos anticomuns). ${ }^{1510}$

\footnotetext{
${ }^{1506}$ Ver, e.g., PARISI; SCHULZ; DEPOORTER, 2001, p. 5; SVEN et al., 2006, p. 6-7.

${ }^{1507}$ Cf. EISENBERG, 2001, p. 232.

${ }^{1508}$ Cf. EISENBERG; HELLER, 1998.

1509 Sobre a tragédia dos recursos comuns, cf. item 3.2.1.1.2 supra.

${ }^{1510}$ Cf. BUCHANAN; YOON, 2000, p. 4 .
} 
Para que emirja uma tragédia dos anticomuns não é necessário que para todo uso de um bem, seus cotitulares precisem obter a autorização dos demais. O recurso será subutilizado, mesmo quando os cotitulares estiverem autorizados a utilizá-lo para a satisfação de suas necessidades, na hipótese do exercício do direito de licenciá-lo depender da anuência de outros indivíduos. ${ }^{1511}$ Tampouco é necessário que todos cotitulares de direitos gozem do direito de exclusão. A tragédia dos anticomuns pode surgir desde que, ao menos, duas partes distintas gozem de um direito de exclusão, ${ }^{1512}$ que quando exercido por uma delas, inabilita a outra a utilizar o bem em consonância com seu desejo.

O regime de propriedade anticomuns pode ser dividido em duas categorias: anticomuns horizontal ou simultâneo e anticomuns vertical ou seqüencial. No regime de propriedade anticomuns horizontal ou simultâneo, duas ou mais partes são coproprietárias de um mesmo recurso, estando interligadas em uma mesma relação horizontal, ou seja, em

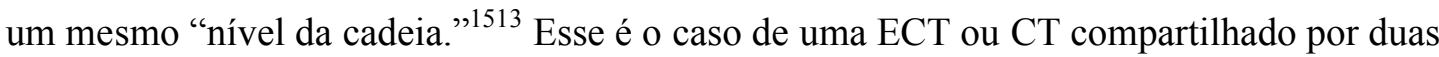
ou mais comunidades tradicionais. Terceiros apenas poderão utilizá-los, assim que obtiverem uma autorização unânime e simultânea de todos os cotitulares de direitos.

No regime de propriedade anticomuns vertical ou seqüencial, cada titular de um direito de exclusão pode exercitá-lo seqüencialmente, i.e. cada um ocupa um nível diferente na cadeia, não mantendo relações diretas. ${ }^{1514}$ Esse é o caso quando o uso de um RBI depender da obtenção de autorizações de partes diversas, que atuam em momentos diferentes, e.g. autorizações da comunidade tradicional detentora de uma ECT e de uma agência governamental, competente para atestar a sustentabilidade ambiental ou a conveniência do projeto proposto. A natureza do direito de exclusão conferido à agência governamental difere da natureza daquele conferido à comunidade tradicional, mas, ainda assim, configuram, de fato, um direito de exclusão do uso do RBI, que será exercido em momentos e com propósitos diferentes.

O regime de propriedade anticomuns seqüencial também está presente quando um agente depende, para a realização de algum projeto criativo ou de inovação, de insumos de

${ }^{1511}$ Cf. PARISI; SCHULZ; DEPOORTER, 2001, p. 11.

${ }^{1512}$ Cf. HELLER, 1998, p. 669.

${ }^{1513}$ PARISI; SCHULZ; DEPOORTER, op.cit., p. 13.

${ }^{1514}$ Ibid., p. 13 
duas ou mais fontes diferentes. Por exemplo, uma instituição de pesquisa disposta a desenvolver uma nova droga, a partir da associação entre o recurso biológico A e um determinado CT médico conexo a este recurso biológico, precisará da autorização tanto das comunidades quanto dos Estados pertinentes. As comunidades e os Estados não integram uma mesma relação horizontal, porquanto detêm direitos de propriedade sobre RBIs diversos. Se uma ou outra parte se opuser a licenciar o uso de seu RBI, nem o CTA nem o recurso biológico terão seu valor completo, e o projeto de $\mathrm{P} \& \mathrm{D}$ não poderá sair do papel. ${ }^{1515}$ Assim, projetos de criação de novas produções literárias, artísticas ou científicas que dependerem do uso conjunto de uma variedade de RBIs podem se tornar reféns de uma única autorização retida, em caso de inexistência de substitutos. ${ }^{1516}$

Um exemplo concreto de uma invenção que poderia ter deixado de ser introduzida no mercado, em virtude do uso de múltiplos recursos protegidas por direitos de exclusivo é o "arroz dourado". Essa variedade de arroz geneticamente modificado apresenta grandes quantias de betacaroteno e pode, no futuro, servir como uma fonte de vitamina A para as populações de regiões pobres, onde sua deficiência é responsável por altas taxas de mortalidade infantil e deficiência visual. ${ }^{1517}$ Para o desenvolvimento desta variedade de arroz foram utilizados 15 componentes técnicos protegidos por algum tipo de direito de exclusivo e 70 invenções protegidas por patentes, depositadas em países industrializados. ${ }^{1518}$ Portanto, o lançamento nos países industrializados desse produto depende da obtenção de 85 autorizações diferentes. ${ }^{1519}$ A falta de uma única autorização é suficiente para bloquear sua exploração.

Nesse caso específico, a tragédia dos anticomuns foi evitada por intervenção direta da empresa Syngenta, principal condutora do projeto, bem como por conta da pressão da opinião pública, que lograram persuadir todos os titulares de insumos técnicos utilizados a concederem licenças para uso humanitário de suas invenções. A licença concedida autoriza

\footnotetext{
1515 Cf. PARISI; SCHULZ; DEPOORTER, 2001, p. 13.

${ }^{1516}$ Cf. CARRIER, 2003, p. 135.

${ }^{1517}$ Cf. KOWALSKI; KRYDER, 2002, p. 52.

1518 No site do projeto "arroz dourado" (http://www.goldenrice.org/), há informações de que das 70 invenções patenteadas, utilizadas no desenvolvimento do arroz dourado, "apenas" 12 foram depositadas em países em desenvolvimento. Conseqüentemente, o número de autorizações necessárias para o lançamento desse produto no mercado de países em desenvolvimento não seria de 85 , mas giraria em torno de 27 , ao se contar as demais autorizações necessárias para se utilizar os demais componentes protegidos por outros direitos de exclusivo. De qualquer forma, o número ainda é substancial e o potencial de emergência de uma tragédia dos anticomuns é concreta.

${ }^{1519}$ Cf. KOWALSKI; KRYDER, op.cit., p. 56.
} 
a exploração do arroz dourado, no território de países em desenvolvimento, por pequenos agricultores, cuja renda anual não ultrapasse US\$ $10.000,00 .{ }^{1520}$ Ultrapassado esse patamar de renda, os agricultores dos países em desenvolvimento têm de celebrar um acordo de licenciamento com a Syngenta, previamente ao cultivo.

Especificamente no contexto dos CTAs e dos recursos biológicos, há a possibilidade de surgirem dois tipos de tragédias dos anticomuns: cada um destes recursos pode ser de titularidade de múltiplas comunidades tradicionais ou Estados, o que pode conduzir à uma tragédia dos anticomuns simultânea. E um usuário pode precisar empregar dois ou mais RBIs em um mesmo projeto, podendo, conseqüentemente, emergir uma tragédia dos anticomuns seqüencial. Uma parte interessada em utilizar uma determinada associação de CTA e recurso biológico pode ser vencida pelas dificuldades para obter o CPLI de todos os cotitulares do CTA e do recurso biológico. Em suma, a tragédia dos anticomuns pode emergir quando sobre um mesmo recurso dois ou mais indivíduos ou instituições puderem exercer um direito de exclusão, sejam eles cotitulares ou não de um direito de propriedade, bem como quando dois ou mais insumos complementares forem controlados por partes distintas. ${ }^{1521}$

O risco de emergência da tragédia dos anticomuns cresce com:

i. O incremento do número de cotitulares do direito de exclusão: maior o número de cotitulares, maiores as chances de que não alcancem um consenso sobre a conveniência de autorizar seu uso por terceiros e a respeito das condições em que o uso poderá se dar; ${ }^{1522}$

ii. A heterogeneidade dos interesses dos cotitulares de direito: mais heterogêneos são os interesses dos titulares de direitos de exclusão, mais difícil será alcançar decisões convergentes, pois cada parte pauta sua conduta por interesses diversos. ${ }^{1523}$ No que tange ao PBI, cada categoria de RBI é controlado por grupos que perseguem objetivos diferentes. Por outro lado, os usuários dos RBIs são a

\footnotetext{
${ }^{1520}$ Cf. POTRYKUS, [200-], p. 8.

${ }^{1521}$ Cf. PARISI; SCHULZ; DEPOORTER, 2004, p. 184.

1522 Ver, e.g., PARISI; SCHULZ; DEPOORTER, 2004, p. 182; BRUSH; CARRIZOSA, 2004, p. 73; EPSTEIN, 1993, p. 556.

${ }^{1523}$ Cf. HELLER, 1998, p. 655.
} 
indústria criativa, da biotecnologia, farmacêutica, instituições públicas, universidades, grupos que igualmente apresentam interesses e objetivos diversos entre si. Assim, há grandes dificuldades de comunicação entre potenciais usuários e provedores de RBIs para alcançarem acordos que sejam razoáveis e aceitáveis a todos os envolvidos. ${ }^{1524}$ Não é, pois, incomum que uma parte apresente demandas que a outra considere irrealista, já que cada parte envolvida na negociação desconhece a realidade e as dificuldades enfrentadas pelas demais;

iii. A obscuridade das fronteiras do recurso objeto do direito de propriedade: quando não se tem clareza sobre o objeto protegido, o número de cotitulares do recurso pode se ampliar ou se reduzir, dependendo da configuração que se reconheça ao objeto; ${ }^{1525}$

iv. A falta de informação por parte dos cotitulares de direitos sobre o verdadeiro potencial comercial de seu bem: desconhecendo esses dados, cada cotitular sobrevalorizará seus bens e descartará com facilidade propostas que não atinjam suas expectativas, ainda que irreais, pois estarão focados em extrair dos potenciais usuários os maiores benefícios possíveis. ${ }^{1526}$ Tais demandas, vistas em conjunto, podem facilmente ultrapassar a fronteira do razoável e desestimular o uso produtivo de recursos, que apresentem potencial lucrativo inferior aos custos de transação; ${ }^{1527} \mathrm{e}$

v. Ausência ou fraqueza das limitações e exceções aos direitos de exclusivo conferidos: à medida que os direitos conferidos se aproximam do modelo de direito de propriedade absoluto (ilimitado; não sujeito à exceções e limitações), maiores as chances de que o recurso regido pelo regime de anticomuns seja subutilizado. ${ }^{1528}$ Por exemplo, as propostas de regimes internacionais para a proteção de RBIs não oferecem aos seus potenciais usuários a oportunidade de requererem licenças compulsórias, na hipótese dos titulares de RBIs não concordarem em licenciá-los, em condições razoáveis.

${ }_{1524}$ Cf. EISENBERG, 2001, p. 235.

${ }^{1525}$ Cf. HELLER, 1998, p. 655-656.

${ }^{1526}$ Cf. HELLER; EISENBERG, 1998, p. 701.

${ }_{1527}$ Cf. SVEN et al., 2006, p, 16.

${ }^{1528}$ Cf. LAMETTI, 2003, p. 365-366. 
Com a subutilização dos RBIs, menor será o volume de novos produtos gerados a partir deles e, conseqüentemente, menores serão os benefícios deles derivados. No que tange especificamente aos recursos da biodiversidade, sempre que for denegado o acesso científico e produtivo a um recurso biológico único (i.e. aquele que não conta com substitutos), novos processos e produtos deixarão de ser desenvolvidos e novos conhecimentos deixarão de ser gerados. ${ }^{1529}$ Enfim, continuaremos a conhecer muito pouco a herança biológica da humanidade e a não empregá-la em favor de seu bem-estar.

A tragédia dos anticomuns gera desincentivos para a conservação das dimensões ambiental e humana do PBI. Não havendo recursos econômicos suficientes para oferecer às comunidades tradicionais os meios necessários para viverem condignamente junto à natureza, estas podem optar ou por degradar os ecossistemas em que vivem, ou por imigrar, abrindo espaço para que terceiros explorem insustentavelmente as áreas até então conservadas por elas. Em outras palavras, um regime de propriedade, estruturado de maneira a conduzir à tragédia dos anticomuns, pode apresentar como outro efeito colateral a tragédia dos recursos comuns, pois a erosão do valor econômico dos RBIs, em virtude do levantamento de obstáculos ao seu uso produtivo, impede a geração de incentivos econômicos indispensáveis para a conservação das dimensões ambiental e humana do PBI.

Se os futuros regimes internacionais de proteção dos RBIs tornarem seu uso produtivo e sustentável mais custoso que a obtenção de licenças para extração madeireira e mineira e condução de outras atividades ambientalmente insustentáveis, podemos estar certos que os ecossistemas que sustentam o PBI e as comunidades tradicionais continuarão sujeitos a um processo de franca decadência, ${ }^{1530}$ sem mencionar que a meta dos países em desenvolvimento de se desenvolverem sustentavelmente permanecerá como tal. ${ }^{1531}$

Um regime de direito de propriedade não se mostra adequado para tutelar CTAs e recursos biológicos, mesmo que os direitos de uso e exclusão sejam centralizados, respectivamente, nas mãos de uma única comunidade tradicional ou de um único Estado. Considerando que o uso simultâneo dos CTAs e dos recursos biológicos que a eles se

\footnotetext{
${ }^{1529}$ Cf. CAULFIELD et al., 2006, p. 1091.

${ }^{1530}$ Ver, e.g., GRAJAL, 1999, p. 8; COX, 2001, p. 37; SWANSON; GOESCHL, 2007, p. 13-14.

${ }^{1531}$ Cf. SACHS, 2007b, p. 111.
} 
associam é indispensável para que os setores científico e industrial possam empregá-los como insumos no processo de inovação, ${ }^{1532}$ o titular de um destes RBIs poderia agir estrategicamente e supervalorizá-lo, já que estaria ciente de que, sem sua autorização, o uso do outro RBI não seria possível.

Dentro desse contexto, é fundamental que os futuros regimes de proteção dos CTAs e recursos biológicos se estruturem de modo a tratá-los como um único recurso. ${ }^{1533} \mathrm{Em}$ outras palavras, embora os recursos biológicos sejam de titularidade dos Estados e os CTAs pertençam a comunidades tradicionais, os regimes legais em negociação deveriam unificá-los obrigatoriamente em um recurso fictício, ${ }^{1534}$ formado pela associação de RBIs complementares e interdependentes, impedindo, assim, que a não obtenção de uma autorização a um determinado RBI, esvazie o valor daquele que o complementa. ${ }^{1535} \mathrm{O}$ objetivo do agrupamento obrigatório de RBIs complementares e interdependentes não é beneficiar ao máximo um dos titulares de RBIs em detrimento do outro, mas tornar realidade os benefícios que ambos poderiam alcançar, se cooperassem voluntariamente. ${ }^{1536}$

Com o fito de unificá-los em um recurso único ficcional, poder-se-ia cogitar em centralizar o direito de propriedade dos CTAs e recursos biológicos nas mãos de uma única instituição, representativa dos Estados e das comunidades. Contudo, como a capacidade econômica desses bens somente se realiza quando aperfeiçoados pelas ferramentas da ciência ocidental, já que são matérias-primas mais ou menos brutas, este único titular de direitos sempre poderia obstaculizar seu uso pelos setores produtivo, ${ }^{1537}$ em detrimento dos interesses das comunidades tradicionais e da humanidade. ${ }^{1538}$

Embora o direito de propriedade possa erguer obstáculos de difícil superação para a utilização de recursos que apenas serão socialmente úteis, quando disseminados e aplicados amplamente (RBIs laicos, i.e. recursos da biodiversidade, CTs e ECTs laicas), é um mecanismo útil para prevenir usos culturalmente desrespeitosos de bens sensíveis, a saber, as ECTs de valor espiritual. Um regime de propriedade configura uma opção de

\footnotetext{
1532 Ver, e.g., PARISI; SCHULZ; DEPOORTER, 2001, p. 16-20; ONWUEKWE, 2004, p. 73.

${ }^{1533}$ Ver, e.g., COOMBE, 1998-1999, p. 90; SCBD, UNEP/CBD/WG8J/4/INF/18, p. 3.

${ }^{1534}$ Cf. GRAFF; ZILBERMAN, 2001b, p. 9.

1535 Ver, e.g., VOGEL, 2004, p. 239; COLANGELO, 2004, p. 32; GRAFF et al., 2001, p. 16.

${ }^{1536}$ Cf. EPSTEIN, 1993, p. 567.

1537 Cf. HELLER, 2001, p. 89.

${ }^{1538}$ Cf. RAMANNA; SMALE, 2004, p. 439.
} 
mecanismo legal capaz de assegurar o respeito às normas consuetudinárias das comunidades tradicionais, que regem o uso de material sagrado em contextos nãocomunitários. O reconhecimento de um direito de propriedade sobre ECTs sagradas faculta às comunidades tradicionais o poder de controlar os contextos e condições em que poderiam ser veiculadas. ${ }^{1539}$

Em síntese, um regime de direito de propriedade não se mostra adequado para proteger CTs, recursos da biodiversidade e ECTs despidas de valores espirituais (RBIs laicos), porquanto o valor social destes RBIs apenas pode ser realizado quando amplamente disseminados e aplicados pela sociedade. Sem que estes RBIs sejam aplicados produtivamente, eles serão incapazes de gerar incentivos econômicos para a conservação da diversidade biocultural. As ECTs sagradas, por sua vez, considerando que o interesse das comunidades tradicionais é restringir ao máximo sua disseminação, podem ser protegidas com sucesso mediante um regime de propriedade, ainda que este conduza à tragédia dos anticomuns.

\section{§1 CASO UNIFESP-KRAHô}

Para comprovar que a tragédia dos anticomuns não constitui uma figura teórica, despida de valor prático, trataremos, em largos traços, de um caso controverso que envolveu, há alguns anos, a Universidade Federal de São Paulo (UNIFESP) e a etnia indígena Krahô.

Entre 1999 e 2001, Eliana Rodrigues, então pesquisadora e doutoranda junto ao Departamento de Psicobiologia da UNIFESP, conduziu pesquisa de campo junto a comunidades indígenas pertencentes à etnia Krahô, fixadas no estado do Tocantins. Esta etnia indígena se encontrava dividida, àquela época, em 18 comunidades independentes. Considerando a falta de tempo e de recursos econômicos, a pesquisadora optou por conduzir sua pesquisa de campo junto a 3 das 18 comunidades Krahô. O objetivo da pesquisa, que serviu de base à sua tese de doutorado, era coletar plantas e outros recursos biológicos medicinais, utilizados pelos xamãs da etnia Krahô para o tratamento de

\footnotetext{
${ }^{1539}$ Cf. UNESCO; OMPI, 1985, p. 48; LUCAS-SCHLOETTER, 2004, p. 366.
} 
enfermidades relacionadas ao sistema nervoso central, e comparar os usos tradicionais com os aqueles identificados para as mesmas plantas pelo sistema científico formal.

A legalidade das atividades de pesquisa de campo junto às aldeias Krahô escolhidas dependeu da obtenção de autorizações de três instituições, a saber, Comissão de PósGraduação em Psicobiologia da UNIFESP; Comitê de Ética em Pesquisa da UNIFESP (CEP) e Fundação de Amparo à Pesquisa do Estado de São Paulo (FAPESP), órgão que concedeu bolsa de estudos para Eliana Rodrigues. Cumulativamente, para acessar as Terras indígenas, onde estão localizadas as três aldeias pesquisadas, Rodrigues precisou obter autorizações de outras instâncias: Fundação Nacional do Índio (FUNAI); Conselho Nacional de Desenvolvimento Científico e Tecnológico (CNPq); e Comissão de Ética em Pesquisa do Ministério da Saúde (CONEP). A obtenção desse conjunto de autorizações consumiu em torno de três anos (quadro 4).

Quadro 4: Autorizações obtidas previamente e durante a consecução do projeto

\begin{tabular}{|c|c|c|}
\hline Instituição & Data de Envio & Data de Aprovação \\
\hline UNIFESP & Setembro/1998 & Setembro/1998 \\
\hline $\begin{array}{l}\text { Fundação de Amparo à } \\
\text { Pesquisa do Estado de São } \\
\text { Paulo (FAPESP) }\end{array}$ & Novembro/1998 & Janeiro/1999 \\
\hline $\begin{array}{llcr}\text { Comitê } & \text { de } & \text { Ética } & \text { em } \\
\text { Pesquisa } & \text { da } & \text { Universidade } \\
\text { Federal de } & \text { São } & \text { Paulo } \\
(\text { CEP }) & & & \\
\end{array}$ & Janeiro/2000 & Novembro/2000 \\
\hline $\begin{array}{l}\text { Fundação Nacional do } \\
\text { Índio (FUNAI) }\end{array}$ & Fevereiro/2000 & Julho/2001 \\
\hline $\begin{array}{l}\text { Conselho Nacional de } \\
\text { Desenvolvimento } \\
\text { Científico e Tecnológico } \\
(\mathrm{CNPq})\end{array}$ & Novembro/2000 & Dezembro/2000 \\
\hline $\begin{array}{l}\text { Comissão de Ética em } \\
\text { Pesquisa do Ministério da } \\
\text { Saúde (CONEP) }\end{array}$ & $\begin{array}{l}\text { Processo encaminhado à } \\
\text { CONEP diretamente pelo } \\
\text { CEP }\end{array}$ & Junho/2001 \\
\hline
\end{tabular}

Fonte: RODRIGUES; CARLINI; ASSIMAKOPOULOS (2005:121) 
No período de três anos, Rodrigues coletou 255 plantas originárias do Brasil, sendo muitas delas desconhecidas pela comunidade científica internacional, e 548 instruções sobre como aplicá-las para um total de 139 indicações terapêuticas distintas. ${ }^{1540}$

Em 2001, ao final do período de pesquisa de campo, a UNIFESP, apoiada por duas empresas farmacêuticas brasileiras, reconhecendo o potencial farmacológico das plantas e do know-how dos índios Krahô, propôs às três comunidades pesquisadas um protocolo de intenções, onde lhes foi oferecida a cotitularidade de toda e qualquer patente que viesse a ser concedida no Brasil e no exterior sobre qualquer invenção derivada dos CTAs e recursos biológicos transmitidos; a metade dos royalties a serem pagos à UNIFESP pelos licenciados das invenções patenteadas; e construção de uma infraestrutura nas terras das comunidades indígenas, para que seus membros cultivassem as plantas que seriam utilizadas durante a pesquisa e desenvolvimento dos novos medicamentos e, posteriormente, em sua fase de produção industrial. ${ }^{1541}$ As comunidades indígenas aceitaram o acordo proposto, assinando-o por meio de uma organização civil denominada VYTY-CATI, aparentemente competente para representar seus interesses.

À época da assinatura do acordo, o Brasil havia editado há pouco a Medida Provisória no. 2.052 (MP), ${ }^{1542}$ que disciplinou pela primeira vez a proteção dos recursos da biodiversidade brasileiros e dos CTAs, como resposta a um escândalo envolvendo a associação Bioamazônia e a empresa farmacêutica Novartis. ${ }^{1543}$ Em poucas palavras, a MP confere às comunidades tradicionais um direito de propriedade sobre os CTAs por elas conservados, bem como sobre os recursos da biodiversidade presentes em suas terras. Nos termos da MP, o acesso a estes RBIs dependeria de uma autorização expedida pela comunidade tradicional pertinente, que tomaria a forma de um termo de consentimento prévio, livre e esclarecido e um acordo de repartição de benefícios. Uma vez firmado o

${ }^{1540}$ Cf. RODRIGUES, 2001, p. 74.

1541 O Protocolo de Intenções foi firmado entre a Associação das Comunidades Timbira do Maranhão e Tocantins - VYTY-CATI e a UNIFESP, em 22 de fevereiro de 2001.

1542 Medida Provisória no. 2052, de 29 de junho de 2000. Esta MP foi reeditada até agosto de 2001 (MP no. 2.186-16, de 23 de agosto de 2001), a qual, ainda hoje, permanece em vigor.

${ }^{1543}$ Em breves, palavras, o escândalo decorreu do fato da associação e a empresa farmacêutica terem celebrado um acordo de transferência de 10.000 amostras de microorganismos, que seriam coletados na floresta amazônica do Brasil, em troca do pagamento de cerca de 2.5 milhões de francos suíços, ou seja, o equivalente a 250,00 francos suíços por amostra transferida. A sociedade civil, os círculos científicos e políticos brasileiros julgaram o acordo contrário aos interesses brasileiros, ao perpetuar a posição do Brasil como mero provedor de matérias-primas aos países industrializados. Cf. PEÑA-NEIRA; DIEPERINK; ADINK, 2002. 
acordo com as comunidades pertinentes, a parte interessada em utilizar produtivamente os CTAs e/ou recursos biológicos teria de obter uma autorização do Conselho de Gestão do Patrimônio Genético (CGEN). O CGEN é um órgão governamental competente para, dentre outras funções, deliberar sobre o acesso aos recursos da biodiversidade brasileira e aos CTAs. Embora a primeira versão da MP que disciplinou o acesso aos recursos biológicos e CTAs tenha sido editada em meados de 2000, o CGEN somente entrou em operação em abril de 2002.

Em face da complexidade da MP; da falta de expertise no Brasil para compreendêla adequadamente e da inexistência do CGEN até abril de 2002, a UNIFESP receava que a associação indígena VYTY-CATI não tivesse autoridade legal para firmar o acordo de repartição de benefícios, em nome das comunidades provedoras de CTs e recursos da biodiversidade.

A fim de sanar as dúvidas pertinentes à autoridade legal da associação, a Universidade organizou reuniões entre o final de 2001 e o início de 2002, das quais participaram representantes do Poder Público brasileiro, das comunidades indígenas pesquisadas, antropólogos, bem como líderes das comunidades indígenas não-participantes do acordo. A conclusão alcançada foi que a associação VYTY-CATI não estava investida na competência para representar a etnia Krahô, em um acordo de repartição de benefícios. Em outras palavras, chegou-se à conclusão que, em face do marco legal brasileiro de proteção dos recursos da biodiversidade e dos CTAs, a UNIFESP apenas poderia utilizar os recursos biológicos e CTAs de titularidade das comunidades Krahô entrevistadas, se obtivesse autorização de todas as 18 comunidades, que compõem a etnia. A partir deste resultado, a UNIFESP decidiu postergar o início do projeto de P\&D até encontrar uma solução ao impasse sobre a titularidade dos recursos biológicos e CTAs acessados. ${ }^{1544}$

Pouco tempo após a decisão de suspender o início das atividades de $\mathrm{P} \& \mathrm{D}$, as comunidades Krahô, que não participaram do acordo de repartição de benefícios proposto pela UNIFESP, pediram à Fundação Nacional do Índio (FUNAI) a tomada de ações legais contra a UNIFESP, com base na suposta apropriação de seus CTAs e recursos biológicos. Estes grupos desejavam receber da UNIFESP uma indenização no valor de R \$ 25 milhões

${ }^{1544}$ Cf. IZIQUE, 2002, p. 26-28. 
pelo acesso não-autorizado dos CTAs e recursos biológicos, conservados pela etnia Krahô. 1545 Ironicamente, as comunidades que reivindicavam direitos não haviam participado da pesquisa de campo conduzida pela pesquisadora da UNIFESP, nem apresentaram quaisquer evidências que sugerissem que os CTAs e recursos biológicos transferidos à universidade eram de fato compartilhados por todas as comunidades que compõem a etnia Krahô.

Objetivando dar um ponto final à controvérsia e às acusações contra sua idoneidade e de seus pesquisadores, em janeiro de 2003, a UNIFESP apresentou ao CGEN uma solicitação de autorização de uso dos CTAs e recursos biológicos, previamente transferidos pelas comunidades pesquisadas, substanciada pelo termo de CPLI e pelo contrato assinado pela associação VYTY-CATI anos antes. O CGEN decidiu que a documentação apresentada era insuficiente para a concessão da autorização requerida, pois não havia sido assinada por todos os líderes da etnia Krahô. Em face da posição do CGEN, a UNIFESP tinha duas opções: ou desistir do projeto ou tentar obter o CPLI dos líderes de todas as 18 comunidades Krahô. Corajosamente, a universidade optou pela última alternativa.

Ao longo do ano de 2003, a UNIFESP se reuniu em inúmeras oportunidades com os líderes de todas as comunidades Krahô e com seus representantes legais, notadamente, representantes da FUNAI. Apesar de todo o empenho da UNIFESP, nunca chegaram a um acordo, porquanto ou as comunidades demandavam o pagamento de importâncias muito altas, ou o financiamento de projetos que poderiam gerar novas controvérsias legais. ${ }^{1546}$

Como as negociações se arrastaram por muito tempo e os envolvidos na negociação estiveram à beira de ter sua reputação arranhada com acusações infundadas, ao final de 2003, as empresas farmacêuticas que apoiavam a iniciativa da UNIFESP desistiram do projeto. Em paralelo, a Universidade perdeu o prazo para assinar o acordo de financiamento oferecido pela FAPESP para a realização do projeto, que havia sido

1545 Ver, e.g., LOPES, 2002; FOLHA DE SÃO PAULO, 2002.

${ }^{1546}$ As comunidades Krahô demandavam da UNIFESP o financiamento de um projeto de revitalização da medicina tradicional Krahô, que envolveria a construção de clínicas totalmente equipadas, que seriam operadas pelos xamãs da etnia e serviriam não apenas aos membros das comunidades, mas também a pessoas externas à comunidade. As comunidades demandavam, também, o apoio técnico da UNIFESP para capacitálos a produzir produtos fitoterápicos, os quais seriam distribuídos pelo poder público para outras comunidades indígenas. Na hipótese da UNIFESP financiar um projeto desta natureza, passaria também a ser coresponsabilizada por danos causados aos pacientes e aos usuários dos produtos desenvolvidos pelas comunidades Krahô. Por esta razão, a Universidade se opôs ao projeto (FUNAI, 2003). 
oferecido em junho de 2003. A universidade desejou desistir, mas foi incentivada pela presidência da FUNAI e por um assessor especial da Presidência da República do Brasil a buscar um novo financiador para a empreitada.

Ao longo do ano de 2004, a UNIFESP tentou identificar um novo financiador, mas sem sucesso. ${ }^{1547}$ Assim, o projeto UNIFESP-Krahô morreu formalmente em 2004, como resultado da emergência de uma tragédia dos anticomuns. $\mathrm{Na}$ falta de um consenso entre todas as comunidades, que compõem a etnia Krahô, a UNIFESP não pôde utilizar os CTAs e recursos biológicos, que já tinha em seu poder. Àquela época, possivelmente com o objetivo de proteger ao máximo os interesses materiais da etnia Krahô, o CGEN aplicou a MP de modo a conferir às 18 comunidades Krahô um direito de propriedade sobre os CTAs e recursos biológicos que, ao menos, algumas das comunidades conservam.

No entanto, a realidade mostrou que essa tentativa de conferir direitos de controle do uso da diversidade biocultural brasileira a um número expressivo de comunidades e agências governamentais criou obstáculos insuperáveis para a geração de benefícios econômicos em seu favor: contabilizando as autorizações obtidas por Rodrigues, durante a primeira fase da pesquisa, mais as 18 autorizações das comunidades Krahô, sem as quais o CGEN não poderia autorizar o uso dos recursos da biodiversidade e CTAs coletados, a transformação destes insumos em produtos socialmente úteis dependia de 24 autorizações diferentes.

No fim, todos perderam: uma universidade pública brasileira séria e um grupo de pesquisadores comprometidos tiveram sua reputação arranhada e perderam a oportunidade de pesquisar recursos da biodiversidade desconhecidos pelos círculos científicos internacionais; o setor privado brasileiro perdeu a oportunidade de gerar inovação, a partir das fortalezas culturais, biológicas e humanas do Brasil; e comunidades indígenas materialmente fragilizadas perderam a oportunidades de se beneficiarem dos recursos econômicos que teriam sido gerados, se o projeto UNIFESP-Krahô tivesse saído do papel.

Engana-se quem acredita que os resultados decepcionantes alcançados pelo projeto UNIFESP-Krahô seja um episódio isolado no Brasil: desde o início da aplicação da

${ }^{1547}$ Cf. UNIFESP, 2004. 
Medida Provisória 2.186-16, em abril de 2002, até agosto de 2008, tão-somente 58 autorizações de acesso a recursos da diversidade biocultural brasileira foram concedidas pelo governo brasileiro. ${ }^{1548}$ É interessante notar que, dentre as autorizações concedidas, apenas uma se refere a um projeto com objetivos similares aos do projeto UNIFESP-Krahô (uso da biodiversidade e de conhecimentos tradicionais com o propósito de desenvolver novos produtos comerciais) e apenas 24 autorizações se referem a acesso a recursos da biodiversidade com fins econômicos. Enfim, o marco legal do Brasil vem gerando resultados socioeconômicos pífios, quando temos em mente que este país detém a maior biodiversidade do orbe terrestre.

Ironicamente, enquanto os setores produtivos tentam se desvencilhar de uma teia burocrática que os impede de aplicar a diversidade biocultural brasileira para fins úteis e sustentáveis, a biodiversidade brasileira vem sendo substituída muito rapidamente por campos de soja e pastos para gado de corte para exportação. ${ }^{1549}$ Se o marco legal for incapaz de estimular a geração de renda a partir da biodiversidade, de maneira sustentável, ela certamente continuará a ser destruída para dar lugar a atividades "produtivas" no curto prazo, ainda que insustentáveis no médio e longo prazo.

\subsubsection{PROBLEMA II: PRINCíPIO DA EXAUSTÃo DE DIREITOS}

Nenhuma das discussões em andamento indicou qual o princípio de exaustão de direitos seria aplicável aos direitos conferidos aos titulares de RBIs: exaustão nacional, regional ou internacional. No âmbito do DPI convencional, o princípio da exaustão de direitos tem como função fixar limites ao direito de controle, investido nos titulares de DPIs, sobre os bens tangíveis que incorporam sua propriedade intelectual: o titular de um DPI, quando introduzir no mercado, diretamente ou por meio de um licenciado, um produto que agrega sua propriedade intelectual, terá esgotado seu direito de se opor ao seu uso subseqüente por terceiros não-autorizados, pois já foi devidamente remunerado pelo uso comercial de sua propriedade intelectual. ${ }^{1550}$

\footnotetext{
1548 EMERICK, 2008.

1549 Ver, e.g., PROLONGEAU; MARIE, 2007; GREEPEACE, 2006a; GREEPEACE, $2006 \mathrm{~b}$.

${ }^{1550}$ Cf. HEATH, 1999.
} 
No mesmo sentido do DPI convencional, o princípio da exaustão aplicado ao contexto do PBI é competente para estabelecer os limites dos direitos das comunidades tradicionais e dos Estados sobre os produtos, que incorporarem direta ou indiretamente seus RBIs. Assim que o titular de um determinado RBI for recompensado financeiramente, no momento da primeira comercialização de cada produto que incorporá-lo, seu direito de controlar os usos subseqüentes deste produto estaria exausto.

Os Estados podem optar por uma das três configurações do princípio da exaustão de direitos: nacional, regional ou internacional. Previamente à avaliação das diferentes configurações do princípio da exaustão de direitos, é importante traçar duas premissas básicas para a compreensão adequada de seu funcionamento. Primeiramente, deve-se ter claro que uma mesma produção intelectual pode (e normalmente é) protegida em múltiplas jurisdições por seu titular, que pode exercer seus DPIs diretamente ou por meio de um licenciado. Em segundo lugar, os DPIs são direitos territoriais, fruindo uma vida independente, mesmo quando um mesmo bem esteja protegido, em múltiplas jurisdições. Por exemplo, uma mesma invenção pode estar patenteada no Brasil e na Argentina. Após a concessão da patente argentina, um concorrente local pode impugnar sua validade com sucesso. $\mathrm{O}$ resultado do litígio não será hábil a comprometer a validade da patente brasileira.

Retornando aos tipos de exaustão de direitos, na exaustão nacional, seu fatogerador é a introdução de um bem protegido por um DPI em território nacional (e.g. Brasil), diretamente por seu titular ou por um terceiro por ele autorizado. ${ }^{1551}$ Por exemplo, quando um licenciado remunerar o titular de uma patente sobre um medicamento em virtude de sua comercialização no Brasil, o titular da patente brasileira não poderá impedir sua circulação no mercado local. No entanto, se o mesmo produto farmacêutico for produzido na Argentina pelo titular da patente argentina, e uma empresa distribuidora exportá-lo ao Brasil, o titular da patente brasileira poderá impedir sua importação, pois seu direito somente é exausto quando o produto for introduzido, em território brasileiro, diretamente por ele ou com o seu consentimento. Logo, no caso do princípio da exaustão nacional, o titular da patente brasileira teria um direito de importação, isto é, a prerrogativa

${ }^{1551}$ Cf. JEHORAM, 1996, p. 2-4. 
de controlar as importações, inclusive de produtos genuínos, produzidos legalmente no exterior, sob autorização do titular da patente local.

O princípio da exaustão regional de direitos é adotado pela União Européia e trata a introdução de um produto, protegido por DPI, em um dos 27 Estados membros da UE, por seu titular ou licenciado como fato-gerador da exaustão dos direitos dos titulares de DPIs paralelos, válidos em outros Estados membros da UE. No entanto, se o mesmo produto, originário de um país externo à UE, for introduzido em um dos Estados membros da UE, sem a anuência do titular do DPI local, este poderá impedir sua entrada e comercialização.

Por fim, no caso do princípio da exaustão internacional, o titular de um DPI, válido em um país que adota este princípio (“mercado local”), não poderá impedir nem a entrada, nem a comercialização local de produtos idênticos ao seu, desde que protegidos por um DPI no país de origem da exportação, e sua introdução no mercado local tenha sido realizada diretamente pelo titular do DPI estrangeiro ou por um licenciado. Assim, por exemplo, um medicamento patenteado produzido no Brasil, país que adota o princípio da exaustão nacional de direitos, poderia ser exportado ao Japão, o qual adota o princípio da exaustão internacional de direitos, e o titular da patente japonesa, que incide sobre o medicamento importado do Brasil, nada poderia fazer para impedir sua entrada e comercialização no Japão.

O objetivo central do princípio da exaustão internacional é afastar obstáculos injustificados ao comércio internacional de produtos protegidos por DPI, enquanto o princípio da exaustão nacional cria restrições ao livre comércio, ao conferir ao titular de DPIs paralelos um direito de importação em cada uma das jurisdições, onde sua produção intelectual é protegida, o que lhe permite controlar a comercialização de seus produtos em todos estes mercados. ${ }^{1552}$

O tema do princípio da exaustão de direitos ganha relevância em vista da possibilidade de que CTs e ECTs sejam compartilhados por comunidades, baseadas em países diversos e, no caso de recursos biológicos, em virtude do fato de poderem existir em condições in situ em dois ou mais países. Se os futuros regimes internacionais de proteção

${ }^{1552}$ Cf. VERMA, 1998. 
dos RBIs permitirem que seus Estados contratantes adotem o princípio da exaustão nacional de direitos, os titulares de direitos sobre RBIs fruirão de um direito de importação, que poderá ser exercido de maneira a obstaculizar o comércio internacional de bens que incorporem RBIs, licitamente adquiridos em outros países. Tomemos um exemplo baseado na Lei Modelo do Pacífico, a qual adota o princípio da exaustão nacional de direitos, i.e. confere às comunidades tradicionais um direito de importação sobre bens que incorporem seus CTs ou ECTs, sem sua autorização. Em nosso exemplo, um mesmo CT é compartilhado por duas comunidades, baseadas em dois Estados membros da Comunidade do Pacífico (A e B), cujos ordenamentos jurídicos incorporaram fielmente os termos da Lei Modelo. Uma empresa que acessar legalmente o referido CT, no país A, e tentar exportar um produto derivado deste conhecimento ao país $\mathrm{B}$, terá suas exportações embargadas e ainda estará sujeita à aplicação de sanções civis e penais, ${ }^{1553}$ se não tiver obtido o CPLI da comunidade baseada no país importador. ${ }^{1554}$

Assim, se os Estados contratantes dos futuros regimes internacionais adotarem o princípio da exaustão nacional de direitos, na hipótese de um produto incorporar um RBI compartilhado por comunidades baseadas em diversos países, o distribuidor deste produto, se desejar comercializá-lo em todos estes territórios, será obrigado a negociar um acordo de licenciamento com todas as comunidades pertinentes.

Retornando à hipótese indicada, se, por outro lado, os Estados optarem pela adoção do princípio da exaustão internacional de direitos, a comunidade do país B não poderia embargar nem a importação nem a comercialização de produto que incorporou o CT compartilhado. Caso o acordo de repartição de benefícios celebrado entre a empresa exportadora e a comunidade A não contemplar o pagamento de benefícios em favor da comunidade do país $\mathrm{B}$, esta sairá prejudicada.

Poder-se-ia pensar em superar este problema por meio da associação do princípio da exaustão internacional de direitos com a introdução, nos futuros regimes internacionais, da obrigação de que os acordos de repartição de benefícios contemplem a canalização de benefícios, em favor das demais comunidades (CTs e ECTs) ou Estados (recursos biológicos), que compartilharem um mesmo RBI. Nesta hipótese, como cada cotitular de

${ }^{1553}$ Cf. SECRETARIAT OF THE PACIFIC COMMUNITY, 2002, art. 26 e seguintes.

${ }^{1554}$ Ibid., art. 7(4). 
um mesmo RBI teria a liberdade para celebrar acordos de repartição de benefícios de maneira independente, recordando que pode existir uma multiplicidade de fontes provedoras de um mesmo RBI, os potenciais usuários poderiam optar por negociar um acordo de repartição de benefícios com aquele Estado ou comunidade que fixasse as condições mais favoráveis (i.e. os royalties mais baixos). Conseqüentemente, os benefícios a serem repartidos seriam pífios.

\subsubsection{PROBLEMA III: AUSÊNCIA DE UM REgISTRO OBRIGATÓRIO PARA OS RBIS PROTEGIDOS}

Com o objetivo de facilitar e desonerar ${ }^{1555}$ o gozo e o exercício de direitos por parte dos detentores de RBIs, quase todas as propostas examinadas (com exceção daquela referente à proteção de ECTs singulares) adotam o princípio da ausência de formalidades, ${ }^{1556}$ incorporado à Convenção de Berna, ${ }^{1557}$ liberando seus titulares da obrigação de registrar seus RBIs ou de cumprir qualquer outra formalidade.

As comunidades tradicionais e países em desenvolvimento rechaçam a idéia de registros públicos, ao considerá-los uma ferramenta institucionalizada de fomento à apropriação indébita de RBIs. ${ }^{1558}$ Os registros concentrariam em poucos pontos de acesso, RBIs desconhecidos pelo grande público, bem como aqueles que já são acessíveis, mas não facilmente. No entanto, um registro público de RBIs apenas facilitaria sua apropriação, se existisse de maneira destacada de um esquema legal de proteção. A disseminação pública dos RBIs registrados, se apoiada em um regime internacional de proteção, tal como ocorre com as produções intelectuais protegidas pelos DPIs, não implicaria em autorização indiscriminada para usos gratuitos.

Uma das principais contribuições do regime de proteção da PI ao desenvolvimento criativo e científico é a troca de direitos de exclusivo, válidos temporariamente, pelo

\footnotetext{
1555 Cf. SCBD, UNEP/CBD/WG8J/5/3/Add.2, para. 48.

${ }^{1556}$ Cf. VON LEWINSKI, 2008, p. 117-120.

${ }^{1557}$ Cf. art. 5(2), CB.

${ }^{1558}$ Cf. SCBD, op.cit., para. 39.
} 
oferecimento à sociedade de acesso a novos conhecimentos e expressões culturais, responsáveis por fixar novos pontos de partida ao seu desenvolvimento cultural e científico. ${ }^{1559}$ Em nome da hipossuficiência das comunidades tradicionais e dos países em desenvolvimento, os regimes propostos na CCDB e OMPI propõe o afastamento dos pontos positivos dos regimes vigentes de PI. O resultado dessa postura será a criação de regimes de propriedade intelectual para o PBI mais desequilibrados que aqueles em vigor para a proteção de produções intelectuais, geradas na esfera da cultura ocidental.

Pelas razões indicadas no capítulo $3,{ }^{1560}$ o registro público dos RBIs objeto de proteção não deveria ser tratado como um obstáculo ao exercício de direitos, mas como uma medida hábil a fomentar seu desfrute pelos Estados e comunidades tradicionais. ${ }^{1561}$

\subsubsection{PROBLEMA IV: REIVINDICAÇÕES DE DIREITOS DE LONGO ALCANCE}

Palmilhando a mesma trilha dos regimes desequilibrados contemporâneos de PI, ${ }^{1562}$ os regimes internacionais propostos para a proteção dos RBIs - com algumas exceções (e.g. ECTs secretas) - perseguem a proteção legal tanto para a expressão e aplicação de idéias quanto para as idéias de per si, que as permeiam: ${ }^{1563}$ porquanto os RBIs são genericamente recursos informacionais brutos, que se apresentam em um estado mais ou menos distante de um produto pronto e acabado a ser introduzido no mercado, os detentores de RBIs reivindicam o poder de controlar não apenas o uso de seus RBIs na forma desenvolvida ou conservada por eles, mas também todos novos produtos e processos, resultantes do emprego direto ou indireto desses recursos, com o objetivo de extrair renda da exploração comercial indireta de seus RBIs e de controlar as condições em que serão aplicados. ${ }^{1564}$ Em outras palavras, os detentores de RBIs desejam que os regimes

${ }^{1559}$ Cf. EISENBERG, 2002, p. 419, 426.

${ }^{1560}$ Cf. $\S \S 1$ e 1.2 , item 3.2.1.4.1.

${ }^{1561}$ Cf. LUCAS-SCHLOETTER, 2004, p. 367.

${ }^{1562} \mathrm{Cf}$ § 1, item 3.2.1.2.1.

${ }^{1563}$ Ver, e.g., WIPO, WIPO/GRTKF/IC/12/5(b)), anexo, p. 130; DAES, 1997, para. 68, 70, 71, 130.

${ }^{1564}$ Ver, e.g., a Lei Modelo da Comunidade do Pacífico, que reconhece às comunidades tradicionais o direito de controlar qualquer transformação, adaptação e criação de produções científicas e artísticas derivadas de seus CTs e ECTs. Em outras palavras, o projeto reconhece a estes grupos o direito de impedir a comercialização, importação e exportação de produções derivadas de seus RBIs (SECRETARIAT OF THE PACIFIC COMMUNITY, 2002, art. $7^{\circ}$, alíneas (e) (h)). 
internacionais lhes confiram um direito de reivindicar proteção de longo alcance sobre seus RBIs. ${ }^{1565}$

No direito das patentes, as reivindicações de longo alcance (reach-through claim) conferem aos titulares de patentes que recaem sobre invenções de pré-mercado ${ }^{1566}$ um direito de propriedade, que se estende sobre todos os produtos resultantes da aplicação de sua invenção. ${ }^{1567}$

Um exemplo permitirá apreender a importância e os desafios envolvidos em se reconhecer direitos de longo alcance aos titulares de RBIs: uma empresa pode utilizar uma determinada associação entre um recurso biológico e um CT conexo como ponto de partida para um projeto de P\&D. O CTA sugere que dado recurso biológico é útil para a cura da leucemia. A empresa, após a realização de testes de bioatividade, descobriu que o recurso biológico estudado contém, em verdade, uma molécula com bioatividade para a cura da distrofia muscular. Nesta hipótese, a invenção foi desenvolvida mediante o uso de uma informação protegida (CTA), que indicou à empresa que o recurso biológico pesquisado apresentava alguma bioatividade. Sem embargo, o resultado final do processo de P\&D (nova droga para a distrofia muscular) não podia ser previsto a partir do mero exame dos RBIs absorvidos no processo de P\&D. ${ }^{1568}$ O CTA utilizado serviu como uma ferramenta de pesquisa para se alcançar a invenção, mas não continha em si a própria invenção desenvolvida. No contexto do exemplo apresentado, se os futuros regimes internacionais conferirem às comunidades tradicionais direitos de propriedade de longo alcance, a comunidade titular do CTA, utilizado indiretamente para o desenvolvimento da droga para o tratamento da distrofia muscular, teria direitos sobre este produto.

Uma subcategoria de reivindicação de longo alcance é a de quase-longo alcance (quasi reach-through claim). Neste caso, o titular do RBI e seu usuário podem prever, com segurança, que do RBI podem derivar novos produtos. ${ }^{1569} \mathrm{Na}$ hipótese de um recurso biológico fictício ser exitosamente aplicado por comunidades tradicionais para o

\footnotetext{
${ }^{1565}$ Ver, e.g., WIPO, WIPO/GRTKF/IC/2/3, para. 87; BOSTYN, 2007, p. 69.

${ }^{1566}$ Invenções de pré-mercado são aquelas, que não estão prontas ao comércio e ao consumo (KADLE, [200]); são usualmente empregadas no desenvolvimento de outras invenções, prontas ao mercado, e.g., reagentes e outras ferramentas de pesquisa.

${ }^{1567}$ Ver, e.g., HINDLE, 2005; VÉRON; MOUSSA, [200-], p.1-3.

1568 Cf. BRANTS, 2006.

${ }^{1569}$ Cf. CHRISTIE; LIM, 2005, p. 8.
} 
tratamento do diabetes, será possível prever, com alguma segurança, que o recurso biológico indicado contém ao menos uma molécula bioativa com capacidade para controlar os níveis de glicemia no homem. Sua identificação é uma mera questão de aplicação de recursos técnicos e tempo. O direito de adaptação conferido pelo projeto de disposições da OMPI às comunidades tradicionais sobre suas ECTs registradas configura um exemplo de direito de propriedade de quase-longo alcance, ao conferir às comunidades tradicionais o direito de controlar o resultado de todas as aplicações de suas ECTs registradas. ${ }^{1570}$

Sem surpresas, os países industrializados se mostram contrários às reivindicações de longo alcance. Neste sentido, Bostyn critica a investidura de um direito de propriedade de longo alcance nos provedores de recursos biológicos e CTAs, porquanto, em sua perspectiva limitada, tais provedores não desenvolveram qualquer atividade inventiva, que justifique o pagamento de benefícios. Segundo sua visão ilógica, o único vínculo que subsistiria entre os provedores de recursos biológicos e CTAs e o inventor é "o fato de que a invenção não teria sido realizada sem o acesso ao recurso genético original". ${ }^{1571}$ Ora, se um produto não existiria sem o uso de um determinado RBI, como julgar frágil uma reivindicação de longo alcance sobre produtos derivados desses recursos, quando, na esfera do direito das patentes, o emprego de invenções protegidas, no processo de desenvolvimento de um novo produto, depende da obtenção, pelo usuário subseqüente, de uma licença dos inventores que o antecedeu? ${ }^{1572}$

O principal objetivo das reivindicações de longo alcance é exatamente o de recompensar os Estados e comunidades tradicionais, cujos RBIs foram diretamente ou indiretamente benéficos ao desenvolvimento ou criação de algum novo produto. Porquanto os setores produtivos realizam modificações mais ou menos pronunciadas nos RBIs quando de sua utilização comercial, o reconhecimento de direitos em favor de comunidades tradicionais e Estados, apenas quando fossem utilizados inalteradamente ou com mínimas alterações, levaria ao esvaziamento de seus direitos. Este é exatamente o caso das ECTs secretas não-registradas: o projeto de disposições da OMPI propõe que as

\footnotetext{
${ }^{1570}$ No presente estudo, será empregado o termo reivindicação de longo alcance de maneira a englobar tanto a reivindicação de longo alcance propriamente dita quanto a reivindicação de quase longo alcance, ou seja, no sentido de que os direitos dos titulares de RBIs se estendem sobre os produtos derivados, direta ou indiretamente, de seus RBIs.

${ }^{1571}$ Cf. BOSTYN, 2007, p. 69, tradução nossa.

${ }^{1572}$ Ver, e.g., o art. 31(1), Acordo TRIPS, que disciplina o licenciamento compulsório de invenções utilizadas no desenvolvimento de uma nova invenção.
} 
comunidades tradicionais titulares dessa categoria de ECT não gozem de um direito de longo alcance. Conseqüentemente, terceiros poderiam utilizá-las como inspiração ou para a criação de obras derivadas, e as comunidades tradicionais não teriam o direito de receber qualquer remuneração pelo uso de suas ECTs. ${ }^{1573}$

Embora a posição ecoada por Bostyn seja discriminatória, reivindicações de longo alcance, quando associadas a um regime de direito de propriedade, podem engendrar graves problemas. Um primeiro aspecto negativo é a incerteza trazida aos usuários de RBIs, que não poderão explorar suas produções intelectuais derivadas, sem a autorização dos titulares dos RBIs utilizados. ${ }^{1574}$ Em outras palavras, as reivindicações de propriedade de longo alcance fragmentam a titularidade da nova produção intelectual derivada, abrindo espaço para a emergência de uma tragédia dos anticomuns.

Um segundo aspecto negativo se relaciona à possibilidade de uso de múltiplos RBIs no processo de criação ou desenvolvimento de um novo produto, e.g. a criação de uma obra artística que absorve ECTs de diferentes fontes. Nesse contexto, a investidura de direitos de propriedade de longo alcance nos detentores de RBIs encarece sobremaneira o lançamento de produtos que utilizam dois ou mais RBIs, podendo mesmo torná-los economicamente inviáveis.

Por fim, a associação de direitos de propriedade longo alcance com a supressão ou restrição do alcance das limitações aos direitos conferidos cria obstáculos intransponíveis à condução, inter alia, de pesquisas científicas e atividades educativas e criativas, envolvendo RBIs. ${ }^{1575}$ Surpreendentemente, as propostas de regimes de proteção para RBIs conferem mais poderes aos seus potenciais titulares de direitos que aqueles geralmente conferidos aos titulares de patentes de invenção e de direitos autorais.

\subsubsection{PROBLEMA V: INADEQUAÇÃO DAS LIMITAÇÕES AOS DIREITOS DE EXCLUSIVO}

${ }^{1573}$ Cf. WIPO, [200-]c., p. 23.

${ }^{1574}$ Cf. CHRISTIE; LIM, 2005, p. 3-4.

${ }^{1575}$ Cf. EISENBERG, 2002, p. 427-428. 
Os regimes de PI não excluem completamente terceiros não-autorizados do uso de bens intelectuais protegidos, porquanto a exclusão total seria inviável em termos legais, econômicos e técnicos.

Sob a ótica legal, qualquer regime, que exclua totalmente terceiros não-autorizados do uso de um bem intelectual protegido, infringiria os direitos de terceiros à privacidade $\mathrm{e}$ à liberdade de expressão criativa e científica. Por essa razão, os regimes de patentes tendem a oferecer ao público exceções de pesquisa, i.e. autorizam a condução de investigações que envolvam invenções patenteadas; os regimes de direitos autorais tendem a liberar o uso de obras literárias e artísticas para fins educativos, de pesquisa, informação do público. Sob as perspectivas técnica e econômica, não existe tecnologia que viabilize a repressão de todo e qualquer uso de um bem intangível por terceiros não-autorizados; e mesmo que houvesse, os custos seriam impraticáveis. ${ }^{1576}$ Afinal, qual o custo de monitorar mais de 6 bilhões de seres humanos?

As negociações em curso voltadas à proteção de RBIs caminham em sentido diverso. O regime internacional negociado no marco da $\mathrm{CDB}$ não oferece qualquer exceção aos direitos de exclusivo, investidos nos Estados e comunidades tradicionais. Já o projeto de disposições da OMPI para proteção de CTs autoriza terceiros a utilizar apenas CTs medicinais para fins de saúde pública e em âmbito doméstico; autoriza igualmente as comunidades tradicionais a conservarem suas práticas de intercâmbio intercomunitário de CTs.

A primeira limitação indicada oferece espaço para esvaziar o direito das comunidades tradicionais a receber benefícios pela exploração de seus CTs. Oferecer, inclusive aos países industrializados, a oportunidade de excluir do âmbito de proteção a aplicação de CTs para fins de saúde pública pode colocar em risco a própria viabilidade do sistema. Uma vez que cada Estado terá a prerrogativa de definir quais aplicações estarão fora do alcance do direito de exclusivo das comunidades, os países industrializados poderiam adotar limitações que impactarão nos interesses econômicos das comunidades tradicionais, e.g. a produção de medicamentos derivados de um determinado CT por uma empresa farmacêutica privada, sob encomenda do governo de um país industrializado, para

${ }^{1576}$ Cf. HUGHES, 1997, p. 130. 
sua distribuição na rede de saúde pública local. Por outro lado, condicionar o uso de CTs medicinais por organizações que prestam serviços públicos de saúde, em países pobres, à obtenção do CPLI das comunidades pertinentes, limitará a capacidade destes países de satisfazer as necessidades de seus cidadãos.

Quanto à segunda limitação, as trocas intercomunitárias de RBIs têm a capacidade de disseminá-los amplamente, abrindo espaço para que um número cada vez maior de grupos se veja na condição de cotitular de direitos sobre eles. Se os Estados optarem por um regime de propriedade anticomuns para a proteção de RBIs, sua associação à liberdade das comunidades tradicionais de disseminá-los livremente, acentuará ainda mais a probabilidade de emergência de uma tragédia dos anticomuns insuperável, em virtude do número cada vez maior de cotitulares de direitos. Comunidades tradicionais interessadas em extrair benefícios econômicos de seus RBIs, ao perceberem que a manutenção de suas práticas de intercâmbio intercomunitário gera obstáculos à celebração de acordos de acesso e repartição de benefícios, podem optar por alterar suas práticas e tradições.

A fim de superar o problema da tragédia dos anticomuns, seria uma alternativa conceder autonomia a cada comunidade tradicional, deixando de ser necessária a obtenção do CPLI de todos os potenciais grupos que compartilham um mesmo RBI. Nesta hipótese, as comunidades poderiam optar por desistir da prática de livre intercâmbio de RBIs, a fim de prevenir que outras comunidades concorressem com elas, na negociação de acordos de repartição de benefícios envolvendo seus RBIs. As comunidades que desejassem aceder aos RBIs de outras comunidades passariam a estar obrigadas a pagar pelos materiais e conhecimentos acessados, o que certamente limitaria o intercâmbio de RBIs. ${ }^{1577}$ Portanto, de uma forma ou de outra, a proteção de RBIs mediante um regime de propriedade, delineado com o objetivo de salvaguardar o livre intercâmbio intercomunitário de RBIs, incentivaria alterações de fato nesta tradição. ${ }^{1578}$

Por outro lado, a proibição pura e simples das práticas de livre intercâmbio intercomunitário, com o objetivo de minimizar as chances de emergência de uma tragédia

\footnotetext{
${ }^{1577}$ Cf. WIPO, 2001, p. 193.

${ }^{1578}$ Ver, e.g., FAUCHART; VON HIPPEL, 2006, p. 7; EISENBERG, 2001, p. 243.
} 
dos anticomuns, poria em risco a própria sobrevivência dos RBIs e das comunidades tradicionais que deles dependem. ${ }^{1579}$

O projeto de disposições da OMPI para a proteção de ECTs igualmente autoriza o livre intercâmbio intercomunitário de ECTs, bem como seu uso não-autorizado para fins de informação do público, ensino, pesquisa, preservação, desde que estes usos não sejam julgados ofensivos pelas comunidades pertinentes. Além dos problemas identificados, relacionados à expansão contínua do número de cotitulares de direitos, resultante das práticas de livre intercâmbio, o projeto da OMPI, ao mesmo tempo em que parece oferecer uma ampla liberdade de acesso às ECTs para fins não-comerciais, coloca o exercício desta "liberdade" nas mãos das comunidades tradicionais, ao lhes conferir a liberdade de se oporem a aplicações que as ofendam. Considerando que cabe às comunidades pertinentes determinar o que é ou não ofensivo segundo seus valores e opiniões, poderão silenciar vozes dissonantes. ${ }^{1580} \mathrm{Em}$ nome do respeito às diferenças culturais, o projeto da OMPI promoverá um absolutismo ético, marcado pela preponderância da visão das comunidades tradicionais sobre as demais. ${ }^{1581}$ Certamente esse não é o tipo de política que promoverá o tipo de diversidade cultural, que a comunidade internacional formalmente almeja.

\subsubsection{PROBLEMA VI: TERMO DE PROTEÇÃO}

Os regimes em discussão propõem ou a proteção dos RBIs perpetuamente (CDB), ou enquanto os RBIs forem tratados pelas comunidades pertinentes como um atributo de sua identidade cultural (OMPI), i.e. por tempo indeterminado. A idéia de proteção dos RBIs perpetuamente ou por tempo indeterminado, quando examinada em isolamento dos demais dispositivos que compõem as propostas de regimes internacionais, é facilmente justificável, sobretudo se os regimes propostos objetivarem a promoção de objetivos de natureza pública. ${ }^{1582}$ Podemos mencionar como um precedente nessa direção a Lei de Direitos Autorais, Desenhos Industriais e Patentes do Reino Unido, que confere ao Hospital Infantil Great Ormond Street, em Londres, o direito perpétuo de receber

\footnotetext{
${ }^{1579}$ Cf. SHIVA, 2001, p. 104.

${ }^{1580}$ Cf. BROWN, M., 1998, p. 199.

1581 Ibid., p. 199.

1582 Cf. BRUSH, 1994, p. 27-28.
} 
remuneração pela “interpretação pública, publicação comercial, radiodifusão ou inclusão em uma transmissão a cabo da peça 'Peter Pan', de autoria de James Matthew Barrie, ou por qualquer adaptação desta obra, embora os direitos autorais sobre a obra tenham expirado em 31 de dezembro de 1987". ${ }^{1583}$

Contudo, a proteção dos RBIs perpetuamente ou por um período indeterminado, quando examinada em face dos demais elementos dos regimes propostos (mecanismo de proteção calcado em direitos de propriedade, reivindicações de longo alcance, limitações inexistentes ou severamente reduzidas, ausência de registro obrigatório dos RBIs protegidos), teria o efeito de prevenir o uso produtivo, criativo, científico dos RBIs ou por tempo indeterminado (ECTs e CTs) ou permanentemente (recursos biológicos e CTAs), tornando mais pobre a base de insumos informacionais da sociedade. ${ }^{1584}$

\subsubsection{PROBLEMA VII: LIBERDADE CONTRATUAL}

Teoricamente, regimes de direito de propriedade oferecem às comunidades tradicionais e Estados nacionais a liberdade para negociarem com terceiros as condições, que regerão o uso de seus RBIs. ${ }^{1585}$ No entanto, a associação entre direito de propriedade e liberdade contratual está repleta de fraquezas.

No momento em que potenciais usuários se aproximam de Estados ou comunidades tradicionais para expressarem seu interesse em negociar um acordo de acesso aos seus RBIs, terão de explicitar os projetos que têm em mente, para que os titulares de direitos possam propor condições adequadas à natureza do projeto. ${ }^{1586}$ Compartilhar informações sigilosas sobre projetos em áreas sensíveis pode pôr em risco sua própria viabilidade, já que sempre pode haver um vazamento de informações. Potenciais usuários de RBIs podem optar por não assumir esse tipo de risco e descartá-los de seus projetos.

\footnotetext{
1583 Art. 301, United Kingdom Copyright, Designs and Patents Act 1988, tradução nossa.

${ }^{1584}$ Cf. WIPO, WIPO/GRTKF/IC/5/3, para. 28-29.

${ }^{1585}$ Cf. HASSEMER, 2004, p. 216.

${ }^{1586}$ Cf. SCOTCHMER, 1991, p. 36.
} 
Existe comumente uma assimetria de poder e de informação entre as comunidades tradicionais e os potenciais usuários de RBIs, que pode pressioná-las ou a autorizar seu uso mediante o pagamento de benefícios infinitesimais ${ }^{1587}$ ou a demandar benefícios nãorazoáveis, que embargam o andamento das negociações. A hipossuficiência das comunidades poderia ser minorado, se as negociações envolvessem obrigatoriamente a participação de antropólogos, vinculados a entidades respeitáveis, como a Sociedade Internacional de Etnobiologia. ${ }^{1588}$ Porém, a assessoria de profissionais que desconhecem a realidade dos setores industrial, cultural e científico poderia auxiliar as comunidades tradicionais apenas na apresentação de demandas não-razoáveis e inaceitáveis aos potenciais usuários.

Para evitar o embargo de usos produtivos de RBIs, os regimes poderiam permitir que seus usuários postergassem a negociação dos acordos de repartição benefícios para o momento em que houvesse um produto pronto a ser introduzido no mercado. ${ }^{1589}$ Contudo, essa opção igualmente geraria inconvenientes e obstáculos à liberdade criativa e científica: após o desenvolvimento de um novo produto, que pode ter consumido investimentos não desprezíveis, os titulares dos RBIs estarão na posição privilegiada de poder impedir sua entrada no mercado. Essas circunstâncias favorecem a imposição de condições leoninas aos usuários de RBIs, que podem tornar comercialmente desinteressante a introdução do novo produto no mercado, ou desestimular outras empresas a investir em projetos envolvendo RBIs. ${ }^{1590}$

Outro problema que a associação entre direitos de propriedade e contratos oferece é que, dependendo de como as normas locais são interpretadas, os usuários podem ter de celebrar o acordo de acesso e repartição de benefícios apenas com um dos coproprietários de um RBI, excluindo os demais do esquema de benefícios, ou com todos os coproprietários, o que impedirá o andamento das negociações.

\footnotetext{
${ }^{1587}$ Ver, e.g., LEISTNER, 2004, p.136; FERNANDO, 2003, p. 64.

${ }^{1588}$ Cf. SCBD, UNEP/CBD/WG8J/2/INF/1, para. 34-36.

${ }^{1589}$ No Brasil, por pressão das comunidades científica e industrial, o marco legal local que disciplina o acesso aos recursos da biodiversidade e aos CTAs permite a celebração do contrato de repartição de benefícios, decorrentes da exploração comeciais destes recursos, entre o usuário e o provedor, quando já existir um produto final, apto a ser introduzido no mercado (cf. BRASIL, Decreto no. 6.159/07).

${ }^{1590}$ Cf. SCOTCHMER, op.cit., p. 32-33.
} 
Ademais, como existem muitos RBIs publicamente acessíveis, há espaço para que os potenciais usuários destes recursos continuem a utilizá-los, de modo não ostensivo, sem a autorização de seus titulares. Na ausência de uma estrutura adequada de monitoramento de infrações, o direito de propriedade conferido será ineficaz.

\subsection{ALGUNS RESULTADOS ALCANÇADOS PELA IMPLEMENTAÇÃo DA CDB}

A CDB é o único acordo internacional em vigor que disciplina a proteção de duas categorias de RBIs, por intermédio do reconhecimento de direitos de propriedade, o que a torna numa fonte de experiência valiosa. Nestes mais de quinze anos, desde sua entrada em vigor internacional, países com grandes acervos de RBIs vêm seguindo a mesma receita: reconhecimento de direitos de propriedade aos Estados e comunidades tradicionais sobre, respectivamente, seus recursos biológicos e CTAs. As experiências nacionais alcançaram resultados muito similares, que não devem ser negligenciados pelos negociadores.

Com o objetivo de impedir a apropriação indébita dos CTAs e recursos da biodiversidade, as legislações nacionais e regionais dedicadas a assegurar o cumprimento da CDB tendem a conferir aos titulares de direitos poderes de controle excessivo sobre sua disseminação, dificultando aplicações mesmo para fins não-comerciais. Em termos gerais, pode-se afirmar que esses regimes restringem, substancialmente, ${ }^{1591}$ o acesso aos CTs e recursos biológicos pelos setores produtivos, ${ }^{1592}$ sua liberdade científica e criativa ${ }^{1593}$ e, naturalmente, a capacidade destes recursos gerarem benefícios econômicos e de outra natureza para a manutenção das comunidades tradicionais e da biodiversidade. ${ }^{1594}$ Brasil, Bolívia, Costa Rica, ${ }^{1595}$ China, Colômbia, ${ }^{1596}$ Equador, Índia, Peru, ${ }^{1597}$ Panamá, ${ }^{1598}$ Portugal, ${ }^{1599}$ Tailândia, ${ }^{1600}$ Venezuela, ${ }^{1601}$ Filipinas ${ }^{1602}$ são alguns dos países que já têm em

${ }^{1591}$ Cf. MULLER, 2004, p. 255 (o artigo menciona que a organização boliviana Fundación Amigos para la Naturaleza e o United States Department for Agriculture apresentaram uma solicitação de autorização de acesso a variedades selvagens de amendoim boliviano, que seriam coletadas e depositadas em bancos de germoplasma na Bolívia e no exterior, com o fim de conservá-los. O Governo da Bolívia não respondeu à solicitação de acesso, embora os proponentes tivessem preenchido os requisitos legais exigidos pelo marco legal local.

${ }^{1592}$ Cf. CARRIZOSA, 2004, p. 295 (este estudo examinou os resultados da implementação dos regimes de acesso a recursos biológicos da Costa Rica, EUA, México, Filipinas e Colômbia e concluiu que, no período entre 1991-2004, apenas 22 autorizações de acesso foram aprovadas, neste grupo de países).

1593 Cf. KOWALSKI; KRYDER, 2002, p. 53.

${ }^{1594}$ Ver, e.g., SAFRIN, 2004, p. 668; COX, 2001, p. 37.

1595 Cf. MEDAGLIA, 2004b, p. 207.

${ }^{1596}$ Ver, e.g., FAJARDO, 2004, p. 230; FERREIRA-MIANI, 2004. 
vigor regimes de propriedade para disciplinar a proteção de seus recursos biológicos e CTAs. Seus marcos legais produziram resultados econômicos pífios; ${ }^{1603}$ colocaram na clandestinidade pesquisadores sérios, que continuam a produzir cientificamente a despeito da falta de autorizações; ${ }^{1604}$ obstaculizaram a condução de atividades científicas sem fito comercial; ${ }^{1605} \mathrm{e}$, freqüentemente, esfriaram o interesse dos setores produtivo e científico em pesquisá-los, aprimorá-los e transformá-los em produtos não apenas rentáveis, mas acima de tudo úteis à humanidade. ${ }^{1606}$

Os maiores prejudicados pela adoção de regimes repressivos são os cientistas dos países em desenvolvimento. Contando com aportes financeiros muito limitados, não dispõem nem dos meios nem do tempo necessários para obterem todas as autorizações de acesso requeridas pelos marcos legais adotados nos últimos anos. ${ }^{1607}$ No fim, recursos escassos, muitas vezes provenientes de fontes públicas, são desviados dos laboratórios para os departamentos jurídicos envolvidos na solução de imbróglios legais. Neste diapasão, os advogados passaram a desempenhar um papel tão relevante para a ciência quanto os próprios cientistas. ${ }^{1608}$

\footnotetext{
${ }^{1597}$ Cf. COMUNIDAD ANDINA, Decisión 391, artigos 46-47; PERU, Ley 27.811/2002, artigos 42, 49 e 50.

1598 Cf; PANAMÁ, Ley no. 20, artigos 17-19.

1599 Cf. PORTUGAL, Decreto-Lei no. 118/2002, artigos 3(4), $7^{\circ}$ e 14.

1600 Cf. Tailândia, Act on protection and promotion of Traditional Thai Medicinal Intelligence, artigos 46, $52,73,77$.

${ }^{1601}$ Cf. CORREA, 2005 b.

1602 Cf. AGUILLON, 2007.

${ }^{1603}$ Cf. CARRIZOSA, 2004, p. 296.

${ }^{1604}$ Ver, e.g., BALAZINA, 2009; LEWINSOHN, 2009.

1605 Cf. PRATHAPAN et al., 2008 (O Biological Diversity Act da Índia estabeleceu um regime de acesso extremamente complicado, que inclusive criou obstáculos para a condução de pesquisas taxonômicas cujo objetivo é o desenvolvimento da ciência básica, sem qualquer fim comercial). Sobre os efeitos perversos do marco legal da Colômbia, que disciplina o acesso aos recursos da biodiversidade local, sobre o desenvolvimento científico e tecnológico deste país, a partir de seus recursos da biodiversidade ver DUARTE; VELHO, 2008 (o artigo indica, inter alia, que em dez anos, 1998-2008, apenas 12 autorizações de acesso a recursos da biodiversidade colombiana, foram autorizados pela autoridade local)

1606 Ver, por exemplo, LOUWAARS et al., 2006 (o artigo trata dos obstáculos ao desenvolvimento de pesquisas agronômicas, a partir da transposição da CDB aos ordenamentos jurídicos domésticos); GRAJAL, 1999, p.8 (sublinha que a implementação da CDB nos países andinos, mediante a adoção de um regime de propriedade, diminuiu o ritmo de pesquisas taxonômicas na região); IZIQUE; DE OLIVEIRA, 2006 (trata dos efeitos negativos da edição da Medida Provisória 2.186-16 sobre os negócios da empresa Extracta, no que tange ao desenvolvimento de novas moléculas bioativas derivadas dos recursos da biodiversidade brasileira); HAMILTON, 2003, p. 12, 44-45 (trata de experiências legais nacionais, que limitaram sobremaneira o acesso aos recursos da biodiversidade, mesmo para a condução de projetos de pesquisa taxonômica); REVKIN, 2002.

${ }^{1607}$ Cf. GRAJAL, 1999, p.7. A título de exemplo, no caso UNIFESP-Krahô, a pesquisadora Eliana Rodrigues levou quase três anos para obter todas as autorizações necessárias para a condução da pesquisa de campo, sem as quais não poderia realizar sua tese de doutoramento. A UNIFESP, por sua vez, consumiu quase três anos para tentar obter (sem sucesso) as autorizações das 18 comunidades, que compõem a etnia Krahô.

${ }^{1608}$ Cf. BROWN, G. p. 1.
} 
Em face das dificuldades para se acessar legalmente recursos biológicos e CTAs, o que ocorre é que os pesquisadores de países em desenvolvimento estão deixando de conduzir pesquisas com RBIs de países cujas legislações são restritivas, ${ }^{1609}$ ou passaram a não compartilhar os resultados das pesquisas que realizam a respeito de RBIs utilizados sem autorização. Nos dois cenários, é sempre a sociedade quem perde, pois sem pesquisa e sem difusão do conhecimento, o ritmo de desenvolvimento científico e industrial diminui. ${ }^{1610}$

Os resultados alcançados por essas legislações vão contra as expectativas dos países ricos em termos bioculturais, que imaginavam que o interesse dos setores industriais pelos CTAs e recursos biológicos os instigaria a se subordinar a regimes legais desequilibrados. Apesar desses resultados decepcionantes, Argentina, ${ }^{1611}$ a Organização da Unidade Africana ${ }^{1612}$ e o Secretariado da Comunidade do Pacífico em conjunto com o Fórum das Ilhas do Pacífico ${ }^{1613}$ propuseram projetos legislativos de proteção de RBIs apoiados no direito da propriedade.

Os regimes em vigor, por envolverem custos de transação altíssimos, se mostram discriminatórios, pois são acessíveis somente àqueles usuários capazes de suportar seus custos (grandes conglomerados empresariais). Pequenas e médias empresas e instituições acabam excluídas da oportunidade de acessar licitamente recursos biológicos e CTAs, ${ }^{1614}$ porquanto não dispõem dos recursos financeiros para se envolverem em longos processos burocráticos, cujos resultados são incertos. Em decorrência dos custos envolvidos no processo de acesso a recursos biológicos e CTAs, as empresas continuarão a priorizar seus investimentos em produtos altamente lucrativos, enquanto as necessidades e interesses das populações mais pobres, que poderiam ser satisfeitas por meio do desenvolvimento de produtos e serviços derivados de RBIs, permanecerão negligenciados. ${ }^{1615}$

\footnotetext{
${ }^{1609}$ Cf. SAFRIN, 2004, p. 670.

${ }^{1610}$ Cf. GRAJAL, 1999, p.8.

${ }^{1611}$ Cf. ARGENTINA, 2002, art. $6^{\circ}$ e seguintes.

1612 Cf. ORGANIZATION OF AFRICAN UNITY, 2000, artigos 5o, 18-20.

${ }^{1613}$ Cf. SECRETARIAT OF THE PACIFIC COMMUNITY, 2002.

${ }^{1614}$ Cf. CARRIZOSA, 2004, p. 297.

${ }^{1615}$ Cf. DUBOCK, 2005, p. 5-6.
} 
Os regimes que disciplinam o acesso a recursos biológicos e CTAs alteraram o enfoque da CDB. Sob a ótica dessas legislações, a CDB deixou de ter como objetivo principal a conservação da biodiversidade para se transformar em mais um acordo comercial, centrado na geração de benefícios econômicos. ${ }^{1616}$ A experiência de implementação da CDB nos remete de volta ao período pré-Estocolmo, quando o crescimento econômico puro e simples era tratado como sinônimo de desenvolvimento. Contraditoriamente, apesar da valorização de objetivos econômicos, as legislações em vigor, ao invés de facilitarem o acesso produtivo a recursos biológicos e CTAs (fatogerador de qualquer benefício econômico), estabelecem regras ultra-restritivas que o inibe.

Como resultado das dificuldades enfrentadas pelos potenciais usuários de recursos biológicos e CTAs a partir da implementação da CDB em âmbito doméstico, não é sábio ignorar que a alocação de direitos de propriedade em favor de comunidades tradicionais e Estados impôs obstáculos à inovação e à criatividade, sem trazer quaisquer benefícios palpáveis aos novos titulares de direitos. Uma vez alocados direitos de propriedade sobre estes RBIs, com grande dificuldade ocorrem transações que os transfiram àquelas melhor capacitadas a extrair seus melhores benefícios sociais e econômicos. ${ }^{1617}$

\subsubsection{AVALIAÇÃO DA ADEQUAÇÃO DAS PROPOSTAS EM CONSTRUÇÃO E DEBATES NA CDB E OMPI EM FACE DOS QUATRO CRITÉRIOS DE OPERACIONALIZAÇÃO DO QUADRO CONCEITUAL DE DESENVOLVIMENTO SUSTENTÁVEL}

\subsubsection{CRITÉRIOS DE OPERACIONALIZAÇÃO 1 E 2}

Direito de acesso amplo e facilitado ao PBI pelas comunidades tradicionais e sociedade em geral; e geração de benefícios econômicos no curto, médio e longo prazo, a serem revertidos em favor da conservação da biodiversidade e da melhoria da qualidade de vida das comunidades tradicionais

Antes de partirmos para a avaliação, cumpre-nos esclarecer que trataremos conjuntamente dos critérios de operacionalização 1 e 2, tendo em vista que o direito de acesso é uma condição sem a qual a geração de benefícios econômicos derivados dos RBIs é inviável.

${ }^{1616}$ Cf. MEDAGLIA, 2004a, p. 119.

${ }^{1617}$ Cf. EISENBERG, 2001, p. 226. 
A idéia de um direito de propriedade absoluto, tal como cristalizada na famosa definição de Blackstone -"that sole and despotic dominion which one man claims and exercises over the external things of the world, in total exclusion of the right of any other individual in the universe" - é tratada como fantasiosa e destacada da realidade, porquanto qualquer direito de propriedade estaria sujeito a diversas limitações, voltadas a reconciliar interesses privados com os de ordem pública. ${ }^{1618}$ No entanto, os negociadores envolvidos na construção de um marco legal internacional para a proteção dos RBIs, freqüentemente, se pautam pelo parâmetro irreal de Blackstone, sem atentarem para as conseqüências que advirão sobre o desenvolvimento científico e cultural da sociedade e sobre a própria sobrevivência dos recursos e grupos humanos que se propõem a proteger. Se se substituir, na definição de Blackstone, o termo "homem" (man) por "comunidade" ou "Estado", terse-á a essência das propostas discutidas.

Fundamentalmente, as poucas "limitações" oferecidas aos direitos de exclusivo conferidos aos detentores de RBIs ou submetem seu exercício à vontade dos titulares de direitos ${ }^{1619}$ ou visam a resguardar as práticas das comunidades tradicionais de disseminar e intercambiar livremente seus RBIs. ${ }^{1620}$ Embora necessária, esta última limitação produzirá algum dos dois efeitos negativos: Disseminará amplamente os RBIs e, reflexamente, incrementará continuamente o número de codetentores dos mesmos RBIs e das chances de emergência de uma tragédia dos anticomuns, na hipótese dos regimes adotados condicionarem seu acesso à obtenção da autorização de todos codetentores. Alternativamente, o livre intercâmbio de RBIs conduzirá à emergência de uma competição entre os codetentores de um mesmo RBI, na hipótese dos regimes adotados conferirem a cada um a liberdade para licenciar seus recursos, independentemente da vontade dos demais cotitulares. Em ambos os casos, a geração de incentivos econômicos será embargada.

Contraditoriamente, ao mesmo tempo em que os regimes examinados conferem amplos direitos de exclusão aos titulares, excluem de seu escopo CTs associados ou não à

\footnotetext{
${ }^{1618}$ Ver, e.g., HELLER, 2000, p. 419; LAMETTI, 2003, p. 365-369.

1619 Cf. WIPO, Disposiciones revisadas para la protección de las expresiones culturales tradicionales/expresiones del folclore, art. 5(a), in fine.

1620 Cf. WIPO, Disposiciones revisadas para la protección de las expresiones culturales tradicionales/expresiones del folclore, art. 5(a)(i); WIPO, Revised provisions for the protection of traditional knowledge, art. 8(1)(i).
} 
biodiversidade e ECTs compartilhados por grandes contingentes humanos. A conservação destes RBIs em domínio público incentivará terceiros a utilizá-los para fins produtivos, porquanto gratuitos, em detrimento daqueles outros sujeitos aos regimes de proteção.

A fim de tornar o sistema mais adequado às necessidades dos usuários, poder-se-ia oferecer ao público amplas limitações aos direitos de exclusivo conferidos e/ou limitar temporalmente seu termo de proteção. ${ }^{1621}$ No entanto, limitações de amplo alcance restringiriam sobremaneira as oportunidades dos titulares de direitos de receberem uma retribuição pelo uso produtivo de seus RBIs. A fixação de um termo de proteção limitado, por sua vez, poderia estimular potenciais usuários a aguardarem sua expiração para, então, explorá-los livremente. Por outro lado, em caso de adoção de um regime de propriedade anticomuns com duração ilimitada, o uso de limitações de alcance restrito atacaria permanentemente a liberdade de expressão criativa e inventiva da sociedade.

Com o objetivo de promover atividades científicas envolvendo RBIs (sem fins lucrativos), poder-se-ia estabelecer normas de acesso facilitado para estes fins, em comparação com as regras que disciplinam seu acesso para fins comerciais. No entanto, na prática esta diferença não teria qualquer valia, já que, no presente, centros de investigação, com freqüência, se envolvem em atividades de pesquisa aplicada. ${ }^{1622}$ No fim, a partir do momento que estas instituições desenvolvessem um possível produto com potencial econômico, teriam de assumir o risco das negociações voltadas à obtenção de uma licença para exploração do novo produto não chegarem a lugar algum. Este não é o cenário em que investimentos de recursos cada vez mais escassos são realizados. No mais, esta diferenciação se equivoca ao estabelecer regras restritivas para atividades comerciais, quando em verdade, sem aplicações econômicas, não será possível derivar recursos indispensáveis para a promoção da diversidade biocultural.

Ainda que a multiplicidade de titulares de um mesmo RBI e a amplitude dos direitos conferidos não criassem quaisquer embaraços ao funcionamento dos regimes propostos, a ausência de um registro público obrigatório, que ensejasse a identificação

1621 Ver, e.g., SCOTCHMER, 1991, p. 35; WIPO, WIPO/GRTKF/IC/12/5(b), anexo, p. 33 (posição do Japão).

${ }^{1622}$ Cf. GRAJAL, 1999, p. 7. 
clara daquilo que é protegido e da identidade dos cotitulares de direitos, ${ }^{1623}$ dificultaria a negociação de acordos de licenciamento e, ainda, colocaria a sociedade em geral na posição insegura de não saber ao acerto o que pode ou não ser livremente utilizado.

Portanto, as propostas examinadas propõem alterações em um número importante de elementos centrais dos regimes convencionais de PI, com o propósito de afastar os obstáculos que impedem sua aplicação para a proteção de RBIs, sem atentarem para os resultados dessas alterações sobre seu funcionamento (quadro 4). Estas alterações culminaram na criação de regimes híbridos de propriedade intelectual, ${ }^{1624}$ porquanto assentados sobre a associação de elementos do regime de patentes, do de direitos autorais e de outros elementos dissociados destes dois paradigmas.

Quadro 5: Elementos alterados nas propostas de regime de propriedade para RBIs em relação aos regimes convencionais de proteção da PI

\begin{tabular}{|l|l|l|}
\hline $\begin{array}{c}\text { Elementos } \\
\text { alterados pelas } \\
\text { propostas de } \\
\text { proteção dos RBIs }\end{array}$ & $\begin{array}{l}\text { Regimes } \\
\text { convencionais de } \\
\text { PI }\end{array}$ & $\begin{array}{l}\text { Propostas de } \\
\text { regimes de } \\
\text { propriedade } \\
\text { intelectual para } \\
\text { proteção de RBIs }\end{array}$ \\
\hline Matéria de proteção & $\begin{array}{l}\text { Expressão e } \\
\text { execução de idéias }\end{array}$ & $\begin{array}{l}\text { Proteção das } \\
\text { expressões e } \\
\text { execuções de idéias } \\
\text { e das idéias } \\
\text { subjacentes }\end{array}$ \\
\hline $\begin{array}{l}\text { Limitações aos } \\
\text { direitos conferidos }\end{array}$ & $\begin{array}{l}\text { Presença de } \\
\text { limitações } \\
\text { dedicadas à } \\
\text { proteção da } \\
\text { liberdade de } \\
\text { expressão criativa e } \\
\text { científica de } \\
\text { terceiros }\end{array}$ & $\begin{array}{l}\text { Inexistência ou } \\
\text { presença de } \\
\text { limitações } \\
\text { aplicáveis } \\
\text { restritivamente, } \\
\text { especialmente } \\
\text { dedicadas à } \\
\text { proteção das } \\
\text { práticas das } \\
\text { comunidades } \\
\text { tradicionais de livre } \\
\text { intercâmbio de } \\
\text { RBIs. }\end{array}$ \\
\hline Termo de proteção & Limitado & $\begin{array}{l}\text { Perpétuo ou } \\
\text { indeterminado }\end{array}$ \\
\hline Condição & Registro prévio ou & Desnecessidade de \\
\hline
\end{tabular}

${ }^{1623}$ Cf. BIBER-KLEMM, 2006, p. 158.

${ }^{1624}$ Cf. WESTKAMP, 2005, p. 114. 


\begin{tabular}{|c|c|c|}
\hline & $\begin{array}{l}\text { fixação em um } \\
\text { substrato } \\
\text { permanente ou } \\
\text { semipermanente }\end{array}$ & $\begin{array}{l}\text { registro ou fixação } \\
\text { em um substrato } \\
\text { permanente ou } \\
\text { semipermanente }\end{array}$ \\
\hline Direitos morais & $\begin{array}{l}\text { Reconhecimento de } \\
\text { direitos morais de } \\
\text { paternidade e } \\
\text { integridade para } \\
\text { obras literárias e } \\
\text { artísticas e } \\
\text { reconhecimento de } \\
\text { um direito moral de } \\
\text { paternidade para as } \\
\text { produções técnicas. }\end{array}$ & $\begin{array}{l}\text { Reconhecimento de } \\
\text { direitos morais de } \\
\text { paternidade e } \\
\text { integridade tanto } \\
\text { para CTs quanto } \\
\text { para ECTs. }\end{array}$ \\
\hline
\end{tabular}

O acesso a um recurso tutelado por direitos de propriedade envolve a identificação de seu conteúdo e limites e do proprietário pela parte interessada; a instauração de um processo de negociação entre o proprietário e o potencial usuário e, uma vez alcançado um acordo, sua cristalização em um contrato. ${ }^{1625}$ Os custos envolvidos neste processo são geralmente altos para objetos bem delineados, cujos titulares são facilmente identificáveis. Mas para RBIs, cuja titularidade e a própria existência não é facilmente determinável, os custos de transação tornam impraticável sua alocação para os fins mais produtivos, ${ }^{1626}$ congelando a capacidade de evolução criativa e inventiva da sociedade. ${ }^{1627}$ Isto tudo porque as propostas examinadas centralizam sua atenção nos poderes dos detentores de RBIs de impedir sua apropriação indébita, ${ }^{1628}$ enquanto negligenciam os imperativos de satisfazer as demandas dos setores industrial, científico e cultural de acessar ampla e facilitadamente estes recursos a fim de ativar o fato-gerador de recursos materiais para a conservação da diversidade biocultural.

Concluindo, os regimes propostos na CCDB e OMPI, calcados em direitos de propriedade, não preenchem a condição de assegurar o direito de uso amplo e facilitado aos RBIs protegidos pelos setores produtivos da sociedade, ao mesmo tempo em que conservam em domínio público os chamados CTs e ECTs populares. Neste contexto, o espaço para que esses regimes venham a gerar algum benefício econômico no curto, médio

\footnotetext{
1625 Cf. COASE, 1960, p. 7.

1626 Ver, e.g., BELL; PARCHOMOVSKY, 2002, p. 5-6; DAVID; FORAY, 2002, p. 18-19; MACHLUP; PENROSE, 1950, p. 24.

${ }_{1627}$ Ver, e.g., BOYLE, 2003a, p. 17; EUROPEAN COMMUNITY, 2002, p. 1-2.

${ }^{1628}$ Cf. HEATH; WEIDLICH, 2003, p. 90.
} 
e longo prazo é mínimo. Ainda que esses regimes sejam estruturados de maneira a evitar uma tragédia dos anticomuns, os potenciais benefícios materiais reversíveis aos titulares de direitos seriam irrelevantes, como resultado da multiplicidade de fontes de RBIs a que poderiam recorrer os usuários.

Assumindo que os regimes propostos não conduzissem nem à uma tragédia dos anticomuns nem ao achatamento dos benefícios econômicos devidos aos detentores de RBIs, ainda assim, ao menos a proposta em construção no marco da CDB seria portadora de falhas, quando avaliada em face do quadro conceitual de desenvolvimento. O esqueleto da proposta de RI, em seu estado atual, não obriga a reversão dos benefícios derivados da exploração de recursos biológicos e CTAs para a conservação das diversidades biológica e cultural. A conservação do PBI não defluirá automaticamente do pagamento de benefícios econômicos às comunidades tradicionais e Estados; é fundamental vincular seu recebimento à sua aplicação na conservação da biodiversidade e na realização dos direitos humanos dos membros das comunidades tradicionais.

Em suma, embora um regime de acesso aberto aos RBIs não tenha gerado quaisquer incentivos para a sua conservação, não será a adoção de um regime promotor da restrição do acesso a todas as categorias de RBIs que criará as condições necessárias para a proteção multidimensional do $\mathrm{PBI}{ }^{1629}$ Muito pelo contrário. Os custos de transação produzidos pelos regimes examinados transformarão os RBIs em uma riqueza inacessível e improdutiva. Não vivemos em uma realidade de custos de transação zero, onde independentemente da eficiência das alocações iniciais dos direitos de propriedade, seus titulares sempre alcançarão a alocação mais produtiva para seus recursos. ${ }^{1630}$ Portanto, os envolvidos nas negociações de regimes de proteção de RBIs devem atentar para os obstáculos que as propostas podem para transferir os RBIs aos fins mais produtivos, sob a perspectiva social e econômica.

\subsubsection{CRITÉRIO DE OPERACIONALIZAÇÃo 3}

Reconhecimento às comunidades tradicionais de um direito moral de atribuição e de um direito moral de integridade em relação às ECTs sagradas

${ }^{1629}$ Ver, e.g., COLANGELO, 2004, p. 6; KANSA; SCHULTZ; BISSELL, KANSA, 2005, p. 19.
${ }^{1630}$ Cf. EPSTEIN, 1993, p. 555-556. 
A proposta de regime internacional, em negociação no marco da $\mathrm{CDB}$, não confere às comunidades tradicionais um direito moral de atribuição, quando utilizados publicamente por terceiros. No entanto, ao propugnar que lhes seja reconhecido um direito de controle total desses RBIs, esses grupos poderiam demandar dos usuários a atribuição da fonte destes recursos, em todas as formas de aplicação.

Os projetos de disposições da OMPI explicitamente conferem às comunidades tradicionais direitos morais de atribuição e de oposição aos usos culturalmente desrespeitosos de ECTs sagradas e CTs, cabendo às comunidades determinar quais usos infringiriam seus valores culturais. O projeto, por um lado, acerta ao reconhecer às comunidades tradicionais o direito de prevenir usos desrespeitosos de ECTs sagradas, mas se equivoca ao estendê-lo também aos RBIs de natureza técnica (CTs), porquanto tal prerrogativa poderia ser usada para impedir o desenvolvimento científico da humanidade, a partir da investigação e aprimoramento do know-how desses grupos.

Concluímos nossa análise reiterando que se, por um lado, o direito da propriedade é inadequado para a proteção de RBIs laicos, porquanto seu valor social apenas se realiza quando amplamente aplicados por comunidades tradicionais e pelos setores produtivos da sociedade dominante, por outro lado, o mesmo mecanismo mostra-se adequado a tutelar ECTs sagradas contra usos culturalmente desrespeitosos, ainda que o regime conduza à uma tragédia dos anticomuns. Isto por que, neste último caso, o objetivo central perseguido pelas comunidades é impedir a livre disseminação desta categoria de ECTs fora de contextos comunitários.

\subsubsection{CRITÉRIO DE OPERACIONALIZAÇÃO 4}

Efetividade dos regimes de proteção em escala global

Os elementos que compõem a base para o futuro regime internacional, dedicado à proteção dos recursos da biodiversidade e dos CTs conexos, em construção no marco da CDB, e as propostas de disposições da OMPI para a proteção de CTs e ECTs advogam pelo estabelecimento de agências, investidas na competência de facilitar a observância dos direitos dos titulares sobre os RBIs. A proposta OMPI para a proteção de CTs não é clara a respeito das características da agência; possivelmente, ela exerceria as funções de uma 
OGD, especialmente porque este é o tipo de organização mais adequado para a gestão de bens intelectuais tutelados por direitos de propriedade, ao permitir que seus titulares fixem individualmente as condições, sob as quais eles poderão ser licenciados. A suposta OGD seria competente para apoiar as comunidades tradicionais na negociação e celebração de acordos de licenciamento; no monitoramento de infrações; na propositura de ações judiciais contra potenciais infratores, sempre que sua ajuda fosse solicitada.

Já o projeto de disposições da OMPI para ECTs e a proposta-base de regime internacional associado à CDB determina, com clareza, a criação de uma OGD, competente para apoiar as comunidades tradicionais e os Estados no processo de negociação de acordos de licenciamento; auxiliá-los no monitoramento de infrações aos seus direitos e na defesa de seus direitos. ${ }^{1631}$

Embora uma agência de apoio às comunidades tradicionais seja um elemento indispensável ao bom funcionamento dos futuros regimes internacionais, uma simples OGD não seria capaz de superar as dificuldades trazidas pelos projetos em negociação na CCDB e na OMPI. Primeiramente, porque muitas agências governamentais de países em desenvolvimento não teriam os recursos para identificar, de modo independente, infrações de direitos, já que não controlam os meios técnicos para avaliar casos de apropriação indébita, quando os RBIs forem profundamente modificados por processos técnicos. Muitas comunidades tradicionais tampouco possuiriam os meios para se deslocarem até as organizações em busca auxílio, em caso de supostas infrações. Se a agência de apoio não for munida de um banco de dados, com informações claras, completas e atualizadas sobre todos os RBIs protegidos, ${ }^{1632}$ muitos atos de apropriação indébita continuarão a ocorrer.

Como reflexo da inexistência de um registro público obrigatório para os RBIs, bem como das grandes chances de emergência de uma tragédia dos anticomuns ou do achatamento dos benefícios econômicos, poucos acordos de licenciamento seriam celebrados e quando celebrados, seriam pouco rentáveis. Mas se os RBIs não gerarem renda, a OGD não teria os meios para ser autosustentável. Assim, ao menos que os Estados injetem continuamente recursos para apoiar seu funcionamento, sua vida útil seria curta.

1631 Cf. WIPO, Disposiciones revisadas para la protección de las expresiones culturales tradicionales/expresiones del folclore, art. $4^{\circ}$.

${ }_{1632} \mathrm{O}$ projeto de disposições da OMPI para ECTs limita-se a demandar o registro de ECTs portadoras de um valor moral ou espiritual singular (art. 3(a)). 
No contexto presente de crise mundial, é presumível que os Estados dêem preferência a regimes capazes de alcançar autosustentabilidade.

Ainda que os Estados optem por tornar obrigatório o registro dos RBIs protegidos e invistam na organização de gestão a competência para exercer os direitos associados àqueles RBIs compartilhados por duas ou mais comunidades nacionais, com o fito de superar os obstáculos ao seu uso, na hipótese destes recursos serem compartilhados por dois ou mais Estados (recursos biológicos) ou por duas ou mais comunidades (CTs e ECTs), domiciliadas em países diferentes, persistirá o espaço para a emergência de concorrência interestatal ou intercomunitária. Para atrair o interesse de potenciais licenciados, os detentores de um mesmo RBI se veriam pressionados a reduzir as taxas de royalties, derrubando, assim, as perspectivas de geração de benefícios, em níveis adequados. Portanto, para evitar a concorrência entre codetentores de um mesmo RBI, é fundamental um regime que demande a união de todos eles (inclusive os baseados em países diversos), sob os auspícios de uma única organização de gestão de direitos.

Em suma, os regimes examinados, assentados sobre direitos de propriedade, ainda que apoiados por uma OGD, não seriam apto a promover simultaneamente o acesso amplo e facilitado aos RBIs, nem gerar benefícios econômicos e impedir atos de apropriação indébita.

\subsubsection{OMC: PROPOSTA dOS PAÍSES EM DESENVOLVIMENTO DE EMENDA DO ACORdo TRIPS}

Apesar dos termos inclusivos presentes na Declaração Ministerial de Doha, que incluiu, no mandato de negociação da Rodada Doha, o exame da relação entre o Acordo TRIPS e a CDB e a proteção dos CTs e das ECTs, ${ }^{1633}$ os países em desenvolvimento priorizaram a solução para o conflito entre a CDB e o capítulo de patentes do Acordo TRIPS. O Brasil e outros países em desenvolvimento, ${ }^{1634}$ com fundamento na experiência

\footnotetext{
${ }^{1633}$ Cf. WTO, WT/MIN(01)/DEC/1, para. 19.

1634 Dentre eles, o Grupo Africano, o Grupo dos Países Menos Desenvolvidos, China, Colômbia, Cuba, República Dominicana, Equador, Índia, Ilhas Maurício, Paquistão, Paraguai, Peru, Tailândia, Tanzânia, Venezuela. Atualmente, 80 dos 153 Estados membros da OMC apóiam a proposta (MARA; NEW, 2008).
} 
legislativa de um número importante de países, ${ }^{1635}$ propuseram, em 2006, uma emenda ao Acordo TRIPS (art. 29 bis), que visa a transformá-lo em uma ferramenta de exigibilidade da $\mathrm{CDB}^{1636}$ e de prevenção da concessão de patentes de baixa qualidade. ${ }^{1637}$ Nos termos da proposta, a concessão de patentes pelos Estados membros da OMC para invenções que direta ou indiretamente empreguem recursos biológicos e/ou CTAs seria condicionada ao cumprimento, pelo depositante da patente, de três condições:

Condição I: Divulgação da fonte provedora do recurso biológico e, quando for o caso, do CTA utilizado, bem como de seu país de origem. País de origem é entendido como o país, onde o recurso biológico existe naturalmente em condições in situ ou o país que o obteve legalmente de seu país de origem; ${ }^{1638}$ e, no que concerne aos CTAs, o país de domicílio das comunidades tradicionais titulares dos CTAs utilizados. Os países em desenvolvimento demandam a divulgação do país de origem dos recursos biológicos e dos CTAs utilizados no desenvolvimento de invenções e não simplesmente a fonte imediata do recurso/conhecimento, e.g. uma determinada coleção ex situ ou revista científica.

Haveria a obrigação de divulgação de origem dos recursos biológicos e/ou CTAs sempre que forem utilizados direta e substancialmente no desenvolvimento da invenção reivindicada; configurarem uma condição para o desenvolvimento da invenção; facilitarem seu desenvolvimento; ou tiverem sido utilizados como ferramentas para se chegar à invenção final. ${ }^{1639}$ Em outras palavras, sempre que esses recursos forem utilizados em alguma fase de desenvolvimento de uma invenção, ainda que de maneira incidental, haveria a obrigação de divulgação de sua origem. ${ }^{1640}$

Condição II: Apresentação de provas de que o usuário obteve o CPLI do país de origem do recurso biológico e/ou da comunidade tradicional provedora de CTAs, em conformidade com o disposto nas legislações nacionais pertinentes.

1635 Ver COMUNIDAD ANDINA, Decisión 486, art. 26(h)(i); PARLAMENTO EUROPEU, Diretiva 98/44/CE, parágrafo preambular no. 27. Sobre as legislações da África do Sul, Brasil, Costa Rica, Dinamarca, Egito, Espanha, Filipinas, Índia, Noruega, Nova Zelândia, Romênia, Suécia, Venezuela, consultar, e.g., WTO, IP/C/W/447; BLAKENEY, 2005; HOARE, 2006. Sobre a legislação chinesa, ver GRAIN, 2008c.

${ }^{1636}$ Ver, e.g., WTO, IP/C/W/474; WIPO, WIPO/GRTKF/IC/12/8(a), para. 9; WTO, IP/C/W/438, para. 5.

${ }^{1637}$ Cf. WTO, IP/C/W/434, para. 5.

${ }^{1638}$ Id., IP/C/W/470, para. 4.

${ }^{1639}$ Ver, e.g., WTO, IP/C/W/429, para. 8; WTO, IP/C/W/475, para. 9-11.

${ }^{1640}$ Cf. WTO, IP/C/M/46, para. 47. 
Condição III: Apresentação de evidências de que o usuário repartiu ou repartirá benefícios com os países e/ou comunidades provedoras, e.g. apresentação do contrato de repartição de benefícios. ${ }^{1641} \mathrm{Na}$ hipótese do marco legal do país provedor não obrigar o potencial usuário a obter o CPLI e a repartir benefícios com os Estados e/ou comunidades provedoras, o usuário apresentará uma declaração dos provedores confirmando esta informação. ${ }^{1642}$

Nos termos da proposta, em caso de descumprimento dessas obrigações, o pedido de patente não seria processado até que cumpridas integralmente. Se a patente já tiver sido concedida e, se for descoberto que as informações prestadas pelo titular da patente eram falsas ou incompletas, a patente poderá ter sua exigibilidade suspensa, ficando liberado seu uso por terceiros não-autorizados. Alternativamente, a patente poderá ser revogada, na hipótese das informações incorretas ou incompletas tiverem sido prestadas com objetivos fraudulentos, ou se a falta de informações impediu a autoridade de patentes de determinar corretamente a patenteabilidade da invenção. ${ }^{1643}$

Os fundamentos do art. 29bis proposto estão no próprio Acordo TRIPS, que autoriza os Estados membros da OMC a adotarem regimes de patentes, que reconciliem os interesses dos inventores com interesses públicos. ${ }^{1644}$ No entanto, o Acordo TRIPS limitase a oferecer aos seus Estados contratantes uma prerrogativa; o art. 29bis proposto pretende alterar o quadro de prerrogativas das partes do TRIPS, ao tornar obrigatória a adoção de medidas protetoras de interesses ambientais e humanos.

A fim de superar os malefícios trazidos por uma possível omissão legislativa na esfera nacional, o art. 29bis, se adotado, fixaria as obrigações mínimas que qualquer usuário de recursos biológicos e CTAs, originários de algum Estado membro da $\mathrm{OMC}$, teria de observar, caso o país-fonte destes RBIs não contasse com um marco legal para a matéria. $^{1645}$

\footnotetext{
${ }^{1641}$ Id., IP/C/W/442, para. 3-10.

${ }^{1642} \mathrm{Id}$., IP/C/W/475, para. 23-24.

${ }^{1643} \mathrm{Id}$., IP/C/W/429, para. 13.

${ }^{1644} \mathrm{Cf}$. artigos $7^{\circ}$ e $8^{\circ}$, Acordo TRIPS.

${ }^{1645}$ Ver, e.g., WTO, IP/C/W/438, para. 12; WTO, IP/C/W/442, para. 11.
} 
A proposta de emenda do Acordo TRIPS não goza de uma vida independente, figurando apenas como um dos elementos de um possível regime legal internacional voltado à proteção dos recursos biológicos e CTAs contra atos de apropriação indébita. ${ }^{1646}$ Essa proposta deve ser examinada em conjunto com aquelas em negociação no marco da CDB e OMPI, pois objetiva essencialmente torná-las exigíveis internacionalmente. Visto em isolamento, o art. 29bis proposto não parece contar com problemas. Mas quando examinado em associação com aquelas propostas que vão ganhando corpo na OMPI e CCDB, é possível inferir um número de problemas, capazes de prevenir sua adoção.

\subsubsection{SUPOSTOS BENEFÍCIOS E REAIS PROBLEMAS DO PROPOSTO ART. 29BIS}

Os proponentes da emenda do art. 29 do Acordo TRIPS defendem sua adoção como medida de compatibilização deste acordo com a CDB, com fundamento nas razões a seguir tratadas.

\subsection{FÁCIL CUMPRIMENTO DAS OBRIGAÇÕES}

Segundo os proponentes da emenda, as exigências previstas no art. 29bis seriam facilmente cumpridas pelos depositantes de patentes e trariam a vantagem de estimular a criação de um ambiente seguro e transparente para uma aproximação construtiva entre, de um lado, os países em desenvolvimento e comunidades tradicionais e, do outro, os setores usuários de recursos biológicos e CTAs. ${ }^{1647}$

É equivocado considerar que as obrigações enunciadas na proposta seriam cumpridas sem dificuldades pelos depositantes de patentes, porquanto os países detentores de diversidade biocultural contariam com carta branca para estabelecerem regimes domésticos de proteção de seus recursos biológicos e CTAs. É de se prever que os Estados membros da OMC adotariam as propostas em construção na esfera da CDB e da OMPI, já que o art. 29bis proposto se assenta sobre o princípio do CPLI. As conseqüências da

\footnotetext{
${ }^{1646}$ Cf. CORREA, 2005a, p. 13.

${ }^{1647}$ Cf. WTO, IP/C/W/356, para. 13.
} 
adoção destes regimes serão danosas à conservação multidimensional do PBI, conforme visto nas seções anteriores deste capítulo.

Os proponentes da emenda ao Acordo TRIPS julgam ser uma tarefa simples a obtenção do CPLI dos provedores de CTAs e recursos biológicos, ${ }^{1648}$ o que, em verdade, pode envolver um processo tremendamente complexo. Conforme discutido anteriormente, um usuário de um CTA poderia obter o CPLI de uma dada comunidade tradicional e, mais tarde, receber reivindicações de outras comunidades tradicionais, que compartilham o mesmo conhecimento. Havendo dúvidas sobre a validade do CPLI obtido, um processo judicial ou administrativo poderia ser instaurado no país onde foi depositado o pedido de patente, o que sobrestaria seu processamento ou, se a patente já tiver sido concedida, sua exigibilidade. A autoridade julgadora pode chegar à conclusão de que o usuário do CTA agiu de boa-fé, não lhe exigindo a observância de novas obrigações. ${ }^{1649}$ Mas até se chegar a esse ponto, quanto tempo terá fluído? Até que a decisão final sobre a validade do CPLI sobrevenha, ninguém saberá ao certo se o pedido de patente virá a ser processado ou se a patente já concedida se conservará válida. Nesse contexto de insegurança, o titular do pedido/patente possivelmente não terá interesse em investir em sua exploração nem terceiros em licenciá-la.

Não se quer com isso defender que toda proposta que gere custos aos usuários de RBIs deva ser descartada. Certamente, quaisquer propostas trarão encargos. Do mesmo modo que os países em desenvolvimento assumiram o pesado ônus associado ao Acordo TRIPS, é previsível que a adoção de um marco legal internacional de proteção para o PBI obrigará a comunidade internacional a assumir custos associados à sua transposição para a esfera doméstica. ${ }^{1650} \mathrm{O}$ problema é a qualidade do ônus imposto pelo novo regime: se criar obstáculos ao desenvolvimento econômico, social, cultural e tecnológico e impedir a geração de benefícios materiais, sem os quais a tarefa de conservação da diversidade biocultural será inviável, certamente será um ônus injustificável.

\footnotetext{
${ }^{1648}$ Cf. WTO, IP/C/W/470, para. 7.

1649 Ibid., para. 6.

${ }^{1650}$ Id., IP/C/W/368/Rev.1, para. 150.
} 


\subsection{ECONOMIA DOS RECURSOS ESCASSOS DOS PAÍSES EM DESENVOLVIMENTO}

Segundo os proponentes da emenda, o mecanismo incorporado ao art. 29bis facilitaria a observância transnacional dos marcos legais nacionais, que disciplinam o acesso aos recursos da biodiversidade e aos CTAs, e evitaria que recursos escassos de países em desenvolvimento fossem despendidos em procedimentos administrativos e judiciais, relacionados à revogação de patentes que recaem sobre invenções assentadas sobre recursos biológicos e CTAs ilicitamente acessados. ${ }^{1651}$

Os proponentes ignoram que, na hipótese da proposta ser aprovada, os países em desenvolvimento precisarão incorrer em custos vultosos de monitoramento das patentes depositadas em todo o mundo (ou ao menos perante os escritórios de patentes dos mercados mais importantes), para se assegurarem que os depositantes de patentes respeitaram as obrigações previstas em suas legislações.

A emenda do art. 29 tampouco impedirá a emergência de litígios nacionais e internacionais envolvendo sua observância pelos depositantes de patentes. No mais, sempre haverá espaços para a prática de fraudes, que certamente será ampliado na ausência de uma estrutura funcional de monitoramento do cumprimento das obrigações.

\subsection{SEGURANÇA JURÍDICA E TRANSPARÊNCIA}

$\mathrm{Na}$ perspectiva dos proponentes da emenda, o mecanismo traria transparência às relações entre usuários de RBIs e provedores, ao estabelecer obrigações comuns a todos os Estados membros da OMC. ${ }^{1652}$ Segundo os proponentes do art. 29bis, o estabelecimento de um denominador comum para todos os regimes de proteção dos CTAs e recursos biológicos permitiria a harmonização internacional dos pilares de sustentação destes regimes e a redução dos custos de transação envolvidos no acesso a estes recursos. ${ }^{1653}$ No mais, a emenda traria segurança jurídica aos provedores de CTAs e recursos da

\footnotetext{
${ }^{1651}$ Ver, e.g., WTO, IP/C/W/356, para. 12; WTO, IP/C/W/484, para. 15. ${ }^{1652}$ Ver, e.g., WTO, IP/C/W/443, para. 9; WTO, IP/C/W/459, para. 10.

${ }^{1653}$ Cf. WTO, IP/C/W/443, para. 24.
} 
biodiversidade, ao conferir a um órgão central - a OMC - o papel de autoridade central de monitoramento da observância do regime e de solução de possíveis litígios. ${ }^{1654}$

O estabelecimento de algumas obrigações mínimas que os usuários de CTAs e recursos biológicos deveriam cumprir, a fim de obterem patentes associadas a estes recursos, não é suficiente para trazer transparência e previsibilidade aos regimes nacionais. Com base nos termos do art. 29bis, é sabido que esses regimes nacionais terão como pilares o CPLI dos provedores de recursos biológicos e CTAs e a obrigação de repartição de benefícios "justos e equitativos", mas a proposta é omissa sobre como essas obrigações deverão ser cumpridas: CPLI de quem? Em que consiste uma repartição "justa e equitativa"? E o que é mais grave, a proposta não define o que sejam recursos biológicos e CTAs.

Assim, apesar dos patamares mínimos fixados pela proposta, pontos importantes permanecem em aberto e os regimes nacionais de proteção dos recursos biológicos e CTAs diferirão uns dos outros. No fim, se a proposta de emenda do Acordo TRIPS for adotada, teremos uma colcha de retalhos legal, que trará insegurança jurídica aos usuários dessas categorias de RBIs e ainda instaurará uma competição entre os titulares de CTAs e recursos biológicos não-exclusivos.

Quanto ao papel da OMC no funcionamento do mecanismo proposto, diferentemente do argumentado pelos proponentes, o funcionamento do mecanismo proposto dependeria da intervenção das autoridades administrativas e judiciais de múltiplas jurisdições. O sistema de solução de controvérsias da OMC opera apenas para a solução de litígios interestatais, por exemplo, na hipótese de um membro da OMC não transpor ao seu ordenamento jurídico o art. 29bis. Em caso de práticas fraudulentas e inobservância das obrigações insculpidas no art. 29bis por parte de titulares de patentes, concedidas em algum dos Estados membros da OMC, os provedores dos RBIs apropriados ilicitamente terão de recorrer às autoridades locais dos países pertinentes para assegurar o respeito aos seus direitos.

${ }^{1654}$ Id., IP/C/W/459, para. 10. 


\subsection{MELHORIA DA QUALIDADE DAS PATENTES CONCEDIDAS}

O dispositivo proposto reprimiria a prática de atos de apropriação indébita de CTAs e recursos biológicos mediante patentes, ao facilitar o trabalho dos examinadores de patentes. $^{1655}$

Nos pedidos de patentes de invenção, o depositante tem a obrigação de descrever a invenção; e caracterizar o estado da técnica existente até o momento do depósito, a novidade da invenção e o passo inventivo, envolvido em seu desenvolvimento. Na perspectiva dos proponentes da emenda do Acordo TRIPS, a divulgação da origem dos CTs e recursos biológicos utilizados ensejaria o aprimoramento do processo de exame das condições substantivas de patenteabilidade, prevenindo a concessão de patentes que não as cumprirem. ${ }^{1656}$

A repressão das práticas de apropriação desses RBIs por meio do sistema de patentes dificilmente seria alcançável, na ausência de um banco de dados, acessível aos escritórios de patentes de todo o mundo (inclusive em termos lingüísticos), que congregue os CTAs de todas as comunidades tradicionais do mundo, de maneira suficientemente clara e completa, bem como os componentes intangíveis de todos os recursos biológicos da Terra, caracterizadas molecularmente.

Um titular de um pedido de patente que recaia sobre uma invenção, derivada de um CTA e/ou recurso biológico, pode optar por omitir que utilizou RBIs no processo de P\&D, porquanto a ciência desconhece grande parte dos recursos biológicos existentes e do arcabouço cultural das inúmeras comunidades tradicionais, que se espalham por todos os biomas, bem como em virtude do fato de que as invenções reivindicadas podem diferir substancialmente dos RBIs dos quais derivam. ${ }^{1657}$ Assim sendo, ao menos que as comunidades e os Estados prejudicados tenham provas cabais que atestem a prática de um ato de apropriação indébita, não terão os meios de derrubar o argumento de que a invenção foi desenvolvida por meios independentes, sem o uso de recursos biológicos e CTAs acessados ilicitamente.

\footnotetext{
${ }^{1655} \mathrm{Cf}$. WTO, IP/C/W/356, para. 15.

${ }^{1656}$ Cf. SCBD, UNEP/CBD/WG8J/5/INF/10, para. 8.

${ }^{1657}$ Cf. WTO, IP/C/W/447, p. 5.
} 
Embora existam alguns bancos de dados de CTAs, desconhecemos a existência de inventários internacionais que identifiquem os componentes intangíveis dos recursos da biodiversidade. Para a organização um inventário desta natureza, os países em desenvolvimento precisariam realizar investimentos maciços para inventariar seus recursos biológicos e seus componentes intangíveis; caracterizar suas estruturas moleculares e identificar suas aplicações industriais e; finalmente, agregá-los a bancos de dados mundialmente acessíveis. A realização de um projeto dessa magnitude depende de investimentos de grande monta e de mão-de-obra qualificada, recursos que muitos países em desenvolvimento não possuem. Ainda que os tivessem, bancos de dados com as características mencionadas teria como principal utilidade prevenir a concessão de patentes sobre invenções, desenvolvidas com RBIs apropriados ilicitamente. Investimentos dessa monta são desproporcionais à utilidade dos benefícios reais gerados às comunidades tradicionais e países em desenvolvimento.

Portanto, mesmo que a divulgação de origem viabilizasse a identificação de informações presentes no estado da técnica, relacionadas aos recursos biológicos e CTAs absorvidos pela invenção reivindicada, tal exigência seria de pouca valia para impugnar a validade de patentes concedidas sobre invenções derivadas destes RBIs. O art. 27(1) do Acordo TRIPS oferece aos Estados contratantes a discricionariedade para determinar quando uma invenção será nova e inventiva, não sendo lícito impedi-los de tutelar invenções que, sob a ótica das comunidades tradicionais e dos países em desenvolvimento, não são nem novas nem inventivas. ${ }^{1658}$ Uma solução para os conflitos entre o Acordo TRIPS e a CDB deve fazê-lo com a menor interferência possível no regime internacional de propriedade intelectual, sob pena da proposta não ter espaço para prosperar, em virtude do poder concentrado pelos grupos que representam os titulares de DPIs.

\section{§1 INUTILIDADE DA DIVULGAÇÃO DE ORIGEM PARA A AVALIAÇÃO DA NOVIDADE}

Para avaliar se uma invenção apresenta novidade, o examinador de patente compara o objeto do pedido de patente com as invenções encontradas no estado da técnica

\footnotetext{
${ }^{1658}$ Ver, e.g., WTO, IP/C/W/472, para. 44; WTO, IP/C/M/43, para. 40.
} 
pertinente. Havendo identidade entre a invenção reivindicada e a invenção que integra o estado da técnica, aquela não será nova. ${ }^{1659}$

Quando o marco legal de patentes de um Estado determina que pertence ao estado da técnica os conhecimentos disponibilizados, em forma escrita, originários de qualquer lugar do mundo, o examinador de patentes, encarregado de avaliar a patenteabilidade de uma invenção derivada de um recurso biológico $\mathrm{X}$, pesquisará amplamente o estado da técnica associado a este RBI, não se limitando a buscar informações técnicas associadas ao recurso biológico $\mathrm{X}$, originário do país indicado, no pedido de patente, como seu país de origem. Isto porque, é presumível que todas as amostras deste recurso biológico sejam portadoras das mesmas características técnicas, independentemente de sua origem. Por outro lado, quando o marco legal de um Estado determina pertencer ao seu estado da técnica apenas aqueles conhecimentos disponibilizados em seu território nacional, o examinador de patentes se limitará a explorar os bancos de dados nacionais, que poderão conter informações sobre recursos biológicos locais ou de outros Estados. Nesta hipótese, o examinador de patentes não poderá recorrer a fontes de informações técnicas de outros países. Portanto, na prática, é irrelevante a divulgação da origem do recurso biológico para a determinação da novidade da invenção que o utilize. ${ }^{1660}$

Ainda que os recursos biológicos intangíveis e os CTAs integrassem, genericamente, o estado da técnica, haveria espaço para os setores produtivos contornarem a falta de novidade de invenções baseadas substancialmente nestes RBIs. Muitos países industrializados, e dia-a-dia, um número maior de países em desenvolvimento estão concedendo patentes para invenções que integram o estado da técnica, mas para as quais foram identificadas novas aplicações. Essas reivindicações são conhecidas como reivindicações de segundo uso ou de tipo Suíço ${ }^{1661}$ e retiram sua novidade da nova aplicação de uma invenção antiga. Um exemplo famoso é o medicamento comercializado com a marca comercial Viagra (citrato de Sildanafil). Originalmente, esta droga foi desenvolvida para o tratamento de doenças cardiovasculares; no presente, é comercializado para tratamento de disfunção erétil.

\footnotetext{
${ }^{1659}$ Cf. WTO, IP/C/W/472, para. 57.

${ }^{1660} \mathrm{Id} ., \mathrm{IP} / \mathrm{C} / \mathrm{W} / 472$, para. 49-51, 53-55.

${ }^{1661}$ Cf. CORREA; SHABALALA, 2007.
} 


\section{§2 INUTILIDADE DA DIVULGAÇÃO DE ORIGEM PARA A AVALIAÇÃO DO PASSO INVENTIVO}

Se a invenção reivindicada passar pelo teste da novidade, o examinador terá de verificar se a invenção envolve um passo inventivo. Para isso, levantará o estado da técnica associado à invenção reivindicada e identificará as similitudes e diferenças existentes entre eles. Em um segundo momento, conjugará o estado da técnica relacionado à invenção reivindicada com as técnicas comuns ao setor tecnológico pertinente, com o objetivo de se munir de ferramentas para responder à seguinte pergunta: um técnico que atua na área relacionada à invenção reivindicada a teria desenvolvido, com facilidade, em face da realidade técnica presente? Em caso negativo, a invenção envolveria um passo inventivo. ${ }^{1662} \mathrm{~A}$ divulgação da origem do recurso biológico e/ou CTA utilizados, porquanto não oferece qualquer informação sobre as características técnicas destes RBIs, não facilita o trabalho de determinação da inventividade da invenção reivindicada. ${ }^{1663}$

O caso da patente norte-americana US 5.401.504, que reivindicava proteção para a aplicação da cúrcuma indiana como cicatrizante, ilustra a inadequação do requisito de divulgação de origem dos recursos biológicos para se impedir a concessão de patentes sobre invenções que abusivamente se apropriam de recursos biológicos e CTAs. ${ }^{1664} \mathrm{~A}$ referida patente foi, equivocadamente, concedida pelo USPTO, em virtude de seu desconhecimento a respeito da existência de um determinado CT milenar da Índia, relacionado à aplicação medicinal da cúrcuma. $\mathrm{O}$ pedido de patente fazia referência inequívoca à origem indiana da cúrcuma; no entanto, não sendo tal informação pertinente para a determinação da novidade e da inventividade da invenção, o USPTO concedeu a patente. $^{1665}$

Tacitamente, os países em desenvolvimento parecem crer que os escritórios de patentes, ao receberem pedidos de patentes que reivindiquem proteção para uma invenção biotecnológica, a partir das informações indicadas sobre a origem do recurso biológico e/ou do CTA utilizado, sairiam em busca dos RBIs supostamente utilizados a fim de compará-los com a invenção efetivamente reivindicada e, então, determinar sua novidade e inventividade. Certamente, tal visão é fantasiosa. A obrigação de divulgação da origem

\footnotetext{
${ }^{1662}$ Cf. WTO, IP/C/W/472, para. 59

${ }^{1663}$ Ibid., para. 65.

${ }^{1664} \mathrm{Cf}$. WTO, IP/C/M/49, para. 102.

${ }^{1665}$ Ibid.
} 
ofereceria aos examinadores de patentes, no máximo, uma sugestão para buscarem maiores informações a respeito da invenção reivindicada. Considerando que, no presente, o processo de exame de pedidos de patentes já não é capaz nem mesmo de cobrir todas as revistas e materiais científicos disponibilizados no mundo, é irrealista presumir que as autoridades de patentes sairão em busca de informações inacessíveis em seus bancos de dados técnicos, apenas porque o pedido de patente divulgou a origem do recurso biológico e/ou CTA utilizado no processo de P\&D. ${ }^{1666}$ E uma vez que os escritórios de patentes vêm dirigindo suas atividades para incrementar a produtividade de seus examinadores, negligenciando a qualidade das patentes concedidas, é de se esperar que não buscarão mais informações do que aquelas ordinariamente já empregadas em seu trabalho diário. ${ }^{1667}$

Por fim, é válido reiterar que não existe um número suficiente de bancos de dados sobre CTAs, disponibilizados em língua inglesa e em formato acessível pelos escritórios de patentes. Se um dos objetivos do artigo 29bis é prevenir a concessão de patentes improcedentes, a melhor solução para o problema é o estabelecimento de bancos de dados públicos sobre CTAs e elementos intangíveis dos recursos biológicos. Ao menos que informações técnicas a respeito de CTAs e recursos da biodiversidade estejam centralizadas em bancos de dados públicos, será impossível a um examinador de patentes obter informações a esse respeito, no momento da realização do exame dos pedidos, se disponibilizadas apenas oralmente. ${ }^{1668}$

Considerando a discricionariedade fruída pelos Estados membros da OMC de definirem o que é invenção e os critérios substantivos de patenteabilidade; a prática dos escritórios de patentes dos países industrializados de conceder proteção a invenções, que ostentam níveis cada vez mais baixos de inventividade e novidade; e a dificuldade de se vencer litígios técnicos relacionados à validade de patentes apenas com informações orais, seria mais produtivo que os países em desenvolvimento transferissem as discussões sobre medidas voltadas ao aprimoramento da qualidade das patentes para o Comitê sobre

${ }_{1666} \mathrm{Cf}$. WTO, IP/C/W/472, para. 31.

1667 O sindicato dos funcionários do Escritório Europeu de Patentes (EEP) vem criticando a política do Escritório de excessiva valorização da produtividade dos examinadores de patentes, em detrimento da qualidade das patentes concedidas (STAFF UNION OF THE EUROPEAN PATENT OFFICE, 2006). A mesma organização divulgou, em 2004, uma pesquisa conduzida junto aos funcionários do EEP a respeito da qualidade das patentes por ele concedidas. 72,57\% dos entrevistados respondeu que houve uma queda na qualidade das patentes concedidas no biênio, 2002-2004 (STAFF UNION OF THE EUROPEAN PATENT OFFICE, 2004).

${ }^{1668} \mathrm{Cf}$. WTO, IP/C/M/49, para. 23-24. 
Desenvolvimento e Propriedade Intelectual da OMPI, que é o órgão competente para implementar a Agenda do Desenvolvimento desta organização, e passassem a enfocar na criação de um regime de proteção positiva dos CTAs, apto a engendrar, em favor das comunidades tradicionais e dos países ricos em termos bioculturais, as condições materiais para perseguirem seu desenvolvimento sustentável.

\subsection{AMPLIAÇÃO DA PARTICIPAÇÃO DAS COMUNIDADES TRADICIONAIS NO PROCESSO DE EXAME DE PATENTES}

$\mathrm{Na}$ perspectiva dos proponentes, a emenda do art. 29 permitiria que indivíduos, conhecedores dos RBIs incorporados ilicitamente à invenção reivindicada, tomassem conhecimento dos pedidos depositados e, assim, apresentassem subsídios técnicos aos examinadores de patentes, que ensejariam a aferição da novidade e da inventividade da invenção reivindicada. ${ }^{1669}$

É uma quimera crer que esse objetivo seria facilmente atingível: em regra geral, comunidades tradicionais não detêm recursos para contratarem profissionais habilitados a examinar o conteúdo das reivindicações, arroladas em pedidos de patentes, em face de seus CTAs e recursos biológicos. E ainda que tivessem tal capacidade, os subsídios apresentados teriam de comprovar que seus CTAs e recursos biológicos de fato integram o estado da técnica, ou seja, que a invenção tradicional foi divulgada publicamente, de maneira suficientemente clara e detalhada, ao ponto de permitir que um técnico, portador de conhecimentos da área pertinente à invenção, possa reproduzi-la com independência. ${ }^{1670}$ A mera divulgação de origem dos recursos biológicos e CTAs, empregados no desenvolvimento de uma invenção, não traz consigo informações técnicas imprescindíveis para a impugnação da validade de uma invenção, com fundamento em sua falta de novidade ou inventividade.

Por fim, ainda que os subsídios apresentados lograssem revogar um patente ou impedir a concessão de um pedido de patente, a aplicação de uma sanção desta natureza atacaria a oportunidade das comunidades tradicionais e dos países provedores de recursos

\footnotetext{
${ }^{1669}$ Cf. WTO, IP/C/W/403, para. 6, 10, 11.
}

${ }^{1670}$ Cf. HUFT, 1994-1995, p. 1721. 
biológicos de receberem benefícios econômicos pelos aportes oferecidos, haja vista que as patentes costumam ser o instrumento-padrão, utilizado pela indústria para proteger seus investimentos: ${ }^{1671}$ Nos termos da proposta de emenda do Acordo TRIPS, uma vez suspenso o processamento de um pedido de patente depositado ou revogada uma patente já vigente, terceiros não-autorizados desfrutariam da liberdade para explorar as invenções - e conseqüentemente, os RBIs apropriados -, naqueles mercados que estiverem fora do alcance das autoridades dos Estados de origem destes RBIs. ${ }^{1672}$ Assim sendo, o art. 29bis promoveria uma nova distorção comercial mediante a criação de um ambiente inóspito à proteção da inovação, o que conduziria à perda de investimentos em $P \& D$ e facilitaria a apropriação tanto de CTAs e recursos biológicos como das invenções que os utilizaram.

Em face do imperativo de geração de recursos econômicos em prol do desenvolvimento sustentável das comunidades tradicionais e da conservação da biodiversidade, a sanção mais adequada seria aquela que, ao invés de impedir a obtenção de patentes ou sua exigibilidade, obrigasse seu titular a remunerar adequadamente os titulares dos RBIs utilizados sem-autorização.

\subsubsection{OUTRAS CRÍTICAS À PROPOSTA DE ART. 29BIS}

\subsection{CARÁTER DISCRIMINATÓRIO}

A proposta é discriminatória com os usuários de CTAs e recursos biológicos que recorrem ao sistema de patentes para proteger suas inovações e investimentos, ao não estabelecer qualquer vínculo entre, de um lado, os regimes internacionais, regionais e nacionais de proteção de variedades vegetais (e.g. os acordos da UPOV) e, do outro, a CDB.

\footnotetext{
${ }^{1671}$ Cf. WIPO, WIPO/GRTKF/IC/7/15, para. 198 (a Biotechnology Industry Organization (BIO), em uma intervenção realizada em uma reunião do CIG da OMPI, deixou claro que propostas de reforma do regime de patentes, que criem obstáculos à proteção das invenções desenvolvidas pela indústria da biotecnológica, são inaceitáveis).

${ }^{1672}$ Cf.WTO, IP/C/W/434, para. 10
} 
Tampouco lida com o fato de que CTAs e recursos biológicos podem ser apropriados mediante a comercialização de produtos, sobre os quais não recaem patentes. ${ }^{1673}$ Embora existam exemplos de apropriações lucrativas de recursos biológicos e CTAs por meio de patentes, a verdade é que uma patente não é sinônimo de sucesso comercial, sendo possível que produtos comercialmente lucrativos não venham a ser patenteados. ${ }^{1674}$ Nos termos da proposta de emenda, no caso de um produto não-patenteado compreender recursos biológicos e/ou CTAs apropriados indebitamente, seus titulares terão de tolerar sua comercialização, salvo se forem comercializados em um Estado que conte com legislação dedicada à reprimir a apropriação indébita de CTs e recursos biológicos.

Os Estados proponentes da emenda do Acordo TRIPS poderiam contra-argumentar que uma solução complementar já está sendo negociada na OMPI e na CCDB. No entanto, qualquer solução legal alcançada nesses foros será mais fraca que uma adotada na esfera da OMC. Sabidamente, as normas que integram o sistema OMC contam com um sistema de solução de controvérsias, que assegura sua observância por todos os membros da organização. Logo, ao proporem uma solução tão limitada, os países em desenvolvimento estão deixando escapar a oportunidade de realmente superar o problema da apropriação indébita de seus RBIs.

\subsection{EXCLUSÃO DOS CTAS POPULARES}

Vista a proposta de emenda em conjunto com o projeto de disposições da OMPI para a proteção de CTs e o esqueleto de regime internacional, em construção no marco da $\mathrm{CDB}$, os CTAs populares, i.e. aqueles compartilhados por grandes contingentes humanos, estariam fora de seu escopo.

\subsection{EXCLUSÃO DAS ECTS DO ESCOPO DA PROPOSTA DE EMENDA DO ACORDO TRIPS}

A proposta injustificadamente exclui de seu escopo as ECTs, embora apresentem valor comercial. Uma proposta de emenda mais abrangente é advogada por William Fisher,

${ }^{1673} \mathrm{Cf}$. WTO, IP/C/W/449, para. 22.

${ }^{1674}$ Cf. BOSTYN, 2007, p. 82. 
que recomendou a inserção no Acordo TRIPS de três cláusulas, que autorizariam a suspensão da exigibilidade de patentes, direitos autorais e marcas comerciais, protegidos nos países membros da OMC, sempre que derivassem substancialmente de RBIs e fossem empregados em violação às normas de algum Estado membro da OMC. ${ }^{1675}$

Em comum com o art. 29bis proposto, o ponto fraco da proposta de Fisher é o oferecimento aos Estados membros da OMC de uma ampla discricionariedade para a adoção de regimes legais de proteção de RBIs. Essa discricionariedade não seria necessariamente mal utilizada, mas poderia ser empregada para a adoção de regimes de propriedade, que, conforme visto anteriormente, freqüentemente superlimitam o uso lícito dos RBIs e, por conseguinte, atividades criativas, inventivas e comerciais.

No mesmo diapasão da proposta de Fisher, o Grupo Africano apresentou, na OMC, uma proposta mais abrangente de regime de proteção para o PBI. A proposta africana estabelece um feixe de direitos, investido nos detentores de CTs e ECTs, e obrigações mínimas que os Estados membros da OMC deveriam observar, ao definirem os critérios substantivos de patenteabilidade. O Grupo Africano propugnou a investidura nos detentores de CTs e ECTs de um feixe de direitos, composto pelas prerrogativas de: ${ }^{1676}$

i. $\quad$ Controlar sua comercialização e qualquer tipo de uso destes RBIs;

ii. Ter respeitados por terceiros os aspectos espirituais associados aos seus CTs e ECTs;

iii. Receber uma remuneração pelo uso de seus CTs e ECTs;

iv. Impedir terceiros de usar, oferecer à venda, comercializar, exportar e importar seus CTs e ECTs ou qualquer artigo que os agregue, desde que não obtido o CPLI das comunidades pertinentes.

A proposta africana advoga também pela limitação da liberdade dos Estados membros da OMC de determinar as condições substantivas de proteção para invenções e obras literárias e artísticas, que utilizarem respectivamente, CTs e ECTs. Nos termos da proposta, "[a] presença de conhecimentos tradicionais, em qualquer forma ou em qualquer estágio, deverá impugnar a novidade e inventividade para propósitos de patentes e a

${ }^{1675}$ Cf. FISHER, 2007.

${ }^{1676}$ Cf. WTO, IP/C/W/404, p.7-9 (itens 2(c)e 6(a)(c)). 
originalidade para propósitos de direitos autorais, sob as leis de todos os Membros". ${ }^{1677}$ Pode-se inferir dos termos da proposta, que mesmo conhecimentos técnicos e expressões artísticas secretas seriam hábeis a impugnar a validade de uma patente ou de um direito autoral, uma vez que a proteção dos CTs e ECTs independeria de qualquer registro. ${ }^{1678}$

Se por um lado, a proposta salvaguardaria os detentores de RBIs de atos de apropriação indébita de seus recursos sagrados e secretos, por outro, abriria amplos espaços para condutas fraudulentas, já que membros de minorias poderiam construir os termos de suas reivindicações de direitos com base nas características das produções intelectuais criadas pelos supostos infratores de seus direitos.

A expansão do escopo da emenda do Acordo TRIPS é indispensável para se alcançar uma proteção inclusiva para o PBI. No entanto, a fim de compatibilizar sua proteção com as necessidades dos usuários destes recursos - tal como exigido pelo art. $7^{\circ}$ próprio Acordo TRIPS ${ }^{1679}$ - é igualmente indispensável que a emenda determine os elementos fundamentais dos regimes nacionais ou regionais de proteção dos RBIs, com vistas a viabilizar seu acesso amplo pelas comunidades tradicionais e setores produtivos e a proteção das produções intelectuais derivadas dos RBIs. Em outras palavras, uma emenda ao Acordo TRIPS deve propor um regime que confira proteção positiva aos RBIs.

\subsubsection{4 "FORUM SHOPPING"}

A proposta de emenda ao Acordo TRIPS ignora que recursos biológicos e CTAs freqüentemente são compartilhados por duas ou mais comunidades ou Estados. Haja vista que a proposta dos países em desenvolvimento oferece aos Estados membros da OMC certa liberdade para estruturarem seus regimes regulatórios de acesso aos recursos biológicos e CTAs, poderão surgir conflitos entre comunidades tradicionais e Estados, sempre que um mesmo CTA e/ou recurso biológico for compartilhado, respectivamente,

${ }^{1677}$ Cf. WTO, IP/C/W/404, p.7 (itens 2(d)).

1678 Ibid., p. 8, (item 4(a)).

${ }^{1679}$ O Acordo TRIPS determina, como seu objetivo, que "[a] proteção e a aplicação de normas de proteção dos direitos de propriedade intelectual devem contribuir para a promoção da inovação tecnológica e para a transferência e difusão de tecnologia, em benefício mútuo de produtores e usuários de conhecimento tecnológico e de uma forma conducente ao bem-estar social e econômico e a um equilíbrio entre direitos e obrigações." 
por comunidades baseadas em países diferentes ou por Estados diferentes, cujas legislações concedem tratamento diverso aos mesmos recursos. ${ }^{1680}$

Considerando que o art. 29bis não determina quais CTAs e recursos biológicos devem ser protegidos, o marco legal, por exemplo, do Peru poderia tratar determinada categoria de CTA como não-elegível para proteção legal e, por isso, livremente acessível, enquanto a legislação brasileira poderia reconhecer às comunidades tradicionais locais um direito de propriedade sobre o mesmo CTA. O potencial usuário, ciente dessa diferença regulatória, previsivelmente optaria pela legislação mais benéfica aos seus interesses (no caso, a peruana). No fim, uma proposta que objetiva a correção de um desequilíbrio, abrirá espaço para que os interesses econômicos das comunidades tradicionais e dos Estados ricos em termos bioculturais permaneçam descobertos.

Portanto, como a emenda em exame restringiu-se a propor uma nova condição de patenteabilidade, sem estabelecer uma real harmonização dos marcos legais de proteção dos recursos biológicos e CTAs, se adotada, estimulará os potenciais usuários destes recursos a praticarem "forum shopping".

\subsection{RESTRIÇÃO DO USO DO SISTEMA DE PATENTES}

Também em virtude da liberdade oferecida pela proposta aos Estados membros da OMC para estabelecerem seus regimes de proteção dos CTAs e recursos biológicos, estes poderão, inadvertidamente, adotar regimes de propriedade anticomuns, que dificultarão ou impedirão o acesso e uso lícito desses RBIs. Conseqüentemente, se os usuários desses RBIs não obtiverem a autorização de acesso de duas ou mais comunidades e/ou autoridades governamentais, não lograrão obter proteção para as invenções desenvolvidas, ainda que não se oponham a compartilhar benefícios materiais com os provedores dos insumos empregados. Este tipo de problema apenas poderia ser evitado se a proposta de emenda do Acordo TRIPS obrigasse os Estados membros da OMC a adotarem regimes facilitadores do acesso e uso produtivo dos CTAs e recursos biológicos.

${ }^{1680}$ Cf. KOOPMAN, 2006, p. 144-145. 


\subsection{MANUTENÇÃO EM "DOMÍNIO PÚBLICO" DOS CTAS E RECURSOS BIOLÓGICOS PUBLICAMENTE ACESSÍVEIS}

A proposta de art. 29bis oferece aos Estados membros da OMC a discricionariedade para definir a matéria que estaria sujeita às obrigações nele enunciadas. Sem embargo, como o pilar de sustentação do dispositivo proposto é o regime internacional de patentes, aqueles CTAs e recursos biológicos intangíveis que estiverem em domínio público (i.e. integrarem o estado da técnica) poderiam não ser elegíveis para proteção, pois poderiam impedir a concessão de patentes que recaiam sobre invenções que deles derivem. Por conseguinte, nenhum benefício teria de ser repartido com os provedores destes RBIs, já que a indústria biomédica e biotecnológica depende fortemente de patentes para explorar seus produtos.

Em outras palavras, o âmbito de proteção do artigo 29bis dependerá da definição dos termos "novidade", "inventividade" e "matéria de proteção", adotada pelos Estados membros da OMC. Dependendo da jurisdição, uma invenção derivada de recursos biológicos intangíveis e CTAs em "domínio público" pode não ser patenteável. A não concessão de patentes pode prejudicar a produção de efeitos dos acordos de repartição de benefícios, que costumam condicionar o pagamento de benefícios à obtenção de patentes sobre a invenção desenvolvida e sua posterior exploração comercial. O sistema de patentes, embora tão criticado, continuaria a exercer o poder de esvaziar os regimes nacionais que disciplinam a proteção dos recursos biológicos e CTAs.

\subsection{DESVINCULAÇÃO DO RECEBIMENTO DOS BENEFÍCIOS ECONÔMICOS DE SUA APLICAÇÃO PARA FINS SUSTENTÁVEIS}

A emenda não demanda que os benefícios pagos a título de contraprestação pelo uso de recursos da biodiversidade e CTAs sejam revertidos em benefício da conservação da biodiversidade e da melhoria da qualidade de vida das comunidades tradicionais. Sem a imposição desta obrigação aos países ricos em RBIs, a emenda ao TRIPS atestaria que a CDB tornou-se mais um acordo comercial. 


\subsubsection{CONTRAPROPOSTAS DE ALGUNS PAÍSES INDUSTRIALIZADOS}

\subsubsection{Proposta da NorUega}

A Noruega propôs uma emenda ${ }^{1681}$ ao Acordo TRIPS e a todos os acordos internacionais e regionais relacionados à proteção de patentes, que exigiria dos depositantes de patentes, cujas invenções foram desenvolvidas direta ou indiretamente a partir de recursos biológicos e CTs, o cumprimento de duas obrigações.

A primeira consiste na divulgação do país de origem destes recursos, i.e. país onde os recursos biológicos existem em condições in situ; e no caso dos CTs, o país onde as comunidades tradicionais que o conservam estão domiciliadas. Na hipótese desses RBIs tiverem sido obtidos em um país diverso do de origem, o depositante deverá indicar o país provedor dos recursos utilizados.

No que tange à segunda obrigação, caso o marco legal do país de origem ou do país provedor condicionem o acesso a estes RBIs à obtenção do CPLI dos Estados ou comunidades tradicionais pertinentes, o depositante da patente deverá apresentar informações a respeito do cumprimento desta obrigação. Na hipótese do recurso biológico e/ou CTA utilizado existir em dois ou mais países diferentes, a obtenção do CPLI de um dos cotitulares seria suficiente para dar cumprimento à obrigação. Todas as informações fornecidas pelo depositante da patente seriam então divulgadas, por meio do mecanismo de informação pública da CDB (Clearing House mechanism) a fim de viabilizar o monitoramento pelas comunidades tradicionais e Estados de possíveis infrações aos seus direitos.

Na hipótese o depositante da patente se recusar ou não puder cumprir com essas condições, o processamento da patente seria suspenso, até a apresentação das informações demandadas, salvo se comprovada a impossibilidade de fazê-lo. Se a patente fosse concedida e, posteriormente, fosse descoberto que as informações apresentadas eram falsas ou incompletas, o titular da patente estaria sujeito à aplicação de sanções administrativas,

${ }^{1681} \mathrm{Cf}$. WTO, IP/C/W/473, IP/C/W/491. 
civis e penais. No entanto, nenhuma delas poderia interferir na validade da patente concedida.

A proposta da Noruega permite que os depositantes de patentes apresentem informações distorcidas e falsas, já que não teriam a obrigação de comprovar a veracidade daquilo que é apresentado, cabendo aos Estados e comunidades tradicionais, potencialmente, usurpados a tarefa de monitorar a veracidade das informações apresentadas ou omitidas.

Considerando que a proposta permitiria, em caso de CTAs e recursos biológicos presentes em dois ou mais Estados, a obtenção do CPLI de qualquer um dos titulares de direitos, o depositante da patente teria a discricionariedade para obter o termo de CPLI junto ao Estado ou comunidade mais frágil.

Ademais, a proposta norueguesa, tal qual a proposta de art. 29bis patrocinada pelos países em desenvolvimento, falha ao se esquivar de avaliar as dificuldades técnicas envolvidas no monitoramento de atos de apropriação de recursos biológicos e CTs, na falta de um banco de dados internacional, que identifique os elementos intangíveis dos recursos da biodiversidade, e os associem aos CTs pertinentes. Seria mais ou menos simples determinar a licitude de um depósito de pedido de patente, que reivindicasse proteção para um produto cosmético, preparado com o óleo da castanha da Pará, a partir de uma indicação popular amplamente conhecida no Brasil. Mas, na hipótese deste mesmo depositante isolar uma proteína bioativa da castanha do Pará e reivindicar uma patente sobre ela, se revelar ao escritório de patentes informações falsas a respeito da origem da invenção, possivelmente nenhuma comunidade ou Estado conseguiria determinar, com segurança, a inidoneidade das informações apresentadas, se o material reivindicado e sua verdadeira origem forem desconhecidos pela ciência. Em outras palavras, tanto a proposta da Noruega quanto a proposta apoiada pelos países em desenvolvimento presumem ser facilmente identificável a origem dos recursos biológicos utilizados em invenções, caso seus usuários divulguem informações falsas sobre sua origem, quando, em verdade, as técnicas de biotecnologia apagam ou arrefecem os vínculos existentes entre, de um lado, produções técnicas e, do outro, os recursos biológicos e CTs utilizados no processo de P\&D. 


\subsubsection{PROPOSTA DA UE}

A UE, ${ }^{1682}$ por sua vez, propõe a emenda do Acordo TRIPS e de outros acordos internacionais e regionais de patentes, que passariam a exigir dos depositantes de patentes a divulgação do país de origem dos recursos biológicos e CTs utilizados no desenvolvimento de suas invenções. Na hipótese de não disporem desta informação, poderiam divulgar a fonte secundária do RBI utilizado, e.g. coleções ex situ, publicações científicas.

A proposta européia é extremamente indulgente para com os depositantes de patentes e negligente para com os titulares de recursos biológicos e CTs: aqueles apenas precisariam divulgar a origem dos RBIs utilizados, se sua invenção fosse direta e conscientemente derivada de um CT ou das propriedades de um recurso biológico. Surpreendentemente, caberia ao depositante determinar se a invenção reivindicada encontra-se nesta situação. A única obrigação que caberia ao escritório de patentes seria a de verificar se o depositante declarou a origem do recurso biológico ou CT utilizado. Portanto, nem sempre seria obrigatória a divulgação da origem dos RBIs utilizados; e quando o depositante julgasse conveniente, poderia optar por indicar apenas a fonte secundária que proveu os RBIs utilizados.

Na hipótese do depositante não apresentar as informações requeridas, a patente não seria processada, fato este que certamente pouco ocorreria. As informações apresentadas pelo depositante seriam encaminhadas às autoridades do país indicado como fonte dos RBIs utilizados, quando o depositante indicasse o país de origem.

A proposta européia evidentemente não enfrenta com seriedade a tarefa de reconciliar o Acordo TRIPS com a CDB, figurando mais como uma proposta diplomática para "mostrar" ao mundo seu compromisso de corrigir as iniqüidades associadas ao regime de patentes, e conservar o sistema de patentes desequilibrado como de costume: uma proposta que deixa uma ampla discricionariedade aos depositantes de patentes para decidirem quando precisariam divulgar a origem dos RBIs utilizados, e que também lhes oferece a opção de indicarem a fonte secundária dos recursos utilizados, transfere

${ }^{1682}$ Cf. WIPO, WIPO/GRTKF/IC/8/11, para. 2-7; WTO, IP/C/3/383, para. 46-57. 
integralmente aos países em desenvolvimento e comunidades tradicionais o ônus de fazer valer seus direitos. Enfim, nada muito diferente do que já ocorre hoje, sem qualquer emenda ao Acordo TRIPS.

\subsubsection{Proposta da Sú́Ça}

Em sentido similar à proposta européia, a Suíça ${ }^{1683}$ descarta qualquer emenda ao Acordo TRIPS, mas propõe que o regulamento do Patent Cooperation Treaty (PCT) ${ }^{1684}$ seja emendado, de maneira a permitir que os Estados contratantes deste tratado exijam dos depositantes de patentes, quando os pedidos entrarem em fase nacional de processamento, a divulgação da fonte dos recursos biológicos e/ou CTs que fizeram uso direta e conscientemente para o desenvolvimento da invenção reivindicada. Se as informações não forem providas, o Estado poderia impedir o processamento do pedido.

A proposta suíça segue a sina das demais propostas dos países industrializados, estruturadas de maneira a conservar as prerrogativas dos usuários do sistema de patente, ao mesmo tempo em que não colaboram com a construção de relações de apoio mútuo entre a CDB e o regime internacional de proteção da PI. O primeiro equívoco da proposta suíça é oferecer aos Estados a liberdade para demandar dos usuários do sistema PCT a divulgação da fonte dos recursos biológicos e CTs utilizados. Possivelmente, apenas os países em desenvolvimento agregariam esta obrigação aos seus marcos legais nacionais, enquanto os países industrializados se conservariam em omissão.

Em segundo lugar, a proposta suíça determina que o depositante da patente quando obrigado a fazê-lo - divulgue a fonte dos recursos biológicos e CTs utilizados, o que inclui tanto os países de origem dos recursos biológicos e as comunidades que de fato conservam os CTs empregados, quanto coleções ex situ e literatura científica em geral. ${ }^{1685}$

\footnotetext{
${ }^{1683}$ Cf. WTO, IP/C/W/400/Rev.1.

1684 Os domiciliados nos Estados contratantes do PCT desfrutam da prerrogativa de depositarem pedidos de patente, perante determinadas autoridades designadas, nos quais indicarão todas as jurisdições, onde os pedidos deverão tramitar. O PCT não envolve a concessão de uma patente válida internacionalmente; o pedido de patente depositado por intermédio do sistema será "decomposto" em vários pedidos de patentes, os quais tramitarão perante os escritórios de patentes indicados no pedido. O propósito do PCT é facilitar o depósito de pedidos de patentes que recaem sobre uma mesma invenção, em múltiplas jurisdições.

${ }^{1685}$ Cf. WTO, IP/C/W/433, para. 12.
} 
Conseqüentemente, haveria grande espaço de manobra para que os usuários destes RBIs contornassem possíveis obrigações legais, ao elegerem uma fonte secundária (ainda que fictícia ou forjada) como fonte provedora do recurso biológico ou CT utilizado.

Em terceiro lugar, no mesmo sentido da proposta européia, o depositante da patente somente seria obrigado a divulgar informações, se: (i) sua invenção depender "de propriedades específicas do recurso biológico," desde que o depositante da patente comprovadamente tivesse tido contato direto com ele a fim de estudar suas aplicações; e (ii) se a invenção derivar conscientemente de um CT.

O propósito da proposta é evitar que um inventor seja obrigado a repartir benefícios, quando desenvolver, por exemplo, um produto farmacêutico derivado de um recurso biológico que, 'coincidentemente', é utilizado por comunidades tradicionais para aplicações terapêuticas semelhantes ao novo medicamento desenvolvido. ${ }^{168}$ A Suíça oferece, pois, um grande espaço para os depositantes de patentes alegarem que desenvolveram, de modo independente, invenções que, em verdade, somente foram possíveis graças ao uso de recursos biológicos e CTs. Com o acervo técnico controlado pelo setor industrial, ser-lhes-ia fácil "comprovar" que suas invenções derivadas de recursos biológicos, "por um golpe de sorte", coincidiram com conhecimentos tradicionais associados ao recurso biológico utilizado, não cabendo às comunidades pertinentes quaisquer benefícios.

\subsubsection{AVAliaÇão da PROPOSTA do ART. 29BIS EM FACE dO QUADRO CONCEITUAL de DESENVOLVIMENTO SUSTENTÁVEL}

Antes de passarmos para a avaliação da proposta de emenda do Acordo TRIPS advogada pelos países em desenvolvimento, deve-se ter presente que a questão do reconhecimento dos direitos morais dos titulares de CTAs e recursos biológicos não tem relevância para essa proposta. A questão do direito moral de atribuição apenas ganha importância, quando a produção intelectual derivada for utilizada publicamente; já o dispositivo proposto gira em torno de uma nova condição de patenteabilidade, a ser preenchida por invenções derivadas de recursos biológicos e CTAs.

${ }^{1686} \mathrm{Id} ., \mathrm{IP} / \mathrm{C} / \mathrm{W} / 423$, para. 27-28. 
As críticas aqui apresentadas não devem ser interpretadas como um apoio às políticas iníquas dos EUA $^{1687}$ e Japão, que se mostram veementemente contrárias à reforma do sistema TRIPS/OMC com o objetivo de torná-lo um instrumento de observância da CDB. Tampouco devem ser tratadas como uma saudação às propostas da UE, Noruega e Suíça que, apesar de suas diferenças mínimas, basicamente, advogam por soluções que não interfiram nas prerrogativas dos titulares de patentes e tampouco apóiem os países em desenvolvimento e suas comunidades marginalizadas a reverter a tendência corrente (e antiga) de apropriação sistemática de seu PBI. Neste sentido, em termos substanciais, as propostas deste último grupo não se afastam da política japonesa e norteamericana.

Conforme vimos, a proposta de art. 29bis, advogada pelos países em desenvolvimento, deve ser examinada em associação aos regimes em construção no marco da CDB e OMPI. Por este prisma, a proposta de emenda do Acordo TRIPS limitará o acesso lícito aos CTAs e aos recursos biológicos; restringirá a geração de benefícios econômicos a partir de sua exploração produtiva e, ainda, criará entraves à obtenção de patentes sobre produções intelectuais derivadas destes RBIs. Se por ventura, a adoção da emenda viabilizar a geração de benefícios econômicos (o que não parece ser o caso), nada em seus termos assegura sua reversão em favor da conservação da diversidade biológica e em benefício da melhoria do padrão de vida das comunidades tradicionais.

Apesar destas e das demais críticas apresentadas anteriormente, uma emenda ao Acordo TRIPS pode torná-lo um instrumento efetivo de proteção do PBI, desde que a proposta de emenda sofra certas alterações.

Com o objetivo de facilitar a vida dos usuários de RBIs, a comprovação de que o acesso a eles foi lícito deveria ser atestado por um certificado, expedido por essa organização de gestão nacional, regional ou internacional, investida na competência de administrar tais recursos. Os escritórios de propriedade industrial apenas precisariam verificar a autenticidade do certificado para dar início ao processamento das patentes; na

\footnotetext{
${ }^{1687}$ As observações sobre a política norte-americana a respeito da compatibilização do Acordo TRIPS com a CDB são baseadas na política adotada durante a gestão Bush. Ainda não é possível afirmar se, neste ponto, o governo Barack Obama adotará uma nova postura frente ao problema.
} 
sua falta, o pedido não seria processado. Uma vez assegurada a autenticidade do certificado, menores seriam as chances do usuário enfrentar qualquer reivindicação legal que interferisse na validade de sua patente.

A fim de tornar o Acordo TRIPS e a CDB verdadeiramente compatíveis, é preciso que a concessão dos certificados de proteção de cultivar seja igualmente condicionada à apresentação daquele certificado já indicado, expedido pela organização de gestão, que atestaria a licitude do acesso ao germoplasma.

Mas ainda assim, a emenda do Acordo TRIPS estaria incompleta, pois não estenderia proteção às ECTs. Como os únicos RBIs tutelados pela proposta (recursos biológicos e CTAs) são freqüentemente incapazes de gerar benefícios econômicos no curto e médio prazo, a sustentabilidade da diversidade biocultural permaneceria em perigo, em virtude da falta de meios para sustentá-la até que os CTAs e recursos biológicos fossem incorporados a produtos prontos ao mercado.

Conforme indicado anteriormente, uma das grandes fraquezas da proposta de emenda é não conferir proteção aos CTAs e recursos biológicos, quando apropriados por uma pessoa física ou jurídica, que não reivindica proteção patentária para suas produções intelectuais deles derivadas. O único meio de corrigir esta iniqüidade seria integrar ao Acordo TRIPS dispositivos que confiram proteção positiva aos RBIs (inclusive aos CTs e ECTs populares), que poderia ser oposta em face daqueles que os utilizassem no desenvolvimento de produções intelectuais em geral, independentemente se tuteladas ou não por DPIs. No sentido de complementar a proteção positiva reconhecida aos titulares de CTAs e recursos da biodiversidade, a concessão de registros sanitários para produtos que os incorporassem também poderia ser condicionada à apresentação do já referido certificado internacional; na ausência do certificado, o produto não poderia ser comercializado. No mesmo sentido da proposta aqui apresentada, na área dos direitos das patentes, os países industrializados vêm exercendo sua influência sobre as autoridades sanitárias de países em desenvolvimento, para que deixem de conceder autorizações de comercialização para produtos que infrinjam direitos de patentes de terceiros. Em outras palavras, as agências de vigilância sanitária passariam a condicionar a concessão de registros para medicamentos e produtos químicos em geral à comprovação de sua 
segurança, eficácia e respeito aos direitos de propriedade intelectual de terceiros. Este mecanismo é conhecido popularmente como "linkage." 1688

Com o propósito de prevenir a instauração de regimes nacionais desequilibrados, a emenda ao Acordo TRIPS deveria determinar, com clareza, o regime de proteção sobre o qual o art. 29bis se estruturaria. Para se evitar a reinvenção da roda e antinomias, o ideal seria que os regimes de proteção negociados na OMPI e no marco da CDB fossem replicados no âmbito da $\mathrm{OMC}$, dotando-lhes de força. Se for oferecida ampla liberdade aos Estados escolherem os regimes de proteção de seus RBIs, podem optar por alternativas que tornem tão burocrático e caro seu acesso lícito, que os setores produtivos ou se desinteressariam em utilizá-los ou optariam por utilizá-los sem autorização, em busca de sua sustentabilidade econômica, assumindo o risco de nunca conseguirem proteção às suas produções intelectuais.

Quanto ao mecanismo legal adequado para a proteção do PBI no âmbito da OMC, a única coisa que é possível afirmar no momento, vis-à-vis os comentários tecidos quando foram examinados os projetos de disposições da OMPI e o projeto de regime internacional, em construção no marco da $\mathrm{CDB}$, é que um regime calcado em direitos de propriedade é inadequado para tutelar RBIs laicos.

\subsection{REGRAS DE REPRESSÃO DA CONCORRÊNCIA DESLEAL}

\subsubsection{UMA BREVE INTRODUÇÃO AO FUNCIONAMENTO DO SISTEMA DE REPRESSÃO DA CONCORRÊNCIA DESLEAL}

O regime internacional de repressão à concorrência desleal, alicerçado no art. 10bis da Convenção de Paris, tem como origem a action en concurrence déloyale, criada pelas cortes francesas a partir da aplicação extensiva das cláusulas gerais de responsabilidade civil do Código Civil francês - que obrigam todo aquele que, por dolo ou negligência, gerar

${ }^{1688}$ Cf. JUCÁ; MATTOS, 2008. 
prejuízos a outrem a indenizar os prejudicados ${ }^{1689}$ - para a proteção de comerciantes idôneos, vítimas de atos concorrenciais desonestos. ${ }^{1690}$

Um dos legados da Revolução Francesa foi o reconhecimento a todos de uma ampla liberdade de iniciativa comercial, industrial e, portanto, concorrencial. ${ }^{1691}$ Sem surpresas, no período que a sucedeu, os agentes do mercado começaram a abusar da liberdade recém-conquistada, utilizando ferramentas voltadas ou a atacar os demais concorrentes ou a desviar sua clientela por meios desonestos.

Com o objetivo central de proteger o conjunto de relações estabelecidas entre um agente comercial e sua clientela, as cortes francesas, paulatinamente, expandiram o alcance de aplicação das cláusulas gerais de responsabilidade civil do Código Civil francês, passando a: resguardar a reputação empresarial contra atos concorrenciais aptos a estabelecer confusão entre produtos e serviços derivados de fontes distintas; reprimir a apropriação ilícita de segredos comerciais e industriais e o uso de falsas alegações, capazes de denegrir a reputação de agentes econômicos idôneos, bem como outras práticas concorrenciais desonestas, hábeis a desviar injustamente a clientela de terceiros. ${ }^{1692} \mathrm{O}$ sistema de repressão da concorrência desleal surge, então, para restringir a concorrência, apenas quando algum agente do mercado se valer de instrumentos desonestos com o propósito de promover seus negócios frente à concorrência. ${ }^{1693}$

$\mathrm{O}$ direito da concorrência desleal desempenha um papel complementar àquele reservado aos DPIs, atuando nas lacunas onde o último é incapaz de alcançar. Não tem como propósito central a proteção ativa de produções intelectuais contra atos de apropriação; ${ }^{1694}$ tampouco objetiva reprimir atos comerciais, capazes de interferir na lucratividade de um concorrente. Afinal, no contexto do mercado, o sucesso mercantil de uns freqüentemente se correlaciona com a decadência de outros. O sistema de repreensão da concorrência desleal se limita a interferir em situações em que um agente persegue seu sucesso mercantil por intermédio da apropriação ilícita dos esforços e investimentos

\footnotetext{
${ }^{1689}$ Cf. artigos 1382 e 1383, Código Civil Francês.

${ }^{1690}$ Cf. HENNING-BODEWIG, 2006, p. 2.

${ }^{1691}$ Cf. DERENBERG, 1955, p. 2.

1692 Ibid., p. 4.

${ }^{1693}$ Ver, e.g., SELL, 1957-1958, p. 483; DE VREY, 2005, p. 180.

${ }^{1694}$ Cf. DE VREY, 2005, p. 180-181.
} 
alheios, ao invés de persegui-lo por meio do aprimoramento de sua capacidade técnica ou publicidade, enfim, pelos meios lícitos, disponíveis a todo comerciante e industrial. ${ }^{1695}$

Portanto, o objeto central tutelado pelo sistema é o bom funcionamento da livre concorrência, ao assegurar um ambiente competitivo justo, onde todos os participantes se pautarão por um mesmo corpo de regras. ${ }^{1696}$ Reflexamente, o sistema, ainda que tacitamente, tutela os interesses consumeristas. A relação entre proteção do consumidor e o bom funcionamento da concorrência é claro: quando é assegurado que todos os agentes do mercado se conduzirão honestamente, há maior concorrência e produtos melhores e mais acessíveis; e quando o consumidor é protegido contra atos voltados a interferir desonestamente em seu padrão de consumo, os concorrentes probos têm maiores chances de sobrevivência. ${ }^{1697}$

Os avanços legais carreados pelas cortes francesas foram introduzidos, gradualmente, no marco da Convenção de Paris entre 1900 e 1925 e, hoje, se apresentam consolidados em seu art. 10bis. Este dispositivo adota o sistema misto de definição de atos de concorrência desleal: ${ }^{1698}$ conta com uma cláusula geral, nos moldes dos artigos 1382 e 1382 do Código Civil francês, que determina, genericamente, a obrigação dos Estados membros da CP de assegurar "aos nacionais dos países da União proteção efetiva contra a concorrência desleal”. ${ }^{1699}$ Uma segunda cláusula completa a geral, pois aclara, ainda que em termos igualmente genéricos, seu escopo, ao definir ato de concorrência desleal como "qualquer ato de concorrência contrário aos usos honestos em matéria industrial ou comercial." ${ }^{1700}$ A cláusula final, por sua vez, assinala algumas práticas comerciais desleais que devem ser reprimidas pelos Estados contratantes da CP, todas elas dedutíveis da cláusula geral, ${ }^{1701}$ a saber (art. 10bis (3)),

$1^{\circ}$. Todos os atos suscetíveis de, por qualquer meio, estabelecer confusão com o estabelecimento, os produtos ou a atividade industrial ou comercial de um concorrente;

\footnotetext{
${ }^{1695}$ Cf. SANDERS, 1997, p. 86-87.

${ }^{1696}$ Cf. HENNING-BODEWIG, RUIJSENAARS, 1994, para. 9.

${ }^{1697}$ Cf. HENNING-BODEWIG, 2006, p. 8-9.

${ }^{1698}$ Cf. MENÉNDEZ; ALFREDO, 2004, p. 68.

${ }^{1699} \mathrm{Cf}$. art. 10bis (1), CP.

${ }^{1700} \mathrm{Cf}$. art. 10bis, (2), CP.

${ }^{1701}$ Cf. LEITÃO, 2000, p. 34.
} 
$2^{\circ}$. As falsas alegações no exercício do comércio, suscetíveis de desacreditar o estabelecimento, os produtos ou a atividade industrial ou comercial de um concorrente;

$3^{\circ}$. As indicações ou alegações cuja utilização no exercício do comércio seja suscetível de induzir o público em erro sobre a natureza, modo de fabricação, características, possibilidades de utilização ou quantidade das mercadorias.

As práticas indicadas refletem o desenvolvimento jurisprudencial na matéria, à época da revisão da $\mathrm{CP}$, mas figuram apenas como ilustrações de práticas repreensíveis juridicamente. Sempre que um agente do mercado se sentir lesado por alguma prática comercial ou industrial desonesta, não proibida textualmente pela $\mathrm{CP}$ ou pelos marcos legais domésticos que a implementam, poderá acionar o Poder Judiciário, com suporte na cláusula geral de repressão da concorrência desleal. Seus termos são suficientemente amplos e flexíveis para reprimir novas práticas desleais, emergentes no cenário comercial e industrial contemporâneo. ${ }^{1702}$ Em face de um alegado caso de concorrência desleal, não previsto textualmente na CUP ou nos marcos domésticos, as autoridades judiciais avaliarão a presença dos seguintes fatores:

i. Existência de um prejuízo potencial ou real, decorrente de um ato praticado no contexto do mercado. ${ }^{1703}$ Para que um ato concorrencial se configure como desleal é suficiente que apresente a potencialidade de prejudicar os competidores, os consumidores ou a ordem pública. ${ }^{1704}$

ii. Existência de uma relação concorrencial direta entre o autor da prática desleal e sua vítima (i.e. atuam em um mesmo nicho de mercado) ou indireta (autor e réu não atuam em um mesmo mercado, mas ambos são agentes comerciais ou industriais). ${ }^{1705}$

\footnotetext{
${ }^{1702}$ Cf. LEITÃO, 2000, p. 33.

${ }^{1703}$ Cf. MENÉNDEZ, 2004, p. 49-50.

${ }^{1704}$ Ibid., p. 52-53.

${ }^{1705}$ Ibid., p 55.
} 
iii. Infração a algum parâmetro valorativo da lealdade concorrencial: ${ }^{1706}$ historicamente, o direito da concorrência desleal surgiu como um meio de proteção dos negociantes honestos. Neste contexto, as práticas comerciais e industriais honestas, vigentes no território onde se buscava proteção, assim como as práticas honestas vigentes no comércio internacional ${ }^{1707}$ eram os parâmetros mais comuns, contra os quais o judiciário avaliava a deslealdade de um ato comercial. Sem embargo, no presente, as cortes em múltiplas jurisdições vêm ampliando o conjunto de valores e normas utilizadas como parâmetro de avaliação, podendo levar em conta os interesses tutelados pelas normas constitucionais locais; os interesses do público consumidor, afetado pelas práticas alegadamente desonestas e interesses dos demais concorrentes idôneos afetados. ${ }^{1708}$ Uma vez infringido algum dos parâmetros de lealdade adotados, o julgador considerará o ato desleal, em regra, independentemente da culpabilidade do agente. ${ }^{1709}$

iv. Inexistência de um contrato entre as partes litigantes: segundo Menéndez, o ato de concorrência desleal decorre de uma quebra do "dever geral de comportar-se lealmente e não da violação de uma relação contratual." 1710

Assim, o funcionamento do sistema de repressão à concorrência desleal está intimamente ligado à atuação judicial, independendo de qualquer sistema de registro prévio, administrado por autoridades governamentais. ${ }^{1711}$ A aptidão de acompanhar o desenvolvimento das atividades comerciais e reprimir novas estratégias comerciais e industriais desonestas, imprevistas pelos legisladores, é a grande fortaleza do sistema e, ao mesmo tempo, sua fraqueza, porquanto a determinação da deslealdade de um ato depende da visão do juiz do caso, das circunstâncias do caso concreto e dos parâmetros utilizados para a avaliação da desonestidade do ato, sendo, freqüentemente, imprevisível o resultado de litígios desta natureza. ${ }^{1712}$

\footnotetext{
1706 Ibid., p .60.

${ }^{1707}$ Cf. BODENHAUSEN, 2004, p. 144.

1708 Cf. HENNING-BODEWIG; RUIJSENAARS, 1994, para. 37.

${ }^{1709}$ Cf. MENÉNDEZ; 2004, p. 50-51.

${ }^{1710}$ Ibid., p. 53.

${ }^{1711}$ Cf. HENNING-BODEWIG; RUIJSENAARS, op.cit., para. 11 e 27.

${ }^{1712}$ Cf. SANDERS, 1997, p. 23.
} 


\subsubsection{EXPANSÃO DO OBJETO DE PROTEÇÃO}

Ao longo do século XX, o sistema de repreensão da concorrência desleal alterou seu enfoque: originalmente, o sistema apenas era acionado naqueles casos em que subsistia uma relação concorrencial direta ou indireta entre o autor de um suposto ato de concorrência desleal e sua vítima. No presente, conforme já adiantamos, o sistema tende a ser utilizado também para proteger o consumidor e assegurar o bom funcionamento da livre concorrência. ${ }^{1713}$ Por essa razão, em vários países europeus, ${ }^{1714}$ atos de violação de normas públicas e de direitos de terceiros, não-qualificáveis como agentes do mercado, são tratados como atos de concorrência desleal, pois conferem aos seus agentes uma vantagem competitiva não desfrutada pelos demais agentes do mercado, que se conduzem em conformidade com o ordenamento jurídico vigente. ${ }^{1715}$ Conforme bem destaca Adelaide Leitão, passou-se de um "direito de danos individuais para um direito de ordenação dos comportamentos desleais." 1716

Conseqüentemente, a alteração do objeto de proteção igualmente interferiu no entendimento do que constitua um ato de concorrência desleal. Adelaide Leitão sublinha que o ato de concorrência desleal "deixou de ser visto como um acto de desvio de clientela para ser cada vez mais concebido como um acto de intervenção no mercado." ${ }^{1717}$ Neste diapasão, em 1996, a OMPI publicou uma Lei Modelo de Repressão da Concorrência Desleal (Lei Modelo), que se propõe a auxiliar seus Estados membros a cumprir com as obrigações insculpidas no art. 10 bis da CUP. A Lei Modelo, refletindo a perspectiva mais contemporânea a respeito do objeto de proteção do sistema de repressão da concorrência desleal, propõe a repreensão de "qualquer ato ou prática, realizada no curso de atividades industriais ou comerciais, que sejam contrárias às práticas honestas", ${ }^{1718}$ deixando para trás a definição de ato de concorrência desleal, insculpida na $\mathrm{CP}$, que se limita a reprimir atos concorrenciais diretos ou indiretos, qualificados como desonestos.

\footnotetext{
${ }^{1713}$ Cf. HENNING-BODEWIG, 2006, p. 3-6.

1714 Ibid.

1715 Cf. LEITÃO, 2000, p. 37.

${ }^{1716}$ Ibid., p. 25-26.

1717 Ibid., p. 43.

${ }^{1718}$ WIPO, Model provisions on protection against unfair competition, art. 10.
} 
De qualquer modo, a expansão do escopo do sistema de repressão da concorrência desleal não alterou o elemento característico dos atos de concorrência desleal, a saber, o fato de resultar da violação de normas, sejam elas sociais - aquelas que disciplinam as atividades de uma determinada comunidade de agentes do mercado -, estejam elas incorporadas ao ordenamento jurídico geral. Independentemente da natureza das normas infringidas, sua infração confere ao infrator uma vantagem competitiva, que o coloca em posição superior a dos demais concorrentes. ${ }^{1719}$

É neste contexto de expansão do alcance do regime internacional de repressão da concorrência desleal que o projeto de disposições da OMPI para a proteção dos CTs se apresenta. ${ }^{1720}$ Este se estrutura, fundamentalmente, sobre a doutrina da repressão da apropriação indébita (doctrine of misappropriation), inaugurada pela decisão da Suprema Corte dos EUA proferida no caso International News Services (INS) v. Associated Press (AP), em 1918. As empresas envolvidas neste litígio atuavam como agências de notícias. A INS enviava aos seus associados, por telex, as notícias publicadas pela AP em seus boletins, divulgados em Nova York, baseados na costa oeste americana. Em virtude do fuso horário, as notícias veiculadas pela AP eram publicadas, pelas associadas à INS simultaneamente ou até mesmo com antecedência em relação às publicações da AP. ${ }^{1721}$ Como a INS suportava custos operacionais menores que a AP, tinha condições de oferecer, nos mercados da costa oeste americana, os mesmos produtos (notícias) por preços inferiores aos praticados pela AP.

Àquela época, o marco legal de direitos autorais norte-americano não reconhecia direitos autorais sobre artigos jornalísticos. Por esta razão, a INS sentia-se livre para se apropriar das notícias divulgadas pela AP. Como forma de reprimir a prática de apropriação indébita de produções intelectuais não-protegidas por DPIs, a Suprema Corte norte-americana reconheceu, em favor da AP, um direito de quase-propriedade sobre as notícias, geradas por suas operações.

\footnotetext{
${ }^{1719}$ Cf. LEITÃO, 2000, p. 58-59.

${ }^{1720}$ Conforme visto no item 4.2.2.2.2 supra, o projeto de disposições para a proteção das ECTs se centra, fundamentalmente, na instituição da propriedade. Contudo, um de seus dispositivos confere às ECTs não registradas proteção por meio do sistema de repressão da concorrência desleal, conforme será visto mais adiante.

${ }^{1721}$ Ver, e.g., COMMENTS [...],1976-1977, p. 476; BEVERLY-SMITH, 2002, p. 28.
} 
Diferentemente de um direito de propriedade "completo", um direito de quasepropriedade não é oponível erga omnes; apenas é acionável por seu "potencial" titular quando um concorrente se apropria de suas produções intelectuais, de modo a interferir em sua capacidade de recuperar os investimentos realizados. ${ }^{1722}$ Terceiros interessados em explorar as notícias publicadas pela AP com objetivos não-comerciais, poderiam fazê-lo amplamente, independentemente da vontade da agência. Portanto, o direito de quasepropriedade não autoriza seu titular a condicionar toda forma de uso de seu bem à obtenção de seu consentimento; o direito de controle apenas poderá ser exercido em relação àquelas partes que desejarem utilizá-lo com o fito de lucro. Em outras palavras, o direito de exclusão, conferido ao titular de um direito de quase-propriedade, apenas pode ser exercido em face de terceiros que explorarem o bem com objetivos desonestos, e.g. a obtenção de uma vantagem econômica à custa de um concorrente. ${ }^{1723}$

Dissemos que o direito de quase-propriedade apenas é acionável por seu "potencial" titular, pois figura como um direito de propriedade a posteriori a um litígio judicial, ou seja, seu reconhecimento depende de uma intervenção judicial, ${ }^{1724}$ enquanto o direito de propriedade comum independe de qualquer intervenção judicial, sendo, portanto, um direito a priori. Ao início de um litígio, envolvendo uma acusação de apropriação indébita de uma produção intelectual não-protegida por um DPI, inexiste qualquer presunção legal favorável à reivindicação do autor da ação. O resultado do litígio dependerá da maneira e das condições sob as quais o réu explorou o bem intangível e dos benefícios por ele auferidos, e não da existência de algum direito pré-existente que cabe ao autor da ação. Em vista disso, o foco de análise é a conduta do réu ${ }^{1725}$ e não alguma relação especial existente entre um indivíduo ou instituição e seu objeto apropriado por terceiro. Apenas ao final do litígio, será sabido se o Poder Judiciário reconheceu um direito de quase-propriedade ao autor da ação em relação ao bem supostamente apropriado. $\mathrm{Na}$ hipótese do Poder Judiciário reconhecê-lo em favor do autor da ação, este poderá excluir tão-somente o concorrente desonesto da fruição do bem ilicitamente apropriado. Enfím, após o reconhecimento do direito de quase-propriedade pelo Poder Judiciário, seu titular possui os mesmos poderes conferidos ao titular de um direito de propriedade convencional, com a diferença que seus direitos apenas poderão ser exercidos seletivamente.

${ }^{1722}$ Cf. MISAPPROPRIATION [...],1954-1955, p. 321.

${ }^{1723}$ Cf. SMITH, 2007, p. 13.

${ }^{1724}$ Cf. SANDERS, 1997, p. 85.

${ }^{1725}$ Cf. SELL, 1957-1958, p. 498. 
A doutrina da repressão da apropriação indébita trouxe uma contribuição importante ao desenvolvimento do sistema de repressão da concorrência desleal. Até sua emergência, o sistema era acionável para prevenir a apropriação de bens comercialmente valiosos mediante o emprego de meios desleais, e.g. apropriação de segredos industriais por meios fraudulentos. A Suprema Corte dispensou este requisito para a caracterização de um ato como de concorrência desleal, julgando suficiente que o agente se enriquecesse injustamente às expensas do criador do bem apropriado. ${ }^{1726}$ Primeiramente, porque gozou de uma vantagem comercial injusta, que normalmente apenas pode ser usufruída contra o pagamento de uma compensação em favor de seu criador. E em segundo lugar, porque a apropriação do bem interfere na capacidade de seu criador de recuperar os investimentos realizados. ${ }^{1727}$

Em poucas palavras, a doutrina da repressão da apropriação indébita objetiva prevenir a apropriação dos frutos do trabalho e dos investimentos alheios. Sempre que um agente do mercado se apropriar, sem custos ou com custos diminutos, de bens desenvolvidos por terceiros, resultantes de investimentos consideráveis, e a apropriação interferir na capacidade do criador ou titular deste bem de colher os frutos de seu investimento, há um ato de apropriação indébita. ${ }^{1728}$

Basicamente, o ilícito de apropriação indébita se confunde com o ilícito civil de enriquecimento sem causa, presente tanto nos ordenamentos jurídicos dos países filiados ao sistema romano-germânico quanto naqueles filiados ao sistema da Common Law. ${ }^{1729}$ Em termos gerais, há enriquecimento sem causa, quando houver uma transferência involuntária de riqueza de uma parte a outra (i); a parte prejudicada sofrer um empobrecimento, seja uma diminuição concreta em seu patrimônio, seja a perda de uma oportunidade econômica (ii), ${ }^{1730}$ enquanto o autor do ilícito goza de uma vantagem econômica, cuja retenção é considerada injusta, seja porque fere a equidade e os bons costumes, seja porque foi obtida graças à prática de um ato ilícito (iii). ${ }^{1731}$

\footnotetext{
${ }^{1726}$ Cf. SANDERS, 1997, p. 135.

${ }^{1727}$ Cf. SELL, 1957-1958, p. 486-487.

${ }^{1728}$ Cf. KELLER, 1997, p. 415.

${ }^{1729}$ Cf. GIGLIO, 2003, p. 456.

${ }^{1730}$ Cf. LEITÃO, 2000, p. 182.

${ }^{1731}$ Ver, e.g., GREENFIELD, 2006, p. 217; FAGAN, 2001, p. 640.
} 
Em princípio, o que diferencia o ilícito de apropriação indébita do de enriquecimento sem causa é que o primeiro ocorre em um cenário concorrencial, ou seja, o beneficiário desonesto e sua vítima são agentes do mercado, enquanto no segundo caso, não é uma condição que as partes concorram direta ou indiretamente. Contudo, considerando que, no presente, as normas de repressão da concorrência desleal vêm sendo aplicadas para reprimir atos praticados em detrimento do bom funcionamento da concorrência, mesmo quando inexiste qualquer relação de concorrência direta ou indireta entre autor e vítima, no fim, a diferença entre enriquecimento sem causa e apropriação indébita desapareceu.

Dado que existem dúvidas se o art. 10 bis da CP obrigaria seus Estados contratantes a prevenir atos de apropriação indébita e, se entre eles, se incluiriam os atos de apropriação indébita de CTs, ${ }^{1732}$ o projeto de disposições da OMPI para a proteção de CTs se assenta substancialmente sobre uma associação entre a doutrina da apropriação indébita e as normas tradicionais do sistema de repressão da concorrência desleal, modificadas com vistas a facilitar a satisfação das demandas das comunidades tradicionais.

Seguindo a estrutura do art. 10bis da CP, o projeto da OMPI conta com uma cláusula geral de repressão da apropriação indébita, que identifica, em termos elásticos, os elementos característicos dos atos a serem reprimidos. ${ }^{1733} \mathrm{E}$ com o objetivo de trazer alguma previsibilidade ao sistema, o projeto determina, de maneira não-exaustiva, alguns atos que deveriam ser obrigatoriamente reprimidos pelos Estados contratantes de um possível acordo internacional de proteção dos CTs. O conteúdo da cláusula geral e das condutas textualmente proibidas será examinado adiante.

Conforme já mencionado, o projeto da OMPI realiza algumas alterações em relação ao sistema convencional de repressão da concorrência desleal. Uma delas se relaciona ao objeto de proteção: o projeto pretende resguardar, centralmente, as comunidades tradicionais contra atos de apropriação indébita de seus RBIs; em caráter secundário, os competidores honestos, ao prevenir a atuação de agentes de mercado que desenvolvem novos produtos, processos e serviços a partir de RBIs apropriados ilicitamente. Outra alteração digna de nota foi realizada para proteger as comunidades tradicionais e,

${ }^{1732}$ Cf. WIPO, WIPO/GRTKF/IC/13/5(b) Rev., para. 96-100.

${ }^{1733}$ Cf. WIPO, Revised provisions for the protection of traditional knowledge, art. 1 (1), (2). 
reflexamente, o bom funcionamento da livre concorrência: o projeto de disposições reprime atos de apropriação indébita de CTs, praticados em detrimento de comunidades tradicionais, independentemente destes grupos se qualificarem como agentes do mercado.

Com o propósito de permitir que as comunidades tradicionais tenham a oportunidade de controlar seus RBIs, em consonância com suas normas consuetudinárias, o projeto propõe a ampliação das normas que serão utilizadas como parâmetro de avaliação da honestidade dos atos praticados por terceiros. Em caso de acusações de apropriação indébita de CTs, o parâmetro central de honestidade seria composto, fundamentalmente, pelas normas consuetudinárias das comunidades tradicionais pertinentes. ${ }^{1734}$

\subsubsection{O PROJETO DE DISPOSIÇÕES DA OMPI PARA A PROTEÇÃO DOS CTS}

Antes de examinarmos os dispositivos do projeto da OMPI, assentados sobre o sistema de repressão da concorrência desleal, vale relembrar que devem ser vistos dentro do contexto já identificado anteriormente, formado pelos dispositivos que tratam dos princípios, matéria de proteção, limitações aos direitos conferidos, termo de proteção etc., aplicáveis ao projeto da OMPI como um todo. ${ }^{1735}$

\subsubsection{Cláusula GERAL de REPRESSÃo AOS ATOS DE APROPRIAÇÃo INDÉBITA do PROJETO DE DISPOSIÇÕES PARA CTS}

A primeira cláusula do art. $1^{\circ}$ do projeto de disposições da OMPI, seguindo a estrutura do art. 10 bis da Convenção de Paris, determina secamente que "os conhecimentos tradicionais devem estar protegidos contra os atos de apropriação indébita". Em seguida, sua segunda cláusula define apropriação indébita de três maneiras diferentes, a saber: ${ }^{1736}$

\footnotetext{
${ }^{1734} \mathrm{Cf}$. WIPO, Revised provisions for the protection of traditional knowledge, art. 1(5).

${ }^{1735} \mathrm{Cf}$. o item 4.2.2.2.1 Esta observação é igualmente aplicável à seção dedicada a examinar os dispositivos calcados em regras de responsabilidade.

${ }^{1736} \mathrm{Cf}$. WIPO, Revised provisions for the protection of traditional knowledge, art. 1(2).
} 
(1) "Toda aquisição, apropriação ou utilização de conhecimentos tradicionais por meios desleais ou ilícitos [...]"

(2) “A apropriação indébita também pode consistir na obtenção de beneficios comerciais a partir da aquisição, apropriação ou utilização de conhecimentos tradicionais, quando a pessoa que os utilizar saiba, ou não saiba por negligência, que foram objeto de aquisição ou apropriação por meios desleais;"

(3) A prática de "outras atividades comerciais contrárias aos usos honestos [...] mediante as quais sejam obtidos benefícios iníquos a partir dos conhecimentos tradicionais".

O conteúdo dessas três definições complementares de apropriação indébita é desenvolvido pelo art. 1(3) do projeto, que ilustra alguns atos de apropriação indébita, que devem ser reprimidos. Por uma questão de praticidade, serão examinadas as definições gerais de apropriação indébita em conjunto com as condutas específicas sujeitas à repressão legal.

\subsubsection{APROPRIAÇÃO DOS CTS POR MEIOS DESLEAIS OU DESONESTOS}

A cláusula geral define como ato de apropriação "toda aquisição, apropriação ou utilização de conhecimentos tradicionais por meios desleais ou ilícitos". O inciso (i) do parágrafo $3^{\circ}$ do mesmo dispositivo ilustra alguns meios desleais ou ilícitos que, se empregados, qualificariam a aquisição dos CTs como indébita, a saber, "roubo, suborno, coação, fraude, violação de propriedade alheia, descumprimento de contrato ou instigação ao descumprimento, abuso de confiança ou instigação ao abuso, descumprimento de obrigações fiduciárias ou daquelas derivadas de outro tipo de relação confidencial, engano, impostura, apresentação de informação enganosa para a obtenção do consentimento fundamento prévio para aceder aos conhecimentos tradicionais."

O projeto estipula que a determinação do que sejam atos desleais ou desonestos também “deve reger-se, na medida do possível e segundo convenha, pelo respeito às 
práticas, normas, leis e acordos consuetudinários do titular dos conhecimentos." Isto significa que os Estados contratantes de um futuro acordo internacional, que reproduza o conteúdo do projeto de disposições da OMPI, se comprometeriam a envidar seus melhores esforços para avaliar a deslealdade de um alegado ato de apropriação de CTs contra o conjunto de normas sociais e valores culturais, compartilhados pelas comunidades pertinentes.

O dispositivo em exame reprime a apropriação indébita de CTs por meios desleais, independentemente da existência de uma relação de concorrência direta ou indireta entre o autor do ato de apropriação e a comunidade prejudicada. A mera transferência de um CT a um indivíduo ou instituição, mediante a prática de algum ato desonesto ou desleal seria condição suficiente para sua caracterização como um ato de apropriação indébita.

\title{
4.3.2.3 ENRIQUECIMENTO SEM CAUSA
}

A segunda definição de ato de apropriação indébita, insculpida no art. 1(1) do projeto da OMPI, se desdobra, em seu parágrafo $3^{\circ}$, em dois atos, que refletem com maior clareza a doutrina da repressão da apropriação indébita, a saber:

\begin{abstract}
"Alegações ou asseverações falsas sobre a titularidade ou o controle dos conhecimentos tradicionais, em particular, a aquisição, a reivindicação ou a obtenção de direitos de propriedade intelectual sobre conhecimentos tradicionais, quando tais direitos não têm validez legal, tendo em conta a natureza dos conhecimentos e as condições relativas ao acesso aos mesmos". ${ }^{1737}$
\end{abstract}

"Se se acedeu a conhecimentos tradicionais, o uso comercial ou industrial de conhecimentos tradicionais, sem compensar de maneira justa e adequada os titulares reconhecidos dos conhecimentos, quando se faça com ânimo de lucro e outorguem uma vantagem tecnológica ou comercial ao seu usuário, e quando for legítimo compensar os titulares dos conhecimentos, tendo em conta as circunstâncias em que o usuário os adquiriu." ${ }^{1738}$

${ }^{1737}$ WIPO, Revised provisions for the protection of traditional knowledge, Art. 1(3)(iii).

${ }^{1738}$ Ibid., art. 1(3)(iv), grifo nosso. 
No primeiro caso, o projeto propõe que seja uma causa de revogação de DPIs, concedidos sobre CTs de per si ou sobre produtos deles derivados, o fato de terem sido acessados de maneira desonesta. Em condições normais, um DPI apenas é adquirido sobre inovações que tragam algum acréscimo à base de conhecimentos da sociedade e que, conseqüentemente, ofereçam ao seu titular uma vantagem comercial frente à concorrência. Logo, a aquisição de um DPI sobre CTs ou produtos derivados, quando acessados de modo desonesto, traria uma vantagem iníqua ao seu titular, que o projeto da OMPI deseja combater.

A segunda conduta assinalada se assemelha à primeira, com a diferença de que não é uma condição para sua caracterização que seu autor tenha reivindicado ou obtido algum DPI sobre o CT apropriado indebitamente. Na hipótese em exame, os CTs utilizados ofereceriam ao usuário desonesto uma vantagem tecnológica ou comercial injusta, que o colocaria em posição de destaque frente à concorrência. ${ }^{1739}$ A vantagem seria "injusta" porque seu usuário não recompensou adequadamente as comunidades tradicionais pertinentes (e.g. celebrou um acordo de repartição de benefícios pro forma) ou não transferiu qualquer benefício às comunidades titulares do CT apropriado.

Nas duas hipóteses, um obstáculo comum ao exercício dos direitos conferidos às comunidades tradicionais deriva do fato de que um terceiro, que supostamente se apropriou ilicitamente de um CT, pode comprovar que o identificou, por meio de engenharia reversa de produtos tradicionais comercializados pela comunidade pertinente ou desenvolveu, de maneira independente, conhecimentos similares ou idênticos aqueles conservados pela comunidade. Nestas circunstâncias, não haveria nada que as comunidades tradicionais pudessem fazer para impedir a concessão ou o exercício de um DPI relacionado a esses conhecimentos, ou para bloquear seu uso por terceiros. ${ }^{1740}$

A segunda hipótese legal encerra outras dificuldades para a caracterização de uma conduta como ato de apropriação indébita. Como reflexo da ausência de um DPI, a comprovação da vantagem comercial ou tecnológica conferida pelo CT depende do

\footnotetext{
${ }^{1739}$ Esse dispositivo foi fortemente influenciado por um dispositivo da Lei Modelo da OMPI de repressão da concorrência desleal, que qualifica como um ato de concorrência desleal a apropriação não-autorizada de um benefício comercial, que traga ao seu autor uma vantagem em face de seus concorrentes. Cf. WIPO, Model Provisions on Protection Against Unfair Competition, para. 1.08 e art. 1(1)(b).

${ }^{1740}$ Cf. REICHMAN, 2003, p. 293.
} 
conjunto probatório que os autores da ação seriam capazes de trazer ao processo. Ademais, o projeto da OMPI determina que apenas haveria apropriação indébita se, em face das circunstâncias do caso, fosse "legítimo" esperar que o usuário recompensasse as comunidades pertinentes, deixando à discricionariedade dos Estados a determinação das condições sob as quais seria devido o pagamento de uma compensação às comunidades tradicionais. $^{1741}$

Um último aspecto complicador da segunda hipótese legal relaciona-se ao oferecimento de espaço às comunidades tradicionais para impugnarem a validade de acordos de repartição de benefícios supostamente injustos. Um tribunal comum teria condições para realizar este tipo de avaliação? Se a perspectiva das comunidades tradicionais sobre o que seja um esquema equânime tiver prioridade - como parece ser a posição cristalizada no projeto da OMPI -, é possível que muitos acordos de licenciamento venham a ser revogados, ainda que não o sejam.

\subsubsection{CLÁUSULA RESIDUAL}

A terceira definição de ato de apropriação indébita, contida na cláusula geral do projeto da OMPI, constitui uma cláusula residual, que se prestaria a conservar continuamente a habilidade do sistema para prevenir a apropriação indébita de CTs. ${ }^{1742}$ Seguindo a doutrina da repressão da apropriação indébita, o projeto qualifica genericamente como um ato de apropriação indébita, aquele que outorgar ao seu agente uma vantagem de natureza econômica, ainda que ele não tenha lançado mão de qualquer artifício desonesto para dele se apropriar.

\subsubsection{APLICAÇÃO DO ART. 10 BIS DA CP EM FAVOR DAS COMUNIDADES TRADICIONAIS}

${ }^{1741}$ Cf. WIPO, Revised provisions for the protection of traditional knowledge, art. 1(5).

${ }^{1742} \mathrm{Cf}$. WIPO, Revised provisions for the protection of traditional knowledge, art. 1(2). 
O projeto da OMPI igualmente se propõe a dirigir a interpretação do art. 10bis da Convenção de Paris, com o fito de facilitar sua aplicação em favor da salvaguarda dos interesses das comunidades tradicionais.

\subsection{INDICAÇÕES OU ALEGAÇÕES FALSAS SOBRE A RELAÇ̃̃o ENTRE OS PRODUTOS OU SERVIÇOS PROVIDOS E COMUNIDADES TRADICIONAIS}

A Convenção de Paris obriga seus Estados contratantes a proibir o uso de “indicações ou alegações cuja utilização no exercício do comércio seja suscetível de induzir o público em erro sobre a natureza, modo de fabricação, características, possibilidades de utilização ou quantidade das mercadorias." (art. 10bis (3) (3)). O projeto da OMPI para a proteção dos CTs esclarece que tal dispositivo pode e deve ser aplicado com o propósito de impedir a utilização de "afirmações falsas ou enganosas, mediante as quais se indica que um produto ou serviço foi produzido ou prestado com a participação ou a aprovação dos titulares de conhecimentos tradicionais ou que a exploração comercial dos produtos ou serviços beneficia os titulares de conhecimentos tradicionais". ${ }^{174}$

Um campo frutífero para o uso de afirmações falsas é o publicitário. No entanto, qualquer tipo de comunicação, desde que originária de um agente desleal e endereçada ao público consumidor, pode veicular alegações falsas ou enganosas. ${ }^{1744}$ Quaisquer comunicações endereçadas ao público devem ser pautadas pelo princípio da verdade, isto é, devem ser capazes de informar o público sobre as reais características dos produtos e serviços objeto da comunicação. O uso de afirmações suscetíveis de induzir o público consumidor a acreditar que os produtos ou serviços comercializados foram endossados por comunidades tradicionais ou as beneficiarão, rompe com este princípio, prejudicando o consumidor, que se pautará por informações equivocadas; os concorrentes idôneos, ${ }^{1745}$ que poderão ter sua clientela drenada pelo falso compromisso ético de um concorrente desleal; e as próprias comunidades tradicionais, que terão seu nome e imagem aplicados como alavancas comerciais de produtos e serviços, que em nada as favorecerão.

\footnotetext{
${ }^{1743}$ WIPO, Revised provisions for the protection of traditional knowledge, art. 1(4).

1744 Cf. HENNING-BODEWIG; RUIJSENAARS, 1994, para. 75.

${ }^{1745}$ Ibid., para. 21 e 35.
} 
Para a caracterização da veiculação pública de informações falsas ou enganosas como um ato de concorrência desleal, é dispensável que o público consumidor seja, de fato, enganado pelas informações divulgadas; é suficiente que as informações sejam capazes de levá-lo a erro. Cada corte é livre para determinar o consumidor-padrão contra o qual avaliará o potencial danoso das afirmações veiculadas. Normalmente, esta avaliação se baseia no resultado de enquetes, conduzidas junto ao público-alvo do produto ou serviço promovido com as afirmações falsas ${ }^{1746}$ a fim de atestar, empiricamente, sua capacidade de imprimir no consumir alguma idéia equivocada, apta a induzi-lo a alterar seus hábitos de consumo. $^{1747}$

\subsection{ATOS SUSCETÍVEIS DE CRIAR CONFUSÃO A RESPEITO DA FONTE DOS PRODUTOS OU SERVIÇOS PROVIDOS}

A Convenção de Paris obriga seus Estados contratantes a reprimir "[t]odos os atos suscetíveis de, por qualquer meio, estabelecer confusão com o estabelecimento, os produtos ou a atividade industrial ou comercial de um concorrente" (art. 10bis (3)(1)). O projeto de disposições da OMPI realiza pequenas alterações neste dispositivo para ajustá-lo a um cenário, em que se admite a presença de comunidades tradicionais, na condição de agentes do mercado. Neste sentido, o projeto da OMPI determina que os titulares de conhecimentos tradicionais devem ser protegidos contra "atos capazes de criar confusão a respeito dos produtos ou serviços" por eles providos. ${ }^{1748}$

O objetivo dos autores de atos confusórios é a apropriação da reputação de um indivíduo ou empresa bem colocada no mercado, por meio do uso de um meio ardiloso, capaz de ludibriar o público sobre a identidade da real fonte produtora/provedora de um determinado produto ou serviço. Assim sendo, uma condição para a caracterização desta conduta desleal é que as comunidades tradicionais prejudicadas comercializem produtos e/ou prestem serviços. ${ }^{1749}$

$\mathrm{O}$ ato de concorrência desleal mais suscetível de estabelecer confusão entre produtos de fontes diversas é a reprodução ou imitação de marcas comerciais de terceiros. Para que as comunidades tradicionais possam reivindicar proteção contra concorrentes

${ }_{1746}^{174}$ Cf. HENNING-BODEWIG, 2006, p. 39.

${ }^{1747}$ Cf. WIPO, 1996, para. 4.06.

${ }^{1748} \mathrm{Cf}$. WIPO, Revised provisions for the protection of traditional knowledge, art. 1(4).

${ }^{1749}$ Cf. HENNING-BODEWIG; RUIJSENAARS, 1994, para. 111. 
desleais, não é necessário que seus signos distintivos estejam registrados; basta que seus produtos ou serviços ostentem um sinal distintivo, associado pelo público consumidor à comunidade que de fato os produz ou presta. ${ }^{1750}$

\subsection{ATOS VOLTADOS A GERAR DESCRÉDITO DOS PRODUTOS E SERVIÇOS PRESTADOS POR COMUNIDADES TRADICIONAIS}

Os Estados contratantes da Convenção de Paris estão obrigados a reprimir a veiculação de "falsas alegações no exercício do comércio, suscetíveis de desacreditar o estabelecimento, os produtos ou a atividade industrial ou comercial de um concorrente" (art. 10bis (3)(1)). Em sentido similar, o projeto de disposições da OMPI determina que os titulares de CTs devem estar protegidos contra "afirmações falsas, no exercício do comércio, que desacreditem [...] [seus] produtos ou serviços". ${ }^{1751}$

A prática deste ato desleal também depende de que as comunidades tradicionais atuem como agentes do mercado, produzindo mercadorias e prestando serviços. A caracterização deste ato de concorrência desleal é bastante simples: a mera comprovação de que as informações divulgadas são falsas e potencialmente prejudiciais à credibilidade dos produtos e serviços das comunidades tradicionais seria suficiente para atestar a natureza desleal do ato praticado. ${ }^{1752}$

\subsubsection{AVALIAÇÃo dos disPositivos do PROJETO da OMPI de PROTEÇÃo dos CTS EM FACE DO QUADRO CONCEITUAL DE DESENVOLVIMENTO SUSTENTÁVEL}

\subsubsection{CRITÉRIOS DE OPERACIONALIZAÇÃO 1 E 2}

Direito de acesso amplo e facilitado ao PBI pelas comunidades tradicionais e sociedade em geral; e geração de benefícios econômicos no curto, médio e longo prazo, a serem revertidos em favor da conservação da biodiversidade e da melhoria da qualidade de vida das comunidades tradicionais

No que tange aos dispositivos associados à aplicação do art. 10bis da Convenção de Paris, ${ }^{1753}$ alterado em face da realidade das comunidades tradicionais, não foi identificado

\footnotetext{
${ }^{1750}$ Ibid., para. 52.

${ }^{1751}$ WIPO, Revised provisions for the protection of traditional knowledge, art. 1(4)..

1752 Cf. HENNING-BODEWIG; RUIJSENAARS, 1994, para. 89.

${ }^{1753} \mathrm{Cf}$. WIPO, Revised provisions for the protection of traditional knowledge, art. 1(4).
} 
quaisquer problemas que mereçam atenção: os dispositivos se beneficiam da experiência construída pelos Estados membros da CP em suas mais de oito décadas de aplicação; as condutas reprimidas são descritas de maneira, suficientemente, clara e objetiva, trazendo segurança tanto às comunidades tradicionais quanto aos agentes do mercado. No entanto, as mesmas observações não são extensíveis aos demais dispositivos do projeto da OMPI.

\subsection{DIFICULDADES TÉCNICAS E ECONÔMICAS PARA A DEFESA DOS DIREITOS DAS COMUNIDADES}

Um dos principais gravames decorrente da adoção de uma abordagem de concorrência desleal para a proteção de CTs, se relaciona ao fato de que geralmente a determinação do escopo dos direitos conferidos às comunidades tradicionais depende do esclarecimento do conteúdo de termos juridicamente indeterminados pelos tribunais. $\mathrm{O}$ processo de concreção destes termos envolveria tanto a aplicação de noções de honestidade e lealdade vigentes na sociedade dominante, quanto aquelas compartilhadas pelas comunidades tradicionais pertinentes. Em virtude das normas consuetudinárias de comunidades tradicionais não estarem cristalizadas em nenhum documento publicamente acessível; tendo em conta as peculiaridades dos sistemas legais de cada jurisdição e, finalmente, as perspectivas únicas de cada julgador, seria impossível a determinação, em abstrato, do alcance dos direitos conferidos às comunidades tradicionais sobre seus $\mathrm{CTs},{ }^{1754}$ que variaria em cada jurisdição nacional: Ao mesmo tempo em que a flexibilidade de um regime fundado no sistema de repressão da concorrência desleal permite a proteção dos CTs em situações imprevistas, por outro lado, essa mesma flexibilidade gera incertezas aos potenciais titulares de direitos e usuários de CTs, quanto ao alcance de seus direitos e obrigações. ${ }^{1755}$ Naturalmente, é possível afirmar, com segurança, que o uso de espionagem para a obtenção de um CT secreto configuraria um ato de apropriação indébita. ${ }^{1756}$ No entanto, não é igualmente claro se o uso de um CT publicamente acessível por uma instituição científica, que lhe conferiu uma vantagem tecnológica clara, configuraria ou não um ato de apropriação indébita. Seria, neste caso, legítimo esperar que a instituição negociasse um acordo de licenciamento com as

\footnotetext{
${ }^{1754}$ Ver, e.g., BARLOW, 1997, p. 366; COTTIER; PANIZZON, 2006, p. 226-227.

1755 Cf. SELL, 1957-1958, p. 496-497.

${ }^{1756}$ Cf. WIPO, Revised provisions for the protection of traditional knowledge, art. 1(3)(i).
} 
comunidades pertinentes? Qual autoridade seria competente para determinar a legitimidade da expectativa das comunidades?

No mais, não se deve negligenciar que processos judiciais podem ser extremamente morosos e consumir grandes somas de recursos que, sabidamente, é tudo o que as comunidades tradicionais não dispõem. Se grupos marginalizados tiverem de investir muito tempo e somas vultosas para lograrem proteger seus CTs nas múltiplas jurisdições, onde podem ser apropriados, é certo que o regime será um fiasco.

Para tornar o cenário ainda mais complexo, conforme visto anteriormente, um CT supostamente apropriado indebitamente pode ser compartilhado por comunidades tradicionais distintas, portadoras de normas consuetudinárias diferenciadas. Nesta hipótese, como seria formado o parâmetro de honestidade contra o qual o Poder Judiciário avaliaria o suposto ato de apropriação? Seriam aplicáveis, cumulativamente, as normas de todas as comunidades cotitulares de direitos? Se tiverem de ser aplicadas cumulativamente e havendo conflito entre as normas admitidas, como seria resolvida a antinomia? Caso se opte por dar preponderância a um determinado conjunto de normas, qual seria o critério a guiar a escolha?

Sendo improvável a pré-determinação, com segurança, do alcance e dos limites dos direitos conferidos às comunidades tradicionais, os potenciais usuários de CTs poderiam praticar, inconscientemente, atos de apropriação indébita. ${ }^{1757} \mathrm{~A}$ conseqüência da insegurança jurídica é o empobrecimento do domínio público e a balcanização das relações entre comunidades tradicionais e os usuários de CTs.

Nesse clima de insegurança, potenciais usuários de boa-fé se viriam obrigados a abordar as comunidades tradicionais que conservam os CTs de interesse, com o objetivo de obter sua autorização para toda forma de uso - exceto para aquelas claramente excluídas de sua esfera de controle, i.e. as limitações tratadas na alínea item 4.2.2.2.1, §8 supra - e, assim, minorar as chances de litígios judiciais. Dependendo das dificuldades envolvidas na identificação dos titulares dos CTs de interesse, os custos para a obtenção do CPLI das comunidades titulares podem ser excessivos, ao ponto de esfriar o interesse dos potenciais

${ }^{1757}$ Cf. MENÉNDEZ; 2004, p. 65. 
usuários de CTs. Conseqüentemente, as chances dos CTs, protegidos por este tipo de mecanismo, virem a gerar benefícios econômicos em favor do bem-estar material das comunidades tradicionais seriam, no melhor dos cenários, mínimas.

\subsection{AUSÊNCIA dE PROTEÇÃo POSITIVA AOS CTS}

Regimes calcados em regras de repressão da concorrência desleal não reconhecem proteção positiva às comunidades tradicionais; a proteção apenas seria acionada, quando da prática de um suposto ato de apropriação indébita. A contrario sensu, na hipótese de um terceiro aplicar técnicas honestas para desenvolver um conhecimento similar ou idêntico a um CT protegido (e.g. engenharia reversa), as comunidades titulares de direitos não teriam direito algum. E mesmo que insistissem em levar este tipo de caso aos tribunais, considerando o poderio econômico e técnico controlado pelos usuários de CTs, estes facilmente contornariam acusações de apropriação indébita. No fim, os CTs se conservariam em domínio público.

Historicamente, o sistema de repressão da concorrência desleal surgiu para beneficiar organizações ou indivíduos capacitados a extrair benefícios econômicos de seus bens intangíveis. Seu propósito central é o de afastar do caminho de agentes do mercado idôneos, aqueles concorrentes que procuram obstaculizar desonestamente o desenvolvimento de suas atividades econômicas. Em sentido diverso, em regra, as comunidades tradicionais não arregimentam as condições para explorarem diretamente seus CTs. Por esta razão, seus CTs apenas lhes trarão benefícios materiais, quando licenciados por terceiros. Contudo, uma vez que os dispositivos examinados não conferem proteção positiva aos CTs, nem determinam, com clareza, o escopo dos direitos conferidos, e recordando que o projeto da OMPI dispensa as comunidades da obrigação de registro dos CTs, estes grupos teriam grande dificuldade para atrair a atenção de organizações interessadas em licenciar seus CTs. Potenciais usuários de CTs publicamente acessíveis poderiam optar por apropriá-los e deixar para discutir em juízo, se as comunidades gozam de algum direito.

Para concluir, um mecanismo calcado no sistema de repressão da concorrência desleal é adequado para afastar impedimentos desonestos da trilha de agentes do mercado 
probos, mas não para promover usos produtivos dos CTs, com o objetivo maior de gerar desenvolvimento científico e material da sociedade dominante e das comunidades provedoras.

\subsection{Problemas RElacionados AOS REgIMES BASEAdos EM DIREITO DE PROPRIEDADE}

Ainda que presumíssemos que todos os potenciais usuários de CTs são idôneos e se dispõem a negociar acordos de licenciamento com as comunidades titulares dos CTs de interesse, o sistema proposto não seria menos disfuncional: relembrando que os dispositivos examinados conferem às comunidades tradicionais um direito de quasepropriedade, composto por um conjunto de direitos muito próximo daquele associado ao direito de propriedade convencional, as críticas apresentadas no item 4.2.3 supra, relacionados às falhas das propostas fundadas em direitos de propriedade são aqui aplicáveis. Portanto, ainda que partíssemos da premissa irreal indicada, o regime calcado em um regime de repressão da concorrência desleal limitaria grandemente o acesso produtivo aos CTs protegidos, enquanto liberaria o uso de CTs populares, interferindo, assim, na geração de recursos econômicos a partir deles.

\subsubsection{CRITÉRIO DE OPERACIONALIZAÇÃo 3}

Reconhecimento às comunidades tradicionais de um direito moral de atribuição

Conforme já assinalado em outras oportunidades, os dispositivos examinados nesta seção não formam uma proposta de autônoma de regime de proteção dos CTs; compõem apenas uma parte de uma proposta maior da OMPI, dedicada à proteção dos CTs. Por esta razão, devem ser avaliados em conjunto com a seção dedicada aos dispositivos assentados sobre direitos de propriedade e com a seção dedicada aos dispositivos calcados em um regime de responsabilidade.

No que tange especificamente aos dispositivos associados ao sistema de repressão da concorrência desleal, estes não conferem às comunidades tradicionais quaisquer direitos 
morais; mas outros dispositivos do projeto disciplinam os direitos morais das comunidades tradicionais. ${ }^{1758}$

\subsubsection{CRITÉRIO DE OPERACIONALIZAÇÃO 4}

Efetividade dos regimes de proteção em escala global

Haja vista que os dispositivos fundados em regras de repressão da concorrência desleal conferem às comunidades tradicionais um direito de quase-propriedade, que se aproxima substancialmente do feixe de direitos que é próprio ao direito de propriedade tradicional, as críticas tecidas anteriormente, acerca da incapacidade de regimes de propriedade para assegurarem a efetiva proteção do PBI em suas múltiplas dimensões são aqui aplicáveis, ${ }^{1759}$ mas com um agravante.

Recordando as dificuldades associadas a transformar RBIs em bens economicamente rentáveis - por conta da possível emergência de uma tragédia dos anticomuns ou dos royalties achatados, decorrentes da existência de múltiplas fontes provedoras ou, ainda, em virtude do escopo dos direitos conferidos às comunidades tradicionais depender da intervenção do Poder Judiciário - é possível que a organização de gestão proposta pelo projeto de disposições da OMPI não seja capaz de alavancar os recursos indispensáveis para a instauração de processos judiciais, nas inúmeras jurisdições, onde os CTs possam ser apropriados ilicitamente. Na hipótese de uma empresa depositar, em dez jurisdições diferentes, um pedido de patente para uma invenção, construída substancialmente sobre um CT apropriado indebitamente, a organização de gestão teria de persegui-la judicialmente em todas essas jurisdições, se as comunidades pertinentes desejarem, de fato, reprimir este ato. Os gastos para esse périplo judicial são imprevisíveis, mas indiscutivelmente altos. Não sendo sempre possível identificar, com segurança, o escopo dos direitos investidos nas comunidades, pode ser que, sopesando os custos certos contra os benefícios duvidosos, a organização de gestão de direitos julgue mais razoável evitar a instauração de litígios judiciais, o que teria como resultado a conservação dos CTs tal como já se encontram no presente: desprotegidos. Despida de recursos financeiros, a organização criada para a defesa dos titulares de CTs seria apenas simbólica.

${ }_{1758}$ Cf. item 4.2.2.2.1, § 7 supra.

${ }^{1759} \mathrm{Cf}$. item 4.2.4 supra. 


\subsection{Propostas ASSENTADAS SOBRE UM REGIME DE RESPONSABILIDADE}

O projeto de disposições da OMPI para a proteção de ECTs estabelece um regime de proteção especial para ECTs publicamente acessíveis e não-registradas: seu acesso é liberado a todo aquele que cumprir com determinadas condições, pré-fixxadas em lei. ${ }^{1760}$ Em sentido similar, o projeto de disposições para a proteção dos CTs permite (não obriga) que os Estados sujeitem o uso daqueles conhecimentos publicamente acessíveis ao cumprimento de determinadas condições, pré-determinadas em lei. ${ }^{1761}$ As condições a serem cumpridas serão discutidas mais adiante, mas o que interessa no momento é ter presente que, as comunidades tradicionais não gozariam da prerrogativa de excluir do uso destas categorias de ECTs e CTs, terceiros que as observassem fielmente. Em princípio, pareceria que os projetos de disposições da OMPI propõem a proteção de ECTs e CTs publicamente acessíveis por um regime de responsabilidade (RR).

Tradicionalmente, um RR oferece a terceiros uma licença automática e obrigatória de exploração comercial dos bens protegidos, ${ }^{1762}$ impedindo seus titulares de excluir terceiros de seu uso, desde que paguem uma retribuição econômica pré-fixada, ${ }^{1763} \mathrm{em}$ termos não-discriminatórios, i.e. sua fixação caberia a um órgão neutro (e.g. um árbitro, um comitê técnico ou o Estado, por meio de legislação), de modo a impedir que seu titular agregasse ao preço valores e julgamentos pessoais, ${ }^{1764}$ que poderiam tornar o recurso comercialmente desinteressante ao mercado. Se o uso proposto não tiver propósitos comerciais, o RR disponibiliza aos usuários uma licença automática gratuita.

Em comparação a um regime de propriedade, um RR despe seu titular do direito de controlar o uso do bem protegido e de fixar as condições e as modalidades de uso, ${ }^{1765}$ cabendo-lhe fundamentalmente um direito de remuneração pelo uso comercial de seu recurso. Apenas na hipótese do usuário não cumprir com as condições pré-fixadas, poderia o titular de direitos exclúí-lo do uso. Por outro lado, o direito de exclusão não poderia ser

\footnotetext{
${ }^{1760} \mathrm{Cf}$. WIPO, Revised draft provisions for the protection of traditional cultural expressions/expressions of folklore, art. 3(b), (i), (ii) e (iv).

${ }^{1761} \mathrm{Cf}$. WIPO, Revised provisions for the protection of traditional knowledge, art. 8(2).

${ }^{1762} \mathrm{Cf}$. WIPO, WIPO/GRTKF/IC/6/14, para. 102.

${ }^{1763}$ Ver, e.g., REICHMAN, 2000, p. 1794; MUNZER, 2005, p. 150.

${ }^{1764}$ Ver, e.g., KRAUSS, 2000, p. 783; CALABRESI; MELAMED, 1972, p. 1092.

1765 Cf. MICHELMAN, 2004, p. 666.
} 
exercido, se surgirem divergências entre o usuário e o titular de direitos sobre o quantum devido, a título de remuneração pelo uso comercial do bem. Nesta hipótese, após o esclarecimento, por uma corte arbitral ou pela justiça comum, do quantum de fato devido, apenas se o usuário se opuser a pagar a soma estipulada, então, o titular de direitos poderia excluí-lo do uso do bem protegido.

Em sumário, RRs conservam os bens protegidos como se estivessem em domínio público, para aqueles que anuem em cumprir com as condições pré-fixadas, porquanto gozarão da liberdade de explorá-los da maneira que lhes aprouver, ao mesmo tempo em que impede o enriquecimento sem causa de seus usuários comerciais e industriais, que é uma das principais vantagens oferecidas pelos regimes de propriedade e quasepropriedade. Ocupa, pois, uma posição intermediária entre um regime de acesso aberto e regimes de propriedade e de quase-propriedade. ${ }^{1766}$

RRs não se confundem com um sistema de licenciamento compulsório, presente, notadamente, nas leis de patentes. ${ }^{1767}$ Uma licença compulsória, de fato, é concedida por uma autoridade governamental à revelia da vontade do titular da patente e os royalties, a serem pagos a título de remuneração, igualmente são fixados por uma autoridade governamental. Contudo, sua concessão envolve um complexo processo administrativo e/ou judicial, iniciado mediante uma petição da parte interessada, que, geralmente, terá de comprovar que tentou, sem êxito, negociar um acordo de licenciamento com o titular da patente, em termos razoáveis. ${ }^{1768}$ A autoridade governamental avaliará as condições do caso concreto e oferecerá ao titular da patente a oportunidade para indicar as razões, para que a licença não fosse concedida. Se optar por concedê-la, a licença valeria apenas por um período limitado e caberia ao Estado fixar uma remuneração ad hoc, tendo em conta o caso concreto. Ainda que a licença seja concedida, o titular da patente estaria investido no direito de recorrer aos tribunais para reverter a decisão estatal. ${ }^{1769}$ Enfim, uma licença compulsória configura uma exceção ao direito de exclusivo investido no titular da patente, enquanto RRs não investem em seu titular um direito de exclusão; ${ }^{1770}$ seu processo de concessão é caro, moroso, porquanto individualizado, enquanto um regime de

\footnotetext{
${ }^{1766}$ Cf. CHANDER; SUNDER, 2004, p. 1370.

${ }^{1767}$ Cf. art. 31, Acordo TRIPS.

${ }^{1768}$ Art. 31 (b), Acordo TRIPS.

1769 Cf. Art. 31(j), Acordo TRIPS.

${ }^{1770}$ Cf. REICHMAN, 2000, p. 1794.
} 
responsabilidade se funda em licenças automáticas e gerais em favor de qualquer usuário, que se disponha a pagar a remuneração pré-fixada, em bases neutras. ${ }^{1771}$

RRs são consideradas o mecanismo legal mais adequado para a proteção daqueles recursos para os quais o processo de precificação e negociação é tão complexo que os custos de transação relacionados figurariam como obstáculos à conclusão de possíveis acordos, ${ }^{1772}$ bem como para aqueles recursos, em relação aos quais, o exercício do direito de exclusão de terceiros não-autorizados é tremendamente oneroso ou tecnicamente impossível (e.g. bens informacionais). ${ }^{1773}$

\subsubsection{OS PROBLEMAS DO PROJETO DA OMPI PARA ECTS}

As propostas da OMPI para proteção de ECTs livremente acessíveis e nãoregistradas e para a proteção dos CTs publicamente acessíveis, sem embargo, envolvem alterações em relação a um RR padrão, que basicamente lograram desnaturá-lo. O projeto da OMPI sujeita o uso comercial de ECTs publicamente acessíveis e não-registradas ao cumprimento cumulativo das condições de (i) a (iv) e o uso não-comercial desta categoria de ECTs, ao cumprimento cumulativo das condições (i) e (ii):

i. Reconhecimento das "comunidade[s] pertinente[s] como a fonte de toda obra ou produção derivada das" ECTs, ${ }^{1774}$

ii. Respeito ao direito de integridade das comunidades pertinentes sobre suas ECTs; ${ }^{1775}$

iii. Pagamento de uma remuneração equitativa em favor das comunidades pertinentes; sua fixação caberá à uma agência representativa dos interesses dos titulares de direitos, em conjunto com as comunidades titulares de direitos; ${ }^{1776} \mathrm{e}$

${ }^{1771}$ Cf. SMITH, 2007, p. 36.

${ }^{1772}$ Ver, e.g., KRAUSS, 2000, p. 788; BELL; PARCHOMOVSKY, 2002, p. 19.

${ }_{1773}$ Cf. CALABRESI; MELAMED, 1972, p. 1107, 1110.

${ }^{1774}$ Cf. WIPO, Revised draft provisions for the protection of traditional cultural expressions/expressions of folklore, art. 3(1)(b) (i).

${ }_{1775}$ Ibid., art. 3(1)(b) (ii).

${ }^{1776}$ Ibid., art. 3(1)(b) (iv). 
iv. Abstenção do uso de quaisquer indicações ou afirmações falsas, enganosas ou confusas, que sugiram aprovação ou algum vínculo com as comunidades, que conservam as ECTs, utilizadas direta ou indiretamente no desenvolvimento de produtos ou serviços. ${ }^{1777}$

O cumprimento da condição (i) não engendraria qualquer obstáculo ao funcionamento do sistema, se as ECTs publicamente acessíveis fossem registradas, porquanto o registro indicaria claramente as comunidades titulares de direitos. $\mathrm{Na}$ falta de um registro público, os usuários podem enfrentar grandes dificuldades para identificar as comunidades-fonte das ECTs de interesse; superá-la pode envolver pesados custos.

Quanto às demais condições, elas permitem que as comunidades tradicionais interfiram na fixação do conteúdo das obrigações, a serem cumpridas pelos potenciais usuários, para que então possam desfrutar de uma licença teoricamente 'automática'.

\subsubsection{DIREITO MORAL DE INTEGRIDADE}

Nos termos do projeto da OMPI, as comunidades pertinentes teriam o direito de se opor à "toda deformação, mutilação ou outra modificação das [...] [ECTs] ou a outro atentado às mesmas", isto é, poderiam se opor a qualquer alteração ou aplicação de suas ECTs; neste último caso, ainda que não envolvessem qualquer alteração em sua forma de apresentação original, caso discordem das alterações ou usos empreendidos. Nenhum usuário teria condições de identificar, com independência, quais alterações e usos receberiam a chancela dos titulares de direitos e quais poderiam sujeitá-los à sua oposição, salvo se os consultasse previamente a cada uso ou modificação planejada.

\subsubsection{Pagamento de UMA REMUneraÇão EQÜITATIVA}

${ }^{1777}$ Ibid., art. 3(1)(b) (iii). 
A fixação da remuneração a ser recolhida pelos usuários comerciais e industriais de ECTs caberia à organização de gestão de direitos, brevemente tratada no item 4.2.2.2.2, §7 supra. A remuneração seria fixada individualmente, em face de cada caso concreto e sempre envolveria a participação das comunidades titulares de direitos.

Ao menos, dois problemas podem surgir, ao se permitir o envolvimento das comunidades no processo de precificação das ECTs. Em primeiro lugar, em virtude da falta de um registro público obrigatório das ECTs protegidas, pode ser impossível a identificação dos titulares de direitos. Em segundo lugar, algumas comunidades podem ser identificadas e, após a fixação da remuneração, novas comunidades que compartilham uma mesma ECT podem reivindicar o direito de participar do processo de precificação. Nesta hipótese, o projeto da OMPI nada dispõe a respeito da revogação do processo anterior de precificação. Se revogado, em nome do respeito do CPLI de todos os cotitulares de direitos, o processo de exploração comercial das ECTs seria suspenso, até que chegassem a um novo acordo e o potencial usuário o aceitasse.

Em segundo lugar, a participação das comunidades no processo de precificação permite a agregação ao valor da taxa de licenciamento de seus preconceitos sobre o quão lucrativo serão os produtos e serviços derivados de suas ECTs e outros julgamentos culturais.

\subsubsection{ABSTENÇÃo dO USO DE ALEGAÇões FALSAS OU ENGANOSAS}

Esta condição recebeu influência clara do art. 10bis (3)(3) da Convenção de Paris, que qualifica como ato de concorrência desleal o uso de "indicações ou alegações cuja utilização no exercício do comércio seja suscetível de induzir o público em erro sobre a natureza, modo de fabricação, características, possibilidades de utilização ou quantidade das mercadorias."

Conforme visto anteriormente, esse dispositivo objetiva assegurar que as relações comerciais se estruturem sobre o princípio da verdade. É compreensível a repressão deste tipo de comportamento por industriais, comerciantes e prestadores de serviços que 
planejem ganhar espaço no mercado, por meio da disseminação de informações falsas sobre seus produtos e serviços. No entanto, no caso de um agente do mercado, fiel cumpridor das condições pré-fixadas em lei, é natural que qualquer referência à comunidade-fonte das ECTs, que serviram de base ao desenvolvimento do produto ou serviço prestado, possa sugerir ao público (e com razão) a aprovação dos titulares de direitos ou a existência de algum vínculo com eles. Mesmo que as informações disseminadas, por exemplo, em campanhas publicitárias, dêem a entender que uma determinada comunidade apoiou o lançamento de um produto derivado de suas ECTs, quando ela silenciou a este respeito, a partir do momento que a comunidade fixou a remuneração em patamares aceitáveis ao usuário e se absteve de exercitar seu direito de integridade, quando poderia ter se conduzido de outro modo, com o objetivo de embargar a comercialização do produto, pode-se afirmar que a comunidade, tacitamente, apoiou o produto ou serviço.

Mais uma vez, para que os usuários comerciais possam ter a segurança de que as informações prestadas publicamente, em relação aos produtos ou serviços derivados de ECTs, não lhes trariam problemas futuros, teriam de discutir com as comunidades pertinentes o conteúdo de sua estratégia publicitária, das embalagens dos produtos e de qualquer comunicação voltada ao público, previamente à introdução no mercado dos produtos e serviços baseados em ECTs.

\subsubsection{UM REGIME DE PROPRIEDADE DISFARÇADO DE RR}

O que antes de uma análise detida se pareceria com um RR, em verdade, nada mais é do que um regime de propriedade disfarçado: a partir do momento que as comunidades desfrutam do poder de definir a remuneração a lhes ser paga pelo uso comercial de suas ECTs e as condições de sua utilização pública (mesmo para fins não comerciais), as quais, inclusive, podem ser moldadas de maneira a impedir seu uso comercial e não-comercial, o suposto regime de responsabilidade se transfigurou em um regime de propriedade comum.

Outra indicação de que o RR, em verdade, é um regime de propriedade decorre das sanções aplicáveis aos responsáveis pela infração ao direito moral de integridade das 
comunidades e pelo uso de alegações falsas ou confusas: sanções civis e/ou penais. ${ }^{1778} \mathrm{Na}$ prática, essas sanções se qualificam como um direito de exclusão. Afinal, qual empresário sério optaria por continuar a explorar um produto ou serviço que colocaria em risco sua reputação, seus negócios e ainda sua liberdade de ir e vir?

Contraditoriamente, o direito de propriedade aparentemente forte, investido nas comunidades titulares de direitos, se desmorona com facilidade. A OMPI esclarece, nos comentários ao projeto de disposições, que o direito das comunidades não compreende reivindicações de longo alcance, se estendendo apenas às ECTs e não sobre as obras delas derivadas. ${ }^{1779}$ Logo, um usuário poderia superar todas as dificuldades para acessar uma ECT publicamente acessível por meio da criação de uma obra contemporânea nela inspirada ou dela derivada, não sendo obrigado a pagar qualquer remuneração às comunidades pertinentes. Se por um lado, essa limitação ao direito das comunidades assegura a liberdade criativa de terceiros, pelo outro, esvazia os direitos patrimoniais das comunidades tradicionais, e ainda afronta seu direito moral de integridade, ironicamente assegurado pelo projeto da OMPI a estes grupos.

\subsubsection{CONHECIMENTOS TRADICIONAIS E REGIME DE RESPONSABILIDADE}

Em sentido similar ao projeto da OMPI para a proteção de ECTs, o projeto de disposições para a proteção dos CTs permite que os Estados liberem o uso comercial de CTs publicamente acessíveis, por aqueles que observarem as seguintes condições:

i. Pagamento de uma remuneração equitativa à(s) comunidade(s) pertinente(s) ${ }^{1780}$

ii. Identificação das comunidades-fonte do CT utilizado, em todos os produtos dele derivados; ${ }^{1781}$

${ }^{1778}$ Cf. WIPO, Revised draft provisions for the protection of traditional cultural expressions/expressions of folklore, art. 3(b) (ii) (iii).

${ }^{1779}$ Cf. WIPO, [200-]c , p. 23.

${ }^{1780} \mathrm{Cf}$. WIPO, Revised provisions for the protection of traditional knowledge, art. 8(2).

${ }^{1781}$ Ibid., art. 6(3). 
iii. Na hipótese do CT de interesse ostentar "um valor moral ou espiritual especial para" a comunidade titular de direitos, esta poderá se opor ao seu "uso ofensivo voluntário [...] por terceiras partes [...], quando constitu[ir] claramente uma mutilação, distorção ou modificação injuriosa deste conhecimento e [...] [for] contrário à ordem pública ou à moral;" ${ }^{1782} \mathrm{e}$

iv. Respeito aos valores culturais da comunidade(s) pertinente(s). ${ }^{1783}$

\section{Condição I: Remuneração equitativa}

O projeto não é claro sobre a quem caberia a competência para a fixação da remuneração, mas parece que a autoridade nacional ou regional de gestão de direitos, ${ }^{1784}$ responsável por apoiar as comunidades na tarefa de proteção e defesa de seus interesses materiais e morais associados aos CTs, seria o único órgão competente para fazê-lo, ${ }^{1785}$ não cabendo às comunidades o direito de participar do processo de precificação. O projeto da OMPI não dispõe se a autoridade nacional fixaria os benefícios de modo geral ou individualmente. Se os Estados contratantes de um possível acordo internacional, que compreender o mesmo conteúdo do projeto de disposições da OMPI, optarem pela segunda alternativa, o acesso aos CTs deixaria de ser expedito e seguro.

\section{Condição II: Direito de atribuição das comunidades fonte dos CTs}

$\mathrm{Na}$ falta de um registro público obrigatório dos CTs protegidos, os usuários teriam de assumir o ônus de rastrear as comunidades titulares dos CTs que lhes interessam. Esta tarefa pode ser simples, podendo estar claramente indicada, por exemplo, na publicação científica que divulgou publicamente o CT de interesse, como pode não sê-lo. Neste último caso, como os usuários deveriam se conduzir? Publicar um comunicado em jornais de grande circulação do país ou região, onde provavelmente a comunidade-fonte do CT se encontra? E se a comunidade viver em condições de isolamento? E se não tiver acesso aos meios de comunicação?

\footnotetext{
1782 Ibid., art. 1(3)(v).

${ }^{1783}$ Ibid., art. 6(3).

${ }^{1784}$ Cf. item 4.2.2.2.1, §10.

${ }^{1785} \mathrm{Cf}$. WIPO, Revised provisions for the protection of traditional knowledge, art. 13(1) (a) (iv).
} 


\section{Condições III e IV: Respeito aos valores culturais das comunidades tradicionais e à ordem pública e à moral}

$\mathrm{Na}$ hipótese dos CTs encerrarem um valor moral ou espiritual para as comunidades que os conservam, os usuários assumirão o ônus de assegurar que os usos propostos não infringirão os valores culturais das comunidades pertinentes, nem a ordem pública ou a moral vigente nos territórios em que operam. Nos termos da proposta, apenas poderão ser excluídos do uso das ECTs aqueles que infringirem, cumulativamente, os valores culturais das comunidades titulares de direitos, a ordem pública e/ou a moral.

Embora, o conceito de ordem pública e moralidade sejam fluídos e variem em cada jurisdição, o grande desafio aos usuários seria o de determinar os valores culturais das comunidades tradicionais pertinentes. Seus usuários apenas teriam a segurança de estar se conduzindo em conformidade com as normas consuetudinárias e valores das comunidades pertinentes, se as conhecessem em todas as suas nuances ou se sujeitarem todas as atividades envolvendo CTs ao seu crivo crítico. Para isso, é imprescindível que sejam capazes de identificar e localizar as comunidades titulares de direitos, o que, na ausência de um registro público obrigatório, seria uma tarefa de difícil realização. E mesmo que não fosse tão complicada a identificação, certamente seria o processo de negociação com a comunidade, que poderia fixar condições inaceitáveis para a condução do projeto proposto.

Em princípio, em virtude da necessidade de infração cumulativa dos valores culturais das comunidades tradicionais e da ordem pública e/ou dos valores morais vigentes nos territórios em que opera, dificilmente os potenciais usuários seriam excluídos do uso de CTs publicamente disponíveis, na hipótese de os empregarem para o desenvolvimento de produtos biotecnológicos e biomédicos para fins nobres, e.g. medicamentos, variedades vegetais, novas tecnologias industriais.

No entanto, os poderes das comunidades tradicionais são mais amplos do que se poderia imaginar, quando se examina, em isolamento, o art. 1(3)(v) do projeto de disposições da OMPI: O art. 6(3) do projeto determina que todo e qualquer uso de CTs, sejam eles portadores ou não de valores espirituais, culturais ou morais especiais, se sujeite à observância estrita das normas sociais das comunidades titulares de direitos, mesmo que os usos propostos não configurem uma afronta à ordem pública ou aos valores morais, 
vigentes na sociedade dominante. Esta obrigação, na prática, solapa aquela insculpida em seu art. 1(3)(v), que oferece às comunidades tradicionais o direito de se opor às alterações e aos usos de seus CTs portadores de um valor moral ou espiritual especial, apenas quando ferirem, cumulativamente, seus valores morais e a ordem pública e/ou a moral. Por conseguinte, não há problemas em se suprimir a condição III da lista de requisitos, que devem ser cumpridos pelos potenciais usuários de CTs publicamente acessíveis, uma vez que a condição IV a ela se sobrepõe e com grandes vantagens para as comunidades tradicionais.

\subsubsection{REPETIÇÃO DO ERRO: DIREITO DE PROPRIEDAdE VELADO PARA CTS PUBLICAMENTE ACESSÍVEIS}

Repetindo o equívoco do projeto de disposições para ECTs, os dispositivos examinados, veladamente estendem um direito de propriedade aos CTs publicamente acessíveis, ao obrigarem seus usuários a observarem valores culturais das comunidades titulares de direitos, o que certamente abre as comportas para que estas controlem todas as alterações e aplicações de seus CTs, sob a justificativa de que estão apenas se assegurando de que seus valores culturais estão sendo fielmente respeitados por terceiros. ${ }^{1786}$ Assim, mesmo que a fixação dos royalties caiba a um órgão neutro, os usuários ainda estariam sujeitos a condições a serem fixadas por comunidades, cuja identidade e normas sociais ou são desconhecidas ou de difícil aferição. Portanto, embora o projeto de disposições da OMPI ofereça, formalmente, aos Estados uma alternativa ao regime de propriedade com o propósito de desburocratizar o uso de CTs publicamente acessíveis, na prática, sua oferta desembocou no mesmo ponto de partida: um mecanismo assentado sobre direitos de propriedade.

Em virtude da escassez de propostas políticas de regimes de proteção para RBIs efetivamente calcados em um RR, avaliaremos outras duas, que se assentam, ainda que parcialmente, sobre este mecanismo, apresentadas pela doutrina.

\subsubsection{Propostas dOUTRINÁRIAS}

${ }^{1786}$ Cf. DAES, 1997, para. 27-28. 


\subsubsection{Proposta de ReIChMAN \& LeWIS}

Reichman \& Lewis propuseram, com base em uma proposta anterior de Reichman, ${ }^{1787}$ um regime de proteção para CTs denominado regime de responsabilidade compensatória (RRC), o qual se funda em um regime de pliability. ${ }^{1788} \mathrm{Um}$ regime de pliability resulta da associação de um regime de propriedade a um regime de responsabilidade (RR) e determina em que condições cada um deles operará. ${ }^{1789}$

Existem dois tipos de regime de pliability: o simultâneo e o sucessivo. No regime de pliability simultâneo, o regime de propriedade e o de RR são aplicáveis simultaneamente, mas em circunstâncias diversas. ${ }^{1790}$ Por exemplo, os regimes de direitos autorais protegem obras literárias e artísticas mediante um regime de pliability, pois o uso das obras protegidas para fins comerciais depende da obtenção do consentimento do titular de direitos (direito de propriedade); no entanto, o uso destes mesmos bens para fins de informação do público (e.g. direito de citação) é livre e gratuito, independendo da vontade do titular de direito (RR, que fixa em zero a taxa de remuneração). ${ }^{1791}$

Já no regime de pliability sucessivo, inicialmente o bem é protegido por um regime de propriedade ou um de responsabilidade; uma vez cumprida determinada condição prédeterminada, o regime de proteção do recurso se altera. ${ }^{1792}$ Por exemplo, um terreno pode ser protegido por direitos de propriedade. Na hipótese do Estado dele precisar para a satisfação de interesses públicos, poderá desapropriá-lo, pagando uma remuneração adequada ao titular do bem.

O RRC proposto por Reichman e Lewis configura um regime de pliability simultâneo e teria como infraestrutura um registro público, onde as comunidades, voluntariamente, registrariam as CTs protegidas ${ }^{1793}$ e uma organização de gestão coletiva de direitos (OGCD). A organização de gestão seria competente para: fixar, em bases não-

\footnotetext{
${ }^{1787}$ Cf. REICHMAN, 2000.

1788 A palavra da língua inglesa "pliability" significa flexibilidade. Optamos por utilizar o termo em língua inglesa, uma vez que inexiste, em língua portuguesa, um termo técnico capaz de designar um regime jurídico híbrido, composto pela associação de direitos de propriedade e um regime de responsabilidade.

${ }^{1789}$ Cf. BELL; PARCHOMOVSKY, 2002, p. 7, 10, 34-35.

${ }^{1790}$ Ibid., p. 38-39.

${ }^{1791}$ Cf. BELL; PARCHOMOVSKY, 2002, p.41.

1792 Ibid., p. 38-39.

${ }^{1793}$ Cf. REICHMAN; LEWIS, 2005, p. 356.
} 
discriminatórias, as taxas de royalties a serem pagas pelos usuários, em conformidade com a participação do CT no desenvolvimento do produto final; coletar os royalties devidos e distribuí-los aos titulares de direitos; e para solucionar possíveis controvérsias sobre a distribuição de benefícios.

A proposta de Reichman e Lewis confere às comunidades tradicionais dois direitos, a saber: um direito de propriedade e um direito de remuneração. As comunidades gozariam do direito temporário de impedir terceiros não-autorizados de explorar cópias dos CTs registrados. ${ }^{1794}$ Uma vez expirado o termo de proteção, terceiros poderiam explorá-los livremente. Este direito nada mais é que um direito de propriedade, que seria oponível contra os produtos que se limitassem a absorver os CTs tal como registrados, sem qualquer agregação de valor. Assim, por exemplo, uma indústria que imite uma fórmula medicinal tradicional infringiria o direito de exclusivo das comunidades tradicionais pertinentes, que poderiam impedi-la de continuar a produzi-lo.

Além do direito de propriedade, as comunidades titulares de direitos gozariam de um direito de remuneração: aquele que utilizar um CT registrado, como um ponto de partida de um novo produto ou processo (produto), aprimorando-o tecnicamente ou como um "tijolo" na construção de uma tecnologia que dele se distancia, estaria obrigado a recolher à OGCD uma taxa pré-fixada, que variaria de acordo com o papel desempenhado pelo CT no produto final (grande, média ou de pequena importância).

A proposta de Reichman \& Lewis acerta ao conferir às comunidades tradicionais direitos de longo alcance, i.e. sobre os produtos derivados dos CTs, já que raramente os RBIs são utilizados na mesma forma de apresentação, desenvolvida pelas comunidades tradicionais.

A fim de preservar a liberdade científica, a obrigação de repartição de benefícios apenas subsistiria, se o CT fosse utilizado para fins comerciais; se empregado em projetos não-comerciais, o fato-gerador da obrigação de repartição de benefícios não seria acionado. $^{1795}$

\footnotetext{
1794 Ibid., p. 359.

1795 Cf. REICHMAN; LEWIS, 2005, p. 362.
} 
Nos termos da proposta, o novo produto derivado de um CT registrado seria igualmente protegido por um RRC, o que significa que terceiros não estariam autorizados, por um tempo limitado, a reproduzir e comercializar cópias do novo produto, mas poderiam utilizá-lo, bem como o CT que lhe serviu de base, como insumo em outros projetos de inovação tecnológica. ${ }^{1796}$ Por exemplo, uma empresa de produtos naturais poderia utilizar um determinado CT medicinal hábil a curar, digamos, a malária (CTx), com o objetivo de agregar-lhe valor e, assim, desenvolver uma terapia mais segura ao homem (produto $\mathrm{X}$ ), desde que pagasse a remuneração pré-fixada pela OGCD. Posteriormente, uma empresa farmacêutica poderia lançar mão do $\mathrm{CTx}$, bem como do produto $\mathrm{X}$ como pontos de partida para um novo produto (produto $\mathrm{Xx}$ ), se recolhesse à OGCD royalties pelo uso tanto do CTx quanto do produto $\mathrm{X} .{ }^{1797}$

A maior fortaleza da proposta de Reichman e Lewis é o afastamento de obstáculos ao acesso produtivo e científico de CTs. Sem embargo, a proposta também conta com falhas importantes.

\subsection{AS FRAQUEZAS DA PROPOSTA DE REICHMAN \& LEWIS}

\section{§1 DIREITO DE EXCLUSIVO CONFERIDO SOBRE OS CTS TAL QUAL REGISTRADOS}

Esse direito não é de grande valia às comunidades tradicionais, quando recordamos que a maior parte destes grupos vive em condições de penúria material, estando longe de controlarem os meios para explorarem, diretamente, produtos que incorporem seus CTs. Por exemplo, a exploração comercial de produtos que incorporem CTs medicinais depende de um sofisticado e moroso processo de registro perante as autoridades sanitárias, que pode consumir dezenas de milhões de dólares. Este direito só faria algum sentido no contexto de empresas inovadoras, pois lhes ofereceria um período para recuperar seus investimentos por intermédio da exploração do novo produto, em condições especiais. ${ }^{1798}$

\section{§2 ProteÇÃo TEMPORALMENTE LIMITADA}

\footnotetext{
${ }^{1796}$ Ibid., p. 359- 361.

${ }_{1797}$ Ibid., p. 359- 361 .

${ }^{1798}$ Cf. REICHMAN, 2000, p. 1778.
} 
A limitação do termo de proteção dos direitos conferidos às comunidades tradicionais pelo RRC, sob a ótica do quadro conceitual de desenvolvimento sustentável, não se sustenta. As comunidades poderiam ser beneficiadas por um tempo determinado, ainda que longo, mas após a expiração do termo de proteção, voltariam a não ter uma renda constante e confiável, o que poderia levá-las, mais cedo ou mais tarde, a ter de destruir o entorno natural em que vivem, em nome de sua sobrevivência.

\section{§3 ProteÇão das InOVaÇões derivadas de CTS POR MEIO DE UM RRC}

Embora concordemos com os proponentes, que a proteção das produções intelectuais derivadas de CTs, mediante um regime de RRC, favoreceria a liberdade criativa, é preciso não ignorar que, no presente, os grupos representativos dos interesses dos grandes conglomerados se oporiam a este mecanismo de proteção, ao interferir em sua liberdade de recorrer ao sistema de patentes. Logo, o que parece mais adequado seria tutelar os CTs por meio de um RRC, sem impedir que terceiros protejam suas produções intelectuais derivadas mediante patentes ou por meio de outros DPIs, desde que o escopo dos DPIs reivindicados fosse modulado para não embargar o uso dos CTs protegidos pelo RRC. $^{1799}$

A organização não-governamental Consumer Project on Technology (CPTech) defende uma proposta de mecanismo de proteção para CTs, que altera a proposta de Reichman e Lewis e, aparentemente, se encaminha em direção à nossa recomendação de não interferir na liberdade dos usuários de CTs de patentear suas produções técnicas: nos termos da proposta, os usuários de CTs gozariam de uma licença obrigatória automática para usá-los produtivamente, bem como da discricionariedade para patentear suas produções técnicas. No entanto, a invenção patenteada igualmente estaria sujeita à uma licença automática e obrigatória, concedida em favor da comunidade titular do CT utilizado, com o objetivo de lhe autorizar a exploração da invenção patenteada, desde pagos os royalties ao titular da patente. ${ }^{1800}$

\footnotetext{
1799 Nesse sentido, o art. 12.3(d), TIRFAA proíbe a reivindicação de DPIs sobre os recursos da agrobiodiversidade geridos pelo sistema multilateral da FAO que possam embargar sua livre disseminação.

${ }^{1800}$ Cf. WIPO, WIPO/GRTKF/IC/6/14, para. 102.
} 
A proposta da CPTech é insustentável, sob a perspectiva política e econômica: sabidamente, a maioria das comunidades tradicionais vive em condições de miséria material, sendo incapazes técnica e economicamente de explorarem invenções. Para compensar sua incapacidade, a legislação poderia autorizá-las a sublicenciar a patente a terceiros, que poderiam optar por explorá-la deslealmente, até expulsar do mercado o titular da patente licenciada.

Outro aspecto que a CPTech ignora é que RBIs, freqüentemente, são compartilhados por duas ou mais comunidades tradicionais. A fim de proteger os interesses de todos os cotitulares, a legislação poderia conceder a cada comunidade o direito a receber uma licença automática obrigatória. A concessão de múltiplas licenças destruiria o direito de exclusivo temporário conferido ao titular da patente, bem como seu papel de incentivo econômico para inovar. As comunidades tradicionais seriam beneficiadas com as múltiplas licenças, já que receberiam benefícios de todas as empresas que explorassem a invenção. Mas como este esquema retiraria do mercado aquelas empresas que se engajam em atividades de $\mathrm{P} \& \mathrm{D}$, a sociedade como um todo seria prejudicada.

\section{§4 EXCLUSÃO DOS CTS POPULARES DO ESCOPO DE PROTEÇÃO}

Se esta categoria de CTs for mantida em domínio público, eles possivelmente concorrerão diretamente com os CTs protegidos; e é de se presumir que os potenciais usuários darão preferência aos CTs gratuitos. Mas mesmo que assim não ocorra, na hipótese dos CTs protegidos serem mais valiosos comercialmente, a exclusão dos CTs populares do escopo de proteção encerra uma importante fonte de recursos econômicos.

\section{§5 DESRESPEITO AO DIREITO MORAL DE ATRIBUIÇÃO DAS COMUNIDADES TRADICIONAIS}

A proposta centra-se na realização dos direitos materiais das comunidades tradicionais e negligencia a realização de seu direito moral de atribuição. ${ }^{1801}$ Este problema poderia ser superado, sem criar qualquer embaraço ao uso dos CTs, se fosse agregada uma nova condição mínima a ser observada pelos usuários de CTs, ao lado da obrigação de

${ }^{1801}$ Cf. YU, 2007, p. 1102. 
pagar royalties pré-fixados: o reconhecimento das comunidades-fonte dos CTs em quaisquer comunicações públicas, relacionadas aos produtos deles derivados. Uma vez que o regime seria operacionalizado por uma OGCD, munida de um registro obrigatório, estas informações estariam sempre à mão dos usuários.

\section{§6 INCAPACIDADE PARA A PROTEÇÃO DAS ECTS SAGRADAS}

A característica central do RRC, porquanto associado a um RR, é despir os titulares de direitos da prerrogativa de excluir terceiros não-autorizados do uso dos bens protegidos e, reflexamente, investir nos usuários o direito de utilizá-los para agregação de valor. Considerando que o interesse das comunidades tradicionais ante as ECTs sagradas é controlar sua disseminação, aplicação e transformação por indivíduos externos ao grupo, o RRC seria inapto a conferir às comunidades tradicionais um direito moral de integridade sobre suas ECTs sagradas, sem que o regime se desnaturasse.

\section{§7 NÃO INCLUSÃO NO RRC DOS RECURSOS DA BIODIVERSIDADE E ECTS}

Conforme já tratado, os CTAs são despidos de qualquer importância técnica e econômica, quando destacados dos recursos da biodiversidade. Conseqüentemente, de nada adiantará para uma instituição gozar da liberdade de usar CTs, se tiver de enfrentar um regime burocrático e custoso para acessar o recurso biológico associado ao CT de interesse. Os usos múltiplos e paralelos dos CTs seriam embargados, se os recursos biológicos conexos aos CTs não forem disciplinados por um RR.

Ademais, a proposta ignora que a extensão do RRC para a proteção de ECTs laicas seria um instrumento fantástico para gerar recursos econômicos em favor das comunidades tradicionais, no curto e médio prazo. 
A proposta de Reichman \& Lewis se apóia em uma OGCD de alcance nacional. Essa organização seria competente para promover o acesso facilitado aos RBIs por ela geridos, ao impedir a emergência da tragédia dos anticomuns, quando compartilhados por duas ou mais comunidades nacionais.

Contudo, uma OGCD de alcance nacional não seria hábil a superar os problemas gerados pelo compartilhamento de um mesmo RBI por dois ou mais Estados (recursos da biodiversidade) ou por duas ou mais comunidades, fixadas em países diferentes (ECTs ou CTs). Na hipótese de um mesmo CT ser compartilhado por duas comunidades tradicionais, cada uma delas baseada em um país diferente (A e B), se o país A disciplinar a proteção de RBIs por meio de um regime de responsabilidade, mas o país B disciplinar sua proteção por meio de direitos de propriedade, no momento que uma empresa, baseada no país A, tentar exportar para o país B um produto, que incorpora o CT acessado licitamente em A, se B adotar o princípio da exaustão nacional de direitos, as exportações serão embargadas, até que o exportador observe o marco legal de B, que pode ser complexo e de difícil cumprimento.

Em outras palavras, o RRC seria relevante para empresas e instituições que atuam localmente. Para aquelas organizações que desejarem atuar no mercado internacional, se o RRC não tiver alcance internacional, assegurando aos usuários de RBIs a liberdade de operarem internacionalmente, os benefícios potenciais do regime desaparecerão.

\subsubsection{O CARTEL DA BIODIVERSIDADE DE JOSEPH VOGEL}

O economista Joseph Vogel, partindo da premissa de que os CTAs e recursos da biodiversidade são bens públicos que geralmente podem ser providos por múltiplas fontes, porquanto podem ser compartilhados por dois ou mais Estados ou comunidades tradicionais, propôs a adoção de um protocolo à $\mathrm{CDB}$, que reformularia o conceito de soberania dos Estados sobre seus recursos biológicos e das comunidades tradicionais sobre seus CTAs: os Estados contratantes do protocolo e suas comunidades tradicionais teriam o direito a participar de um "Cartel da Biodiversidade." ${ }^{1802}$ Mais especificamente, nos termos

${ }^{1802}$ Ver, e.g., VOGEL, 1995, 2004, 2000 a, 2000 b, 2000 c, 2007a, 2007 b. 
da proposta de Vogel, os Estados nacionais e comunidades tradicionais seriam despidos do direito de negociar bilateralmente a remuneração pelo uso de seus recursos biológicos e CTAs. ${ }^{1803}$ No que tange aos recursos da biodiversidade, terceiros gozariam de uma licença automática para acessá-los, investigá-los e aplicá-los produtivamente. ${ }^{1804}$ Já no que tange aos CTAs, as comunidades tradicionais gozariam da liberdade de proibir o acesso aos seus conhecimentos. Todavia, na hipótese de um mesmo CT ser compartilhado por duas ou mais comunidades, se uma delas autorizar o acesso, as demais partes que o compartilham não poderiam interferir na transação.

Em nenhuma hipótese, os Estados e comunidades tradicionais gozariam da liberdade para negociar a taxa de remuneração aplicável ao contrato de licenciamento: o protocolo proposto por Vogel fixaria a remuneração em 15\% sobre o faturamento do produto derivado de recursos biológicos e CTAs. ${ }^{1805}$ Em caso de acesso simultâneo a um recurso biológico e a um conhecimento tradicional conexo, os royalties seriam repartidos em duas partes iguais; uma seria revertida em favor dos Estados nacionais que compartilham o recurso biológico e a outra parcela em favor das comunidades tradicionais, que compartilham o CT pertinente.

Com o objetivo de tornar a proposta politicamente factível, independentemente de qualquer reforma do Acordo TRIPS, Vogel defende que o protocolo à CDB se limitasse a reconhecer proteção aos CTAs conservados em sigilo, pois são os únicos que se qualificariam como segredos comerciais, nos termos do Acordo TRIPS (art. 39(2)). Nos termos da proposta, caberia à cada comunidade tradicional pesquisar, se o corpo de conhecimentos técnicos por ela conservado integra ou não o domínio público, por exemplo, por meio de pesquisas na internet, em bancos de revistas técnicas etc.

Nos termos da proposta de Vogel, caberia aos titulares de direitos a tarefa de monitorar o uso de seus recursos biológicos e conhecimentos tradicionais por terceiros. ${ }^{1806}$ A fim de facilitar o monitoramento, as partes contratantes do protocolo proposto se comprometeriam a emendar suas legislações de patentes, com o propósito de obrigar os

\footnotetext{
${ }^{1803}$ Cf. VOGEL, 2004, p. 231.

${ }^{1804}$ Informações obtidas mediante mensagens eletrônicas, enviadas por Joseph Henry Vogel, em 26 de maio de 2009.

${ }^{1805}$ Isso significa que os Estados e as comunidades tradicionais, no mesmo sentido da proposta de Reichman e Lewis (2005), gozariam de direitos de longo alcance.

${ }^{1806}$ Cf. VOGEL, 2007b, p. 12.
} 
depositantes de pedidos de patentes a divulgar a espécie do recurso biológico de onde derivou o novo produto comercial.

Na hipótese de um Estado ou comunidade tradicional, domiciliada em um Estado contratante do protocolo, identificar um produto patenteado, cujo titular não recolheu os royalties devidos, as autoridades locais estariam autorizadas a cobrar uma taxa de 39\%, que incidiria retroativamente sobre a renda resultante da comercialização dos produtos até a data da descoberta do ilícito. Caso o titular do DPI tente burlar o protocolo, declarando que seu produto não lança mão de recursos biológicos e/ou CTAs tutelados pelo Cartel, quando a verdade é outra, a taxa de $39 \%$ perduraria até a patente expirar. No mais, na hipótese de alguma organização exportar a algum Estado contratante do protocolo um produto, que incorpora um RBI presente em um dos Estados parte do protocolo, o qual foi obtido em um Estado não-signatário do protocolo, as autoridades aduaneiras do país importador aplicariam uma taxa de importação pré-fixada.

Os benefícios econômicos (royalties, sanções pecuniárias, taxas de importação) seriam recolhidos pelo usuário do recurso biológico e/ou CTA a um fundo, administrado pela Secretaria da CDB, que teria a competência para identificar, por meio de análises taxonômicas, a espécie a que pertence o recurso biológico que deu origem ao produto biotecnológico desenvolvido por terceiros. ${ }^{1807}$ No mais, estas análises teriam por fim identificar o grupo de Estados, que conservam o recurso biológico explorado, em condições in situ. Assim, seria viável beneficiar economicamente todos os Estados que compartilham um mesmo recurso.

A proposta de Vogel se assenta tanto sobre um regime de responsabilidade quanto sobre um de propriedade: enquanto os Estados não gozariam de um direito de excluir terceiros não-autorizados do uso de seus recursos biológicos, as comunidades tradicionais teriam o direito de não autorizar o acesso e uso de seus CTAs. No entanto, neste último caso, uma vez autorizado o acesso por uma das partes que compartilha um mesmo conhecimento, as demais não poderiam excluir terceiro do uso de seu conhecimento. Em nenhum caso, caberia aos Estados ou comunidades tradicionais a competência para negociar os benefícios econômicos devidos ou aos Poderes Judiciário e Executivo dos

${ }^{1807}$ Cf. VOGEL, 2007b, p. 9. 
Estados contratantes para fixar as sanções pelo uso não-autorizado de recursos biológicos e CTAs, tutelados pelo protocolo, uma vez que as sanções e os royalties seriam fixados, de maneira neutra, pelo protocolo.

A proposta de Vogel, ao atentar ao fato de que os CTAs e recursos da biodiversidade podem ser compartilhados por duas ou mais comunidades tradicionais e/ou Estados nacionais, é valorosa, porquanto, ao mesmo tempo em que restringe a liberdade contratual dos Estados e comunidades tradicionais, previne o achatamento dos benefícios econômicos resultantes da exploração comercial dos CTAs e recursos da biodiversidade; diminui os custos de transação envolvidos no acesso; promove o comércio internacional, uma vez que tacitamente se assenta sobre o princípio da exaustão internacional de direitos e impede a concorrência desleal praticada por produtos importados, desenvolvidos com RBIs obtidos em países que não os protegem. Contudo, sua proposta apresenta, além do problema decorrente do reconhecimento de um direito de propriedade em favor das comunidades tradicionais (mitigado pela pré-fixação da remuneração e sanções aplicáveis), ao menos, outras sete fraquezas em relação à proposta de Reichman \& Lewis.

\subsection{AS FRAQUEZAS DA PROPOSTA DE VOGEL}

\section{§1 FALTA DE UMA LICENÇA GRATUITA PARA FINS NÃO-COMERCIAIS}

A proposta de Cartel da Biodiversidade não oferece uma licença automática obrigatória gratuita àqueles indivíduos e instituições que desejarem explorar os CTAs e recursos biológicos para fins não-comerciais, restringindo, portanto, a liberdade científica e a capacidade dos países pobres e de suas instituições filantrópicas de utilizá-los para fins humanitários.

\section{§2 TAXA DE REMUNERAÇÃO ÚNICA}

Vogel propõe a adoção de uma taxa única de remuneração (15\%), aplicável a todo e qualquer uso dos CTAs e recursos biológicos tutelados pelo protocolo, mesmo que utilizados apenas incidentalmente, enquanto James Love indica como 5\% o patamar médio de royalties pago para invenções farmacêuticas nos EUA; e entre 2 e $4 \%$, o patamar médio pago para invenções 
farmacêuticas no Japão. ${ }^{1808}$ A fixação de royalties em patamar tão alto, quando recordamos que o desenvolvimento de produtos biotecnológicos e biomédicos pode envolver a associação de um número substancial de insumos e tecnologias, poderia tornar seu uso economicamente insustentável.

\section{§3 EXCLUSÃo dOS CTAS PUBLICAMENTE ACESSÍVEIS, INCLUSIVE dOS CTAS POPULARES DO ESCOPO DE PROTEÇÃO}

Nos termos da proposta, os usuários de recursos biológicos e CTAs públicos pagariam a mesma taxa de $15 \%$ ao fundo do Cartel. Contudo, os benefícios seriam integralmente revertidos em favor dos Estados nacionais, titulares do recurso biológico que deu origem a um produto comercial biotecnológico. Somente quando o CTA utilizado fosse publicamente inacessível, caberia às comunidades pertinentes uma participação nos benefícios recolhidos ( $50 \%$ do total).

Conseqüentemente, sob a perspectiva das comunidades tradicionais, a proposta de Vogel excluiria do escopo de proteção do protocolo todos os CTs publicamente acessíveis, o que envolve um volume considerável de recursos, tendo em vista as práticas das comunidades tradicionais de amplo compartilhamento de seu PBI com outros grupos e culturas. No mais, sempre que os CTAs sigilosos fossem descobertos por engenharia reversa ou outros meios honestos, os direitos das comunidades tradicionais evaporariam.

\section{§4 INCAPACIDAdE PARA PROTEÇÃO DE ECTS}

A proposta de Vogel não seria suficientemente flexível para estender proteção às ECTs, porquanto o regime de proteção de segredos comerciais é voltado à proteção de informações técnicas, mas não artísticas.

\section{§5 DESINCENTIVO AO INTERCÂMBIO DE RBIS}

${ }^{1808}$ Cf. LOVE, 2001. 
A proteção dos CTAs por meio de segredos comerciais fomentaria as comunidades tradicionais a encerrarem suas práticas de compartilhamento intercomunitário e intercultural de seu PBI, em prejuízo de sua própria sustentabilidade no médio e longo prazo, já que não mais teriam acesso a recursos, informações e conhecimentos capazes de facilitar sua sobrevivência, em um contexto de miséria material.

\section{§6 Monitoramento}

Caberia às comunidades tradicionais e aos Estados pertinentes a tarefa de monitorar o uso não-autorizado de seus RBIs por meio do exame dos pedidos de patentes depositados internacionalmente. Sabidamente, muitos países ricos em termos bioculturais e comunidades tradicionais não disporiam dos recursos econômicos e técnicos para a consecução desta tarefa; neste contexto, estes grupos continuariam a ser espoliados.

A proposta de Vogel presume que pode ser simples para um Estado ou comunidade determinar a origem de um produto biotecnológico: após o isolamento do recurso biológico intangível, derivado de um recurso biológico tangível acessado indebitamente, pode ser impossível determinar a real origem biológica do produto. Uma companhia pode declarar, no momento do depósito de uma patente para um novo produto biomédico, que ele resultou de técnicas de química recombinante, quando em verdade o produto foi extraído de um recurso biológico, presente em um Estado contratante do protocolo. Neste contexto, se o recurso biológico que deu origem ao produto biomédico for desconhecido pela ciência, quem terá recursos técnicos para impugnar a validade da afirmação fraudulenta?

\section{§7 FALTA DE UM REGISTRO OBRIGATÓRIO}

$\mathrm{Na}$ falta de um registro obrigatório, seria difícil a aproximação entre, de um lado, comunidades tradicionais e Estados nacionais e, do outro, potenciais usuários e recursos biológicos e CTAs. 


\subsubsection{AVAliaÇão Da ADEQUAÇÃo Das PROPOSTAS EXAMINAdAS EM FACE DO QUADRO CONCEITUAL DE DESENVOLVIMENTO SUSTENTÁVEL}

Conforme vimos, os dispositivos dos projetos da OMPI para proteção de CTs e ECTs publicamente acessíveis, embora pareçam protegê-los mediante um RR, em verdade, conferem às comunidades tradicionais que os conservam um direito de propriedade como outro qualquer. Conseqüentemente, as observações já tecidas anteriormente acerca da inadequação das propostas de regimes de propriedade para tutelar aqueles RBIs, cujo valor social apenas se realiza quando amplamente utilizados (RBIs laicos), se aplicam igualmente aqui. ${ }^{1809}$ No entanto, não perderemos a oportunidade de avaliar a adequação das propostas de Reichman \& Lewis e Vogel frente ao quadro conceitual de desenvolvimento sustentável.

\subsubsection{CRITÉRIOS DE OPERACIONALIZAÇÃO 1 E 2}

Direito de acesso amplo e facilitado ao PBI pelas comunidades tradicionais e sociedade em geral; e geração de benefícios econômicos no curto, médio e longo prazo, a serem revertidos em favor da conservação da biodiversidade e da melhoria da qualidade de vida das comunidades tradicionais

A proposta de Reichman \& Lewis, ao se basear parcialmente em um regime de responsabilidade, promove a desburocratização do acesso aos CTs, ampliando as oportunidades de que venham a ser aplicados produtivamente e, naturalmente, as chances de geração de recursos econômicos em favor da conservação da diversidade biocultural. Como o RRC se estenderia também aos CTs publicamente acessíveis, as tradições das comunidades de livre intercâmbio seriam respeitadas.

Sem embargo, a proposta de Reichman \& Lewis não estende proteção aos CTs populares, nem às ECTs e recursos biológicos; seu caráter é nacional, não impedindo, pois, a emergência de concorrência entre Estados e comunidades que vivem em países diferentes e compartilham os mesmos CTs. Estes fatores poderiam ceifar a viabilidade do regime, quando for possível acessar um mesmo CT junto a uma comunidade, que fixe uma remuneração mais baixa que àquela pré-estabelecida pelo RRC. A conseqüência da competição é a redução dos benefícios econômicos que poderiam ser gerados pelo regime.

${ }^{1809}$ Cf. item 4.2.4. 
Ademais, se o país que adotar um RRC não possuir um mercado consumidor relevante, o regime não terá nenhuma funcionalidade, pois terceiros poderão se apropriar ilicitamente dos CTs administrados pelo regime e utilizá-los em outros mercados. Na falta de um regime internacional, os titulares de direitos nada poderiam contra os usuários desonestos. Logo, um RRC nacional seria factível para países ricos em PBI que detêm um mercado consumidor forte, capaz de atrair a atenção e o interesse dos usuários de CTs para neles introduzir seus produtos. Estes países, lamentavelmente, ainda são em número reduzido: e.g. Brasil, China, Índia e Indonésia.

No mesmo sentido da proposta de Reichman \& Lewis, a proposta de Vogel promoveria o acesso amplo e facilitado aos CTs e recursos biológicos, em projetos altamente lucrativos, mas como a proposta fixa uma única taxa de remuneração, projetos pouco lucrativos envolvendo-os poderiam ser descartados por seus proponentes. No mais, no caso de CTs secretos, conservados por uma única comunidade, se esta se opor ao acesso, o conhecimento não poderia ser aplicado.

Haja vista que a proposta de Vogel se estrutura, em parte, sobre o regime de proteção de segredos comerciais, seria conseqüentemente incapaz de tutelar os interesses materiais das comunidades tradicionais em relação aos CTs publicamente acessíveis e às ECTs em geral. Neste contexto, os maiores beneficiários seriam os Estados nacionais, e não os grupos envolvidos na conservação da biodiversidade. Assim, a associação entre, de um lado, uma taxa de remuneração única, fixada em patamar elevado e, do outro, a exclusão do escopo do regime de ECTs em geral e CTAs publicamente acessíveis, derrubaria as chances de o regime gerar benefícios econômicos suficientes no curto e médio prazo, em prol da conservação da diversidade biocultural.

No mais, nem a proposta de Reichman \& Lewis nem o Cartel da Biodiversidade de Vogel vinculam a aplicação dos recursos econômicos recebidos em favor da conservação da diversidade biocultural e da melhoria da qualidade de vida das comunidades tradicionais. Finalmente, a proposta de Vogel, ao estender proteção apenas aos CTAs publicamente inacessíveis e que assim se conservam, estimula as comunidades tradicionais a encerrarem em definitivo as tradições responsáveis pela própria existência destes RBIs. 


\subsubsection{CRITÉRIO DE OPERACIONALIZAÇÃo 3}

Reconhecimento às comunidades tradicionais de um direito moral de atribuição em relação aos RBIs em geral e de um direito moral de integridade em relação às ECTs sagradas

Nenhuma das duas propostas passa por este critério, pois se ocupam, unicamente, com a proteção de interesses econômicos dos Estados e comunidades.

\subsubsection{CRITÉRIO DE OPERACIONALIZAÇÃO 4}

Efetividade dos regimes de proteção em escala global

O RRC proposto por Reichman \& Lewis se estrutura sobre uma OGCD nacional, que viabilizaria, em princípio, o exercício de direitos pelas comunidades tradicionais sobre seus RBIs, em território nacional, mas não em escala internacional. Caso o país seja comercialmente irrelevante, o regime de responsabilidade compensatória não terá capacidade para assegurar o respeito aos interesses materiais dos locais, já que os usuários de seu PBI lá não precisarão operar.

Por outro lado, o Cartel da Biodiversidade proposto por Vogel, porquanto dotado de alcance global, facilitaria a efetividade transfronteiriça do regime internacional. No entanto, falta ao Cartel uma organização internacional, competente para recolher royalties, monitorar infrações e articular com as autoridades aduaneiras a aplicação de sanções pela infração aos direitos assegurados pelo protocolo. Um regime que se apóie apenas no poder econômico e administrativo de países em desenvolvimento e comunidades marginalizadas estará fadado ao fracasso.

No mais, considerando que a proposta de Vogel seria inapta a estender proteção para ECTs em geral e recordando que os recursos da biodiversidade podem levar mais de uma década para serem transformados em produtos finais, a biodiversidade e as comunidades tradicionais continuariam em perigo, na falta de incentivos econômicos para apoiá-las no curto e médio prazo.

\subsubsection{ALGUMAS EXPERIÊNCIAS CONCRETAS DE RRS}


O uso de RRs para a proteção de produções intelectuais não é algo novo. Na seara dos direitos autorais pode receber a denominação de "domaine public payant", quando utilizado para a proteção de obras literárias e artísticas já caídas em domínio público. Este tipo de regime libera o uso comercial de obras literárias e artísticas já em domínio público, cabendo aos usuários apenas a obrigação de comunicar à organização responsável pela gestão do sistema os usos empreendidos das obras e efetuar o pagamento da remuneração devida, calculada com base em taxas pré-estabelecidas. ${ }^{1810}$ A renda gerada pela exploração comercial das obras em domínio público, geralmente, é revertida em prol de projetos culturais e educacionais.

Na seara dos direitos conexos, a Convenção de Roma para a proteção dos artistas intérpretes e executantes confere a estes profissionais apenas um direito de remuneração ${ }^{1811}$ pela radiodifusão e outras comunicações públicas de suas interpretações, fixadas em fonogramas, quando realizadas com objetivos comerciais. ${ }^{1812}$ Em regra, esta remuneração é pré-fixada, em termos não-discriminatórios, por uma OGCD, que também é competente para, inter alia, recolher a remuneração, perseguir supostos infratores e distribuir os royalties coletados a quem de direito.

Alguns países já protegem ECTs e CTs mediante RRs ou regimes que se aproximam a um RR. A título de exemplo, ${ }^{1813}$ podemos mencionar a Bolívia, cuja Lei de Direitos Autorais libera o uso não-comercial de ECTs e sujeita sua exploração comercial apenas à obrigação do pagamento de uma taxa à Dirección Nacional de Derechos de Autor, que poderá variar entre $10 \%$ a $50 \%$ da remuneração que caberia pelo uso comercial de obras similares, protegidas por direitos autorais. ${ }^{1814} \mathrm{O}$ resultado financeiro da exploração comercial das ECTs é dirigido ao Estado, que se encarregará de aplicá-lo em benefício da valorização do patrimônio cultural boliviano. ${ }^{1815} \mathrm{Na}$ hipótese da identidade da

\footnotetext{
${ }^{1810}$ Ver, e.g., WIPO, 1983-1984, p. 148-159; HARVEY, 1994, p. 34-35.

1811 Cf. WIPO, 1985, p. 61.

1812 Art. 13, Convenção de Roma.

1813 No mesmo sentido, ver anexo VII, art. 59(1), AFRICAN INTELLECTUAL PROPERTY ORGANIZATION, Revising the Bangui Agreement of March 2, 1977, on the Creation of an African Intellectual Property Organization. Este dispositivo do acordo de Bangui, o qual se aplica a 16 países africanos, estabeleceu um regime de "domaine public payant" para a proteção de ECTs.

${ }^{1814}$ Cf. art. 60, Bolívia, Ley no. 1322.

${ }^{1815}$ Cf. art. 61, Bolívia, Ley no. 1322.
} 
comunidade-fonte da ECT explorada for conhecida, o Estado lhe transferirá 10\% da renda total auferida. ${ }^{1816}$

O Peru estabeleceu, em 2002, o Regime de Proteção dos Conhecimentos Coletivos dos Povos Indígenas associados aos Recursos Biológicos, ${ }^{1817}$ que protege CTAs em domínio público por um mecanismo similar a um RR. A lei peruana entende por conhecimentos tradicionais em domínio público aqueles publicamente acessíveis. No que tange aos CTs que adentraram o domínio público nas últimas duas décadas, qualquer instituição está automaticamente autorizada a explorá-los comercialmente, desde que reverta um percentual da renda bruta, obtida da exploração comercial de produtos e serviços que incorporá-los, ao Fundo para o Desenvolvimento dos Povos Indígenas (fundo). ${ }^{1818}$ Esta regra não estabelece um verdadeiro RR, ao não pré-fixar os royalties que deveriam ser recolhidos ao Fundo. Nenhuma instituição idônea, que paute sua conduta pela segurança jurídica, se arriscaria a investir no desenvolvimento de produtos e processos com CTs, sabendo que a taxa de royalties poderia ser fixada em um patamar abusivo.

$\mathrm{Na}$ esfera internacional, a FAO opera um genuíno RR, competente para reger o acesso a um amplo leque de recursos da agrobiodiversidade. Em virtude da sobrevivência da humanidade depender destes recursos e da inexistência no mundo de um único país capaz de satisfazer, com autosuficiência, suas próprias necessidades alimentícias, ${ }^{1819}$ a comunidade internacional reconheceu, tacitamente, que o regime de acesso instaurado pela $\mathrm{CDB}$, fundado na associação entre direitos fortes de propriedade e autonomia contratual, se estendido aos recursos da agrobiodiversidade, restringiria o acesso a estes recursos para fins de melhoramento vegetal. ${ }^{1820}$

Como resposta às dificuldades criadas pelo regime da $\mathrm{CDB}$ e considerando a falta de uma regra clara acerca do regime aplicável aos recursos biológicos que integram as

\footnotetext{
${ }^{1816}$ Cf. art. 62, Bolívia, Ley no. 1322.

${ }^{1817}$ Cf. PERU, Ley 27.811.

${ }^{1818}$ Cf. artigos 13 e 37, PERU, Ley 27.811.

${ }^{1819}$ Para a agricultura não é importante simplesmente a diversidade de espécies vegetais, mas a diversidade intra-específica (diversidade dentro de uma espécie), a qual depende do acesso contínuo a novas fontes de recursos biológicos (FAO, 2008).

${ }^{1820}$ Em média, o desenvolvimento de uma nova variedade vegetal envolve 60 recursos biológicos distintos, originados em dezenas de países; se o acesso a estes recursos dependesse da celebração de acordos de licenciamento com o país de origem de cada recurso, a segurança alimentar do mundo estaria em sério risco (MOORE ; TYMOWSKI, 2005, p.3.).
} 
coleções ex situ, formadas no período anterior à sua entrada em vigor, ${ }^{1821}$ a comunidade internacional negociou, entre 1993 e 2001, um novo acordo internacional, substituto do Acordo Internacional da FAO sobre Recursos Fitogenéticos (AIFAO): o Tratado International sobre os Recursos Fitogenéticos para a Alimentação e Agricultura (TIRFAA). ${ }^{1822}$ Sua grande contribuição à realização da meta de segurança alimentar foi estabelecer um regime de acesso especial para os recursos da agrobiodiversidade (sistema multilateral), com o objetivo de abrir caminho para a sua aplicação em projetos de pesquisa científica e tecnológica, relacionados ao setor agrícola e alimentício. ${ }^{1823}$

Em nome da segurança alimentar da humanidade, os Estados contratantes do TIRFAA, no exercício de sua soberania sobre seus recursos biológicos, transferiram ao sistema multilateral seu poder de disciplinar o acesso aos seus recursos biológicos listados no anexo $\mathrm{I}^{1824}$ do tratado (art. 10(2)), e assim também procederam os Centros Internacionais de Investigação Agronômica (CIIAs) do Grupo Consultivo para a Investigação Agronômica Internacional (GCIAI), ${ }^{1825}$ que transferiram contratualmente ao sistema multilateral o poder de gestão de suas coleções ex situ (art. 15), que congregam em torno de 600.000 amostras distintas de recursos da agrobiodiversidade, ${ }^{1826}$ coletadas antes da entrada em vigor do TIRFAA. ${ }^{1827}$

Conforme já indicado, o sistema multilateral é regido por um RR, o qual confere a qualquer pessoa física ou jurídica, pública ou privada, domiciliada em qualquer dos

${ }^{1821}$ Cf. FAO, Resolution 7/93.

1822 Aprovado em 2 de novembro de 2001 (FAO, Résolution 3/2001); em vigor internacional desde 29 de junho de 2004.

${ }^{1823}$ Cf. art. 10.2, TIRFAA

${ }^{1824}$ Os recursos biológicos incluídos no anexo I do TIRFAA correspondem a $80 \%$ das fontes de energia vegetais, que sustentam a humanidade no presente. (INTERNATIONAL PLANT [...], 2004).

${ }^{1825}$ GCIAI é uma parceira fundada em 1971 e apoiada por 47 países, 4 fundações internacionais e 13 organizações regionais e internacionais, com o objetivo de promover pesquisas científicas na área agrícola, notadamente, na área de melhoramento vegetal. Os resultados das pesquisas são oferecidos gratuitamente às instituições públicas e privadas de todo o mundo, com o fím último de promover a segurança alimentar e o

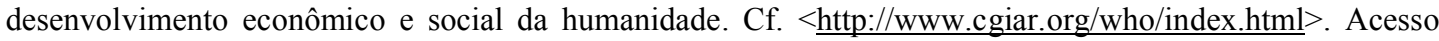
em: 11 set. 2008.

${ }_{1826}^{18}$ Cf. INTERNATIONAL PLANT [...],2004.

1827 Os acordos assinados entre os CIIAS e a FAO estão disponíveis em: $<\underline{\text { http://www.planttreaty.org/art15 es.htm> }}$. Em 26 de outubro de 1994, doze Centros Internacionais de Investigação Agronômica (CIIAs) transferiram à comunidade internacional, representada pela FAO, todas suas coleções ex situ, assumindo, desde então, o papel de depositários destas coleções em seu poder, em nome e em benefício da comunidade internacional. Isto significou que o acesso a estas coleções foi liberado gratuitamente. Como estes acordos foram celebrados em um vácuo legal, porquanto existiam dúvidas sobre a titularidade das coleções, os acordos recentes firmados entre estes CIIAS e a FAO, sob o amparo do art. 15 do TIRFAA, vieram a reconfirmar os acordos de 1994 (FAO, 1994). 
Estados contratantes do TIRFAA (art. 12(2)), uma licença automática obrigatória de acesso aos recursos biológicos das coleções do GCIAI $^{1828}$ e àqueles listados no anexo I do tratado, conservados pelos Estados contratantes do tratado, para sua aplicação em pesquisas científicas e tecnológicas, relacionadas à alimentação e à agricultura (art. 12(3)(a)).

No momento do acesso, o usuário assina um acordo padrão de transferência de materiais biológicos (art. 12(4)), por meio do qual contrai duas obrigações. A primeira é a de recolher uma taxa pré-fixada a um fundo especial da FAO ${ }^{1829}$ cuja base de cálculo será a renda resultante da comercialização de um novo produto, comercializado como semente/material de propagação ou como um novo produto biotecnológico, que incorpore o recurso biológico acessado ou algum de seus elementos intangíveis (e.g. seqüências genéticas). ${ }^{1830}$ Neste último caso, a obrigação apenas subsiste se sobre o produto biotecnológico recair algum DPI ou qualquer outra restrição de natureza legal, contratual ou tecnológica, capaz de interferir na liberdade de terceiros de utilizá-lo gratuitamente, em atividades de melhoramento vegetal, científicas e tecnológicas. ${ }^{1831}$ Caso o novo produto possa ser livremente utilizado por terceiros em projetos de P\&D relacionados ao setor agrícola e alimentício, ainda que seja explorado comercialmente por seu desenvolvedor, este não estará obrigado a reverter benefícios à FAO. ${ }^{1832}$

A segunda obrigação é a de não reivindicar DPIs sobre o material recebido, em sua forma natural, a fim de prevenir o surgimento de obstáculos legais ao funcionamento do sistema multilateral. ${ }^{1833}$

Os resultados já alcançados pelo sistema multilateral da FAO constituem prova inconteste da capacidade de RRs para promover o acesso amplo e facilitado a RBIs e, conseqüentemente, gerar recursos econômicos em favor da conservação da diversidade biocultural: entre $1^{\circ}$ de janeiro e $1^{\circ}$ de agosto de 2007, apenas onze CIIAS transferiram 97.669 amostras de recursos biológicos a instituições públicas e privadas, sob o amparo do

\footnotetext{
${ }^{1828}$ Cf. FAO, IT/GB-2/07/Report, para. 68; FAO, IT/GB-2/7/Inf.11, anexo I.

${ }^{1829} \mathrm{Cf}$. anexos 2 e 3, FAO, Resolución 1/2006.

${ }^{1830}$ A obrigação de pagamento de royalties não se estende à comercialização de produtos alimentícios ou recursos vegetais comercializados como matéria-prima industrial (art. 2, FAO, Resolución 1/2006).

${ }^{1831}$ Cf. FAO, Resolución 1/2006, art. 6(7).

1832 Ibid., art. 6(8).

${ }^{1833}$ Cf . art. 12.3(d), TIRFAA; art. 6(2), Resolución 1/2006.
} 
sistema multilateral. ${ }^{1834}$ É de se notar que a iniciativa privada tem recorrido com freqüência ao sistema, o que aponta seu grande potencial para gerar benefícios econômicos. ${ }^{1835}$

O sistema multilateral da FAO tem como ponto de partida a impossibilidade de se identificar, com segurança, as comunidades agrícolas responsáveis pelo desenvolvimento dos recursos da agrobiodiversidade e a iniqüidade que adviria do reconhecimento, em favor de uma delas, de direitos de propriedade em relação a estes recursos. Por esta razão, os recursos financeiros depositados no fundo são revertidos para projetos em favor da sustentabilidade dos agricultores tradicionais de todo o mundo. ${ }^{1836}$ Para isso, de tempos e tempos, a FAO abre uma competição, em que instituições públicas e privadas, fixadas nos Estados contratantes do TIRFAA, podem apresentar projetos relacionados à promoção da agrobiodiversidade e da agricultura tradicional. Aqueles que melhor se adequarem às diretrizes técnicas determinadas pela FAO serão por ela financiados.

Em função dos baixos custos de transação envolvidos no acesso aos recursos da agrobiodiversidade geridos pelo sistema multilateral da FAO - os quais serão ainda mais reduzidos no futuro próximo ${ }^{1837}$ - e do amplo leque de recursos administrados pelo sistema, os Estados envolvidos na negociação de um regime internacional para os recursos da biodiversidade e CTAs, no marco da CDB, devem ter em mente que, se optarem por proteger os recursos da agrobiodiversidade sob seu controle (i.e. aqueles não incluídos nas coleções dos CIIAS e no anexo I do TIRFAA), por meio de um regime fundado em direitos de propriedade, possivelmente alcançarão resultados pífios. Se uma instituição de pesquisa puder acessar, sem qualquer burocracia, um leque amplíssimo de recursos da agrobiodiversidade, porque se submeteria a um regime caro, pesado e imprevisível?

Ademais, alguns recursos da agrobiodiversidade de extrema relevância para a humanidade foram excluídos do sistema multilateral da FAO (e.g. soja, amendoim), bem como muitos outros recursos que, embora sejam subutilizados, são extremamente nutritivos e, por isso mesmo, valiosos para uma população em franco crescimento, pobre de recursos e meios para alimentar-se adequadamente. Um RR, em contraponto a um

\footnotetext{
${ }^{1834}$ Cf. FAO, IT/GB-2/7/Inf.11, para. 7.

${ }^{1835}$ Cf. NNADOZIE, 2008.

${ }^{1836}$ Cf. art. 13(3), TIRFAA.

1837 A FAO planeja lançar o Global Information System (GIS), o qual permitirá a consulta, pela internet, ao catálogo dos recursos geridos pelo sistema multilateral, bem como sua aquisição, por meio da assinatura de contratos eletrônicos (NNADOZIE, 2008).
} 
regime baseado em direitos de propriedade, viabilizaria o acesso amplo e facilitado a estes recursos de valor social inquestionável. ${ }^{1838}$

\subsubsection{AS FORTALEZAS DE UM REGIME DE RESPONSABILIDADE PARA A PROTEÇÃO DE RBIS}

Ignorando as imperfeições das propostas de Reichman, Lewis e Vogel, a aplicação de um regime de responsabilidade, na esfera internacional, para a proteção de RBIs laicos traria vantagens incontestes aos seus titulares, à natureza, aos setores científico, produtivo e cultural e à sociedade em geral, notadamente:

i. Liberação do uso gratuito dos RBIs para fins não-comerciais, e.g. científico, educacionais, informativos e mesmo tecnológicos e produtivos, desde que com objetivos humanitários, ou seja, para a pesquisa e o desenvolvimento de novos produtos, notadamente por órgãos públicos e organizações sem fins lucrativos, a serem integralmente revertidos em favor de populações marginalizadas de países pobres; ${ }^{1839}$

ii. Permite o uso de reivindicações de longo alcance, com o objetivo de proteger os direitos materiais das comunidades tradicionais e Estados sobre produtos derivados de seus RBIs, sem com isso impedir a liberdade científica e criativa e o desenvolvimento comercial do setor privado;

iii. Facilita o acesso aos RBIs protegidos pelos setores produtivo, científico e cultural da sociedade dominante. ${ }^{1840}$ Ao invés de contrariar a natureza de bens públicos dos RBIs, RRs respeitam suas peculiaridades, notadamente, a facilidade com que se disseminam internacionalmente e as dificuldades técnicas e econômicas para se excluir terceiros não-autorizados. Simultaneamente, RRs tiram bom proveito das peculiaridades dos RBIs, já que maior a disseminação dos RBIs, maior a

\footnotetext{
${ }^{1838}$ Cf. LOUWAARS et al, 2006, p. 61.

${ }^{1839}$ Cf. BENNETT, A.B, 2007, p. 44.

${ }^{1840}$ Ver, e.g., BESSEN; MASKIN, 2006, p. 3.
} 
probabilidade de serem aplicados produtivamente e, conseqüentemente, mais robustas serão as oportunidades de geração de benefícios econômicos. ${ }^{1841}$

iv. Redução dos custos envolvidos em projetos de P\&D nas áreas biotecnológica e biomédica. Quanto não se economizará em tempo, recursos materiais e humanos com o acesso facilitado, pelos setores científico e produtivo, a um acervo rico e desconhecido de conhecimentos técnicos? ${ }^{1842}$ Quando acessá-los é uma tarefa quase impossível, as instituições científicas e industriais precisam duplicar esforços e investimentos, já realizados pelas comunidades, para tentar "redescobri-los", de maneira independente ${ }^{1843}$

v. Prevenção da emergência da tragédia dos anticomuns, mesmo nos casos de RBIs compartilhados por duas ou mais comunidades tradicionais, Estados ou até mesmo por grandes contingentes humanos, ao mesmo tempo em que respeita o desejo legítimo das comunidades tradicionais de tutelar os interesses materiais de todos os grupos que compartilham um mesmo RBI. ${ }^{1844}$ Conseqüentemente, RRs promovem a paz e o entendimento entre as comunidades tradicionais; ${ }^{1845}$

vi. Oferecimento às comunidades tradicionais das condições para conservarem a cultura de livre compartilhamento intercomunitário ${ }^{1846}$ e intercultural ${ }^{1847}$ de seu PBI, sem que com isso se encaminhem em direção à uma tragédia dos anticomuns ou se sujeitem à apropriação indébita de seu PBI por membros externos aos grupos;

vii. $\mathrm{O}$ aprimoramento contínuo dos RBIs junto às suas fontes naturais, humanas e culturais, como resultado da manutenção da cultural da livre difusão intercomunitária; ${ }^{1848}$

${ }^{1841}$ Ver, e.g., BARLOW, 1997, p. 356, 357; SAFRIN, 2004, p. 670.

${ }^{1842}$ Cf. MACHLUP; PENROSE, 1950, p. 28.

${ }^{1843}$ Cf. REICHMAN; LEWIS, 2005, p. 341.

${ }^{1844}$ Cf. WIPO, 2001, p. 71, 88.

${ }^{1845}$ Ver, e.g., NAKASHIMA, 2004, p. 132; WIPO, WIPO/GRTKF/IC/9/INF/4, anexo, para. 17.

1846 Ver, e.g., INTERNATIONAL INSTITUTE FOR ENVIRONMENT AND DEVELOPMENT, 2008; WIESSNER, 2001, p. 272; POSEY, 2004a, p. 122-123.

${ }^{1847}$ Cf. WIPO, 2001, p. 200.

${ }^{1848}$ Cf. BIBER-KLEMM, 2004, p. 102. 
viii. Promoção da diversidade cultural e do entendimento intercultural;

ix. Viabiliza a associação construtiva entre RBIs complementares, notadamente, recursos biológicos e CTAs, que poderão ser facilmente associados pelas instituições mais capacitadas a agregar-lhes valor; ${ }^{1849}$

x. Redução dos custos de transação envolvidos no funcionamento do sistema, ${ }^{1850}$ uma vez que os termos dos acordos de licenciamento e as taxas de royalties seriam préfixados, não havendo espaço para a discussão de pontos substantivos. Assim, o espaço para emergência de litígios e para a demanda de assistência legal seria minorado. ${ }^{1851}$ Com a redução dos custos de transação, mesmo empresas e centros de pesquisa com recursos econômicos diminutos, em comparação com o poder econômico dos grandes conglomerados, poderiam se envolver em atividades de inovação e criativas envolvendo RBIs; ${ }^{1852}$

xi. Enseja o acesso a RBIs, sem a necessidade de que os potenciais usuários divulguem aos titulares de direitos os projetos em que pretendem aplicá-los. Devido à possibilidade de vazamento de informações sigilosas sobre os futuros projetos, se os potenciais usuários tivessem de compartilhar informações a esse respeito - tal como ocorre nos regimes de propriedade -, possivelmente se desinteressariam em acessá-los; ${ }^{1853} \mathrm{e}$

xii. Prevenção de acusações de abuso de poder econômico: mesmo que um número gigantesco de RBIs de todo o mundo venha a ser controlado por uma única OGCD - o que certamente poderia alçá-la à uma posição dominante no mercado $^{1854}$ - recordando, primeiramente, que os royalties seriam fixados por um órgão neutro, comprometido em fixá-los em consonância com as práticas vigentes

1849 Consultar, e.g., SAMPATH, 2005, p. 156-158; PARISI; SCHULZ, DEPOORTER, 2001, p. 18-20; SMITH, 2007, p. 30.

${ }^{1850}$ Cf. COLANGELO, 2004, p. 14.

${ }^{1851}$ Cf. BROWN, G.O, 2003, p. 1.

1852 Cf. GUPTA, 2002, p. 387.

1853 Cf. RAI; EISENBERG, 2003, p. 159.

${ }^{1854}$ Cf. HELFER, 2006, p. 85. 
no mercado a fim de conservar sua atratividade comercial; e em segundo lugar, que a organização não gozaria da prerrogativa de excluir os usuários que anuíssem em pagar a remuneração fixada, a organização não estaria sujeita a acusações, baseadas em recusa a licenciar, fixação dos royalties em níveis abusivos ou discriminação de usuários que ocupam uma mesma posição. ${ }^{1855}$

Em sumário, regimes internacionais voltados à proteção dos RBIs, se apoiados em um regime de responsabilidade, preencheriam os critérios 1 e 2 do quadro conceitual de desenvolvimento sustentável, ao fomentarem o uso amplo e facilitado dos RBIs tanto para fins não comerciais quanto para fins econômicos. Desde que apoiados por uma OGCD com atuação internacional, também lograriam preencher o terceiro critério do quadro conceitual.

Todavia, um regime de responsabilidade é um instrumento totalmente inadequado para a proteção das ECTs sagradas, porquanto o interesse das comunidades, em relação a esta categoria de RBI, é inverso àquele promovido por um RR. Tampouco é útil para tutelar o desejo das comunidades tradicionais de serem reconhecidas publicamente por suas contribuições ao desenvolvimento material, cultural e científico da sociedade.

\subsection{PROPOSTA DE MECANISMO LEGAL E INSTITUCIONAL DE PROTEÇ̃̃o DO PBI}

Em virtude das peculiaridades de cada categoria de RBI e dos interesses divergentes que justificam a proteção de cada uma delas, não é aconselhável protegê-los, na esfera internacional, por meio de um único tipo de mecanismo de proteção. ${ }^{1856}$

Se os futuros acordos internacionais optarem por tutelá-los por meio de direitos de propriedade de longo alcance, as ECTs de natureza sagrada serão protegidas contra aplicações e alterações culturalmente desrespeitosas, satisfazendo as demandas das comunidades tradicionais de ver seus valores religiosos respeitados. Por outro lado, regimes de propriedade limitariam ou impediriam o uso criativo, inovador e produtivo de recursos biológicos, CTs e ECTs laicos, ou, no melhor dos cenários, promoveriam uma

\footnotetext{
${ }^{1855}$ Cf. FICSOR, 2002, p. 144.

${ }^{1856}$ Cf. COMMISSION ON INTELLECTUAL PROPERTY RIGHTS, 2002, p. 80.
} 
competição entre codetentores de um mesmo RBI, em detrimento dos interesses da sociedade e das próprias comunidades tradicionais.

Os futuros regimes internacionais, se assentados sobre um direito de quasepropriedade (regras de repressão à concorrência desleal), sofreriam de mazelas similares àquelas engendradas pela aplicação de um regime de propriedade, com o agravante de que os contornos dos direitos investidos nos detentores de RBIs não seriam sempre claros e sua concreção sempre dependeria de intervenção judicial. O sistema poderia ser útil residualmente, se figurasse apenas como um elemento secundário do marco legal, dedicado à repressão somente daqueles atos de concorrência desleal, já disciplinados pelo art. 10bis da CP.

A aplicação de um regime de responsabilidade para a proteção internacional de RBIs permitiria sua proteção efetiva, quando conservados por uma única comunidade ou Estado, por duas ou mais comunidades ou Estados, ou mesmo por grandes contingentes humanos, sem gerar como efeito colateral uma tragédia dos anticomuns. RRs trazem a vantagem de reconciliar os interesses materiais das comunidades tradicionais com o imperativo de conservar a liberdade científica e criativa da sociedade em geral, ao afastar as amarras ao uso dos RBIs, ao mesmo tempo em que potencializa a geração de recursos econômicos para o cumprimento das obrigações disciplinadas pela CDB, PIDESC, PIDCP e pelos instrumentos da UNESCO relacionados à promoção da diversidade cultural.

Isto não significa que um regime de responsabilidade seria o instrumento ideal, em face do quadro conceitual de desenvolvimento sustentável: um regime de responsabilidade padrão (i.e. aquele cuja única condição para o acesso e uso do recurso protegido é o pagamento de uma remuneração pré-fixada neutralmente) não oferece qualquer proteção aos interesses morais dos titulares de direitos; é inapto para controlar das aplicações e alterações de ECTs de natureza sagrada; e se apoiado por uma OGCD de alcance nacional, não seria capaz de impedir a concorrência entre cotitulares de um mesmo RBI.

Em face do quadro conceitual de desenvolvimento sustentável, um futuro marco legal internacional de proteção de RBIs poderia ser formado pela associação simultânea dos seguintes mecanismos de proteção e elementos: 
Elemento I: Associação obrigatória do regime internacional à um organização de gestão dos direitos das comunidades tradicionais e Estados, composta pelos elementos mínimos identificados no capítulo 3, a saber, registro público obrigatório para os RBIs protegidos e uma rede de instituições científicas;

Elemento II: Inclusão na matéria de proteção de ECTs e CTs populares, i.e. ECTs e CTs compartilhados por grandes contingentes humanos. O exercício dos direitos associados a esta categoria de RBIs caberia aos Estados cujo patrimônio cultural os compreenda. Contudo, os benefícios econômicos auferidos deveriam ser integralmente revertidos em projetos dedicados à conservação da diversidade biocultural.

Elemento III: Proteção das ECTs sagradas por meio de um direito de propriedade de longo alcance e de direitos morais de atribuição e de integridade, válidos perpetuamente. A proteção das ECTs sagradas e dos demais RBIs ficaria condicionada ao seu registro na organização indicada no item (i) supra.

No momento do registro das ECTs sagradas, as comunidades tradicionais indicariam se existem alguns usos (e.g. usos não-lucrativos, científicos, culturais) que poderiam ser liberados e, em caso positivo, as condições que terceiros teriam de cumprir. As condições seriam agregadas ao registro, e possíveis interessados em utilizá-las saberiam, de antemão, as limitações que recaem sobre essas ECTs. Se concordassem com as condições, a organização de gestão inseriria as condições fixadas pela comunidade, no contrato padrão de licenciamento, sem a necessidade de abordar a comunidade. Se os licenciados desrespeitassem os termos do contrato ou terceiros em geral ferissem as estipulações da comunidade, a organização de gestão, em nome dos grupos prejudicados, excluiria os infratores do uso da ECT.

Elemento IV: Instauração de um regime de pliability de longo alcance para a proteção de RBIs laicos (ECTs laicas, CTs e recursos biológicos em geral). Por tempo ilimitado, as comunidades tradicionais e os Estados desfrutariam de um direito de remuneração pelo uso comercial destes RBIs, bem como de um direito de atribuição (em relação aos CTs e ECTs). Estes direitos se estenderiam também às importações aos Estados parte de um hipotético acordo internacional de proteção do PBI, que incorporassem algum RBI, quando 
provenientes de Estados não-signatários do referido acordo. Em outras palavras, terceiros poderiam utilizar os RBIs protegidos, desde que recolhessem os royalties pré-fixados, bem como reconhecessem as fontes dos RBIs incorporados, em todas as formas de usos públicos, diretos e indiretos. Em caso de importação de produtos que incorporassem RBIs protegidos no país de importação, obtidos em Estados não-contratantes do hipotético acordo internacional de proteção do PBI, as importações poderiam ser introduzidas e comercializadas nos Estados contratantes do acordo, desde que os produtos reconhecessem publicamente a fonte dos RBIs neles agregados e fossem recolhidos os royalties devidos. Se estas condições fossem descumpridas, os titulares de direitos teriam um direito de embargar sua entrada nos referidos territórios (direito de propriedade).

Em caso de uso de RBIs laicos para fins não-comerciais, os usuários seriam obrigados a reconhecer a fonte dos RBIs utilizados, em todas aplicações públicas, mas não estariam obrigados a pagar qualquer remuneração. Como o registro público da organização de gestão teria informações a respeito dos titulares dos RBIs registrados, os usuários conseguiriam se desincumbir desta tarefa com facilidade.

Elemento V: Adoção do princípio da exaustão internacional de direitos.

Elemento VI: Condicionamento da concessão de registros sanitários e títulos de propriedade intelectual sobre produções intelectuais derivadas de RBIs protegidos à apresentação de um certificado, concedido pela organização de gestão, indicada no item (i) supra. O certificado seria válido internacionalmente e teria a função de atestar que os RBIs utilizados por terceiros para fins econômicos foram acessados licitamente.

Elemento VII: Reversão integral dos benefícios pagos pelos usuários dos RBIs em favor da conservação da biodiversidade e da melhoria da qualidade de vida das comunidades tradicionais.

No capítulo 3, foi indicado que não seria possível, naquele momento, indicar qual a organização mais adequada para administrar os RBIs, porquanto não era sabido qual o mecanismo legal ou associação de mecanismos seria apropriado para protegê-los em suas 
múltiplas dimensões. ${ }^{1857}$ A partir da identificação da associação de mecanismos mais ajustado a proteger internacionalmente as diferentes categorias de RBIs, será igualmente possível tratar da configuração ideal da organização de gestão, apta a operacionalizar um regime internacional, construído sobre a associação dos elementos indicados nos itens (i) a (vii) supra. Denominaremos essa organização de Organização de Gestão Coletiva do Patrimônio Biocultural Imaterial (OGCPBI).

É importante salientar que um regime internacional de proteção do PBI apenas seria capaz de salvaguardar as múltipas dimensões do PBI, bem como promover desenvolvimento sustentável, se todos esses elementos estiverem presentes simultaneamente. A falta de qualquer um deles acarretará um desequilíbrio na proteção de algum dos interesses que o quadro conceitual de desenvolvimento sustentável se propõe a proteger. Por exemplo, conforme discutido no capítulo 3, o acesso amplo e facilitado aos recursos da biodiversidade para fins produtivos, geralmente, é incapaz de gerar benefícios econômicos no curto e médio prazo para a promoção da diversidade biocultural, enquanto as ECTs permitem a geração de benefícios econômicos, no curto e médio prazo. Se a comunidade internacional optar por proteger apenas os recursos da biodiversidade e CTAs, conservando as ECTs em domínio público, o futuro regime será incapaz de promover a sustentabilidade das comunidades tradicionais e da biodiversidade.

\subsubsection{CARACTERÍSTICAS DA OGCPBI}

\subsubsection{FUSÃO FUNCIONAL ENTRE UMA OGCD E UMA OGD}

Em face das peculiaridades das diversas categorias de RBIs e dos mecanismos legais identificados para sua proteção, a configuração ideal para uma organização de gestão do PBI resulta da fusão das funções exercidas por uma organização de gestão coletiva de direitos (OGCD) e uma organização de gestão de direitos (OGD).

Uma OGCD seria justificável para a gestão das ECTs laicas, CTs e recursos da biodiversidade, porquanto estes recursos já são utilizados em massa em todo o mundo, e a

${ }^{1857}$ Cf. item 3.2.1.4.1. 
tendência é que seu uso só aumente, à medida que o acesso for facilitado e se tornarem mais visíveis pela sociedade dominante. Além do mais, os titulares de direitos sobre RBIs não costumam dispor de recursos econômicos e técnicos para monitorar, individualmente, o uso de seus RBIs em escala global; negociar acordos de licenciamento adequados e perseguir potenciais infratores. E ainda que tivessem tais recursos, a união de todos os detentores de RBIs em uma única organização fortalece sobremaneira sua posição negocial $^{1858}$ e previne a emergência de concorrência entre cotitulares de um mesmo RBI ou de RBIs semelhantes.

No mais, uma OGCD se acomoda perfeitamente às características de um RR ou de um regime de pliability, já que os Estados e comunidades tradicionais gozariam, fundamentalmente, de um direito de remuneração, viabilizando, assim, a instauração pela OGCD de um sistema de gestão standardizado para os RBIs laicos.

Já uma OGD seria competente para gerir ECTs sagradas, porquanto o interesse central de seus titulares é a prevenção de usos culturalmente desrespeitosos. As comunidades detentoras de ECTs sagradas seriam as únicas partes competentes para proibir seu uso ou para fixar as condições de uso por terceiros, em contextos nãotradicionais. As comunidades poderiam, por exemplo, sujeitar a exploração de suas ECTs à conservação de sua integridade; condicionar o uso da ECT à atribuição de créditos à comunidade pertinente, em todas obras derivadas; limitar a aplicação das ECTs apenas em contextos culturais ou informativos etc. ${ }^{1859} \mathrm{Em}$ outras palavras, caberia tão-somente às comunidades o poder de determinar, de acordo com suas normas culturais, as condições a serem observadas por terceiros, porquanto o regime lhes reconheceria um direito de propriedade de longo alcance. À OGD caberia a responsabilidade de assegurar que os desejos das comunidades fossem integralmente respeitados por potenciais licenciados e terceiros em geral. Por conseguinte, seria inadequado a este propósito que uma organização investida na autoridade de fixar condições de licenciamento homogêneas tanto para RBIs laicos quanto para ECTs sagradas.

$1{ }^{1858}$ Ver, e.g., GERVAIS, 2006, p. 18; WIPO, WIPO/GRTKF/IC/12/5(b)), anexo, p. 163; BROWN, M., 2005, p. 53.

${ }^{1859}$ Cf. KANSA, SCHULTZ; BISSELL, 2005, p. 14-15. 


\subsubsection{ALCANCE GLOBAL}

Em razão dos RBIs serem recursos abundantes, freqüentemente compartilhados por dois ou mais Estados nacionais (recursos biológicos) ou comunidades tradicionais (CTs e ECTs), que podem inclusive viver em países diversos, a criação de organizações nacionais para a gestão de RBIs engendraria uma competição entre os codetentores de um mesmo RBI e a reflexa queda de seus preços em escala global, ${ }^{1860}$ ou a emergência de uma guerra legal e política pela titularidade de direitos. Tendo esta realidade como pano de fundo, a organização ideal para a gestão de direitos sobre RBIs deveria ser única e ter alcance global. Em outras palavras, uma única organização seria competente para gerir os RBIs de todos os Estados contratantes do regime internacional de proteção do PBI.

A operação de uma única organização de gestão facilitaria a auditoria de suas atividades pelos titulares de direitos, reduzindo os espaços para a prática de fraudes, ${ }^{1861}$ ensejaria a defesa dos preços dos RBIs no mercado internacional ${ }^{1862}$ e reduziria os custos operacionais do sistema. ${ }^{1863}$

Em virtude das peculiaridades de cada categoria de RBI, poder-se-ia pensar em uma organização global para cada uma das três categorias de RBIs. Nesse sentido, na seara dos direitos autorais e conexos, direitos diferentes (e.g., direitos reprográficos, direitos mecânicos, direitos dos intérpretes) geralmente são geridos por organizações separadas, com o propósito de evitar que os interesses de um grupo mais poderoso dirijam o funcionamento da organização, em detrimento dos interesses dos grupos mais vulneráveis. ${ }^{1864}$ No caso de RBIs, a realidade é diferente: as comunidades tradicionais são titulares de um volume substantivo de RBIs (CTAs e ECTs). Os recursos biológicos, por sua vez, ganham valor, quando comercializados conjuntamente com os CTs. Assim sendo, não seria justificável a instituição de organizações separadas para cada categoria de RBI.

Seria igualmente problemático, em nome da conservação da liberdade das comunidades tradicionais e dos Estados de escolherem os meios de gestão de seus

\footnotetext{
${ }^{1860}$ Ver, e.g., HELFER, 2006, p. 106; VOGEL, 2000d, p. 109; VOGEL, 2007a.

${ }^{1861}$ Cf. DRAHOS, 2000.

${ }^{1862}$ Cf. UNGA, Resolution 3202, item VII, para 1(a).

1863 Cf. BRUSH, 1994, p. 33.

${ }^{1864}$ Cf. FICSOR, 2002, p. 134.
} 
RBIs, ${ }^{1865}$ tornar opcional ${ }^{1866}$ a participação na OGCPBI, pelo menos, enquanto estes grupos não detiverem a capacidade econômica e técnica para negociarem acordos de licenciamento justos e monitorarem os usos de seus RBIs, em escala global. O sistema de gestão coletiva ruiria, se apenas alguns RBIs fossem administrados pela organização e outros idênticos ou funcionalmente similares fossem conservados fora de seu alcance: os RBIs administrados pela OGCPBI, uma vez que estariam apoiados por um sistema de gestão forte, possivelmente estariam sujeitos ao pagamento de taxas de royalties mais elevadas que aquelas aplicáveis aos RBIs diretamente administrados por seus titulares, em virtude de sua posição negocial fragilizada ante os potenciais usuários. É natural que os usuários optem por aqueles RBIs mais baratos, o que tornaria inviável o funcionamento da organização. Se essa não intermediar, continuamente, a celebração de um volume importante de acordos de licenciamento, é presumível que não terá caixa suficiente nem importância política, para manter em funcionamento a estrutura mínima indispensável para assegurar a observância dos direitos administrados, em escala global. O conseqüente desmantelamento da OGCPBI colocaria novamente as comunidades e Estados, que haviam optado por transferir-lhe a gestão de seus RBIs, em uma posição negocial débil. ${ }^{1867}$

No mais, se a participação na OGCPBI fosse opcional, poderíamos aventar a hipótese das comunidades tradicionais optarem por lhe transferir a gestão de seus CTAs e os Estados nacionais se negarem a submeter seus recursos biológicos à mesma organização. Haja vista que a realização do valor social, científico e econômico dos CTAs depende de sua fusão com os recursos da biodiversidade, a não-participação dos Estados na organização despiria os CTAs de qualquer relevância prática. ${ }^{1868}$ Os Estados poderiam contra-argumentar que o interessado em utilizar uma determinada associação entre um recurso biológico e um CTA poderia buscar acesso ao recurso biológico pertinente junto ao seu país de origem. Mas como o potencial usuário teria de cumprir, ao menos, com dois procedimentos burocráticos para acessar RBIs complementares, os custos de transação poderiam alcançar patamares elevados. Isso sem contar que sempre há a possibilidade de que o Estado consultado crie obstáculos ao acesso, ou que Estados que compartilham o mesmo recurso biológico expressem o desejo de participarem da negociação do acordo de licenciamento.

\footnotetext{
${ }^{1865}$ Cf. DAES, 1997, 175 (c).

${ }^{1866}$ A favor da instituição de uma OGCD opcional para a gestão global de CTAs, ver DRAHOS, 2000.

${ }^{1867}$ Cf. HELFER, 2006, p. 103-106.

${ }^{1868}$ Cf. VOGEL, 2000b, p. 24.
} 
Enfim, permitir a participação opcional na OGCPBI contraria sua sustentabilidade e resultaria em seu desmantelamento; e o mais importante, ataca as oportunidades das comunidades tradicionais e dos Estados de maximizar sua renda, derivada da exploração comercial de seus RBIs.

\subsubsection{FUNÇÕES DA OGCPBI}

A OGCPBI, porquanto dotada de um sistema de registro obrigatório dos RBIs protegidos, possivelmente estaria apta a identificar todos os codetentores de um mesmo RBI e a distribuir benefícios em favor deles todos, independentemente de onde estiverem. Tendo em mente que a regra é que os titulares de RBIs sejam grupos materialmente marginalizados, a OGCPBI teria sucursais nacionais, a fim de facilitar o registro dos RBIs. Estas sucursais, apoiadas por uma equipe formada por antropólogos e etnobiólogos, seriam responsáveis por abordar as comunidades tradicionais para verificar seu interesse em registrar seus RBIs e, se assim desejassem, realizariam a coleta e o registro dos RBIs a serem protegidos. ${ }^{1869}$ Uma vez registrados perante as representações nacionais, o registro valeria internacionalmente. Esse é o único meio para tornar o regime de fato acessível por todos beneficiários e ao mesmo tempo respeitoso para com as sensibilidades das comunidades tradicionais.

Neste momento é importante um esclarecimento. A abordagem das comunidades para verificar seu interesse em registrar não significa que existiriam dois regimes paralelos de proteção: um para os RBIs registrados e outro para os RBIs não-registrados. A única proteção a que estariam sujeitos os RBIs não-registrados seria aquela relacionada à capacidade fática das comunidades tradicionais para controlarem seu uso e impedirem sua disseminação para além de suas fronteiras.

A OGCPBI também seria competente para: ${ }^{1870}$

\footnotetext{
${ }^{1869}$ Cf. HANSEN; VANFLEET, 2003, p. 18.

${ }^{1870}$ Ver, e.g., BIBER-KLEMM et al., 2006, p. 268-275; CLARK; KOSKINEN-OLSSON, 1998, p. 229; GRAFF et al, 2001, p. 16; DRAHOS, 2000, p. 247-248; WIPO, WIPO/GRTKF/IC/9/INF/4, anexo I, para. 66.
} 
i. Receber solicitações de acesso aos RBIs registrados;

ii. Redigir acordos-padrão de licenciamento para RBIs laicos e celebrar acordos de licenciamento com as partes interessadas;

iii. No momento da assinatura do contrato de licenciamento pelo usuário, expedição de certificado internacional, que serviria como um passaporte, competente a atestar a licitude do acesso ao RBI objeto do acordo. O certificado seria útil para viabilizar a reivindicação de DPIs e a obtenção de registros de comercialização, em relação a produções intelectuais que incorporem algum dos RBIs geridos pela OGCPBI. Na hipótese de outras comunidades tradicionais ou Estados apresentarem reivindicações em face do usuário legalizado, caberia à OGCPBI resolver a disputa, mantendo a salvo o contrato já em vigor e as atividades conduzidas sob seu amparo;

iv. Receber notificações dos licenciados, onde indicam, de tempos em tempos, os usos empreendidos com os RBIs licenciados. Com base nas informações prestadas, a organização expediria faturas;

v. Tutelar os RBIs objeto de publicações, mas ainda não-registrados, seja porque seus titulares são desconhecidos, seja em razão da impossibilidade de identificálos, seja porque seus titulares ainda não tiveram a oportunidade de registrá-los (RBIs órfãos ${ }^{1871}$ ). ${ }^{1872}$ Por exemplo, uma instituição que acessar um CTA mediante consulta à uma publicação científica, caso ele ainda não tenha sido registrado perante a OGCPBI, esta representaria a comunidade detentora do RBI em um acordo de licenciamento e, se possível identificá-la com alguma facilidade, lhe encaminharia os benefícios recebidos. Caso não fosse possível identificá-la de pronto, a organização conservaria os benefícios recolhidos, em depósito, até sua identificação. Se impossível sua identificação, os benefícios recebidos seriam

${ }^{1871}$ Cf. WIPO, WIPO/GRTKF/IC/13/4(b) Rev, para. 94.

${ }^{1872}$ Esse mecanismo é conhecido pela denominação de licenças extendidas e teve origem nas organizações de gestão coletiva de direitos autorais e conexos, em operação nos países nórdicos (FICSOR, 2006, p. 48). 
revertidos em favor de projetos de melhoria da qualidade de vida de comunidades tradicionais;

vi. Estabelecer um sistema neutro de cálculo de tarifas, competente para fixar tarifas diferenciadas para o uso de RBIs laicos, segundo sua contribuição ao desenvolvimento do produto final (usos primários e secundários). ${ }^{1873}$ As tarifas seriam fixadas segundo as práticas do mercado, não cabendo aos Estados nacionais ou às comunidades tradicionais o direito de interferir no processo de precificação. $^{1874}$

A fim de tornar economicamente viável o acesso a RBIs complementares - e.g. um determinado recurso biológico e o CT a ele associado ou ECTs que podem ser empregadas, conjuntamente, na criação de um novo produto -, o sistema de tarifas fixaria condições especiais de acesso a conjuntos complementares de RBIs, a serem aplicados em um mesmo produto, ao invés de aplicar, cumulativamente, as taxas de royalties que seriam devidas, se acessados individualmente. ${ }^{1875}$

vii. No que tange às ECTs sagradas, assegurar que a vontade das comunidades titulares de direitos seja observada integralmente.

viii. Monitorar, em escala global, as aplicações empreendidas com os RBIs registrados e identificar possíveis infrações aos direitos conferidos e perseguir judicialmente potenciais infratores; ${ }^{1876}$

ix. Administrar uma câmara arbitral internacional para a solução de litígios envolvendo quebra de contratos de licenciamento. ${ }^{1877}$ Com o objetivo de trazer

${ }^{1873}$ Cf. SWANSON; GOESCHL, 2007, p. 21.

${ }^{1874}$ Cf. YU, 2007, p. 1101.

${ }^{1875}$ Ver, e.g, GRAFF et al., 2001, p. 16; AOKI, SCHIFF, 2007a, p. 24. O acordo-padrão de transferência de recursos fitogenéticos para a agricultura, em uso pelo sistema multilateral da FAO, fixa uma taxa de royalty única, quando uma mesma parte acessar dois ou mais recursos biológicos. A cláusula da FAO é demasiadamente favorável aos usuários de recursos fitogenéticos, pois uma mesma parte pode utilizar um amplo leque de recursos e pagar a mesma taxa que seria devida, caso utilizasse um único recurso. De qualquer forma, a cláusula do acordo-padrão da FAO serve para chamar a atenção sobre a necessidade de se estabelecer royalties diferenciados para o uso de RBIs complementares, a fim de evitar que os custos impingidos sobre os usuários inviabilizem seus projetos. Cf. FAO, Resolución 1/2006, anexo, 2, cláusulas $1 \mathrm{e}$ 2.

${ }^{1876}$ Cf. MGBEOJI, 2001-2002, p. 186. 
segurança a todos os envolvidos, a corte arbitral seria composta por profissionais técnicos, idôneos e desvinculados de qualquer grupo de interesses; ${ }^{1878} \mathrm{e}$

x. Recolher royalties junto aos usuários de RBIs e distribuí-los às partes pertinentes. Na hipótese dos RBIs serem compartilhados por duas ou mais comunidades ou Estados, caberia à organização notificar todas as partes interessadas a respeito dos benefícios em depósito, para que se reunissem com o objetivo de discutir como reparti-los. ${ }^{1879}$

A OGCPBI funcionaria como um "balcão único" (one-stop-shop) ${ }^{1880}$ para os potenciais usuários de RBIs, onde poderiam acessar um portfólio ímpar de bens informacionais, por meio da celebração de acordos de licenciamento expeditos. Este "balcão único" poderia ser acessível on-line àquelas instituições e indivíduos précadastrados, ${ }^{1881}$ viabilizando, assim, o acesso aos RBIs por organizações e indivíduos de todo o mundo. Deste modo, a OGCPBI multiplicaria o potencial econômico dos RBIs, ao trazer-lhes visibilidade global e facilitar a aproximação entre detentores de RBIs e potenciais usuários que geralmente não os acessariam, em razão do desconhecimento de sua existência. ${ }^{1882}$ Ademais, ofereceria a empresas e organizações de pequeno porte a oportunidade de acessar e explorar insumos intelectuais e informacionais que geralmente são explorados apenas por grandes conglomerados, em virtude dos altos custos envolvidos no acesso. ${ }^{1883}$

Atestando a viabilidade do que ora se propõe, o Departamento de Pesquisa e Inovação da Universidade de Edimburgo, Escócia, opera um mecanismo de licenciamento expedito de tecnologias, desenvolvidas nesta universidade, denominado Click-Thru Licensing. ${ }^{1884}$ Tal mecanismo permite o licenciamento de tecnologias por meio de um site público, que indica as tecnologias disponíveis para licenciamento. O site conta com uma breve descrição das tecnologias, suas potenciais aplicações, o valor da taxa de

1877 Cf. GRAFF; ZILBERMAN, 2001a, p. 1179.

${ }^{1878}$ Cf. TANSEY et al., 2000, p. 133.

${ }^{1879}$ Cf. MOUCHET, 1983-1984, p. 141.

${ }^{1880}$ Cf. CLARK; KOSKINEN-OLSSON, 1998.

${ }^{1881}$ Ver, e.g., GRAFF; ZILBERMAN, 2001b, p. 6; CLARK; KOSKINEN-OLSSON, 1998, p. 231.

${ }^{1882}$ Cf. BIBER-KLEMM et al., 2006, p. 270.

${ }^{1883}$ Ibid., p. 277.

1884 Informações sobre o funcionamento do sistema Click-Thru Licensing foram extraídas de $<\underline{\text { http://licensing.research-innovation.ed.ac.uk/> }}$. Acesso em: 3 de março de 2009. 
licenciamento e os termos do contrato de licenciamento. Terceiros interessados em licenciar alguma das tecnologias lá oferecidas são obrigados a se cadastrar eletronicamente e a assinar um contrato eletrônico- padrão. A Universidade, então, encaminha ao novo licenciado uma fatura de pagamento e, dependendo da natureza da tecnologia objeto do contrato, envia os materiais licenciados via correio. O sistema é tão simples quanto comprar livros pela internet.

\subsubsection{ALCANCE INTERNACIONAL DA REDE DE ORGANIZAÇÕES CIENTÍFICAS}

Nos termos do quadro conceitual de desenvolvimento sustentável, foi esclarecido que uma organização, competente para gerir os direitos associados aos recursos biológicos e CTAs, não lograria desincumbir-se bem desta tarefa, se não fosse apoiada por uma rede de instituições científicas, capacitada a analisar taxonomicamente os recursos biológicos lá depositados; avaliar sua bioatividade; isolar os recursos biológicos intangíveis que apresentem bioatividade; identificar seu valor científico e técnico, seja mediante a aplicação de tecnologias de ponta, seja mediante sua aplicação com o propósito de validar CTAs.

A realização dessas atividades em relação a um número desconhecido, mas gigantesco de recursos biológicos e CTs, demanda recursos econômicos, humanos e tecnológicos, que a maioria esmagadora dos países detentores de RBIs está longe de controlar. No entanto, existem alguns países em desenvolvimento, que contam com capacidade de P\&D próxima a dos países mais industrializados. Por exemplo, África do Sul, Brasil, Cuba, China, Coréia do Sul, Egito e Índia apresentam capacidade científica destacada no setor biotecnológico. ${ }^{1885}$ Suas instituições científicas, notadamente as governamentais, poderiam compor uma rede científica de apoio à OGCPBI.

Sem embargo, se apenas as instituições e cientistas de um seleto grupo de países em desenvolvimento puderem participar das atividades relacionadas aos RBIs, o regime internacional não aproximará os países mais fragilizados da trilha que os conduzirá a um desenvolvimento sustentável. Afinal, um regime dedicado à promoção da produtividade

${ }^{1885}$ Cf. THORSTEINSDÓTTIER et al., 2004a, 2004b. 
científica e tecnológica de apenas alguns poucos países contraria a própria concepção de desenvolvimento sustentável. ${ }^{1886}$

A fim de tornar realidade o compromisso da comunidade internacional de fomentar a cooperação científica internacional, com o fim último de catalisar o desenvolvimento endógeno científico, cultural e tecnológico de todos os países em desenvolvimento ${ }^{1887}$ e expandir a base de conhecimentos da humanidade a respeito da biodiversidade, ${ }^{1888}$ a rede internacional deveria compreender as instituições de pesquisa mais capacitadas dos países em desenvolvimento. No entanto, as equipes de cientistas envolvidos nos projetos incluiriam profissionais de todos os países em desenvolvimento, participantes do regime. Aqueles países que ainda não detivessem recursos humanos qualificados para as atividades demandadas, poderiam encaminhar assistentes de pesquisa para lá se capacitarem.

Assim, as instituições de pesquisa integrantes da rede internacional ofereceriam aos Estados e comunidades tradicionais sua infraestrutura científica e recursos humanos, para a agregação de valor aos RBIs e aprimoramento e/ou desenvolvimento da capacidade científica dos pesquisadores de outros países em desenvolvimento. À medida que outros Estados contratantes do regime internacional desenvolvessem suas capacidades científicas e tecnológicas, poderiam investir na formação de instituições de pesquisa, as quais seriam agregadas à rede internacional de instituições de pesquisa.

A presença na OGCPBI de uma infraestrutura de geração de conhecimentos a partir das fortalezas bioculturais, humanas e técnicas dos países em desenvolvimento, além de facilitar a prevenção de atos de apropriação indébita, ainda: aumenta substancialmente a renda dos detentores de RBIs; ${ }^{1889}$ fomenta o estudo e o conhecimento da biodiversidade e do arcabouço cultural dos povos marginalizados; incita a conservação e aplicação do PBI para a solução das necessidades da humanidade; aproxima construtivamente sistemas distintos de conhecimento; promove o desenvolvimento científico e industrial do setor produtivo de países marginalizados, ao lhe disponibilizar uma nova vantagem

\footnotetext{
${ }^{1886}$ Cf. SACHS, 2007g, p. 308.

1887 Ver, e.g., UNESCO, Recomendación relativa a la situación de los investigadores científicos, para. 16-18 e 31; ECOSOC, Resolution 1826(LV), preâmbulo e para. 3, 5 e 6; UNGA, Resolution A/RES/44/14, item (b), para 2; art. 18(4), CDB.

${ }_{1888}$ Cf. FAO, 1996a, para. 218, 241, 258, 293.

${ }^{1889}$ Cf. SAFRIN, 2004, p. 684.
} 
competitiva; ${ }^{1890}$ cria um ambiente cientificamente estimulante e economicamente recompensador, capaz de reverter a tendência de "fuga de cérebros" dos países em desenvolvimento para os industrializados; ${ }^{1891}$ por fim, representa uma medida concreta de observância de compromissos internacionais, que obrigam seus Estados parte a cooperarem no atendimento da meta comum de progresso material e social $^{1892}$ e da promoção da diversidade cultural. ${ }^{1893}$

Os países em desenvolvimento, insistentemente, advogam pela inclusão, em resoluções, ${ }^{1894}$ acordos comerciais ${ }^{1895}$ e ambientais ${ }^{1896}$, de dispositivos que encorajem ou obriguem os países industrializados a lhes transferir tecnologia de ponta e/ou a apoiar a capacitação técnica de seus recursos humanos. ${ }^{1897}$ Já é tempo de se reconhecer que esses dispositivos são letra morta e que os países industrializados farão de tudo para dificultar o desenvolvimento tecnológico dos países pobres, ${ }^{1898}$ já que, em verdade, se opõem a qualquer ameaça ao seu status quo, sobretudo em um período de crise econômica global. Portanto, salvo se os países em desenvolvimento se associarem entre si com o objetivo de explorarem conjuntamente suas riquezas naturais, culturais e humanas, ${ }^{1899}$ permanecerão, por tempo indefinido, no papel de meros provedores de matéria-prima barata aos países industrializados.

No presente, o único caminho viável de desenvolvimento dos países pobres é aquele pautado por uma estratégia de cooperação Sul-Sul, ${ }^{1900}$ que se estruture sobre suas

\footnotetext{
${ }^{1890}$ Cf. PEOPLE DAILY, 2001.

1891 As diásporas de cientistas - as levas de imigrantes qualificados dos países em desenvolvimento em direção aos países industrializados - desempenha um importante papel no incremento constante do abismo econômico e tecnológico que separa os países em desenvolvimento dos industrializados (SÉGUIN et al., 2006, p. 79). Relevante mencionar, que a Agenda do Desenvolvimento da OMPI dedica uma de suas recomendações à adoção de políticas capazes de reverter a tendência de "fuga de cérebros" dos países em desenvolvimento (WIPO, 2007, recomendação no. 39).

1892 Ver, e.g., UNESCO, Recomendación relativa a la situación de los investigadores científicos, para. 42; artigos 55-56, Carta das Nações Unidas: artigos 2(1), 15(iv), PIDESC.

${ }^{1893}$ Cf. artigos 12, 15 e 17, CPPDEC; artigos 13(d)(i), (iii), 19, CSPCI.

${ }^{1894}$ Ver, e.g., UNGA, Resolution 2542, para. 23(d); UNGA, Resolution A/RES/35/56, para. 120; UNGA.

${ }^{1895}$ Ver, e.g., art. 66, TRIPS.

${ }^{1896}$ Ver, e.g., art. 19(2), CDB.

${ }^{1897}$ Cf. SCBD, 2002, apêndice 2, item 2, alíenas (f) -(g), (j), (m). Ver também as recomendações 26 e 28 , WIPO, 2007.

${ }^{1898}$ Ver, e.g., RAW, 2001-2002, (Isaías Raw relata um episódio em que o F. Lovejoy, então Subsecretário do Interior dos EUA, procurou dissuadir o Brasil do plano de criar um centro de pesquisas biotecnológicas na Amazônia).

1899 Cf. UNITED NATIONS ENVIRONMENT PROGRAMME; UNITED NATIONS UNIVERSITY INSTITUTE OF ADVANCED STUDIES, 2008, p. 85; COPCBD, Decision IX/25.

${ }^{1900}$ Cf. UNGA, Resolution 3201, para. 4(s).
} 
fortalezas locais. A agregação à OGCPBI de uma verdadeira "Casa de Salomão", ${ }^{1901}$ onde as riquezas e capacidades técnicas dos cientistas formais e dos 'cientistas da natureza' se complementam, viabilizaria o desenvolvimento sustentável de países historicamente espoliados e catequizados na crença do desvalor de suas riquezas naturais, humanas e culturais.

O levantamento da "Casa de Salomão" dependerá da disposição dos países em desenvolvimento e de suas comunidades tradicionais de deixar para trás memórias amargas das relações conflituosas e desrespeitosas com as instituições que simbolizam o ocidente, bem como da compreensão de que o cientista ocidental congrega um arcabouço científíco, que não se confunde nem substitui o arcabouço intelectual das comunidades culturais. Ao invés de alimentarem discussões infrutíferas sobre qual sistema de conhecimentos é superior, seria mais produtivo se os países em desenvolvimento, suas comunidades tradicionais e instituições científicas se unissem para superarem as limitações do conhecimento humano. ${ }^{1902}$

\subsubsection{FUNDO DE GESTÃO DOS BENEFÍCIOS ECONÔMICOS DERIVADOS DA EXPLORAÇÃO DO PBI}

Como reflexo dos RBIs serem geralmente compartilhados por diversas comunidades tradicionais e Estados, a OGCPBI depositaria os benefícios econômicos coletados, como resultado da exploração comercial dos RBIs por ela geridos, em um fundo específico para cada RBI. Por exemplo, o resultado econômico de um grupo de moléculas derivadas da planta $\mathrm{X}$ seria depositado em um fundo atrelado a este recurso biológico,

\footnotetext{
${ }^{1901}$ BACON, em A Nova Atlântida, trata da instituição mais importante do reino fictício de Bensalem: a Casa de Salomão. Esta seria uma grande instituição de pesquisa, onde indivíduos, dotados de capacidades científicas diferenciadas e complementares, se uniriam, com o objetivo único de conhecer as "causas e movimentos secretos das coisas, assim como para a ampliação dos limites do império humano para tornar possíveis todas as coisas" (BACON, [20--], p. 37). A Casa de Salomão figura, acima de tudo, como uma instituição democrática: não apenas os cientistas de ponta, com estofo para a condução de grandes projetos de inovação, dela participam (os chamados "pioneiros"); uma gama variada de profissionais, que vai desde os aprendizes até o pioneiros, atuaria organicamente com o propósito de expandir as fronteiras do conhecimento humano. (BACON, [20--], p. 26, 46, 47).

1902 No sentido de confirmar a relevância prática da associação construtiva entre os conhecimentos das comunidades culturais e a ciência ocidental, ver MORRISON, 2008 (cientistas e indígenas se uniram para mapear regiões desconhecidas da costa da Austrália, na região da ilha de Bremer).
} 
facilitando, assim, sua gestão pelos cotitulares de direitos. ${ }^{1903}$ Se as moléculas derivadas dessa planta $\mathrm{X}$ foram associadas a algum conhecimento tradicional, o percentual que caberia às comunidades tradicionais pelo uso de seu know-how seria depositado em outro fundo.

Com o propósito de manter em funcionamento a estrutura da OGCPBI, no caso de CTAs e recursos biológicos e produtos derivados, sugerimos ${ }^{1904}$ que $50 \%$ dos royalties recebidos fossem revertidos em favor da OGCPBI; sendo que 25\% deste total seriam canalizados para a cobertura dos custos operacionais da organização (pessoal, estrutura de monitoramento internacional, instalações físicas, organização de coleções ex situ com os recursos biológicos depositados e produtos derivados etc.), enquanto os $75 \%$ restantes seriam transferidos para as instituições de pesquisa envolvidas nas atividades de agregação de valor aos RBIs. Esses recursos serviriam para cobrir gastos com salários dos pesquisadores, material de laboratório, aquisição de novos aparatos etc.

A outra metade dos royalties seria dividida, em partes iguais, com o grupo de Estados que compartilham o recurso biológico, de onde foi extraída a molécula licenciada e com os titulares do CTA, agregado ao produto derivado do recurso biológico. Na hipótese dos recursos biológicos ou produtos derivados licenciados não se associarem a qualquer conhecimento tradicional, os $50 \%$ dos royalties recolhidos seriam revertidos em prol dos Estados titulares do recurso biológico pertinente.

No caso de licenciamento de ECTs, caberia à OGCPBI 12,5\% dos royalties pagos, e os $87,5 \%$ restantes seriam revertidos aos titulares de direitos. É importante ter claro que os percentuais indicados são apenas sugestões, que não se baseiam em qualquer estudo econômico. O que realmente importa é ter presente o imperativo de se canalizar uma parcela dos benefícios, em favor da manutenção da OGCPBI e da rede de instituições científicas.

À primeira vista pode parecer que o percentual revertido à OGCPBI é exagerado. No entanto, os recursos que lhe são canalizados serviriam para a própria defesa do PBI:

\footnotetext{
${ }^{1903}$ Cf. GUPTA, 2004, p. 114-116;

1904 A sugestão aqui apresentada de esquema de repartição de benefícios se baseia em um dos esquemas utilizados pela Universidade de Illinois em Chicago para repartir os benefícios, resultantes da exploração comercial de produtos farmacêuticos, derivados da biodiversidade (SOEJARTO, 2001, p. 31).
} 
reiteramos que, sem uma organização funcional e operante, os direitos conferidos aos Estados e comunidades tradicionais seriam inócuos. Os investimentos realizados em pesquisas servem para agregar valor aos RBIs, notadamente CTAs e recursos biológicos, majorando os royalties pagos aos titulares de direitos, ao mesmo tempo em que capacitam países em desenvolvimento a criarem as condições para o surgimento de instituições de pesquisa e, porque não, de empresas locais.

Recordando que os futuros regimes internacionais de proteção de RBIs, se moldados em consonância com as diretrizes traçadas pelo quadro conceitual de desenvolvimento sustentável, não se prestariam simplesmente a gerar renda, os recursos recolhidos pela OGCPBI deveriam ser distribuídos aos titulares de direitos, desde que se comprometam a investi-los: na conservação e/ou restauração dos biomas, em que os recursos biológicos explorados existem em condições in situ; em projetos de conservação in situ ${ }^{1905}$ e ex situ dos RBIs; em projetos de melhoria da qualidade de vida de todos os membros das comunidades tradicionais pertinentes, ${ }^{1906}$ sem qualquer tipo de tratamento discriminatório em favor de um grupo (e.g. curandeiros) sobre os demais, por exemplo, em projetos de capacitação profissional, saúde, educação, moradia.

A fim de assegurar que o compromisso assumido pelos detentores de RBIs seja observado, a OGCPBI estaria igualmente autorizada a monitorar as aplicações dos recursos distribuídos e os resultados alcançados. Logo, os cotitulares de direitos desfrutam de liberdade para compartilhar entre si os recursos recolhidos pela organização, bem como para escolher onde os aplicarão, na medida em que os destinarem a projetos relacionados à promoção da diversidade biológica e da melhoria da qualidade de vida das comunidades tradicionais. Sempre que se afastarem destes objetivos, a OGCPBI suspenderia o repasse dos royalties aos Estados e/ou comunidades que desrespeitarem as diretrizes de investimentos a que se vincularam.

\subsection{CONCLUSÕES}

\footnotetext{
1905 Sobre recomendações de estratégias de conservação in situ de recursos da agrobiodiversidade ver BRUSH, 2004, p. 44.

${ }^{1906}$ Cf. SAHAI, 2004, p. 288.
} 
A aplicação do quadro conceitual de desenvolvimento sustentável às propostas em debate/construção na arena internacional ensejou não apenas a identificação das fraquezas e limitações de cada uma delas; permitiu, acima de tudo, identificar a aptidão genérica de esquemas fundados em direito de propriedade, direito de quase-propriedade (regras de repressão da concorrência desleal), regime de responsabilidade e de pliability para salvaguardarem os RBIs, em suas múltiplas dimensões.

Regimes fundados em direitos de propriedade são úteis para a proteção daqueles RBIs que não devem ser disseminados e utilizados amplamente, a saber, as ECTs de natureza sagrada, porquanto super-restringem sua disseminação pública e asseguram os direitos morais das comunidades tradicionais. Seu efeito colateral é o embargo da aplicação produtiva destes recursos por terceiros, limitando, assim, a geração de recursos econômicos.

Os regimes de quase-propriedade apresentam como fortaleza a flexibilidade de se adequarem a novos contextos, protegendo os RBIs em situações imprevistas pelos legisladores. Por outro lado, o exercício dos direitos depende da intervenção do Poder Judiciário, e os resultados dos litígios são imprevisíveis.

Os regimes de responsabilidade, por sua vez, se mostram adequados para a proteção daqueles RBIs, cujo valor social apenas se realiza quando amplamente aplicados (RBIs laicos), porquanto fomentam sua aplicação produtiva e a geração de recursos econômicos. Todavia, são incapazes de promovem a proteção dos direitos morais dos titulares de direitos.

Finalmente, os regimes de pliability se assentam sobre a associação entre direito de propriedade e regime de responsabilidade, com o objetivo de agregar suas virtudes e superar suas fraquezas individuais. São capazes de proteger, simultaneamente, interesses de natureza moral e aqueles de natureza econômica dos detentores de RBIs, ao mesmo tempo em que salvaguardam a liberdade de acesso da sociedade aos RBIs. Enfim, sob a ótica do quadro conceitual de desenvolvimento sustentável, nenhum desses mecanismos, em isolamento, se mostra adequado para proteger o conjunto de RBIs, que compõe o PBI. 
Em face desses resultados e do conjunto de critérios de operacionalização, que compõe o quadro conceitual de desenvolvimento sustentável, foi possível delinear um arranjo legal e institucional, hábil a promover a proteção internacional do PBI em sua integralidade (quadro 5), o qual se afasta substancialmente das propostas de regimes internacionais, em discussão na CCDB, OMC e OMPI (quadro 6).

Assim sendo, o presente estudo sustenta que essas propostas, se transformadas em acordos vinculantes, poderão pôr em risco tanto os interesses dos detentores de RBIs (interesses ambientais, culturais, morais e econômicos) quanto outros interesses da sociedade, resguardados pelo direito internacional, notadamente, a liberdade de iniciativa e a de expressão criativa e científica.

Quadro 6: Sumário dos elementos essenciais de um regime internacional apto a proteger as quatro dimensões do PBI

\begin{tabular}{|c|c|c|c|}
\hline $\begin{array}{l}\text { Categoria de } \\
\text { RBIs }\end{array}$ & $\begin{array}{l}\text { Mecanismo legal } \\
\text { de proteção }\end{array}$ & $\begin{array}{l}\text { Tipo de } \\
\text { organização de } \\
\text { gestão }\end{array}$ & $\begin{array}{l}\text { Vinculação dos } \\
\text { benefícios } \\
\text { recebidos em } \\
\text { favor da } \\
\text { conservação da } \\
\text { biodiversidade e } \\
\text { da melhoria da } \\
\text { qualidade de vida } \\
\text { das comunidades } \\
\text { tradicionais }\end{array}$ \\
\hline ECTs sagradas & $\begin{array}{c}\text { Direito de } \\
\text { propriedade de } \\
\text { longo alcance }+ \\
\text { direitos morais de } \\
\text { atribuição e de } \\
\text { integridade }\end{array}$ & $\begin{array}{c}\text { Características da } \\
\text { organização de } \\
\text { gestão (OGCPBI): } \\
\text { i. Participação } \\
\text { obrigatória; } \\
\text { ii. Alcance global; } \\
\text { iii. Investida na } \\
\text { competência de } \\
\text { gerir todas as } \\
\text { categorias de RBIs; } \\
\text { iv. Investida nas } \\
\text { funções típicas de } \\
\text { uma OGCD (gestão } \\
\text { de RBIs laicos) e de } \\
\text { uma OGD (gestão }\end{array}$ & Sim \\
\hline
\end{tabular}


CAPÍTULO 4 | 456

\begin{tabular}{|c|c|c|c|}
\hline & & $\begin{array}{l}\text { de ECTs sagradas); } \\
\text { v. Apoiada por uma } \\
\text { rede internacional } \\
\text { de instituições } \\
\text { científicas; } \\
\text { vi. Competente para } \\
\text { emitir certificados, } \\
\text { que atestariam } \\
\text { internacionalmente } \\
\text { a licitude do acesso } \\
\text { aos RBIs. }\end{array}$ & \\
\hline RBIs laicos & $\begin{array}{c}\text { i. Regime de } \\
\text { pliability que } \\
\text { confere direitos de } \\
\text { longo alcance, i.e. o } \\
\text { uso comercial dos } \\
\text { RBIs fica } \\
\text { condicionado ao } \\
\text { pagamento de uma } \\
\text { remuneração e ao } \\
\text { respeito do direito } \\
\text { de atribuição dos } \\
\text { titulares de RBIs. } \\
\text { No caso de } \\
\text { produtos } \\
\text { importados, se os } \\
\text { importadores } \\
\text { desrespeitarem o } \\
\text { direito de } \\
\text { atribuição, sua } \\
\text { entrada no mercado } \\
\text { seria embargada. } \\
\text { ia } \\
\text { ii. Concessão de } \\
\text { DPIs e registros de } \\
\text { comercialização, a } \\
\text { partir da } \\
\text { apresentação do } \\
\text { certificado } \\
\text { expedido pela } \\
\text { OGCPBI. }\end{array}$ & Ibidem & Sim \\
\hline
\end{tabular}


Quadro 7: Sumário dos elementos centrais das propostas de regimes legais em construção/discussão na arena internacional

\begin{tabular}{|c|c|c|c|}
\hline $\begin{array}{c}\text { Foro } \\
\text { internacional e } \\
\text { categoria de } \\
\text { RBI }\end{array}$ & $\begin{array}{c}\text { Mecanismo legal } \\
\text { proposto }\end{array}$ & $\begin{array}{c}\text { Tipo de } \\
\text { organização } \\
\text { de gestão }\end{array}$ & $\begin{array}{l}\text { Vinculação dos benefícios } \\
\text { recebidos em prol da } \\
\text { conservação da } \\
\text { biodiversidade e/ou do } \\
\text { bem-estar das } \\
\text { comunidades tradicionais }\end{array}$ \\
\hline OMPI - CT & $\begin{array}{c}\text { Associação entre } \\
\text { direito de propriedade } \\
+ \text { direito de quase- } \\
\text { propriedade }+ \text { direitos } \\
\text { morais de integridade e } \\
\text { atribuição }\end{array}$ & $\begin{array}{l}\text { OGD nacional } \\
\text { ou regional }\end{array}$ & Sim \\
\hline OMPI - ECTs & $\begin{array}{l}\text { ECTs secretas: direito } \\
\text { de propriedade de } \\
\text { alcance restrito } \\
\text { ECTs laicas: direito de } \\
\text { propriedade de alcance } \\
\text { restrito + direitos } \\
\text { morais de atribuição e } \\
\text { de integridade }\end{array}$ & Não se aplica & Sim \\
\hline $\begin{array}{l}\text { OMPI - ECTs } \\
\text { sagradas }\end{array}$ & $\begin{array}{l}\text { Direito de propriedade } \\
\text { de longo alcance }+ \\
\text { direito moral de } \\
\text { atribuição }+ \text { direito } \\
\text { moral de integridade }\end{array}$ & OGD nacional & Sim \\
\hline CCDB - CTA & $\begin{array}{l}\text { Direito de propriedade } \\
\text { de longo alcance }\end{array}$ & OGD nacional & Não \\
\hline $\begin{array}{l}\text { CCDB - recursos } \\
\text { da biodiversidade }\end{array}$ & $\begin{array}{l}\text { Direito de propriedade } \\
\text { de longo alcance }\end{array}$ & OGD nacional & Não \\
\hline $\begin{array}{l}\text { OMC - CTAs e } \\
\text { recursos da } \\
\text { biodiversidade }\end{array}$ & $\begin{array}{l}\text { Direito de propriedade } \\
\text { de longo alcance }\end{array}$ & Não se aplica & Não \\
\hline
\end{tabular}




\section{CONSIDERAÇÕES FINAIS}

Defendemos no presente estudo que o PBI se compõe de recursos intangíveis que não se confundem com aqueles gerados no seio da sociedade ocidental. Embora o PBI compartilhe a dimensão imaterial com as produções intelectuais comuns, apresenta outras três dimensões: a ambiental (os ecossistemas naturais), a humana (comunidades tradicionais) e a cultural (os valores culturais pertencentes às comunidades tradicionais, que permeiam sua conduta conservacionista e as normas sociais que regem a produção e a disseminação de suas produções intelectuais). A proteção dessas quatro dimensões do PBI depende de recursos econômicos, que apenas poderão ser gerados, se uma parte dos RBIs (os RBIs laicos) puderem ser explorados pelos setores produtivos de países industrializados e em desenvolvimento.

Frente às peculiaridades do PBI, foi proposto um quadro conceitual de desenvolvimento sustentável, apto a servir tanto como um parâmetro contra o qual podem ser avaliadas as propostas de regimes de proteção dos RBIs, em discussão/construção na esfera internacional, quanto para guiar a elaboração de regimes verdadeiramente capazes de proteger, simultaneamente, suas múltiplas dimensões.

Em termos mais específicos, o quadro conceitual de desenvolvimento sustentável avalia a capacidade dos regimes internacionais propostos de: (i) promover o acesso amplo e facilitado aos RBIs pelos setores produtivos da sociedade dominante e pelos membros das comunidades tradicionais; (ii) gerar benefícios econômicos, em bases perenes, e de canalizá-los em prol da conservação da biodiversidade e da realização dos direitos humanos dos componentes das comunidades tradicionais; (iii) assegurar o respeito aos direitos morais dos titulares de RBIs; e (iv) exigir a observância dos direitos assegurados, em escala global. A observância desses quatro critérios operacionais tem como objetivos maiores assegurar: a sustentabilidade das fontes humanas (comunidades tradicionais) e ambientais (ecossistemas naturais) dos RBIs; o desenvolvimento material, científico e cultural da sociedade dominante; e o respeito às culturas diferenciadas das comunidades tradicionais, dentro de certos limites fixados pelo direito internacional. Portanto, o quadro conceitual proposto vai muito além da avaliação da aptidão dos regimes propostos de prevenir atos de apropriação indébita dos RBIs. 
No capítulo final, foram avaliadas, em face do quadro conceitual de desenvolvimento sustentável, as principais propostas de regimes de proteção dos RBIs, em debate/construção no cenário internacional. A aplicação do quadro conceitual permitiu a identificação das fortalezas e limitações dos regimes propostos, assentados sobre direito de propriedade, direito de quase-propriedade (regras de repressão da concorrência desleal) e regras de responsabilidade. Ensejou, ainda, o delineamento de uma proposta de mecanismo legal e institucional apto a proteger o PBI em suas múltiplas dimensões, em escala global.

A análise realizada no capítulo 4, a partir da contraposição das propostas de regimes internacionais ao quadro conceitual, demonstrou que a preocupação central dos negociadores é o estabelecimento de regimes legais, que confiram aos detentores de RBIs o poder de controlá-los ao máximo, com o propósito de habilitá-los a extrair renda e prevenir infrações aos valores culturais das comunidades tradicionais.

Para alcançar esses objetivos, as propostas examinadas associam agências de apoio aos titulares de direitos, competentes a auxiliá-los na tarefa de defender seus RBIs contra atos de apropriação indébita, a esquemas fundamentados em direitos de propriedade ou mecanismos legais alternativos (direitos de quase-propriedade e regras de responsabilidade). A configuração-padrão desses mecanismos alternativos foi alterada a fim de expandir o escopo dos direitos assegurados aos detentores de RBIs. Essas modificações resultaram na transfiguração desses mecanismos alternativos em regimes de propriedade disfarçados.

Os regimes propostos - sejam eles assentados explicita ou tacitamente sobre direitos de propriedade -, se adotados pela comunidade internacional, gerarão custos sociais, ambientais, culturais e econômicos, imprevistos por seus proponentes. Os regimes examinados prejudicarão tanto a matéria e os grupos que deveriam ser prioritariamente resguardados, quanto outros interesses, igualmente relevantes e tutelados pelo direito internacional, notadamente, a liberdade da sociedade de conduzir atividades científicas, produtivas e criativas em prol da satisfação de suas necessidades médicas, alimentares, culturais e ambientais. 
Sob a justificativa de facilitar o gozo e o exercício de direitos pelas comunidades tradicionais e Estados, as propostas examinadas adotam o princípio da ausência de formalidades, típico dos regimes de direitos autorais, dispensando seus titulares da obrigação de registrar os RBIs protegidos. O que os proponentes ignoram é que a falta de um registro obrigatório dificulta a identificação da matéria protegida, bem como de seus titulares e obstaculiza a aproximação entre potenciais usuários de RBIs e seus detentores. Ademais, não sendo possível se diferenciar, com segurança, as matérias protegidas daquelas em domínio público, a sociedade como um todo perde a liberdade de utilizar quaisquer recursos informacionais que possam lembrar um RBI. Como confirmar se determinada expressão artística, cuja autoria é desconhecida, figura ou não como uma ECT protegida, se inexiste um registro público obrigatório?

Sob a ótica das quatro dimensões do PBI, as propostas tentam tutelar suas dimensões imaterial e cultural, deixando descobertas as dimensões humana e ambiental. Sem embargo, a proteção conferida é apenas aparente: recordando que os RBIs são freqüentemente compartilhados por duas ou mais comunidades tradicionais ou Estados nacionais, os regimes propostos instigarão os codetentores de um mesmo RBI a concorrerem entre si ou desembocarão em uma tragédia dos anticomuns. Em ambos os casos, os recursos econômicos gerados serão pífios. Se uma parcela substancial de RBIs não for aplicada continuamente em atividades produtivas, os novos titulares de direitos e suas organizações de apoio não disporão dos recursos financeiros, sem os quais o monitoramento e a repreensão, em escala global, dos atos de apropriação indébita serão impraticáveis.

Naturalmente, é possível prever que alguns Estados, fundações internacionais e $\mathrm{ONGs}^{1907}$ injetarão recursos para apoiar a implementação dos futuros regimes internacionais. Mas é certo que este apoio não duraria para sempre; tampouco seria suficiente para beneficiar todos os titulares de RBIs. Assim, ainda que as propostas examinadas se tornem acordos internacionais vinculantes, os resultados de sua aplicação

\footnotetext{
1907 É digno de nota o trabalho realizado pela ONG Public Interest Intellectual Property Advisors (PIIPA), que presta gratuitamente serviços legais de natureza consultiva e judicial para titulares de RBIs (e.g. elaboração de contratos de licenciamento, defesa judicial contra titulares de DPIs conferidos sobre RBIs ou sobre produções intelectuais derivadas de RBIs apropriados indebitamente). Para maiores informações sobre o trabalho da PIIPA visitar: $<\underline{\text { http://www.piipa.org/ }>\text {. }}$
} 
serão decepcionantes, ao conservarem de fato os RBIs em domínio público (pelo menos aqueles detidos por comunidades tradicionais e Estados pobres em recursos financeiros).

Mutua defende que o discurso de direitos humanos é permeado por uma metáfora que compreende três personagens: os bárbaros, as vítimas e os salvadores. Nessa metáfora, o papel de bárbaro é desempenhado pelos autores de atos contrários à dignidade das vítimas. As vítimas são representadas pelos membros de minorias, os refugiados, as mulheres, as crianças e as populações dos países em desenvolvimento. O papel de salvador é desempenhado, inter alia, pela ONU, governos ocidentais e ONGs. ${ }^{1908}$ Aplicando essa metáfora ao contexto das discussões relacionadas à proteção do $\mathrm{PBI}$, os bárbaros seriam representados, fundamentalmente, pelas indústrias biomédica, agrobiotecnológica e cultural e instituições de pesquisa, sobretudo dos países industrializados. As vítimas seriam representadas pelas comunidades tradicionais e pelos países em desenvolvimento. Por fim, o papel de salvador seria desempenhado por ONGs, agências e programas da ONU, OMC e também pelos países em desenvolvimento.

No contexto dessa metáfora, o que se observa é que as vítimas e seus salvadores se opõem sistematicamente aos bárbaros, mediante a propositura de medidas que inibam, ao máximo, o uso de seus RBIs, ignorando suas reivindicações pelo estabelecimento de regimes facilitadores do uso de RBIs, ${ }^{1909}$ que proporcionem aos usuários segurança jurídica $^{1910}$ e a liberdade para protegerem suas produções intelectuais derivadas de RBIs. ${ }^{1911}$

Diferentemente da perspectiva compartilhada pelas vítimas e seus salvadores, as demandas ecoadas pelos bárbaros lhes são também favoráveis. Em palavras mais claras, os países em desenvolvimento e as comunidades tradicionais ainda não atentaram que a salvaguarda de seus interesses associados ao PBI é dependente do resguardo dos interesses dos setores produtivo, científico, cultural de utilizar os RBIs laicos; ${ }^{1912}$ inclusive, muitos

\footnotetext{
${ }^{1908}$ Cf. MUTUA, 2001, p. 203-204.

1909 Ver, e.g., ROBERTS, 2004; MULLER, 2004, p. 261 (menciona a posição contrária dos cientistas à qualquer regime que gere obstàculos à condução de pesquisas científicas e aplicadas, conforme ecoadas no XVI International Botanical Congress); ICC, 2008a, 2008b; WIPO, WIPO/GRTKF/IC/12/5(b), anexo, p. 23, 30, 99 e 100; BIBER-KLEMM, 2004, p. 98; LEISTNER, 2004, p. 143.

${ }^{1910}$ Ver, e.g., WIPO, WIPO/GRTKF/IC/12/5(b), anexo, p. 40, 43 (posição das associações Intellectual Property Owners Association e União Internacional de Editores).

${ }^{1911} \mathrm{Cf}$. WTO, IP/C/M/42, para 108.

1912 Cf. CARRIZOSA, 2004, p. 300.
} 
países em desenvolvimento com capacidade produtiva e científica avançada ignoram que propostas de regimes, que limitem o acesso aos RBIs laicos, atacará sua capacidade de desenvolvimento econômico. ${ }^{1913} \mathrm{Se}$ este grupo de RBIs não gerar riqueza material, comunidades tradicionais pobres continuarão a se desmantelar e a biodiversidade, que sustenta estes grupos e seu PBI, continuará a ser substituída por atividades econômicas lucrativas e ambientalmente insustentáveis, notadamente, pela agricultura e agropecuária. Recursos materiais substanciosos apenas serão gerados se os RBIs laicos puderem ser explorados o mais livremente possível.

Plutarco sabiamente ensina que o homem muito se beneficiaria, se desse ouvido às críticas ecoadas por seus adversários e procurasse corrigir suas máculas por eles indicadas:

"Um homem queria fazer perecer Prometeu, o Tessálio. Feriu-o com sua espada e furou um flegmão, de sorte que lhe salvou a vida, livrando-o desse abscesso que se abriu. Tal é muitas vezes o efeito de uma maledicência ditada pela cólera ou pela inimizade: ela cura nossa alma de uma doença insuspeita que tínhamos negligenciado. Mas as pessoas, em sua maior parte, quando são censuradas, não procuram saber se essas reprimendas têm fundamento, mas usam recriminações e acusam seu agressor de um vício diferente. Imitam nisso a artimanha de lutadores em combate com a poeira: no lugar de se livrarem pessoalmente dos defeitos estigmatizados por seus inimigos, borrifam-se mutuamente com eles, de sorte que, na peleja em que sucumbem alternadamente, se acham então enodoados e enegrecidos."

Isso é exatamente o que os países em desenvolvimento e os representantes das comunidades tradicionais se negam a fazer. Optaram por apoiar mecanismos legais "espúrios", ${ }^{1915}$ que internalizam valores oriundos da sociedade ocidental, centrados na maximização dos direitos de controle dos RBIs e na superlimitação dos direitos de acesso do público a estes insumos informacionais. ${ }^{1916}$ Ironicamente, a política obsoleta de maximização dos DPIs é objeto de críticas ferozes, ecoadas pelos países em desenvolvimento, ${ }^{1917}$ e figura como a motivação para estes países articularem a Agenda do

${ }^{1913}$ Cf. VAN OVERWALLE, 2003, p. 4.

${ }^{1914}$ PLUTARCO, 1997, p. 14.

${ }^{1915}$ Cf. RIBEIRO, 2007, p. 72.

${ }^{1916}$ Cf. AOKI, 1998, p. 27.

1917 Ver, e.g., INTERNATIONAL EXPERT GROUP ON BIOTECHNOLOGY, INNOVATION AND INTELLECTUAL PROPERTY, 2008; BOYLE, 2007, p. 11-12; WTO, IP/C/W/228, para. 9 (neste 
Desenvolvimento da OMPI, por meio da qual buscam superar o modelo ocidental de repressão da difusão do conhecimento, cristalizado nos regimes contemporâneos de PI. Como lutar exitosamente contra um modelo ultrapassado e destruidor de oportunidades de desenvolvimento, ao limitar a expansão científica e cultural, ${ }^{1918}$ quando os países em desenvolvimento recorrem a ele para proteger seu PBI? Plutarco chama a atenção ao imperativo da coerência em todas as esferas, quando adverte que "nada seria mais vergonhoso nem mais mortificante que ver recair sobre si a censura que se teria feito a outrem."1919

O reconhecimento explícito ou tácito de direitos de propriedade para RBIs laicos culminará, portanto, na reafirmação dos regimes ocidentais de PI e poderá inviabilizar a consecução de projetos políticos de reforma destes regimes, em consonância com as demandas dos países em desenvolvimento. Sem notarem, estes países apóiam a tendência de fortalecimento abusivo dos direitos conferidos aos titulares de produções intelectuais. ${ }^{1920}$ Mais amplos forem os direitos de propriedade conferidos aos titulares de RBIs, mais fortalecidos poderão ser os regimes tradicionais de PI.

Cinco são os aspectos mais irracionais de se proteger RBIs laicos mediante direitos de propriedade. O primeiro é impor aos membros da sociedade, que já gozam de livre acesso ao RBIs, a obrigação de se conduzirem como "pseudo-ignorantes", ${ }^{1921}$ enquanto não obtiverem as autorizações de todos os titulares de direitos (o que pode muito bem nunca ocorrer).

O segundo é limitar o acesso e uso de recursos, cujo real potencial científico ou comercial é basicamente desconhecido pela humanidade. Quando se impede, por exemplo, a pesquisa de um determinado recurso da biodiversidade, não se está impedindo que um único produto seja disseminado no mercado, mas sim uma "tecnologia bruta", que uma vez pesquisada, conhecida e decomposta em suas partes constitutivas, pode alavancar o desenvolvimento de múltiplos produtos social e comercialmente valiosos. ${ }^{1922}$ Mas como as

documento, o Brasil claramente critica a ampliação do alcance do regime de patentes sobre invenções biotecnológicas, em virtude de seus efeitos sobre a liberdade científica e de iniciativa).

1918 Cf. DOS SANTOS, 2007.

${ }^{1919}$ PLUTARCO, 1997, p. 10-11.

${ }^{1920}$ Cf. RAMANNA; SMALE, 2004, p. 428; BROWN, M., 1998, p. 204; GRAIN; CERVANTES, 2006.

1921 Cf. comentário de J.A. Barnes ao artigo de Michael Brown (1998, p. 206).

1922 Cf. RAI; EISENBERG, 2003, p. 171. 
aplicações latentes de um RBI, freqüentemente, são desconhecidas a priori, qual organização ou indivíduo racional assumiria os riscos e os custos de se envolver em uma negociação cara e morosa, cujo sucesso pode depender da autorização unânime de grupos que conservam fronteiras humanas e normas sociais pouco (ou nada) conhecidas? ${ }^{1923}$

Em terceiro lugar, os países industrializados ${ }^{1924}$ e seu setor empresarial ${ }^{1925}$ já se opõem à qualquer proposta de regime de proteção dos RBIs. Se os regimes propostos tiverem o potencial de interferir em suas operações comerciais e em sua capacidade de perseguir proteção legal para suas produções intelectuais, é provável que as negociações em curso não cheguem a lugar algum. Ainda que os países em desenvolvimento alcancem acordos internacionais vinculantes, se os países industrializados ficarem de fora, muito pouco se alterará no cenário presente, marcado pela apropriação sistemática dos RBIs, nas jurisdições dos países industrializados.

Em quarto lugar, regimes fundados em direitos de propriedade limitam as oportunidades dos detentores de RBIs extraírem recursos materiais para a conservação da biodiversidade, bem como para promover o desenvolvimento material das comunidades tradicionais.

Por fim, regimes calcados, exclusivamente, em direitos de propriedade impedem que os Estados nacionais cumpram com seus compromissos internacionais, insculpidos, inter alia, na CDB, PIDESC, PIDCP, CSPCI.

Apesar da inabilidade dos regimes baseados em direitos de propriedade para protegerem RBIs laicos, eles não são sempre repreensíveis: estes regimes são os mais adequados para salvaguardarem as ECTs sagradas, pois conferem às comunidades tradicionais a prerrogativa de controlar suas modificações e aplicações, permitindo-lhes assegurar o respeito às suas normas culturais e religiosas.

\footnotetext{
${ }^{1923}$ Ver, e.g., DRAHOS, 2007, p. 392.

1924 Sobre a posição dos EUA, ver WTO, IP/C/W/257, IP/C/W/469, IP/C/W/449, IP/C/W/434, IP/C/W/341. Sobre a posição do Japão, ver WTO, IP/C/W/472, IP/C/M/29, para. 155, 156.

${ }^{1925}$ Ver, e.g., ICC, 2002, 2005a; 2008a.
} 
Quando examinamos o imperativo de se proteger o PBI a partir do prisma dos artigos 8(j) e 15(1) e (5) da CDB e do artigo $31(1)^{1926}$ da Declaração das Nações Unidas sobre os Direitos dos Povos Indígenas, as propostas de regimes legais, que asseguram às comunidades tradicionais e aos Estados um direito de controle de seus RBIs, parecem legalmente adequadas. Contudo, para uma parcela expressiva da comunidade internacional (apêndice I), em virtude dos acordos internacionais de que é parte, é insuficiente a adoção de regimes apenas aptos a combater a apropriação indébita dos RBIs: quando se agrega ao terreno sobre o qual devem ser construídos os futuros regimes internacionais, inter alia, os dispositivos do Pacto Internacional de Direitos Econômicos, Sociais e Culturais; do Pacto Internacional de Direitos Civis e Políticos; da Convenção para a Salvaguarda do Patrimônio Cultural Imaterial; da Convenção sobre a Proteção e a Promoção da Diversidade das Expressões Culturais e mesmo outros dispositivos da própria CDB, a liberdade dos Estados para eleger mecanismos legais de proteção do PBI é restringida substancialmente, e direitos de propriedade se mostram aceitáveis para tutelar tão-somente ECTs de natureza sagrada.

Os futuros regimes internacionais de proteção dos RBIs devem, portanto, ter como fundação o acquis do direito internacional. Teoricamente, os projetos da OMPI estão comprometidos em assegurar sua consistência com outros acordos internacionais. ${ }^{1927}$ A $\mathrm{CCDB}$, de maneira mais limitada, recentemente encomendou pareceres legais, que avaliaram a consistência legal do futuro regime internacional de proteção dos recursos da biodiversidade e CTAs com, inter alia, a CDM, o TIRFAA e as propostas de regimes em negociação na OMPI e OMC. ${ }^{1928}$ Contudo, nenhum desses foros se ocupou em avaliar a consistência de suas propostas em face dos objetivos maiores da CDB (conservação da diversidade biológica e geração de benefícios econômicos para financiar projetos conservacionistas), do marco internacional de proteção dos direitos humanos e da diversidade cultural.

${ }^{1926}$ O art. 31(1) da Declaração dispõe: "Os povos indígenas têm o direito de manter, controlar, proteger e desenvolver seu patrimônio cultural, seus conhecimentos tradicionais, suas expressões culturais tradicionais e as manifestações de suas ciências, tecnologias e culturas, compreendidos os recursos humanos e genéticos, as sementes, os medicamentos, o conhecimento das propriedades da fauna e da flora, as tradições orais, as literaturas, os desenhos, os esportes e jogos tradicionais e as artes visuais e interpretativas. Também têm o direito de manter, controlar, proteger e desenvolver sua propriedade intelectual sobre o mencionado patrimônio cultural, seus conhecimentos tradicionais e suas expressões culturais tradicionais."

${ }^{1927}$ Cf. item 4.2.2.2.1, §2 os projetos de disposições da OMPI para a proteção de CTs e ECTs adotam o Princípio do respeito a outros instrumentos e processos internacionais e regionais e cooperação com os mesmos.

${ }^{1928}$ Cf. BULMER, 2009; MEDAGLIA, 2009; JOHNSTON; VIERROS, 2009. 
Há mais de quatro décadas, os países em desenvolvimento, apoiados por suas comunidades locais, se empenham, sem sucesso, na construção de regimes internacionais de proteção dos RBIs. A alteração do curso da história depende, pelo menos em parte, da mudança de postura dos Estados e dos grupos defensores dos interesses das comunidades tradicionais: salvo se deixarem de centralizar sua atenção sobre os beneficios privados auferíveis pelos detentores de RBIs e passarem a avaliar, simultaneamente, os beneficios e custos sociais, ecológicos, culturais e econômicos globais, que decorrerão da adoção das propostas em negociação, ${ }^{1929}$ o PBI e suas fontes humanas, ambientais e culturais continuarão em franca erosão, em detrimento do bem-estar da humanidade.

${ }^{1929}$ Ver, e.g., COASE, 1960, p. 21- 23; BROWN, M., 2005, p. 50; DESCOLA, 1998, p. 180-183. 


\section{REFERÊNCIAS BIBLIOGRÁFICAS ${ }^{1930}$}

ABATE, T. Shaman Quits The Drug Business. San Francisco Chronicle, San Francisco, 3 Feb., $1999 . \quad$ Disponível: <http://www.sfgate.com/cgibin/article.cgi?file=/chronicle/archive/1999/02/03/BU6549.DTL $>$. Acesso em: 17 abril 2009.

ABC NEWS. Indigenous rangers, marine scientists team up to map seabed. ABC News, 25 de outubro de 2008. Disponível em: < http://www.abc.net.au/news/stories/2008/10/25/2401047.htm>. Acesso em; 20 abr. 2009.

ACHER, J. Noruega inaugura “Arca de Noé” para preservar sementes. Reuters, 26 de fevereiro de 2008. Disponível em: http://noticias.uol.com.br/ultnot/internacional/2008/02/26/ult27u64908.jhtm>. Acesso em: 28 abr. 2009.

Acordo sobre Aspectos dos Direitos de Propriedade Intelectual Relacionados ao Comércio. Anexo 1(c), Ata Final que Incorpora os Resultados da Rodada Uruguai de Negociações Comerciais Multilaterais do GATT. Marrakesh, 15 de abril de 1994.

ADCOCK, M; LLEWELYN, M. Micro-organisms, Definitions and Options under TRIPS (occasional paper 2). Genebra: Quaker United Nations Office, 2000. 20 p.

AFRICAN INTELLECTUAL PROPERTY ORGANIZATION. Agreement Revising the Bangui Agreement of March 2, 1977, on the Creation of an African Intellectual Property Organization. Bangui (Central African Republic), February 24, 1999.

AGRAWAL, A. Indigenous and scientific knowledge: some critical comments. IK Monitor, vol. 3, no. 3, [199-?]. Disponível em: <http://www.nuffic.nl/ciran/ikdm/33/articles/agrawal.html>. Acesso em: 02 abril 2008.

AGRAWAL, A. Livelihoods, carbon, and diversity on community forests: tradeoffs or win wins? In: RIGHTS, FORESTS AND CLIMATE CHANGE, Oslo, 2008. Disponível em: $<$ http://rightsandclimate.org/2008/10/15/session-1-setting-the-scene/>. Acesso em: 17 nov. 2008 .

Agreement between the Kingdom of Thailand and Japan for an Economic Partnership.

AGUILLON, A.B. Traditional knowledge in the Philipinnes: progress of IPR protection. Asia Pacific Tech Monitor, March-April 2007. Disponível em:

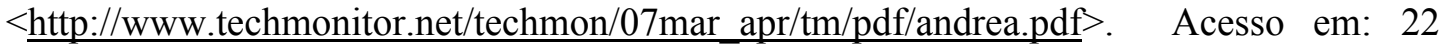
nov. 2008.

1930 A lista de referências bibliográficas foi organizada segundo o disposto na ABNT NBR 10520 (ASSOCIAÇÃO BRASILEIRA DE NORMAS TÉCNICAS, 2002). 
AHMED, F. U. The protection of traditional knowledge in Bangladesh. In: Twarog, S.; Kapoor, P. (Ed.). Protecting and promoting traditional knowledge: systems, national experiences and international dimensions. New York \& Geneva: United Nations, 2004, p. 185-192.

ALARCÓN, R.; MORALES, M. Estudo de caso 1: Banisteriopsis caapi. El cártel de la biodiversidad: transformación de conocimientos tradicionales en secretos comerciales. Quito: CARE, 2000, p. 81-91.

ALARCÓN-CHÁIRES, P. Riqueza ecológica versus pobreza social. Contradicciones y perspectivas del desarrollo indígena en Latinoamérica. In: CIMADAMORE, A.; EVERSOLE, R; MCNEISH, J. Pueblos indígenas y pobreza: Enfoques multidisciplinarios. Buenos Aires: Programa CLACSOCROP, 2006, p. 41-70.

ALDÉ, L. Etnia, pra que te quero. Revista de História da Biblioteca Nacional, ano 2, no. 18 , p. 16-27, março de 2007.

ALRU. UNESCO: International Protector. Aboriginal Law Bulletin, 1985, vol. 1, no. 17. Disponível em: $\quad<$ http://www.austlii.edu.au/au/journals/AboriginalLB/1985/84.html $>$. Acesso em: 4 agosto 2008.

ALVES, R. R.N.; ROSA, I. M.L. Biodiversity, traditional medicine and public health: where do they meet? Journal of Ethnobiology and Ethnomedicine, vol. 3, no. 14, 2007. Disponível em: < http://www.ethnobiomed.com/content/3/1/14> . Acesso em: 17 abril 2009.

AMERICAN ANTHROPOLOGICAL ASSOCIATION (EXECUTIVE BOARD). Statement on Human Rights. American Anthropologist, New Series, vol. 49, no. 4, p. 539-543, 1947.

- Committee for Human Rights. American Anthropological Association Declaration on Anthropology and Human Rights. Arlington, 1999a.

. Declaration on Anthropology and Human Rights. Arlington, 1999 b.

AMODIO. E. Notas sobre consentimiento informado: Lecciones aprendidas de la experiencia investigativa de UNICEF Venezuela. FPII/2005/WS.2/12/Add.1. New York: United Nations, 2005.

ANAYA, S.J. International human rights and indigenous peoples: the move toward the multicultural state. Arizona Journal of International and Comparative law, vol 21, p. 13- 61, 2004.

ANDERSON, J. The politics of indigenous knowledge: Australia's proposed communal moral rights bill. University of New South Wales Law Journal, vol. 27, p. 585-604, 2004.

ANDERSON, I.; LOFF, B. Voices lost: Indigenous health and human rights in Australia. The Lancet, vol. 364, p. 1281-1282, 2 de outubro de 2004. 
AOKI, K. Neocolonialism, anticommons property, and biopiracy in the (Not-So-Brave) new world order of international intellectual property Protection. Indiana Journal of Global Legal Studies, vol. 6, p. 11- 58, 1998.

AOKI, R.; SCHIFF, A. Intellectual property clearinghouses: the effects of reduced transaction costs in licensing. [S.1], Social Science Research Network, 2007a. Disponível em: $<$ http://ssrn.com/abstract=989266 $>$. Acesso em: 20 abr. 2009.

Promoting access to intellectual property: patent pools, copyright collectives and clearinghouses. [S.1], Social Science Research Network, 2007b. Disponivel em: < http://papers.ssrn.com/sol3/papers.cfm?abstract_id=976852>. Acesso em: 20 abr. 2009.

ARGENTINA. Proyecto de Ley sobre Acceso a los Recursos Genéticos de Diversidad

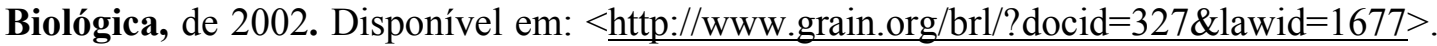
Acesso em. 22 abr. 2009.

ARNOLD, D. Plurality and transition: knowledge systems in nineteenth-century India. In: PRINCETON HISTORY OF SCIENCE SEMINAR, EUA, 24 de outubro de 2003. Disponível

em: $<$ http://www.princeton.edu/ hos/Workshop $\% 20 I \% 20$ papers/Arnold $\% 20$ History $\% 20$ of $\% 20$ Science\%20paper.htm $>$. Acesso em:17 de maio de 2008.

ARROW, K. J. Economic Welfare and the Allocation of Resources for Invention. Santa Monica, California: The Rand Corporation, 1959. 23 p. Disponível em: $<$ http://www.rand.org/pubs/papers/2006/P1856.pdf $>$. Acesso em: 16 julho 2008.

ARTIC indigenous languages: time for action. ICE News- Daily News, 26 de outubro de 2008. Disponível em: < http://www.icenews.is/index.php/2008/10/26/arctic-indigenouslanguages-\%E2\%80\%93-time-for-action/>. Acesso em 20 abril 2009.

ARTS LAW CENTRE OF AUSTRALIA. Arts Law submission on draft Copyright Amendment (ICMR) bill 2003 (Executive Summary). Woolloomooloo: Arts Law Centre of Australia, 2006. Disponível em: $<$ http://www.artslaw.com.au/_documents/files/ICMRLetterAndExecutiveSummary2006.p df>. Acesso em: 17 out. 2008.

ASSOCIAÇÃO BRASILEIRA DE NORMAS TÉCNICAS. NBR 10520: informação documentação: citações em documentos: apresentação. Rio de Janeiro, 2002. 7 p.

AUSTRALIA'S ATTORNEY-GENERAL'S LEGAL PRACTICE. International Trade Law and Intellectual Property Branch. Stopping the rip-offs: intellectual property protection for Aboriginal and Torres Islander peoples. [S.1.], 1994, p. 33.

BACA, M. R. Barriers to innovation: intellectual property transaction costs in scientific collaboration. Duke Law \& Technology Review, no. 4, 2006. Disponível em: $<$ http://www.law.duke.edu/journals/dltr/articles/2006dltr0004.html $>$. Acesso em: 17 abril 2009. 
BACON, F. La nueva Atlántida. p. 49. [S.1], eBooket, [20--]. Disponível: $<$ http://www.dominiopublico.gov.br/pesquisa/DetalheObraDownload.do?select action=\&c o_obra $=5736 \&$ co_midia $=2>$. Acesso em: 17 abril 2009.

BAGLEY, E. Could the Way Food Looks Give Real Clues As to What is Really Healthy For Us to Eat? Ezine Articles, 2008. Disponível: <http://ezinearticles.com/?Could-the-Way-Food-Looks-Give-Real-Clues-As-to-Whatis-Really-Healthy-For-Us-to-Eat?\&id=1262707>. Acesso em: 15 mar. 2009.

BAIL, C. What is the future role for the CBD in the preservation of plant genetic resources and biological diversity: a plea for policy coherence. In: COTTIER, T.; MAVROIDIS, P.; PANIZZON, M.; LACEY, S. (Ed.). Intellectual Property: trade, competition, and sustainable development. Ann Arbor: Michigan University, 2002, p. 515-523.

BALAZINA. A. Estudo de plantas médicas indígenas cai na ilegalidade. Folha de São Paulo, São Paulo, 18 de julho de 2009. Disponível em: $<$ http://www1.folha.uol.com.br/folha/ciencia/ult306u423633.shtml $>$. Acesso em: 22 abr. 2009.

BALICK, M. J. Traditional knowledge: lessons from the past, lessons for the future, p. 30. In: CONFERENCE ON BIODIVERSITY AND BIOTECHNOLOGY AND THE PROTECTION OF TRADITIONAL KNOWLEDGE, 2003, Washington D.C., Whashington University. Disponível em:

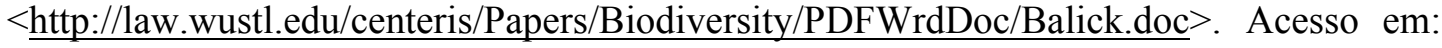
1 julho 2008.

BANCO INTERNACIONAL DE RECONSTRUCCIÓN Y FOMENTO. Informe sobre el desarrollo mundial 1998-1999: el conocimiento al servicio del desarrollo. Washington D.C.: Banco Mundial, 1998-1999. 22 p.

BARLOW, J.P. The economy of ideas: everything you know about intellectual property is wrong. In: MOORE, A. D. (Ed.) Intellectual property: moral, legal, and international dilemmas. Lanham: Rowman \& Littlefield Publishers, 1997, p. 349-371.

BARNETT, H. G. On Science and Human Rights. American Anthropologist, New Series, vol. 50, no. 2., p. 352-355, 1948.

BARSH, R.L. How do you patent a landscape? The perils of dichotomizing cultural and intellectual property. International Journal of Cultural Property, vol. 8, no. 1, p. 14-47, 1999.

BARTON, J.H. Preserving the global scientific and technological commons. Geneva: UNCTAD, [200-]. Disponível em: <http://stdev.unctad.org/capacity/Barton.doc $>$. Acesso em: 17 out. 2008.

BASSO, M. O direito internacional da propriedade intelectual. Porto Alegre: Livraria do Advogado, 2000. 328 p. 
BEAT-GRABER, C. The New UNESCO Convention on Cultural Diversity: A Counterbalance to the WTO? Journal of International Economic Law, vol. 9, no. 3, p. 553-574, 2006.

BELDER, L. A new concept of cultural property? Thinking on rights regarding ownership of cultural heritage, and the call for a strong public domain. Artigo circulado na reunião do Project Group Culture, Creativity, Copyright, em Uppsala, 21 de setembro de 2007. (artigo não publicado; cópia em arquivo com o autor).

BELL, A.; PARCHOMOVSKY, G. Of property and anti-property: the perverse virtues of transactions costs and anticommons. University of Pennsylvania Law School, Institute for Law and Economics, research paper no. 03-04, 2003. 75 p.

. Pliability Rules. Ramat Gan: Bar-Ilan University, Faculty of Law, 2002. 102 p.

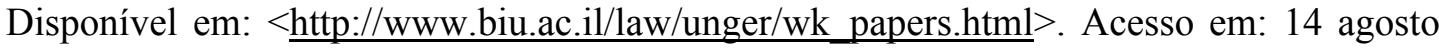
2008.

. Reconfiguring property in three dimensions (paper 178). Philadelphia: University of Pennsylvania Law School, 2007. 62 p. Disponível em: $<$ http://lsr.nellco.org/cgi/viewcontent.cgi?article=1182\& context=upenn/wps $>$. Acesso em: 10 julho 2008.

BENNETT, A.B. Reservation of rights for humanitarian uses. In: KRATTIGER, A.; MAHONEY, R.T.; NELSEN, L; THOMSON, J.A.; BENNETT, A.B.; SATYANARAYANA, K.; GRAFF, GD; FERNANDEZ, C.; KOWALSKI, SP (Eds.). Intellectual Property Management in Health and Agricultural Innovation: A Handbook of Best Practices. MIHR: Oxford \& PIPRA: Davis, California, p. 41-45, 2007.

BENNETT, J. W. Science and Human Rights: Reason and Action. American Anthropologist, New Series, vol. 51, no. 2, p. 329-336, 1949.

BESSEN, J.; MASKIN, E. Sequential Innovation, Patents, and Imitation. [S.1.], Research Innovation, 2006. 57 p. Disponível em: $<$ http://www.researchoninnovation.org/patrev.pdf $>$. Acesso em: 24 julho 2008.

BEVERLY-SMITH, H. The commercial appropriation of personality. Cambridge: Cambridge University Press, 2002, p. 364.

BHATTI, S. T. Intellectual property and traditional knowledge: the work and the role of the World Intellectual Property Organization (WIPO). In: Twarog, S.; Kapoor, P. (Ed.). Protecting and promoting traditional knowledge: systems, national experiences and international dimensions. New York \& Geneva: United Nations, 2004, p. 121-130.

BIADGLENG, E.T.; TELLEZ, V.M. The changing structure and governance of intellectual property enforcement. Geneva: South Centre, 2008. 64 p.

BIBER-KLEMM, S. Origin and allocation of traditional knowledge and traditional PGRFA: basic questions. In: BIBER-KLEMM; COTTIER, T. (Eds.). Rigths to plant genetic resources and traditional knowledge: basic issues and perspectives. Oxfordshire \& Cambridge: CABI, 2006, p. 157-172. 
Protection of traditional knowledge on biological diversity at the international level: reflections in connection with world trade. In: Twarog, Sophia; Kapoor, Promila (Ed.). Protecting and promoting traditional knowledge: systems, national experiences and international dimensions. New York \& Geneva: United Nations, 2004, p. 95-105.

BIBER-KLEMM, S.; CULLET, P.; GERMANN, C.; NASCIMENTO-MÜLLER, A.; CURCI, J.; Flanking policies in national and international law. In: BIBER-KLEMM, S.; COTTIER, T. (Eds.). Rigths to plant genetic resources and traditional knowledge: basic issues and perspectives. Oxfordshire \& Cambridge: CABI, 2006, p. 239-279.

BIERER, D. E.; CARLSON, T. J.; KING, S.R. Shaman Pharmaceuticals: Integrating Indigenous Knowledge, Tropical Medicinal Plants, Medicine, Modern Science and Reciprocity into a Novel Drug Discovery Approach. [S.1.], Network Science, 1996. Disponível em: <http://www.netsci.org/Science/Special/feature11.html $>$. Acesso em: 29 julho 2008.

BITTAR, E.C.B. O direito na pós-modernidade e reflexões frankfurtianas. $2^{\mathrm{a}}$. Edição. Rio de Janeiro: Editora Forense Universitária, 2009. 560 p.

BLAKENEY, M. Proposals for the Disclosure of Origin of Genetic Resources in Patent Applications. In: 9th International Conference on Agricultural Biotechnology: Ten Years After, 2005, Ravello. Disponível em:

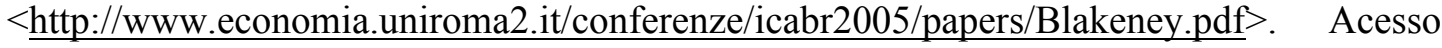
em: 17 abril 2009.

BLANCO, J. L.B. Harnessing traditional knowledge for development and trade: the Philippines experience. In: Twarog, S.; Kapoor, P. (Ed.). Protecting and promoting traditional knowledge: systems, national experiences and international dimensions. New York \& Geneva: United Nations, 2004, p. 293-297.

BODENHAUSEN, G.H.C. Guide to the application of the Paris convention for the protection of industrial property as revised at Stockholm in 1967. (WIPO publication no. 611 (E)). Geneva: BIRPI-WIPO, 2004. 255 p.

BOLÍVIA. Ley no. 1322, de 13 de abril de 1992. Derecho de Autor.

BOSCH, X. UNICEF calls for action to protect indigenous children. The Lancet, vol. 363, p. 789, 6 de março de 2004 .

BOSTYN, S. J.R. Genetic Resources and IP protection: A weak legal basis for a good cause. In: LL.M. CONFERENCE: TRADITIONAL KNOWLEDGE AND INTELLECTUAL PROPERTY -- LOOKING AT THE FUTURE, 2007, Turin. 89 p. Apresentação PowerPoint disponível em: $<$ http://www.turinip.com/Torino\%20Conference-final-080907-biodiversity.ppt $>$. Acesso em: 23 agosto 2008 .

BOYLE, J. Cultural environmentalism and beyond. Law \& Contemporary Problems, vol. 70, p. 5-21, 2007. 
. Foreword: the opposite of property? Law and Contemporary Problems, vol. 66, nos. 1- 2, p. 1-32, 2003 a.

. The Second Enclosure Movement and the Construction of the Public Domain. Law and Contemporary Problems, vol. 66, p. 33-74, 2003b. Disponível em: $<$ http://ssrn.com/abstract=470983 $>$. Acesso em: 17 abril 2009.

BRAGDON, S.H. Major legal regimes affecting plant genetic resources (PGR): the convention on biological diversity (CBD), the international undertaking (IU) and the TRIPs agreement. In: COTTIER, T.; MAVROIDIS, P.; PANIZZON, M.; LACEY, S. (Ed.). Intellectual Property: trade, competition, and sustainable development. Ann Arbor: Michigan University, 2002, p. 441-453.

BRANDT, R. Entrevista para a TV. Estadão sobre a missão da FUNASA para vacinação de índios isolados da Amazônia brasileira. Estado de São Paulo, São Paulo, 2008. Disponível em:

$<$ http://www.estadao.com.br/interatividade/Multimidia/ShowVideos.action?destaque.idGui dSelect=DD60826819E8450298CF70E508F49FE1 > . Acesso em: 31 maio 2008.

BRANTS, J. Reach-through claims SPC's. Sint-Martens-Latem: De Clercq, Brants \& Partners, 2006. Disponível em: <http://www.ipeg.com/_UPLOAD\%20BLOG/JBDCBseminar101106-v2.ppt $>$. Acesso em: 17 abril 2009.

BRASIL E FRANÇA criam instituto para explorar Amazônia. Folha de São Paulo, São Paulo, 24 de dezembro de 2008. Disponível em:

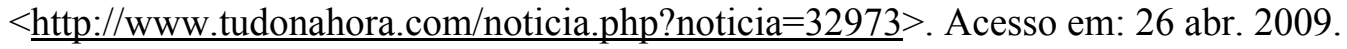

BRASIL. Constituição (1988). Constituição Federal da República do Brasil. Brasília, DF: Senado, 1988.

1973.

Lei no. 5.988, de 14 de dezembro de 1973. Brasília, DF: Congresso Nacional,

Lei no. 9.610, de 19 de fevereiro de 1998. Altera, atualiza e consolida a legislação sobre direitos autorais e dá outras providências. Brasília, DF: Congresso Nacional, 1998.

Medida Provisória no. 2.186-16, de 23 de agosto de 2001. Brasília, DF: Presidência da República, 2001.

. Tribunal de Justiça do Rio Grande do Sul. Embargos infringentes no.70005218722, do $5^{\circ}$ Grupo Cível do Tribunal de Justiça do Estado do Rio Grande do Sul, Porto Alegre, 20 de agosto de 2004. Embargante: H. Stern Comércio e Indústria S/A. Embargada: Maria Bernadete Conte. Relatora: Mara Larsen Chechi.

BRECHT, B. O círculo de giz caucasiano. São Paulo: Cosac \& Naify, 2002.

BROWN, G.O. How the next copyright revolution can help the next scientific revolution. PLoS Bio, vol 1, no. 1, 2003. Disponível em: < http://biology.plosjournals.org/perlserv/?request=getdocument\&doi=10.1371\%2Fjournal.pbio.0000009\&ct=1>. Acesso em: 30 abr. 2009. 
BROWN, M. Can culture be copyrighted? Current Anthropology, vol. 39, no. 2, p. 193 222, 1998.

Heritage trouble: recent work on the protection of intangible cultural property. International Journal of Cultural Property, vol. 12, p. 40-61, 2005.

BRUSH, S.B. Providing farmer's rights through in situ conservation of crop genetic resources (Background study paper no. 3) Roma: FAO, 1994. 44 p.

BRUSH, S.B.; CARRIZOSA, S. Implementation pathways. In: CARRIZOSA, S.; BRUSH, S.B.; WRIGHT, B.D.; MCGUIRE, P.E. (Eds.) Accessing biodiversity and sharing the benefits: lessons from implementation of the Convention on Biological Diversity. Gland \&Cambridge: IUCN, 2004, p. 67-78.

BUCHANAN, J.M.; YOON, Y.J. Symmetric tragedies: commons and anticommons. Journal of Law and Economics, vol. 43, no. p. 1-14.

BUCKLEY, L. Conference on traditional Chinese medicine marks shift towards global market, raises concerns about social and ecological impact. Worldwatch Institute, 12 de outubro de 2005. Disponível: <http://www.worldwatch.org/node/47>. Acesso em: 13 jun. 2008 .

BULMER, J. Draft study on relationship between an international regime on ABS and other international instruments and fora which govern the use of genetic resources: International Treaty on Plant Genetic Resources for Food and Agriculture and the Food and Agriculture Organisation's Commission on Genetic Resources for Food and Agriculture. Montreal: Secretariat of the Convention on Biological Diversity, January 2009.

BURHENNE-GUILMIN, F.; CASEY-LEFKOWITZ. The Convention on Biological Diversity: A hard won global achievement. Yearbook of International Environmental Law, vol. 3, p. 43-59, 1992.

CAHIR, J. The public domain: right or liberty. In: WAELDE, C.; MACQUEEN, H. (Ed.). Intellectual Property: the many faces of the public domain. Cheltenham: Edward Elgar, 2007, p. 35-52.

CALABRESI, G.; MELAMED, A. D. Property rules, liability rules, and inalienability: one view of the cathedral. Harvard Law Review, vol. 85, no. 6, p. 1089- 1128, 1972.

CAMERON, J; GRAY, K.R. Principles of international law in the WTO dispute settlement body. International and Comparative Law Quarterly, vol.50, p. 248-298, 2001.

CAMPBELL, E. G.; CLARRIDGE, B. R.; GOKHALE, M.; BIRENBAUM, L.; HILGARTNER, S.; HOLTZMAN, N.A.; BLUMENTHAL, D. Data Withholding in Academic Genetics. The Journal of the American Medical Association, vol. 287, no. 4, January 23, p. 473-480, 2002. Disponível em: <http://jama.amaassn.org/cgi/content/full/287/4/473 > . Acesso em: 2 de agosto de 2008 . 
CANADA INSTITUTES OF HEALTH RESEARCH. CIHR Guidelines for Health Research Involving Aboriginal People. OTTAWA: CIHR, 2007. 45 p.

CARLINI, E.; RODRIGUES, E. Plantas Medicinais do Brasil: o pesquisador brasileiro consegue estudá-las? Revista Fitos, vol. 1, no. 02, p. 8-18, novembro de 2005.

CARNEIRO DA CUNHA, M. Deve o conhecimento ser livre? A invenção da cultura e os direitos de propriedade intelectual. Revista Sexta Feira, Antropologia, Artes e Humanidades, no. 3, p. 93-94, 1998.

. International bodies and traditional knowledge. In: Twarog, S.; Kapoor, P. (Ed.). Protecting and promoting traditional knowledge: systems, national experiences and international dimensions. New York \& Geneva: United Nations, 2004, p. 91-92.

CARRIER, M.A. Resolving the patent-antitrust paradox through tripartite innovation. Vanderbilt Law Review, vol. 56, p. 101-165, 2003.

CARRIZOSA, S. Conclusions, lessons, and recommendations. In: CARRIZOSA, S.; BRUSH, S.B.; WRIGHT, B.D.; MCGUIRE, P.E. (Eds.) Accessing biodiversity and sharing the benefits: lessons from implementation of the Convention on Biological Diversity. Gland \&Cambridge: IUCN, 2004, p. 295-301.

Carta das Nações Unidas. Assinada em 25 de junho de 1945.

CAS-IP-CGIAR. Getting the word IN; the EPO non-patent literature databases. Roma, 10 de maio de 2009. Disponível em: < http://www.cas-ip.org/tag/non-patentliterature/>. Acesso em: 1 jun. 2009.

CASSIOLATO, J.E.; ELIAS, L.A.; ZUCOLOTO, G. Avaliação econômica da capacidade do Brasil para a fabricação dos medicamentos para HIV/AIDS. In: ROSSI, F. (Ed.) Avaliação técnica, econômica e legal da capacidade de produção de anti-retrovirais no Brasil. Brasília: PNUD; Programa de DST e AIDS do Ministério da Saúde do Brasil, 2008, p. 153-222. Estudo não publicado; cópia em arquivo com o autor.

CAULFIELD, T.; COOK-DEEGAN, R.M.; KIEFF, F.S.; WALSH, J.P. Evidence and anecdotes: an analysis of human gene patenting controversies. Nature Biotechnology, vol. 24, no. 9, p. 1091-1094, 2006.

\section{Central America-Dominican Republic-United States Free Trade Agreement.}

CHAMBRE DES REPRÉSENTANTS DE BELGIQUE. Projet de loi modifiant la loi du 28 mars 1984 sur les brevets d'invention, en ce qui concerne la brevetabilité des inventions biotechnologiques. Bruxelles, 21 juin 2002.

CHANDER, A.; SUNDER, M. The romance of the public domain. California Law Review, vol. 92, p. 1331-1373, 2004.

CHEN, J. There's no such thing as biopiracy....and it's a good thing too. McGeorge Law Review, vol. 37, p. 2-32, 2006. 
CHEN, L. Aging: A New Human Rights Concern: A Policy-Oriented Perspective. Proceedings of the American Society of International Law, vol. 81, p. 169-175, 1987.

. The United Nations Convention on the Rights of the Child: A Policy-Oriented Overview. New York Law School Journal of Human Rights, vol. 7, p. 16-29, 1989.

CHENG, B. General principles of law as applied by international courts and tribunals. London: Stevens \& Sons Limited, 1953.

CHERNIKOFF, L. Striking Africa-inspired dresses are turning up all over. NY Daily News, New York, $1^{\text {o }}$ de maio de 2008. Disponível em: < http://www.nydailynews.com/lifestyle/2008/05/01/2008-05-

01_striking_africainspired_dresses_are turn-1.html>. Acesso em: 20 abril 2009.

CHIVIAN, E. Environment and health: 7. Species loss and ecosystem disruption - the implications for human health. Canadian Medical Association Journal, vol. 164, no. 1, p. 66-69, 2001.

CHRISTIE, A.F.; LIM, A. Reach-through Patent Claims in Biotechnology: An Analysis of the Examination Practices of the United States, European and Japanese Patent Offices. Melbourne: University of Melbourne Legal Studies Research Paper no. 176, 2005. 64 p. Disponível em: $<$ http://ssrn.com/abstract=934951 $>$. Acesso em: 30 dezembro 2008.

CIPRIANO, R. Índios Krahô realizam $5^{\mathrm{a}}$ Feira de Troca de Sementes. EMBRAPA, Brasília, 25 de novembro de 2004.2 Disponível em: $<$ http://www.embrapa.br/imprensa/noticias/2002/setembro/bn.2004-11-25.5008725430/>. Acesso em: 13 fev. 2009.

CLARK, C; KOSKINEN-OLSSON, T. New alternatives for centralized management: "one-stop-shops". WIPO (Ed.). WIPO international forum on the exercise and management of copyright and neighboring rights in the face of the challenges of digital technology. Geneva: WIPO, 1998, p. 227-242.

CLOATRE, E. From international ethics to European Union policy: a case study on biopiracy in the EU's biotechnology directive. Law \& Policy, vol. 28, no. 3, p. 345-367, 2003.

COASE, R.H. The problem of social cost. 1960. 23. p. Disponível em:

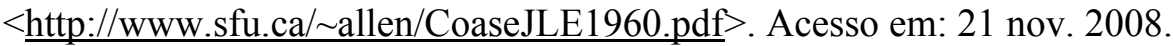

COLANGElO, G. Avoiding the Tragedy of the Anticommons: Collective Rights Organizations, Patent Pools and the Role of Antitrust. LUISS Law and Economics Lab Working Paper no. IP-01-2004. Roma, LUISS Guido Carli 2004. 84 p. Disponível em:

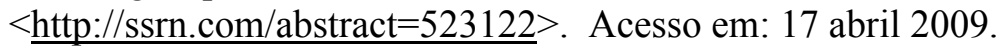

COMIMISSION ON INTELLECTUAL PROPERTY RIGHTS. Integrating intellectual property rights and development policy. London: Commission on Intellectual Property Rights, 2002. 178 p. 
Comment: The misappropriation doctrine after the copyright revision act of 1976. Dickinson Law Review, vol. 81, p. 469-492, 1976-1977.

COMMISSION ON HUMAN RIGHTS. Principles and guidelines for the protection of the heritage of indigenous peoples. E/CN.4/Sub.2/1994/31, anexo. Geneva: Economic and Social Council, 8 July 1994.

Review of Developments Pertaining to the Promotion and Protection of the Rights of Indigenous Peoples, Including their Human Rights and Fundamental Freedoms: Joint Statement from the Indigenous World Association and Indigenous Media Network. E/Cn.4/Sub.2/AC.4/2005/CR. Geneva, 13 Jul. 2005.

COMMITTEE ON CIVIL AND POLITICAL RIGHTS. General comment no. 06: the right to life (art. 6). Geneva, 30 April 1982.

. General comment no. 12: the right to self-determination of peoples (Art. 1). Geneva, 13 Mar. 1984.

General comment no. 22: the right to freedom of thought, conscience and religion. CCPR/C/21/Rev.1/Add.4. Geneva, 30 Jul. 1993.

General comment no. 23: the rights of minorities (Art. 27). CCPR/C/21/Rev.1/Add.5. Geneva, 8 April 1994.

General comment no. 31 : the nature of the general legal obligation imposed on states parties to the Covenant. CCPR/C/21/Rev.1/Add.13. Geneva, 29 Mar. 2004.

COMMITTEE ON ECONOMIC, SOCIAL AND CULTURAL RIGHTS. Cultural Life in the context of human rights: background paper submitted by Ms. Yvonne Donders. E/C.12/40/13. Geneva: Economic and Social Council, 9 May 2008. 7 p.

Cultural rights and universality of human rights. Background paper submitted by Mr. Patrick Thornberry. E/C.12/40/15. Geneva: Economic and Social Council, 9 May 2008. $21 \mathrm{p}$.

General comment 3: the nature of States parties obligations (Art. 2, par.1). 1991/23. Geneva: Office for the High Commissioner for the Human Rights, 14 Dec. 1990.

General comment no. 17: the right of everyone to benefit from the protection of the moral and material interests resulting from any scientific, literary or artistic production of which he or she is the author (article 15, paragraph 1 (c), of the Covenant). E/C.12/GC/17. Geneva, 12 Jan. 2006.

Integrating cultural concerns in the interpretation of general individual rights: lessons from the international human rights case law. Background paper submitted by Ms. Julie Ringelheim. E/C.12/40/4. Geneva: Economic and Social Council, 9 May 2008.15 p. 
No copyright and no domination of cultural markets: two conditions for realising active participation in cultural life. Background paper submitted by Mr. Joost Smiers. E/C.12/40/6. Geneva: Economic and Social Council, 9 May 2008. 4 p.

. Observación general no. 14: El derecho al disfrute del más alto nivel posible de salud (artículo 12 del Pacto Internacional de Derechos Económicos, Sociales y Culturales). E/C.12/2000/4 .Ginebra, 11 ago. 2000.

Observación general 12: El derecho a una alimentación adecuada (art. 11). E/C.12/1999/5. Ginebra, 12 mayo 1999.

. Proyecto de observación general no. 9: la aplicación interna del Pacto. E/C.12/1998/24. Ginebra, 3 dic. 1998.

Le droit de participer à la vie culturelle contenu et importance pour la réalisation de tous les droits de l'homme: Document de travail soumis par M. Patrice Meyer-Bisch. E/C.12/40/8. Genève: Conseil Économique et Social, 9 mai 2008. 11 p.

Pauvreté et accès à la culture: document de travail soumis par Mme. Annelise Oeschger. E/C.12/40/14. Genève: Conseil Économique et Social, 9 mai 2008. 3 p.

COMMITTEE ON THE ELIMINATION OF RACIAL DISCRIMINATION. General recommendation no. 14: Definition of discrimination (Art. 1, par.1). Geneva, 22 Mar. 1993.

General recommendation no. 23: indigenous peoples. Geneva: Office of the High Commissioner for Human Rights, 18 Aug. 1997.

. General recommendation no. 21: right to self-determination. Geneva: Office of the High Commissioner for Human Rights, 23 Aug. 1996.

General recommendation no. 24: reporting of persons belonging to different races, national/ethnic groups, or indigenous peoples (Art. 1). Contido no anexo V, do documento A/54/18. Geneva, 27 Aug. 1999.

General recommendation no. 20: non-discriminatory implementation of rights and freedoms (Art. 5). A/51/18. Geneva, 15 Mar. 1996.

. General recommendation no. 26: article 6 of the convention. A/55/18, anexo V. Geneva, 24 Mar. 2000.

. General recommendation no. 30: Discrimination against non citizens. Geneva, $1^{\text {st }}$ Oct. 2004.

COMUNIDAD ADINA. DECISIÓN 486. Régimen común sobre propiedad industrial. Lima, 14 de setembro de 2001. 
Decisión 391. Régimen común sobre acceso a los recursos genéticos. Caracas, 02 de julho de 1996.2 Disponível em: $<$ http://www.comunidadandina.org/normativa/dec/D391.htm>. Acesso em: 22 abr. 2009.

CONCEIÇÃO, P.; HEITOR, M.V.; SIRILLI, G; WILSON, R. The "swing of the pendulum" from public to market support for science and technology: Is the U.S. leading the way? Technological Forecasting and Social Change, vol. 71, no. 6, p. 553-578, 2004.

COPCBD. DECISION II/9: Forests and biological diversity. Jacarta, 6-17 de novembro de 1995

DECISION VII/19: Access and benefit-sharing as related to genetic resources. UNEP/CBD/COP/7/21. Kuala Lumpur,9 - 20 Fev. 2004.

DECISION IV/9: Implementation of Article 8(j) and related provisions. Bratislava, 4-15 de novembro de 1998.

. DecisION IX/12: Access and benefit-sharing. UNEP/CBD/COP/DEC/IX/12. Montreal, 9 Oct. 2008.

DECISION VI/7: Identification, monitoring, indicators and assessments. UNEP/CBD/COP/6/20. Haia, 7-19 abr. 2002.

Decision V/16: Article 8(j) and related provisions. UNEP/CBD/COP/5/23. Nairóbi, 12-26 de maio de 2000.

. DeCISION III/14: Implementation of Article 8 (j). UNEP/CBD/COP/3/38. Buenos Aires, 1-15 de novembro de 1996.

DeCISION II/8: Preliminary consideration of components of biological diversity particularly under threat and action which could be taken under the Convention.Jacarta, 617 de novembro de 1995.

. DeCision V/26: Access to genetic resources. Nairóbi, 12-26 de maio de 2000.

2006.

DeCISION VIII/5: Article 8(j) and related provisions. Curitiba, 20-31 de março de

DeCISION IX/13: Article 8(j) and related provisions. Bonn, 19-30 de maio de 2008.

DeCISION VIII/4: Access and benefit-sharing. Curitiba, 20-31 de março de 2006.

DECISION IX/25: South-South cooperation on biodiversity for development. Bonn, 19-30 de maio de 2008.

DeCISION VI/10: Article 8(j) and related provisions. UNEP/CBD/COP/6/20. Haia, 7-19 abr. 2002. 
DeCision V/5: Agricultural biological diversity: review of phase I of the programme of work and adoption of a multi-year work programme. UNEP/CBD/COP/5/23. Nairóbi, 12-26 de maio, 2000.

CONFERENCE ON THE HUMAN ENVIRONMENT. Declaration of the United Nations Conference on the Human Environment 1972. Estocolmo, 1972.

Convenção das Nações Unidas sobre o Direito do Mar. Assinada em Montego Bay, Jamaica, em 10 de dezembro de 1982.

Convenção de Berna para a Proteção das Obras Literárias e Artísticas, de 9 de setembro de 1886, revista em Paris, a 24 de julho de 1971.

Convenção de Paris para proteção da Propriedade Industrial. Revisão de Estocolmo, 1967.

Convención de Roma para la protección de los artistas intérpretes o ejecutantes, los productores de fonogramas y los organismos de radiodifusión. Roma, 1961.

Convenção de Viena sobre o Direito dos Tratados. Adotada em Viena, em 26 de maio de 1969.

Convenção no. 169 da OIT sobre povos indígenas e tribais. Genebra, 27 jun. 1989.

Convenção para a Salvaguarda do Patrimônio Cultural Imaterial. Paris, 17 out. 2003.

Convenção sobre a Promoção e a Proteção da Diversidade das Expressões Culturais. Paris, 20 out. 2005

Convenção sobre Diversidade Biológia. Rio de Janeiro, 5-14 de junho de 1992.

Convention on the Grant of European patents (European Patent Convention). Munique, 5 de outubro de 1973

Convenção das Nações Unidas de Combate à Desertificação (nos países afetados por seca grave e/ou desertificação, particularmente na África).

COOMBE, R. J. Intellectual property, human rights \& sovereignty: new dilemmas in international law posed by the recognition of indigenous knowledge. 6 Indiana Journal of Global Legal Studies, vol. 6, p. 59-115, 1998-1999.

The recognition of indigenous peoples'and community traditional knowledge in international law. St. Thomas Law Review, vol. 14, p. 275- 285, 2001-2002.

COOMBE, R.J.; HERMAN, A. Rhetorical Virtues: Property, Speech, and the Commons on the World-Wide Web. Anthropological Quarterly, vol. 77, no. 3, p. 557-572, 2004.

CORREA, C. M. Cuestiones y opciones acerca de la protección de los conocimientos tradicionales: los conocimientos tradicionales y la propiedad intelectual. Geneva: Quaker United Nations Office, 2001. 32 p. 
Establishing a disclosure of origin obligation in the TRIPS agreement (Occasional paper 12). Genebra: Quaker United Nations Office, 2003. 11 p. Disponível em: $<$ http://www.quno.org/geneva/pdf/economic/Occassional/Dec-of-Origin.pdf $>$. Acesso em: 17 abr. 2009.

The politics and practicalities of a disclosure of origin obligation (Occasional paper 16). Genebra: Quaker United Nations Office, 2005a. 10 p. Disponível em: $<$ http://www.quno.org/geneva/pdf/economic/Occassional/Politics-of-Dec-of-Origin.pdf $>$. Acesso em: 17 abr. 2009.

Do national access regimes promote the use of genetic resources and benefit sharing? International Journal of Environment and Sustainable Development, vol. 4, no. 4, p. 444-463, 2005b.

CORREA, C.M.; SHABALALA, D. Salud pública y patentes farmacêuticas: segundos usos. In: RODRIGUES JR.; E.B.; POLIDO, F. Propriedade Intelectual: novos paradigmas internacionais, conflitos e desafios. Rio de Janeiro: Elsevier, 2007, p. 153-181.

CORTE INTERAMERICANA DE DERECHOS HUMANOS. Sentença no caso comunidad indígena Yakye Axa vs. Paraguay, San José, Costa Rica, 17 junho de 2005.

Sentença no caso Comunidad Indígena Sawhoyamaxa v. Paraguay. San José, Costa Rica, 29 de março de 2006a.

. Voto fundamentado do juiz A.A. Cançado Trindade no caso Comunidad Indígena Sawhoyamaxa v. Paraguay. Sentença proferida em 29 de março de 2006b.

. Voto fundamentado do juiz A.A. Cançado Trindade, no caso Comunidad Indígena Yakye Axa v. Paraguay. Sentença proferida em 6 de febrero de 2006c.

Sentença proferida no Caso Claude Reyes y otros $v$. Chile. Sentença proferida em 19 de setembro de 2006 d. 2007.

Sentença proferida no caso Saramaka People $v$. Suriname; em 28 de novembro de

COSTANZA, R.; D’ARGE, R.; DE GROOT, R.; FARBER, S.; GRASSO, M.; HANNON, B.; LIMBURG, K.; NAEEM, S.; O’NEILL, R.; PARUELO, J.; RASKIN, R.G.; SUTTON, P.; VAN DEN BELT, M. The value of the world's ecosystem services and natural capital. Nature, vol. 387, p. 253-260, 1997.

COTTIER, T.; PANIZZON, M. A new generation of IPR for the protection of traditional knowledge in PGR for food, agricultura and pharmaceutical Uses. In: BIBER-KLEMM; COTTIER, T. (Eds.). Rigths to plant genetic resources and traditional knowledge: basic issues and perspectives. Oxfordshire \& Cambridge: CABI, 2006, p. 203-237.

COX, P. A. Ensuring equitable benefits: the Falealupo covenant and the isolation of antiviral drug prostratin from a Samoan medicinal plant. Pharmaceutical Biology, vol. 39, no. 1, p. 33-40, 2001. 
CRUCIBLE II GROUP (THE). Seedling Solutions: policy options for genetic resources: people, plants, and patents revisited. Ottawa, Roma \& Uppsala: International Development Research Centre/International Plant Genetic Resources Institute/Dag Hammarskjöld Foundation, 2000. $121 \mathrm{p}$.

CUMBRE MUNDIAL DE LA SOCIEDADE DE LA INFORMACIÓN. Declaración de Principios: Construir la sociedad de la información - un desafío global para el nuevo milenio. WSIS-03/GENEVA/4-S. Genebra, 12 de maio de 2004.

CUNNINGHAM, D; TOBIN, B.; WATANABE, K. Tracking genetic resources and international access and benefit sharing governance: The role of certificates of origin (Background paper for Smithsonian/UNU-IAS Roundtable on certificates of origin ( 9 September 2004)). Yokohama: United Nations University, 2004. 4 p. Disponível em: $<\mathrm{http}$ ://www.ias.unu.edu/binaries2/Certificates_of_origin_backgr_paper.doc $>$. Acesso em: 30 jun. 2008.

DAES, E.I. Intellectual property and indigenous peoples. Proceedings of the American Society of International Law, vol. 95, p. 143-150, 2001.

Protection of the heritage of indigenous people. New York \& Geneva: Office of the High Commissioner for Human Rights, 1997. 30 p.

DAG HAMMARSKJÖLD FOUNDATION. What Now: the 1975 Dag Hammarskjöld Report on development and international cooperation. Uppsala: Dag Hammarskjöld Foundation, 1975. 129 p.

DALTON, R. Bioprospects less than gold. Nature, no. 429, p. 598-600, 2004.

DASMANN, R.F. Called by the Wild: The Autobiography of a Conservationist. Berkeley e Los Angeles: University of California Press, 2002. 269 p.

DAVID, P.A.; FORAY, D. An introduction to the economy of the knowledge society. International Social Science Journal, vol. 54, no. 171, p. 9-23, 2002.

DE ALMEIDA, G. Veneno contra o câncer: substância extraída de serpentes pode deter a migração da doença para o resto do corpo. Revista Isto é, edição no. 2042, de 24 de dezembro de 2008. Disponível em: $<$ http://www.terra.com.br/istoe/istoe/sumarios/sumario 1571.htm $>$. Acesso em: $26 \mathrm{dez}$. 2008.

Declaração Universal dos Direitos do Homem. Aprovada pela Assembléia Geral das Nações Unidas, em 10 de dezembro de 1948.

Declaração Universal sobre a Diversidade Cultural. Paris, 2 nov. 2001.

Declaração Universal sobre Bioética e Direitos Humanos. Paris, 19 de outubro de 2005.

DE LA CRUZ, R. Descripción de la comprensión corriente del consentimiento libre, previo e informado de los pueblos indígenas como un asunto metodológico, en las 
actividades relacionadas con pueblos indígenas: significado y desafíos. FPII/2004/WS.2/5. New York: United Nations, 2005.

DE VREY, R.W. Towards a European unfair competition law: a clash between legal families. Leiden \& Boston: Brill Academic Publishers, 2005. 398 p.

DEAZLEY, R. Copyright's public domain. In: WAELDE, C.; MACQUEEN, H. (Ed.). Intellectual Property: the many faces of the public domain. Cheltenham: Edward Elgar, 2007, p. 21-34.

Declaração Americana dos Direitos e Deveres do Homem. Aprovada na IX Conferência Internacional Americana, em Bogotá, em abril de 1948.

DELMANTO, C.; DELMANTO, R; DELMANTO JR., R.; DELMANTO, F.A. Código Penal Comentado. $5^{\mathrm{a}}$.ed. Rio de Janeiro: Renovar, 2000.

DENHEZ, M. International protection of expressions of folklore: UNESCO follow-up to the 1989 recommendation on the safeguarding of traditional culture and folklore. In: UNESCO-WIPO (Ed.). World Forum on the Protection of Folklore (organized by the United United Nations Educational, Scientific and Cultural OrganizationUNESCO-and the World Intellectual Property Organization-WIPO-in cooperation with the Department of Intellectual Property, Ministry of Commerce, Government of Thailand). WIPO publication no. 758.Geneva: UNESCO-WIPO, 1998, p. 197-211.

DERENBERG, W.J. The influence of the French code civil on the modern law of unfair competition. American Journal of Comparative Law, vol. 4, p. 1- 34, 1955.

DESCOLA, P. Deve o conhecimento ser livre? Os direitos de propriedade intelectual e suas vicissitudes. Revista Sexta Feira, Antropologia, Artes e Humanidades, no. 2, p. 93-94, 1998.

DINWOODIE, G. B.; DREYFUSS, R.C. Patenting science: protecting the domain of accessible knowledge. In: GUIBAULT, L.; HUGENHOLTZ, P.B. (Ed.). The Future of the Public Domain: Identifying the Commons in Information Law. Alphen aan den Rijn: The Kluwer Law International, 2006, p. 191-222.

DNDI. Proposta brasileira na OMS sobre doenças negligenciadas é discutida no Rio de Janeiro. DNDI, Rio de Janeiro, 28 de março de 2006. Disponível em: < http://www.dndi.org.br/Portugues/texto noticias.aspx?id=59>. Acesso em: 17 jan. 2009.

DOS SANTOS, L.G. Paradoxos da Propriedade Intelectual. Conferência Intellectual Property: Tensions between the Logic of Capital and Social and Developmental Demands, IEEIBR, São Paulo, 8 e 9 de março de 2007. 18 p.

DOVE, A. When science rides the MTA. Journal of Clinical Investigation, vol. 110, no. 4, p. 425-427, 2002. Disponível em: <http://www.jci.org/articles/view/16546> . Acesso em: 2 agosto 2008 . 
DRAHOS, P. A networked responsive regulatory approach to protecting traditional knowledge. In: GERVAIS, D.J. (org.). Intellectual Property, Trade and Development: strategies to optmize economic development in a TRIPS-Plus Era. New York, Oxford University Press, 2007, p. 385-415.

. Expanding Intellectual Property's Empire: the Role of FTAs. Barcelona: Grain, 2003. 19 p. Disponível em: <http://www.grain.org/rights/tripsplus.cfm?id=28>. Acesso em: 23 setembro 2008.

. Freedom and diversity: a defence of the intellectual commons. [S.1], Australasian Intellectual Property Law Resources, 2006. Localização: $<$ http://www.austlii.edu.au/au/other/AIPLRes/2006/1.html>. Acesso em: 17 out. 2008.

- Indigenous knowledge, intellectual property and biopiracy: is a global biocollecting society the answer. European Intellectual Property Review, vol. 22, no. 6, p. 245-250, 2000.

\begin{tabular}{l} 
Geneva, $\quad$ WIPO, $1998.13 \mathrm{p} . \quad 10$ Disponível \\
$<$ https://www.wcl.american.edu/pijip/download.cfm?downloadfile=33DED7E1-A0B5- \\
E036-F98B9AAEDFE1B222\&typename=dmFile\&fieldname=filename $>$. Acesso em: 04 \\
\hline dez. 2008.
\end{tabular}

DREYFUSS, R.C.; LOWENFELD, A.F. Two achievements of the Uruguay round: putting TRIPS and dispute settlement together. Virginia Journal of International Law, vol. 37, p. $275-334,1996-1997$.

DUARTE, O.; VELHO; L. Análisis del marco legal en Colombia para la implementación de prácticas de Bioprospección. Acta Biológica Colombiana, v. 13, p. 103-122, 2008.

DUBOCK, A. Golde rice: the patioting of influence. In: 9th International Conference on Agricultural Biotechnology: Ten Years After, 2005. Disponível em: $<\underline{\text { http://www.goldenrice.org/PDFs/Dubock 9th_ICABR_2005.pdf }}>$. Acesso em: 17 abril 2009.

DUTFIELD, G. A rights-free world: is it workable, and what is the point? In: WAELDE, C.; MACQUEEN, H. (Ed.). Intellectual Property: the many faces of the public domain. Cheltenham: Edward Elgar, 2007, p. 211-225.

- Developing and implementing national systems for protecting traditional knowledge: experiences in selected developing countries. In: Twarog, S.; Kapoor, P. (Ed.). Protecting and promoting traditional knowledge: systems, national experiences and international dimensions. New York \& Geneva: United Nations, 2004a, p. 141-153.

Intellectual property, biogenetic resources and traditional knowledge. London: Earthscan, 2004b. 234 p.

- Protecting traditional knowledge and folklore: a review of progress in diplomacy and policy formulation. Geneva: ICTSD-UNCTAD, 2003. 57 p. 
TRIPS-related aspects of traditional knowledge. Case Western Reserve Journal of International Law, vol. 33, p. 233- 275, 2001.

EAGLETON, T. The idea of Culture. Oxford: Blackwell, 2000. 168 p.

ECOSOC. Commission on human rights. Prevention of discrimination and protection of indigenous peoples and minorities: Indigenous peoples and their relationship to land. E/CN.4/Sub.2/2001/21. Geneva, 11 June 2001. 77 p. julho de 1995.

Science and technology for development. Resolution 1995/54. Geneva, 28 de

The role of modern science and technology in the development of nations and the need to strengthen economic, technical and scientific co-operation among States. Resolution 1826(LV). New York, 10 de agosto de 1973.

. Quinto informe del experto independiente en el derecho al desarrollo, Sr. Arjun Sengupta, presentado de conformidad con la resolución 2002/69 de la comisión: Marcos para la cooperación para el desarrollo y el derecho al desarrollo. E/CN.4/2002/WG.18/6. New York, 18 set. 2002.

EDMONDS INSTITUTE. Out of Brazil: a peanut worth billions (to the US). Edmonds: Edmonds Institute, 2006. Disponível em: <http://www.edmondsinstitute.org/outofbrazil.pdf $>$. Acesso em: 22 setembro 2008.

EISENBERG, R.S. Bargaining over the transfer of proprietary research tools: is this market failing or emerging? In: DREYFUSS, R.C.; ZIMMERMAN, D.L; FIRST, H. (Eds.) Expanding the boundaries of intellectual property: innovation policy for the knowledge society. Oxford: Oxford University Press, 2001, p. 223-249.

. Patents on DNA sequences: molecules and information. In: ELKIN-KOREN, N; NETANEL, N.W. (Eds.). The commodification of information. The Hague: Kluwer Law International, 2002, p. 415-431.

EKPERE, J.A. Sui generis legislation and protection of community rights in Africa. In: Twarog, S.; Kapoor, P. (Ed.). Protecting and promoting traditional knowledge: systems, national experiences and international dimensions. New York \& Geneva: United Nations, 2004, p. 235-239.

EMERICK, M.C. Acesso aos recursos genéticos e aos conhecimentos tradicionais associados: legislação vigente e consulta pública sobre o APL. Apresentação de Power Point realizada para a FEBRAPLAME, em $1^{\circ}$ de setembro de 2008, em São Paulo.

EPSTEIN, R. A. Holdouts, externalities, and the single owner: one more salute to Ronald Coase. Journal of Law and Economics, vol. 36, no. 1, p. 553-586, 1993.

ERMERT, M. Symposium calls for end of binary discussion of rightsholders versus pirates. IP Watch, Genebra, 8 de setembro de 2008. Disponível em: < http://www.ip- 
watch.org/weblog/2008/09/08/conference-calls-for-end-of-binary-discussion-ofrightsholders-versus-pirates/>. Acesso em: 20 abril 2009.

ETC GROUP. Biopiracy+10: captain hook awards-2002. ETC Group Communiqué no. 75, p.1-10, 2002.

. Extreme Genetic Engeneering: an introduction to synthetic engeneering. Ottawa: ETC Group, 2007a. 64 p.

. Hollow Victory: Enola Bean Patent Smashed At Last (Maybe). ETC Group, Ottawa, 29 de abril de 2008a. Disponível em: < http://www.etcgroup.org/upload/publication/pdf_file/683 > . Acesso em: 20 abril 2009. 2005.

. Oligopolio S.A. 2005. ETC GROUP Communiqué no. 91, p. 1-17, nov.-dec.

Patenting the "climate genes"... and capturing the climate agenda. ETC GROUP Communiqué, no. 99, p. 1-30. May/June, 2008b.

Proctor's gamble: yellow bean patent owner sues 16 farmers and processors in US. ETC Group, Ottawa, 17 December 2001. Disponível em: <www.etcgroup.org>. Acesso em: 10 outubro 2008.

The World's Top 10 Seed Companies - 2006. Ottawa: ETC Group, 2007b. Disponível em: <http://www.etcgroup.org/upload/publication/pdf file/615>. Acesso em: 17 abril 2009.

EUROPEAN COMMUNITY. Written submission on folklore from the European Community and its Member States for the 3rd WIPO Intergovernmental Committee on Genetic Resources, Traditional Knowledge and Folklore Geneva, 13-21 June, 2002. [S.1.], 2002. 4 p. 4 Disponível em: $<$ http://ec.europa.eu/internal market/copyright/docs/wipo/wipo-folklore en.pdf $>$. Acesso em: 16 ago. 2008.

EUROPEAN PARLIAMENT; THE COUNCIL; THE EUROPEAN ECONOMIC AND SOCIAL COMMITTEE; THE COMMITTEE OF THE REGIONS. Addressing the challenges of deforestation and forest degradation to tackle climate change and biodiversity loss. Brussels, 17 Oct. 2008.

EUROPEAN PATENT OFFICE. Protecting traditional knowledge: India opens online database to EPO examiners. Munique, 11 fev. 2009. Disponível em: $<$ http://www.epo.org/topics/news/2009/20090211.html>. Acesso em 1 jun. 2009.

EVANS, P.C. Patent rights in biological material. Genetic Engeneering \& Biotechnology News, vol. 26, no. 17, 2006. Disponivel em: < http://www.genengnews.com/articles/chitem.aspx?aid=1880\&chid=0>. Acesso em 20 abril 2009.

EVATT, E. Enforcing indigenous cultural rights: Australia as a case-study. In: NIEC, H. Cultural Rights and Wrongs: a collection of essays in commemmoration of the 50th 
anniversary of the Universal Declaration of Human Rigths. Paris: UNESCO Publishing \& Institute of Art and Law, 1998, p. 57-80.

FAGAN, D.N. Achieving restitution: the potential unjust enrichment claims of indigenous peoples against multinational corporations. New York University Law Review, vol. 76, p. 626-663, 2001.

FAJARDO, M. P. P. Protection of traditional knowledge, access and benefit sharing, and intellectual property rights: the Colombian experience. In: Twarog, S.; Kapoor, P. (Ed.). Protecting and promoting traditional knowledge: systems, national experiences and international dimensions. New York \& Geneva: United Nations, 2004, p. 223-234.

FARNSWORTH, N. R. ; AKERELE, O.; BINGEL, A.S.; SOEJARTO, D.D.; GUO, Z. Medicinal plants in therapy. Bulletin of the World Health Organization, vol. 63, no. 6, p. $965-981,1985$.

FAUCHART, E.; VON HIPPEL, E. Norms-based intellectual property systems: the case of French chefs. MIT Sloan School of Management Working Paper 4576-06. Cambridge, Massachussets: MIT, 2006. 32 p.

FELDMAN, M.P. The Internet revolution and the geography of innovation. International Social Science Journal, vol. 54, no. 171, p. 47-56, 2002.

FERNANDO, J. L. NGOs and production of indigenous knowledge under the condition of postmodernity. Annals of the American Academy of Political and Social Science, vol. 590, p. 54-72, 2003.

FERREIRA-MIANI, P. Colombia: access and exchange of genetic resources. In: CARRIZOSA, S.; BRUSH, S.B.; WRIGHT, B.D.; MCGUIRE, P.E. (Eds.) Accessing biodiversity and sharing the benefits: lessons from implementation of the Convention on Biological Diversity. Gland \&Cambridge: IUCN, 2004, p. 79- 100.

FICSOR, M. Collective management of copyright and related rights. Geneva: World Intellectual Property Organization, 2002. 165 p.

Collective management of copyright and related rights in the digital, networked environment: voluntary, presumption-based, extended, mandatory, possible, inevitable? In: GERVAIS, D.J. (Ed.). Collective management of copyright and related rights. Alphen aan den Rijn: The Kluwer Law International, 2006, p. 37-83.

Attempts to provide international protection for folklore by intellectual property rights. In: UNESCO-WIPO (Ed.). World Forum on the Protection of Folklore (organized by the United United Nations Educational, Scientific and Cultural Organization-UNESCO — and the World Intellectual Property OrganizationWIPO - in cooperation with the Department of Intellectual Property, Ministry of Commerce, Government of Thlailand). WIPO publication no. 758.Geneva: UNESCOWIPO, 1998, p. 215- 226. 
FILIPINAS. Indigenous Peoples Rights Act. Republic Act no. 8371, 28 of July, 1997. Disponível em: <http://www.wipo.int/export/sites/www/tk/en/laws/pdf/phil_indig.pdf $>$. Acesso em: 22 abr. 2009.

FISHER, W. Two thoughts about traditional knowledge. Law \& Contemporary Problems, vol. 70, p. 131-133, 2007.

FLETCHER, M.L.M. Theoretical restrictions on the sharing of indigenous biological knowledge: implications for freedom of speech in tribal law. Kansas Journal of Law \& Public Policy, vol. 14, p. 525-560. 2005.

FOLHA DE SÃO PAULO. Técnico da Funai afirma que vai processar pesquisador da Unifesp. Folha de São Paulo, São Paulo, 13 de agosto de 2002. Disponível em:

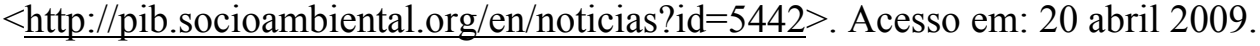

FONTES, E; DA ROCHA, F.G.; VARELLA, M.D. Biossegurança \& Biodiversidade: contexto científico e regulamentar. Belo Horizonte: Del Rey, 1999.

FOOD AND AGRICULTURE ORGANIZATION OF THE UNITED NATIONS. Safeguarding biodiversity, sharing benefits, feeding the world. Roma: FAO, [200-]. 6 p. Disponível em: <ftp://ftp.fao.org/ag/agp/planttreaty/training/brochure07 en.pdf $>$. Acesso em: 2 dez. 2008.

Agreement between [name of centre] and the Food and Agriculture Organization of the United Nations (FAO) placing collections of plant germplasm under the auspices of FAO. Roma: FAO, 1994. Disponível em: $<$ ftp://ftp.fao.org/ag/cgrfa/GS/cgtexte.pdf> $>$. Acesso em: 10 out. 2008.

Biotechnology and food security. World Food Summit. 10-13 de junho de 2002. 2 p. Disponível em: <http://www.fao.org/worldfoodsummit/english/fsheets/biotech.pdf $>$. Acesso em: 26 abr. 2009.

Declaración de Interlaken. Aprovada pela Conferência Técnica Internacional sobre Recursos Zoogenéticos para a Agricultura e a Alimentação. Interlaken, Suíça, 3-7 setembro de $2007 \mathrm{a}$.

Global plan of action for the conservation and sustainable utilization of plant genetic resources for food and agriculture. Adotada pela International Technical Conference on Plant Genetic Resources. Leipzig, 17-23 jun. 1996a.

Leipzig Declaration on conservation and sustainable utilization of plant

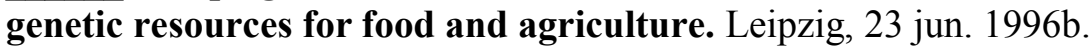

Órgão Reitor do Tratado Internacional de Recursos Fitogenéticos para Alimentação e Agricultura. Resolución 1/2006. Resolução que estabelece o Acuerdo normalizado de transferencia de material.

Report of the governing body of the International Treaty on Plant Genetic Resources for Food and Agriculture. IT/GB-2/07/Report. Rome, Oct.-Nov. 2007. 
Resolución 3/91. Roma, 9-27 nov. 1991.

. Resolución 4/89: Interpretación concertada del Compromiso Internacional. Roma, 11-29 nov. 1989.

Resolución 5/89: Derechos del agricultor. Roma, 11-29 nov. 1989.

Resolución 8/83 del $22^{\circ}$ periodo de sesiones de la Conferencia de La FAO. Roma, 5-23 nov. 1983.

Resolution 7/93: Revision of the International Undertaking on Plant Genetic Resources. Roma, 1993.

Résolution 3/2001: adoption du Traité international sur les ressources phytogénétiques pour l'alimentation et l'agriculture et dispositions provisoires en vue de son application. Roma, 2 nov. 2001.

. Contexto: Perspectivas y cuestiones importantes. Roma: FAO, 2008. Disponível em: $<$ http://www.planttreaty.org/presentations/p1 es/player.htm $>$. Acesso em: 10 set. 2008 .

- El Tratado International sobre los Recursos Fitogenéticos para la Alimentación y la Agricultura. Roma: FAO, 2004. 45 p.

Experiencia de los centros del Grupo Consultivo sobre Investigación Agrícola Internacional (GCIAI) con la aplicación de los acuerdos del órgano rector, con particular referencia al acuerdo normalizado de transferencia de material. IT/GB2/7/Inf.11. Roma: FAO, oct.-nov. 27. 10 p.

Examen del Acuerdo de Transferencia de Material Destinado a la Utilización por los Centros Internacionales de Investigación Agrícola para los Recursos Fitogenéticos para la Agricultura y la Alimentación no Incluido en el Anexo 1 del Tratado. IT/GB-2/07/13 Rev.1. Roma: oct.-nov. 2007. 7 p.

. El desarrollo de los derechos del agricultor en el contexto del compromiso internacional y del artículo 9. IT/GB-2/07/Inf.6. Roma, oct.-nov. 2007. 4 p.

Plan de acción mundial sobre los recursos zoogenéticos y la Declaración de Interlaken aprobados por la Conferencia técnica internacional sobre los recursos zoogenéticos para la agricultura y la alimentación Interlaken, Suiza, 3-7 septiembre 2007. Roma: Comisión de recursos genéticos para la alimentación y la agricultura, 2007b.

FRANÇA. Code de la propriété intellectuelle. Disponível em: $<$ http://www.legifrance.gouv.fr/affichCode.do;jsessionid=0C0BD88F4C2565AE3451456 DB6250B7E.tpdjo04v_3?idSectionTA=LEGISCTA000006161636\&cidTexte=LEGITEXT 000006069414\&dateTexte=20090601 > . Acesso em 1 jun. 2009.

FRANCIONI, F.; LENZERINI, F.; MASSIMILIANO M.; MORGERA, E. Options and modalities for the improvement of international environmental governance through the establishment of a UN environmental organization. Paris: France Dilplomatie, [200- 
?]. $70 \quad$ p. $\quad$ Disponível em:

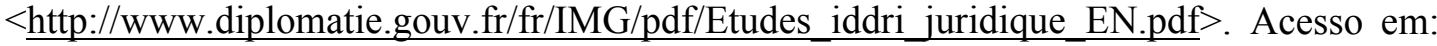
17 nov. 2008.

Free trade Agreement between The Republic of China (Taiwan) and the Republic of Panama.

FREIRE, J.R.B. O patrimônio cultural indígena. [200-?]. Disponível em:

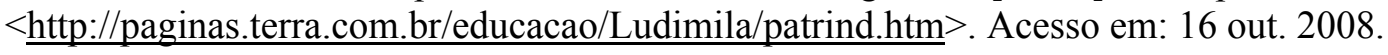

FUNDAÇÃO NACIONAL DO ÍNDIO. Ofício no. 211/CGEP/03. Brasília, 7 nov. 2003.

GAIA; GRAIN. Ten reasons not to join UPOV. Global Trade and Biodiversity in Conflict, no.2, 1998. Disponível em: < http://www.grain.org/briefings/?id=1>. Acesso em: 17 abril 2009.

TRIPS versus CBD: Conflicts between the WTO regime of intellectual property

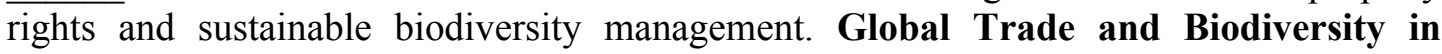
Conflict, no. 1, 1998. Disponível em: <http://www.grain.org/briefings/?id=24>. Acesso em: 21 agosto 2008.

GARFORTH, K. Life as chemistry or life as biology? An ethic of patents on genetically modified organisms. In: CONFERENCE PATENTING LIVES, 2005, Queen Mary Intellectual Property Research Institute, Londres. 25 p. Trabalho em arquivo com o autor.

GERAQUE, E. Garimpo biológico: como usar plantas da floresta para curar doenças? Folha de São Paulo, São Paulo, 21 de outubro de 2007. Disponível em: < http://www.jornaldaciencia.org.br/Detalhe.jsp?id=51640>. Acesso em: 26 abr. 2009.

GERVAIS, D. J. Spiritual but not Intellectual? The Protection of Sacred Intangible Traditional Knowledge. Cardozo Journal of International and Comparative Law, vol. 11, p. 467-495, 2003.

. The changing role of copyright collectives. In: Collective management of copyright and related rights. Alphen aan den Rijn: The Kluwer Law International, 2006, p. 3-36.

. The TRIPS Agreement: Drafting History and Analysis. London: Sweet \& Maxwell, 1998. 275 p.

. Traditional Knowledge \& Intellectual Property: A TRIPS-Compatible Approach. Michigan State Law Review, p. 137-166, 2005.

GIBSON, J. Audiences in tradition: traditional knowledge and the public domain In: WAELDE, C.; MACQUEEN, H. (Ed.). Intellectual Property: the many faces of the public domain. Cheltenham: Edward Elgar, 2007, p. 174-188.

GIGLIO, F. A systematic approach to 'unjust' and 'unjustified' enrichment. Oxford Journal of Legal Studies, vol. 23, no. 3, p. 455-482, 2003. 
GIRARDI, G. Estudos focam doenças tropicais: plantas e animais são esperança contra Chagas, leishmaniose e malária. O Estado de São Paulo, São Paulo, 6 de agosto de 2008a. Disponível em: < http://www.estadao.com.br/vidae/not vid218866,0.htm $>$. Acesso em: 20 abril 2009.

Múltiplas ações na vegetação paulista: pesquisas no cerrado e na mata atlântica indicam possíveis fármacos. O Estado de São Paulo, São Paulo, 6 de agosto de 2008b. Disponível em: < http://www.estadao.com.br/vidae/not_vid218876,0.htm>. Acesso em: 20 abril 2009.

Peixe venenoso pode render antiasmático para grávidas. O Estado de São Paulo, São Paulo, 6 de agosto de 2008c. Disponível em: < http://www.estadao.com.br/vidae/not_vid218870,0.htm>. Acesso em: 20 abril 2009.

. Remédios que vêm das toxinas. O Estado de São Paulo, São Paulo, 6 de agosto de 2008d. Disponível em: < http://www.estadao.com.br/vidae/not_vid218876,0.htm>. Acesso em: 20 abril 2009.

GOLD, E. R.; CARBONE, J. Myriad genetics: in the eye of the policy storm. Montreal: McGill University. International Expert Group on Biotechnology, Innovation and Intellectual Property, 2008. 59 p.

GOLD, E.R.; CAULFIELD, T.A. The moral tollbooth: a method that makes use of the patent system to address ethical concerns in biotechnology. The Lancet, vol. 359, p. 2268$2270,2002$.

GOLD, E.R; CASTLE, D.; CLOUTIER, L.M. Agrobiotecnologia nos tribunais: patentes, privilégios e presunções. In: RODRIGUES JR., E.B; POLIDO, F. (Eds.). Propriedade Intelectual: Novos paradigmas internacionais, conflitos e desafios. Rio de Janeiro: Elsevier, 2007, p. 275-300

GORJESTANI, N. Indigenous knowledge for development: opportunities and challenges. In: Twarog, S.; Kapoor, P. (Ed.). Protecting and promoting traditional knowledge: systems, national experiences and international dimensions. New York \& Geneva: United Nations, 2004, p. 241-262.

GRAFF, G.; ZILBERMAN, D. An intellectual property clearinghouse for agricultural biotechnology. Nature Biotechnology, vol. 19, no. 12, p. 1179-1180, $2001 \mathrm{a}$.

. Towards an Intellectual Property Clearinghouse for Agricultural Biotechnology. IP Strategy Today, no.3, p. 1-12, 2001b. Disponível em:

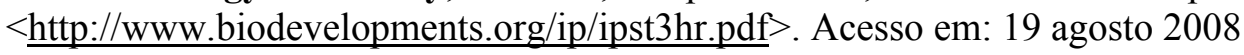

GRAFF, G.D.; RAUSSER, G.D.; SMALL, A.A. Agricultural biotechnology's complementary intellectual assets. New York, 2001. Disponível em: $<$ http://www.columbia.edu/ aas69/Pubs/Graff-Rausser-Small-AgBiotech.pdf $>$. Acesso em: 9 outubro 2008.

GRAFF, G; BENNETT, A; WRIGHT, B.; ZILBERMAN, D. Intellectual Property Clearinghouse mechanisms for Agriculture: Summary of an Industry, Academia, and 
International Development Round Table. IP Strategy Today, no. 3, p. 15-38, 2001. Disponível em: $<$ http://www.biodevelopments.org/ip/ipst3hr.pdf $>$. Acesso em: 19 agosto 2008.

GRAIN. Latin America's Free Trade Agreements with the European Union - An agenda for domination. Barcelona: GRAIN, 2008a. Disponível em:

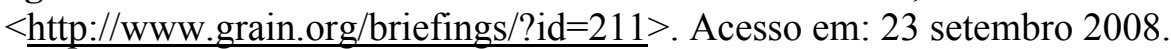

. "TRIPS-plus" through the back door. Barcelona: GRAIN, 2001. Disponível em: <www.grain.org/publications/trips-plus-en.cfm>. Acesso em: 23 setembro 2008.

Bilateral agreements imposing TRIPS-plus intellectual property rights on biodiversity in developing countries. Barcelona: GRAIN, 2008b. Disponível em:

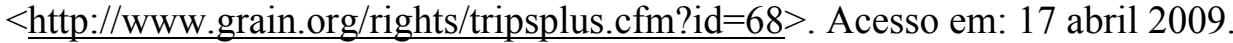

Enmienda a la ley de patentes de China. GRAIN, Barcelona, 08 oct. $2008 \mathrm{c}$. Disponível em: $<$ http://www.grain.org/bio-ipr/?id=556> $>$. Acesso em: 10 oct. 2008.

Japan digs its claws into biodiversity through FTAs. Barcelona: GRAIN, 2007. Disponível em: <http://www.grain.org/articles files/atg-11-en.pdf $>$. Acesso em: 23 setembro 2008.

GRAIN; CERVANTES, S. R. FTAs: trading away traditional knowledge. Barcelona: GRAIN, 2006. Disponível em: <http://www.grain.org/briefings/?id=196\# ftnref30 $>$. Acesso em: 23 setembro 2008.

GRAJAL, A. Biodiversity and the nation state: regulating access to genetic resources limits biodiversity research in developing countries. Conservation Biology, vol. 13, no. 1, p. 6$10,1999$.

GREENFIELD, D.F. Greenberg v. Miami Children's Hospital: unjust enrichment and the patenting of human genetic material. Annals Health Law, vol. 15, p. 213-250, 2006.

GREENGRASS, B. Plant variety protection and the protection of traditional knowledge. In: Twarog, S.; Kapoor, P. (Ed.). Protecting and promoting traditional knowledge: systems, national experiences and international dimensions. New York \& Geneva: United Nations, 2004, p. 135-139.

GREENPEACE. Soya traders agree moratorium on Amazon deforestation following customer pressure. London, 25 July 2006. Notícia disponível em: $<\underline{\text { http://www.greenpeace.org.uk/forests/media/pressrelease.cfm?ucidparam }=200607251058}$ 55\&CFID=6518733\&CFTOKEN=73533536> . Acesso em 31 dez. 2006.

Eating up the Amazon. Amsterdam, april 2006. Artigo disponível em: $<$ http://www.greenpeace.org/international/press/reports/eating-up-the-amazon>. Acesso em 31 dez. 2006.

. Greenpeace showcases the solution to Indonesia's rapid forest destruction and rising carbon emissions. Greepeace International, 31 de outubro de 2008. Disponível em: 
$<$ http://www.greenpeace.org/international/press/releases/greenpeace-showcases-the-solut $>$. Acesso em: 20 abril 2009.

GRIER, J.H. Section 301 of the 1974 Trade Act. [S.1]: U. S. Department of Commerce,

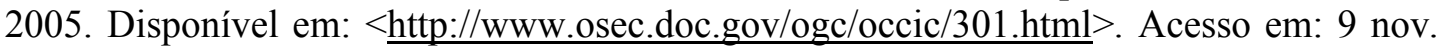
2008.

GROSHEIDE, F.W. General Introduction. In: GROSHEIDE, F.W.; BRINKHOF, J.J. (Eds.). Molengrafica Series 2002: Intellectual Property Law. Antwerp, Intersentia, 2002, p. 1-33.

GRUBB, P.W. Patents for chemicals, pharmaceuticals and biotechnology: fundamentals of global law, practice and strategy. 4th ed. Oxford: Oxford University Press, 2004. p. 511.

GRUPO DE FRIBURGO. Os Direitos Culturais: Declaração de Friburgo. Friburgo, Suíça:L'Institut Interdisciplinaire d'Éthique et des Droits de l'Homme, 7 de maio de 2007.

GUPTA, A.K. Conserving biodiversity and rewarding associated knowledge and innovation systems: Honey Bee perspective. In: COTTIER, T.; MAVROIDIS, P.; PANIZZON, M.; LACEY, S. (Ed.). Intellectual Property: trade, competition, and sustainable development. Ann Arbor: Michigan University, 2002, p. 373-402.

- From Sink to Source: The Honey Bee Network Documents Indigenous Knowledge and Innovations in India. Innovations, vol. 1, no. 3, p. 49-66, 2006.

WIPO-UNEP Study on the role of intellectual property rights in the sharing of benefits arising from the use of biological resources and associated traditional knowledge (WIPO Publication no. 769). Geneva: WIPO-UNEP, 2004. 326 p.

HALEWOOK, M; CHERFAS, J.J.; ENGELS, J.M.M.; HAZEKAMP, T.; HODGKIN, T; ROBINSON, J. Farmers, landraces and property rights: challenges to allocating sui generis intellectual property rights to communities over their varieties. In: BIBER-KLEMM; COTTIER, T. (Eds.). Rigths to plant genetic resources and traditional knowledge: basic issues and perspectives. Oxfordshire \& Cambridge: CABI, 2006, p. 173-202.

HAMILTON, A. Medicinal plants and conservation: issues and approaches. London: WWF-UK, 2003. $51 \mathrm{p}$.

HAMILTON, C. 'Biopiracy' as a Challenge to Intellectual Property Rights Systems. Development, vol. 49, no. 4, p. 94-100, 2006.

HAMWEY, R. Traditional knowledge and the environment: statement by the United Nations Environment Programme. In: Twarog, S.; Kapoor, P. (Ed.). Protecting and promoting traditional knowledge: systems, national experiences and international dimensions. New York \& Geneva: United Nations, 2004, p. 345-346.

HANSEN, S. A.; VANFLEET, J.W. Traditional knowledge and intellectual property: a handbook on issues and options for traditional knowledge holders in protecting their 
intellectual property and maintaining biological diversity. Washington: American Association for the Advancement of Science, 2003. 85 p.

HANSEN, S; BREWSTER, A.; ASHER, J.; KISIELEWSKI, M. The Effects of Patenting in the AAAS Scientific Community. Washington D.C., American Association for the Advancement of Science, 2006. 40 p. Disponível em: $<$ http://sippi.aaas.org/survey/AAAS_IP_Survey_Report.pdf $>$. Acesso em: 4 agosto 2008.

HARDIN, G. An ecolate view of the human predicament. Pestoskey: The Garret Hardin Society, [197-?]. Disponível em:

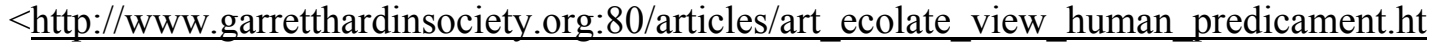
ml>. Acesso em: 25 agosto 2008.

Carrying Capacity as an Ethical Concept. The Social Contract, p. 48- 57, inverno de 2001a. Disponível em: $<$ http://www.garretthardinsociety.org/articles_pdf/cc_ethical_concept.pdf >. Acesso em: 25 agosto 2008.

Disponível

Cultural Carrying Capacity. Pestoskey: The Garret Hardin Society, 1986. $<$ http://www.garretthardinsociety.org:80/articles/art_cultural_carrying_capacity.htm> Acesso em: 25 agosto 2008.

. Extensions of "The Tragedy of the Commons". Science, vol. 280. no. 5364, p.
$682-683$,
1998.

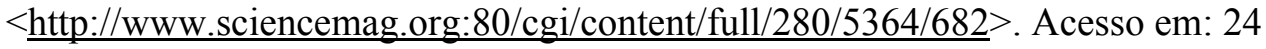

. Protection, Yes. But Against Whom? For Whom? The Social Contract, p. 19-22, inverno de $2001 \mathrm{~b}$.

. The Tragedy of the Commons. Science, vol. 162, p. 1243-1248, 1968.

HARDING, S. Defining traditional knowledge: lessons from cultural property. Cardozo Journal of International and Comparative Law, vol. 11, p. 511-518, 2003-2004.

HARDON, J.J.; VOSMAN, B; VAN HINTUM, T.J.L. Identifying genetic resources and their origin: the capabilities and limitations of modern biochemical and legal systems (Background study paper no. 4). Roma: FAO, 1994. 19p.

HARVEY, E.R. El dominio público pagante en la legislación comparada (con especial referencia al caso argentino). Boletín de Derecho de Autor, vol. 28, no. 4, p. 31-40, 1994.

HASSEMER, M. Genetic Resources. In: VON LEWINSKI, S. (Ed.). Indigenous heritage and intellectual property: genetic resources, traditional knowledge and folklore. The Hague/London/New York: Kluwer Law International, 2004, p. 151-220.

HATHAWAY, O. Do Human Rights Treaties Make a Difference?. Yale Law Journal, vol. 111, p. 1935-2042, 2002. 
HAYEK, F. A. The use of knowledge in society. The American Economic Review, vol. 35 , no. 4, p. 519-530, 1945.

HEATH, C. Parallel Imports and International Trade. Geneva: WIPO, 1999. 13 p.

. The most-favoured nation treatment and intellectual property rights . In: HEATH,

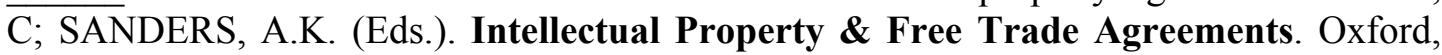
Hart Publishing, 2007, pp. 127-154.

HEATH, C; WEIDLICH, S. Intellectual property: suitable for protecting traditional medicine. Intellectual Property Quaterly, no. 1, p. 69-96, 2003.

HEIDE, T. P. The moral right of integrity and the global information infrastructure: time for a new approach? University California Davis Journal of International Law \& Policy no. 211, p. 213-257, 1996.

HELFER, L.R. Collective management of copyright and human rights: an uneasy alliance. In: GERVAIS, D.J. (Ed.). Collective management of copyright and related rights. Alphen aan den Rijn: The Kluwer Law International, 2006, p. 85-113.

- Toward a Human Rights Framework for Intellectual Property. University California Davis Law Review, vol. 40, p. 971-1020, 2007.

HELlER, M. A. The boundaries of private property. Yale Law Journal, vol. 108, p. 1163-1123, 1999.

. The tragedy of the anticommons: property in the transition from Marx to markets.

Harvard Law Review, vol. 111, p. 621-688, 1998.

Critical approaches to property institutions: three faces of private property. Oregon Law Review, vol. 79, p. 417- 434, 2000.

. The Dynamic Analytics of Property Law. Theoretical Inquiries in Law, vol. 2, no. 1, p. $79-95,2001$.

HELLER, M.A.; EISENBERG, R.S. Can patents deter innovation? The anticommons in biomedical research . Science, vol. 280, no. 5364, p. 698-701, 1998.

HENNING-BODEWIG, F. Unfair competition law: European Union and member states. The Hague: Kluwer Law International, 2006. 251 p.

HENNING-BODEWIG, F.; RUIJSENAARS, H. Protection against unfair competition (WIPO Publication no. 725 (E)). Geneva: WIPO, 1994. 88 p.

HETTINGER, E.C. Justifying intellectual property. In: MOORE, A. D. (Ed.) Intellectual property: moral, legal, and international dilemmas. Lanham: Rowman \& Littlefield Publishers, 1997, p. 17-37.

HINDLE, A. Reach-through claims. Edinburgh: Hindle Lowther, 2005. Disponível em:

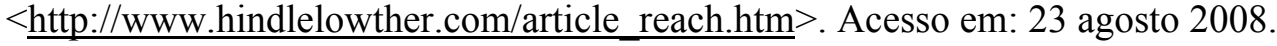


HOARE, A. L. Disclosure requirements in patent applications: the state of the art of national and regional measures. London: Chatham House, 2006. 22 p. Disponível em: $<$ http://www.chathamhouse.org.uk/files/6405_iprbackground.doc $>$. Acesso em: 23 setembro 2008.

HONKO, L. Copyright and folklore. FF Network 21, p. 8-10, março 2001.

HONORÉ, T. Ownership. In: Oxford: Claredon Press, 1987, p. 161-192.

HOSSFELD, U; THORNSTRÖM, C.G. „Rasches Zupacken“: Heinz Brücher und das botanische Sammelkommando der SS nach Russland 1943. In: Heim, S. (Ed.), Autarkie und Ostexpansion: Pflanzenzucht und Agrarwissenschaft im Nationalsozialismus. Wallstein, Göttingen, p. 119-144, 2002a.

. Instant appropriation: Heinz Brücher and the SS botanical collecting command to Russia 1943. Plant Genetic Resources Newsletter, no. 129, p. 39-42, 2002 b.

HOWELL, R.G. The interconnection of intellectual property and cultural property ("Traditional Knowledge"). [200-?]. 29 p. Disponível em: $<$ http://www.fphlcc.ca/downloads/interconnection-of-ip-cultural-property.pdf $>$. Acesso em: 3 outubro 2008.

HOWKINS, J. Creativity, innovation and intellectual property: a new approach for the $21^{\text {st }}$ century. In: WAELDE, C.; MACQUEEN, H. (Ed.). Intellectual Property: the many faces of the public domain. Cheltenham: Edward Elgar, 2007, p. 118-126.

HUDSON, E. Cultural institutions, law and indigenous knowledge: a legal primer on the management of Australian indigenous collections. Melbourne: Intellectual Property Research Institute of Australia, 2006. 98 p.

HUFT, M.J. Indigenous peoples and drug discovery research: a question of intellectual property rights. Northwestern University Law Review, vol. 89, p. 1678-1730, 19941995.

HUGHES, J. The philosophy of intellectual property. In: MOORE, A. D. (Ed.) Intellectual property: moral, legal, and international dilemmas. Lanham: Rowman \& Littlefield Publishers, 1997, p. 107-177.

HUIZENGA, D.E.; PABST, P.L. The consistent inconsistency of the world's patent systems. Tissue Engineering, vol. 5, no. 3, p. 287-289, 1999.

HUMAN RIGHTS COMMITTEE. Considerations of reports submitted by states parties under article 40 of the Covenant. CCPR/C/BRA/CO/2. Geneva, 1 Dec. 2005. 6 p.

IBARRA, M. Statement by the International Indian Treaty Council. In: Twarog, S.; Kapoor, P. (Ed.). Protecting and promoting traditional knowledge: systems, national 
experiences and international dimensions. New York \& Geneva: United Nations, 2004, p. 347-348.

ICTSD. UNESCO aborda relação entre cultura e comércio. Pontes: entre o comércio e o desenvolvimento sustentável, São Paulo, vol. 3, no. 6, p. 9, dezembro de 2007.

ÍNDIA. Bill No. LXVI of 2008: The Protection and Utilisation of Public Funded Intellectual Property Bill, 2008. O projeto de lei está disponível em: $<$ http://www.prsindia.org/docs/bills/1229425658/1229425658 The Protection and_Utilis ation of Public Funded_Intellectual_Property_Bill_2008.pdf > . acesso em: 4 abr. 2009.

INDIGENOUS PEOPLE'S CAUCUS. Agenda item 11: future work. Geneva: WIPO Intergovernmental Committee on Intellectual Property, Genetic Resources, Traditional Knowledge and Folclore, 13-17 Oct. 2008.

INPI. Diretrizes para o exame de pedidos de patente nas áreas de biotecnologia e farmacêutica depositados após 31/12/1994. Rio de Janeiro, 06 de agosto de 2002.

INSTITUTO NACIONAL DE DEFENSA DE LA COMPETENCIA Y DE LA PROTECCIÓN DE LA PROPIEDADE INTELECTUAL. Manual explicativo de la Ley 27811 - Régimen de Protección de los Conocimientos Colectivos de los Pueblos Indígenas Vinculados a los Recursos Biológicos. Lima: Sociedad Peruana de Derecho Ambiental - INDECOPI, [200-]. 8 p.

INTERGOVERnMENTAL PANEL ON FORESTS. Proposals for Action. [200-?]. Propostas Disponível em:

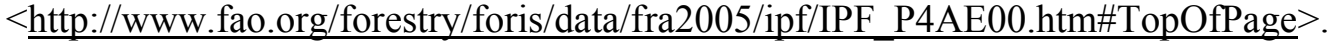

Acesso em: 17 jan. 2009.

INTERNATIONAL CHAMBER OF COMMERCE. Access and Benefit Sharing: General Observations and Positions Submitted for the 9th Conference of the Parties of the UN Convention on Biological Diversity (Document $n^{\circ}$ 450/1035). Paris: ICC, 2008a. Disponível:

$<$ http://www.iccwbo.org/uploadedFiles/ICC/policy/intellectual_property/Statements/ABS $\% 20$ submission\%20COP-9\%20final\%2016-05-08.pdf $>$. Acesso em: 5 de agosto de 2008.

Comments on WIPO gap analysis on traditional raditional knowledge knowledge (Document $\mathrm{n}^{\circ}$ 450/1039). Paris: ICC, 2008b. Disponível em: $<$ http://www.iccwbo.org/uploadedFiles/ICC/policy/intellectual property/Statements/WIPO \%20gap\%20analysis\%20TK\%20final.pdf>. Acesso em: 5 ago. 2008

. Commission on Intellectual Property and the Commission on Biosociety.TRIPS

Should Not be Re-opened to Mandate Special Disclosure Requirements in Patent Applications (Document $\mathrm{n}^{\circ}$ 450/1006). Paris: ICC, 2005a. Disponível: $<$ http://www.iccwbo.org/uploadedFiles/ICC/policy/intellectual_property/Statements/TRIP S\%20and\%20Source\%20Disclosure\%20Requirements.pdf $>$. Acesso em: 5 de agosto de 2008 .

Commission on Intellectual Property. The importance of incremental innovation for Development (Submission to the World Health Organisation's 
Commission on Intellectual Property Rights, Innovation and Public Health - Document $\mathrm{n}^{\circ}$ 450/1001). Paris: ICC, 2005b. 11 p. Disponível em: $<$ http://www.iccwbo.org/uploadedFiles/ICCsubWHO_CIPIH.pdf $>$. Acesso em: 5 agosto 2008).

Doha Round negotiations: the inclusion of patent disclosure requirements proposals (Document $\mathrm{n}^{\circ}$ 450/1038). Paris: ICC, 2008c. Disponível em: $<$ http://www.iccwbo.org/uploadedFiles/ICC/policy/intellectual_property/Statements/Patent $\% 20$ disclosure \%20requirements\%20July\%2008.pdf $>$. Acesso em: 5 agosto 2008.

L'accord relatif aux ADPIC et la Convention sur la diversité biologique : quel conflit ? (Document $\mathrm{n}^{\circ}$ 450/897 Rev.2). Paris: ICC, 1999. Disponível em: $<$ http://www.iccwbo.org/id439/index.html $>$. Acesso em: 2 agosto 2008.

Should patent applicants disclose the origin of biological materials on which they file patents? Should they demonstrate Prior Informed Consent (PIC) for their use? (Document $\mathrm{n}^{\circ}$ 450/941) Paris : ICC, 2002. Disponível em: $<$ http://www.iccwbo.org/id516/index.html> . Acesso em: 2 agosto 2008.

INTERNATIONAL CONGRESS OF ETHNOBIOLOGY. The Declaration of Belém. Belém do Pará, 22 jul. 1988.

INTERNATIONAL COUNCIL FOR SCIENCE. Access to databases: a set of principles for science in the internet era. Paris, jun. 2000.

. ICSU Statement on freedom in the conduct of science. Paris, out. 1995.

. ICSU Statement on gene patenting. Paris, jun. 2002a.

- Meeting report - 4th meeting of the ICSU committee on freedom and responsibility in the conduct of science. Paris: ICSU Secretariat, 2008. 16 p.

. Science and Traditional Knowledge: Report from the ICSU study group on $\overline{\text { science }}$ and traditional knowledge. Paris, Março de 2002b. 16 p.

ICSU Statement on Gene Patenting. Paris, jun. 2002c.

INTERNATIONAL COURT OF JUSTICE. Western Sahara: advisory opinion of 16 October 1975. In: United Nations. Summaries of judgments, advisory opinions and orders of the International Court of Justice. New York: United Nations, 1992, p. 100102.

INTERNATIONAL EXPERT GROUP ON BIOTECHNOLOGY, INNOVATION AND INTELLECTUAL PROPERTY (THE). Toward a new era of intellectual property: from confrontation to negotiation. Montreal: Innovation Partnership, 2008. 8 p.

INTERNATIONAL FEDERATION OF PHARMACEUTICAL MANUFACTURERS \& ASSOCIATIONS. A review of existing data exclusivity legislation in selected countries. $5^{\text {th }}$ ed. Geneva, 2005. 36 p. 
International Institute for Environment and Development. Protecting Community Rights over Traditional knowledge: Implications of Customary Laws \& Practices. Research Partners' Workshop in Panama, 19-23 November 2007. LONDON: IIED, 2008. 17 p.

INTERNATIONAL LAW ASSOCIATION. New Delhi Declaration of Principles of International Law relating to Sustainable Development. New Delhi, 2-6 Apr. 2002.

INTERNATIONAL PLANT genetic resources treaty enters into force. FAO, Roma, 29 de junho de 2004.2 Disponível em: $<$ http://www.fao.org/newsroom/en/news/2004/47027/index.html $>$. Acesso em: 10 set. 2008.

INTERNATIONAL SOCIETY OF ETHNOBIOLOGY. Code of Ethics. Discussed and adopted at the General Assembly of the International Society of Ethnobiology held during the 10 th International Congress of Ethnobiology, Chiang Rai, Thailand, 8 November 2006. Executive Summary and Glossary of Terms added at the 11th International Congress of Ethnobiology, Cusco, Peru, 26 June 2008.

INTERNATIONAL UNION FOR THE PROTECTION OF NEW VARIETIES OF PLANTS. International Convention for the Protection of New Varieties of Plants. of December 2, 1978.

. International Convention for the Protection of New Varieties of Plants, 1991.

ISLA, A. Conservation as Enclosure: An ecofeminist perspective on sustainable development and biopiracy in Costa Rica. Capitalism, Nature and Socialism, vol. 16, no. 3, p. 49-62, 2005.

IZIQUE, C. O preço da indefinição: pesquisadores do CEBRID interrompem pesquisa com os Krahô. Revista FAPESP, no. 77, p. 26-28, julho de 2002.

IZIQUE, C.; DE OLIVEIRA, M. Entrevista: Caminho de Pedras. Revista Pesquisa FAPESP, São Paulo, edição no. 120, fevereiro de 2006. Disponível em: $<$ http://www.revistapesquisa.fapesp.br/?art=2719\&bd=1\&pg=1\&lg=>. Acesso em: $30 \mathrm{abr}$. 2009.

JANKE, T. Minding the culture: case studies on intellectual property and traditional cultural expressions. Geneva: World Intellectual Property Organization, 2003. 170 p.

New Media Cultures: protocols for producing indigenous Australian new media. [S.1]: Aboriginal and Torres Straits Islander Arts Boards \& Australia Council, 2002a. 46 p.

. Song Cultures: protocols for producing indigenous Australian music. [S.1]: Aboriginal and Torres Straits Islander Arts Boards \& Australia Council, 2002b. 45 p.

. Visual Cultures: protocols for producing indigenous Australian visual arts and craft. [S.1]: Aboriginal and Torres Straits Islander Arts Boards \& Australia Council, 2002c. $48 \mathrm{p}$. 
Writing Cultures: protocols for producing indigenous Australian literature. [S.1]: Aboriginal and Torres Straits Islander Arts Boards \& Australia Council, 2002d. 41 p.

JANSSEN, E. Limits to expression on religion in France. Amsterdam: IVIR, 2009. 29 p. Disponível em: $<$ http://www.ivir.nl/publications/janssen/Limits to expression_on_religion_in_France.pdf >. Accesso em: 25 de maio de 2009.

JEFFERSON, T. Letter to Isaac McPherson. 13 Aug. 1813. Disponível em: $<$ http://nyet.org/>. Acesso em: 23 jul. 2008.

JEHORAM, H.C. International exhaustion versus importation right: a murky area of intellectual property law. Amsterdam: Institute for Information Law, University of Amsterdam, $1996 . \quad 15 \quad$ p. $\quad$ Disponível em: http://www.ivir.nl/publications/cohen jehoram/Cohen2.doc >. Acesso em: 22 abr. 2009.

JISHNU, L. Roche`s blockbuster patent and biodiversity. Business Standard, New Deli \& Mumbai, 16 de maio de 2008. Disponível em: $<$ http://www.businessstandard.com/india/storypage.php?autono=322824>. Acesso em: 20 abril 2009.

JÓFEJ-KAINGANG, L.F. A proteção legal do patrimônio cultural dos povos indígenas no Brasil. ARAÚJO, A.V. (Ed.). Povos indígenas e a lei dos "brancos": o direito à diferença. Brasília: Ministério da Educação do Brasil \& UNESCO, 2006, p. 122-145. Coleção Educação para Todos. Série Vias dos Saberes n. 3.

JOHNSON, M. RESEARCH ON TRADITIONAL ENVIRONMENTAL KNOWLEDGE: ITS DEVELOPMENT AND ITS ROLE. IN: . LORE: CAPTURING TRADITIONAL ENVIRONMENTAL KNOWLEDGe. OtTAWA: InTERNATIONAL DeVElopment RESEARCH CENTRE, 1992, P. 3-22. DISPONÍVEL EM: < HTTP://WWW.IDRC.CA/OPENEBOOKS/644-6/>. ACESSO EM: 29 JULHO 2008.

JOHNSTON, S.; VIERROS, M. THE RELATIONSHIP BETWEEN AN INTERNATIONAL REgIME ON ABS AND THE ATS AND UNCLOS. MONTREAL: SCBD, 2009. DISPONÍVEL EM: $\quad<$ HTTP://WWW.CBD.INT/DOC/SIDE-EVENTS/ABS/ABSWG-07/ID1630B-UNU-IAS.PDF>. ACESSO EM: 14 ABR. 2009.

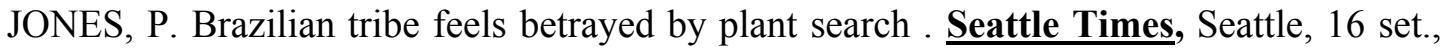
2002 . Disponível em: $<$ http://community.seattletimes.nwsource.com/archive/?date=20020916\&slug=btbiopiracy 09>. Acesso em: 20 abril 2009.

JORNAIS republicam charge de Maomé na Dinamarca. Estado de São Paulo, São Paulo, 13 de fevereiro de 2008. Disponível em:

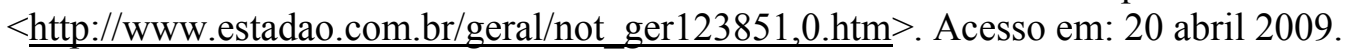

JUCÁ, A.P; MATTOS, E. A devida proteção a informações não-divulgadas e o registro de medicamentos genéricos no Brasil. Brasília: Escola da AGU, 2008. 15 p.

KADLE, R. Reach-Through Claims Declared Invalid. Hodgson Russ, [200-]. Disponível em: $\quad<$ http://www.hodgsonruss.com/Home/Offices/Boca_Raton_FL/Articles/ReachThroughClaimsDeclaredInvalid $>$. Acesso em: 23 agosto 2008. 
KALINOE, L. Legal options for the regulations of intellectual and cultural property in Papua New Guinea. In: HIRSCH, E; STRATHERN, M. (Eds.). Transactions and creations: property debates and the stimulus from Melanesia. New York \& Oxford: Berghahn Brooks, 2004, p. 40-59.

KAMIL, S. The protection of traditional knowledge in Indonesia. In: Twarog, S.; Kapoor, P. (Ed.). Protecting and promoting traditional knowledge: systems, national experiences and international dimensions. New York \& Geneva: United Nations, 2004, p. 193-196.

KANSA, E. C.; SCHULTZ, J.; BISSELL, A. N. Protecting Traditional Knowledge and Expanding Access to Scientific Data: Juxtaposing Intellectual Property Agendas via a "Some Rights Reserved" Model. International Journal of Cultural Property, vol. 12, no. 3, p. 285-314, 2005. Disponível em: $<$ http://www.alexandriaarchive.org/IJCP\%20Article\%20FINAL share.pdf $>$. Acesso em: 17 abril 2009.

KAPP, C. WHO examines the health of indigenous peoples. The Lancet, vol. 354, p. 1982, 4 de dezembro de 1999.

KARBOLO, M. K. O. Promoting development among the indigenous Loita Maasai pastoralists of Kenya. In: Twarog, S.; Kapoor, P. (Ed.). Protecting and promoting traditional knowledge: systems, national experiences and international dimensions. New York \& Geneva: United Nations, 2004, p. 273-277.

KARJALA, D.S. Misappropriation as a third intellectual property paradigm. Columbia Law Review, vol. 94, p. 2594-2609, 1994.

KATZ, L. Exclusion and Exclusivity in Property Law. Kingston: Queen's Faculty of Law, Legal Studies Research Paper Series, Accepted Paper No. 08-02, 2008. 66 p.

KAUSHIK, A. Protecting traditional knowledge, innovations and practices: the Indian experience. In: Twarog, S.; Kapoor, P. (Ed.). Protecting and promoting traditional knowledge: systems, national experiences and international dimensions. New York \& Geneva: United Nations, 2004, p. 85-90.

KEAL, P. European Conquest and the Rights of Indigenous Peoples: The moral backwardness of international society. Cambridge: Cambridge University Press, 2003. 276 p.

KELLER, B. P. Condemned to repeat the past: the reemergence of misappropriation and other common law theories of protection for intellectual property. Harvard Journal of Law \& Technology, vol. 11, no. 2, p. 401- 428, 1997.

KEVLES, D.J. A history of patenting life in the United States with comparative attention to Europe and Canada. Luxembourg: Office for Official Publications of the European Communities, 2002. 84 p. 
Key US senators warn Bush administration on ACTA. IP Watch, Geneva, 3 de outubro de 2008. Disponível em: < http://www.ip-watch.org/weblog/2008/10/03/key-us-senatorswarn-bush-administration-on-acta/>. Acesso em: 20 abril 2009.

KHALFAN, A.; SEGGER, M.C.C. Sustainable development law: principles, practices \& prospects. Oxford: Oxford University Press, 2004. 464 p.

. International human rights and international sustainable development law. Montreal: $\quad$ CISDL, 2002. 8 p. Disponível em: < http://www.cisdl.org/pdf/WSSD_HR\&SD.pdf> . Acesso em: 20 abr. 2009.

KIMBRELL, N. Land and People focuses on its namesakes. Daily Star, Beirut, 12 de dezembro de 2008. Disponível em: < http://www.dailystar.com.lb/article.asp?edition id=1\&categ $\mathrm{id}=1 \&$ article $\mathrm{id}=98374>$.

Acesso em: 29 abr. 2009.

KIRKPATRICK, C.; LEE, N. WTO new round: sustainability impact assessment study phase two report (executive summary). Manchester: Institute for Development Policy and Management and Environmental Impact Assessment Centre, University of Manchester, 1999a. 19 p.

. WTO new round: sustainability impact assessment study - phase one report. Manchester: Institute for Development Policy and Management and Environmental Impact Assessment Centre, University of Manchester, 1999b. 178 p.

KIRSH, S. Property limits: debates on the body, nature and culture. In: HIRSCH, E; STRATHERN, M. (Eds.). Transactions and creations: property debates and the stimulus from Melanesia. New York \& Oxford: Berghahn Brooks, 2004, p. 22-39.

KOOPMAN, J. Amidst peril and progress: conservation of diversity and patent law. In: BOGERS, R.J.; CRAKER, L.E.; LANGE, D. (Eds.). Medicinal and Aromatic Plants: Agricultural, Commercial, Ecological, Legal, Pharmacological and Social .Wageningen UR Frontis Series, vol. 17, p. 129- 154, 2006.

Reconciliation of proprietary interests in genetic and knowledge resources: hurry cautiously! Ecological Economics, vol. 53, p. 523-541, 2005.

KOWALSKI, S.P.; KRYDER, R.D. Golden rice: a case study in intellectual property management and international capacity building. Risk: Health, Safety \& Environment, vol. 47, p. 47-67, 2002.

KRAUSS, M. I. Property rules vs. liability rules. In: BOUCKAERT, B.; DE GEEST, G. (Ed.). Encyclopedia of Law and Economics, vol, II. Cheltenham: Edward Elgar, 2000, p. $782-794$

KUMAR, V. Protecting traditional knowledge: systems and experiences in Sri Lanka. In: Twarog, S.; Kapoor, P. (Ed.). Protecting and promoting traditional knowledge: systems, national experiences and international dimensions. New York \& Geneva: United Nations, 2004, p. 299-303. 
KUNDNANI, A. Where do you want to go today? The rise of information capital. Race and Class, vol. 40, p. 49-71, 1998-1999.

KURUK, P. Protecting folklore under modern intellectual property regimes: a reappraisal of the tensions between individual and communal rights in Africa and the United States. American University Law Review, vol. 48, p. 769-849, 1998-1999.

KUTTY, P.V.V.G. National experiences with the protection of expressions of folklore/traditional cultural expressions. Geneva: WIPO, 2002. 44 p.

LAGES, C. Bordados do Piauí vão decorar a França. Moda Brasil, São Paulo, [200-]. Disponível em:

$<$ http://www2.uol.com.br/modabrasil/terezina_link/walter_piaui_franca/index.htm $>$.

Acesso em: 14 abr. 2009.

LAMETTI, D. The concept and conceptions of intellectual property as seen through the lens of Property. In: COMANDÉ, G; PONZANELLI, G. (Eds.). Scienza e diritto nel prisma del diritto comparato. Torino: Giappichelli, 2004, p. 269-295.

The concept of property: relations through objects of social wealth. University of Toronto Law Journal, vol. 53, p. 325- 378, 2003.

LAMY, P. The WTO and its Agenda for Sustainable Development. New Haven: Yale University, 24 de outubro de 2007. Disponível em: $<$ http://www.wto.org/english/news_e/sppl_e/sppl79 e.htm $>$. Acesso em: 3 de maio de 2008 .

LARSON-GUERRA, J.; LÓPEZ-SILVA, C.; CHAPLEA, F.; FERNÁNDEZ-UGALDE, F.; SOBERÓN, J. Mexico: Between Legality and Legitimacy In: CARRIZOSA, S.; BRUSH, S.B.; WRIGHT, B.D.; MCGUIRE, P.E. (Eds.) Accessing biodiversity and sharing the benefits: lessons from implementation of the Convention on Biological Diversity. Gland \&Cambridge: IUCN, 2004, p. 123- 152.

LATIFF; A; ZAKRI, A.H. Zakri. Biodiversity and traditional knowledge: the Malaysian experience. In: Twarog, S.; Kapoor, P. (Ed.). Protecting and promoting traditional knowledge: systems, national experiences and international dimensions. New York \& Geneva: United Nations, 2004, p. 305-312.

LECHNER, S.; GUBAYDULLINA, Z.; BIZER, K. The allocation of property rights to intangible cultural assets. Göttingen: Georg-August-Universität Göttingen, 2008. 16 p. Disponível em: <http://www2.vwl.wiso.uni-goettingen.de/departmentpaper/No 136.pdf $>$. Acesso em: 11 outubro 2008.

LEISTNER, M. Analysis of different areas of indigenous resources. In: VON LEWINSKI, S. (Ed.). Indigenous heritage and intellectual property: genetic resources, traditional knowledge and folklore. The Hague/London/New York: Kluwer Law International, 2004, p. $49-150$.

LEITÃO, A.M. Estudo de direito privado sobre a cláusula geral de concorrência desleal. Coimbra: Livraria Almedina, 2000. 208 p. 
LESSIG, L. The architecture of innovation. Duke Law Journal, vol. 51, p.1783-1801, 2002.

LÉVI-STRAUSS, C. O pensamento selvagem. 6a. ed. Campinas, SP: Papirus, 2006. 320 p.

LEWINSOHN, T. Degradação ambiental e controle excessivo da pesquisa ameaçam a biodiversidade brasileira. Entrevista concedida à G. Barata. Revista Ciência e Cultural, vol. 61, no. 1, 2009. Disponível em:

$<$ http://cienciaecultura.bvs.br/scielo.php?script=sci_arttext\&pid=S0009-

$67252009000100007 \& \operatorname{lng}=\mathrm{pt \& nrm}=\mathrm{iso} \& \operatorname{lng}=\mathrm{pt}>$. Acesso em 25 maio 2009.

LEWIS, W. H.; ELVIN-LEWIS, M. P. Medicinal plants as sources of new therapeutics. Annals of the Missouri Botanical Garden, vol. 82, no. 1, p. 16-24, 1995.

LI, X.; LI, W. Inadequacy of Patent Regime on Traditional Medicinal Knowledge: a diagnosis of 13-year traditional medicinal knowledge patent experience in China. The Journal of World Intellectual Property, vol. 10, no. 2, p. 125-148, 2007.

LIPSZYC, D. Derecho de autor y derechos conexos. Buenos Aires: Ediciones UNESCO - CERLAC - ZAVALIA, 2001. 933 p.

LIU, B. Past cultural achievement as a future technological resource : contradictions and opportunities in the intellectual property protection of Chinese medicine in China. UCLA Pacific Basin Law Journal, vol. 21, no.1, p. 75-98, 2003.

LOCKE, J. Da Propriedade. In: Segundo tratado sobre o governo civil e outros escritos: ensaio sobre a origem, os limites e os fins verdadeiros do governo civil. Tradução de Magda Lopes e Marisa Lobo da Costa. Petrópolis: Vozes, 1994, p. 97-112.

LOPES, R.J. Índio quer lucrar: o caso da tribo que quis receber 25 milhões de reais por seus conhecimentos de ervas medicinais paralisa uma pesquisa pioneira. Revista Exame, São Paulo, 28 de junho de 2002. Disponível em: < http://portalexame.abril.com.br/degustacao/secure/degustacao.do?COD_SITE=35\&COD RECURSO=211\&URL_RETORNO=http://portalexame.abril.com.br/revista/exame/edicoe s/0825/negocios/m0041408.html >. Acesso em: 20 abril 2009.

LOSHIN, J. Secrets revealed: how magicians protect intellectual property without Law. [S.1], Social Science Research Network, 2007. 37 p. Disponível em: $<$ http://ssrn.com/abstract=1005564 $>$. Acesso em: Jan. 2008.

LOUWAARS, N.P.; THÖRN, E.; ESQUINAS-ALCÁZAR, J.; WANG, S.; DEMISSIE, A.; STANNARD, C. Access to plant genetic resources for genomic research for the poor: from global policies to target-oriented rules. Plant Genetic Resources Newsletter, vol. 4, no. 1, p. $54-63,2006$.

LOVE, J. Compulsory Licensing: Models For State Practice In Developing Countries, Access to Medicine and Compliance with the WTO TRIPS Accord. New York: United Nations Development Programme, 2001. 
LUCAS-SCHLOETTER, A. Folklore. In: VON LEWINSKI, S. (Ed.). Indigenous heritage and intellectual property: genetic resources, traditional knowledge and folklore. The Hague/London/New York: Kluwer Law International, 2004, p. 259-378.

MACHLUP, F.; PENROSE, E. The patent controversy in the nineteenth century. Journal of Economic History, vol. 10, no. 1, p. 1-29, 1950.

MACMILLAN, F. Altering the contours of the public domain. In: WAELDE, C.; MACQUEEN, H. (Ed.). Intellectual Property: the many faces of the public domain. Cheltenham: Edward Elgar, 2007, p. 98-117.

MAGAlHÃeS, F. Rendas dos Morros da Mariana viram tema de documentário. Agência SEBRAE de Notícias Piauí, 23 de outubro de 2006. Disponível em: $<$ http://sebraepi.achanoticias.com.br/noticia.kmf?cod=5377057 $>$. Acesso em: 14 abr. 2009.

MAHESHWARI, J.K. Maintenance and conservation of 'heirloom' varieties in Indian agroecosystems. In: SPERLING, L, LOEVINSOHN, M. (orgs.). Using Diversity: enhancing and maintaining genetic resources on-farm. Ottawa: IDRC, 1997. Disponível em: $<$ http://www.idrc.ca/fr/ev-85308-201-1-DO TOPIC.html $>$. Acesso em: 20 de junho de 2008.

MANDERVILLE, T. An information economics perspective on innovation. International Journal of Social Economics, vol. 25, no. 2/3/4, p. 357-364, 1998.

MARA, K.; NEW, W. TRIPS Council: half of WTO membership backs biodiversity amendment. IP Watch, Geneva, 14 de março de 2008. Disponível em: < http://www.ipwatch.org/weblog/2008/03/14/trips-council-half-of-wto-membership-backs-biodiversityamendment/>. Acesso em: 20 abril 2009.

MARKS, S. The Human Right to Development: Between Rhetoric and Reality. Harvard Human Rights Journal, vol. 17, p. 139-168, 2004.

MARSHALL, A. Open Secrets. Nature Biotechnology, vol. 22, p.1, 2004. Supplement to Nature Publishing Group.

MATAS da Austrália absorvem o triplo do CO2 imaginado. O Estado de São Paulo, São Paulo, 11 de agosto de 2008. Disponível em: < http://www.estadao.com.br/noticias/geral,matas-da-australia-absorve-o-triplo-do-co2imaginado,221506,0.htm>. Acesso em 20 abril 2009.

MBEVA, J. M. Experiences and lessons learned regarding the use of existing intellectual property rights instruments for the protection of traditional knowledge in Kenya. In: Twarog, S.; Kapoor, P. (Ed.). Protecting and promoting traditional knowledge: systems, national experiences and international dimensions. New York \& Geneva: United Nations, 2004, p. 167-174.

MCCONNELL, F. The Biodiversity Convention - a negotiating history: a personal account of negotiating the United Nations Convention on Biological Diveristy and after. London: Kluwer Law International, 1996, 288 p. 
MCDOUGAL, M. S.; LASSWELL, H.D; CHEN, L. Human Rights and World Public Order: A Framework for Policy-Oriented Inquiry. The American Journal of International Law, vol. 63, no. 2, p. 237-269, 1969.

MCGOWN, J. Out of Africa: Mysteries of Access and Benefit Sharing. Edmonds: Edmonds Institute; African Centre for Biosafety, 2006. 54 p. Disponível em:

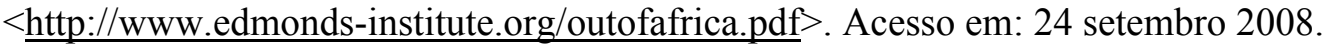

MCNEIL JR., D.G. Jump-start on slow trek to treatment for a disease. New York Times, New York, 8 de janeiro de 2008. Disponível em: < http://www.nytimes.com/2008/01/08/health/research/08slee.html $>$. Acesso em: 20 abril 2009.

MEDAGLIA, J.C. Costa Rica: legal framework and public policy. In: CARRIZOSA, S.; BRUSH, S.B.; WRIGHT, B.D.; MCGUIRE, P.E. (Eds.) Accessing biodiversity and sharing the benefits: lessons from implementation of the Convention on Biological Diversity. Gland \&Cambridge: IUCN, 2004a, p. 101-121.

Access to genetic resources, protection of traditional knowledge, and intellectual property rights: the Costa Rica experience. In: Twarog, S.; Kapoor, P. (Ed.). Protecting and promoting traditional knowledge: systems, national experiences and international dimensions. New York \& Geneva: United Nations, 2004b, p. 197-212.

Study on the relationship between the ABS international regime and other international instruments which govern the use of genetic resources: the World Trade Organization (WTO); the World Intellectual Property Rights Organization (WIPO); and the Union for the Protection of New Varieties of Plants (UPOV) (DRAFT). Montreal: Secretariat of the Convention on Biological Diversity, 2009. 21 p.

MEDEIROS, L; BARROS, J.F.; DA COSTA, O.B.; FRONER, D. Relatório final sobre a consulta pública no. 2 do CGEN. Brasília: Ministério do Meio Ambiente, Fevereiro de 2008. 21 p. Disponível em: $<$ http://www.mma.gov.br/estruturas/sbf_dpg/_arquivos/relatorio_final_cp02.pdf $>$. Acesso em: 20 abr. 2009.

MENÉNDEZ, S.A.G. Competencia desleal: actos de desorganización del competidor. $1^{\mathrm{a}}$. ed. Buenos Aires: Lexis Nexis Argentina, 2004. 224 p.

MENESCAL, A.K. Changing WIPO's ways? The 2004 development agenda in historical perspective. The Journal of World Intellectual Property, vol. 8, no. 6, p. 761-796, $2005 \mathrm{a}$.

Those behind the TRIPS agreement: the influence of the ICC and the AIPPI on international intellectual property decisions. Intellectual Property Quarterly, no. 2, p. $155-182,2005 b$.

MERTON, R. K. Descubrimientos unicos y descubrimientos multiples en la ciencia. In: STORER, N. W. (Ed.). La sociologia de la ciência, 2: Investigaciones teóricas y empíricas. Madrid: Alianza Editorial, 1977a, p. 444-476 
La estructura normativa de la ciencia. In: STORER, N. W. (Ed.). La sociologia de la ciência, 2: Investigaciones teóricas y empíricas. Madrid: Alianza Editorial, 1977b, p. 355- 368

The Matthew Effect in Science, II: cumulative advantage and the symbolism of intellectual property. ISIS, vol. 79, p. 606-623, 1988.

The Matthew effect in science. Science, vol. 159, no. 3810, p. 56-63, 1968.

MGBEOJI, I. Patents and traditional knowledge of the uses of plants: is a communal patent regime part of the solution to the scourge of bio piracy? Indiana Journal of Global Legal Studies, vol. 9, no. 1, p. 163-186, 2001.

MICHELMAN, F. Ethics, economics, and the law of property. Tulsa Law Review, vol. 39, p. 663-690, 2004.

MILL, J.S. Utilitarianism. Kitchener: Batoche Books, 2001, 63 p.

MILLIKIN, M.R. WWW.misappropriaton.com: protecting trade secrets after mass dissemination on the internet. Washington University Law Quaterly, vol. 78, p. 931-954, 2000 .

MISAPPROPRIATION as unfair competition. Syracuse Law Review, vol. 6, p. 317- 327, 1954-1955.

MOONEY, P. R. Why we call it biopiracy. In: SVARSTAD, H.; DHILION, S.S. (Ed.) Responding to Bioprospecting: From Biodiversity in the South to Medicines in the North. Oslo: Spartacus Forlag AS, 2000, p. 37-44.

MOORE, G. ; TYMOWSKI, W. Explanatory guide to the International Treaty on Plant Genetic Resources for Food and Agriculture. Gland \& Cambridge: IUCN, 2005. $212 \mathrm{p}$.

MORALES, M. Un marco legal para el cártel. El cártel de la biodiversidad: transformación de conocimientos tradicionales en secretos comerciales. Quito: CARE, 2000, p. 49-60.

MORRISON, J. Indigenous Australians in unique position to help climate fight. ABC News, 7 de novembro de 2008. Disponível em: < http://www.abc.net.au/news/stories/2008/11/07/2412974.htm>. Acesso em 20 abril 2009.

MOUCHET, C. Problems of the "Domaine Public Payant". Columbia Journal of Art and the Law, vol. 8, p. 137-147, 1983-1984.

MULLER, M.R. Regulating bioprospecting and protecting indigenous people's knowledge in Andean Community: Decision 391 and its overall impacts in the region. In: Twarog, S.; Kapoor, P. (Eds.). Protecting and promoting traditional knowledge: systems, national experiences and international dimensions. New York \& Geneva: United Nations, 2004, p. 241-264. 
MUNZER, S. R. The Commons and the Anticommons in the Law and Theory of Property. In: GOLDING, M. P.; EDMUNDSON, W. A. (Ed.). The Blackwell Guide to the philosophy of law and legal theory. Oxford: Blackwell, 2005, p. 148-162.

MUTUA, M. Savages, victims, and saviors: the metaphor of human rights. Harvard International Law Journal, vol. 42, p. 201-245, 2001.

NAIDITCH, S. Nos passos das Havaianas: a Grendene quer ter uma marca mundial e seguir a trilha da concorrente. Mas não é tão fácil como parece. Revista Exame, São Paulo, 16 março 2007. Disponível em: < http://portalexame.abril.com.br/revista/exame/edicoes/0888/mundo/m0123997.html $>$. Acesso em: 20 abril 2009.

NAKASHIMA, D. The Local \& Indigenous Knowledge Systems programme of UNESCO. Indigenous Peoples' Centre for Documentation, Research and Information (doCIP), Update 76, p. 20-23, July/September 2007.

Traditional knowledge: resisting and adapting to globalization. In: Twarog, S.; Kapoor, P. (Ed.). Protecting and promoting traditional knowledge: systems, national experiences and international dimensions. New York \& Geneva: United Nations, 2004, p. 131-134.

NAKASHIMA, D. What relationship between scientific and traditional systems of knowledge? Some introductory remarks. In: CETTO, A.M.; SCHNEEGANS, S; MOORE, H. World Conference on Science. Science for the twenty-first century: a new commitment. Paris: UNESCO, 2000, p. 432.

NATURE. The complex realities of sharing genetics assets. Nature, vol. 392, no. 6676, p. $525,1998$.

NERSESSIAN, D. Rethinking cultural genocide under international law. Human Rights Dialogue, $\quad$ series $2, \quad$ no. $12,2005.2$ Disponível: $<$ http://www.cceia.org/resources/publications/dialogue/2 12/section_1/5139.html $>$.

Acesso em: 16 setembro 2008).

NEWMAN, D. J.; CRAGG, G. M.; SNADER, K. M. The influence of natural products upon drug discovery. Natural Products Reports vol. 17, p. 215-234, 2000.

NIEC, H. Casting the foundations for the implementation of cultural rights. In:

Cultural Rights and Wrongs: a collection of essays in commemmoration of the 50th anniversary of the Universal Declaration of Human Rigths. Paris: UNESCO Publishing \& Institute of Art and Law, 1998, p. 176-189.

NIÑO, R. F.; BERNAL, L. E.; CONTRERAS, J. J. Strengthening public policy for a sustainable exchange of knowledge between national and international interests: recent legislative developments in the area of traditional knowledge in Venezuela. In: Twarog, S.; Kapoor, P. (Ed.). Protecting and promoting traditional knowledge: systems, national experiences and international dimensions. New York \& Geneva: United Nations, 2004, p. 221-222. 
NNADOZIE, K. THE INTERNATIONAL TREATy on PLANT GENETIC RESOURCES For Food aNd AGRICULTURE. IN: ACCESS TO GENETIC RESOURCES, TRADITIONAL KNOWLEDGE AND BENEFIT SHARING: UNDOING THE KNOT IN A\&BS TRANSACTIONS: IN SEARCH OF AmiCABLE Solutions, 2008, BREMEN. APRESENTAÇÃo DE POWERPOINT, DISPONÍVEL $E M$ : $<$ HTTP://WWW.FEU.UNIBREMEN.DE/DOWNLOADS/WORKSHOP/PRESENTATIONS/NNADOZIE.PPT>. ACESSO EM: 10 SETEMBRO 2008.

NOAM, E. Two cheers for the commodification of information. In: ELKIN-KOREN, N; NETANEL, N.W. (Eds.). The commodification of information. The Hague: Kluwer Law International, 2002, p. 43-59.

NOVA ZELÂNDIA. Trade Marks Act. 2002.

. Patents Bill: draft for consultation. Disponível em:

<http://www.med.govt.nz/upload/3358/draftbill.pdf $>$. Acesso em: 28 abr. 2009.

NUFFIELD COUNCIL ON BIOETHICS. The ethics of patentings DNA: a discussion paper. London: Nuffield Council on Bioethics, 2002a. 93 p.

The ethics of research related to healthcare in developing countries. London: Nuffield Council on Bioethics, 2002b. 204 p.

Nuremberg Code (The), 1947. British Medical Journal, vol. 313, no. 7070, p. 448, 1996.

OAKERSON, R. J. Analyzing the commons: a framework. In: BROMLEY, D.W. (Ed.). Making the commons work: theory, practice and policy. San Francisco: ICS Press, 1992, p. 41-59.

OFFICE OF CLIMATE CHANGE. Climate Change: Financing Global Forests Executive Summary. London: Office of Climate Change, 2008. 253 p.

OFFICE OF THE HIGH COMMISSIONER FOR HUMAN RIGHTS. Fact sheet no.2 (Rev.1): The international bill of human rights. Geneva, June 1996.

OLDHAM, P. Global Status and Trends in Intellectual Property Claims: Genomics, Proteomics and Biotechnology (UNEP/CBD/WG-ABS/3/INF/4). Montreal: Secretariat of the Convention on Biological Diversity. Ad hoc open-ended working group on access and benefit-sharing, $2005.70 \mathrm{p}$.

Global Status and Trends in Intellectual Property Claims: Microorganisms.Lancaster: ESRC Centre for Economic and Social Aspects of Genomics (CESAGen), 2004. 42 p. Disponível em: $<$ http://www.cesagen.lancs.ac.uk/resources/docs/microorganisms/microorganismspublishe d.doc $>$. Acesso em: 24 setembro 2008. 
ONWUEKWE, C.B. The commons concept and intellectual property rights regime: whither plant genetic resources and traditional knowledge? Pierce Law Review, vol. 2. no. 1, p. 65-90, 2004.

OEA. La situación de los derechos humanos de los indígenas en las Américas. OEA/Ser.L/VII.108; doc. 62. Washington D.C., 20 oct. 2000. Disponível em: < http://www.cidh.org/Indigenas/indice.htm>. Acesso em: 20 abr. 2009.

Proposed American Declaration on the Rights of Indigenous Peoples. Approved by the Inter-American Commission on Human Rights. Washington, D.C., 26 fev. 1997.

ORGANIZACIÓN DEL TRATADO DE COOPERCIÓN AMAZÓNICA. Declaración de Caracas. Caracas, VI reunión de ministros de relaciones exteriores de Tratado de Cooperación Amazónica, 6 de abril de 2000.

Declaración de Manaos sobra la Conferencia de las Naciones Unidas sobre el Medio Ambiente y el Desarrollo. Manaus, 10 e 11 de fevereiro, 1992.

Declaración de Lima. V Reunión de Ministros de Relaciones Exteriores del $\overline{\text { Tratado }}$ de Cooperación Amazónica. Lima, 4 e 5 de novembro de 1995.

OIT. Convenio número 169 sobre pueblos indígenas y tribales: un manual. Ginebra, 2003. 105 p.

. ILO Declaration on fundamental principles and rights at work. CIT/1998/PR20A. Geneva, junho de 1998.

ORGANIZATION OF AFRICAN UNITY. African Model Legislation for the Protection of the Rights of Local Communities, Farmers and Breeders, and for the Regulation of Access to Biological Resources of 2000. Disponível em: $<$ http://www.chr.up.ac.za/hr_docs/african/docs/oau/oau4.doc $>$. Acesso em: 22 abr. 2009.

OSTROM, E.; BURGER, J.; FIELD, C. B.; NORGAARD, R.B.; POLICANSKY, D. Revisiting the Commons: Local Lessons, Global Challenges. Science, vol. 284. no. 5412, p. 278-282, 1999.

OSTROM, E.; HESS, C. Artifacts, facilities, and content: information as a common-pool resource. Law \& Contemporary Problems, vol. 66, nos. 1-2, p. 44-79, 2003.

OSTROM, E.; OSTROM, V. Public Goods and Public Choices. Bloomington: Indiana University, [19_]. 26 p. Disponível em: $<$ http://polsci.colorado.edu/ moiverj/OstromPG\&PC.PDF $>$. Acesso em: 8 julho 2008.

OVIEDO, G.; GONZALES, A.; MAFFI, L. The importance of traditional ecological knowledge and ways to protect it. In: Twarog, S.; Kapoor, P. (Ed.). Protecting and promoting traditional knowledge: systems, national experiences and international dimensions. New York \& Geneva: United Nations, 2004, p. 71-82. 
OZDEMIR, V.; WILLIAMS-JONES, B.; GLATT, S.J.; TSUANG, M.T.; LOHR, J.B.; REIST, C. Shifting emphasis from pharmacogenomics to theragnostics. Nature Biotechnology, vol. 24, no. 8, p. 942-946, 2006.

PACCE, L. Gisele quer salvar água do Xingu. O Estado de São Paulo, São Paulo, 25 de maio de 2006. Disponível em: < http://www.estado.com.br/editorias/2006/05/25/cad1.93.2.20060525.8.1.xml>. Acesso em: 22 abr. 2009.

PACCE, L. Desfiles de verão em Paris refletem a crise anunciada. O Estado de São Paulo, São Paulo, 14 de outubro de 2008. Disponível em: < http://www.estadao.com.br/estadaodehoje/20081014/not_imp259414,0.php>. Acesso em: 27 abr. 2009.

Pacto Internacional de Direitos Civis e Políticos. Adotado por meio da Resolução 2200A (XXI) da AGONU, em 16 de dezembro de 1966

Pacto Internacional de Direitos Econômicos, Sociais e Culturais. Adotado por meio da Resolução 2200A (XXI) da AGONU, em 16 de dezembro de 1966.

PÁCON, A. M. The Peruvian proposal for protecting traditional knowledge. In: Twarog, S.; Kapoor, P. (Ed.). Protecting and promoting traditional knowledge: systems, national experiences and international dimensions. New York \& Geneva: United Nations, 2004, p. 175-180.

PANAMÁ. Law no. 20, June 26, 2000, on the special intellectual property regime upon collective rights of indigenous communities, for the protection of their cultural identities and traditional knowledge. Disponível em: $<$ http://www.wipo.int/export/sites/www/tk/en/laws/pdf/panama indigenous.pdf $>$. Acesso em: 22 abr. 2009.

PANDEYA, R.; KOSHY, J. Ginger can't be patented in Europe now. Mint/The Wall Street Journal, 6 de fevereiro de 2009. Disponível em: $<$ http://www.livemint.com/2009/02/05214415/Ginger-can8217t-be-patented.html $>$. Acesso em: 22 abr. 2009.

PANEL OF EXPERTS CONVENED BY THE SECRETARY-GENERAL OF THE UNITED NATIONS CONFERENCE ON THE HUMAN ENVIRONMENT. The Founex Report on Development and Environment, 1971. In: SOUTH CENTRE. The south and sustainable development conundrum: from Stockholm 1972 to Rio 1992 to Johannesburg 2002 and beyond. Geneva: South Centre, 2002, p. 35-76.

PARISI, F. The Fall and Rise of Functional Property. George Mason Law \& Economics Research Paper No. 05-38, 2005. 31 p. Disponível em: $<$ http://ssrn.com/abstract=850565 $>$. Acesso em: 17 abril 2009.

PARISI, F.; SCHULZ, N.; DEPOORTER, B. Simultaneous and Sequential Anticommons. European Journal of Law and Economics, vol. 17, p. 175-190, 2004.

- Duality in Property: Commons and Anticommons (Würzburg Economic Papers no. 21). Würzburg: Universität Würzburg Lehrstuhl für Volkswirtschaftslehre, 
insbesondere Industrieökonomik, 2001. 30 p. Disponível em: $<$ http://www.wifak.uniwuerzburg.de/wilan/wifak/vwl/vwl1/wepdownload/wep21.pdf $>$. Acesso em: 23 julho 2008 .

PARLAMENTO EUROPEU. Directiva 98/44/CE, de 6 de Julho de 1998. Diretiva relativa à proteção jurídica das invenções biotecnológicas.

PAUWELYN, J. Bridging fragmentation and unity: international law as a universe of interconnected islands. Michigan Journal of International Law, vol. 25, p. 903-916, 2004.

PEÑA-NEIRA, S.; DIEPERINK, C.; ADINK, H. Equitably sharing benefits from the utilization of natural genetic resources: the Brazilian interpretation of the Convention on Biological Diversity. Utrecht, University of Utrecht, 2002. 18 p. Disponível em: < http://igitur-archive.library.uu.nl/milieu/2007-0222-201207/dieperink 02 equitably.pdf $>$.

Acesso em: 20 abril 2009.

PEOPLE DAILY. Nobel Laureate Calls for Modernization of Traditional Chinese Medicine. China Education and Research Network, outubro de 2001. Disponível em: $<$ http://www.edu.cn/20011031/3007583.shtml $>$. Acesso em: 13 jun. 2008

PERMANENT FORUM ON INDIGENOUS ISSUES. Report of the international expert group meeting on the international regime on access and benefit-sharing and indigenous people's human rights of the Convention on Biological Diversity. E/C.19/2007/8. New York: Economic and Social Council, 14 Mar. 2007. 19 p.

PERSIC, A.; MARTIN, G. Links between biological and cultural diversity: concepts, methods and experiences. Report of an international workshop. Paris: UNESCO, 2008. 47 p.

PERU. Ley 27.811, de 24 de julio de 2002. Régimen de protección de los conocimientos colectivos de los pueblos indígenas vinculados a los recursos biológicos. Disponível em:

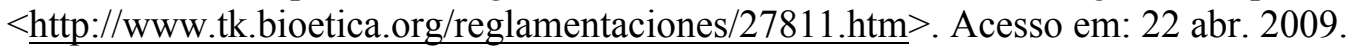

PETERSMANN, E.U. Time for a United Nations 'Global Compact' for Integrating Human Rights into the Law of Worldwide Organizations: Lessons from European Integration. European Journal of International Law vol. 13, no. 3, p. 621-650, 2002.

PIONER, C. Refazendo a renda. Diário do Nordeste, Fortaleza, 12 de abril de 2009. Disponível em: $<$ http://diariodonordeste.globo.com/materia.asp?codigo $=629478>$. Acesso em: 14 abr. 2009.

PLUTARCO. Como tirar proveito de seus inimigos. Tradução Isis Borges B. da Fonseca. São Paulo: Martins Fontes, 1997. 121 p.

PORTAL IMPRENSA. Juiz proíbe nova tiragem da Playboy por foto polêmica de Carol Castro. Portal Imprensa, 26 de agosto de 2008. Disponível em: $<$ http://portalimprensa.uol.com.br/portal/ultimas_noticias/2008/08/26/imprensa22007.shtm 1>. Acesso em: 20 abril 2009. 
PORTELA, L. Fitoterapia desenvolvida na UFMA ajuda no tratamento contra a AIDS. ASCOM, $1^{\circ}$ de dezembro de 2004.

PORTUGAL. Decreto-lei no. 118/2002, de 5 de abril de 2002. Estabelece o regime jurídico do registro, conservação, salvaguarda legal e transferência do material vegetal autóctone com interesse para a actividade agrária, agro-florestal e paisagística. Disponível em: < http://www.tk.bioetica.org/reglamentaciones/118.htm>. Acesso em: 22 abr. 2009.

POSEY, D. A. Can cultural rights protect traditional cultural knowledge and biodiversity? In: NIEC, H. Cultural Rights and Wrongs: a collection of essays in commemmoration of the 50th anniversary of the Universal Declaration of Human Rigths. Paris: UNESCO Publishing \& Institute of Art and Law, 1998, p. 42-56.

Commodification of the sacred through intellectual property rights. Journal of Ethnopharmacology, vol. 83, nos. 1-2, p. 3-12, 2002.

Diachronic ecotones and anthropogenic landscapes in Amazonia: contesting the consciousness of conservation. Ethnoecology as applied anthropology in Amazonian development. In: PLENDERLEITH, K. (Org.). Indigenous knowledge and ethics: a Darrell A. Posey Reader. London: Routledge, 2004a, p. 121-132.

Ethnobiology and ethnodevelopment: importance of traditional knowledge and traditional peoples. In: PLENDERLEITH, K. (Org.). Indigenous knowledge and ethics: a Darrell A. Posey Reader. London: Routledge, 2004b, p. 63-69.

. Ethnoecology as applied anthropology in Amazonian development. In: PLENDERLEITH, K. (Org.). Indigenous knowledge and ethics: a Darrell A. Posey Reader. London: Routledge, 2004c, p. 70-120.

. Finders keeper won't do any more: Darrell Posey says the time has come for a $\overline{\text { rethink }}$ on bioprospecting. In: PLENDERLEITH, K. (Org.). Indigenous knowledge and ethics: a Darrell A. Posey Reader. London: Routledge, 2004d, p. 169-171.

. Indigenous knowledge and green consumerism: co-operation or conflict? In: PLENDERLEITH, K. (Org.). Indigenous knowledge and ethics: a Darrell A. Posey Reader. London: Routledge, 2004e, p. 148-154.

. Indigenous knowledge, biodiversity, and international rights: learning about forests from the Kayapó Indians of the Brazilian Amazon. In: PLENDERLEITH, K. (Org.). Indigenous knowledge and ethics: a Darrell A. Posey Reader. London: Routledge, 2004f, p. 133-140.

- Indigenous peoples and Traditional Resources Rights: a basis for equitable relationships? In: PLENDERLEITH, K. (Org.). Indigenous knowledge and ethics: a Darrell A. Posey Reader. London: Routledge, 2004g, p. 172-194. 
Intellectual property rights and just compensation for indigenous knowledge.

Anthropology Today, vol. 6, no. 4, p. 13-16, 1990.

. Intellectual property rights: what is the position of ethnobiology? In: PLENDERLEITH, K. (Org.). Indigenous knowledge and ethics: a Darrell A. Posey Reader. London: Routledge, 2004h, p. 143-147.

. The 'balance sheet' and the 'sacred balance': valuing the knowledge of indigenous and traditional peoples. In: PLENDERLEITH, K. (Org.). Indigenous knowledge and ethics: a Darrell A. Posey Reader. London: Routledge, 2004i, p. 195-205.

- The application of ethnobiology in the conservation of dwindling natural resources: lost knowledge or options for the survival of the planet. In: PLENDERLEITH, K. (Org.). Indigenous knowledge and ethics: a Darrell A. Posey Reader. London: Routledge, 2004j, p. 53-62.

Traditional resource rights (TRR): de facto self-determinatoin for indigenous peoples. In: PLENDERLEITH, K. (Org.). Indigenous knowledge and ethics: a Darrell A. Posey Reader. London: Routledge, 2004k, p. 155-168.

POSEY, D.A; DUTFIELD, G. Beyond intellectual property: toward traditional resource rights for indigenous peoples and local communities. Ottawa: IDRC, 1996. 250 p.

POTRYKUS, I. The golden rice "tale", [200-]. 14 p. Disponível em: $<$ http://www.goldenrice.org/PDFs/The_GR_Tale.pdf $>$. Acesso em: 22 out. 2008.

PRATHAPAN, K. D.; RAJAN, P.D.; NARENDRAN, T. C.; VIRAKTAMATH, C. A.; ARAVIND, N. A.; POORANI, J. Death sentence on taxonomy in India. Current Science, vol. 94, no. 2, p. 170-171, 2008. Disponível em: < http://www.ias.ac.in/currsci/jan252008/170.pdf>. Acesso em: 20 abril 2009.

PROLONGEAU, H.; MARIE, B. L'Amazonie asphyxiée par le soja. Paris: Le Monde Diplomatique, 18 set. 2007.

Protocolo Adicional a la Convención Americana sobre Derechos Humanos en Materia de Derechos Económicos, Sociales y Culturales (Protocolo de San Salvador). Adotado em El Salvador, em 17 de novembro de 1988.

QUIGGIN, R. Performing cultures: protocols for producing indigenous Australian performing arts. [S.1]: Aboriginal and Torres Straits Islander Arts Boards \& Australia Council, 2002. $55 \mathrm{p}$.

RAFI. Bio-piracy: the story of natural coloured cottons of Americas. Ottawa: RAFI, 1993. 8 p. $\overline{15,2002 .}$

Biopiracy - RAFI's Sixth Annual Update. RAFI Communiqué, maio/junho p. 1- 
RAFI; INDIGENOUS PEOPLES'BIODIVERSITY NETWORK. COPs and Robbers: transfer-sourcing indigenous knowledge and pirating medicinal plants. RAFI Occasional paper series, vol. 1, no. 4, p. 1-20, 1994.

RAHMAN, A. Development of an integrated traditional and scientific knowledge base: a mechanism for accessing and documenting traditional knowledge for benefit sharing, sustainable socio-economic development and poverty alleviation. In: Twarog, S.; Kapoor, P. (Ed.). Protecting and promoting traditional knowledge: systems, national experiences and international dimensions. New York \& Geneva: United Nations, 2004, p. 313-323.

RAI, A.K.; EISENBERG, R.S. The Public and the Private in Biopharmaceutical Research. In: BOYLE, J. Collected Papers: Conference on the public domain. Durham: Center for the Study of the Public Domain, 2003, p. 157-175. Disponível em:

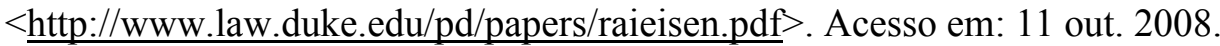

RAMANNA, A.; SMALE, M. Rights and access to plant genetic resources under India's new law. Development Policy Review, vol. 22, no. 4, p. 423-442, 2004.

RAW, I. Bioamazonia, Novartis e o Brasil. Boletim SBQ, no. 177, 2000-2002. Disponível em: $<$ http://www.sbq.org.br/publicacoes/beletronico/bienio2/boletim177.htm $>$. Acesso em: 9 out. 2008.

REGIÃO amazônica como tendência mundial. Diário do Pará, Belém do Pará, 20 de junho de 2004. Disponível em: < http://negocios.amazonia.org.br/index.cfm?fuseaction=noticiaImprimir\&id $=112570>$. Acesso em: 20 abril 2009.

REICHMAN, J.H. Of green tulips and legal kudzu: repacking rights in subpatentable innovation. Vanderbilt Law Review, vol. 53, p. 1743-1798, 2000.

. Saving the patent law from itself: informal remarks concerning the systemic

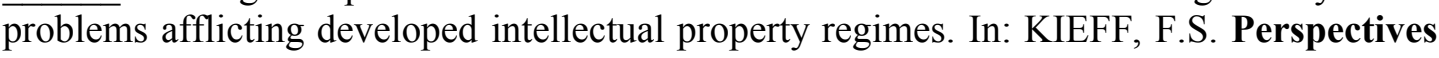
on properties of the human genome project. San Diego, EUA, Elsevier: 2003, p. 289303.

REICHMAN, J.H.; LEWIS, T. Using liability rules to stimulate local innovation in developing countries: application to traditional knowledge. In: MASKUS, K.E.; REICHMAN, J.H. (Eds.). International public goods and transfer of technology under a globalized intellectual property regime. Cambridge: Cambridge University Press, 2005, p. 337-366,

REINO UNIDO. House of Lords. Decisão de apelação no caso Merrell Dow Pharmaceuticals Inc. and others (Appellants) v. H.N. Norton \& Co. Limited (Respondents), proferida em 26 de outubro de 1995. Disponível em: $<$ http://www.bailii.org/uk/cases/UKHL/1995/14.html>. Acesso em: 17 dez. 2008. 
RESNIK, D.B. Owning the genome: a moral analysis of DNA patenting. New York: State University of New York Press, 2004. 235 p.

REUTER, P. Introducción al derecho de los Tratados. México: Fondo de Cultura Económica, 1999. 340 p.

REVKIN, A. C. Biologists Sought a Treaty; Now They Fault It. The New York Times, Nova York, 7 maio 2002.2 Disponível em: $<$ http://www.nytimes.com/2002/05/07/science/earth/07TREA.html?ex=1027403128\&ei=1 \&en=3d3f8b2d615cad54>. Acesso em: 17 abril 2009.

RIBEIRO, D. As Américas e a civilização: processo de formação e causas do desenvolvimento desigual dos povos americanos. São Paulo: Companhia das Letras, 2007. $527 \mathrm{p}$.

O povo brasileiro: a formação e o sentido do Brasil. São Paulo: Companhia das Letras, 2006. $435 \mathrm{p}$.

RICKETSON, S. The Berne convention for the protection of literary and artistic works: 1886-1986. The Hague: Kluwer Law International, 1987. 1030 p.

RIGHTS AND RESOURCES INITIATIVE; RAINFOREST FOUNDATION NORWAY. Forest Peoples' Rights Key to Reducing Emissions from Deforestation. Oslo, 15 de outubro de 2008. Disponível em: $<$ http://rightsandclimatechange.files.wordpress.com/2008/10/rri_rfn_oslo_conference_rele ase.pdf >. Acesso em: 20 abril 2009.

RIMMER, M. Never Neverland: Peter Pan and perpetual copyright. inCITE, December 2004.. Disponível em: < http://www.alia.org.au/publishing/incite/2004/12/copyright.html $>$. Acesso em: 21 fev. 2009.

RITCHIE, M; DAWKINS, K.; VALLIANATOS, M. Intellectual property rights and biodiversity: the industrialization of natural resources and traditional knowledge. St. John's Journal of Legal Commentary, vol. 11, p. 431-453, 1995-1996.

ROBERTS, T. Protecting traditional knowledge: an industry view. In: Twarog, S.; Kapoor, P. (Ed.). Protecting and promoting traditional knowledge: systems, national experiences and international dimensions. New York \& Geneva: United Nations, 2004, p. 93-94.

RODAS, J.G. Carta de 30 de março de 2009, endereçada aos professores, funcionários e alunos da Faculdade de Direito da Universidade de São Paulo (Ref.: Digitalização da Biblioteca da Faculdade de Direito da USP). Disponível em: $<$ http://www.direito.usp.br/digitalizacao biblioteca 2009.pdf $>$. Acesso em: 15 de maio de 2009.

RODRIGUES, E. Usos rituais de plantas que indicam ações sobre o Sistema Nervoso Central pelos índios Krahô, com ênfase nas psicoativas. 2001. 153 p. Tese de doutoramento - Universidade Federal de São Paulo, São Paulo, 2001. 
RODRIGUES, E.; CARLINI, E.; ASSIMAKOPOULOS, C.T. Conhecimento tradicional e repartição de benefícios: o caso dos índios Krahô. In: MING, L.C.; DE CARVALHO, I; DE VASCONCELLOS, M.C.; RADOMSKI, M.I.; COSTA, M.A.G. (Eds.). Direitos de recursos tradicionais: formas de proteção e repartição de benefícios. Botucatu, SP: SBEE, 2005, p. 115-146.

RODRIGUES JR., E. B.; HEATH, C. Trade Mark Act, Secs. 3(1) (iii), 4(1)(xvi) "Cupuaçu". International Review of Intellectual Property and Competition Law, vol. 71, no. 1, p. 98-103, 2006.

RODRIGUES, T.F. Um olhar do design sobre a iconografia indígena. A ornamentação corporal kayapó: um estudo de caso. 2006. 104 p. Dissertação (mestrado em design) Pontifícia Universidade Católica, Rio de Janeiro, 2006.

ROSENTHAL, J. Politics, culture, and governance in the development of prior informed consent in indigenous communities. Current Anthropology, vol. 47, no. 1, p. 119-128, 2006.

ROYAL SOCIETY OF THE ARTS. The Adelphi Charter on creativity, innovation and intellectual property. London, 13. out. 2005.

ROYAL SOCIETY. Keeping science open: the effects of intellectual property policy on the conduct of science. London: The Royal Society, 2003. 47 p. Disponível em: $<$ http://royalsociety.org/displaypagedoc.asp?id=11403 > . Acesso em: 31 julho 2008.

RUDDLE, K. Systems of knowledge: dialogue, relationships and process. In: CETTO, A.M.; SCHNEEGANS, S; MOORE, H. World Conference on Science. Science for the twenty-first century: a new commitment. Paris: UNESCO, 2000, p. 433-434.

RUNGE, C.F. Common property and collective action in economic development. In: BROMLEY, D.W. (Ed.). Making the commons work: theory, practice and policy. San Francisco: ICS Press, 1992, p. 17-37.

SACHS, I. Crescimento econômico e progresso social reconsiderados: o domíno da política. In: SACHS, I; VIEIRA, P.F. (Eds.). Rumo à ecossocioeconomia: teoria e prática do desenvolvimento. São Paulo: Cortez, 2007a, p. 378- 385

Crises de mau desenvolvimento no Norte: uma saída. In: SACHS, I; VIEIRA, P.F. (Eds.). Rumo à ecossocioeconomia: teoria e prática do desenvolvimento. São Paulo: Cortez, 2007b, p.108-121.

Desenvolvimento em harmonia com a natureza: padrões de consumo, usos do tempo e do espaço, perfis de recursos e opções tecnológicas. In: SACHS, I; VIEIRA, P.F. (Eds.). Rumo à ecossocioeconomia: teoria e prática do desenvolvimento. São Paulo: Cortez, 2007c, p. 122-151.

. Em busca de novas estratégias de desenvolvimento. In: SACHS, I; VIEIRA, P.F. (Eds.). Rumo à ecossocioeconomia: teoria e prática do desenvolvimento. São Paulo: Cortez, 2007d, p. 247-284. 
O desenvolvimento enquanto apropriação dos direitos humanos. In: SACHS, I; VIEIRA, P.F. (Eds.). Rumo à ecossocioeconomia: teoria e prática do desenvolvimento. São Paulo: Cortez, 2007e, p. 349- 356.

O jogo da harmonização. In: SACHS, I; VIEIRA, P.F. (Eds.). Rumo à ecossocioeconomia: teoria e prática do desenvolvimento. São Paulo: Cortez, 2007f, p. 96107.

. Sustentabilidade social e desenvolvimento integral. In: SACHS, I; VIEIRA, P.F. (Eds.). Rumo à ecossocioeconomia: teoria e prática do desenvolvimento. São Paulo: Cortez, 2007g, p. 285-314.

SAFRIN, S. Hyperownership in a time of biotechnological promise: the international conflict to control the building blocks of life. American Journal of International Law, vol. 98, p. 641-685, 2004.

SAHAI, S. Commercialization of traditional knowledge and benefit sharing. In: Twarog, S.; Kapoor, P. (Ed.). Protecting and promoting traditional knowledge: systems, national experiences and international dimensions. New York \& Geneva: United Nations, 2004, p. 279-292.

SAINI, N. Sanofi-Aventis: Taxotere to benefit from indication expansion. Pharmaceutical Business Review, 19 de outubro de 2006. Disponível em: <http://www.pharmaceuticalbusiness-review.com/article feature.asp?guid=586612DC-B80F-44CE-8F5DAC06893674AF>. Acesso em: 23 jan. 2009.

SALPIN, C.; GERMANI, V. Patenting of research results related to genetic resources from areas beyond national jurisdiction: the crossroads of the Law of the Sea and Intellectual Property Law. Review of European Community \& International Environmental Law, vol. 16, no. 1, p. 12- 23, 2007.

SALZBERGER, E. M. Economic analysis of the public domain. In: GUIBAULT, L.; HugenholtZ, P.B. (Ed.). The Future of the Public Domain: Identifying the Commons in Information Law. Alphen aan den Rijn: The Kluwer Law International, 2006, p. 27-57.

SAMPAIO, H. A experiência do Artesanato Solidário. In: Políticas Culturais para o Desenvolvimento: Uma base de dados para a cultura. Brasília: UNESCO, 2003, p. 43-50.

SAMPATH, P. G. Regulating bioprospecting: Institutions for drug research, access, and benefit-sharing. New York; United Nations University Press, 2005. 289 p.

SAMUELSON, P. Challenges in mapping the public domain. In: GUIBAULT, L.; Hugenholtz, P.B. (Ed.). The Future of the Public Domain: Identifying the Commons in Information Law. Alphen aan den Rijn: The Kluwer Law International, 2006, p. $7-25$.

Digital information, digital networks, and the public domain. In: BOYLE, J. Collected Papers: Conference on the public domain. Durham: Center for the Study of the 
Public Domain, 2003, p. 80-107. Disponível em: $<$ http://www.law.duke.edu/pd/papers/samuelson.pdf $>$. Acesso em: 11 out. 2008.

SANDERS, A.K. Unfair competition law: the protection of intellectual and industrial creativity. Oxford: Clarendon Press, 1997, p. 229

SANTILI, J. Socioambientalismo e novos direitos: proteção jurídica à diversidade biológica e cultural. São Paulo: Pierópolis, 2005. 303 p.

SANTOS, L.M.V.V.S. Os Krahós e a reintrodução de sementes nativas, 1999. In: FUJIWARA, L.M.; ALESSIO, N.L.N.; FARAH, M.F.S. (Eds.). 20 Experiências de gestão pública e cidadania. São Paulo: Programa Gestão Pública e Cidadania, 1999, p. 313 .

SANWAL, M. Trends in global environmental governance: the emergence of a mutual supportiveness approach to achieve sustainable development. Global Environmental Politics, vol. 4, no. 4, p. 16-22, 2004.

SCHECHTER, R.E.; THOMAS, J.R. Intellectual property: the law of copyrights, patents and trademarks. Eagan: Thomson West, 2003. 915 p.

SCHLEIN, L. Rights of world's indigenous people continue to be violated. WordPress, Geneva, 17 Aug. 2008. Disponível em: < http://www.voanews.com/english/archive/2008-

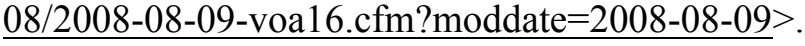

SCHRIJVER, N. The Evolution of Sustainable Development in International Law: Inception, Meaning and Status. Recueil des Cours: Collected Courses of the Hague Academy of International Law, tome 329 de la collection, p. 231-411, 2007.

SCOTCHMER, S. Standing on the Shoulders of Giants: Cumulative Research and the Patent Law. Journal of Economic Perspectives, vol. 5, no. 1, p. 29-41, 1991.

SECRETARÍA DE LA CONFERENCIA MUNDIAL SOBRE LA CIENCIA. Nota introductoria al Programa en Pro de la Ciencia: Marco General de Acción. Budapeste: UNESCO e ICSU, 26 de junho a $1^{\circ}$ de julho de 1999.

SCBD. Enfoque por Ecosistemas (Directrices del CDB). Montreal, 2004a. 50 p.

Principios y directrices de Addis Abeba para la utilización sostenible de la diversidad biológica (Directrices del CDB). Montreal, 2004b. 21 p.

Akwé:Kon guidelines. Montreal, 2004c. 29 p.

Ad hoc open-ended inter-sessional working group on article 8(j) and related provisions of the Convention on Biological Diversity. Compilation of views concerning an ethical code of conduct to ensure respect for the cultural and intellectual heritage of indigenous and local communities. UNEP/CBD/WG8J/5/INF/15. Montreal, 19 June 2007. $28 \mathrm{p}$. 
Ad hoc open-ended inter-sessional working group on article $8(\mathrm{j})$ and related provisions of the Convention on Biological Diversity. Synthesis of case-studies and relevant information on article $8(j)$ and related provisions of the Convention on Biological Diversity. UNEP/CBD/WG8J/1/INF/2. Montreal, 24 Feb. 2000. 26 p.

Ad hoc open-ended inter-sessional working group on article $8(\mathrm{j})$ and related provisions of the Convention on Biological Diversity. Compilation and overview of existing instruments, guidelines, codes and other activities relevant to the programme of work for the implementation of article $8(j)$ and related provisions. UNEP/CBD/WG8J/2/INF/1. Montreal, 27 Nov. 2001. 24 p.

Ad hoc open-ended inter-sessional working group on article $8(\mathrm{j})$ and related provisions of the Convention on Biological Diversity. Composite report on the status and trends regarding the knowledge, innovations and practices of indigenous and local communities relevant to the conservation and sustainable use of biodiversity. UNEP/CBD/WG8J/3/INF/1. Montreal, 28 Sept. 2003. 65 p.

. Ad hoc open-ended inter-sessional working group on article 8(j) and related provisions of the Convention on Biological Diversity. Composite report on the status and trends regarding the knowledge, innovations and practices of indigenous and local communities. UNEP/CBD/WG8J/4/INF/9. Montreal, 21 Dec. 2005. 38 p.

Ad hoc open-ended inter-sessional working group on article $8(\mathrm{j})$ and related provisions of the Convention on Biological Diversity. The outcome of the Intergovernmental Forum on Forests (IFF) relevant to the ad hoc open-ended intersessional working group on article $8(\mathrm{j})$ and related provisions of the Convention on Biological Diversity. UNEP/CBD/WG8J/1/INF/5. Montreal, 28 Feb. 2000. 6 p.

Ad hoc open-ended inter-sessional working group on article $8(\mathrm{j})$ and related provisions of the Convention on Biological Diversity. Workshop on cultural, environmental and social impact assessments based on the Akwé:Kon voluntary guidelines and aimed at further strengthening the understanding of the link between environment and cultural diversity, conducted in cooperation with the symposium on conserving cultural and biological diversity: the role of the sacred natural sites and cultural landscapes. UNEP/CBD/WG8J/4/INF/14. Montreal, 21 Dec. 2005. 15 p.

Ad hoc open-ended inter-sessional working group on article $8(\mathrm{j})$ and related provisions of the Convention on Biological Diversity. Report of the international conference on indigenous and scientific knowledge on the sustainable use of plants. UNEP/CBD/WG8J/1/INF/4. Montreal, 11 Feb. 2000. 8 p.

- Ad hoc open-ended inter-sessional working Group on article 8(j) and related provisions of the Convention on Biological Diversity. Report of the technical workshop on indigenous tradicional knowledge. UNEP/CBD/WG8J/4/INF/16. Montreal, 8 Dec. 2005. 19 p.

Ad hoc open-ended inter-sessional working Group on article 8(j) and related provisions of the Convention on Biological Diversity. Development of elements of sui generis systems for the protection of traditional knowledge, innovations and practices. UNEP/CBD/WG8J/4/INF/18. Montreal, 24 Nov. 2005. 7 p. 
Ad hoc open-ended inter-sessional working group on article 8(j) and related provisions of the Convention on Biological Diversity. Report of the UNPFII's International Expert Group Meeting on the Convention on Biological Diversity's International Regime on Access and Benefit-sharing and Indigenous People's Human Rights. UNEP/CBD/WG8J/5/INF/10. Montreal, 31 July 2007.

Bonn Guidelines on access to genetic resources and fair and equitable sharing of the benefits arising out of their utilization. Montreal, 2002. $20 \mathrm{p}$.

. Conferencia de las partes en el Convenio sobre la Diversidad Biológica. Informe de la primera reunión del grupo de trabajo especial de composición abierta del período entre sesiones sobre el artículo 8 (j) y disposiciones conexas del Convenio sobre la Diversidad Biológica. UNEP/CBD/COP/5/5. Montreal, 12 abr. 2000. 35 p.

- Consideraciones para elaborar directrices técnicas para registrar y documentar los conocimientos tradicionales y los posibles riesgos de dicha documentación. UNEP/CBD/WG8J/5/3/Add.2. Montreal, 28 jul. 2007. 13 p.

Conference of the parties to the Convention on Biological Diversity. Report of the fifth meeting of the ad hoc open-ended working group on article 8(j) and related provisions of the Convention on Biological Diversity. UNEP/CBD/COP/9/7. Montreal, 13 Nov. 2007. 51 p.

Conferencia de las partes en el Convenio sobre la Diversidad Biológica. Informe de la cuarta reunión del grupo de trabajo especial de composición abierta entre períodos de sesiones sobre el artículo $8(\mathrm{j})$ y disposiciones conexas del Convenio sobre la Diversidad Biológica. UNEP/CBD/COP/8/7. Montreal, 30 enero 2006. 48 p.

Grupo de trabajo abierto de composición abierta entre períodos de sesiones sobre el artículo 8 (j) y disposiciones conexas del Convenio sobre la Diversidad Biológica. Esbozo de informe integrado sobre la situación y tendencias relativas a los conocimientos, innovaciones $\mathbf{y}$ prácticas de la comunidades indígenas $\mathbf{y}$ locales. $\mathrm{UNEP} / \mathrm{CBD} / \mathrm{WG} 8 \mathrm{~J} / 2 / 5$. Montreal, 27 nov. 2001. 12 p.

Grupo de trabajo abierto de composición abierta entre períodos de sesiones sobre el artículo 8 (j) y disposiciones conexas del Convenio sobre la Diversidad Biológica. Informe integrado sobre la situación y tendencias relativas a los conocimientos, innovaciones y prácticas de la comunidades indígenas y locales de importancia para la conservación $y$ utilización sostenible de la diversidad biológica. UNEP/CBD/WG8J/3/4. Montreal, 28 sept. 2003. 17 p.

Grupo de trabajo abierto de composición abierta entre períodos de sesiones sobre el artículo 8 (j) y disposiciones conexas del Convenio sobre la Diversidad Biológica. Elaboración de los elementos de un sistema sui generis para la protección de los conocimientos, innovaciones y prácticas tradicionales. UNEP/CBD/WG8J/3/7. Montreal, 24 Oct. 2003. 25 p.

. Grupo de trabajo abierto de composición abierta entre períodos de sesiones sobre el artículo 8 (j) y disposiciones conexas del Convenio sobre la Diversidad Biológica. 
Cooperación internacional entre las comunidades indígenas $\mathbf{y}$ locales. $\mathrm{UNEP} / \mathrm{CBD} / \mathrm{WG} 8 \mathrm{~J} / 1 / 4$. Montreal, 10 enero 2000. 7 p.

Grupo de trabajo abierto de composición abierta entre períodos de sesiones sobre el artículo 8 (j) y disposiciones conexas del Convenio sobre la Diversidad Biológica. Modalidades jurídicas y de otro tipo de protección para los conocimientos, las innovaciones y las prácticas de las comunidades indígenas y locales con estilos de vida tradicionales de importancia para la conservación y el uso sostenible de la diversidad biológica. UNEP/CBD/WG8J/1/2. Montreal, 10 enero 2000. 20 p.

Grupo de trabajo abierto de composición abierta entre períodos de sesiones sobre el artículo 8 (j) y disposiciones conexas del Convenio sobre la Diversidad Biológica. Evaluación de la eficacia de los actuales instrumentos subnacionales, nacionales e internacionales particularmente de los instrumentos de derechos de propiedad intelectual que puedan tener repercusiones en la protección de los conocimientos y prácticas de las comunidades indígenas y locales. UNEP/CBD/WG8J/2/7. Montreal, 27 nov. 2001. $33 \mathrm{p}$.

Grupo de trabajo abierto de composición abierta entre períodos de sesiones sobre el artículo 8 (j) y disposiciones conexas del Convenio sobre la Diversidad Biológica. Antecedentes para el proyecto de directrices o recomendaciones para realizar evaluaciones de las repercusiones culturales, ambientales y sociales de las actividades propuestas por ser realizadas en lugares sagrados o en tierras o aguas ocupadas o utilizadas por las comunidades indígenas y locales. UNEP/CBD/WG8J/2/6/Add.1. Montreal, 27 nov. 2001. 25 p.

Grupo de trabajo abierto de composición abierta entre períodos de sesiones sobre el artículo 8 (j) y disposiciones conexas del Convenio sobre la Diversidad Biológica. Proyecto modificado de los elementos de un código de conducta ética para asegurar el respeto al patrimonio cultural y intelectual de las comunidades indígenas y locales. UNEP/CBD/WG8J/5/7. Montreal, 28 jul. 2007. 12 p.

Grupo de trabajo abierto de composición abierta entre períodos de sesiones sobre el artículo 8 (j) y disposiciones conexas del Convenio sobre la Diversidad Biológica. Régimen internacional sobre acceso y participación en los beneficios: colaboración con el grupo de trabajo especial de composición abierta sobre acceso y participación en los beneficios de las comunidades indígenas y locales. UNEP/CBD/WG8J/5/4. Montreal, 28 jul. 2007.4 p.

Grupo de trabajo abierto de composición abierta entre períodos de sesiones sobre el artículo 8 (j) y disposiciones conexas del Convenio sobre la Diversidad Biológica. Elaboración de los elementos de sistemas sui generis para la protección de los conocimientos, innovaciones y prácticas tradicionales. UNEP/CBD/WG8J/4/7. Montreal, 24 nov. 2005. 26 p.

Grupo de trabajo abierto de composición abierta entre períodos de sesiones sobre el artículo 8 (j) y disposiciones conexas del Convenio sobre la Diversidad Biológica. Elaboración de los elementos de sistemas sui generis para la protección de los conocimientos, innovaciones $\mathbf{y}$ prácticas tradicionales para identificar elementos prioritarios. UNEP/CBD/WG8J/5/6. Montreal, 20 sept. 2007. 18 p. 
Grupo de trabajo abierto de composición abierta entre períodos de sesiones sobre el artículo 8 (j) y disposiciones conexas del Convenio sobre la Diversidad Biológica. Recomendaciones del foro permanente de las Naciones Unidas para las cuestiones indígenas. UNEP/CBD/WG8J/5/9. Montreal, 20 jul. 2007. 9 p.

. Recommendations of the United Nations Permanent Forum on Indigenous Issues.

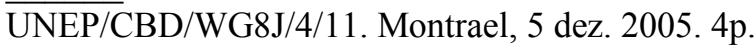

Traditional knowledge and the Convention on Biological Diversity: note by the Executive Secretary. In: Twarog, Sophia; Kapoor, Promila (Ed.). Protecting and promoting traditional knowledge: systems, national experiences and international dimensions. New York \& Geneva: United Nations, 2004, p. 111-119.

. Grupo de Trabajo Especial de Composición Abierta sobre Accesso y Participación en los Beneficios. Anexo a la decisión VIII/4 (a) acerca del régimen internacional sobre accesso y participación en los beneficios. UNEP/CBD/WG-ABS/5/2. Montreal, 14 sept. 2007.

Informe del grupo de trabajo especial de composición abierta entre períodos de sesiones sobre el artículo 8 (j) y disposiciones conexas del Convenio sobre la Diversidad Biológica sobre la labor realizada en su segunda reunión. $\mathrm{UNEP} / \mathrm{CBD} / \mathrm{COP} / 6 / 7$. Montreal, 14 de feb. 2002. 43 p.

The Global Taxonomy Iniciative - The Response to a Problem. Montreal, [2009?]. 2p. Disponível em: <http://www.cbd.int/doc/publications/gti-brochure-en.pdf $>$. Acesso em: 27 de maio de 2009.

. Traditional Knowledge and Biological Diversity. UNEP/CBD/TKBD/1/2. Montreal, 18 Oct. 1997.

SECRETARIAT OF THE PACIFIC COMMUNITY. Pacific Regional Framework for the Protection of Traditional Knowledge and Expressions of Culture, de 2002. Disponível em: < http://www.sprep.org/att/IRC/eCOPIES/Pacific_Region/102.pdf> Acesso em: 22 abr. 2009.

SECRETARIAT OF THE PERMANENT FORUM ON INDIGENOUS ISSUES. Contribution of the Indian Law Resource Center: Indigenous peoples right of free prior informed consent with respect to indigenous lands, territories and resources. FPII/2005/WS.2/6. New York: United Nations, 2005.

. Contribution of the ILO. FPII/2005/WS.2/4. New York: United Nations, 2005.

FAO activities on prior and informed consent: activities involving indigenous peoples. PFII/2005/WS.2/14. New York: United Nations, 2005.

. Free prior informed consent and beyond: the experience of IFAD.

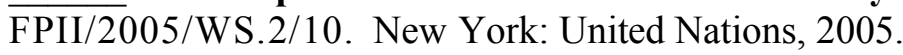


Nota de información preparada por la Secretaría de la Organización Mundial de la Propiedad Intelectual (OMPI). New York: United Nations, 2005.

UNDP and the principie and practice of free, prior and informed consent (FPIC). PFII/2005/WS.2/15. New York: United Nations, 2005.

UNICEF's submission: Methodologies regarding free prior and informed consent and indigenous Children. FPII/2005/WS.2/12. New York: United Nations, 2005.

SCHIWY-RAUSCH, G. Traditional Knowledge at the EPO: Present \& Future. Munique: European Patent Office, 2006a. 21 p. Disponível em: < http://pame.europeanpatent-office.org/pubs/hararepdf/tk_aripo_present_future.pdf $>$. Accesso em $1^{\circ}$ jun. 2009.

. Minimum Documentation under PCT: Inclusion of TK. Munique: European Patent Office, 2006b. 19 p. Disponível em:

$<$ http://documents.epo.org/projects/babylon/eponet.nsf/0/e2261bfc4d866685c125735b005

b6a31/\$file/tk_aripo_min_pct_en.pdf $>$. Accesso em $1^{\circ}$ jun. 2009.

SEEDQUEST. Embrapa doa variedade de trigo tradicional para produtores de Alto Paraíso. SeedQuest, 10 de maio de 2005. Disponível em: $<$ http://www.seedquest.com/News/releases/2005/may/12234.htm $>$. Acesso em: 13 fev. 2009.

SÉGUIN, B.; STATE, L.; SINGER, P.A.; DAAR, A.S. Scientific diasporas as an option for brain drain: re-circulating knowledge for development. International Journal of Biotechnology, vol. 8, nos. 1-2, p. 78-90, 2006.

SELL, E.W. The Doctrine of misappropriation in unfair competition: The Associated Press doctrine after forty years. Vanderbilt Law Review, vol. 11, p. 483-499, 1957-1958.

SEN, A.K. Desenvolvimento como liberdade. Tradução Laura Teixeira Motta. São Paulo: Companhia das Letras, 2000. 409 p.

SENA, C.S. An overview of a current understanding of FPIC as a methodological issue in activities relating to indigenous peoples: significance and challenges. New York: United Nations - Secretariat of the Permanent Forum on Indigenous Issues, 2005.

SEWELL JR., W.H. The Concept(s) of Culture. In: BONNELL, V.E.; HUNT, L. (Ed.). Beyond the cultural turn. Berkeley: University of California Press, 1999, p. 35-61.

SHERMAN B.; WISEMAN, S. Towards an Indigenous Public Domain? In: GUIBAULT, L.; HUGEnholTZ, P.B. (Ed.). The Future of the Public Domain: Identifying the Commons in Information Law. Alphen aan den Rijn: The Kluwer Law International, 2006, p. 259-278.

SHIELDS, P. M.; TAJALLI, H. Intermediate theory: the missing link to successful student scholarship. Journal of Public Affairs Education, vol. 12, no. 3, p. 313-334, 2006. 
SHIFFRIN, S. V. Lockean arguments for private intellectual property. In: MUNZER, S. R. (Ed.). New Essays in the Legal and Political Theory of Property. Cambridge: Cambridge University Press, 2001, p. 138-167.

SHIVA, V. Biopirataria: a pilhagem da natureza e do conhecimento. Tradução de Laura Cardellini Barbosa de Oliveira. Petrópolis, RJ: Vozes, 2001. 152 p.

Bioprospecting as Sophisticated Biopiracy. Journal of Women in Culture and Society, vol. 32, no. 2, p. 307-313, 2007.

The neem tree: a case history of biopiracy. Singapore: Third World Network, [199-]. Disponível em: <http://www.twnside.org.sg/title/pir-ch.htm>. Acesso em: 24 setembro 2008.

SINGH, K. UNESCO and cultural rights. In: NIEC, H. Cultural Rights and Wrongs: a collection of essays in commemmoration of the 50th anniversary of the Universal Declaration of Human Rigths. Paris: UNESCO Publishing \& Institute of Art and Law, 1998, p. 146-160.

SKLOOT, R. Taking the least of you. The New York Times Magazine, New York, 16 April, 2006. Disponível em: $<$ http://www.nytimes.com/2006/04/16/magazine/16tissue.html?pagewanted=1\&_r=1 $>$.

Acesso em: 5 set. 2008.

SMITH, H. E. Intellectual property as property: delineating entitlements in information. Yale Law Journal, vol. 116, no. 8, pp.1742-1822, 2007.

SOEJARTO, D.D. University of Illinois at Chicago's (UIC) policy of benefit sharing in research on drugs derived from natural products. In: WORLD HEALTH ORGANIZATION. Report of the Inter-Regional Workshop on Intellectual Property Rights in the Context of Traditional Medicine. WHO/EDM/TRM/2001.1. Geneva, 2001, p. 30-33.

SOLOMON, M. Strengthening traditional knowledge systems and customary laws. In: Twarog, S.; Kapoor, P. (Ed.). Protecting and promoting traditional knowledge: systems, national experiences and international dimensions. New York \& Geneva: United Nations, 2004, p. 155-165.

SOME indigenous Indian drugs. The Lancet, edição de 4 de setembro de 1909, p. 730731.

SOPLÍN, S.; MULlER, M.R. El Desarrollo de un Régimen Internacional de Acceso y Distribución de Beneficios Equitativo y Eficiente en un Contexto de Nuevos Desarrollos Tecnológicos. Iniciativa para la prevención de la Biopiratería - documentos de investigación, año III, no. 9, p. 1-16, 2008.

SOUTH CENTRE. The south and sustainable development conundrum: from Stockholm 1972 to Rio 1992 to Johannesburg 2002 and beyond. Geneva: South Centre, 2002. 133 p. 
SPIEGEL. Spiegel interview with African economics expert: "For God's Sake, Please Stop the Aid!". Der Spiegel, Hamburg, 4 de julho 2005. Disponível em: < http://www.spiegel.de/international/spiegel $/ 0,1518,363663,00 . h t m l>$. Acesso em: 20 jun. 2008 .

STAFF UNION OF THE EUROPEAN PATENT OFFICE . PAX: a recipe for bad quality. München, SUEPO, 2006. 6 p. Disponível em: $<$ http://www.suepo.org/public/quality quantity/zb1106.pdf $>$. Acesso em: 20 abril 2009.

Results of a staff survey on quality carried out in 2004. Disponível em: $<$ http://www.suepo.org/public/qualsurv.pdf>. Acesso em: 20 abril 2009.

STAHNKE, T.; MARTIN, J.P. (Ed.) Religion and Human Rights: Basic Documents. New York: Center for the Study of Human Rights, Columbia University, 1998. 272 p.

STAVENHAGEN, R. Cultural rights: a social science perspective. In: NIEC, H. Cultural Rights and Wrongs: a collection of essays in commemmoration of the 50th anniversary of the Universal Declaration of Human Rigths. Paris: UNESCO Publishing \& Institute of Art and Law, 1998, p. 1-20.

STEPHENS, C.; PORTER, J; NETTLETON, C.; WILliS, R. UN Declaration on the Rights of Indigenous Peoples. The Lancet, vol. 370, p. 1756, novembro 24, 2007.

STEVENSON, G.G. Common property economics: a general theory and land use applications. Cambridge: Cambridge University Press, 1991. 282 p.

STEWARD, J. H. Comments on the Statement on Human Rights. American Anthropologist, New Series, vol. 50, no. 2, p. 351-352, 1948.

STIGLITZ, J. E. Knowledge as a global public good. In: KAUK, I.; GRUNBERG, I.; STERN, M. A. (Ed.). Global Public Goods: International Cooperation in the $21 \mathrm{st}$ Century. New York: Oxford University Press, 1999, p. 308-325. Disponível em: $<$ http://www.worldbank.org/knowledge/chiefecon/articles/undpk2/index.htm $>$ Acesso em 10 julho 2008.

The theory of international public goods and the architecture of international organizations. New York: United Nations Department for Economic and Social Information and Policy Analysis, 1995. 11 p.

STRATHERN, M. Transaction: an analytical foray. In: HIRSCH, E; STRATHERN, M. (Eds.). Transactions and creations: property debates and the stimulus from Melanesia. New York \& Oxford: Berghahn Brooks, 2004, p. 85-109.

SUBBIAH, S. Reaping what they sow: the basmati rice controversy and strategies for protecting traditional knowledge. British Columbia International \& Comparative Law Review, vol. 27, p. 529-559, 2004.

SUNDER, M. The invention of traditional knowledge. UC Davis Legal Studies Research Paper Series, research paper no. 75, março de 2006. 29 p. 
SVEN, V.; VAN HIEL, A.; PARISI, F.; DEPOORTER, B. From 'tragedy' to 'disaster': welfare effects of commons and anticommons dilemmas. Arlington: George Mason University. George Mason Law \& Economics Research Paper No. 04-23, 2006. 36 p. Disponível em: $<$ http://ssrn.com/abstract=548622>. Acesso em: 30 dezembro 2008.

SWANSON, T.; GOESCHL, T. Property Rights Issues Involving Plant Genetic Resources: Implications of Ownership for Economic Efficiency. Venice: European Summer School in Resource and Environmental Economics, 2007. 30 p. Disponível em:

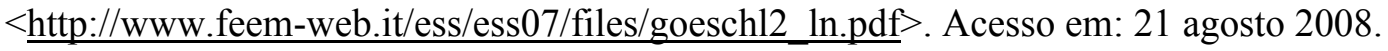

. The Social Value of Biodiversity for R\&D. Environmental and Resource Economics, vol. 22, p. 477-504, 2002.

SZABÓ, I. Cultural Rights. Leiden: A.W. Sijthoff, 1974. 113 p.

TAILÂNDIA. Act on Protection and Promotion of Traditional Thai Medicinal Intelligence, B.E. 2542, de 19 de novembro de 1999. Disponível em: $<$ http://www.wipo.int/export/sites/www/tk/en/laws/pdf/thai medic.pdf $>$. Acesso em: 22 abr. 2009.

TAMANG, P. An overview of the principle of free, prior and informed consent and indigenous peoples in international and domestic law and practices. FPII/2005/WS.2/8. New York: United Nations, 2005.

TANSEY, G; CEAS CONSULTANTS; CENTRE FOR EUROPEAN AGRICULTURAL STUDIES; QUEEN MARY INTELLECTUAL PROPERTY RESEARCH INSTITUTE. The relationship between the agreement on TRIPS and biodiversity related issues: Final Report. [S.1], European Commission, 2000. 135 p. Disponível em:

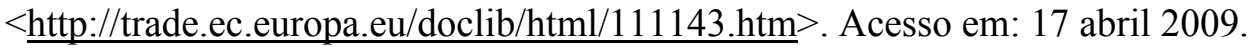

TAUBMAN, A. The public domain and international intellectual property law treaties In: WAELDE, C.; MACQUEEN, H. (Ed.). Intellectual Property: the many faces of the public domain. Cheltenham: Edward Elgar, 2007, p. 53-85.

Terceira minuta do Acordo de Livre Comércio das Américas, de 21 de novembro de 2003. Disponível em: < http://www.ftaa-alca.org/FTAADraft03/>. Acesso em: 01 jul. 2008 .

TERCERA CUMBRE MUNDIAL DE LAS NACIONES UNIDAS SOBRE AMBIENTE Y DESARROLLO. Declaración de Johannesburgo sobre el Desarrollo Sostenible. Aprovada na $17^{\mathrm{a}}$ sessão plenária da Cúpula de Johannesburgo, celebrada em 4 de setembro de 2002.

The Bellagio Declaration. In: ROCKEFELLER CONFERENCE: CULTURAL AGENCY/CULTURAL AUTHORITY: POLITICS AND POETICS OF INTELLECTUAL PROPERTY IN THE POST-COLONIAL ERA, 1993, Bellagio. Disponível em: <http://www.cwru.edu/affil/sce/BellagioDec.html> Acesso em: 22 abr. 2009. 
The Cocoyoc Declaration. In: PATTERNS OF RESOURCES USE, ENVIRONMENT AND DEVELOPMENT STRATEGIES, 8-12 de outubro, 1974, Cocoyoc.

THE ECOLOGIST. Whose common future? Reclaiming the Commons. London: Earthscan Publications, 1993. 216 p.

THOMÉ, C., Coleção da Sta Ephigênia é inspirada na África. O Estado de São Paulo, São Paulo, 11 de janeiro de 2009. Disponível em:

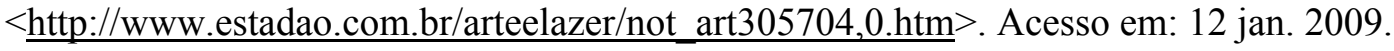

THOMPSON, B. The public domain and the creative author. In: WAELDE, C.; MACQUEEN, H. (Ed.). Intellectual Property: the many faces of the public domain. Cheltenham: Edward Elgar, 2007, p. 132-144.

THOMPSON, C.B. International Law of the Sea/Seed: Public Domain versus Private Commodity. National Resources Journal, vol. 44, p. 841-866, 2004.

THORSTEINSDÓTTIER, H.; QUACH, U.; MARTIN, D.K.; ABDALLAH, D.S.; SINGER, P.A. Introduction: promoting global health through biotechnology. Nature Biotechnology, vol. 22, p. 3-7, 2004a. Supplement to Nature Publishing Group.

Conclusions: promoting biotechnology innovation in developing countries. Nature Biotechnology, vol. 22, p. 48-52, 2004b. Supplement to Nature Publishing Group.

THORSTEINSDÓTTIER, H.; DAAR, A.; SMITH, R.; SINGER, P. Genomics: a global public good? The Lancet, vol. 361 , no. 9361, p. 891- 892, 2003.

TOBIN, B. Certificates of origin: A role for IPR regimes in securing prior informed consent. Yokohama: United Nations University, [20--]. 9 p. Disponível em: < http://www.ias.unu.edu/binaries2/Tobin Certificates of Origin.doc $>$. Acesso em: $30 \mathrm{de}$ jun. 2008.

Towards an International Regime for Protection of Traditional Knowledge: Reflections on the Role of Intellectual Property Rights. In: Bioethical Issues of Intellectual Property in Biotechnology, Tóquio, 2004. 32 p.

TORSEN, M. Untitled, mixed media: mixing intellectual property law with other legal philosophies to protect traditional cultural expressions. Journal of the Copyright Society of the U.S.A., p. 287-312, outono de 2005-inverno de 2006.

Trans-Pacific Strategic Economic Partnership Agreement between Brunei Darussalam, Chile, New Zealand and Singapore.

Treaty on Access to Knowledge (minuta), de 09 de maio de 2005. Disponível em: $<$ http://www.cptech.org/a2k/a2k treaty_may9.pdf $>$. Acesso em: 12 ago. 2008.

TREIGER-BAR-AM, L.K. The moral right of integrity: a freedom of expression. $31 \mathrm{p}$. [S.1], Social Science Electronic Publishing, 2007. Disponível em: $<\underline{\text { http://ssrn.com/abstract }=1019946}>$. Acesso em: 13 out. 2008). 
TROUILLER, P.; OLLIARO, P. Drug development output: what proportion for tropical diseases? The Lancet, vol. 354, no. 9173, p. 164, 1999.

TUFTS Center for the Study of Drug Development pegs cost of a new prescription medicine at $\$ 802$ Million. Tufts Center for the Study of Drug Development, Boston, 30 nov. 2001. Disponível em:

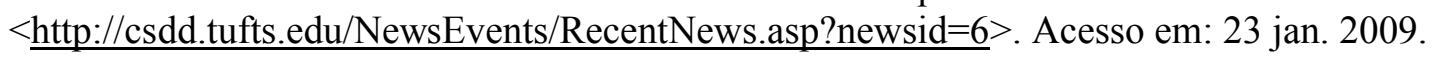

TULALIPE TRIBES OF WASHINGTON. Statement by the Tulalip Tribes of Washington on folklore, indigenous knowledge, and the public domain. Geneva: WIPO, 9 de julho de 2003. Disponível em: $<$ http://www.wipo.int/export/sites/www/tk/en/igc/ngo/tulaliptribes.pdf $>$. Acesso em: 26 abr. 2009.

TWAROG, S. Preserving, protecting and promoting traditional knowledge: national actions and international dimensions. In: Twarog, S.; Kapoor, P. (Ed.). Protecting and promoting traditional knowledge: systems, national experiences and international dimensions. New York \& Geneva: United Nations, 2004, p. 61-70.

UNIFESP. Ofício/reitoria no. 292/2004. São Paulo, 2 de julho de 2004.

UN ISDR ASIA AND PACIFIC. Indigenous knowledge for disaster risk reduction: good practices and lessons learned from experiences in the Asia-Pacific region. Bangkok: UM ISDR Asia and Pacific, 2008. 97 p. Disponível em: $<$ http://www.preventionweb.net/files/3646 IndigenousKnowledgeDRR.pdf $>$. Acesso em: 1 nov. 2008.

UNCTAD-ICTSD. Resource Book on TRIPS and Development. New York: Cambridge University Press, 2005. 829 p.

UNESCO. Conserving cultural and biological diversity: The role of sacred natural sites and cultural landscapes. Paris, 2006. 340 p.

. Convención sobre la protección del patrimonio mundial, cultural y natural. Paris, 23 nov. 1972.

Convención sobre las Medidas que Deben Adoptarse para Prohibir e Impedir la Importación, la Exportación y la Transferencia de Propiedad Ilícitas de Bienes Culturales. París, 14 nov. 1970

. Convention for the Protection of Cultural Property in the Event of Armed Conflict with Regulations for the Execution of the Convention. Haia, 14 de maio de 1954.

. Convention for the Protection of the World Cultural and Natural Heritage. Paris, 17 nov. 1972.

. Declaración sobre las Responsabilidades de las Generaciones Actuales para con las Generaciones Futuras. Paris, 12 nov. 1997. 
Declaration of San José: the struggle against ethnocide. San José, dez. 1981. nov. 1966.

Declaration on the Principles of International Cultural Cooperation. Paris, 4.

Declaration on Race and Racial Prejudice. Paris, 27 de nov. 1978.

. Preliminary study on the technical and legal aspects relating to the desirability relating to the desirability of a standard-setting instrument on cultural diversity. $166 \mathrm{EX} / 28$. Paris, 12 Mar. 2003. 12 p.

. Recomendación relativa a la situación de los investigadores científicos. Paris, 20 de novembro de 1974.

Recomendación sobre la salvaguardia de la cultura tradicional y popular. Paris, 15 nov. 1989.

. Recommendation concerning the International Exchange of Cultural Property.

Paris, 26 nov. 1976.

Recommendation on Participation by the People at Large in Cultural Life and Contribution to It. Paris, 26 nov. 1976.

Statement on Cultural Rights and Human Rights. Documento reproduzido em UNESCO, Meeting of Experts on Cultural Rights as Human Rights (SHC/MD/1). Paris, 30 de setembro de 1968.

UNESCO; WIPO. Draft Treaty for the Protection of Expressions of Folklore Against Illicit Exploitation and Other Prejudicial Actions. Geneva \& Paris, 1984. Documento disponível em: $<$ http://www.copyrightnote.org/statute/cc0014.html $>$. Acesso em: 22 abr. 2009.

UNESCO; WIPO. Model provisions for national laws on the protection of expressions of folklore against illicit exploitation and other prejudicial actions with a commentary prepared by the Secretariats of the UNESCO and WIPO. Paris, 1985. 29 p. Disponível em: $<$ http://www.wipo.int/export/sites/www/tk/en/laws/pdf/unesco wipo.pdf $>$. Acesso em: 20 abr. 2009.

1976. Tunis Model Law on Copyright for Developing Countries. Geneva \& Paris,
Disponível http://portal.unesco.org/culture/en/files/31318/11866635053tunis model law enweb.pdf/tunis model law en-web.pdf $>$. Acesso em: 27 abr. 2009.

UN-HABITAT. The state of the world's cities report: the millennium development goals and urban sustainability: 30 years of shaping the habitat agenda. London: Earthscan/James \& James, 2006. 204 p.

UNIÃO EUROPÉIA. Tribunal de Justiça das Comunidades Européias. Acórdão do tribunal no processo C-377/98. Autor: Reino dos Países Baixos. Réus: Parlamento Europeu 
e Conselho da União Européia. Objeto do litígio: anulação da Diretiva 98/44/CE , que disciplina a proteção jurídica das invenções biotecnológicas. Luxemburgo, 9 de outubro de 2001 .

UNITED NATIONS COMMISSION ON HUMAN RIGHTS. Promoción del disfrute de los derechos culturales de todos y respeto de las distintas identidades culturales. Resolución 2005/20. Ginebra, 14 de abril de 2005.

. Human rights and bioethics. Resolution 1993/91. Geneva, 10 de março de 1993.

. Human rights and extreme poverty. Resolução 1994/12. New York, 25 de fevereiro de 1994.

UNESCOPRESS. Representative List of the Intangible Cultural Heritage of Humanity comes into being in Istanbul. UNESCOPRESS, Paris, 5 de novembro de 2008. Disponível em:

$<$ http://portal.unesco.org/en/ev.php-

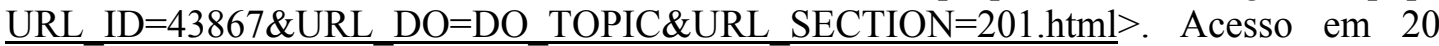
abril 2009.

UNITED NATIONS CONFERENCE ON ENVIRONMENT AND DEVELOPMENT. Agenda 21. Rio de Janeiro, 3 a 14 de junho de 1992. Disponível em: $<$ http://www.un.org/esa/sustdev/documents/agenda21/index.htm $>$. Acesso em: 24 abr. 2009.

Declaração do Rio de Janeiro sobre Meio Ambiente e Desenvolvimento. Rio de Janeiro, 3 a 14 de junho de 1992.

UNITED NATIONS CONFERENCE ON THE HUMAN ENVIRONMENT. Declaration of the United Nations Conference on the Human Environment. Estocolmo, 5-16 de junho de 1972.

UNITED NATIONS DEPARTMENT FOR POLICY COORDINATION AND SUSTAINABLE DEVELOPMENT. Report of the expert group meeting on the identification of principles of international law for sustainable development. New York: United Nations, 1996. 54 p.

UNITED NATIONS DEVELOPMENT PROGRAMME. Human development report 1999. Oxford \& New York: Oxford University Press, 1999. 167 p.

Science and Technology for Sustainable Development: Water, Sanitation and Human Settlements. E/CN.17/2004/10/Add.3. New York, 11 de fevereiro de 2004.

UNITED NATIONS ENVIRONMENT PROGRAMME. Decision 14/26. Nairóbi, 17 de junho de 1987.

Decision 15/12. Nairóbi, 25 de maio de 1989.

Resolution 3 of the Nairobi Conference for the Adoption of the Agreed Text of the Convention on Biological Diversity. Nairóbi, 22 de maio de 1992. 
UNITED NATIONS ENVIRONMENT PROGRAMME; OFFICE OF THE HIGH COMMISSIONER FOR HUMAN RIGHTS. Final text - Meeting of experts on human rights and the environment. Geneva, 16 Jan. 2002. Disponível em: $<$ http://www.unhchr.ch/environment/conclusions.html $>$. Acesso em: 24 out. 2008.

UNITED NATIONS ENVIRONMENT PROGRAMME; UNITED NATIONS UNIVERSITY - INSTITUTE OF ADVANCED STUDIES. Access to genetic resources in Africa: analysing development of ABS policies in four African countries. Nairobi \& Yokohama, 2008. $141 \mathrm{p}$.

UNGA. 2001-2010: Decade to Roll Back Malaria in Developing Countries, Particularly in Africa. Resolution A/RES/62/180. New York, 19 de dezembro de 2007.

Alternative approaches and ways and means within the United Nations system for improving the effective enjoyment of human rights and fundamental freedoms. Resolution 32/130. New York, 16 de dezembro de 1977.

. Convention on Biological Diversity: report of the Second Committee. Resolution A/63/414/Add.6.. New York, 19 de dezembro 2008.

Cumbre Mundial sobre el Desarrollo Sostenible. Resolution A/RES/56/226. New York, 24 de dezembro de 2001.

Cumbre Mundial sobre el Desarrollo Sostenible. Resolution 57/253. New York, 20 de dezembro de 2002.

. Declaración sobre el derecho al desarrollo. Resolution 41/128. New York, 04 de dezembro de 1986.

Declaration on Social Progress and Development. Resolution 2542 (XXIV). New York, 11 de dezembro de 1969.

Declaration on the Elimination of All Forms of Intolerance and of

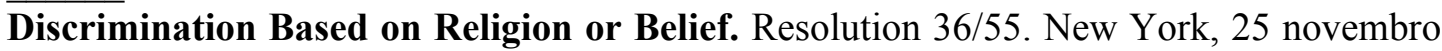
de 1981.

. Declaration on the Establishment of a New International Economic Order. Resolution 3201 (S-VI). New York, 1o de Maio de 1974.

. Development and Environment. Resolution 2849. New York, 20 de dezembro de 1971.

Programme of Action on the Establishment of a New International Economic Order. Resolution 3202. New York, 1o de Maio de 1974. 
Declaration on the Rights of Persons Belonging to National or Ethnic, Religious ANd Linguistic Minorities. ResoluÇão 47/135. NeW YORK: 18 DE DEZEMBRO DE 1992.

Declaration on the Use of Scientific and Technological Progress in the Interests of Peace and for the Benefit of Mankind. Resolução AGONU 3384. New York, de 10 novembro de 1975.

Economic Development and the Conservation of Nature. Resolution 1831 (XVII). New York, 18 de dezembro de 1962.

El derecho al desarollo. Resolution A/RES/63/178. New York, 18 dez. 2008.

. Environmental perspective to the year 2000 and beyond. Resolution $\overline{\mathrm{A} / \mathrm{RES}} / 42 / 186$. New York, $11 \mathrm{dez} .1987$.

Environmental Perspective to the Year 2000 and Beyond. Resolution 42/186. New York, 11 de dezembro de 1987.

- Human rights and scientific and technological developments. Resolution A/RES/42/100. New York, 7 de dezembro de 1987.

. Human Rights and Scientific and Technological Developments. Resolution A/RES/35/130. New York, 11 de dezembro de 1980.

. Human rights and use of scientific and technological developments.

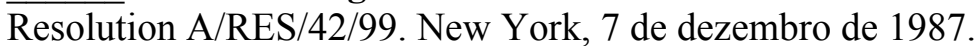

Implementation of the first United Nations Decade for the Eradication of Poverty (1997-2006). Resolution A/RES/60/209. New York, 22 de dezembro de 2005.

- Implementation of the Vienna Programme of Action on Science and Technology for Development. Resolution A/RES/44/14. New York, 26 de outubro de 1989.

- Indivisibility and interdependence of economic, social,cultural, civil and political rights. Resolution A/RES/40/114. New York, 13 de dezembro de 1985.

. International code of conduct on the transfer of technology. Resolution $\overline{\mathrm{A} / \mathrm{RES}} / 48 / 167$. New York, 17 de fevereiro de 1994.

INTERNATIONAL CONVENTION ON THE Elimination OF ALl Forms OF RACIAL DisCRIMINATION. RESOLUTION 2106 (XX). NEW YoRK, 21 DE DEZEMBRO DE 1965.

International Development Strategy for the Third United Nations Development Decade. Resolution A/RES/35/56. New York, 05 de dezembro de 1980.

La globalización y sus consecuencias para el pleno disfrute de todos los derechos humanos. Resolution 62/151. New York, 18 de dezembro de 2007.

Non-legally binding instrument on all types of forests. Resolution 62/98. New York, e 17 de dezembro de 2007. 
Pactos internacionales de derechos humanos. Resolution 62/147. New York, 18 de dezembro de 2007.

. Permanent Sovereignty over Natural Resources. Resolution 1803 (XVII). New York, de 14 de dezembro 1962.

. Process of preparation of the Environmental Perspective to the Year 2000 and Beyond. Resolution 38/161. New York, 19 de dezembro de 1983.

. Report of the World Commission on Environment and Development.

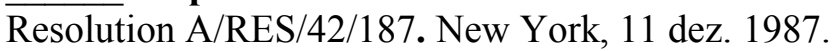

Report of the United Nations Conference on Environment and Development: Non-legally binding authoritative statement of principles for a global consensus on the management, conservation and sustainable development of all types of forests. A/CONF.151/26, vol. III.. New York, 14 Aug. 1992. 5 p.

. Science and technology for development. Resolution 56/182. New York, 21 de dezembro de 2001.

. Tecnología agrícola para el desarrollo. Resolution 62/190. New York, 19 de dezembro de 2007.

. The role of patents in the transfer of technology to under-developed countries. Resolution 1713 (XVI). New York, 19 de dezembro de 1961.

.United Nations Declaration on the Elimination of All Forms of Intolerance and Discrimination Based on Religion or Belief . Resolution 36/55. New York, 25 nov. 1981

United Nations Declaration on the Rights of Indigenous Peoples. Resolution A/61/L.67. New York, 07 de setembro de 2007. set. 2000 .

United Nations Millennium Declaration. Resolution A/RES/55/2. New York, 18

. Universal Declaration of Human Rights. Resolution 217A. New York, 10 dez. 1948.

World Charter for Nature. Resolution 37/7. New York, 28 de outubro de 1982.

2005.

World Summit Outcome. Resolution A/RES/60/1. New York, 24 de outubro

Conclusiones y recomendaciones de la reunión de los Ministros de Ciencia y Tecnología de los Estados Miembros del Grupo de los 77, Angra dos Reis, Brasil, 3 de setembro de 2006. A/61/382. New York, 26 de setembro de 2006. 
Comercio internacional y desarrollo. Resolución A/RES/62/184. New York, 19 de dezembro de 2007.

Ciencia y tecnología para el desarrollo. Resolución 62/201. New York, 19 de

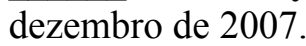

Derechos humanos y diversidad cultural. Resolución 62/155. New York, 18 de $\overline{\text { dezembro de } 2007 .}$

La capacidad empresarial y la privatización como medios de promover el crecimiento económico y el desarrollo sostenible. Resolución 48/180. New York, 21 de dezembro de 1993.

Realización universal del derecho de los pueblos a la libre determinación. Resolución 62/144. New York, 18 de dezembro de 2007.

. Declaración de las Naciones Unidas sobre los derechos de los pueblos indígenas. Resolución A/61/L.67.New York, 12 set. 2007. 2007.

Convenio sobre la Diversidad Biológica. Resolución 62/194. 19 de dezembro de

UNITED NATIONS ORGANIZATION. Convenção para a prevenção e a repressão do crime de genocídio. Adotada por meio da Resolução AGONU 260A (III), de 9 de dezembro de 1948.

UNITED NATIONS SUB-COMMISSION ON HUMAN RIGHTS. Intellectual property and human rights. Resolution 2001/21. Geneva, 16 de agosto de 2001.

Intellectual property rights and human rights. Resolution 2000/7. Genebra, 17 de agosto de 2000.

UNITED STATES OF AMERICA. Circuit Court for the Southern District of New York. Voto do juiz Hand no caso Parke-Davis \& Co. v. H.K. Mulford. Co., 1911.

University of California. Documento disponível em: $<\underline{\text { http://www.audiocasefiles.com/acf cases/8954-moore-v-regents-of-the-university-of- }}$ california $>$ Acesso em: 5 set. 2008.

Supreme Court of United States of America. DIAMOND, Commissioner of Patents and Trademarks v. CHAKRABARTY (447 U.S. 303). Decisão proferida em 16 jun. 1980.

. UNITED STATES, United States Court of Appeals for the Federal Circuit, Amgen Inc. v. Chugai Pharmaceutical Co. 927 F.2d 1200, 19 USPQ2d 1016 (Fed. Cir 1991).

. United States District Court, S.D., Florida, Miami division. Sentença no caso Greenberg v. Miami Children's Hospital Research Institute, Inc., Miami, 29 de maio 2003. 
UNITED STATES PATENT AND TRADEMARK OFFICE. Manual of patent examining procedure (MPEP). $8^{\text {th }}$ ed. Alexandria, Virginia: USPTO, 2008. Disponível em: $<$ http://www.uspto.gov/web/offices/pac/mpep/index.htm>. Acesso em: 3 out. 2008.

VAN BEEK, W.E.A.; JARA, F. “Granular Knowledge” cultural problems with intellectual property and protection. In: GROSHEIDE, F.W.; BRINKHOF, J.J. (Eds.). Molengrafica Series 2002: Intellectual Property Law. Antwerp, Intersentia, 2002, p. 35-59.

VAN CAENEGEN, W. Intellectual property and the idea of progress. Intellectual Property Quaterly, no. 3, p. 237-256, 2003.

VAN OVERWALLE, G. The Implementation of the biotechnology directive in Belgium and its after-effects: the introduction of a new research exemption and a compulsory licence for public health. International Review of Intellectual Property and Competition Law, vol. 37, no. 8, p. 889-1098, 2006.

Holder and User Perspectives in the Traditional Knowledge Debate. Conference on Biodiversity, Biotechnology and the Protection of Traditional Knowledge, Washington University School of Law, Saint Louis, April 4-6, 2003. 16 p.

VERMA, SK. Exhaustion of intellectual property rights and free trade - Article 6 of the TRIPS Agreement. The International Review of Industrial Property and Copyright Law, vol. 29, no. 5, p. 534-567, 1998.

VÉRON, P.; MOUSSA, O. Protecting the results of future research: rearch-through claims in European and U.S. laws. Paris: Véron \& Associés, [200-]. 17 p. Disponível em: $<$ www.veron.com/files/publications/Protecting_the_results_of_future_research.pdf $>$.

Acesso em: 23 agosto 2008.

VERSCHUUREN, J. Principles of environmental law: the ideal of sustainable development and the role of principles of international, European and national environmental law. Baden-Baden: Nomos Verlagsgesellschaft, 2003. 165 p.

VIRALLY, M. Fuentes del derecho international. In: SORENSEN, M. (Ed.). Manual de derecho internacional publico. México, D.F.: Fondo de Cultura Económica, 2000, p. 149-198.

VOGEL, J. H. Una propuesta basada en "La tragedia de los bienes comunes": un museo de bioprospección, de los derechos de propiedad intelectual y del conocimiento público. Revista de Ciencias Sociales, no. 16, p. 118-135, 2007a.

A market alternative to the valuation of biodiversity: the example of Ecuador. ASC Newsletter, vol. 23, no. 5, p. 66-70, 1995.

Fundamentos legales para la distribución de beneficios: la Convención sobre la Diversidad Biológica. __ El cártel de la biodiversidad: transformación de conocimientos tradicionales en secretos comerciales. Quito: CARE, 2000a, p. 5-10. 
La transformación del conocimiento tradicional en secretos comerciales.

El cártel de la biodiversidad: Transformación de conocimientos tradicionales en secretos comerciales. Quito: CARE, 2000b, p. 23-48.

. Las opciones actuales de derechos de propiedad intelectual y su posible aplicación al conocimiento tradicional. El cártel de la biodiversidad: transformación de conocimientos tradicionales en secretos comerciales. Quito: CARE, 2000c, p. 11-22.

El cártel de la biodiversidad: Transformación de conocimientos tradicionales en secretos comerciales. Quito: CARE, 2000d. 168 p.

- Sovereignty as a trojan horse: how the Convention on Biological Diversity morphs biopiracy into biofraud. In: HOCKING, B. A. (Ed.). Indigenous SelfDetermination: an Unresolved Constitutional Issue. Canberra: Aboriginal Studies Press, 2004, p. 228-247.

. The transaction costs of a biodiversity cartel, 2007b. $32 \mathrm{p}$. Manuscrito em arquivo com o autor. Este artigo foi publicado com novo título: Reflecting Financial and Other Incentives of the TMOIFGR: The Biodiversity Cartel. In: MULLER, M.R; LAPEÑA (Eds.). A moving target: genetic resources and options for tracking and monitoring their international flows. Gland: IUCN, 2007, p. 49-76.

- Una justificación económica para el cártel y un protocolo especial para la Convención sobre Diversidad Biológica. El cártel de la biodiversidad: transformación de conocimientos tradicionales en secretos comerciales. Quito: CARE, 2000d, p.103-116.

VON LEWINSKI, S. Final Considerations. In: . Indigenous heritage and intellectual property: genetic resources, traditional knowledge and folklore. The Hague/London/New York: Kluwer Law International, 2004, p. 379-396.

. International copyright law and policy. Oxford: Oxford University Press, 2008, p. $117-120$.

. The protection of folklore. Cardozo Journal of International and Comparative Law, vol. 11, p. 747-768, 2003-2004.

WALLACE, H.; MAYER, S. Scientific research agendas: controlled and shaped by the scope of patentability. In: WAELDE, C.; MACQUEEN, H. (Ed.). Intellectual Property: the many faces of the public domain. Cheltenham: Edward Elgar, 2007, p. 189-199.

WEERAMANTRY, C. Separate opinion of Vice-Presidente Weeramantry. Decisão da Corte Internacional de Justiça no caso Gabčíkovo-Nagymaros Project (Hungary/Slovakia), proferida em 25 de stembro de 1997, p. 88-116.

WEITZMAN, M.L. Recombinant growth. Quarterly Journal of Economics, vol. 113, no. 2, p. 331-360, 1998.

WESterlund, L. Biotech Patents: Equivalency and Exclusions under European and US Patent Law. The Hague: Kluwer Law International, 2002. 351 p. 
WESTKAMP, G. Convergence of Intellectual Property Rights and the Establishment of 'Hybrid' Protection under TRIPS. In: MACMILLAN, F. (Ed.). New Directions in Copyright Law, vol. 1. Chelteham: Edward Elgar, 2005, p. 108-130.

WESTON, J.M. International Court of Justice: advisory opinion on the western Sahara. Harvard International Law Journal, vol. 17, no. 3, p. 609-621, 1976.

WHITT, L.A. Indigenous peoples, intellectual property \& the new imperial science. Oklahoma City University Law Review no. 23, p. 211-259, 1998.

WIESSNER, S. Defending indigenous people's heritage: an introduction. St. Thomas Law Review, vol. 14, p.271-274, 2001.

WILLIAMS, R. Keywords: A Vocabulary of Culture and Society. New York: Oxford University Press, 1983. 356 p.

WORLD BANK. EXPERIENCE OF THE TANGA AIDS WORKING GROUP IN TANZANIA. WASHINGTON, D.C., 2009A. DISPONÍVEL EM:

< HTTP://GO.WORLDBANK.ORG/M9OCMU8G50 > . ACESSO EM: 29 ABR. 2009.

Indigenous Knowledge for Development results. Washington, D.C., $2009 \mathrm{~b}$. Disponível em: < http://go.worldbank.org/CFZJDCEDM0>. Acesso em: 24 abr. 2009.

WORLD CONFERENCE ON SCIENCE. Declaration on Science and the Use of Scientific Knowledge. Budapeste: UNESCO e ICSU, 26 de junho a 1o de julho de 1999.

WORLD CONFERENCE ON HUMAN RIGHTS. Vienna Declaration and Programme of Action. A/CONF.157/23. Viena, 14-25 de junho de 1993.

WIPO. Bioethics and Patent Law: the cases of Moore and the Hagahai people. WIPO Magazine, setembro de 2006a. Disponível em: < http://www.wipo.int/wipo_magazine/en/2006/05/article_0008.html>. Acesso em 20 abril 2009.

Committee of Non-Governmental Experts on the "Domaine Public Payant". Report prepared by the Secretariats and adopted by the Committee. Geneva, Apr. 1982. Columbia Journal of Art and the Law, vol. 8, p. 148-159, 1983-1984.

Disclosure of origin or source of genetic resources and associated traditional knowledge in patent applications: document submitted by the European Community and its Member States. WIPO/GRTKF/IC/8/11. Geneva, 17 May 2005. 5 p.

Disposiciones revisadas para la protección de las expresiones culturales tradicionales/expresiones del folclore: objetivos políticos y principios fundamentales. Geneva, [200-]a. 54 p.

Guia da Convenção de Roma e da Convenção dos Fonogramas (publicação da OMPI no. 617 (P)). Genebra, 1985. 187 p. 
Guide to the copyright and related rights treaties administered by WIPO and glossary of copyright and related rights terms (WIPO publication no. 891 (E)). Geneva, 2003. $317 \mathrm{p}$.

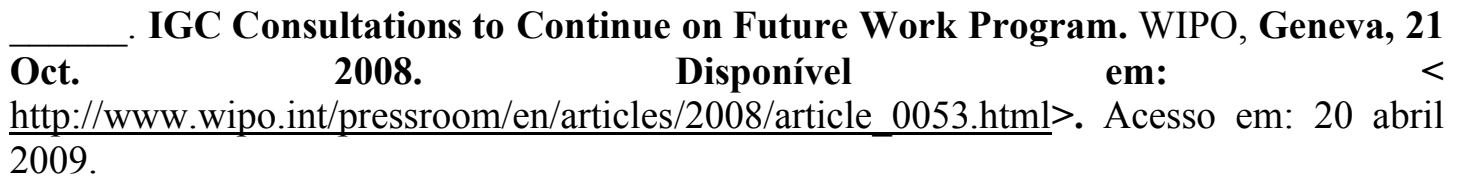

Intellectual property needs and expectations of traditional knowledge holders: WIPO report on fact-finding missions on intellectual property and traditional knowledge (1998-1999). Geneva: WIPO, 2001. 340 p.

Intergovernmental committee on intellectual property and genetic resources, traditional knowledge and folklore. The protection of traditional knowledge: table of written comments on revised objectives and principles. WIPO/GRTKF/IC/11/5(b). Geneva, 18 May 2007. 83 p.

. Intergovernmental committee on intellectual property and genetic resources, traditional knowledge and folklore. Information provided by WIPO Member States concerning practices related to the protection of biotechnological inventions. WIPO/GRTKF/IC/1/6. Geneva, 6 Apr. 2001. 49 p.

Intergovernmental Committee on Intellectual Property and Genetic Resources, Traditional Knowledge and Folklore. Patent system and the fight against biopiracy The Peruvian Experience. WIPO/GRTKF/IC/8/12. Geneva, 30 May 2005. 28 p.

Intergovernmental Committee on Intellectual Property and Genetic Resources, Traditional Knowledge and Folklore. The protection of traditional cultural expressions/expressions of folklore: updated draft outline of policy options and legal mechanisms. WIPO/GRTKF/IC/9/INF/4. Geneva, 27 Mar. 2006. 56 p.

Intergovernmental Committee on Intellectual Property and Genetic Resources, Traditional Knowledge and Folklore. Consolidated analysis of the legal protection of traditional cultural expressions. WIPO/GRTKF/IC/5/3. Geneva, 2 May 2003. $91 \mathrm{p}$.

Intergovernmental Committee on Intellectual Property and Genetic Resources, Traditional Knowledge and Folklore. Operational principles for intellectual property clauses of contractual agreements concerning access to genetic resources and benefitsharing. WIPO/GRTKF/IC/2/3. Geneva, 10 Sept. 2001. 54 p.

Intergovernmental Committee on Intellectual Property and Genetic Resources, Traditional Knowledge and Folklore. The protection of traditional cultural expressions/expressions of folklore: table of written comments on revised objectives and principles. WIPO/GRTKF/IC/11/4(b). Geneva, 19 April 2007. 82 p.

Intergovernmental Committee on Intellectual Property and Genetic Resources, Traditional Knowledge and Folklore. Consolidated survey of intellectual property protection of traditional knowledge. WIPO/GRTKF/IC/5/7. Geneva, 4 April 2003. 20 p. 
Intergovernmental Committee on Intellectual Property and Genetic Resources, Traditional Knowledge and Folklore. Comparative summary of existing national sui generis measures and laws for the protection of traditional knowledge. WIPO/GRTKF/IC/5/INF/4. Geneva, 20 June 2003. 53 p.

Model provisions on protection against unfair competition: articles and notes (WIPO publication no. 832). Geneva, 1996. $68 \mathrm{p}$.

Proposal by Argentina and Brazil for the establishment of a development agenda for WIPO. WO/GA/31/11. Geneva, 27 Aug. 2004.

. Report of the seventh session session of the intergovernamental committee on intellectual property and genetic resources, traditional knowledge and folklore. WIPO/GRTKF/IC/7/15. Gineva, 10 June 2005. 136 p.

Report of the sixth session of the Intergovernmental Committee on Intellectual Property and Genetic Resources, Traditional Knowledge and Folklore. WIPO/GRTKF/IC/6/14. Geneva, 14 Apr. 2004. 121 p.

Report on third session of the WIPO intergovernmental committee on genetic

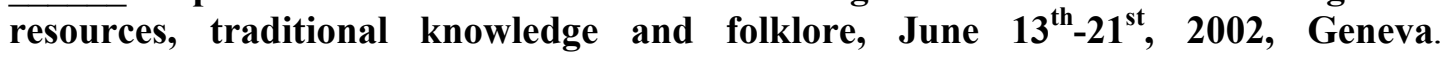
WIPO/GRTKF/IC/3/17. Geneva, 21 Jun. 2002.

Revised draft provisions for the protection of traditional cultural expressions/expressions of folklore: policy objectives and core principles. Geneva [200]c. Disponível em: $<$ http://www.wipo.int/export/sites/www/tk/en/consultations/draft provisions/pdf/draftprovisions-booklet-tce.pdf $>$. Acesso em: 22 abr. 2009.

. Revised provisions for the protection of traditional knowledge. Geneva [200]b. Disponível em: $<\mathrm{http} / /$ www.wipo.int/export/sites/www/tk/en/consultations/draft_provisions/pdf/draftprovisions-booklet-tk.pdf $>$. Acesso em: 8 out. 2008.

Standing Committee on the Law of the Trademarks, Industrial Designs and Geographical Indications. Communication from the permanent mission of Brazil. SCT/16/7. Geneva, 29 Sept. 2006.

- Technical study on disclosure requirements in patent systems related to genetic resources and traditional knowledge. Geneva, [200-]d. 73 p. Disponível em: $<$ http://www.wipo.int/export/sites/www/tk/en/publications/technical_study.pdf $>$. Acesso em: 23 nov. 2008.

The 45 adopted recommendations under the WIPO Development Agenda. Geneva, Oct. 2007. Disponível em: $<$ http://www.wipo.int/export/sites/www/ipdevelopment/en/agenda/recommendations.pdf $>$. Acesso em: 20 nov. 2008.

. The Portuguese sui generis regime for the protection of traditional knowledge (Decree-Law No. 118/2002). Geneva, 25 April 2006b. Documento não publicado, em arquivo com o autor. 
WIPO general assembly: twenty-sixth (12th extraordinary) session Geneva, September 25 to October 3, 2000. WO/GA/26/10. Geneva, 3 Oct. 2000.

- WIPO INTERNATIONAL FORUM ON THE EXERCISE AND MANAGEMENT OF COPYRIGHT AND NEIGHBORING RIGHTS IN THE FACE OF THE CHALLENGES OF DIGITAL TECHNOLOGY. GENEVA, 1998. 290 P.

WIPO Performances and Phonograms Treaty. Geneva, 20 dez. 1996.

Asamblea general de la OMPI: asuntos relacionados con la propiedad intelectual, los recursos genéticos, los conocimientos tradicionales y el folclore. WO/GA/26/6. Ginebra, 25 ago. 2000.

Comité Intergubernamental sobre Propiedad Intelectual y Recursos Genéticos, Conocimientos Tradicionales y Folclore. Los Conocimientos Tradicionales: opciones políticas y jurídicas. WIPO/GRTKF/IC/6/4. Ginebra, 12 dic. 2003. 51 p.

Comité Intergubernamental sobre Propiedad Intelectual y Recursos Genéticos, Conocimientos Tradicionales y Folclore. Declaración de las Naciones Unidas sobre los Derechos de los Pueblos Indígenas. WIPO/GRTKF/IC/12/INF/6. Ginebra, 15 feb. 2008.

Comité Intergubernamental sobre Propiedad Intelectual y Recursos Genéticos, Conocimientos Tradicionales y Folclore. Reproducción del documento WIPO/GRTKF/IC/9/4 "La Protección de las Expresiones Culturales Tradicionales/Expresiones del Folclore: Objetivos y Principios Revisados". WIPO/GRTKF/IC/12/4(c). Ginebra, 6 dic. 2007. 65 p.

Comité Intergubernamental sobre Propiedad Intelectual y Recursos Genéticos, Conocimientos Tradicionales y Folclore. Informe final sobre las experiencias nacionales en materia de protección jurídica de las expresiones del folclore. WIPO/GRTKF/IC/3/10. Ginebra, 25 marzo 2002. 136 p.

Comité Intergubernamental sobre Propiedad Intelectual y Recursos Genéticos, Conocimientos Tradicionales y Folclore. Proyecto de análisis de las carencias de la protección de las expresiones culturales tradicionales. WIPO/GRTKF/IC/13/4(b) Rev. Ginebra, 11 oct. 2008.43 p.

Comité Intergubernamental sobre Propiedad Intelectual y Recursos Genéticos, Conocimientos Tradicionales y Folclore. La Protección de los Conocimientos Tradicionales: proyecto de análisis de carencias: Revisión.WIPO/GRTKF/IC/13/5(b) Rev. Ginebra, 11 oct. 2008.73 p.

Comité Intergubernamental sobre Propiedad Intelectual y Recursos Genéticos, Conocimientos Tradicionales y Folclore. African Group proposal on the protection of traditional knowledge, traditional cultural expressions and genetic resources. WIPO/GRTKF/IC/13/9. Ginebra, 18 sept. 2008. 22 p.

Comité Intergubernamental sobre Propiedad Intelectual y Recursos Genéticos, Conocimientos Tradicionales y Folclore. Recursos genéticos: lista de opciones. WIPO/GRTKF/IC/12/8(a). Ginebra, 7 dic. 2007. 18 p. 
. La protección de los conocimientos tradicionales: reseña objetiva. WIPO/GRTKF/IC/12/5(b). Ginebra, 18 feb. 2008. 165 p.

Propuesta de establecer un programa de la OMPI para el desarrollo: análisis detallado de las cuestiones planteadas en el documento WO/GA/31/11. IIM/1/4. Ginebra, 6 abr. 2005. $32 \mathrm{p}$.

Reconocimiento de los conocimientos tradicionales en el sistema de patentes. WIPO/GRTKF/IC/12/7. Ginebra, 12 feb. 2008. 40 p.

Recursos Genéticos: reseña actualizada de los acontecimientos ocurridos en el plano internacional. WIPO/GRTKF/IC/12/8(b). Ginebra, 15 feb. 2008. 21 p.

Reproducción del documento WIPO/GRTKF/IC/9/5: "La protección de los conocimientos tradicionales: revisión de objetivos y principios". WIPO/GRTKF/IC/12/5(c). Ginebra, 6 dic. 2007. 68 p.

WORLD BANK. Experience of the Tanga AIDS Working Group in Tanzania. Washington, D.C., 2009a. Disponível em: <http://go.worldbank.org/M9OCMU8G50>. Acesso em: 29 abr. 2009.

WORLD COMMISSION ON ENVIRONMENT AND DEVELOPMENT. Our Common Future: Report of the World Commission on Environment and Development. A/42/427. New York: United Nations, 1987. 374 p.

WORLD SUMMIT FOR SOCIAL DEVELOPMENT. Copenhagen Declaration on Social Development. A/CONF.166/9. Copenhagen, 6-12 de março de 1995.

Report of the world summit for social development. A/CONF.166/9. Copenhagen, 6-12 Mar. 1995.

- Programme of Action of the World Summit for Social Development. $\overline{\mathrm{A} / \mathrm{CON}}$ F.166/9. Copenhagen, 6-12 de março de 1995.

WORLD SUMMIT ON SUSTAINABLE DEVELOPMENT. Plan of Implementation of the World Summit on Sustainable Development. Johannesburg, 2002.

WTO. Acordo Constitutivo da Organização Mundial do Comércio. Marrakesh, abril de 1994.

Committee on Trade and Environment. Clarification of the relationship between the WTO and multilateral environmental agreements: Submission by Switzerland (WT/CTE/W/168). Genebra, OMC, 19 October 2000.

Committee on Trade and Environment. The relationship between existing WTO rules and specific trade obligations (STOS) set out in multilateral environmental agreements (MEAS): a Swiss perspective on national experiences and criteria used in the negotiation and implementation of MEAs. TN/TE/W/58. Geneva, 6 Jul. 2005. 
Council for Trade-Related Aspects of Intellectual Property Rights. Communication from Switzerland: additional comments by Switzerland on its proposals submitted to WIPO regarding the declaration of the source of genetic resources and traditional knowledge in patent applications. IP/C/W/423. Geneva, 14 June 2004. 13 p.

Council for Trade-Related Aspects of Intellectual Property Rights. Minutes of meeting held in the Centre William Rappard on 27 to 30 November and 6 December 2000. IP/C/M/29. Geneva, 6 Mar. 2001. 89 p.

Council for Trade-Related Aspects of Intellectual Property Rights. Communication from the European Communities and their Member States: review of article 27.3(b) of the TRIPS Agreement, and the relationship between the TRIPS Agreement and the Convention on Biological Diversity (CBD) and the protection of traditional knowledge and folklore. IP/C/W/383. Geneva, 17 Oct. 2002.17 p.

Council for Trade-Related Aspects of Intellectual Property Rights. Communication from the Permanente Mission of Brazil on behalf of the delegations of Brazil, China, Dominican Republic, Ecuador, India, Pakistan, Peru Thailand, Venezuela, Zambia and Zimbabwe: The relationship between the TRIPS Agreement and the Convention on Biological Diversity (CBD) and the protection of traditional knowledge. IP/C/W/356; IP/C/W/356/Add.1. Geneva, 24 June 2002. 7 p.

Council for Trade-Related Aspects of Intellectual Property Rights. Communication from the United States: technology transfer practices of the US National Cancer Institute's Departmental Therapeutics Programme. IP/C/W/341. Geneva, 25 Mar. 2002. 14 p.

- Council for Trade-Related Aspects of Intellectual Property Rights. Communication from the United States: access to genetic resources regime of the United States national parks. IP/C/W/393. Geneva, 28 Jan. 2003. 7 p.

Council for Trade-Related Aspects of Intellectual Property Rights. Communication from Switzerland: article 27.3(b), the relationship between the TRIPS agreement and the Convention on Biological Diversity, and the protection of traditional knowledge. IP/C/W/400/Rev.1. Geneva, 28 June 2003. 26 p.

Council for Trade-Related Aspects of Intellectual Property Rights. Communication from Bolivia, Brazil, Cuba, Dominican Republic, Ecuador, India, Peru, Thailand, Venezuela. IP/C/W/403. Geneva, 24 June 2003. 6 p.

Council for Trade-Related Aspects of Intellectual Property Rights. Submission from Brazil, Bolivia, Cuba, Ecuador, India, Peru, Thailand and Venezuela. IP/C/W/420; IP/C/W/420/Add.1. Geneva, 2 Mar. 2004. 2 p.

Council for Trade-Related Aspects of Intellectual Property Rights. Joint communication from the African Group: Taking forward the review of article 27.3(b) of the TRIPS Agreement. IP/C/W/404. Geneva, 26 June 2003. 9 p.

Council for Trade-Related Aspects of Intellectual Property Rights. Submission from Brazil, Bolivia, Colombia, Cuba, Dominican Republic, India, Pakistan, Peru, 
Thailand, and Venezuela: Elements of the obligation to disclose the source and country of origin of biological resource and/or traditional knowledge used in an invention. IP/C/W/429; IP/C/W/429, Rev.1; IP/C/W/429/Rev.1/Add.2; IP/C/W/429/Rev.1/Ad..1, IP/C/W/429/Rev.1/Add.3. Geneva, 21 Sept. 2004. 5 p.

Council for Trade-Related Aspects of Intellectual Property Rights. Communication from the United States: Article 27.3(b), relationship between the TRIPS Agreement and the $\mathrm{CBD}$, and the protection of traditional knowledge and folklore. IP/C/W/434. Geneva, 26 Nov. 2004. 8 p.

Council for Trade-Related Aspects of Intellectual Property Rights. Submission from Bolivia, Brazil, Cuba, Ecuador, India, Pakistan, Peru, Thailand and Venezuela: The relationship between the TRIPS Agreement and the Convention on Biological Diversity (CBD) and the protection of traditional knowledge-elements of the obligation to disclose evidence of prior informed consent under the relevant national regime. IP/C/W/438. Geneva, 10 Dec. 2004. 5 p.

Council for Trade-Related Aspects of Intellectual Property Rights. Communication from Switzerland: Further observations by Switzerland on its proposals regarding the declaration of the source of genetic resources and traditional knowledge in patent applications. IP/C/W/433. Geneva, 25 Nov. 2004. 13 p.

Council for Trade-Related Aspects of Intellectual Property Rights. Submission from Bolivia, Brazil, Colombia, Cuba, Dominican Republic, Ecuador, India, Peru and Thailand: The relationship between the TRIPS Agreement and the Convention on Biological Diversity (CBD) and the protection of traditional knowledge - elements of the obligation to disclose evidence of benefit-sharing under the relevant national regime. IP/C/W/442. Geneva, 18 Mar. 2005. 4 p.

Council for Trade-Related Aspects of Intellectual Property Rights. Submission from Brazil and India: The relationship between the TRIPS Agreement and the Convention on Biological Diversity (CBD) and the protection of traditional knowledge Technical observations on issues raised in a communication by the United States. IP/C/W/443. Geneva, 18 Mar. 2005.9 p.

Council for Trade-Related Aspects of Intellectual Property Rights. Communication from Switzerland: The relationship between the TRIPS Agreement and the Convention on Biological Diversity (CBD) and the protection of traditional knowledge and folklore and the review of implementation of the TRIPS Agreement under article 71.1. IP/C/W/446. Geneva, 30 May 2005. 5 p.

Council for Trade-Related Aspects of Intellectual Property Rights. Communication from Peru: Article 27.3(b), relationship between the TRIPS Agreement and the CBD and protection of traditional knowledge and folklore. IP/C/W/441/Rev.1. Geneva, 19 May 2005. 26 p.

Council for Trade-Related Aspects of Intellectual Property Rights. Communication from Peru: Article 27.3(b), relationship between the TRIPS Agreement and the CBD and protection of traditional knowledge and folklore. IP/C/W/447. Geneva, 8 June 2005. $14 \mathrm{p}$. 
Council for Trade-Related Aspects of Intellectual Property Rights. Communication by the United States: Article 27.3(B), relationship between the TRIPS Agreement and the CBD, and the protection of traditional knowledge and folklore. IP/C/W/449. Geneva, 10 June 2005. 9 p.

Council for Trade-Related Aspects of Intellectual Property Rights. Communication from the United States: Article 27.3(b), relationship between the TRIPS Agreement and the $\mathrm{CBD}$, and the protection of traditional knowledge and folklore. IP/C/W/469. Geneva, 13 Mar. 2006. 10 p.

Council for Trade-Related Aspects of Intellectual Property Rights. Communication from Norway: The relationship between the TRIPS Agreement the Convention on Biological Diversity and the protection of traditional knowledge. IP/C/W/473. Geneva, 14 June 2006. 3 p.

Council for Trade-Related Aspects of Intellectual Property Rights. Communication from Norway: The relationship between the TRIPS Agreement the Convention on Biological Diversity and the protection of traditional knowledge. IP/C/W/491. Geneva, May 7, 2007. 4 p.

Council for Trade-Related Aspects of Intellectual Property Rights. Communication from African Group, Brazil, China, Colombia, Cuba, Dominican Republic, Ecuador, India, LDC Group, Mauritius, Pakistan, Paraguay, Peru, South Africa, Thailand, and Tanzania, Venezuela: Doha Work Programme - The outstanding implementation issue on the relationship between the TRIPS Agreement and the Convention on Biological Diversity. IP/C/W/474, IP/C/W/474/Add.1, IP/C/W/474/Add.2 IP/C/W/474/Add.3, IP/C/W/474/Add.4, IP/C/W/474/Add.5, IP/C/W/474/Add.6, IP/C/W/474/Add.7, IP/C/W/474/Add.8. Geneva, 5 July 2006. 2 p.

Council for Trade-Related Aspects of Intellectual Property Rights. Communication from Brazil: Response to questions raised on the draft amendment to TRIPS - Article 29bis (IP/C/W/475). Genebra, WTO, 26 July 2006. 5 p.

Council for Trade-Related Aspects of Intellectual Property Rights. The relationship between the TRIPS Agreement and the Convention on Biological Diversity (CBD) and the protection of traditional knowledge: Technical observations on the United States Submission IP/C/W/449 by Bolivia, Brazil, Colombia, Cuba, India and Pakistan. IP/C/W/459. Geneva, 18 Nov. 2005. 13 p.

Council for Trade-Related Aspects of Intellectual Property Rights. Communication from Bolivia, Cuba, Ecuador, India, Sri Lanka and Thailand. IP/C/W/470. Geneva, 21 Mar. 2006. 6 p.

Council for Trade-Related Aspects of Intellectual Property Rights. Communication from Peru: Analysis of potential cases of biopiracy. IP/C/W/458. Geneva, 7 Nov. 2005. 18 p. 
. Council for Trade-Related Aspects of Intellectual Property Rights. Communication from Japan: the patent system and genetic resources. IP/C/W/472. Geneva, June 13 2006. 13 p.

Council for Trade-Related Aspects of Intellectual Property Rights. Review of the provisions of article 27.3(b): summary of issues raised and points made - Note by the Secretariat. IP/C/W/369/Rev.1. Geneva, 9 Mar. 2006. 36 p.

Council for Trade-Related Aspects of Intellectual Property Rights. The relationship between the TRIPS Agreement and the Convention on Biological Diversity: Summary of issues raised and points made - Note by the Secretariat. IP/C/W/368/Rev.1. Geneva, 8 Feb. 2006. 78 p.

. Council for Trade-Related Aspects of Intellectual Property Rights. Minutes of the meeting held in the Centre William Rappard on 14-15 June 2005. IP/C/M/48. Geneva, 15 Sept. 2005.44 p.

Council for Trade-Related Aspects of Intellectual Property Rights. Minutes of the meeting held in the Centre William Rappard on 1-2 December 2004. IP/C/M/46. Geneva, 11 Jan. 2005. 50 p.

. Council for Trade-Related Aspects of Intellectual Property Rights. Minutes of meeting held in the Centre William Rappard on 8 - 9 and 31 March 2005. IP/C/M/47. Geneva, 3 June 2005. 51 p.

Council for Trade-Related Aspects of Intellectual Property Rights. Minutes of meeting held in the Centre William Rappard on 18 November 2003. IP/C/M/42. Geneva, 4 Feb. 2004. 35 p.

Council for Trade-Related Aspects of Intellectual Property Rights. Minutes of meeting held in the Centre William Rappard on 18-19 February 2003. IP/C/M/39. Geneva, 21 Mar. 2003. 39 p.

Council for Trade-Related Aspects of Intellectual Property Rights. Communication from the United States: Views of the United States on the relationship between the Convention on Biological Diversity and the TRIPS agreement. IP/C/W/257. Geneva, 13 June 2003. 7 p.

Council for Trade-Related Aspects of Intellectual Property Rights. Minutes of meeting held in the Centre William Rappard on 18 to 22 June 2001. IP/C/M/32. Geneva 23 Aug. 2001. 60 p.

Council for Trade-Related Aspects of Intellectual Property Rights. Minutes of meeting held in the Centre William Rappard on 17-19 September 2002. IP/C/M/37/Add.1. Geneva, 8 Nov. 2002. 88 p.

Council for Trade-Related Aspects of Intellectual Property Rights. Minutes of meeting held in the Centre William Rappard on 8 march 2004. IP/C/M/43. Geneva, 7 May 2004. 19 p. 
Council for Trade-Related Aspects of Intellectual Property Rights. Review of the provisions of article 27.3(b): Illustrative list of questions. IP/C/W/273/Rev.1. Geneva, 18 Feb. 2003. 56 p.

. Comité de Comercio y Medio Ambiente. La relación entre las disposiciones del sistema multilateral del comercio y los acuerdos multilaterales sobre el medio ambiente (AMUMA): Comunicación de Suiza. WT/CTE/W/139. Ginebra, 8 jun. 2000.

. Consejo de los Aspectos de los Derechos de Propiedad Intelectual relacionados con el Comercio. Acta de la reunión celebrada en el Centro William Rappard los días 25, 26 y 28 de octubre, 29 de noviembre y 6 de diciembre de 2005. IP/C/M/49. Ginebra, 31 enero $2006.71 \mathrm{p}$.

- Council for Trade-Related Aspects of Intellectual Property Rights. Communication from Peru: response to comments contained in document IP/C/W/469 relating to the Peruvian communication IP/C/W/458. IP/C/W/484. Geneva, 2 Nov. 2006. 5 p.

- Decisión sobre comercio y medio ambiente. Aprovada pelo Comitê de Negociações Comerciais da Rodada Uruguai e adotada pelos Ministros na reunião celebrada em 14 de abril de 1994.

2001.

Doha Ministerial Declaration. WT/MIN(01)/DEC/1. Doha, 14 de novembro de

. Examen del párrafo 3 b) del artículo 27: Comunicación del Brasil._IP/C/W/228. 24 nov. 2000.

. Marrakesh Declaration of 15 April 1994.

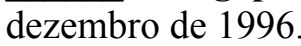

YANO, L. I. Protection of the ethnobiological knowledge of indigenous peoples. UCLA Law Review, vol. 41, p. 443-486, 1993-1994.

YU, P. K. Intellectual Property and the Information Ecosystem. Michigan State Law Review, vol. 2005, no. 1, pp. 1-20.

Reconceptualizing intellectual property interests in a human rights framework.

University of California Davis Law Review, vol. 40, p. 1039-1149, 2007.

YUPARI, A.; JARAMILLO, L.; LOJENGA, R. K.; BRICEÑO, S.; SÁNCHEZ, R. UNCTAD's BIOTRADE Initiative: some considerations on access, benefits sharing and traditional knowledge. In: Twarog, S.; Kapoor, P. (Ed.). Protecting and promoting traditional knowledge: systems, national experiences and international dimensions. New York \& Geneva: United Nations, 2004, p. 325-336.

ZARRILLI, S. International Trade in Genetically Modified Organisms and

Multilateral Negotiations: a new dilemma for developing countries.

UNCTAD/DITC/TNCD/1. Geneva: UNCTAD, 5 de julho de 2000. 45 p. 
ZERDA-SARMIENTO, A.; FORERO-PIÑEDA, C. Intellectual property rights over ethnic communities' knowledge. International Social Science Journal, vol. 54, no. 171, p. 99$114,2002$.

\section{Páginas da internet}

- Amigos do Bem - Contra a Fome e a Miséria no Sertão Nordestino. Disponível em:

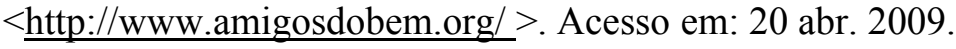

- Artesanato Solidário. Disponível em: <www.artesol.org.br>. Acesso em: 20 abr. 2009.

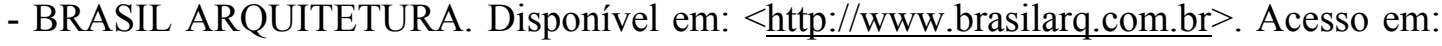
20 abr. 2009.

- Campanha Y IKATU XINGU. Disponível em: <http://www.yikatuxingu.org.br/acampanha>. Acesso em: 20 abr. 2009.

- Centro de Biotecnologia da Amazônia. Informações sobre os serviços prestados. Disponível em: $<$ http://www.suframa.gov.br/cba/servicos.cfm> $>$. Acesso em: 20 abr. 2009.

- Consultative Group on International Agricultural Research. Disponível em:

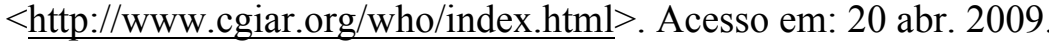

- ETC Group. Glosário: item sobre biopirataria. Disponível em:

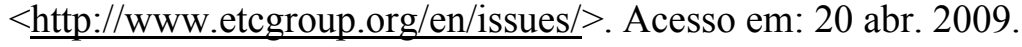

- Extracta Moléculas Naturais S.A. Disponível em: $<\underline{\text { http: } / / w w w . e x t r a c t a . c o m . b r} />$. Acesso em: 20 abr. 2009.

- iBridge Network. Disponível em: $<$ http://www.ibridgenetwork.org/info/about $>$. Acesso em: 20 abr. 2009.

- Lots of Copies Keep Stuff Safe (LOCKSS). Disponível em:

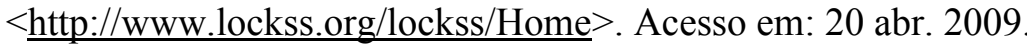

- Ministry of Environment and Forests, Government of India. Disponível em: $<$ http://lmmc.nic.in/prologueLmmc_new.php?Section=two>. Acesso em: 05 dez. 2008.

- Napo Pharmaceuticals. Informações sobre o medicamento Crofelemer. Disponível em: $<$ http://www.napopharma.com/products/sustainability.html $>$. Acesso em: 20 abr. 2009.

- National Indigenous Arts Advocacy Association. Disponível em: $<$ http://www.culture.com.au/exhibition/niaaa/about.htm>. Acesso em: 20 abr. 2009.

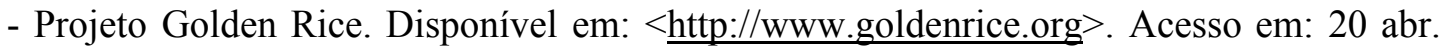
2009. 
- Public Interest Intellectual Property Advisors. Disponível em: <http://www.piipa.org $>$. Acesso em: 20 abr. 2009.

- Secretariado da Convenção sobre Biodiversidade. Lista dos países contratantes da Convenção sobre Diversidade Biológica. Disponível em: $<$ http://www.cbd.int/convention/parties/list/> . Acesso em: 20 abr. 2009.

- Traditional Ecological Knowledge Prior Art Database. Disponível em:

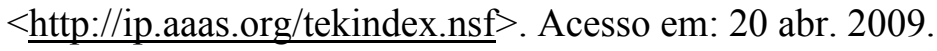

- Traditional Knowledge Digital Library. Disponível em: $<$ http://www.tkdl.res.in/tkdl/langdefault/common/home.asp?GL=Eng $>$. Acesso em: 20 abr. 2009.

- Tratado Internacional sobre los Recursos Fitogenéticos para la Alimentación y Agricultura. Acuerdos concluidos en virtud del Artículo 15 del Tratado. Disponível em:

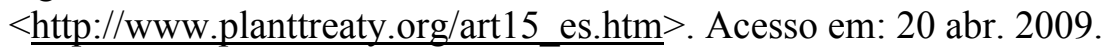

- UNESCO. Lista de países contratantes da Convenção para a Salvaguarda do Patrimônio Cultural Imaterial. Disponível em: $<$ http://portal.unesco.org $/$ la/convention.asp? $\mathrm{KO}=17116 \&$ language $=\mathrm{E} \&$ order $=$ alpha $>$.

Acesso em: 20 abr. 2009.

- _ _ _ Lista de países contratantes da Convenção sobre a Proteção e Promoção da

Diversidade de Expressões Culturais.Disponível em:

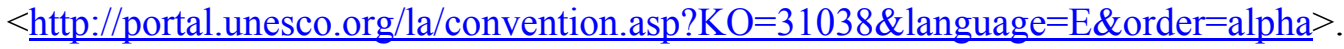

Acesso em: 20 abr. 2009.

- United Nations. Lista dos países contratantes do Pacto Internacional de Direitos Civis e Políticos. Disponível em:

$<$ http://treaties.un.org/Pages/ViewDetails.aspx?src=TREATY\&id=322\&chapter=4\&lang= en>. Acesso em: 20 abr. 2009.

- _. Lista dos países contratantes do Pacto Internacional de Direitos Econômicos, Sociais e Culturais. Disponível em: $<$ http://treaties.un.org/Pages/ViewDetails.aspx?src=TREATY\&id=321\&chapter=4\&lang= en>. Acesso em: 20 abr. 2009.

- University of Edinburgh. Edinburgh Research and Innovation. Disponível em: $<$ http://licensing.research-innovation.ed.ac.uk> . Acesso em: 20 abr. 2009.

- World Bank. Indigenous Knowledge Database. Disponivel em:

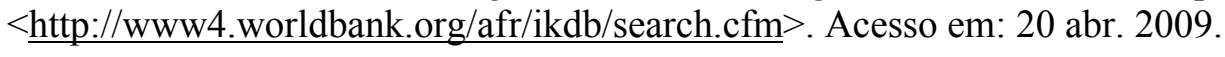

-Wikipedia. Item sobre a Bolívia. Disponível em: $<$ http://es.wikipedia.org/wiki/Bolivia $>$. Acesso em: 20 abr. 2009. 


\section{APÊNDICE I - ESTADOS CONTRATANTES DOS PRINCIPAIS INSTRUMENTOS INTERNACIONAIS, QUE APÓIAM O QUADRO CONCEITUAL DE DESENVOLVIMENTO SUSTENTÁVEL}

\begin{tabular}{|l|l|l|l|l|l|}
\hline \multicolumn{1}{|c|}{ PAÍ́S } & CDB $^{\mathbf{1 9 3 1}}$ & PIDESC $^{\mathbf{1 9 3 2}}$ & PIDCP $^{\mathbf{1 9 3 3}}$ & CSPCI $^{\mathbf{9 3 4}}$ & CPPDEC $^{\mathbf{1 9 3 5}}$ \\
\hline Afghanistan & $\mathrm{X}$ & $\mathrm{X}$ & $\mathrm{X}$ & $\mathrm{X}$ & $\mathrm{X}$ \\
\hline Albânia & $\mathrm{X}$ & $\mathrm{X}$ & $\mathrm{X}$ & $\mathrm{X}$ & $\mathrm{X}$ \\
\hline Algeria & $\mathrm{X}$ & $\mathrm{X}$ & $\mathrm{X}$ & $\mathrm{X}$ & \\
\hline Andorra & & & $\mathrm{X}$ & & $\mathrm{X}$ \\
\hline Angola & $\mathrm{X}$ & $\mathrm{X}$ & $\mathrm{X}$ & & \\
\hline $\begin{array}{l}\text { Antigua and } \\
\text { Barbuda }\end{array}$ & $\mathrm{X}$ & & & & \\
\hline Argentina & $\mathrm{X}$ & $\mathrm{X}$ & $\mathrm{X}$ & $\mathrm{X}$ & $\mathrm{X}$ \\
\hline Armenia & $\mathrm{X}$ & $\mathrm{X}$ & $\mathrm{X}$ & $\mathrm{X}$ & $\mathrm{X}$ \\
\hline Australia & $\mathrm{X}$ & $\mathrm{X}$ & $\mathrm{X}$ & & \\
\hline Austria & $\mathrm{X}$ & $\mathrm{X}$ & $\mathrm{X}$ & & $\mathrm{X}$ \\
\hline Azerbaijan & $\mathrm{X}$ & $\mathrm{X}$ & $\mathrm{X}$ & $\mathrm{X}$ & \\
\hline Bahamas & $\mathrm{X}$ & $\mathrm{X}$ & $\mathrm{X}$ & & \\
\hline Bahrain & $\mathrm{X}$ & $\mathrm{X}$ & $\mathrm{X}$ & & \\
\hline Bangladesh & $\mathrm{X}$ & $\mathrm{X}$ & $\mathrm{X}$ & & $\mathrm{X}$ \\
\hline Barbados & $\mathrm{X}$ & $\mathrm{X}$ & $\mathrm{X}$ & $\mathrm{X}$ & $\mathrm{X}$ \\
\hline Belarus & $\mathrm{X}$ & $\mathrm{X}$ & $\mathrm{X}$ & $\mathrm{X}$ & $\mathrm{X}$ \\
\hline Belgium & $\mathrm{X}$ & $\mathrm{X}$ & $\mathrm{X}$ & $\mathrm{X}$ & \\
\hline Belize & $\mathrm{X}$ & & $\mathrm{X}$ & $\mathrm{X}$ & \\
\hline Benin & $\mathrm{X}$ & & $\mathrm{X}$ & & $\mathrm{X}$ \\
\hline Bhutan & $\mathrm{X}$ & $\mathrm{X}$ & $\mathrm{X}$ & $\mathrm{X}$ & $\mathrm{X}$ \\
\hline Bolivia & $\mathrm{X}$ & $\mathrm{X}$ & $\mathrm{X}$ & $\mathrm{X}$ & $\mathrm{X}$ \\
\hline $\begin{array}{l}\text { Bosnia and } \\
\text { Herzegovina }\end{array}$ & $\mathrm{X}$ & $\mathrm{X}$ & $\mathrm{X}$ & $\mathrm{X}$ & $\mathrm{X}$ \\
\hline Botswana & $\mathrm{X}$ & $\mathrm{X}$ & & & \\
\hline Brazil & $\mathrm{X}$ & & & & \\
\hline $\begin{array}{l}\text { Brunei } \\
\text { Darussalam }\end{array}$ & & & & & \\
\hline & & & & & \\
\hline
\end{tabular}

${ }^{1931}$ Lista dos Estados contratantes está disponível em: < http://www.cbd.int/convention/parties/list/>. Acesso em: 13 abr. 2009.

1932 Lista

dos Estados

contratantes

está

disponível em:

$<$ http://reaties.un.org/Pages/ViewDetails.aspx?src=TREATY\&id=321\&chapter=4\&lang=en $>$. Acesso em: 13 abr. 2009.

1933 Lista dos Estados contratantes está disponível em:

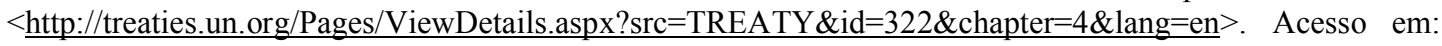
13 abr. 2009.

1934 Lista dos Estados contratantes está disponível em: $<$ http://portal.unesco.org/la/convention.asp?KO=17116\&language=E\&order=alpha $>$. Acesso em: 13 abr. 2009.

${ }^{1935}$ Lista dos Estados contratantes está disponível em:

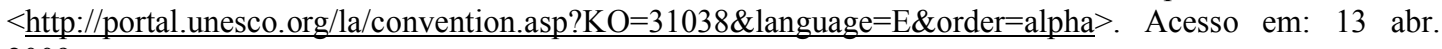
2009. 


\begin{tabular}{|c|c|c|c|c|c|}
\hline Bulgaria & $\mathrm{X}$ & $\mathrm{X}$ & $\mathrm{X}$ & $\mathrm{X}$ & $\mathrm{X}$ \\
\hline Burkina Faso & $\mathrm{X}$ & $\mathrm{X}$ & $\mathrm{X}$ & $\mathrm{X}$ & $\mathrm{X}$ \\
\hline Burundi & $\mathrm{X}$ & $\mathrm{X}$ & $\mathrm{X}$ & $\mathrm{X}$ & $\mathrm{X}$ \\
\hline Cambodia & $\mathrm{X}$ & $\mathrm{X}$ & & $\mathrm{X}$ & $\mathrm{X}$ \\
\hline Cameroon & $\mathrm{X}$ & $\mathrm{X}$ & $\mathrm{X}$ & & $\mathrm{X}$ \\
\hline Canada & $\mathrm{X}$ & $\mathrm{X}$ & $\mathrm{X}$ & & $\mathrm{X}$ \\
\hline Cape Verde & $\mathrm{X}$ & $\mathrm{X}$ & $\mathrm{X}$ & & \\
\hline $\begin{array}{l}\text { Central } \\
\text { African } \\
\text { Republic }\end{array}$ & $\mathrm{X}$ & $\mathrm{X}$ & $\mathrm{X}$ & $\mathrm{X}$ & \\
\hline Chad & $\mathrm{X}$ & $\mathrm{X}$ & $\mathrm{X}$ & $\mathrm{X}$ & $\mathrm{X}$ \\
\hline Chile & $\mathrm{X}$ & $\mathrm{X}$ & $\mathrm{X}$ & $\mathrm{X}$ & $\mathrm{X}$ \\
\hline China & $\mathrm{X}$ & $\mathrm{X}$ & & $\mathrm{X}$ & $\mathrm{X}$ \\
\hline Colombia & $\mathrm{X}$ & $\mathrm{X}$ & $\mathrm{X}$ & $\mathrm{X}$ & \\
\hline Comoros & $\mathrm{X}$ & & & & \\
\hline Congo & $\mathrm{X}$ & $\mathrm{X}$ & $\mathrm{X}$ & & $\mathrm{X}$ \\
\hline Cook Islands & $\mathrm{X}$ & & & & \\
\hline Costa Rica & $\mathrm{X}$ & $\mathrm{X}$ & $\mathrm{X}$ & $\mathrm{X}$ & \\
\hline Côte d'Ivoire & $\mathrm{X}$ & $\mathrm{X}$ & $\mathrm{X}$ & $\mathrm{X}$ & $\mathrm{X}$ \\
\hline Croatia & $\mathrm{X}$ & $\mathrm{X}$ & $\mathrm{X}$ & $\mathrm{X}$ & $\mathrm{X}$ \\
\hline Cuba & $\mathrm{X}$ & & & $\mathrm{X}$ & $\mathrm{X}$ \\
\hline Cyprus & $\mathrm{X}$ & $\mathrm{X}$ & $\mathrm{X}$ & $\mathrm{X}$ & $\mathrm{X}$ \\
\hline $\begin{array}{l}\text { Czech } \\
\text { Republic }\end{array}$ & $\mathrm{X}$ & $\mathrm{X}$ & $X$ & $\mathrm{X}$ & \\
\hline $\begin{array}{l}\text { Democratic } \\
\text { People's } \\
\text { Republic of } \\
\text { Korea }\end{array}$ & $\mathrm{X}$ & $\mathrm{X}$ & $\mathrm{X}$ & $\mathrm{X}$ & \\
\hline $\begin{array}{l}\text { Democratic } \\
\text { Republic of } \\
\text { the Congo }\end{array}$ & $\mathrm{X}$ & $\mathrm{X}$ & $\mathrm{X}$ & & \\
\hline Denmark & $\mathrm{X}$ & $\mathrm{X}$ & $\mathrm{X}$ & & $\mathrm{X}$ \\
\hline Djibouti & $\mathrm{X}$ & $\mathrm{X}$ & $\mathrm{X}$ & $\mathrm{X}$ & $\mathrm{X}$ \\
\hline Dominica & $\mathrm{X}$ & $\mathrm{X}$ & $\mathrm{X}$ & $\mathrm{X}$ & \\
\hline $\begin{array}{l}\text { Dominican } \\
\text { Republic }\end{array}$ & $\mathrm{X}$ & $\mathrm{X}$ & $\mathrm{X}$ & $\mathrm{X}$ & \\
\hline Ecuador & $\mathrm{X}$ & $\mathrm{X}$ & $\mathrm{X}$ & $\mathrm{X}$ & $\mathrm{X}$ \\
\hline Egypt & $\mathrm{X}$ & $\mathrm{X}$ & $\mathrm{X}$ & $\mathrm{X}$ & $\mathrm{X}$ \\
\hline El Salvador & $\mathrm{X}$ & $\mathrm{X}$ & $\mathrm{X}$ & & \\
\hline $\begin{array}{l}\text { Equatorial } \\
\text { Guinea }\end{array}$ & $\mathrm{X}$ & $\mathrm{X}$ & $\mathrm{X}$ & & \\
\hline Eritrea & $\mathrm{X}$ & $\mathrm{X}$ & $\mathrm{X}$ & & \\
\hline Estonia & $\mathrm{X}$ & $\mathrm{X}$ & $\mathrm{X}$ & $\mathrm{X}$ & $\mathrm{X}$ \\
\hline Ethiopia & $\mathrm{X}$ & $\mathrm{X}$ & $\mathrm{X}$ & $\mathrm{X}$ & $\mathrm{X}$ \\
\hline $\begin{array}{l}\text { European } \\
\text { Community }\end{array}$ & $X$ & & & & \\
\hline Fiji & $\mathrm{X}$ & & & & \\
\hline Finland & $\mathrm{X}$ & $\mathrm{X}$ & $\mathrm{X}$ & & $\mathrm{X}$ \\
\hline France & $\mathrm{X}$ & $\mathrm{X}$ & $\mathrm{X}$ & $\mathrm{X}$ & $X$ \\
\hline
\end{tabular}




\begin{tabular}{|c|c|c|c|c|c|}
\hline Gabon & $\mathrm{X}$ & $X$ & $\mathrm{X}$ & $\mathrm{X}$ & $\mathrm{X}$ \\
\hline Gambia & $\mathrm{X}$ & $X$ & $\mathrm{X}$ & & \\
\hline Georgia & $\mathrm{X}$ & $\mathrm{X}$ & $\mathrm{X}$ & $\mathrm{X}$ & $\mathrm{X}$ \\
\hline Germany & $\mathrm{X}$ & $\mathrm{X}$ & $\mathrm{X}$ & & $\mathrm{X}$ \\
\hline Ghana & $\mathrm{X}$ & $\mathrm{X}$ & $\mathrm{X}$ & & \\
\hline Greece & $\mathrm{X}$ & $\mathrm{X}$ & $\mathrm{X}$ & $\mathrm{X}$ & $\mathrm{X}$ \\
\hline Grenada & $\mathrm{X}$ & $X$ & $\mathrm{X}$ & $\mathrm{X}$ & $X$ \\
\hline Guatemala & $\mathrm{X}$ & $\mathrm{X}$ & $\mathrm{X}$ & $\mathrm{X}$ & $\mathrm{X}$ \\
\hline Guinea & $\mathrm{X}$ & $\mathrm{X}$ & $\mathrm{X}$ & $\mathrm{X}$ & $\mathrm{X}$ \\
\hline $\begin{array}{l}\text { Guinea- } \\
\text { Bissau }\end{array}$ & $\mathrm{X}$ & $X$ & & & \\
\hline Guyana & $\mathrm{X}$ & $\mathrm{X}$ & $\mathrm{X}$ & & \\
\hline Haiti & $\mathrm{X}$ & & $\mathrm{X}$ & & \\
\hline Honduras & $\mathrm{X}$ & $\mathrm{X}$ & $\mathrm{X}$ & $\mathrm{X}$ & \\
\hline Hungary & $\mathrm{X}$ & $X$ & $\mathrm{X}$ & $\mathrm{X}$ & $X$ \\
\hline Iceland & $\mathrm{X}$ & $\mathrm{X}$ & $\mathrm{X}$ & $\mathrm{X}$ & $\mathrm{X}$ \\
\hline India & $\mathrm{X}$ & $\mathrm{X}$ & $\mathrm{X}$ & $\mathrm{X}$ & $\mathrm{X}$ \\
\hline Indonesia & $\mathrm{X}$ & $\mathrm{X}$ & $\mathrm{X}$ & $\mathrm{X}$ & \\
\hline $\begin{array}{l}\text { Iran (Islamic } \\
\text { Republic of) }\end{array}$ & $\mathrm{X}$ & $\mathrm{X}$ & $\mathrm{X}$ & $\mathrm{X}$ & \\
\hline Iraq & & $\mathrm{X}$ & $\mathrm{X}$ & & \\
\hline Ireland & $\mathrm{X}$ & $X$ & $\mathrm{X}$ & & $X$ \\
\hline Israel & $\mathrm{X}$ & $\mathrm{X}$ & $\mathrm{X}$ & & \\
\hline Italy & $\mathrm{X}$ & $\mathrm{X}$ & $\mathrm{X}$ & $\mathrm{X}$ & $X$ \\
\hline Jamaica & $\mathrm{X}$ & $\mathrm{X}$ & $\mathrm{X}$ & & $\mathrm{X}$ \\
\hline Japan & $\mathrm{X}$ & $\mathrm{X}$ & $\mathrm{X}$ & $\mathrm{X}$ & \\
\hline Jordan & $\mathrm{X}$ & $\mathrm{X}$ & $\mathrm{X}$ & $\mathrm{X}$ & $\mathrm{X}$ \\
\hline Kazakhstan & $\mathrm{X}$ & $\mathrm{X}$ & $\mathrm{X}$ & & \\
\hline Kenya & $\mathrm{X}$ & $\mathrm{X}$ & $\mathrm{X}$ & $\mathrm{X}$ & $\mathrm{X}$ \\
\hline Kiribati & $\mathrm{X}$ & & & & \\
\hline Kuwait & $\mathrm{X}$ & $\mathrm{X}$ & $\mathrm{X}$ & & $\mathrm{X}$ \\
\hline Kyrgyzstan & $\mathrm{X}$ & $\mathrm{X}$ & $\mathrm{X}$ & $\mathrm{X}$ & \\
\hline $\begin{array}{l}\text { Lao People's } \\
\text { Democratic } \\
\text { Republic }\end{array}$ & $\mathrm{X}$ & $\mathrm{X}$ & & & $\mathrm{X}$ \\
\hline Latvia & $\mathrm{X}$ & $\mathrm{X}$ & $\mathrm{X}$ & $\mathrm{X}$ & $\mathrm{X}$ \\
\hline Lebanon & $\mathrm{X}$ & $\mathrm{X}$ & $\mathrm{X}$ & $\mathrm{X}$ & \\
\hline Lesotho & $\mathrm{X}$ & $\mathrm{X}$ & $\mathrm{X}$ & $\mathrm{X}$ & \\
\hline Liberia & $\mathrm{X}$ & $X$ & $X$ & & \\
\hline $\begin{array}{l}\text { Libyan Arab } \\
\text { Jamahiriya }\end{array}$ & $\mathrm{X}$ & $X$ & $\mathrm{X}$ & & \\
\hline Liechtenstein & $\mathrm{X}$ & $\mathrm{X}$ & $\mathrm{X}$ & & \\
\hline Lithuania & $\mathrm{X}$ & $X$ & $\mathrm{X}$ & $\mathrm{X}$ & $\mathrm{X}$ \\
\hline Luxembourg & $\mathrm{X}$ & $\mathrm{X}$ & $\mathrm{X}$ & $\mathrm{X}$ & $\mathrm{X}$ \\
\hline Madagascar & $\mathrm{X}$ & $\mathrm{X}$ & $\mathrm{X}$ & $\mathrm{X}$ & $\mathrm{X}$ \\
\hline Malawi & $\mathrm{X}$ & $\mathrm{X}$ & $\mathrm{X}$ & & \\
\hline Malaysia & $\mathrm{X}$ & & & & \\
\hline Maldives & $\mathrm{X}$ & $\mathrm{X}$ & $\mathrm{X}$ & & \\
\hline Mali & $\mathrm{X}$ & $\mathrm{X}$ & $\mathrm{X}$ & $\mathrm{X}$ & $\mathrm{X}$ \\
\hline
\end{tabular}




\begin{tabular}{|l|l|l|l|l|l|}
\hline Malta & $\mathrm{X}$ & $\mathrm{X}$ & $\mathrm{X}$ & & $\mathrm{X}$ \\
\hline $\begin{array}{l}\text { Marshall } \\
\text { Islands }\end{array}$ & $\mathrm{X}$ & & & & \\
\hline Mauritania & $\mathrm{X}$ & $\mathrm{X}$ & $\mathrm{X}$ & $\mathrm{X}$ & \\
\hline Mauritius & $\mathrm{X}$ & $\mathrm{X}$ & $\mathrm{X}$ & $\mathrm{X}$ & $\mathrm{X}$ \\
\hline Mexico & $\mathrm{X}$ & $\mathrm{X}$ & $\mathrm{X}$ & $\mathrm{X}$ & $\mathrm{X}$ \\
\hline $\begin{array}{l}\text { Micronesia } \\
\text { Federated } \\
\text { States of }\end{array}$ & $\mathrm{X}$ & & & & \\
\hline Monaco & $\mathrm{X}$ & $\mathrm{X}$ & $\mathrm{X}$ & $\mathrm{X}$ & $\mathrm{X}$ \\
\hline Mongolia & $\mathrm{X}$ & $\mathrm{X}$ & $\mathrm{X}$ & $\mathrm{X}$ & $\mathrm{X}$ \\
\hline Montenegro & $\mathrm{X}$ & $\mathrm{X}$ & $\mathrm{X}$ & & $\mathrm{X}$ \\
\hline Morocco & $\mathrm{X}$ & $\mathrm{X}$ & $\mathrm{X}$ & $\mathrm{X}$ & \\
\hline Mozambique & $\mathrm{X}$ & & $\mathrm{X}$ & $\mathrm{X}$ & $\mathrm{X}$ \\
\hline Myanmar & $\mathrm{X}$ & & & & \\
\hline Namibia & $\mathrm{X}$ & $\mathrm{X}$ & $\mathrm{X}$ & $\mathrm{X}$ & $\mathrm{X}$ \\
\hline Nauru & $\mathrm{X}$ & & $\mathrm{X}$ & & \\
\hline Nepal & $\mathrm{X}$ & $\mathrm{X}$ & $\mathrm{X}$ & & \\
\hline Netherlands & $\mathrm{X}$ & $\mathrm{X}$ & $\mathrm{X}$ & & \\
\hline New Zealand & $\mathrm{X}$ & $\mathrm{X}$ & $\mathrm{X}$ & & $\mathrm{X}$ \\
\hline Nicaragua & $\mathrm{X}$ & $\mathrm{X}$ & $\mathrm{X}$ & $\mathrm{X}$ & $\mathrm{X}$ \\
\hline Niger & $\mathrm{X}$ & $\mathrm{X}$ & $\mathrm{X}$ & $\mathrm{X}$ & $\mathrm{X}$ \\
\hline Nigeria & $\mathrm{X}$ & $\mathrm{X}$ & $\mathrm{X}$ & $\mathrm{X}$ & $\mathrm{X}$ \\
\hline Niue & $\mathrm{X}$ & & & & \\
\hline Norway & $\mathrm{X}$ & $\mathrm{X}$ & $\mathrm{X}$ & $\mathrm{X}$ & $\mathrm{X}$ \\
\hline Oman & $\mathrm{X}$ & & $\mathrm{X}$ & $\mathrm{X}$ \\
\hline Pakistan & $\mathrm{X}$ & $\mathrm{X}$ & & $\mathrm{X}$ & \\
\hline Palau & $\mathrm{X}$ & & $\mathrm{X}$ & $\mathrm{X}$ & $\mathrm{X}$ \\
\hline Panama & $\mathrm{X}$ & $\mathrm{X}$ & $\mathrm{X}$ & $\mathrm{X}$ & $\mathrm{X}$ \\
\hline $\begin{array}{l}\text { Papua New } \\
\text { Guinea }\end{array}$ & $\mathrm{X}$ & $\mathrm{X}$ & $\mathrm{X}$ & $\mathrm{X}$ & \\
\hline Paraguay & $\mathrm{X}$ & $\mathrm{X}$ & $\mathrm{X}$ & $\mathrm{X}$ & $\mathrm{X}$ \\
\hline Peru & $\mathrm{X}$ & $\mathrm{X}$ & $\mathrm{X}$ & $\mathrm{X}$ & $\mathrm{X}$ \\
\hline Philippines & $\mathrm{X}$ & $\mathrm{X}$ & $\mathrm{X}$ & $\mathrm{X}$ & \\
\hline Poland & $\mathrm{X}$ & $\mathrm{X}$ & $\mathrm{X}$ & $\mathrm{X}$ & \\
\hline Portugal & $\mathrm{X}$ & $\mathrm{X}$ & $\mathrm{X}$ & $\mathrm{X}$ & \\
\hline Qatar & $\mathrm{X}$ & & $\mathrm{X}$ & $\mathrm{X}$ & \\
\hline $\begin{array}{l}\text { Republic of } \\
\text { Korea }\end{array}$ & $\mathrm{X}$ & $\mathrm{X}$ & $\mathrm{X}$ & \\
\hline $\begin{array}{l}\text { Republic of } \\
\text { Moldova }\end{array}$ & $\mathrm{X}$ & $\mathrm{X}$ & $\mathrm{X}$ & $\mathrm{X}$ & \\
\hline Romania & $\mathrm{X}$ & $\mathrm{X}$ & $\mathrm{X}$ & $\mathrm{X}$ & $\mathrm{X}$ \\
\hline $\begin{array}{l}\text { Russian } \\
\text { Federation }\end{array}$ & $\mathrm{X}$ & $\mathrm{X}$ & $\mathrm{X}$ & & \\
\hline Rwanda & $\mathrm{X}$ & $\mathrm{X}$ & & & \\
\hline $\begin{array}{l}\text { Saint Kitts } \\
\text { and Nevis }\end{array}$ & $\mathrm{X}$ & & & & \\
\hline Saint Lucia & $\mathrm{X}$ & & & & \\
\hline Saint Vincent & $\mathrm{X}$ & & & & \\
\hline & & & & & \\
\hline
\end{tabular}




\begin{tabular}{|l|l|l|l|l|l|}
\hline $\begin{array}{l}\text { and the } \\
\text { Grenadines }\end{array}$ & & & & & \\
\hline Samoa & $\mathrm{X}$ & & $\mathrm{X}$ & & \\
\hline San Marino & $\mathrm{X}$ & $\mathrm{X}$ & $\mathrm{X}$ & & \\
\hline $\begin{array}{l}\text { Sao Tome and } \\
\text { Principe }\end{array}$ & $\mathrm{X}$ & & & $\mathrm{X}$ & \\
\hline Saudi Arabia & $\mathrm{X}$ & & & $\mathrm{X}$ & \\
\hline Senegal & $\mathrm{X}$ & $\mathrm{X}$ & $\mathrm{X}$ & $\mathrm{X}$ & $\mathrm{X}$ \\
\hline Serbia & $\mathrm{X}$ & $\mathrm{X}$ & $\mathrm{X}$ & & \\
\hline Seychelles & $\mathrm{X}$ & $\mathrm{X}$ & $\mathrm{X}$ & $\mathrm{X}$ & $\mathrm{X}$ \\
\hline Sierra Leone & $\mathrm{X}$ & $\mathrm{X}$ & $\mathrm{X}$ & & \\
\hline Singapore & $\mathrm{X}$ & & & & \\
\hline Slovakia & $\mathrm{X}$ & $\mathrm{X}$ & $\mathrm{X}$ & $\mathrm{X}$ & $\mathrm{X}$ \\
\hline Slovenia & $\mathrm{X}$ & $\mathrm{X}$ & $\mathrm{X}$ & $\mathrm{X}$ & $\mathrm{X}$ \\
\hline $\begin{array}{l}\text { Solomon } \\
\text { Islands }\end{array}$ & $\mathrm{X}$ & $\mathrm{X}$ & & & \\
\hline Somalia & & $\mathrm{X}$ & $\mathrm{X}$ & & \\
\hline South Africa & $\mathrm{X}$ & $\mathrm{X}$ & $\mathrm{X}$ & $\mathrm{X}$ & $\mathrm{X}$ \\
\hline Spain & $\mathrm{X}$ & $\mathrm{X}$ & $\mathrm{X}$ & $\mathrm{X}$ & \\
\hline Sri Lanka & $\mathrm{X}$ & $\mathrm{X}$ & $\mathrm{X}$ & $\mathrm{X}$ & $\mathrm{X}$ \\
\hline Sudan & $\mathrm{X}$ & $\mathrm{X}$ & $\mathrm{X}$ & $\mathrm{X}$ & \\
\hline Suriname & $\mathrm{X}$ & $\mathrm{X}$ & $\mathrm{X}$ & $\mathrm{X}$ & \\
\hline Swaziland & $\mathrm{X}$ & $\mathrm{X}$ & $\mathrm{X}$ & & \\
\hline Sweden & $\mathrm{X}$ & $\mathrm{X}$ & $\mathrm{X}$ & & $\mathrm{X}$ \\
\hline Switzerland & $\mathrm{X}$ & $\mathrm{X}$ & $\mathrm{X}$ & $\mathrm{X}$ & $\mathrm{X}$ \\
\hline $\begin{array}{l}\text { Syrian Arab } \\
\text { Republic }\end{array}$ & $\mathrm{X}$ & $\mathrm{X}$ & $\mathrm{X}$ & $\mathrm{X}$ & $\mathrm{X}$ \\
\hline Tajikistan & $\mathrm{X}$ & $\mathrm{X}$ & $\mathrm{X}$ & & $\mathrm{X}$ \\
\hline Thailand & $\mathrm{X}$ & $\mathrm{X}$ & $\mathrm{X}$ & $\mathrm{X}$ & \\
\hline $\begin{array}{l}\text { The former } \\
\text { Yugoslav } \\
\text { Republic of } \\
\text { Macedonia }\end{array}$ & $\mathrm{X}$ & $\mathrm{X}$ & $\mathrm{X}$ & $\mathrm{X}$ & $\mathrm{X}$ \\
\hline Timor-Leste & $\mathrm{X}$ & $\mathrm{X}$ & $\mathrm{X}$ & & \\
\hline Togo & $\mathrm{X}$ & $\mathrm{X}$ & $\mathrm{X}$ & & \\
\hline Tonga & $\mathrm{X}$ & $\mathrm{X}$ & $\mathrm{X}$ & & \\
\hline $\begin{array}{l}\text { Trinidad and } \\
\text { Tobago }\end{array}$ & $\mathrm{X}$ & $\mathrm{X}$ & $\mathrm{X}$ & & \\
\hline Tunisia & $\mathrm{X}$ & $\mathrm{X}$ & $\mathrm{X}$ & \\
\hline Turkey & $\mathrm{X}$ & $\mathrm{X}$ & $\mathrm{X}$ & \\
\hline Turkmenistan & $\mathrm{X}$ & $\mathrm{X}$ & $\mathrm{X}$ & \\
\hline Tuvalu & $\mathrm{X}$ & & & & \\
\hline Uganda & $\mathrm{X}$ & $\mathrm{X}$ & & & \\
\hline Ukraine & $\mathrm{X}$ & $\mathrm{X}$ & & \\
\hline United Arab \\
Emirates & $\mathrm{X}$ & & & & \\
\hline $\begin{array}{l}\text { United } \\
\text { Kingdom of } \\
\text { Great Britain }\end{array}$ & & & & & \\
\hline
\end{tabular}


APÊNDICE I | 555

\begin{tabular}{|l|l|l|l|l|l|}
\hline $\begin{array}{l}\text { and Northern } \\
\text { Ireland }\end{array}$ & & & & & \\
\hline $\begin{array}{l}\text { United } \\
\text { Republic of } \\
\text { Tanzania }\end{array}$ & $\mathrm{X}$ & $\mathrm{X}$ & $\mathrm{X}$ & & \\
\hline $\begin{array}{l}\text { United States } \\
\text { of America }\end{array}$ & & & $\mathrm{X}$ & & \\
\hline Uruguay & $\mathrm{X}$ & $\mathrm{X}$ & $\mathrm{X}$ & $\mathrm{X}$ & $\mathrm{X}$ \\
\hline Uzbekistan & $\mathrm{X}$ & $\mathrm{X}$ & $\mathrm{X}$ & $\mathrm{X}$ & \\
\hline Vanuatu & $\mathrm{X}$ & & $\mathrm{X}$ & & \\
\hline Venezuela & $\mathrm{X}$ & $\mathrm{X}$ & $\mathrm{X}$ & $\mathrm{X}$ & \\
\hline Viet Nam & $\mathrm{X}$ & $\mathrm{X}$ & $\mathrm{X}$ & $\mathrm{X}$ & $\mathrm{X}$ \\
\hline Yemen & $\mathrm{X}$ & $\mathrm{X}$ & $\mathrm{X}$ & $\mathrm{X}$ & \\
\hline Zambia & $\mathrm{X}$ & $\mathrm{X}$ & $\mathrm{X}$ & $\mathrm{X}$ & \\
\hline Zimbabwe & $\mathrm{X}$ & $\mathrm{X}$ & $\mathrm{X}$ & $\mathrm{X}$ & $\mathrm{X}$ \\
\hline
\end{tabular}

